\title{
State Counter-Insurgency And Political Policing In Colonial And Post-Colonial Malawi, 1891-1994
}

\author{
Paul Brenard Chiudza Banda \\ pbchiudzabanda@mix.wvu.edu
}

Follow this and additional works at: https://researchrepository.wvu.edu/etd

Part of the African History Commons, Diplomatic History Commons, and the Political History Commons

\section{Recommended Citation}

Chiudza Banda, Paul Brenard, "State Counter-Insurgency And Political Policing In Colonial And PostColonial Malawi, 1891-1994" (2019). Graduate Theses, Dissertations, and Problem Reports. 4043. https://researchrepository.wvu.edu/etd/4043

This Dissertation is protected by copyright and/or related rights. It has been brought to you by the The Research Repository @ WVU with permission from the rights-holder(s). You are free to use this Dissertation in any way that is permitted by the copyright and related rights legislation that applies to your use. For other uses you must obtain permission from the rights-holder(s) directly, unless additional rights are indicated by a Creative Commons license in the record and/ or on the work itself. This Dissertation has been accepted for inclusion in WVU Graduate Theses, Dissertations, and Problem Reports collection by an authorized administrator of The Research Repository @ WVU. For more information, please contact researchrepository@mail.wvu.edu. 


\section{Paul Chiudza Banda}

Dissertation submitted to the

Eberly College of Arts and Sciences

At West Virginia University

In partial fulfillment of the requirement

for the degree of

Doctor of Philosophy

In

History

Joseph M. Hodge, PhD, Chair

Robert M. Maxon, PhD

Tamba M'bayo, PhD

Michelle Stephens, PhD

Elias Mandala, PhD

Morgantown, West Virginia

2019

Key Words: Malawi; Counter-Insurgency; Development; Political Policing; Developmental State.

Copyright 2019 Paul Chiudza Banda 


\section{ABSTRACT \\ STATE COUNTER-INSURGENCY AND POLITICAL POLICING IN COLONIAL AND \\ POST-COLONIAL MALAWI, 1891-1964}

\section{Paul Chiudza Banda}

This is a study that adopts the longue durée historical approach to analyze the main causes behind the rise of 'insurgencies' or the so-called resistance against the colonial and post-colonial state in the present-day southern African country called Malawi from 1891 to 1994. In turn, it also uses the concept of 'counter-insurgency' to analyze the various measures the states in question used to defeat the 'insurgents'. To arrive at the conclusions made in the study, I have migrated through various domestic and transnational spaces, personalities, and documents that inform the current study. I also adopt two main historical approaches to conduct the analysis, namely: the politicaleconomy approach and the longue durée approach.

On the history of British colonial rule in the country, between 1891 and 1964, the study has analyzed the rise of anti-state sentiments, right from the point of formal contact between the colonizer and the colonized 'other'. I have highlighted that the factors that contributed to the rise of insurgencies or rebellions were often wide-ranging, including the native people's unhappiness with the loss of political and economic power. The latter mainly took place due to the connection of the colonial policies of land alienation; high rates of taxation; and the elements of forced labor, mainly to aid European enterprises in the country. During the late colonial period, especially after the Second World War, it was the notion of state-led development (or the rise of the 'developmental state') that significantly contributed to the rise of radical forms of anti-colonial resistance, especially following the formation of a new political entity called the Central African Federation (CAF), which brought together the three British territories of Nyasaland (now Malawi), Southern Rhodesia (now Zimbabwe) and Northern Rhodesia (now Zambia).

I have argued that in terms of counter-insurgency, the colonial authorities responded to the various occurrences of native unrest in multiple ways, including the use of brutal force, especially through the police force and the "para-military" group called the Nyasaland Volunteer Reserve (NVR); the use of repressive laws; and also the provision of development and/or socio-economic opportunities 
to the disaffected communities, in the hope that doing so would win over support for the government of the day. I have used such phrases as "the winning of hearts and minds" and "the stick and the carrot," to describe and discuss these counter-insurgency measures. In terms of the development initiatives, I have followed the colonial state's involvement in the country's development from the late 1920s, starting from the enactment of land tenure policies; the Colonial Development Act, 1929; the Colonial Development and Welfare Act, 1940 and 1945; the Colonial Development Corporation, 1948; and the CAF (1953-1963). In the post-World War II era, I have also focused the discussion on how the outbreak of the Cold War provided an impetus for the establishment of the Federation, and for the excuse to describe those who were against the Federation as Communist implants. The so-called "development" mainly served the interests of the metropole.

For the post-colonial state, I argue that what emerged was an "imported state," in the sense that the post-colonial leadership retained most of the policies and principles that had served the predecessor colonial state. I have focused on the rise of the 'developmental state' during the regime of Dr. Hastings Kamuzu Banda (1964 to 1994), who promoted the principles of import substitution industrialization (ISI) through the control of two conglomerates; the Malawi Development Corporation (MDC) and the Press Group of Companies (PGC). I have argued that like the predecessor colonial state, the "protectionism" of the post-colonial state meant that there was little or no liberalism in the political and economic sense. As such, although there were some signs of economic progress between 1964 and 1979, the country's citizens were subjected to various abuses of human rights. Like the colonial period, those who challenged the legitimacy and authority of the Banda regime, were also subjected to various "counter-insurgency" measures that adopted various measures along the same lines as the measures employed by the colonial authorities. In this, the study highlights the roles played by the country's women, youth, and the police force, to help consolidate the Banda regime. I have also zeroed in on the roles played by the international community, especially the British and American Governments, to help consolidate and prolong the Banda regime.

Finally, I have argued that the fall of Dr. Banda' regime in 1994 should be regarded as marking the end of the "post-colonial state," following the dilution or in other cases the complete departure from the policies, practices, and principles that had been "imported" from the colonial to the post- 
colonial state. The fall of Banda regime itself had strong connections with the advent of the economic downturn since the 1979/80 fiscal year, which I have argued, had both domestic and international causative forces. It was the subsequent intervention of international powers (especially the Western donor countries and the Bretton Woods Institutions) in determining the country's economic process, which significantly undermined the powers of the Banda regime, especially after the end of the Cold War. In the end, domestic sources of opposition were also encouraged to spring up, leading to the events of the early 1990s where Banda was forced to give up some of his powers, and was subsequently trounced in the 1994 general elections. 


\section{TABLE OF CONTENTS}

Content Page

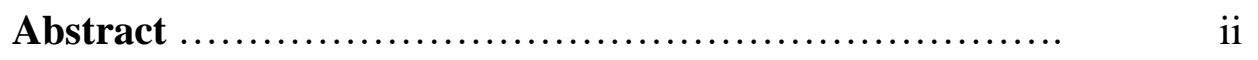

Acknowledgements ..................................... vii

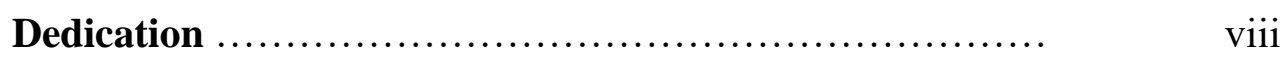

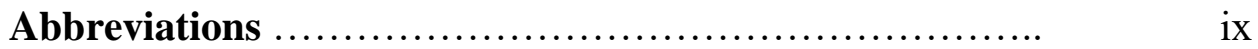

List of Tables ...................................... xiii

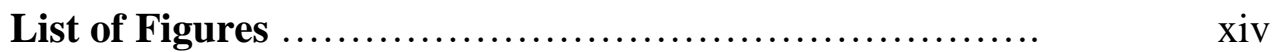

Map of Malawi (Showing Districts, 2019) ................. XV

\section{Chapter 1:}

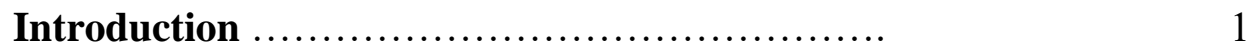

I. Research problem statement

II. Background

III. Review of selected literature

IV. Significance of the study

V. Chapter overview

\section{Chapter 2: Early Forms of African Resistance}

and State Counter-Insurgency, 1891-1914 ................. 38
I. Introduction
II. The first decade of British rule and forms of African resistance
III. The early $20^{\text {th }}$ century and the rise of post-pacification resistance
IV. Conclusion

\section{Chapter 3: The Land, Labor, and Taxation}

Nexus: Whither "Civilizing Mission"

I. Introduction

II. British Imperialism in context

III. The colonial state and land policy formulation

IV. The colonial state and "gentlemanly capitalism": access to African labor and the taxation regime

V. African reactions to the alien land, labor and taxation measures

VI. Conclusion 


\section{Chapter 4: The Winning of Hearts and Minds}

During and after the 1915 African Uprising

I. Introduction

II. The use of brutal force

III. Fines, deportations and censorship

IV. Commissions of inquiry, counter-insurgency, and development

V. The reorganization and role of the police force

VI. Conclusion

\section{Chapter 5: The Politics of Development and the}

Development of Politics in the Late Colonial Era................. 184

I. Introduction

II. The state and colonial development in Nyasaland, 1891-1953

III. Federation and the ambiguity of development, 1953-1963

IV. Counter-insurgency and some dirty work of empire

V. Conclusion

Chapter 6: Post-Colonial Malawi: The Dynamics of an

"Imported State"

I. Introduction

II. Contextualizing the post-colonial state in Africa

III. The Malawian post-colonial State and its development model

IV. The Malawi Police Force and its role in political policing

V. Western support and the consolidation of the Banda regime

VI. Conclusion

\section{Chapter 7: Epilogue: Banda's Downfall - The end of the}

Post-Colonial State?

I. Introduction

II. The international push for regime change

III. Domestic forces for regime change

IV. The state-of-affairs in the post-Banda era

V. Conclusion

Chapter 8: Conclusion

I. Legacies 


\section{Acknowledgements}

This study and indeed my coming to West Virginia University would not have been possible without the assistance I received from Dr. Joseph M. Hodge. Since first meeting with him in Malawi in 2011, he has played an important role in being my mentor, in both academic and nonacademic affairs, and I feel honored to have studied under his tutelage. Special thanks also go to my entire Dissertation Committee, including the Chair (Dr. Joseph M. Hodge) and Drs. Robert M. Maxon, Tamba M'bayo, and Michelle Stephens. I have benefitted a lot from my interactions with all these learned people.

I also acknowledge the role that all members of staff in the Eberly College of Arts and Sciences, especially those in the Department of History, played during my time as a student at West Virginia University (WVU). Martha May and Becky Warnke were particularly helpful to me when I just arrived in the US, and throughout my student years. You will always and forever be in my heart. I also want to particularly thank the Bagby family from whom I received 'The Wesley M. Bagby III Scholarship', Summer 2016.

Special mention also goes to members of staff at the following Libraries and Archives: WVU Library; Library of Congress, Indiana University Library, Syracuse University Library, Chancellor College Library, British National Archives, and Malawi National Archives. Their cooperation in finding the primary documents that I needed for this research is sincerely appreciated. 


\section{Dedication}

To my late Father, and my Loving Mum. You are the greatest parents ever. 


\section{List of Abbreviations}

$\begin{array}{ll}\text { ADMARC } & \text { Agricultural Development and Marketing Corporation } \\ \text { ACHPR } & \text { African Charter on Human and People's Rights } \\ \text { AFORD } & \text { Alliance for Democracy } \\ \text { ALC } & \text { African Lakes Corporation } \\ \text { AP } & \text { Alliance Party } \\ \text { AIS } & \text { African Industrial Society } \\ \text { BAM } & \text { Bank of America } \\ \text { BBC } & \text { British Broadcasting Corporation } \\ \text { BCA } & \text { British Central Africa } \\ \text { BCAC } & \text { British Central Africa Company } \\ \text { BCAP } & \text { British Central Africa Protectorate } \\ \text { BEAC } & \text { Blantyre and East Africa Company } \\ \text { BSAC } & \text { British South Africa Company } \\ \text { BSAP } & \text { British South African Police } \\ \text { BT } & \text { British Treasury } \\ \text { CAC } & \text { Central African Council } \\ \text { CAF } & \text { Central African Federation } \\ \text { CAFU } & \text { Central African Film Unit } \\ \text { CCAM } & \text { Chitukuko Cha Amai M'Malawi } \\ \text { CDA } & \text { Colonial Development Act } \\ \text { CDAC } & \text { Colonial Development Act Committee } \\ \text { CDC } & \text { Colonial Development Cooperation } \\ \text { CDAlinal Development and Welfare Act }\end{array}$




\begin{tabular}{ll} 
COI & Commission of Inquiry \\
CRO & Commonwealth Relations Office \\
DEVPOL & Development Policies \\
DPP & Director of Public Prosecutions \\
DPP & Democratic Progressive Party \\
DRCM & Dutch Reformed Church Mission \\
DSB & Department of Statutory Bodies \\
ESCOM & Electricity Supply Commission of Malawi \\
FBC & Federal Broadcasting Corporation \\
FCS & Free Church of Scotland \\
FID & Federal Information Department \\
FSIB & Federal Security Intelligence Bureau \\
GCHQ & Government Communication Headquarters \\
GDP & Gross Domestic Product \\
ICDA & Interim Committee for a Democratic Alliance \\
IDA & International Development Association \\
IMF & International Monetary Fund \\
IRD & Information Research Department \\
ISI & Import Substitution Industrialization \\
KAU & Kenya African Union \\
KCA & Kikuyu Central Association \\
KAR & Kings African Rifles \\
LEGCO & Legislative Council \\
LESOMA & Socialist League of Malawi \\
MAFREMO & Malawi Freedom Movement \\
MBC & Malawi Broadcasting Corporation \\
MBS & Malawi Book Service \\
MCP & Malayan Communist Party \\
\hline
\end{tabular}




\begin{tabular}{ll} 
MCP & Malawi Congress Party \\
MDC & Malawi Development Corporation \\
MDP & Malawi Democratic Party \\
MHC & Malawi Housing Corporation \\
MNA & Malawi National Archives \\
MP & Member of Parliament \\
MPA & Mlanje Planters Association \\
MUSCCO & Malawi Union of Savings and Credit Cooperative Organization \\
MYP & Malawi Young Pioneers \\
NAC & Nyasaland African Congress \\
NCC & National Consultative Committee \\
NCT & National Compensation Tribunal \\
NDC & National Development Committee \\
NIU & Natives Industrial Union \\
NPIB & Nyasaland Political Intelligence Bureau \\
NOIL & National Oil Industries Limited \\
NSA & National Security Agency \\
NVR & Nyasaland Volunteer Reserve \\
OAU & Organization of African Unity \\
ODI & Overseas Development Institute \\
ODM & Overseas Development Ministry \\
OECD & Organization for European Cooperation and Development \\
PAC & Public Affairs Committee \\
PCD & Presidential Committee on Dialogue \\
PGC & Press Group of Companies \\
PHL & Press Holdings Limited \\
PIM & Providence Industrial Mission \\
PMF & Police Mobile Force \\
\hline NA &
\end{tabular}




\begin{tabular}{ll} 
PP & People's Party \\
PTC & People's Trading Center \\
PWDC & Post War Development Committee \\
PWE & Political Warfare Executive \\
RIC & Royal Irish Constabulary \\
RRR & Royal Rhodesian Regiment \\
SADC & Southern African Development Community \\
SAP & Structural Adjustment Program \\
SHRC & Shire Highlands Railway Company \\
UDF & United Democratic Front \\
UDHR & Universal Declaration of Human Rights \\
UDP & United Democratic Party \\
UK & United Kingdom \\
UMCA & Universities Mission to Central Africa \\
UNDP & United Nations Development Program \\
UNO & United Nations Organization \\
USAID & United States Agency for International Development \\
WENLA & Witwatersrand Native Labor Association \\
ZIM & Zambezi Industrial Mission \\
\hline
\end{tabular}




\section{List of Tables}

Table 2.1: Casualties - Ashanti Field Force.

Table 3.1: Tax Collection in Nyasaland Protectorate, 1895-1914.

Table 4.1: Comparing Government spending on Education in British Colonies, 1916.

Table 4.2: Percentages of Revenue spent on African Education in Nyasaland, 1930-1934.

Table 4.3: Disbursement of Colonial Development Funds, 1930-1936.

Table 4.4: Nyasaland Police Reinforcements, 1921-1938.

Table 5.1: Expenditure by the Nyasaland and Federal Governments on Road Building and Maintenance, 1948-1958. 


\section{List of Figures}

Figure 2.1: A group of Ngoni soldiers, late $19^{\text {th }}$ century.

Figure 2.2: Chief Chikusi (Chikuse), the Ngoni chief.

Figure 2:3: Group of Ngoni chiefs, late $19^{\text {th }}$ century.

Figure 5.1: African Protestors outside Ryall's Hotel, January 1960.

Figure 6.1: Handover of power from the colonial to the post-colonial state, July 1964.

Figure 6.2: Dr. Banda and Henry M. Chipembere, campaigning for a Legco seat, 1962

Figure 6.3: Dr. Banda and Albert A. Muwalo Nqumayo, early 1970s.

Figure 6.4: Dr. Banda dancing with Malawian women.

Figure 6.5: Dr. Banda handing over houses to women of the Women's League.

Figure 6.6: Malawi Young Pioneers, c.1968.

Figure 6.7: Dr. Banda and Kwame Nkrumah, early 1960s.

Figure 6.8: MYP Cadets working in their gardens.

Figure 6.9: Dr. Banda, with Police Commissioner, J.V. Mullin, 1962.

Figure 6.10: Dr. Banda with Aaron Gadama.

Figure 6.11: Dr. Banda with Margaret Thatcher, early 1980s.

Figure 6.12: Dr. Banda with John F. Kennedy, at the White House, May 1961.

Figure 7.1: Malawi Police Force Inspector General - cartoon.

Figure 7.2: The arrest of Chakufwa Chihana, 1992.

Figure 7.3: The end of an era for the post-colonial state - cartoon. 


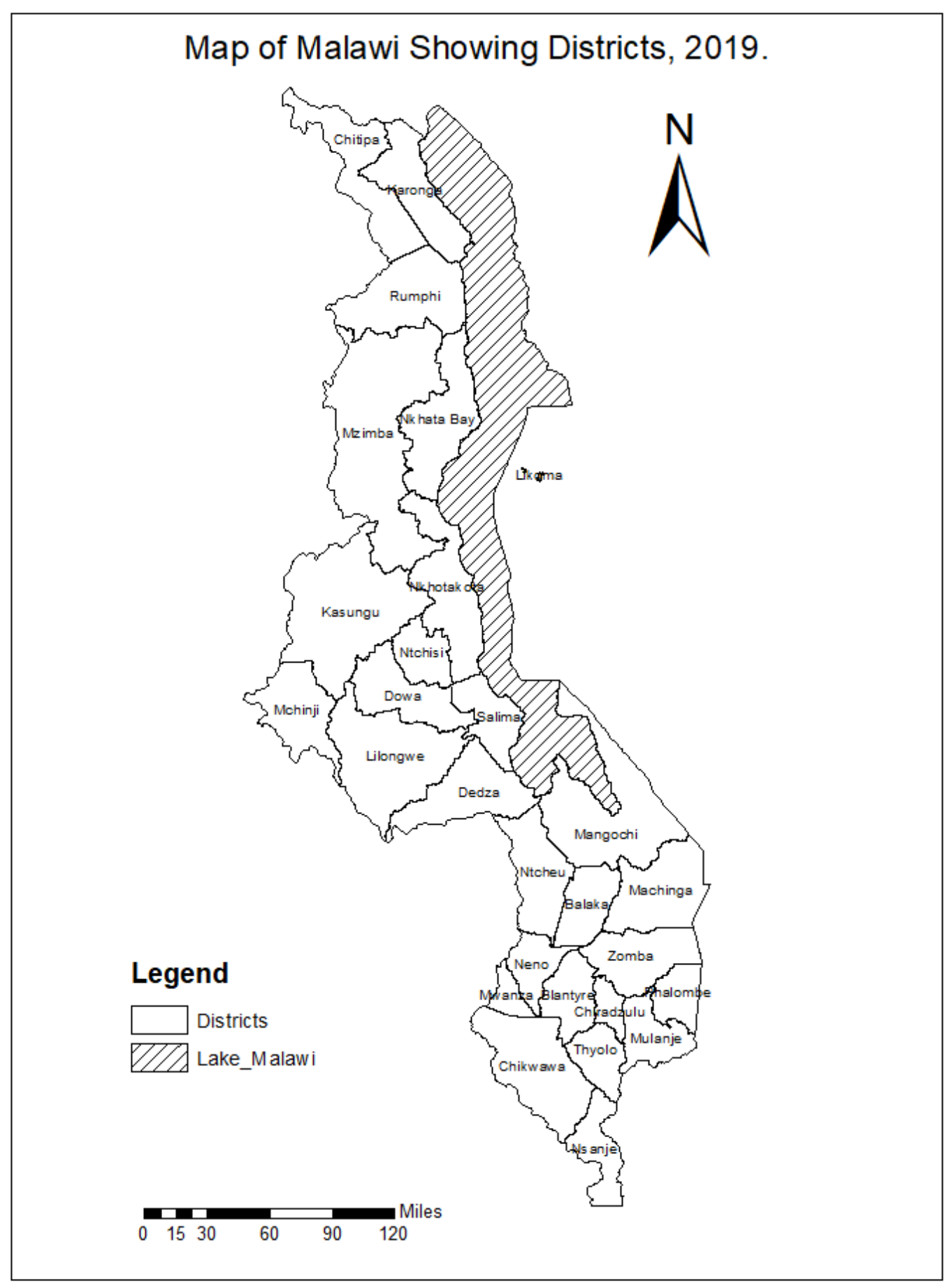




\section{CHAPTER ONE}

\section{INTRODUCTION}

Life can only be understood backwards; but it must be lived forwards. ${ }^{1}$

\section{Research problem statement}

This study adopts the longue durée historical approach ${ }^{2}$ to discuss the occurrence of different forms of insurgency and counter-insurgency in the history of colonial and post-colonial Malawi. The focus is on the underlying causes which compelled subjects, and later, citizens to challenge the authority and legitimacy of the state, both colonial and post-colonial. During the period between 1891-1994 such factors were clearly dynamic, borne out of the prevailing social, political, and economic conditions. Similarly, the reactions of the states were dynamic, and they were determined by the nature of the regimes and the different types of resources at the state's disposal. The reactions, hereafter referred to as "counter-insurgency" measures, were expressed in specific formats, including the use of brutal force (through the state's security forces and other paramilitary groups), the use of repressive laws, and also through the provision of development opportunities to the insurgents or their supporters, so as to make the latter believe that siding with the state would best serve their material needs. State officials used such terms as "rebels", "insurgents", "guerillas", and "radicals" to refer to those who challenged their authority. The counter-insurgency tactics have also been referred to under different monikers, including such

\footnotetext{
${ }^{1}$ Soren Kierkegaard, quoted from Steven D. Price, ed., 1001 Smartest Things Ever Said (Connecticut: The Lyons Press, 2005), 2.

${ }^{2}$ The longue duree approach had its origins in the 1950s and was a brainchild of the Annales school of historical writing in France. Its focus was on the production of historical texts that cover longer historical periods, rather than the short-termism of other texts and academic disciplines. The term "longue durée" literally means "the history of long, even of very long duration". See Jo Guldi and David Armitage, The History Manifesto (Cambridge: Cambridge University Press, 2014), 14-18.
} 
terms as "the stick and the carrot," and "the winning of hearts and minds." In Malawi, during the 1959-60 State of Emergency, and in the aftermath of the "cabinet crisis" of 1964, the leaders of the opposition movements were also called "communists" or "communist sympathizers."4

To date, there is limited literature that has focused on the continuation of practices, systems, structures, and elements from colonial to post-colonial Malawi. The most recent publications by John McCracken and Joey Power have, for instance, concentrated on the colonial period, and thus serve as major influences to analyze the developments of the post-colonial period, especially those aspects that continued from the colonial period. ${ }^{5}$ Another recent work that has approached the history of colonial and post-colonial Malawi is that of Wapulumuka Mulwafu, who primarily focused on the theme of the agrarian policies of the colonial and post-colonial state, matters that will be mentioned in passing in this study. ${ }^{6}$ Harvey Sindima's work comes closer to my own analysis, especially his adoption of the political-economy approach. However, his work was more of a survey of Malawi's history from the pre-colonial to the colonial and post-colonial periods. His work falls short of analyzing the history of Malawi from the perspective of British imperialism, and the connections that one could draw between the colonial and post-colonial state. ${ }^{7}$

\footnotetext{
${ }^{3}$ The works that have used such terms include: Thomas R. Mockaitis, British Counterinsurgency, 1919-60 (New York: St. Martin's Press, 1990). See also Paul Dixon, “'Hearts and Minds'? British Counter-Insurgency from Malaya to Iraq," Journal of Strategic Studies, 32, no.3, (June 2009): 353-381. See also David French, The British Way in Counter-Insurgency, 1945-1967 (Oxford: Oxford University Press, 2011). See also Susan L. Carruthers, Winning Hearts and Minds: British Governments, the Media and Colonial Counter-Insurgency, 1944-1960 (London: Leicester University Press, 1995).

4 'Security Situation in Nyasaland': Statement by Sir Roy Welensky, Federal Prime Minister'. March 10 ${ }^{\text {th }}, 1959$ : CO 1035/143. See also Henry B.M. Chipembere, "Malawi in Crisis," Ufahamu: A Journal of African Studies, 11, no.1, (1981): 76-96. See pp80-83.

5 John McCracken, A History of Malawi, 1859-1966 (UK: James Currey Ltd, 2012). See also Joey Power. Political Culture and Nationalism in Malawi: Building Kwacha (New York: University of Rochester Press, 2010).

${ }^{6}$ Wapulumuka O. Mulwafu, Conservation Song: A History of Peasant-State Relations and the Environment in Malawi, 1860-2000 (Cambridge, UK: The White Horse Press, 2011).

${ }^{7}$ Harvey J. Sindima, Malawi's First Republic: An Economic and Political Analysis (New York: University Press of America, 2002). In the same vein, another similar older work is that of John G. Pike, Malawi: A Political and Economic History (New York: Frederick A. Praeger Publishers, 1968).
} 
There is, thus, a scarcity of comprehensive studies that analyze the history of Malawi from the perspective of British colonial rule, and how the systems, elements, and structures of the colonial period were "imported" into the post-colonial period, bearing in mind that "Malawi" as a country was and still is, in many ways, a "colonial invention". ${ }^{8}$ Most studies tend to present the end of British rule as marking a significant shift - almost an end - of the colonial administrative systems, elements, and structures. Furthermore, there has not been a comprehensive study of Malawi that has tackled the topic of "counter-insurgency" in its wider sense, to include an analysis of the factors that make citizens or subjects challenge the authority and legitimacy of the state; or the similarities of the means and ways in which the states were able to respond, using the concept of "winning hearts and minds" as adopted in this study. One particular issue that has not been explored in detail, for those who have tackled the question of Malawi's development discourse, such as John McCracken, T. David Williams, and Carolyn McMaster, has been the failure to link the rise of state-led or controlled development to the deterioration of liberalism, which this study traces to the colonial period. ${ }^{9}$ On the question of development, there has often been a tendency by Africanist and Malawianist scholars alike to link the notion of "aid with strings attached" with the postcolonial period, especially during the era of the Cold War and also during the era of the Structural Adjustment Programs, which in the case of Malawi dates from 1979-80. But this study takes some steps back, to trace the notion of "aid with strings attached" to the late 1920s, following the enactment of the Colonial Development Act, 1929. Thus, this study argues that it was the notion

\footnotetext{
${ }^{8}$ Here, the concept of "colonial invention" is used to refer to the boundary, language, state institutions, and the legal system, among others, elements that were created during the colonial period. Eric Hobsbawm and Terence Ranger are some of the pioneers of the concept of "invention", focusing on the relations that ensued between the British imperialists and their subjects. See Eric Hobsbawm and Terence Ranger, eds., The invention of tradition (Cambridge: Cambridge University Press, 1983).

${ }^{9}$ For studies that have tackled the question of Malawi's development discourse, see for instance, T. David Williams, Malawi: The Politics of Despair (Ithaca: Cornell University Press, 1975). See also Carolyn McMaster, Malawi: Foreign Policy and Development (London: Julian Friedmann Publishers, 1974).
} 
of "aid with strings attached" that also significantly contributed to the downfall of the post-colonial state in 1994.

The study begins in 1891, as that was the date when British colonial rule was formally established in Malawi. Colonial rule continued up to the granting of independence in July 1964, followed by the confirmation of Malawi's Republic status two years later. The year 1994, this study argues, marked the end of the post-colonial state with the downfall of the regime of Dr. Hastings Kamuzu Banda. The post-Banda era has seen a significant dilution of most of the elements, practices or systems that had been adopted, adapted, or "imported" from the colonial era, including such notions as state-centered or directed development; the use of repressive laws; and the brutal means of dealing with opposition elements. ${ }^{10}$ More importantly, the study demonstrates how notions of "development" became a source for the rise of insurgencies, while the same, was also a mechanism of state counter-insurgency. This study demonstrates that these were recurring themes in the history of both colonial and post-colonial Malawi, while also referring to similar trends or influences from elsewhere in colonial and post-colonial Africa and Asia. The rise of insurgencies and counter-insurgencies in Malawi could be looked at from a historical perspective, and moreover these were not unique to the history of colonial and post-colonial Malawi. The task will therefore be to show the connection or continuation between the rise of insurgencies and the counterinsurgency approaches of the two historical periods. In so doing, the study will reveal that the hand-over of power from the colonizer to the colonized 'other' (i.e. the African nationalist elite) in the early to mid-1960s did not necessarily translate into dramatic changes in the administration of the state.

\footnotetext{
${ }^{10}$ See for instance, Crawford Young, "The End of the Post-Colonial State in Africa? Reflections on Changing African Political Dynamics," African Affairs 103, no.410, (Jan. 2004): 23-49.
} 
The study answers a number of key questions, including: (a) What were the underlying factors behind the rise of African resistance against the establishment and consolidation of British colonial rule in Malawi from 1891 to the mid-1960s?; (b) What were the major counter-insurgency measures employed by the colonial and post-colonial state in Malawi?; (c) What were the origins of the rise of the "developmental state" in the country, and how did the organization of the state in that manner contribute to the rise of state authoritarianism?; Moreover, what role did the international community play to help consolidate the state and indeed contribute towards its downfall? To answer these questions, I relied on both primary and secondary sources of data. The primary sources include such archival materials as government reports, official correspondences, newspaper articles, and unpublished dissertations, among others. These were drawn from several archives and libraries. The secondary sources included books and journal articles drawn from several libraries.

\section{Background}

The country now known as Malawi was a former British protectorate, officially from 1891 to 1966. The history of British interests in the country began with the exploratory journeys of the famous Scottish missionary, Dr. David Livingstone, in the late 1850s. It was his reports which alerted other British missionaries and, later, British administrators to colonize the country. The first British government appointee to work in the country was Sir Harry Hamilton Johnston, who in 1889, was appointed to serve as the Consul, combining his responsibilities for both Nyasaland (now Malawi) and Portuguese East Africa (now Mozambique). It was, however, not until February 1891 that Nyasaland officially became a British protectorate, known as British Central Africa (BCA), following a series of treaties signed between the British and the Portuguese, and following the promise of monetary subsidies from the British South African Company (BSAC) of Cecil John 
Rhodes. The BSAC continued to fund the Protectorate government until 1910, with the funds going towards payment for policing and other state services. In February 1893, the name of the Protectorate was changed to the British Central Africa Protectorate (BCAP). In July 1907, under a new constitution granted to the Protectorate, the name was changed from BCAP to Nyasaland Protectorate. With the change in name came a change of title for the Protectorate's most senior government official, from Commissioner to Governor. The new constitution also allowed for the establishment of executive and legislative councils, in which the latter comprised official and unofficial members nominated under the orders of the British Crown. ${ }^{11}$ Between 1891 and 1966, there were a total of thirteen British Governors, of which the first one, as already alluded to was Sir Harry H. Johnston (1891-1896), while the last was Sir Glyn Smallwood Jones, who served as Governor from 1961 to 1964 , and as Governor-General from 1964 to $1966 .{ }^{12}$

Although the establishment and later consolidation of British rule in the Protectorate was largely peaceful, there were several instances, as will be explained later in this study, where the colonial authorities had to suppress African resistance mainly from non-collaborating chiefs and slave traders. One of the most famous colonial rebellions in Malawi's history was the so-called Chilembwe Uprising of January to February 1915, whose causes and the consequent forms of British counter-insurgency will be analyzed in chapters three and four of this study. ${ }^{13}$

The Protectorate was relatively poor and had limited natural resources with which to attract substantial numbers of British settlers. Most of the settlers in the Protectorate settled in the Shire

\footnotetext{
${ }^{11}$ Annual Report, Nyasaland Report for 1921 (London: HMSO, 1922), 2-4. See also Colin Baker, "A hundred years ago: The Nyasaland Order-in-Council, 1907," Society of Malawi Journal, 60, no.2 (2007): 1-5.

${ }^{12}$ David P. Henige, Colonial Governors, from the $15^{\text {th }}$ century to the present (Milwaukee: The University of Wisconsin Press, 1970), 155-156.

${ }^{13}$ See for instance, George Shepperson and Thomas Price, Independent African: John Chilembwe and the Origins, Setting and Significance of the Nyasaland Native Rising of 1915 (Edinburgh: Edinburgh University Press, 1958).
} 
Highlands, where cooler temperatures allowed for the cultivation of tea and coffee (See map of modern-day Malawi, where the "Shire Highlands" referred to the following districts: Blantyre, Thyolo, Mulanje, Chiradzulu, and Zomba). There were also significant levels of poverty and limited socio-economic development for the first three decades of British rule, in part due to the colonial policy of laissez faire, which initially supported private business investments and development in the colonies from the late nineteenth and early twentieth-centuries. It was not until the Colonial Development Act, 1929, and the Colonial Development and Welfare Act (1940, 1945, 1955 and 1960), that substantial state-led and integrated forms of development were initiated in the Protectorate. In part, the low levels of socio-economic development were used to justify the inclusion of Nyasaland, from 1953 to 1963, into a new political entity, called the Central African Federation (CAF), which brought together the three British territories of Nyasaland, Northern Rhodesia (now Zambia), and Southern Rhodesia (now Zimbabwe). ${ }^{14}$ As it will be discussed in chapter five of this study, while the factors for that decision were mainly economic or developmental in nature, there were also political or strategic considerations that loomed large, especially in relation to the then on-going Cold War. It was also the establishment of the Federation, as I will later discuss, that significantly contributed to the rise of radical forms of nationalism, as nationalist leaders were branded "communist implants", leading to the declaration of a state of emergency in each of the three territories between February and March 1959.

After a series of constitutional talks between 1960 and 1964, Malawi gained its independence in July 1964, and, two years later, its republican status. Between July 1964 and July 1966, Dr. Hastings Kamuzu Banda served as the Prime Minister, and from July 1966 to May 1994, he served

${ }^{14}$ There are so many studies on this topic. See for instance, Andrew Cohen, The Politics and Economics of Decolonization in Africa: The Failed Experiment of the Central African Federation (London: I.B. Tauris, 2017). 
as the country's president. This study argues that the period between July 1964 and May 1994 should be referred to as "the post-colonial state", highlighting several practices, systems, and policies, which were initiated during the colonial period and were continued by or significantly influenced the operations of the 1964 to 1994 Banda regime. It particularly focuses on such factors as the developmental state, the personal rule of Dr. Banda, the authoritarian nature of the regime, the enactment of repressive laws, and the related brutal treatment of perceived "enemies of the state". It also zeroes in on how the Banda regime used the notion of "development" as a tool with which to fight against the opposition elements in the country. Despite the widespread abuses of human rights, the Western powers often "ignored" their magnitude, particularly because Banda was their ally during the Cold War. It was only towards the end of the Cold War in the late 1980s and early 1990s that the West pressurized Banda to liberalize his regime, leading to his subsequent downfall in 1994.

\section{Review of selected literature}

This study has been conducted under the influence of works by scholars who have made contributions towards the study of colonial and post-colonial Africa under the following thematic areas: resistance and "collaboration" to colonial rule; measures employed by the state to suppress resistance and rebellions; the developmental state in late colonial and post-colonial Africa, and its related focus on protectionism. What follows thus is a brief overview of the earlier studies, many of which influenced the findings of this study. Many of them fall under the "political economy approach", in which it is argued that the economic make up of a given society often provides an insight into other related aspects, such as its laws, modes of thought, religious systems, and political organization. One of the main proponents of the approach, Claude Ake, proposed a number of incidents where the approach could be utilized, including: (1) the notion that 
economically-privileged groups tend to have access to social, economic, and political power in society, which means that those with economic power usually have the tendency to encourage the existence of inequalities; (2) there is always tension between the "haves and the have-nots", with the former interested in maintaining the status quo, while the latter have a strong interest in changing the social, economic, and political order; (3) that due to the presence of economic inequality, it is usually not possible to have political democracy (or liberalism, in the case of this study), because political power tends to be polarized around economic power; and (4) that the morality and values of a society tend to support the preservation of the existing division of labor and distribution of wealth in that society. ${ }^{15}$

There are numerous studies that have tackled the subject of resistance to colonial rule in Africa. One key work is that of Ted Gurr, who is a proponent of the "basic frustration-aggression approach". Gurr states that the greater the frustration of a given society, the greater the quantity of aggression against the source of the frustration. From this perspective, it is argued that the proportion of a population that participates in resistance and violence ought to vary with the average intensity of perceived deprivation. Here, mild deprivation will motivate few to violence, while very intense deprivation is more likely to galvanize large segments of a community to act against the source of deprivation. In colonial settings, the coercive capacities of the state and the uses to which they were put were crucial variables that affected the forms and extent of the violence that ensued. When and where the Africans were convinced that they were denied the goods and conditions they expected to access they took up arms against the state. ${ }^{16}$

\footnotetext{
${ }^{15}$ Claude Ake, A Political Economy of Africa (New York: Longman Inc., 1981), 1-2. See also James S. Coleman, "The Resurrection of Political Economy," Mawazo 1, Issue 1, (June 1967): 31-40.

16 Ted Gurr, Why Men Rebel (New Jersey: Princeton University Press, 1970), 3-14.
} 
Writing on the same subject, James Scott argued that the source of resistance against the state revolved around the actions of the dominant group in society, which will generate the reactions of the dominated. In the construction of the "public transcript", one can notice the open interactions between the "official" (colonial state) and "hidden" (frustrations and grievances) transcripts of the dominated. The dominated peoples, despite being aware of the indomitable powers of the colonizer, still found means and ways of challenging those in authority, in most cases without success. When the dominated brought their frustrations onto the public space, or "speaking truth to power", the colonial authorities used weapons at their disposal to subdue the colonized. ${ }^{17}$ In this study, this conceptualization will be used extensively to discuss the grievances of the Africans during the colonial era in Nyasaland, including the Chilembwe Uprising of 1915. The rise of mass nationalism in the post-World War Two era to fight against the imposition of the Central African Federation and later call for independence, can also be explained along the same lines.

Bruce Berman, focusing on the case of colonial Kenya, and indeed most parts of British colonial Africa, analyzed the central role of the state in the social and economic livelihoods of the societies it presided over. The state's involvement often came through conscious and deliberate interventions, which increased steadily with the passage of time. This saw the state play a critical role in the political economy of the colony. To a significant extent, the state served as a dependent superstructure of capitalist development, as it became an instrument of violence and exploitation meted on the Africans, while at the same time setting up conducive conditions for capitalist accumulation. In doing so, the colonial state did not always act as an independent actor, but rather, as an appendage of the metropole, working on behalf and under the directions of London to subdue

\footnotetext{
${ }^{17}$ James C. Scott, Domination and the Arts of Resistance: Hidden Transcripts (New Haven: Yale University Press, 1990), 1-16 and 45-49.
} 
the African population. The operations of the state were also, to an extent, shaped by the prevailing socio-economic forces in the colonies, including whether the Africans resisted or collaborated with the state. ${ }^{18}$

There are several empirical studies that have followed the footpaths of the theoretical works on African reactions to colonial rule. Michael Tidy, for instance, divided African resistance to colonial rule into three major periods, namely: primary resistance, secondary resistance, and modern mass nationalism. Primary resistance took place before the First World War and consisted of armed struggles against the establishment of colonial rule. It had two sub-divisions, initial resistance and post-pacification revolts. Some examples under this phase include the NdebeleShona risings of 1896-97 in Southern Rhodesia and the Maji Maji risings of 1905-07 in Tanganyika. Secondary resistance occurred between the two World Wars and was usually peaceful. It involved the works of welfare associations, trade unions, and religious groups, to challenge the colonial state. Most of such groups were either local or regional in nature rather than cutting across colony-wide boundaries. Modern mass nationalism emerged after the Second World War. Its aim was to fight for independence from colonial rule. It involved political parties that attracted nation-wide support as opposed to the local and regional movements that preceded them. Although many of the movements in this phase were peaceful in nature, some of them were involved in armed struggles, as was the case in Kenya, Zimbabwe, Algeria and Mozambique. ${ }^{19}$

\footnotetext{
${ }^{18}$ Bruce Berman, Control and Crisis in Colonial Kenya: The Dialectic of Domination (London: James Currey Ltd, 1990), 1-9. Bruce Berman also argues that at a time of the 'articulation' of the capitalist and indigenous modes of production, the colonial state did not entirely play the role of only supporting the capitalist sector, but also straddled to help serve the interests of the indigenous or pre-capitalist sector. In that case, the indigenous sector did not get completely wiped out, as it helped to service the shortfalls of the capitalist sector, especially the low wages that were given to the Africans, which were supplemented by indigenous modes of production. See pp. 23-43.

${ }^{19}$ Michael Tidy, A History of Africa, Volume 2: 1840-1914 (New York: Africana Publishing Company, 1981), 14.
} 
Tidy argued further that one also must consider the responses of Africans who "accepted" or "welcomed" the Europeans in their societies, a process called "accommodation." 20 This view is also held by Terence Ranger in his study on African reactions to colonial rule in British East and Central Africa. Ranger posited that the Africans were not without their own agency to decide whether to resist or collaborate. While they would not entirely avoid the imposition of colonial rule, they often had an input in the way colonial rule was established and consolidated. Since the colonial state was often under-staffed and under-funded, the Africans, either as individuals or through their traditional leaders, participated in the formulation of the colonial experience, sometimes at the deliberate invitation of the colonial state. In many cases, it was "smaller" African societies or ethnic groups that often-welcomed British colonial rule, usually in return for protection and to access the goods of the new leadership. There were also other so-called "bigger" societies which were not easily subdued and were only subjugated with the passage of time. The Ngoni of northern Nyasaland fell in this category. The decision to either resist or collaborate was often arrived at after careful consideration by the Africans. ${ }^{21}$

Allen Isaacman and J. Vansina tackled the same subject of African resistance in Central Africa, focusing on the era of primary resistance between 1880 and 1914. The two scholars used case studies drawn from what is present-day Democratic Republic of Congo, Zambia, Malawi, Angola, and Mozambique. They argued that African resistance could be categorized in three broad categories. Firstly, there was resistance which attempted to maintain the sovereignty of the indigenous societies. Secondly, there was resistance targeted against the specific abuses imposed by the colonial regime. Lastly, there were rebellions which aimed to destroy the alien system which

\footnotetext{
${ }^{20}$ Ibid., 14-15.

${ }^{21}$ T.O. Ranger, "African reactions to the imposition of colonial rule in East and Central Africa". In LH. Gann and Peter Duignan, eds., Colonialism in Africa: The History and Politics of Colonialism, 1870-1914, Vol.1 (Cambridge: Cambridge University Press, 1969), 293-324.
} 
had generated the abuses. In the case of Nyasaland, for instance, they highlighted how the Ngoni (Maseko, Gomani, and Mpezeni) fought long battles against the establishment of British colonial rule before they were eventually overwhelmed and subdued. The Ngoni, as highlighted above, and as will be discussed in chapters two and five of this study, were one of the "bigger" and more organized ethnic groups before the advent of colonial rule. Those who fought against the abuses of colonial rule, at the local level, often did so to fight against the efforts of the state to reinforce hegemony and impose capitalist relationships designed to exploit the human and natural resources of Central Africa. The colonial states often collaborated with capitalist elements to exploit the Africans, which in the process generated localized resistance. The abuses involved policies and processes of land alienation, labor exploitation (or forced labor), and the imposition of taxation measures meant to draw labor to colonial and European settler enterprises. The resistance from Africans ranged from armed rebellions, such as the Chilembwe uprising in Nyasaland in 1915. There was also the formation of associations, whose aim was to protect the interests of the "privileged" classes of Africans. In Nyasaland, for instance, between 1912 and 1918, the North Nyasa Native Association (NNNA) and the West Nyasa Native Association (WNNA) were established. Their membership sought to initiate reforms within the colonial system for the benefit of the educated African elite. ${ }^{22}$

What the studies by Michael Tidy, T.O Ranger, A. Isaacman and J. Vansina, as outlined here, failed to appreciate, was the notion that the so-called "collaboration" with colonial rule often

\footnotetext{
${ }^{22}$ A. Isaacman and J. Vansina, "African initiatives and resistance in Central Africa, 1880-1914," In General History of Africa, Vol.7: Africa Under Colonial Domination, 1880-1935 (UNESCO and California: University Press of California, 1985)., 167-193. See also John Iliffe. "The Effects of the Maji Maji Rebellion of 1905-1906 on German occupation policy in East Africa," In Prosser Gifford and Wm. Roger Louis, Britain and Germany in Africa: Imperial Rivalry and Colonial Rule (New Haven: Yale University Press, 1967), 557-575. See also Robert I. Rotberg. "Resistance and Rebellion in British Nyasaland and German East Africa, 1888-1915: A Tentative Comparison," In Ibid, 667-690.
} 
involved the signing of dubious "treaties." Leaders of African communities were duped into signing "treaties" which were in the language of the European colonists. This, in significant measure, led to the alienation of territory from the Africans. This study addresses these issues in chapters two and three, as they formed the basis for resistance at the end of the $19^{\text {th }}$ century and the beginning of the $20^{\text {th }}$ century. The fact that an African chief here or there "welcomed" the European colonists did not always represent the general will of the communities that the chief represented. It also did not mean that the Africans had "welcomed" the Europeans and invited them to stay for good. The African reaction to colonial rule was a complicated and dynamic process, which has not been fully explained by the simplistic binary of "resistance and collaboration." In this study, I also concur with the conceptualization of Klaas van Walvaren and Jon Abbink, that notions of "resistance" and "collaboration" in African history are much broader and deeper than previously represented by early scholarship in the field. It is no longer plausible to simply adopt the two antipoles of "resistance" and "collaboration" as given, rather one must investigate the agency of the Africans involved in trying to find their space following the imposition of colonialism and capitalism. Africans often reacted rationally, having weighed the pros and cons of either resisting or collaborating with the Europeans. People in given societies tended to straddle between the two extremes depending on the prevailing socio-economic and political dynamics of the time. Furthermore, as this study investigates, the studies on resistance against the state must not only be over-concentrated on the colonial period, but focus should also be given to developments of the post-colonial period. ${ }^{23}$ And as Leroy Vail and Landeg White have shown in their studies on colonial Mozambique, studies on resistance and collaboration since the

\footnotetext{
${ }^{23}$ Klaas van Walraven and Jon Abbink, "Rethinking resistance in African history: an introduction," in Jon Abbink and Klaas van Walraven, et al, eds., Rethinking resistance: revolt and violence in African History (Boston: Brill, 2003), 1-9.
} 
early 1970s have also moved from simply analyzing the roles played by African elites, without giving agency to the ordinary African peoples. Histories of resistance and collaboration must also move beyond the realms of military and political history. Many of them experienced European colonial intrusion quite differently from their leaders, and hence reacted out of meeting their selfinterests and basic needs. For instance, there were cases where African peasants showed a quick willingness to produce for the market, in response to the challenges and opportunities brought about by the European intrusion. ${ }^{24}$

There are also several studies that tackle the question of the counter-insurgency measures employed by the colonial authorities in British-ruled colonies, in Africa and beyond. Most of the insurgencies, as I have explained above, began because of feelings or beliefs that European colonialism, in Africa, as elsewhere, had been exploitative and repressive. The seminal work in the field of counter-insurgency studies was that of Sir Robert Thompson, whose work focused on British counter-insurgency measures that were developed in Malaya. These measures were later adopted by the United States in South Vietnam. Thompson himself spent three and half years between 1961 and 1965, as Head of the British Advisory Mission in Malaya. In working out a theory of insurgency and counter-insurgency, Thompson argued that it was first important to understand the driving historical forces or factors that influenced the colonized peoples to challenge European colonial rule. For instance, in the two colonies, the spread of communism, which became one of the driving forces against European rule, had begun in the early 1920s through Chinese immigrants, who targeted students and nationalist political movements as their

\footnotetext{
${ }^{24}$ Leroy Vail and Landeg White, "Forms of Resistance: songs and perceptions of power in colonial Mozambique," The American Historical Review 88, no.4 (October 1983): 883-888. See also Frederick Cooper, "Conflict and Connection: Rethinking colonial African history," American Historical Review 99, no.5 (Dec. 1994): 1520-1524. See also Stephen Ellis, "Colonial conquest in central Madagascar: who resisted what?" in Jon Abbink and Klaas van Walraven, et al, eds., Rethinking resistance: revolt and violence in African History (Boston: Brill, 2003), 69-86.
} 
early "converts." However, it was not until World War Two that the spread of communism became a major threat to European rule, following the Japanese occupation of Vietnam and the British defeat in Malaya. ${ }^{25}$

In terms of counter-insurgency, the British began by suppressing the activities of the Malayan Communist Party (MCP) and banned the party in 1947. This, however, only created more chaos that culminated into the declaration of the State of Emergency in June 1948, which lasted for twelve years until July 1960 when the Federation of Malaya was granted its independence. Thompson argued that from 1948 onwards, the British authorities came up with a number of immediate measures with which to defeat the communist-led insurgents, including the following: (1) the use of military or armed force (through the police, the army, the home guard, the civil guard, and other such organs) to defeat the insurgency during the build-up phase or before it entered the guerilla phase; and (2) the identification of all the possible insurgent combatants and their likely followers before they became fully organized. The role of identification was to be performed by the intelligence organs of the state, targeting those who intended to carry out illegal acts against the state and its security. In the two colonies, it was the Special Branch of the Police which was entrusted with that responsibility, sometimes in coordination with other security organs.

The advantage of relying on the police forces was that they already had a history of close contact with the local communities. From then onwards, other long-term measures of counter-insurgency were put in place, including the need for the government to have a clear political aim - one in which it sought to maintain control of the entire country by controlling forms of law and order and the political and economic sectors. This could be done using state repressive structures, including

${ }^{25}$ Sir Robert Thompson, Defeating Communist Insurgency: The Lessons of Malaya and Vietnam (New York: Frederick A. Praeger Publishers, 1966), 9-23. 
the security forces. There was also a need for the government to function in accordance with the law, as that would increase the legitimacy of the government's authority, which in turn would encourage the people to obey the law. For instance, in Malaya, the colonial authorities enacted strict laws that enabled the government to seize and deport all Chinese personnel found in neutral zones. Through "legal means" the government also imposed collective fines on areas where the inhabitants were uncooperative. The colonial authorities also imposed strict curfews; a mandatory death penalty for carrying arms; life imprisonment for providing supplies or other forms of support for the terrorists; and restricted residence or detention for suspected terrorist supporters, among other measures. In other instances, detainees were brought to public trial to show that justice was being done, but also to spotlight the brutality of terrorist crimes and the whole nature of the insurgent conspiracy, including any direction and assistance received from outside the country. There was also need for the government to have an overall plan in which there should be a coordination of efforts and responsibilities between the administrative, security, and civil efforts of the counterinsurgency. Even without summarily defeating the guerillas, the government had to make sure that it eliminated or minimized the contacts between the guerillas and their civilian supporters. Finally, the government also secured its base area, or capital, before embarking on an all-out anti-guerilla warfare. ${ }^{26}$

Aside from the seemingly repressive nature of the Malayan counter-insurgency, the colonial authorities also provided other development-related programs or projects to the local communities as a means through which to win them over to the government side. For instance, the authorities offered citizenship and more economic and political rights to Chinese immigrant communities, which culminated in the formation of the Alliance Party (AP) made up of the leading Malay,

${ }^{26}$ Ibid., 50-57. 
Chinese, and Indian political associations. In both Malaya and South Vietnam, the authorities also promised the provision of new development projects, such as schools, hospitals, clinics, rural roads, better water supplies, and the supply of electricity. The government also gave up some of its authoritarian powers, which allowed the local elites to partake in their own government. That, however, was a ploy, as it did not mean a loss of government authority. The head of state still retained the authority to lay out policies to guide the direction that the countries took. ${ }^{27}$ The colonial authorities also strengthened the information or communication services of the countries or colonies involved, as information provision was regarded as one of the major tools for counterinsurgency. The information services would work at two levels, namely one which targeted the work of the insurgents; and another which was directed at the public, both of which would help promote "psychological warfare". Targeting the insurgents through various sets of information and propaganda helped to reduce the will of the insurgents to fight and to encourage surrenders. At the same time, the public would also be rallied to provide support for government efforts to end the insurgency. It was the responsibility of the department of information to inform, while the propaganda messages (through newspaper articles, radio messages, films, and censorship) were there to persuade. ${ }^{28}$

In the aftermath of Thompson's work, cited above, there have been numerous studies that have tackled the question of counter-insurgency in the former European colonies in Africa and Asia. The leading scholarship in the field includes that of Thomas Mockaitis, Paul Dixon, David French, Susan Carruthers, Erik Linstrum, Huw Bennet, and Daniel Branch, to name but a few. Their studies

${ }^{27}$ Ibid., 63-72.

${ }^{28}$ Ibid., 90-99. 
have highlighted that counter-insurgency measures have over the years varied from the use of brutal force, repressive laws, state propaganda, and the offer of development opportunities. ${ }^{29}$

This study has been significantly influenced by these earlier studies, many of which are centered on the inter-war period and the era of decolonization. However, there are several shortfalls or gaps that I address. Firstly, there has been a tendency to exclude the various forms of insurgency and counter-insurgency that appeared prior to the Second World War, and whether connections could be drawn between the pre-World War Two and post-World Two developments. Secondly, the studies reviewed mostly focused on the so-called classic period of decolonization (immediately after the Second World War up to the mid-1960s), but limited, if any, effort has been done in scholarship to consider the continuation of the dynamics that led to the rise of "insurgencies" and subsequent "counter-insurgency" measures employed by the postcolonial state. It is naïve to suggest that the end of European colonial rule automatically or immediately led to the end of the grievances that motivated people to challenge the authority and legitimacy of their government; and that the new governments completely departed from the systems of governance that were employed by their colonial predecessor states. In many African countries, Malawi included, the end of colonial rule did not immediately or completely lead to a complete departure from the systems and structures that served the colonial state. As such, it is important to conduct a "longue

\footnotetext{
${ }^{29}$ Thomas R. Mockaitis, British Counterinsurgency, 1919-60 (New York: St. Martin's Press, 1990). See also Paul Dixon, “'Hearts and Minds”? British Counter-Insurgency from Malaya to Iraq,” Journal of Strategic Studies 32, no.3, (June 2009): 353-381. See also David French, The British Way in Counter-Insurgency, 1945-1967 (Oxford: Oxford University Press, 2011). See also Susan L. Carruthers, Winning Hearts and Minds: British Governments, the Media and Colonial Counter-Insurgency, 1944-1960. (London: Leicester University Press, 1995). See also Erik Linstrum, Ruling Minds: Psychology in the British Empire (Cambridge, MA: Harvard University Press, 2016). Huw Bennet, Fighting the Mau Mau: The British Army and Counter-insurgency in the Kenya Emergency (Cambridge: Cambridge University Press, 2013). See also Daniel Branch, Defeating Mau Mau, Creating Kenya: Counterinsurgency, Civil War and Decolonization (Cambridge: Cambridge University Press, 2009).
} 
durée" study that analyzes the continuity and adaptation that took place in the period after the end of European rule.

There are also other influential works that have analyzed the making and unmaking of the postcolonial state in Africa. I will briefly discuss some of the key works in the field, specifically focusing on the advent of the so-called "developmental state", and the associated failures to enhance principles of liberalism, both political and economic, leading to the widespread abuse and disrespect of people's rights. I have highlighted some of the arguments raised in such works at the beginning of chapter six of this study (which focuses on the post-colonial state), as a way of contextualizing and conceptualizing the chapter's contents. Of note is the work of Bertrand Badie who argued that what emerged in the aftermath of European rule in Africa were "imported states". By this he meant that the states in post-colonial Africa were of European origin and character, whose form of organization had been imported into Africa during the colonial period. After the end of colonial rule, the post-colonial leaders continued with similar systems, institutions, and structures (including the political thought, legal systems, economic systems and theories) that served the preceding colonial states, hence the notion of "importing" continued. The "importing actors" imported those systems and other elements that would serve them best, and in the process help to enhance their access to political and economic power. There were also instances where some of the imported systems were adapted or were inter-mixed with traditional ones to suit the needs of the new socio-economic and political environment. ${ }^{30}$

One other influential work in the field is that of Crawford Young who adopted a continent-wide approach of analyzing the post-colonial state in Africa, through which he identified six key phases

\footnotetext{
${ }^{30}$ Bertrand Badie, The Imported State: The Westernization of the Political Order (California: Stanford University Press, 2000), 48-77, 91-96, and 112-139.
} 
which the post-colonial state had undergone, of which I have adopted five in this study, especially due to its conceptualization of the major developments under each phase. The demarcation of the phases, many of which had overlapping characteristics, was done to highlight major developments at each phase. Phase One took place from the late 1950s to the early 1960s, when the dawn of independence seemed to be full of promise. Most post-colonial states during that phase continued with the developmental policies of the colonial state, which were characterized by comprehensive state planning and large-scale public investment. The state was the central actor in the push against underdevelopment. During the first phase, most states led by the nationalist party, experienced substantial economic growth, in part due to the purchase of raw materials by former colonial powers, and because of the substantial economic and material assistance provided from the international aid which was distributed as part of the Cold War.

The second phase, occurred in the mid-1960s and abruptly ended the optimism of the previous phase due to the states' shift from political liberalism to political closure, where both civilian and military regimes outlawed opposition political groups through the enactment of laws that barred such groups directly or indirectly, including the emergence of one-party state systems. Most of the opposition leaders or outspoken critics of the new elite ended up being sent to jails that were once filled by the nationalist leaders. The argument for the single party was that it would help foster national unity and promote national development, and that a democratic culture would have been nurtured within it without the political polarization of multiple parties. Unfortunately, the single party systems only helped to eclipse the political rights of most citizens and did not bring the required national unity. What it achieved was to reproduce incumbent rule and preserve the power and interests of a selected few. Some African leaders, such as Ghana's Kwame Nkrumah, were 
deposed due to such policy shifts, while other governments increased state political surveillance activities for fear of military coups.

The third phase occurred from the late 1960s to the mid-1970s, an era when state expansionism brought about some positive results, especially from the economic perspective. Most of the states adopted indigenization policies and established state-run industries or companies, known as parastatals, which for some time produced considerable profits, and hence helped to back up the Dependency Theorists, such as Samir Amin and Walter Rodney, who had argued that extractive Western capitalism had drained resources from the underdeveloped world. ${ }^{31}$ There was also substantial economic growth due to the loans provided by international lending agencies and nations. Phase four stretched from the late 1970s to the late 1980s, when most African states were in a downward spiral, both politically and economically. Africanist scholars began to use the terms "state crisis" or "state decline" when referring to the pessimistic conditions for most of the African states. Politically, most states degenerated into personal rule characterized by clientelism and neopatrimonialism, where access to state resources was only guaranteed by one's loyalty and obedience to the ruler. There was also widespread corruption as politicians channeled state resources for self-aggrandizement. Most African countries also underwent financial crises due to the failure to pay back the huge debts owed to international money lenders. Those conditions led African countries to accept the Structural Adjustment Programs (SAPs) imposed by the World Bank and the International Monetary Fund (IMF).

\footnotetext{
${ }^{31}$ Here, Crawford Young refers to works by Samir Amin and Walter Rodney, where the argument was that a form of socialism, tied to individual African states helped to propel economic development, as opposed to the capitalist systems promoted by the West. See Samir Amin, Accumulation on a world scale: a critique of the theory of underdevelopment (New York: Monthly Review Press, 1974). See also Walter Rodney, How Europe underdeveloped Africa (London: Bogle L'Ouverture, 1972).
} 
The last but one phase, according to Young, occurred from the late 1980s to the early 1990s, when the so-called "Washington Consensus" introduced

through the SAPS as a therapy for African economies, had been found wanting as most African economies did not respond positively. However, there was some redemption from the political sphere, when political liberalization allowed for the formation of opposition political movements to operate under what has been described as the third wave of democratization. The sixth phase, which is beyond the scope of this study, focuses on the late 1990s up to the early 2000s. This phase which is still in its infancy, has come with some mixed results. In some countries the democratization process has been well established, in other countries there are elements of state collapse due to internal and international forces that have contributed to civil wars and instability. ${ }^{32}$ Young's analysis is a seminal work in the field, particularly for historical studies that adopt a "longue durée historical approach", focusing on developments over a longer period, while not disregarding developments at each of the phases mentioned above.

There are other equally impressive works on the post-colonial state in Africa, whose conceptualization could be located within the periodization adopted by Crawford Young's work, as cited above. Most of the works adopt a pessimistic approach in discussing the historical processes that the post-colonial state has undergone since the age of decolonization to the 1990s. Works by such scholars as Michael Crowder, Martin Doornbos, Frederick Cooper, Jeffrey Herbst, Abdil Ismail Samatar and Ahmed I. Samatar, and Jean-Francois Bayart, all come to mind as essential contributions to the field. ${ }^{33}$

\footnotetext{
${ }^{32}$ Crawford Young, The State in Postcolonial Africa: Fifty Years of Independence, 1960-2010 (Wisconsin: The University of Wisconsin Press, 2012), 10-31.

${ }^{33}$ See the works of Martin Doornbos, "The African State in Academic Debate: Retrospect and Prospect," Journal of Modern African Studies 28, no.2 (June 1990): 179-198. See also Jeffrey Herbst, States and Power in Africa: Comparative Lessons in Authority and Control (New Jersey: Princeton University Press, 2000). See also Abdi Ismail
} 
Michael Crowder, for instance, uses the case study of Nigeria as a reflection of the underdevelopment or the atmosphere of optimism that had taken part in the rest of sub-Saharan Africa for the first quarter century after independence. He posited that at independence, most of the African countries, in both Francophone and Anglophone Africa, adopted liberal principles and constitutions modeled on the metropole, which were generated during the talks that led to independence. There was also optimism that the economies would continue performing well, supported by agricultural production, trade, and industrialization. But by the late 1980 s, all the optimism had disappeared, and all the countries, except Botswana had experienced some form of political and economic upheaval. Some of the key challenges highlighted by Crowder include the establishment of one-party states and its association with authoritarianism; high levels of corruption by the ruling elite; and, high levels of poverty. As a result, by the late 1980s, the dream and optimism of independence and prosperity had been shattered and replaced by a profound disillusion and a state of hopelessness. For Crowder, the challenge for African states was that the dreams of socio-economic and political prosperity failed to materialize largely because they were "manufactured" in Europe, rather than in the individual African states. In his view, the stated "dream" did not consider the contemporary African realities, nor did it consider the legacy of colonial rule that would continue in post-colonial Africa, where liberal principles were rarely in practice. I address such a conceptualization, in chapter six of this study, in agreement with Crowder, that the systems and structures of the post-colonial state in Malawi, often mirrored the preceding colonial state.

Samatar and Ahmed I. Samatar, eds. The African State: Reconsiderations (New Hampshire: Heinemann, 2002). See also Jean-Francois Bayart, The African State: The Politics of the Belly. $2^{\text {nd }}$ edition (Cambridge, UK: Polity Press, 2009). 
Crowder argued that the state of "disaster" which Africa found itself in by the late 1980s should be analyzed as a continuum from the colonial era, and that African independence should not be viewed as a historical dividing line. In other words, the colonial experience played a significant role in influencing what became of post-colonial Africa. He pointed at such processes as statesponsored violence against the opposition forces; the state of underdevelopment where state resources were not meant for the benefit of the masses; the lack of freedom in political and economic circles; the personal power exercised by the rulers and leaders; the enactment of repressive laws; the dependent nature of African economies; and the state structures, including the boundaries and systems that were handed over at independence. He also reiterated that the dream of political and economic liberalization, was not a dream of African leaders at independence, rather it was a dream imposed by the colonizing powers. Many of the African leaders were in favor of the formation of "strong states" or authoritarian states, which they implemented once colonial rule was over. The African nationalist elite had a totally different dream or view about the post-colonial state in which they did not want to tolerate any form of opposition and competition, hence the downward spiral of events in the twenty-five years after independence. Most of the African leaders accepted to take part in constitutional talks that imposed the liberal principles, including allowing the operation of opposition parties, having realized that that they could not achieve independence by using military means. Only those in the opposition after independence seemed to be interested in and committed to liberal democracy. ${ }^{34}$

Similarly, Frederick Cooper, also analyzed developments of post-colonial Africa, which in the first two decades, performed relatively well, in economic terms, before the downward spiral of the late

\footnotetext{
${ }^{34}$ Michael Crowder, "Whose Dream was It Anyway? Twenty-Five Years of African Independence," African Affairs 86, no. 342 (January 1987): 7-24.
} 
1970s and early 1980s moving onwards. His work addressed the rise of state-led development since 1940 (hereafter the late-colonial era) and including the post-colonial period. He thus argued that after almost five decades of independence, in general terms, most African countries had not been associated with significant forms of development for the African masses. He also posited that there was very little or limited change between the colonial and post-colonial states in Africa, in describing both states as 'gatekeeper states', that allowed very little or no room for political and economic participation of the masses or their subjects. For both the late-colonial and post-colonial periods, development measures were mainly put in place for the benefit of the ruling elite, hence the development of notions of "state-led development" or "developmental states." ${ }^{35}$ Under systems of state-led development, roughly from 1940 to the mid-1970s, and beyond, there was the perception that government planning and economic investment (not just the natural operations of the market) would help African economies emerge from decades of backwardness. While there were positive results during the late colonial era and in the early years after independence (characterized by the growth in exports, high levels of literacy, the increase in infrastructural development, and the growth in life expectancy), the success story was however marred by the lack of liberalism (economic and political), as doing so would have posed a threat to the "gate" which the ruling elite were determined to keep or protect. Further challenges followed the economic downturn of the late 1970s and throughout the 1980s, due to both domestic and international forces, processes which affected the provision of basic socio-economic services. By the late 1980s, most African countries had their economies subjected to intervention by international money-lending and donor institutions, such as the Structural Adjustment Programs (SAPs) imposed by the International Monetary Fund (IMF) and the World Bank. Failure to attain

\footnotetext{
${ }^{35}$ Frederick Cooper, African since 1940: The Past of the Present (Cambridge: Cambridge University Press, 2002), 5 $6,17-18,35-36$, and 83-84.
} 
success under the SAPs in part helped to fuel the calls for regime change in most African countries by the late 1980s and early 1990s. At that point, the so-called "gates" had either collapsed, become un-guardable, or had been severely weakened, such that the solutions to revive the economy could only be found through international sources. It was also these international sources that also began to call for changes in the political system and openly provided support to opposition elements in individual African countries. ${ }^{36}$

While the studies by Young, Crowder, and Cooper, among others cited in this study provide an important framework for understanding the post-colonial state in Africa, they are not without several shortfalls. Chief among them is that by putting the state as the subject of analysis, they often overlook the role of African citizens in the making and un-making of the state. As this study highlights in chapters six and seven, the states in Africa are not always as hegemonic as most studies present them. Furthermore, the intervention of the international community is not the only major influence on the operations of the African state. Its operations are in many cases also influenced by the reactions of the people that they govern. In cases where there is "state overreach" the African people have used their agency to call for leadership or regime change.

The continued influence of international actors in African affairs, including the former colonial powers, has led many scholars to question the validity of the concept of "decolonization" in the continent. Some of the scholarship in this field has come from the works of Frederick Cooper, Anthony Clayton, Elizabeth Schmidt, and Catherine Gegout, to name a few. According to Frederick Cooper, while there was "formal" handing over of political power to African leaders,

\footnotetext{
${ }^{36}$ Ibid., 85-89, 156-186, and 196-197. In the same vein, see also Kwame Nkhrumah. Africa Must Unite, $2^{\text {nd }}$ edition. (New York: International Publishers, 1972), 72-78. On the notion of lack of liberalism Nkrumah argued that to achieve national unity and socio-economic development in post-colonial Africa, there was need for the state to control the economic development process, without any form of political opposition.
} 
the states that they have presided over have not often been regarded as equal partners to other global superpowers on the international stage. While "sovereignty" allowed African leaders and their states to act with authority on matters concerning domestic and foreign policy, it is also true to argue that the individual states have always been and remain riven by distinctions, and that some are more powerful and influential than others. The former colonial powers and their allies often looked down upon their former colonial territories, and in the post-colonial period, the former tended to dictate policy formulation in the latter. In other words, "decolonization" did not end the inequality that existed between the global powers and their former colonies. This also translates into the powers that international monetary organizations such as the IMF and the World Bank have over decision-making in African states. Cooper argues that "it would be a mistake either to see colonialism as a phenomenon that could be turned off like a television set - with all problems instantly turned into "African" problems - or to define a colonial "legacy" that determined what African polities could do, without considering the openings and closures that occurred during the process of struggle." 37

I agree with Cooper's analysis, and other such arguments, and grapple with these issues in chapters six and seven of this current study, where I focus on the role of the international community, including the British government and the Bretton Woods Institutions, to influence the state-ofaffairs in post-colonial Malawi. The argument adopted is that Malawi clearly gained

\footnotetext{
${ }^{37}$ Frederick Cooper, "Decolonization in Africa: An Interpretation," In Kwame A. Appiah and Henry Louis Gates, eds., Africana: The Encyclopedia of the African American Experience. (New York: Basic Books, 1999), 571-682. See also Anthony Clayton, "The Military Relations between Great Britain and Commonwealth countries, with particular reference to the African Commonwealth Nations," In W.H. Morris-Jones and Georges Fischer, eds., Decolonization and After: The British and French Experience (London: Frank Cass, 1980), 193-223. See also Catherine Gegout. Why Europe Intervenes in Africa: Security, Prestige and the Legacy of Colonialism (Oxford: Oxford University Press, 2017); and Elizabeth Schmidt, Foreign Intervention in Africa: From the Cold War to the War on Terror (Cambridge: Cambridge University Press, 2013); Ruth Schachter Morgenthau, "French-speaking tropical Africa," In Michael Crowder, ed., The Cambridge History of Africa, Vol.8: c.1940-c.1975 (Cambridge: Cambridge University Press, 1984), 611-673. See, pp.663-673.
} 
"independence" from British rule, through what John Darwin described as "the surrender of political sovereignty over the peoples of Africa and Asia and the emergence of independent nationstates." 38 However, for post-colonial Malawi, the process of "decolonization" remained incomplete and largely superficial. As Darwin put it, "decolonization" should rather be understood as "a partial retraction, redeployment and redistribution of British and European influences in the regions of the extra-European world whose economic, political and cultural life had previously seemed to flow into Western molds." 39 In the case of Malawi, this should be understood because of the continued influence of the former colonial power and her international allies in the country's political and economic developments.

From the accounts and works reviewed above, I have drawn significant lessons and influences that inform the current study. As previously highlighted, there are limited accounts that address or adopt a "longue durée approach" in the study of the history of colonial and post-colonial Malawi, and indeed for the themes that I set out to explore at the outset of this study.

\section{Significance of the study}

This study contributes to the study of the relationship between the state and its subjects and citizens in British colonial Africa, using Malawi as a case study. It also contributes to scholarship that focuses on the continuation of systems and practices that were employed by the colonial state and were adopted and sometimes adapted by the post-colonial state. Specifically, this study has targeted such areas as control of the means and forces of production, such as land and labor; the concept of taxation; state-centered control of the economy and development, as some of the areas

\footnotetext{
${ }^{38}$ John Darwin, Britain and Decolonization: The Retreat from Empire in the Post-War World (New York: Macmillan, 1988), 6.

${ }^{39}$ Ibid., 7.
} 
where subjects and citizens have risen to challenge the legitimacy and authority of the state (hereafter "insurgency"). I have also analyzed the different means (hereafter "counterinsurgency") which the states in question have used over the years to deal with such forces of opposition. That has included such tactics as the use of brutal force; the use of repressive laws; the use of state-sponsored propaganda; and the provision of development and/or socio-economic opportunities to the so-called insurgents or their followers to make it attractive for them to side with the government of the day. I have also departed from those works that only focus on the topic of counter-insurgency in relation to the period of decolonization by analyzing developments that took place both prior to World War Two and those that continued under the post-colonial state.

As I will argue in chapter seven of this study, there is a need to have clear demarcations between what is meant by such terms as "the colonial state" and the "post-colonial state" in the history of Malawi. While the colonial state stretched from 1891 to 1964 (the former referring to the date of formal colonization, and the latter referring to the date of Malawi's independence followed by a Republican status in 1966), I have argued that the fall of Dr. Hastings Kamuzu Banda and his regime in 1994 should be regarded as the end of the post-colonial state in Malawi. My adoption of the "longue durée historical approach" also helps to show the relevance of a historical inquiry in explaining the processes and challenges that societies go through, many of which have answers or antecedents set in the past, sometimes over decades or hundreds of years. This approach was the brainchild of the Annales School in France, propounded by such historical figures as Ferdinand Braudel. It was based on the understanding that while historians were encouraged to borrow from or cooperate with other related disciplines, they should not navigate away from the centrality of 
time in their studies. In other words, the developments of the present and the future, in significant measure are often a mirror image of the historical past. ${ }^{40}$

One other important component of this study is the focus of the role of the international community in influencing both the colonial and post-colonial state. This study pinpoints how the global Cold War and other multi-national players such as the USA, the World Bank, and indeed Britain herself, influenced the historical trajectory that Malawi underwent between 1891 and 1994. Not many studies have focused on the state in Malawi, both the colonial and the post-colonial, as an international actor, and especially how the state was influenced by the Cold War rivalries. The role of the international community has been extensively discussed in chapters five, six, and seven of this study. The argument here is that even with the advent of decolonization in Malawi, the British government and other international powers, continued to exert influence on the country. While their policies and directions helped determined the longevity of the post-colonial state, they were also influential in curtailing its existence in the 1990s.

In doing so, the study also places historical developments in Malawi within the "globalization" paradigm. Beginning from the late $19^{\text {th }}$ century, when Malawi like the rest of Africa was placed under colonial rule, this study shows how the country was part and parcel of some major international events and processes. Malawians and their leaders have throughout the period covered under this study been active participants or agents in the making of their own history, sometimes "voluntarily" participating and in other times opposing their interaction with the international community. In such historical processes, their choice on whether to either "collaborate" or "resist" often had a significant impact on the reactions of the metropole and the

\footnotetext{
${ }^{40}$ For a study of the longue duree historical approach, see Jo Guldi and David Armitage, The History Manifesto (Cambridge: Cambridge University Press, 2014), 14-18.
} 
international community. This includes such historical processes as colonialism, imperialism, the two World Wars, resistance to colonial rule, the great depression, decolonization, colonial and post-colonial development, the Cold War, and the engagement with and influence of the former colonial power, Britain, its American ally, and the Bretton Woods Institutions. As argued by Ralph Austen, it is high time scholars place Africa as a major player in the globalization process, both from a historical perspective and from the contemporary world order. ${ }^{41}$ This, as Zeleza argued, is an essential step in the study of African history, as it moves the focus from the nationalist project and paradigm of the early post-colonial era, with its focus on self-determination, a glorification of the African past, and the nation-state as the primary focus of analysis. Studying African history from a global perspective is essential as it highlights the interconnectedness of historical processes which communities, countries, and continents go through. ${ }^{42}$

\section{Chapter overview}

This study has eight chapters, including the current chapter which serves as the introduction. It has provided information on the research problems, the background to the study, and the review of related literature. Chapter two focuses on the first two decades of British rule in Nyasaland, roughly between 1891 and 1910. This was a period when the colonial state was being established, and required, in most cases, the use of state brutality to deal with African resistance. I have specifically dwelt on the political economy approach, to discuss how material needs determined

\footnotetext{
${ }^{41}$ Ralph A. Austen, "Africa and globalization: colonialism, decolonization and the postcolonial malaise," Journal of Global History, Issue 1 (2006), 403-408. See also Jean-Francois Bayart and Stephen Ellis, "Africa in world history: a history of extraversion," African Affairs 99, no.935, Centenary Issue: a hundred years of Africa (April 2000), 217267. See pp.217-227. See also Frederick Cooper, Colonialism in Question: theory, knowledge, history (Berkeley, CA: University of California Press, 2005), 91-112. See also Carl Death, "An Introduction to Africa and the World," in Nic Cheeseman et al, eds., The African Affairs Reader: key texts in politics, development, and international relations (Oxford: Oxford University Press, 2017), 279-289.

${ }^{42}$ Paul Tiyambe Zeleza, Africa's Resurgence: Domestic, Global and Diaspora Transformations (Los Angeles, CA: TSEHAI publisher, 2014), 315-317 and 333-353.
} 
the relationship that existed between the colonizer and the colonized. The colonial state was keen to set up conducive conditions for the operation of European enterprises in the country, hence the need to eliminate all forms of opposition. Much of what emerged as counter-insurgency, came in the form of 'the stick' against the resisting African societies, something that Crawford Young refers to as the notion of bula matari (literally "he who crushes rocks"). ${ }^{43}$

In chapter three, I critically analyze British colonial rule as a form of a "civilizing mission", by focusing on the land, labor and taxation policies of the colonial state in Nyasaland. I highlight the shortfalls of the "civilizing mission," particularly focusing on the constraints that accompanied British colonial rule. These in turn contributed to the rise of unrest in the protectorate, including the famous Chilembwe Uprising of 1915. In chapter four, I focus on the notion of "winning hearts and minds" as it pertained to the suppression of resistance between 1915 and 1930. I have focused on the use of both "the carrot and the stick," as measures employed by the colonial state to defeat the insurgents. "The stick" refers to the use of brutal force, while "the carrot" refers to the offer of development opportunities. Unlike other works that only focus on the use of brutal force to crush or suppress the Chilembwe uprising and its immediate aftermath, I have highlighted how the initiation of development and welfare programs for the benefit of the colonized peoples, was also used as a counter-insurgency measure. Following this line argument, the chapter advances the argument that the origins of a full-blown state involvement in the development of Nyasaland was in significant measure influenced by the input and demands of the Africans, some of which had been behind the 1915 uprising. It was African agency, as the chapter argues, that triggered the implementation of the tenets of the "civilizing mission." Some of the measures employed by the

\footnotetext{
${ }^{43}$ Crawford Young, The African Colonial State in Comparative Perspective (New Haven: Yale University Press, 1994), 35. Young used the term "Bula Matari" about the Belgian colonial state's activities in Belgian-ruled Congo, now the Democratic Republic of Congo (DRC).
} 
colonial state to meet the demands of the Africans contravened what the European settler community in the protectorate had advocated for. I have also stretched my focus on the colonial police, by adopting a political-economy approach to argue that the operations of the Nyasaland Police reflected the organization of the Nyasaland society of the time. Also important was the utilization of the "para-military" group, known as the Nyasaland Volunteer Reserve (NVR), whose activities and importance to the colonial state, matched what later appeared as a tactic of the postcolonial state, through the creation of the Malawi Young Pioneers (MYP). The Reserve served in both capacities of development, and as an army-in-waiting for the colonial state; and while it started as a non-state actor, its activities were soon legalized and were funded from state coffers.

Chapter five turns to the question of the ambiguity of colonial notions of development, and how these ambiguities contributed to the rise of radical forms of nationalism in the post-World War Two era. I have traced the colonial state's involvement in the development of the Nyasaland Protectorate from the late 1920s onwards, from the enactment of the Colonial Development Act of 1929, to the Colonial Development and Welfare Acts of 1940 and 1945, and the influence of the Colonial Development Corporation (CDC). I have highlighted that while there were advocates of colonial development at the Colonial Office, such as Joseph Chamberlain, the Colonial Secretary, 1895-1903, there was unwillingness by the British Treasury (BT) to commit to colonial development. Many at the BT were of the view that the colonies should be self-supporting, and that private enterprise should spearhead the development initiative. However, following the failure of the private sector to take up that responsibility, especially due to the great depression years of the late 1920s and throughout the 1930s, it became incumbent upon the colonial state to fill the gap. With regards to Nyasaland, I have highlighted that the peak of this state-led development came through the formation of the Central African Federation (CAF). The ambiguity of the notion 
of development at the time was in the fact that the development efforts introduced by the Federation, just like the other earlier development initiatives, were not intended for the benefit of the Africans, contrary to the claims made by the colonial authorities. The development initiatives were designed to serve the exploitative interests of the colonial authorities. After World War Two, Britain was joined by the USA, to extract as much as possible, from Britain's colonial possessions in Tropical Africa. During this phase, the acceleration of insurgency contributed to the declaration of the 1959 State of Emergency. The leaders of the African nationalist movements in the Federation were also referred to as "communist implants" even though there was no significant evidence to justify such claims. In as far as counter-insurgency was concerned at that stage, notions of "the stick and the carrot" also prevailed, where such measures as brutal force (through the activities of the Nyasaland Police Force), legalization of state oppression through the enactment of repressive laws, and indeed the establishment of development initiatives for the benefit of the both the colonizer and the colonized were initiated.

The post-colonial period is discussed in chapter six, where I have argued that Malawi exhibited the characteristics of an "an imported state," where one could trace the continuation of practices and systems that operated under British rule into the post-colonial period. I have focused on the rise of the "developmental state", which I have argued were a continuation from the late colonial era. Once Dr. Banda, the Malawian leader from 1964 to 1994, adopted this policy, he and his cronies created a system which followed a "protectionist" approach, thus barring others from accessing the economic and political opportunities of the time. My research departs from most other studies which overly concentrate on the brutality of the Banda regime, especially through the enactment of repressive laws, and the brutal tactics of the Malawi Police Force and two Youth Movements of the MYP and the Youth League. Instead, I draw attention to the idea that 
"development" was also at the center of Banda's tactics to prolong his stay in power for three decades. This then should be considered as part of his overall counter-insurgency strategy. He incorporated the youth and women, as the main groups through which to carry out his development agenda, while at the same time, operating his neo-patrimonial regime in which he rewarded those close to him through blood, marriage, and political connections. The Youth Movements, as mentioned above, held a similar function to the colonial NVR, as discussed in chapter four, in the sense that during times of peace they were expected to perform development activities, while during times of trouble, they were supposed, and were trained to take up arms in support of the post-colonial state. The MYPs were also placed in various government institutions where they acted as spies, gathering information on those perceived to be in opposition to the regime. Mention has also been made of two influential Western powers, the British and American Governments, especially how their aid helped to sustain the Banda regime. The argument here is that just like other post-colonial states in Africa, the Banda regime survived for three decades, in part through the substantial support it enjoyed from the Western powers. Dr. Banda was regarded as an important regional ally during the Cold War.

The last but one chapter revolves around the argument that the fall of Banda after the 1994 general elections marked the end of the post-colonial state in Malawi. I have attributed the developments that led to Banda's exit from power as emanating from the economic downturn and recession which the country faced since the 1979/80 fiscal year. The economic downturn was brought about by both international and domestic forces, including the increase in global oil prices; huge debts incurred by the Banda regime; environmental challenges; the under-performance of state-run companies; and the civil war in neighboring Mozambique, which blocked Malawi's access to the ports of Nacala and Beira. From this point onwards, Banda lost control of the economy, and had 
to rely on foreign aid from bilateral donors and the Bretton Woods Institutions, which were influenced by principles of the Washington Consensus, through the Structural Adjustment Programs (SAPs). The "Washington Consensus," or the so-called "Neo-Liberalism," among other things called for a reduction of the size and influence of the state in the economy and called for the liberalization of the economy. It also advocated for political liberalization. By the late 1980s and early 1990s, the international money lenders and aid providers had shifted away from simply giving their resources to Malawi but had also begun to demand the liberalization of the regime as a condition for the continuation of provision aid. After the Cold War, the Western powers were no longer in the mood to tolerate the wide-spread abuses of human rights in countries that relied on Western support for both budgetary and developmental aid. The international pressure soon ignited the agency of the Malawian peoples which led to the rise of domestic forms of opposition against the regime, which included not only opposition political movements but members of the clergy and the general citizenry as well.

The last chapter is the conclusion, and it summarizes the major issues raised from chapters two to seven. It also includes a general overview of the lessons to be drawn from studying the history of Malawi over a long historical period, in this case from the colonial to the post-colonial periods. 


\section{CHAPTER TWO}

\section{EARLY FORMS OF AFRICAN RESISTANCE AND STATE COUNTER- INSURGENCY, 1891-1914}

I spoke of contact. Between the colonizer and the colonized there is room only for forced labor, intimidation, pressure, the police, taxation, theft, rape, compulsory crops, contempt, mistrust, arrogance, self-complacency, swinishness, brainless elites, degraded masses. No human contact, but relations of domination and submission which turn the colonizing man into a classroom monitor, an army sergeant, a prison guard, a slave driver, and the indigenous man into an instrument of production. ${ }^{44}$

\section{Introduction}

This chapter focuses on the first two decades of British colonial rule in Nyasaland. During this early phase, the colonial state focused on the establishment of its hegemony and the consolidation of its hold on the Protectorate. It was a phase when the colonizer, as argued by Aime Cesaire, sought to demonstrate his superiority by using the instruments of colonial power such as barbarism, brutal violence and intimidation against the colonized peoples. The colonized peoples were often looked at as uncivilized and without a culture equal to that of the colonizer. ${ }^{45}$ It also details the role of local or African "collaborators" in enhancing the colonial enterprise, which substantiates the notion that the colonial enterprise was a "negotiated" process. It is the position of this chapter to argue that one has to look at the relationship between the colonizer and the colonized as one determined by access to material needs and political power The two sides scrambled over the means and forces of production and also the sources of livelihood, such as land, trade, and labor. The fight over political power often involved the struggle to subjugate some of the African chiefs. Here again, as highlighted in chapter one, the "political economy approach" helps to illuminate

\footnotetext{
${ }^{44}$ Aime Cesaire, Discourse on Colonialism (New York: Monthly Review Press, 1972), 42.

${ }^{45}$ Ibid, 8-9.
} 
the relationships that were created. During the period in question, the protectorate was ruled by four British governors, namely: Sir Harry Hamilton Johnston (1891-1896); Sir Alfred Sharpe (1896-1910); William Henry Manning (1911-1913); and George Smith (1913-1923). And as was the case in most of colonial Africa, the colonizers faced both resistance and collaboration from the African subjects, processes and relations which as I have discussed in chapter one of this study, tended to be very complicated and fluid. To counter the resistance of the Africans, the colonial state employed the brutality of its armed forces (by using military men and policemen, sourced both locally and elsewhere in the British Empire), and the legal system to its advantage, by victimizing the often-defenseless Africans. However, there were limits to which the colonial state could stump its brutal authority on the colonized peoples, hence its reliance on African "collaborators" in the form of chiefs and their subjects.

Crawford Young has described the role of the colonial state at this early phase, and indeed throughout most of the colonial period, as a Bula Matari ("breaker of rocks"), which in a way meant that the state had to adopt the characteristics of total domination to suppress all forms of African resistance. For the period between 1875 and 1914, the colonial state had to create various forms of dominance through the creation of apparatuses, such as the police force, which would discipline and punish the unruly, and ensure that there was adherence to law and order. ${ }^{46}$ There were also attempts by the colonial state to create a physical base essential for the state's survival, which would include controlling African labor and developing a system of tax collection through the use of intermediaries as tax collectors, in order to meet the revenue imperative of the state. At the same time, the state could from time-to-time engage in forcing the African population into

\footnotetext{
${ }^{46}$ Crawford Young, The African Colonial State in Comparative Perspective (New Haven: Yale University Press, 1994), 35-36.
} 
delivering of goods and surrendering land and livestock. ${ }^{47}$ The subject of the involvement of the Nyasaland government in matters of land alienation and collection of taxes will be covered in chapter three of this study.

It is essential to note that at this early phase of the establishment of dominance and consolidation of colonial state structures, the operations of the state were not a one-way process. In other words, while the colonial authorities had their own policy preferences, they were often compelled to make changes following the reactions of the Africans. As already highlighted above, the decisions by Africans to either "resist" or "collaborate" with the British colonists were usually fluid, and this also often affected the policy formulation of the colonial authorities. This argument is advanced in various studies on the early years of British colonial rule across Africa. One such study is by D.A. Low, which focused on the establishment of colonial rule in what is now Uganda in East Africa. In what he terms as "ground level imperialism," Low focused on the reactions of such kingdoms as the Buganda, Busoga, Bunyoro, and the Bankore. The reactions of the leadership of these kingdoms to the establishment of colonial rule were in significant measure the main determinants of the dynamics and operations of the colonial state. The colonial state, which often relied upon tiny numbers of European administrators, owed its establishment and consolidation to the support provided by African employees and the chiefs whom they lived under. It is that form of "construction" of the colonial state that Low termed the "fabrication" of Empire. ${ }^{48}$ I address these

\footnotetext{
${ }^{47}$ Ibid, 78-79 and 99. Similarly, see Thomas Hobbes. Leviathan (London: Penguin Books, 1985 Reprint). Hobbes, in his classic work, advocated for a powerful state, which enforced law and order, as a substitute for the anarchy associated with too much freedom in a given state.

${ }^{48}$ D.A. Low, Fabrication of Empire: The British and the Uganda Kingdoms, 1890-1902 (Cambridge: Cambridge University Press, 2009), 1-27. Another study in which the colonial authorities both sought and acted to both "destroy and conserve" African structures during the same historical phase is that John Lonsdale. See John Lonsdale, "The conquest of Kenya, 1895-1905," in Bruce Berman and John Lonsdale, eds., Unhappy Valley: conflict in Kenya and Africa. Book one: state and class (Athens, OH: Ohio University Press, 1992), 13-39. See also Bruce Berman, Control and Crisis in colonial Kenya: The dialectic of domination (Athens, OH: Ohio University Press, 1990), 52-55. See also Anne Phillips, The enigma of colonialism: British policy in West Africa (London: James Curry, 1989), 10-13.
} 
issues in both chapters two and three of this study. I focus on how the reactions of Africans to the imposition of colonial rule and later to the colonial policies on land, labor and taxation often determined the reactions of the colonial administrators (hereafter "the administrative mind"). In this case then, the establishment and consolidation of colonial rule was more of a "negotiated" process and was often determined by the "periphery" rather than always a top-down influence of the "metropole."

\section{The First Decade of British Rule and forms of African Resistance}

Roland Oliver highlighted that the man given the responsibility for laying the foundations of the Nyasaland Protectorate, as Consul General, Sir Harry Hamilton Johnston, was charged by the Foreign Office (FO) with four responsibilities upon his appointment in 1890: (1) to consolidate the Protectorate of Her Majesty over the native chiefs; (2) to advise the chiefs on their external relations with each other and with foreigners, not interfering unduly with their internal administration; (3) to ensure peace and order, and (4) by every legitimate means, to check the slave trade ${ }^{49}$ However, from the start, Johnston was met with stiff African resistance. Hector Duff, a colonial official in Johnston's administration, noted that although the formal establishment of colonial rule preceded the pacification efforts of the early Christian missionaries, such as the Universities Mission to Central Africa (UMCA), the Free Church of Scotland (FCS), the Dutch Reformed Church Mission (DRCM), and to an extent the African Lakes Corporation (ALC), by the early 1890s, the Protectorate was still torn by internal squabbles (inter-ethnic wars) and external forces (especially Arab slave traders and Portuguese interference). The major external threat came from the activities of Arab slave raiders who collaborated with Yao traders to terrorize

\footnotetext{
${ }^{49}$ Roland Oliver, Sir Harry Johnston and the Scramble for Africa (London: Chatto and Windus, 1959), 205.
} 
other non-militant ethnic groups, largely due to the existence of inter-ethnic jealousy and greed, which was mostly unchecked due to the lack of any fixed and centralized stable power. ${ }^{50}$ On the other hand, the internal warfare often involved rival chiefs in their attempts to capture slaves for sale to Arab slave traders. For instance, Yao chiefs such as Mponda versus or against Zarafi (in the southern province); or a war between the Yao and Angoni peoples; or the Yao against the Atonga peoples..$^{51}$

The Arab slave traders in question, according to a visitor to the Nyasaland Protectorate, Dr. Kerr Cross, were divided into three main classes: (1) the true Muscat traders, who had a white skin, came from Arabia, had gentlemanly manners, dressed in silk, and was invariably hospitable to Europeans; (2) the coast Arabs, who were black, hailed from Zanzibar and were of a different fiber from the first group. In religion, dress and manners, they were of similar character. However, this group was comprised of shrewd, wily and deceitful businessmen, although they tended to be hospitable to Europeans. Finally, the third group were comprised of Africans who copied the deeds of the Arab slave trader in everything. In the clearly biased words of Dr Cross, most of them were said to be "uncivilized and brutes." 52

It was this "hostile atmosphere" which necessitated the establishment of state dominance which would translate into the imposition of some degree of order, essential for creating an atmosphere in which the protectorate would be properly governed. Once Sir Harry Johnston became Consul General, he embarked on military expeditions against the slave raiders. He planned with the Government of India to secure the Protectorate with a small force of Sikhs and Muslim troopers,

\footnotetext{
${ }^{50}$ Hector Livingston Duff, Nyasaland Under the Foreign Office (London: George Bell and Sons, 1906), 16-17. See also T. David Williams, Malawi: The Politics of Despair (Ithaca and London: Cornell University Press, 1978), 46-47.

${ }^{51}$ H.H. Johnston, "The British Central Africa Protectorate," The Geographical Journal 5, no.3 (March 1895), 193217. See pp.194-196.

52 "Reminiscences of Karonga by Dr. Kerr Cross," The Central African Times, September 2 ${ }^{\text {nd }}, 1899$.
} 
under the command of Captain Cecil M. Maguire, of the Hyderabad Contingent. These troops and policemen encountered a considerable amount of African hostility and resistance. Robert Rotberg hinted that Sir Harry Johnston had to assure the FO and the British public that the chiefs who led their peoples against his army were "mere slavers" who fought only to preserve an outmoded social and economic system. In his eyes, these chiefs were scoundrels and renegades, not patriots, who deserved summary treatment. In that case, the existence of the slave trade served to justify attacks against the chiefs who refused to acknowledge the paramountcy or legitimacy of the Johnston administration, and served to mask the existence of an apparently widely felt antipathy toward whites and the British occupation of Nyasaland. ${ }^{53}$

John McCracken posited that upon his arrival in Nyasaland, Sir Harry Johnston was already convinced of the necessity of using force to establish territorial dominance. That then helps to explain why in his first year of administration, he had already sent various military expeditions to attack unfriendly or non-collaborating chiefs, such as the attack on the Yao Chief Chikumbu in Mulanje (who had been at loggerheads with European settlers in his area over payments for purchase of land). The other attacks, led by Captain Cecil Maguire, focused on the Lake Nyasa area, targeting the headquarters of Chiefs Makanjira, Kazembe, and Mponda - all of whom had known links with Swahili-Arab traders. These early attacks involved the burning of houses and dhows that were used for transporting slaves and foodstuffs. It was during the subsequent expedition in December 1891 that Captain Maguire was killed, having run into an ambush laid by the Yao peoples. ${ }^{54}$ Chief Makanjira remained a thorn in the colonial government's operations until his death in 1915. Having killed Captain Maguire and the other members of his contingent,

\footnotetext{
${ }^{53}$ Robert I. Rotberg, "Resistance and Rebellion in British Nyasaland and German East Africa, 1888-1915: A Tentative Comparison," In Prosser Gifford and Wm. Roger Louis, eds. Britain and Germany in Africa: Imperial Rivalry and Colonial Rule (New Haven and London: Yale University Press, 1967)., 672-673.

${ }^{54}$ John McCracken, A History of Malawi, 1859-1966 (Great Britain: James Currey, 2012), 57-58.
} 
Makanjira retreated to the hills, close to the border with Portuguese East Africa, from where he carried out a series of guerilla raids on villages close to Fort Maguire. Makanjira's popularity is said to have remained undiminished, such that when Major Edwards launched a further expedition against him in November 1895, he discovered that Makanjira oversaw thickly populated villages containing as many as 8000 houses. At the time of his death in 1915, Makanjira was still an "independent" chief. ${ }^{55}$

In the central province, the Johnston administration also faced stiff resistance from the Chewa and Ngoni peoples. The Chewa, led by Chief Mwase embarked on a battle against the British-led forces, but it was a short-lived affair, as the Chief ended up committing suicide to avoid being arrested after the colonial troops had overrun his village. Among the Ngoni, Chief Inkosi Gomani Chikusi, also led his people to challenge the colonizers and British mission stations for some considerable time. The chief was, however, captured and summarily executed thereby ending all efforts to resist British occupation. ${ }^{56}$ In his memoirs, R.C.F. Maugham, the government official in charge of the expedition to capture Chief Chikusi, narrated how the Ngoni chief was finally captured and later executed. He hinted that the Ngoni people who arrived in the British Central African territory in the nineteenth century from South Africa, had, by the mid-1890s accepted to

\footnotetext{
${ }^{55}$ Ibid., 60-61. It is important to note that some local chiefs remained unsubdued and hence independent of British colonial rule by the end of the $19^{\text {th }}$ century. For instance, Roger K. Tangri (1970), highlighted that the Ngoni peoples of the northern province under Chief M'belwa avoided direct confrontation with the British partly because of the remoteness of the northern Ngoniland from the sources of economic power in the south, which made it less necessary for the Johnston Administration to attack the area. Furthermore, the northern Ngoni were not an important source of labor for the southern settler estates. It was not until 1904 that the northern Ngoni voluntarily placed themselves under British jurisdiction. See Roger K. Tangri, "The Development of Modern African Politics and the Emergence of a Nationalist Movement in Colonial Malawi, 1891-1958" (PhD Thesis, Faculty of Social Sciences, University of Edinburgh, August 1970), 55-61.

${ }^{56}$ Rotberg, "Resistance and Rebellion in British Nyasaland and German East Africa," 676. For reports of other such expeditions in the central province, see "Sub-Enclosure - Captain W.H. Manning to Commissioner Johnston, $16^{\text {th }}$ October 1896," adopted from Foreign Office (Hereafter FO) - Military Collection, File No.322: British Central Africa, 1896-1898.
} 
be placed under British protection, although they had not yet started paying hut taxes. The Ngoni had also pledged to maintain peace, and in no circumstances to carry arms outside of the area they settled. However, in September 1896, Chikusi’s men began raiding the "restricted zones," which produced an atmosphere of uneasiness among both natives and Christian mission stations. Sir Alfred Sharpe, Acting Commissioner of the Protectorate, reacted to these reports by issuing orders that Chikusi had to be captured:

The Acting Commissioner told me that Chikusi would have to be taught a lesson, a severe one. In defiance of the most definite understanding, he had come down with a strong fighting force into the country between the Kirk range and the Shire River; he had destroyed several Anyanja villages; had attacked a mission station, capturing and putting to death with his own hand several of the mission natives, and, in response to remonstrance, had returned an insolent and defiant reply threatening shortly to gather together his impis (subordinate chiefs) and carry a war of extermination into the Shire Highlands. In these circumstances it was clear that, if no steps were taken, Chifisi and Mombera (Chikusi's subordinate chiefs), who were doubtless watching the situation and 'sitting on the fence', would regard our inactivity as an admission of weakness, and they, in turn would seize the opportunity of breaking out into similar acts of a warlike character. ${ }^{57}$

Maugham then was sent as a colonial official to oversee the expedition led by Captain Stewart, with a force consisting of 80 Sikhs and 60 African troops. Initially Chikusi escaped into neighboring Mozambique, leaving worries for the Nyasaland authorities who feared that he (Chikusi) might have established another headquarters in the Portuguese territory from which to launch attacks into the British Protectorate. A plan was thus hatched to dupe Chikusi into coming back to Nyasaland to amicably settle the matter with the colonial authorities. When Chikusi met with Maugham he had one question to ask: "I come to ask... why the white man brings war to my

\footnotetext{
${ }^{57}$ R.C.F. Maugham, Africa as I Have Known It: Nyasaland-East Africa-Liberia-Senegal (New York: Negro Universities Press, 1969), 164-165. Note that Mr. R.C.F. Maugham, served in the administrations of both Sir Harry Johnston and Sir Alfred Sharpe.
} 
country, kills my people, and burns my villages?” To which Mr. Maugham replied, by laying down the charges against the Ngoni chief, who was then captured and tried before a court martial, and sentenced to death by execution:

You ask me, Chikusi, why we have come with war. I will tell you. You have promised the great white man at Zomba that you would never send armed men past the bottom of the hills. For that you have been left in peace and have never paid taxes to the Government. But in the last moon, what did you do? You come with an impi to the low country. You burned and destroyed Anyanja villages. You attacked the men of God at the mission and have caught and murdered their people. More than that, you have said that soon you would take your impis and carry war across the Shire. For all these things that you have done, I am now going to take you where you will have to give an answer for these crimes. ${ }^{58}$

\footnotetext{
${ }^{58}$ R.C.F. Maugham. Africa as I Have Known It, 176-177. Note that in such raids, the colonial forces often looted from the Africans. In Nyasaland, their target was usually livestock. See for instance, "Memo from A.G. Sharp to Captain Brake, January 27, 1898," adopted from FO - Military Collection, File No.322: British Central Africa, 1896-1898, pp.12-13. See also "Enclosures - Memo No.127, Central Africa, from Acting Commissioner Sharpe to the Marquess of Salisbury, $10^{\text {th }}$ November 1896," adopted from Foreign Office - Military Collection, File No.322: British Central Africa, 1896-1898.
} 


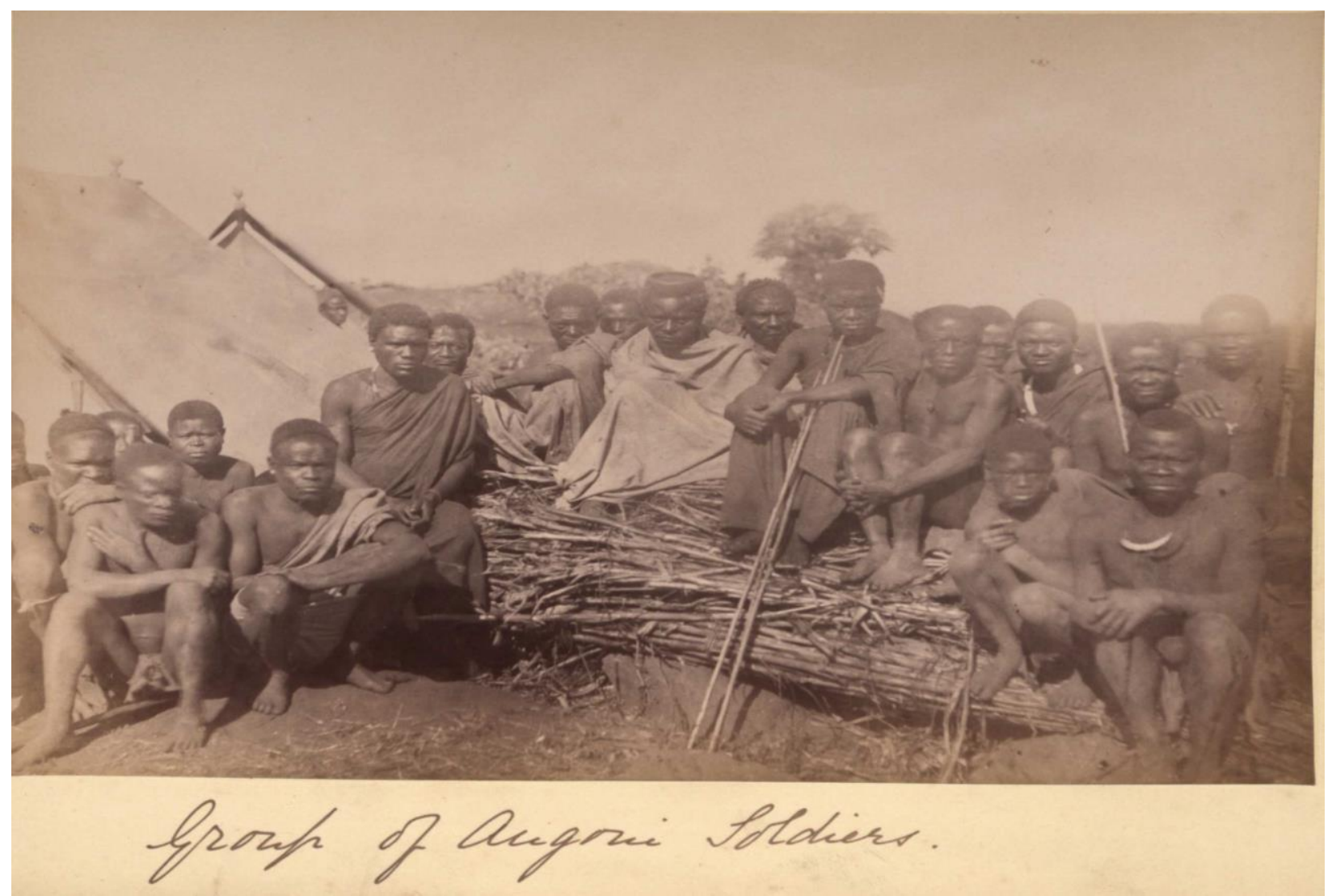

Figure 2.1: A group of Ngoni soldiers, late $19^{\text {th }}$ century. Source: Colonial Office, Photographic Collection. 


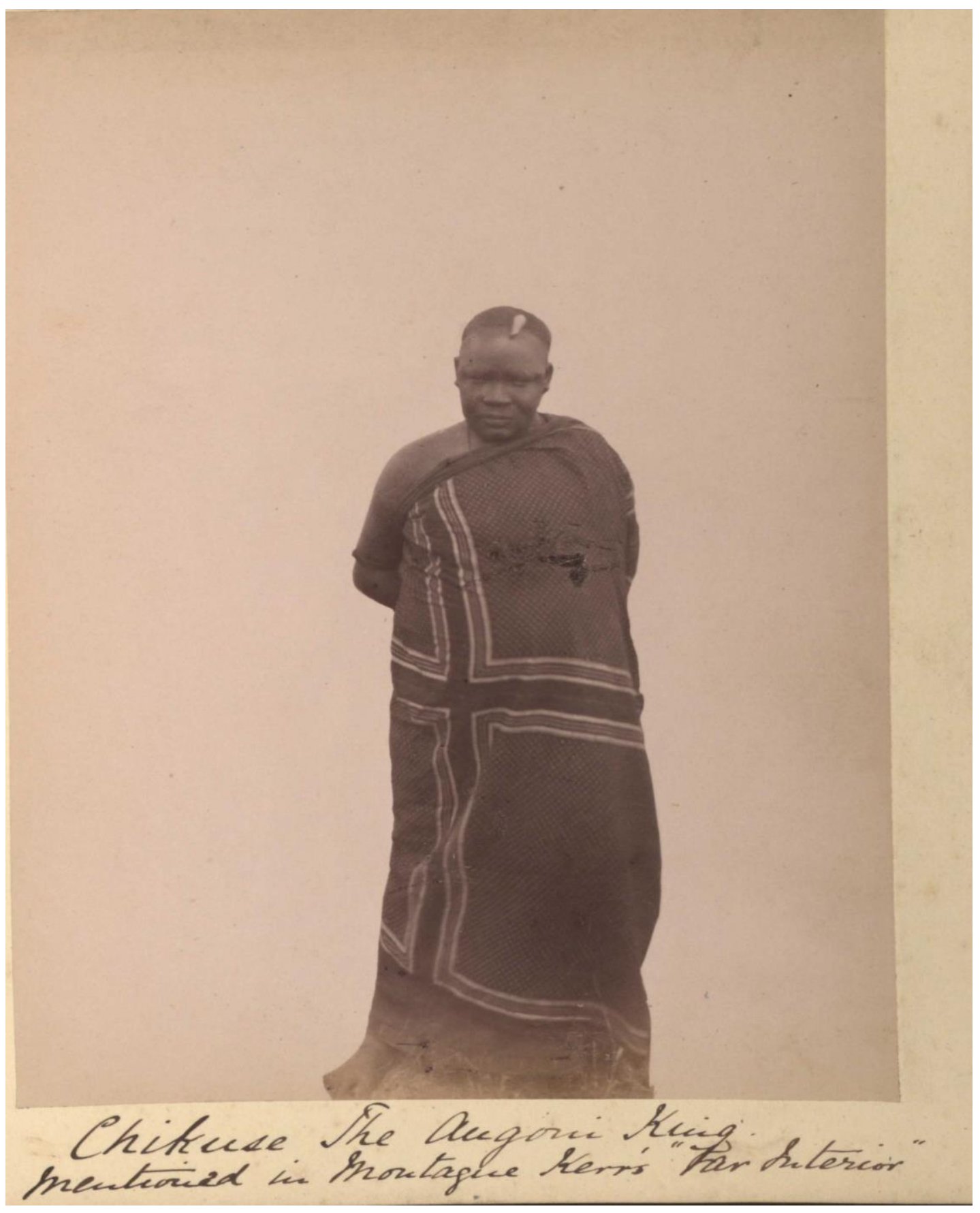

Figure 2.2: Chikuse (Chikusi), the Ngoni Chief. Source: Colonial Office, Photographic Collection. 


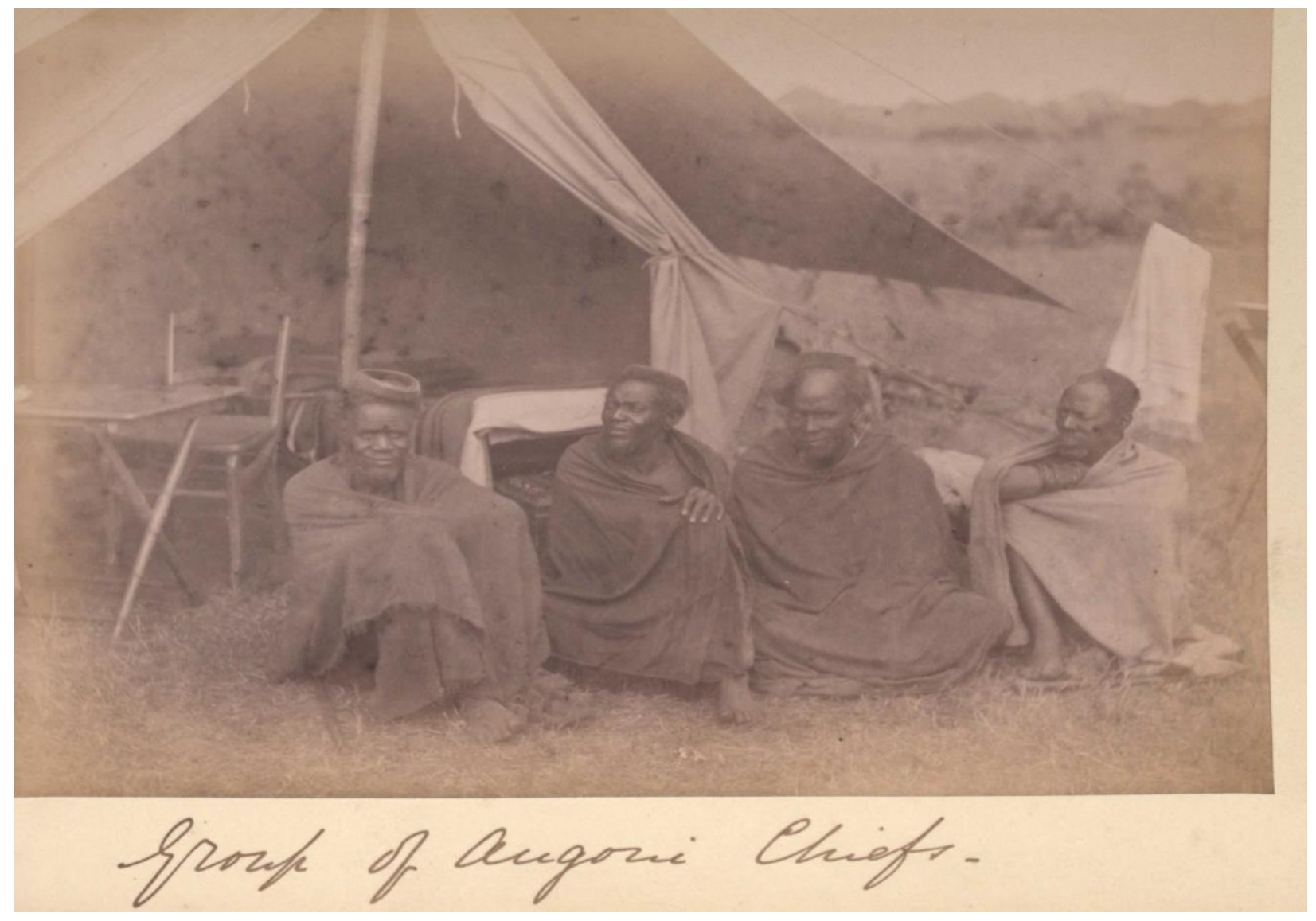

Figure 2.3: Group of Ngoni Chiefs, late $19^{\text {th }}$ century. Source: Colonial Office, Photographic Collection.

The brutal attacks on sovereign African ethnic groups and their peoples were in contravention of what had been agreed at the Berlin Conference of 1884-85 but was however not policed effectively by the European powers. Article Six of Chapter One of the Berlin Act clearly stated that there had to be diplomatic means whereby Africans (ethnic groups) were to enjoy their sovereignty and continue with their religious and cultural practices. The article read as follows:

All the powers exercising sovereign rights or influence in the aforesaid territories bind themselves to watch over the preservation of the native tribes, and to care for the improvement of the conditions of their moral and material well-being, and to help in suppressing of slavery, and especially the Slave Trade. They shall, without distinction of creed or nation, protect and favor all religious, scientific, or charitable institutions, 
and undertakings created and organized for the above ends, or which aim at instructing the natives and bringing home to them the blessings of civilization.

Christian missionaries, scientists, and explorers, with their followers, property, and collections, shall likewise be the objects of special protection.

Freedom of conscience and religious toleration are expressly guaranteed to the natives, no less than to subjects and foreigners. The free and public exercise of all forms of Divine worship, and the right to build edifices for religious purposes, and to organize religious Missions belonging to all creeds, shall not be limited or fettered in any way whatsoever. ${ }^{59}$

Following the early setbacks, colonial state authorities began to look for African collaborators, who were essential towards the establishment of hegemony. For instance, to subdue Chief Makanjira in 1893, the authorities relied on the support of newly established "alliances" with Chief Jumbe (of Kota Kota) and his sub-chief, Chiwaura. In the Northern Province the state used the help of the Angonde peoples to subdue the Swahili-Arab slave trader, Mlozi, who was captured in 1895, while hiding in an underground cellar where he had taken refuge. He was later tried for murder, convicted, sentenced to death, and hanged. ${ }^{60}$ The "collaborating" African groups were for various reasons in need of British protection and alliance. Many of them had long suffered under

\footnotetext{
${ }^{59}$ See Barbara Harlow and Mia Carter, eds., Archives of Empire, Volume II: The Scramble for Africa (Durham and London: Duke University Press, 2003), 31. Felix E. Ekechi has argued by blaming the doctrine of "effective occupation," which was agreed upon at the Berlin Conference, which is stated to have presented the European powers with a "blank check" to use military force to occupy African territories and dominate over the people therein. See Felix E. Ekechi, "The Consolidation of European Rule, 1885-1914," In Toyin Falola, ed., Africa: Colonial Africa, Vol.3, 1885-1939 (Durham, North Carolina: Carolina Academic Press, 2002), 27-33. Lord Frederick Lugard, however, argued that it was the "hinterland theory" and later the concept of "sphere of influence" which made the British to rush into acquiring the territories even without the consent of the colonized peoples. See Frederick John Dealtry Lugard, The Dual Mandate in British Tropical Africa (London: William Blackwood and Sons, 1922). This is a 2012 edition, published by Forgotten Books, 11-12.

${ }^{60}$ Duff, Nyasaland Under the Foreign Office, 26-29. See also Johnston, "The British Central Africa Protectorate," 199-201. Sir Harry Johnston (1897) highlighted that the Angonde (Wankonde) peoples had for decades been involved in a hopeless struggle against the Swahili Arabs under the leadership of Mlozi, who terrorized the Wankonde people in search of slaves. For instance, in 1885, the Wankonde were forcibly removed from their villages and pushed to settle near the Kambwe Lagoon on the shores of Lake Nyasa. The Swahili Arabs surrounded their villages, set fire to the dry reeds, and compelled the wretched Wankonde to enter the water, where hundreds of them were devoured by crocodiles, and large numbers were shot, stabbed, or drowned. See Harry Hamilton Johnston, British Central Africa: An Attempt to Give Some Account of A Portion of the Territories Under British Influence North of the Zambezi (New York: Edward Arnold, 1897), 72-76.
} 
the slave trade perpetrated by the Yao and Swahili-Arabs. For instance, the Makololo and Man'ganja peoples of the Lower Shire, appealed for British protection against the Portuguese, whom they did not deem to be "good colonizers" following the brutality experienced by Africans in neighboring Mozambique. Such groups signed treaties acknowledging the cession of all sovereign rights and for the acceptance of such laws and regulations as might from time-to-time be "imposed" by the Queen's representative. ${ }^{61}$ Some of the support for the colonial state also came from outside the Protectorate. For instance, Sir Harry Johnston convinced the Foreign Office and Lord Salisbury (British Prime Minister) to send gunboats to the Nyasaland Protectorate. The War Office was also persuaded to send guns, shells, rifles and bullets, uniforms, tents and other military equipment. The India Office was also persuaded to send more Sikhs to serve as police officers and to second Indian army officers to the Nyasaland Protectorate. There was also some money which came as an annual subsidy from Cecil John Rhodes's British South Africa Company (BSAC), amounting to $£ 10,000$ per annum, which was used to set up a local police force. ${ }^{62}$

The story of the Makololo peoples, originally from Portuguese East Africa, as narrated by Sir Harry Johnston, is interesting and compelling to tell. Before they became allies of the colonial state, they were one of the most troublesome ethnic groups to work with. For instance, in the mid1880s, having previously been more accommodating and welcoming to the British, including providing porters to serve the British explorer, Dr. David Livingstone, the Makololo peoples under two prominent chiefs, namely Chief Ramakukane and Chief Chipatula, found themselves at loggerheads with early British settlers. Both chiefs had worked and accompanied Dr. David

\footnotetext{
${ }^{61}$ Roland Oliver, Sir Harry Johnston and the Scramble for Africa, 206. For a thorough understanding of the history of resistance and collaboration in colonial Southern and Central Africa, one can see the work of Allen Isaacman and Barbara Isaacman, "Resistance and Collaboration in Southern and Central Africa, 1850-1920," The International Journal of African Historical Studies, 10, no.1 (1977): 31-62.

${ }^{62}$ Oliver, Sir Harry Johnston and the Scramble for Africa, 216-217. See also "BSAC Royal Charter": 'Extract from The London Gazette, Friday, Dec. 20 ${ }^{\text {th }}$ 1889. Source: FO 403.
} 
Livingstone but having settled in the Lower Shire area and established their own chieftaincies, they also began to establish themselves as slave traders and ivory traders, a development which often led them into competition with black Portuguese slave traders (half-caste Portuguese slave traders). Initially, the British missionaries, early explorers, and officials of the African Lakes Corporation (ALC) collaborated with these chiefs, especially because of their strategic position to the trade in ivory.

However, things turned sour in 1884, when a Mr. George Fenwick, a former employee of the Church of Scotland Mission at Blantyre went to Chief Chipatula's headquarters to settle some accounts on the ivory trade with the chief. During their discussion, the two gentlemen disagreed over some details, leading to a verbal war between the two. Mr. Fenwick then took out his rifle and shot the chief dead. When followers of the Chief learned about the shooting, they began to run after Mr. Fenwick. Fearing for his own life, Fenwick rushed out of the chief's hut and ran towards the shores of the Shire River and shouted at the natives "Your chief is dead, I am your chief now." Fenwick successfully crossed the river and ended up seeking refuge at Malo Island. However, Chief Chipatula's followers followed him there, and caught up with him after three days of hiding. Mr. Fenwick was at last overcome and killed, and his head was cut off. From then onwards, most of the Makololo chiefs became inimical to the European settlers (both British and Portuguese). For instance, the natives shot and sunk the little steamer, Lady Nyasa; and they also sent an insolent message to Blantyre (headquarters of the Church of Scotland Mission), demanding that Mrs. Fenwick, the wife of the murdered adventurer, should be delivered over to them, together with an enormous sum as compensation for the death of Chief Chipatula. It took the intervention of Consul 
Foot and Chief Ramakukane to negotiate with Chief Chipatula's followers, to restore peace in the Lower Shire area. ${ }^{63}$

The period from 1895 to the close of the nineteenth century was characterized by less confrontation between the colonizer and the colonized. Roger Tangri argued that for the Africans, they came to realize that their resistance had been a vain and futile attempt. What they attained were mere lessons for the future, for instance, that to challenge British authority or even to try to regain their independence, they had to use non-violent means. Their armed resistance had proved to be ineffective and had exposed the great technological inferiority of African societies. Furthermore, for the resisting groups, the experience of defeat still lingered in their memories for years to come, especially due to the loss of sovereignty and land. ${ }^{64}$ During that first decade, the colonial state impinged only slightly on the lives of most natives in the Protectorate. This then partly explains why, unlike elsewhere in British colonial Africa, Nyasaland did not experience further large-scale "traditionalist types of resistance," 65 except for a few riots. In the Nyasaland Protectorate, the pressures from the administration and the European settlers were less intensive. Furthermore, outside of the Shire Highlands, European settlement was also of little consequence, which meant that the colonial government, constrained by limitations of men and money, also exercised very limited or no authority. A case in point was that of the Northern Angoniland under Chief M'belwa, which remained independent until 1904. In the Shire Highlands itself, there were concerns raised by the Africans, especially on the policies of land alienation and labor recruitment and the illtreatment of laborers, encouraged by the European settlers' intrusion in the area. Some discontent

\footnotetext{
${ }^{63}$ Johnston, British Central Africa, 69.

${ }^{64}$ Roger K. Tangri, "The Development of Modern African Politics and the Emergence of a Nationalist Movement in Colonial Malawi, 62-63.

${ }^{65}$ The concept of "traditionalist type of resistance" here is used to differentiate it from other forms of resistance that appeared later during the colonial period. The later cases included resistance efforts led by religious leaders and political parties.
} 
was also raised in Central Angoniland, an area which was targeted for labor recruitment by the colonial authorities, leading to minor altercations between 1898 and 1901, when the colonial state forced men to work for the settlers to raise money for payment of taxes. ${ }^{66}$ However, most of these disturbances were small and insignificant.

\section{The early $20^{\text {th }}$ century and the rise of post-pacification resistance}

For Nyasaland, the twentieth century began as the previous one had ended, characterized by disturbances, although most of them were small and insignificant. One significant disturbance occurred at the end of 1902, though. This was a case connected to the departure of troops from Nyasaland to British-ruled Somaliland, for defeating an African uprising championed by a secessionist leader known as the Mad Mullah (real name Muhammad Abduallah Hassan). ${ }^{67}$ The Central African Times presented the proceedings of the disturbances as follows:

The facts are briefly as these. The troops have been expecting for some time to be called away to Somaliland, and some months ago (in September) a small detachment went forward. Owing to the bad turn which affairs have taken recently, a cable was received by the Armed Forces ordering the remainder of the Second Battalion of the Kings African Rifles and part of the First Battalion to proceed to Somaliland at once. This order, we say, was expected. The time for movement was short, and hence haste was required. Instead, however, of using legal and common-sense methods, the troops were hurried off, and a system of press gang and terrorism used to raise many of the carriers.

Instead of applying to the large firms in the country, the transport firms, and the planters, who have control of large bodies of labourers and who could as we know from statements made at the Chamber of Agriculture and Commerce meeting, have supplied easily the whole number of carriers, the Collector of Blantyre district was told to get the carriers. Local police and soldiers (all called 'Askari') were used to seize everyone at hand. The result was that on Monday night pandemonium reigned at Blantyre, and the state of excitement into which the native population was thrown is only comparable to

\footnotetext{
${ }^{66}$ Roger K. Tangri, "The Development of Modern African Politics and the Emergence of a Nationalist Movement in Colonial Malawi, 65-68.

${ }^{67}$ Note that the Somaliland Protectorate, which was located on the southern side of Gulf of Aden, came under the control of the British Empire in 1884, and for some time was administered as a dependency of the Government of India. In 1898, the Somaliland Protectorate was transferred to the Foreign Office, and in 1905 to the Colonial Office. In 1940, it was overrun by the Italians, but they were driven out by 1941. See Sir Charles Jeffries, The Colonial Office (London: George Allen and Unwin Ltd, 1956), 79.
} 
the old days when slave raiding and inter-tribal wars were the order of the day. This was not confined to Blantyre, but all along the Zomba road and the Katunga road, carriers were molested, and it is alleged women were assaulted and that several have been carried off." 68

One key witness to these proceedings was a British settler known as Mr. Hetherwick, who compared the brutality by the Askari to the Armenian atrocity (by Turkish forces) ${ }^{69}$ His remarks were as follows:

On Sunday night the local lines of workers belonging to private firms were visited by the Chief Constable and the Sub-Collector, and boys press-ganged all over the place. Most of the local natives fled in terror to the hills round about, and work all over the place was disorganized. These are sober facts of the case in general terms, what they mean anyone who is acquainted with native Askari needs not be told. They mean theft, they mean personal violence, they mean rape, and in extreme cases murder, though happily we have not heard any of any such cases yet. Carriers on the road were not protected by the loads as being evidence of deployment ... These troops ... justified every adverse criticism which has been passed upon them, by such conduct, and have forfeited the sympathy of the whole community. ${ }^{70}$

Had the colonial government authorities simply asked the affected communities to provide the needed carriers without coercion, the communities would probably have willingly provided the sought-after carriers. The paper's editor made these remarks:

People are asking themselves if they are in a British country. The word 'Protectorate' (of natives observe) is a misnomer. The utter incapacity of the military to move troops, is appalling, and remember that is not the first-time similar disturbances, but on a less

\footnotetext{
68 "Reign of Terror under the British Government," The Central African Times, November $1^{\text {st }}, 1902$. See also The Central African Times, November 6 ${ }^{\text {th }}, 1902$, where the paper reported that it was becoming increasingly difficult to defeat the Mad Mullah because he had been receiving assistance from several renegades of different nationalities, including South Africans. In April 1903, for instance, the forces of the Mad Mullah killed Colonel Plunkett, a Briton, and whose regiment had been surrounded. Ten other British officers were wounded, and two maxim guns were confiscated. These troops had exhausted their ammunition in pursuit of the Mad Mullah (The Central African Times, April 23 $\left.{ }^{\text {rd }}, 1903\right)$.

69 Turkey and Armenia had been at loggerheads from the $16^{\text {th }}$ to the $20^{\text {th }}$ centuries, when Armenia was brought under the Ottoman Empire. The Armenians, who were mainly Christian, were compelled to convert to Islam, and were often over-taxed. Armenian resistance, in part led to the Armenian genocide of 1915. See Robert Melson, Revolution and Genocide: on the origins of the Armenian genocide and the holocaust (Chicago: The University of Chicago Press, 1992), 43-70.

70 "Reign of Terror under the British Government," The Central African Times, November 1", 1902.
} 
aggravated scale, have occurred. The greatest condemnation of the authorities is that there is not the slightest shadow of excuse for this conduct, as enough carriers, ready provisioned, were available at short notice. The community would have been only too willing to give every available boy to carry loads to help the Empire in its need, had they been asked, but if the Empire is to be assisted by traversing every tradition of justice and fair dealing, then people will be tempted to use the historic phrase 'perish the Empire'. That a reign of terror such as this should be possible in a civilized country like British Central Africa is incredible and Europeans could not at first believe the evidence of their senses. ${ }^{71}$

The newspaper also reported that the Chamber of Agriculture and Commerce had complained to the colonial government about the gravity of the ill-treatment of the natives. More importantly, for the settlers, they complained that the labor recruitment and/or diversion had been done at a critical time of the year, when the settlers also needed the same manpower to work in the estates of the Shire Highlands. The settlers also recommended that the European and local Askari involved in trespassing in settler estates without warrants should be held responsible and possibly punished with dismissal from the service, and, lastly, that an inquiry should be instituted to scrutinize the conduct of the Askari in question. ${ }^{72}$

In terms of statistics and logistics, Major F.B. Pearce, Acting Commissioner for Nyasaland in 1903, highlighted that the first Somaliland expedition from British Central Africa (BCA) started off in June 1902. That contingent comprised of sixty Sikhs, under the command of Captain Withers. At the end of July 1902, another contingent was also dispatched, this time under the command of Major Plunkett, consisting of five British Officers, two Sikhs, one warrant officer, and 300 native rank and file. The third contingent left at the end of October 1902, under Captain Olivey, and it consisted of seven British Officers, three Sikhs, and 300 rank and file, with one

\footnotetext{
${ }^{71}$ Ibid.

${ }^{72}$ Ibid.
} 
Maxim gun. In the same month, another contingent of the First Battalion of the Kings African Rifles consisting of eight British Officers, three Sikhs, and 350 native troops also left for Somaliland. ${ }^{73}$

It must be highlighted that this was not the first time for the colonial state to utilize the local Askari in overseas engagements. In July 1899, Colonel G.E. Doyle, from the Army and Navy Club, raised his concerns through the editor of The London Times, discussing the role to be played by native battalions across the Empire. Colonel Doyle's remarks were as follows:

Sir, the new system of employing in British dependencies foreign mercenary troops that is, troops other than the Queen's natural born subjects - which has already been much deliberated upon in Parliament in the case of the Chinese regiment, has just received another illustration in the departure, announced in the newspapers last week, of a battalion of Central Africa rifles from East Africa to reinforce the garrison of Mauritius. The object of sending these corps thither appears to be not very clear, since there is already in the Island a force, comprising one British and one Indian regiment, besides artillery and engineers, far more than sufficient to repress any local disturbance, unlikely in such an event that could possibly occur, and the only real danger to which Mauritius can be exposed is that, in case of a great maritime war, an attempt might be to capture it a coup de grace. Without disparagement of the Central African regiment, which will no doubt be brought to a high pitch of discipline and efficiency by the picked officers, the question may be raised whether such corps would be found of much use in coping with such an emergency. Indeed, not to garrison Mauritius with the best of troops seems almost to trifle with the possession of an Island which is of the utmost importance as a cooling station on the long sea route to India. ${ }^{74}$

Lieutenant-Colonel W.H. Manning, Commander of the Armed Forces of British Central Africa Rifles also corroborated what was discussed by Colonel Doyle, by stating that the troops in question were taken from the Second Battalion of the Central Africa Regiment and were dispatched to Mauritius in July 1899. The Battalion consisted of Yaos and Atonga, with a few

\footnotetext{
${ }^{73}$ Great Britain, Report on the Trade and General Conditions of the British Central Africa Protectorate for the year 1902-1903 (London: His Majesty's Stationery Office, hereafter HMSO, 1903).

74 "Foreign Troops and the British Dependencies," The Central African Times, October $14^{\text {th }}, 1899$.
} 
Anguru (Alomwe). After their success in Mauritius they were transferred to the Somaliland Protectorate. $^{75}$

In May 1900, another expedition comprising of four British Officers, seventy-three Sikhs and 267 Nyasaland native troops from the Central Africa Regiment was sent for service to West Africa to assist the Ashanti Field Force (in Ashanti and Kumasi, where they spent seven months). The expeditionary force also comprised of a maxim gun, a medical officer, hospital assistant, and a complement of camp followers, together with 775 carriers from BCA. ${ }^{76}$ Upon returning from West Africa, the casualty figures were as follows:

Table 2.1: Casualties: Ashanti Field Force

\begin{tabular}{|c|c|c|c|c|}
\hline & $\begin{array}{l}\text { British } \\
\text { Officers }\end{array}$ & Sikhs & $\begin{array}{c}1^{\text {st }} \text { Battalion Central } \\
\text { African Regiment }\end{array}$ & Total \\
\hline Killed & $\ldots$ & 2 & 1 & 3 \\
\hline Wounded & 2 & 20 & 20 & 42 \\
\hline \multicolumn{5}{|l|}{ From other causes } \\
\hline (a) Disease & $\ldots$ & 2 & 7 & \\
\hline (b) Invalided & 1 & $\ldots$ & $\ldots$ & $\mathbf{1}$ \\
\hline (c) Invalided to India & $\ldots$ & 12 & $\ldots$ & 12 \\
\hline (d) Discharged as unfit & $\cdots$ & $\cdots$ & 3 & 3 \\
\hline Total & 3 & 36 & 31 & 70 \\
\hline
\end{tabular}

Source: Diplomatic and Consular Reports, Report for the year ending March 31 ${ }^{\text {st }}$, 1901, on the Trade and General Condition of the British Central Africa Protectorate (London: HMSO, October 1901), 16-17.

\footnotetext{
${ }^{75}$ Diplomatic and Consular Reports, Report for the year ending March 31 ${ }^{\text {st }}, 1900$ on the Trade and General Condition of the British Central Africa Protectorate (London: HMSO, August 1900), 23-24.

76 Ibid., 23-24.
} 
Following the demands and pressure from the Chamber of Agriculture and Commerce, in early November 1902, a Court of Inquiry (in the High Court) was instituted to investigate the events of October 1902. The High Court had itself just been created that same year under the British Central Africa Order-in-Council of 1902, which gave the court full jurisdiction over civil and criminal cases, over all persons and all matters in the Protectorate. The inquiry team was made up of the following individuals: Judge J.J. Nunan, who served as Chair of the Committee, and he was also Vice Consul of the Protectorate; Captain Percival, who represented the Armed Forces; Mr. Moggridge, who represented the Blanytre Police; and Mr. Griffin, who served as a Crown Prosecutor.

Procedures were put in place in a way that the court arranged to interrogate European eyewitnesses before African witnesses were brought in. A subpoena was also issued by Judge Nunan to have the chair of the Chamber of Agriculture and Commerce, Mr. Walker, to give evidence in the court proceedings. Other businessmen were also called to give evidence, such as a Mr. Blessby, who was called and examined at length about the loss sustained by men in his employment and as to the disorganization of his business. Most of the evidence presented in court was chilling, and some of the accounts will be highlighted in this chapter. One notable witness, a Mr. Martin Haarseth, gave his side of the story as follows:

The witness said that on the night in question (Sunday, October $26^{\text {th }}, 1902$ ), he had occasion to inspect a brick kiln which he was burning, ongoing to the place he found only three or four boys and not twelve. He sent one of the boys to call the others, but he did not return, ultimately, he went himself to the native location and found there only one little boy, of whom he asked the whereabouts of the other people, the boy did not give an intelligible answer further than that the people had gone 'uko' (over there). On his way back he encountered two gentlemen, they were Mr. Smyly and Mr. Wilson. These gentlemen asked him if he had any boys to give as carriers, but he had none left. He did not know what the matter was. He saw the boy Daniel amongst the boys who were being escorted. He also saw his cook and the store boy. He remonstrated with the 
two gentlemen who oversaw the party for having taken these boys. The boys were released on his complaint. ${ }^{77}$

Another key witness was a Mr. Hynde, and his testimony was as follows: "The next witness heard of the matter on Sunday night about 8 o'clock when several carriers were found hiding in the bush near his house at Michiru. About ten p.m. a boy named David came up to complain to him that he had been seized by the Askari and his clothes and blankets stolen. The boy was practically naked and was suffering from two severe abrasions on his knees. Next morning the boy was sent to the Collector along with a companion who had suffered in a similar manner."78

A Mr. Lindsay also presented some chilling details to the inquiry:

He said he was inside the house at the time but he overhead what passed. There was a good deal of noise. He was on the point of going out to interfere as he believed the soldiers were on the point of assaulting Mr. Drever (a settler). When the officer to whom Mr. Drever complained passed, witness was away. Asked if he saw anything else, witness replied that he saw several things. He was on the verandah when a woman passed carrying what appeared to be a heavy box of ammunition on her head. This woman was also carrying a little child on her back. When she came next to where he was standing the woman fell with the load, and an Askari struck her when she was on the ground with the butt end of his rifle, only a few inches from the baby's head. The woman was then raised up by two Askari and the load again put on her head and they went away. Witness further mentioned that the natives had great reason to be afraid of the police all over the country. The police, in his words, assaulted and raped women, which explained why most women run from their villages when the police came. ${ }^{79}$

\footnotetext{
77 “The Askari Troubles: Official Inquiry," The Central African Times, November $8^{\text {th }}$, 1902. Note that before the establishment of the High Court in 1902, the delivery of justice had been unsystematic and often haphazard. The Africa Order-in-Council of 1889 had led to the establishment of consular courts in British protectorates, with jurisdiction over British subjects. This led to a situation of ambiguity, as these courts could not try Africans, who were expected to be tried under customary laws under native chiefs. See Timothy Kiel Barnekov, "An Inquiry into the Development of Native Administration in Nyasaland, 1888-1939." (Master's Thesis, Department of Political Science, San Jose State College, June 1967), 36-39. See also 'The British Central Africa Order-in-Council 1902,' (Published in British Central Africa Gazette, $31^{\text {st }}$ October 1902).

78 “The Askari Troubles: Official Inquiry," The Central African Times, November 15 1902.

79 Ibid.
} 
An Anguru (Lomwe) woman called Salima also gave her testimony to the Inquiry. She said she remembered when the Askari came to Che Nsomba's village. She was sleeping alone in her hut at the time. The Askari entered her hut and violated her. Asked if any one asked her permission, she said no. Only one Askari assaulted her, and she was not offered money. She said she tried to resist, but the Askari beat her. He struck her with his hands on the face and head. He wore a red cap. ${ }^{80}$ Another woman, named Tuwenao from Mpemba in Blantyre, said she met many soldiers on the Katunga road. She was in the company of her husband (named Pete) and her husband's brother (named Majowe). It was at the foot of Ntonda Hill. Four of the Askari had, she stated, assaulted her. They were together with a lot of Askari. The witness was carrying nsima (porridge) and chimanga (maize), and the Askari took these items from her. The soldiers seized her, and when her husband and his brother interfered, they were beaten by the soldiers, and ran away. She was held by the soldiers and violated. Four soldiers assaulted her. She saw someone in a machila (stretcher) but did not know who it was. She also saw three white men pass before the assault occurred. There was no white man or Indian with the soldiers when she was assaulted. ${ }^{81}$

In summing up the evidence, Judge Nunan stated that having heard all the evidence presented before him, he was convinced that the matter was a serious one. He however argued that while it was possible to charge the police for the atrocities, the army should not be blamed for the disturbances as reported by the key witnesses. He argued that it was within the army's jurisdiction to look for porters when there was a war within the British Empire with the support of the War Office. While feeling sorry that gardens belonging to some European settlers had been vandalized and plundered by the askari, the judge ordered that they should be given some form of

80 “The Recent Disturbances: Official Inquiry before Judge Nunan,” The Central African Times, November $22^{\text {nd }}, 1902$. ${ }^{81}$ Ibid. 
compensation. On the rape allegations, the judge adopted "a blame the victim approach" when he ruled that there was lack of medical evidence, including "laughing the cases out of court" due to lack of permissible evidence. He also laughed off allegations that the Askari could rape the women in the presence of other people and called it "an insult to intelligence". Judge Nunan also questioned the morality of some of the local women, especially Yao women, who he deemed to be unfaithful to their spouses. Of all the policemen accused in these cases, only five were deemed to have cases to answer due to permissible evidence on the rape charges of women and young $\operatorname{girls.~}^{82}$

One can thus clearly see that the delivery of justice at that stage was a "racial-determined" process, in which the Africans, supposedly belonging to an "inferior race," no matter how clear-cut and water tight his/her cases might have been, it was often impossible for them to implicate the colonizer, of an "upper class," and his allies (the African and European askari), who were always given the benefit of doubt by the justice system. The judgment also reflected that the judicial system was part and parcel of a wider system of the domination and subjugation of the Africans by the colonizers and provided a justification of the violence which was meted out on the Africans. Furthermore, the judgment also sent a clear message that the colonial state was not going to tolerate African resistance, in this case, focusing on the resistance to provide labor for state activities. ${ }^{83} \mathrm{In}$ the process, as argued by Martin J. Weiner, the racial-influenced administration of justice also

\footnotetext{
${ }^{82}$ Ibid.

${ }^{83}$ See for instance, Stacey Hynd, "Law, violence and penal reform: state responses to crime and disorder in colonial Malawi, 1900-1959," Journal of Southern African Studies 37, no.3 (Sept. 2011): 433-437. Elsewhere in the British Empire, similar trends of racial-based application of the law were also a common occurrence. See for instance, Elizabeth Kolsky, Colonial Justice in British India: white violence and the rule of law (Cambridge: Cambridge University Press, 2010). See also Martin J. Weiner, An Empire on Trial: race, murder, and justice under British rule, 1870-1935 (Cambridge: Cambridge University Press, 2009). Both Kolsky and Weiner emphasize that the administration of justice in the Empire was often determined by the race of the accused person(s), in many cases favoring the British personnel, both settlers and government officials.
} 
represented one of the contradictions of British colonial rule. This was so because it often undermined the notions of the "civilizing mission," as the colonial project depended upon the subordination of the colonized peoples for the benefit of the small ruling British elite. It also undermined efforts to apply English law across the empire, with its insistence on the equality of individuals under the law, and that all could claim protection under the same. Instead of receiving protection from the law, the colonized were often taken to court rooms, which often served as “arenas" of their subjugation. ${ }^{84}$

Furthermore, to divert the attention of the case from focusing on the plight of the victims, Judge Nunan summoned the proprietor of The Central African Times (Mr. Robert S. Hynde) and the newspaper's editor and publisher (Mr. Harold A.S. Rutherford), to appear before the High Court in Blantyre. They were charged with being in contempt of court for statements made on $8^{\text {th }}$ and $15^{\text {th }}$ November 1902: firstly, that the said weekly newspaper willfully and maliciously misrepresented the evidence presented in the High Court, concerning the charges brought against the army and the police of BCA; secondly, they were also accused of deliberately, willfully, falsely, and maliciously suppressing important portions of the evidence and proceedings in the inquiry; and lastly, that they willfully, falsely, and maliciously published an article in the newspaper, which had falsely quoted the Judge (Judge Nunan) as having stated that a "Reign of Terror" had been produced by the conscription of carriers, which was contrary to the evidence the court had gathered.

Responding to the accusations, Mr. Hynde denied all the charges. He stated that it was impossible for the newspaper to publish the report of the inquiry verbatim, and hence the need for the reporters

\footnotetext{
${ }^{84}$ Weiner, An Empire on Trial, 1-19. Weiner's book used case studies from India, Fiji, Kenya, British Honduras, and Queensland. See also Iza Hussein, "Circulations of law: colonial precedents, contemporary questions," Onati SocioLegal Series 2, no.7 (2012): 18-32.
} 
to summarize some of the evidence presented in the court. In mitigation, he also mentioned that the newspaper had been unable to get a good shorthand writer, as the regular reporter had been absent for some time. As such, the current reporter was only hinting on some important pieces of evidence presented. Mr. Hynde also committed his newspaper to publish a statement in full of the omitted items in the next issue. He also stressed that there was no deliberate malice on the omissions and that no evidence was tampered with. Taking his turn, Mr. Rutherford argued that it was impossible to publish a full report because of the limitations of space and time. About the charge of willfully and maliciously omitting certain portions of the evidence, this was assuredly not the case. He stated that there was no malice in any article, paragraph, or report, which had appeared in the paper.

However, the judge insisted that the two gentlemen were in the wrong, stating that the newspaper articles had been carefully doctored. He thus proceeded to pass the sentence, and fined both gentlemen the sum of $£ 10$ each. Mr. Hynde was ordered to find surety of $£ 250$ for his good behavior, and Mr. Rutherford to find surety of $£ 100$ for good behavior. The judge also demanded that an apology in a prescribed form, which the judge read in court, be inserted in the next issue of the newspaper, and that failing to comply with these orders would lead to their imprisonment. The prescribed apology read as follows:

My Lord, we, Harold A.S. Rutherford, editor and publisher, and Robert Spence Hynde, proprietor of The Central African Times, desire to express our sincere regrets that the report of the inquiry of the High Court into the recent Askari troubles, published in The Central African Times of $8^{\text {th }}$ and $15^{\text {th }}$ November 1902, respectively, which of necessity had to be curtailed owing to limitations of space and time, omitted to publish some portions of the evidence which, in the opinion of the High Court, were essential to the case, and we tender our apologies.

(sgd) Harold A.S. Rutherford. (sgd) R.S. Hynde. ${ }^{85}$

85 “The Recent Disturbances: Official Inquiry before Judge Nunan," The Central African Times, November $22^{\text {nd }}, 1902$. Note that Mr. R.S. Hynde's association with Nyasaland started as far back as 1888, when he came to the Protectorate 
As already alluded to, the Somaliland expedition ended up being costly to the British imperial government, both in terms of human and material resources. The war itself ended in 1904, when the empire's forces were able to defeat the Mad Mullah. The First Brigade was led by LieutenantColonel Manning; the Second Brigade was under Lieutenant-Colonel Fasken; and another contingent was under Major Kenna - making a total strength of 2,200 regulars. These troops surrounded the enemy forces and inflicted the biggest defeat for the Mad Mullah, who himself escaped to a distance where he was unable to make further resistance. 300 of the Mad Mullah's troops were killed by Sikh soldiers; while Major Kenna's regiment is said to have killed about 600 of the fleeing followers of the Mullah. The imperial troops also managed to imprison about 215 followers of the Mad Mullah. In total, the number of enemies killed was estimated to have exceeded $1,200{ }^{86}$ Nyasaland itself paid a heavy price in terms of the total number of casualties suffered. Combined figures from the First and Second Battalions were as follows: British Officers killed totaled 13; while Nyasaland soldiers killed in the fighting totaled 208. Special mention was made of the action at a place called Gamburru, where in one day, seven British Officers and 118 African soldiers from Nyasaland (of the Second Battalion of the Kings African Rifles) were killed in action, besides the killing of over 50 Sikh soldiers and many others. ${ }^{87}$

In 1907, another notable form of "traditional resistance" to colonial rule occurred in response to the imposition of the hut tax and the demands it put on native labor resources. In April of that year, a Chikunda prophetess, known as Chanjiri appeared on the southern Nyasaland and Portuguese

as a mission teacher. Soon afterwards he ventured into coffee and tobacco plantation in the Shire Highlands. In 1895 , he founded the Protectorate's first newspaper called The Central African Planter, which became The Central African Times in 1897. He also served in several prominent positions including as managing director of the Blantyre and East Africa Company and as leader of the Chamber of Agriculture and Commerce. See Robert B. Boeder, Alfred Sharpe of Nyasaland (Blantyre, Malawi: Society of Malawi, 1980), 76.

86 "Somaliland: The British Victory," The Central African Times, February 27 $7^{\text {th }} 1904$.

87 "The Kings African Rifles: Memorial to Officers and men killed in Somaliland," The Central African Times, March $14^{\text {th }}, 1908$. 
East Africa (now Mozambique) border and preached that the Europeans would leave the country by the end of the year and that no more hut taxes needed to be paid to the colonial government. The appearance of Chanjiri also coincided with the explosion of a meteor in the same area, and the prophetess claimed to have miraculous powers, and to have appeared or been sent from heaven. Although her teachings spread across the Protectorate and indeed began to command a large following, the colonial government authorities did not immediately take her seriously until they discovered that the local tax returns showed a total shortage of $£ 3,000$. The official concern also increased when it was learned that the Prophetess had also gained followers amongst several Yao chiefs, who refused to collect taxes on behalf of the state. Many Africans also visited her with tribute, and returned with promises of abundant harvests, and stories pointing to the downfall of the dominant race (i.e. the European colonists). The Nyasaland government then "tactfully dealt with that passive resistance" by sending its spies and asked the Portuguese authorities to remove the woman from the vicinity of the British frontier and the prophetess was also warned about her future conduct. ${ }^{88}$

\section{The Threat from Religious Zealots}

By the early twentieth century, the British colonists in Nyasaland and beyond also expressed concerns about the 'threat' posed by two religious movements present in the protectorate, known as 'Mohammedanism' (associated with Islam) and The Ethiopian Movement (associated with Christianity). The Central African Times carried several articles to warn both the colonial authorities and the missionaries about the threat posed by these movements.

\footnotetext{
${ }^{88}$ Tangri, "The Development of Modern African Politics, 71-72. See also Annual Report, Nyasaland Protectorate: Report for 1907-08 (London: HMSO, September 1908), 22. The notion of "passive resistance" is used here to differentiate from "active resistance" which involved physical fighting between the colonizer and the colonized.
} 
The 'Mohammedan Movement" ${ }^{89}$ (named after followers of Prophet Mohammad) was an Islamic missionary movement which by then was sweeping across most of sub-Saharan Africa. The movement itself had its origins in 1837, when an Algerian jurisconsult, named Sidi Mohammed ibn Ali as Sanusi, established a religious society with the object of reforming Islam in North Africa, and purifying it of the practices that were still being observed by some of the ethnic groups. Sanusi was able to establish a theocratic state without the shedding of a single drop of blood, and on his death in 1859 , he left a brotherhood of enthusiasts to continue the work to which he had devoted his life. The worry for most of the colonial states, including that of Nyasaland, in the nineteenth and twentieth centuries was with the rapid spread of the movement and Islam in general, especially as it had followers in areas where Christian missionaries had penetrated. The followers of Sanusi were building schools and prayer houses to train African youth in the teachings of Sanusi and to turn them away from Western civilization..$^{90}$

Due to these threats, the European settler community in Nyasaland raised the alarm bells, by, among other things, calling on the Nyasaland government to work together with the Christian missionaries to block the spread of Islam. The settlers highlighted that Islam was a foreign religion and that it had strong associations with the slave trade. One notable commentary in the Central African Times read as follows:

\footnotetext{
${ }^{89}$ The notion of "Mohammedan Movement" as used in this study adopts the terminology that was used by European, especially British, colonists in $19^{\text {th }}$ and $20^{\text {th }}$ century Africa. This should have rather been called the "Islamic faith." The British colonists often connected the spread of Islam with the perseverance of slavery, despotism, and disorderliness in Africa. See Jonathan Reynolds, "Good and Bad Muslims: Islam and Indirect Rule in northern Nigeria," International Journal of African Historical Studies 34, no.3 (2001): 601-605. It was also in northern Nigeria where early forms of religious-influenced resistance to colonial rule emerged at the beginning of the $20^{\text {th }}$ century. See Paul E. Lovejoy and J.S. Hogendorn, "Revolutionary Mahdism and Resistance to colonial rule in the Sokoto Caliphate, 1905-6," Journal of African History 31, no.2 (1990): 217-244.

90 "Mohammedanism: Its Spread in Central Africa," The Central African Times, March 23 ${ }^{\text {rd }}$, 1907. For a study of the spread of Islam in the area that is now Malawi, see Edward Alpers, "East Central Africa," in Nehemiah Levtzion and Randall L. Pouwels, eds., The History of Islam in Africa (Athens, OH: Ohio University Press, 2000), 303-325.
} 
No one, we think, would criticize the Government of this country if they discountenanced the religion of Islam, which has done so much harm to the people of Africa. When we see, however, that the Government precludes Christian proselytizing in Mohammedan centers without first referring the matter to the people of the villages, it seems a strange anomaly. So far as we are aware, there is nothing to hinder Mohammedans about so-called Christian villages or centers of Christian influence, and carrying on their propaganda, but the Christian missionaries are required to obtain permission before invading Mohammedan centers. This position merely requires to be stated to show its absurdity. When this country was taken over by Great Britain it was hoped that there would be the greatest scope given to the Christian missions, and in fact it was partly because of the missions that the country was taken over in the first instance. ${ }^{91}$

The newspaper commentary went on to state that Christianity should not have to compete with Islam and 'Mohammedanism' in the country. It stated that Christianity should be estimated and regarded as a "moral policeman," and that if the people in the country adopted Christianity as their religion, the gains would be immense, especially because the religion would assist the natives to be more law-abiding, and that if the natives were to identify with the religion of their rulers, it could help prevent native insurrections. The threat from 'Mohammedanism' was that as a radical movement, it had the potential to inspire the formation of social and democratic brotherhoods, and give power to various tribes, whose combined force would be detrimental to the survival of the colonial state - especially if some new "Madhis" were produced in the protectorate. ${ }^{92}$

\footnotetext{
91 “Commentary,” The Central African Times, July $8^{\text {th }}, 1905$.

92 Ibid. In colonial era East Africa, Muslims also faced the fate of being sidelined during the colonial period, hence the use of such derogatory terms as 'Mohammedanism.' Colonial governments in the region preferred to work with Christian missionaries and sidelined Islamic leaders and followers. See for instance, Abdulaziz Y. Lodhi, "Muslims in Eastern Africa - their past and present," Nordic Journal of African Studies 3, no.1 (1994): 89-90. The picture was somehow different in other parts of colonial Africa. For instance, in parts of French West Africa, some colonial administrators enacted policies, especially at the beginning of the $20^{\text {th }}$ century, that incorporated more Muslims in states structures. The Muslims served as chiefs, interpreters (from French to Arabic and local languages, and vice versa), clerks, and school teachers. There were also cases where Islamic law could continue operating in settling colonial era disputes. In the early years of contact, the French colonists regarded Islamic culture as lagging behind Western civilization, and slightly advanced than sub-Saharan African cultural practices. See Donal Cruise O'Brien, "Towards and 'Islamic Policy' in French West Africa, 1854-1914," Journal of African History 8, no.2 (1967): 303310. See also Jean-Louis Triaud, "Islam in Africa under French colonial rule," in Nehemiah Levtzion and Randall L. Pouwels, eds., The History of Islam in Africa (Athens, OH: Ohio University Press, 2000), 169-172. The use of local Islamic chiefs also served the British under their policy of Indirect Rule in northern Nigeria, especially in the area that
} 
Another British settler, by the name J.J. Reynard, also raised these issues, in an open letter addressed to the colonial authorities. He warned that the Islamic faith had been gaining adherents throughout the Nyasa-Tanganyika region through the work of Swahili slave traders. He highlighted that although the slave trade had been significantly suppressed by European colonial rule in Central Africa, it still left behind a legacy of Islamic 'fundamentalism' which could challenge the spread of Christianity and the stability of the colonial state. Part of his letter, which summed up the general feeling of the European settlers in the Protectorate, read as follows: "the regeneration of Africa will be accomplished by the official, missionary, and trader, who are inculcating by precept and example the blessings of civilization that we have acquired after centuries of Christian teaching. The Crescent will always have its followers, but the Cross will remain supreme wherever the Caucasian predominates." 93

It also became clear that the colonial authorities were getting increasingly concerned about the threat posed by the spread of Islam and this was highlighted in the Colonial Annual Report for Nyasaland for 1906-07: "A "bastard" form of "Mohammedanism" is likewise pervading the masses. This growth has been very remarkable within the last few years; and in most villages in the Shire Highlands will be found a small hut, which is used as a mosque, and the monotonous tones of the worshippers reading from the Koran is not an infrequent feature of village life in the southern portion of the protectorate. At present the native has a most cloudy and indefinite idea of the religion which he thus attempts to follow, but there is no doubt that "Mohammedanism" has

\footnotetext{
was the Sokoto Caliphate, established by Usman dan Fodio's jihad of the early $19^{\text {th }}$ century. This was despite the fact that, as in Nyasaland, the British colonial authorities often had a negative attitude towards the spread of Islam. See Reynolds, "Good and Bad Muslims: Islam and Indirect Rule in northern Nigeria," 601-605.

93 "Mohammedanism in Central Africa," The Central African Times, June 23 $3^{\text {rd }}, 1906$.
} 
found a permanent home in the country and will in the future compete with Christianity for supremacy amongst the aboriginal population". 94

Lord Lugard, a former colonial official in Nyasaland, also hinted at the threat posed by the spread of Islam including in British-controlled Nyasaland. He noted that the Islamic religion or Muslim rule, which targeted the enforcement of the social regulations of the Quran, had made inroads in tropical Africa for several reasons. For instance, unlike the European centered Christian teachings, Islam incorporated African systems of government, modes of dress, and social observance (social ceremonies), such that it was often hard to distinguish between a peasant or laborer who called themselves a 'Mohammedan' from those who were still regarded as pagans. The main worry for the colonial officials was that in their perception, Islam was a more militant religion, which taught contempt for those not its votaries, and that it took advantage of the perceived weaknesses of the African character to convert Africans to the religion. Furthermore, the other worry was that Africans had been through centuries of lawless strife, making the African, a worshipper of force, something which Islam also encouraged. For instance, the connection between Islam and concubines, and the looting of villages were all associated with the spread of the religion. Africans were also attracted to Islam because the religion sanctioned polygamy, a practice which was "natural" to many African tribes. Islam also approved the institution of domestic slavery, hence holding its leaders responsible for the continuation of slave trade in the continent. Islam's great strength was because it combined a social code with simple religious forms, most of which were interwoven with the daily lives of its followers. The contrast then was that Islam seemed to be a

${ }^{94}$ Great Britain, British Central Africa Protectorate: Report for 1906-07 (London: HMSO, September 1907), 26. 
religion most suited as a religion of the tropics, while on the other hand, Christianity was perceived as a religion of the temperate climatic zones..$^{95}$

Also writing on the threat posed by the "Mohammedan movement," Robert Greenstein hinted that there was a growing concern among the missionary and settler communities of the Nyasaland population during the first quarter of the twentieth-century. These two groups were mainly worried because it seemed as if the colonial government was not doing enough to protect their interests, from the perspective that the government felt that their complaints were merely compounded by religious and economic concerns, rather than being a political threat to the colonial state. Greenstein posited that for many Nyasa subjects, Islam was an attractive option primarily because it was a religion that offered a quick route to the social status achieved by nominal adherence to a religious organization distinct from traditional faith. Africans in Nyasaland had become particularly suspicious of the Europeans and resented the long process required for one to be fully accepted as a Christian. For many, conversion to Islam merely meant the acceptance of circumcision, the imitation of a few rituals and prayers, and the observance of the Ramadan fast. Amongst the Yao peoples, Islam also spread faster and easily because of similarities that existed in initiation ceremonies between the Islamic initiation and circumcision called Jando and the Yao's own version called Lupanda. There was also a materialistic aspect (or profit-oriented aspect) connected with the natives' conversion to Islam, especially for those who were converted and given the responsibilities of becoming Islamic teachers (waalimu). The teachers were charging their students a sum of five shillings, to teach them to read and write in Arabic. That amount was almost double the amount one needed to pay the hut tax. As such, more African men were

\footnotetext{
${ }^{95}$ Lugard, The Dual Mandate in British Tropical Africa, 76-77.
} 
encouraged to enter the Islamic schools, to be trained as waalimu, which was a money-making venture for them. ${ }^{96}$ As was the case with other colonial era relations, by the time of the First World War, especially in the aftermath of the Chilembwe uprising of 1915 (see chapter three), the government had come to a point of trusting the Muslim communities. By 1916, Governor Smith had even suggested and appealed, without success, to the Colonial Office, for the Muslims in the protectorate to be granted more autonomy in their religious and educational affairs. The suggestion was rejected at Colonial Office because of fears that the suggestion, if adopted, would have angered the Christian missionaries in the protectorate. However, the Nyasaland government persisted by trying to be 'impartial' in its dealings with the Muslim communities from then onwards, a policy direction which allowed for the growth and spread of Islam in the protectorate. ${ }^{97}$

The Ethiopian Movement, which had a connection to Christianity, had its adherents among European and African religious leaders, who were propagating the concept of "Africa for Africans" mainly in sub-Saharan Africa. Most of its followers were religious leaders who had broken away from the European and American mission stations then operating in colonial Africa. By the early twentieth century, the movement already had a significant following in South Africa, Southern Rhodesia, Portuguese East Africa, South West Africa, Uganda, and the Central African Protectorate (and it would later significantly influence the Chilembwe Uprising of 1915 in Nyasaland). The movement taught Africans that the Europeans had grabbed their countries from their rightful owners, which caused resentment about paying hut and poll taxes. It also taught

\footnotetext{
${ }^{96}$ Robert Greenstein, "The Nyasaland Government's Policy Towards African Muslims, 1900 - '25," In Roderick J. Macdonald, ed., From Nyasaland to Malawi: Studies in Colonial History (Nairobi: East African Publishing House, 1975), 146-148.

${ }^{97}$ Ibid., 164-168.
} 
Africans to resent the coming of Asians into their territories as this would in the long run deprive them of access to employment. ${ }^{98}$

The colonists often exaggerated the threat posed by the movement to suit their needs, and some of their sentiments could best be summarized as follows:

In Africa, the white man is but a drop in the ocean of humanity. The blacks know this. They believe that if they rose all over the country they could make short work of the Europeans. The sacredness of the duty of ridding the country of whites is what the Ethiopian Movement mainly teaches....If the natives of the colonies - Kaffaria, Rhodesia, Portuguese East Africa, German South West Africa, Uganda, and the Central Africa Protectorate - rose, it would not take the white men and the garrisons now in the country, but the armies of Europe to drive them back.... Nominally we have abolished the witch doctor and the medicine man. It would be more rational for the safety of the country to lay by the heels of the preachers of the Ethiopian doctrine. That is, if it is not too late, for the seed has been sown in every kraal from Table Mountain to Central Africa. The situation is not one to be lightly regarded...."99

George Shepperson and Thomas Price also referred to the threat posed by the Watch Tower Movement led by Elliot Kamwana, as part of the Ethiopian Movement in the protectorate. Elliot Kamwana was trained by Joseph Booth, ${ }^{100}$ whom he met in South Africa in 1907. When Elliot Kamwana returned to Nyasaland in 1908 , he began to draw large crowds, many of whom liked his simple teachings, especially the less time it took for one to be baptized. Kamwana also challenged the payment of the hut tax, which had been increased on multiple occasions in the first decade of the twentieth century, which he also attacked because of its associated demands on native labor.

\footnotetext{
98 “African Natives and The Ethiopian Movement," The Central African Times, March 24 $4^{\text {th }}, 1905$.

${ }^{99}$ Ibid. See also "Commentary on the Ethiopian Movement," The Central African Times, February 16 ${ }^{\text {th }}, 1907$. This later newspaper article (February 16 ${ }^{\text {th }}, 1907$, above) raised the concern that the danger posed by the Ethiopian Movement was that its leaders, both European and Black African were hiding behind the vail of the Christian religion hence were difficult to detect and eradicate. As such, the colonial state had to forge an alliance with the settlers and pro-government missions to eradicate this threat before the movement's adherent engage themselves in disturbing the prevailing atmosphere of law and order.

${ }^{100}$ Joseph Booth was an American missionary. He was responsible for the establishment of several mission stations in Africa, including Nyasaland. The list included the Zambezi Industrial Mission, the Africa Evangelical Mission, the Church of Christ, and the Watchtower Movement. See Harry W. Langworthy III, "Joseph Booth, prophet of radical change in Central and South Africa, 1891-1915," Journal of Religion in Africa 16, no.1 (February 1986): 24.
} 
Africans were often compelled to abandon their gardens at various times of the year to work in European settler enterprises, where they could raise funds to pay taxes. Just like Prophetess Chanjiri, discussed above, Elliot Kamwana preached that a new world order was on its way, prophesying that in October 1914, Jesus Christ would come, and that all Europeans would have to leave the country, and that there would be no more oppression from tax-gatherers. In retaliation, the colonial authorities, with the backing of Christian missionaries, stepped in to silence him. He was imprisoned, and, in June 1909 he was deported to Mauritius. In 1914, he was allowed to return to the Protectorate after the danger posed by his prophecy had passed. ${ }^{101}$ The deportation of Kamwana was made in line with the British Central Africa Order-in-Council of 1902, which under the "Removal and Deportation" section provided for a court and/or custodial sentence to be served outside of a given protectorate or colony, in cases where the convict(s) posed a serious security threat if they had not been deported. ${ }^{102}$

\section{Conclusion}

This chapter has established that the process of colonizing the Nyasaland Protectorate and indeed the establishment of dominance involved brutal tactics employed by the colonists. Uncollaborating chieftaincies (such as that of Makanjira, Chikumbu, Mponda and Chikusi Gomani), and other merchant communities and individuals had to be subdued by using state resources such as the army and the police. In other instance, the legal system was also manipulated in favor of the colonial authorities by applying the "blame the victim approach," such as in the 1902 cases of

${ }^{101}$ George Shepperson and Thomas Price, Independent African: John Chilembwe and the Origins, Setting and Significance of the Nyasaland Native Rising of 1915 (Edinburgh: Edinburgh University Press, 1958), 147-156. On the history of the Jehovah's Witnesses and the Watchtower movement in Nyasaland, see J.R. Hooker, "Witnesses and Watchtower in the Rhodesias and Nyasaland," Journal of African History, 6, no.1 (1965), 91-106.

102 "The British Central Africa Order-in-Council 1902," Published in The British Central Africa Gazette of $31^{\text {st }}$ October 1902. 
raping and violation of African women. The use of the law in favor of the Europeans also undermined the concept of the "civilizing mission," a theme which will be explored further in chapter three. The disagreements and/or altercations, it has been argued, often arose when the colonizer and the colonized were fighting for material resources and political power. Counterinsurgency at this stage was also characterized by the tendency to share information and cooperation between the state and the settler community at large to fight against the threat posed by some 'religious zealots,' such as the "Mohammedan Movement" (Islamic faith) and the Ethiopian Movement, leading to the deportation of some religious leaders. The "threats" which these movements posed were also often exaggerated to suit the needs of the European settlers, many of who were Presbyterian and Protestant. The next chapter focuses on a critical analysis of the notion of the principle of the "civilizing mission" in relation to, or parallel with the land, labor and taxation policies of the colonial state. 


\section{CHAPTER THREE}

\section{THE LAND, LABOR, AND TAXATION NEXUS: WHITHER 'CIVILIZING MISSION’}

Many books have been written about colonialism, apartheid, imperialism, the globalization process, and the forces that have shaped the history of Africa. Some accounts of African history are purely romantic and fanciful, others racist and Eurocentric. The concrete reality of the situation is domination and resistance, which has been the true nexus linking Africa to America and Western Europe. Plunder, domination, and the conversion of able-bodied men and women into desperate laborers have characterized Africa's contact with Western and American civilization. Africa's physical resources and its human beings have been prized raw materials for American and Western European industries and world markets. ${ }^{103}$

\section{Introduction}

This chapter covers the period referred to as the age of "new imperialism," from the late $19^{\text {th }}$ century to the beginning of the First World War, to analyze the land, labor, and taxation policies of the colonial state in Nyasaland. In doing so, it offers an assessment of the "civilizing mission" as it applied to British colonial expansion and rule. The mission was championed by the so-called "liberal imperialists" in British society from the late nineteenth century onwards. That pioneer group included such leaders as Edmund Burke, Henry Maine, and James Mill, whose ideas and works helped to generate political and moral or ethical justifications of imperial rule. They argued that imperialism could only be justified if it helped to improve and civilize the colonized peoples. ${ }^{104}$ I argue that although that principle arose out of genuine concerns for the welfare of

\footnotetext{
103 Azwell Banda, "Foreword," in Leo Zeilig, ed., Class Struggle and Resistance in Africa, 2 $2^{\text {nd }}$ edition (Chicago, IL: Haymarket Books, 2009), ix.

104 Karuna Mantena, “The Crisis of Liberal Imperialism”. In Duncan Bell, ed. Victorian Visions of Global Order (Cambridge: Cambridge University Press, 2007), 113-135. In the late $19^{\text {th }}$ and early $20^{\text {th }}$ centuries, the prominent liberal imperialists included such names as William Gladstone, Joseph Chamberlain, Winston Churchill and Lord Elgin. See Ronald Hyam, Elgin and Churchill at the Colonial Office, 1905-1908 (London: Macmillan, 1968), 36-52. See also M.E. Chamberlain, The scramble for Africa, $3^{\text {rd }}$ edition (London: Longman, 2010), 85-86. See also Paul Knaplund, Gladstone and Britain's Imperial Policy (New York: The Macmillan Company, 1927), 65-82.
} 
Africans in Nyasaland, and other parts of the African continent alike, it was overtaken by events, or the so-called "local and empire-wide constraints." In other words, what appeared more appealing and applicable were the economic motivations that characterized the operations of the colonial state, and more importantly, the relations between the state on one hand, and Africans and European settlers on the other hand. For the period under study, the protectorate was under the stewardship of the following colonial officials: Sir Harry H. Johnston (Consul General and Commissioner, 1891-1896); Alfred Sharpe (Commissioner, 1896-1907, and later Governor from 1907-1910); William H. Manning (Governor, 1911-1913); and George Smith (Governor, 19131923). ${ }^{105}$ The rest of the chapter analyzes the policies of the Nyasaland Protectorate government surrounding the acquisition and allocation of land; the extraction and use of native labor; and the collection of taxes, where the authorities straddled to meet the interests of the state, the European settlers, and the African societies. It also covers the reaction of the colonized peoples in the protectorate, which culminated in the 1915 African uprising led by Rev. John Chilembwe of the Providence Industrial Mission (PIM).

\section{British Imperialism in Context}

As previously discussed in chapter two, the colonization of Nyasaland took place at the end of the $19^{\text {th }}$ century. Studies that have been conducted on the expansion of British imperial influence and control for the late nineteenth century and the early twentieth century have historically been discussed from two main perspectives, namely; the economic perspective and the humanitarian perspective, with its emphasis on colonization as a "civilizing mission." That historical era is often referred to as the "Age of New Imperialism," roughly stretching from the early 1880 s up to the

\footnotetext{
105 David P. Henige, Colonial Governors, from the $15^{\text {th }}$ Century to the Present (Milwaukee: The University of Wisconsin Press, 1970), 155-156.
} 
outbreak of the First World War and its immediate aftermath. ${ }^{106}$ The discussion of the land, labor, and taxation policies of the colonial state in Nyasaland, in this chapter, will revolve around that historical period. In the case of Nyasaland (now Malawi), John McCracken suggests that the two decades following the establishment of colonial rule were the most important for the life span of the protectorate. During that time, the colonial authorities established their territorial dominance through force and laid the foundations that shaped the country's economy for the decades that followed. It was an era characterized by various forms of state and capitalist penetration and exploitation through policies and practices of land alienation, revenue collection, and labor exploitation. $^{107}$

There were also several imperatives, as discussed by Crawford Young, which the colonial states in Africa had to fulfill. Among the imperatives, which form part of this analysis, were those of dominance; revenue; and accumulation. The notion of dominance, as used in this study, which has been covered in chapter two, entailed that the state had to continuously engage in a struggle to ensure its supremacy over the colonized. It ensured that no one was above the law, and often used state resources, including the colonial police, to subdue the Africans. In this chapter, I will highlight how the enactment of taxation measures and the control of African labor was also part and parcel of establishing colonial dominance. Then there was the revenue imperative, which also formed the bedrock of the state. This involved taxing the Africans, where the money was used to pay for goods and services offered in individual colonies. This often involved the struggle between the colonial state and its subjects, where the latter were compelled to contribute to the cost of

\footnotetext{
106 For scholarship in the field of 'New Imperialism', see Alice L. Conklin and Ian Christopher Fletcher, eds., European Imperialism, 1830-1930 (New York: Houghton Mifflin and Company, 1999). See also Timothy H. Parsons, The Rule of Empires: Those who built them, those who endured them, and why they always fall (Oxford: Oxford University Press, 2010).

107 John McCracken, A History of Malawi, 1859-1966 (Great Britain: James Currey, 2012), 74-87.
} 
running the state. Sometimes the state adopted a predatory role, when it forced people to pay taxes, processes which often evoked resistance from the Africans. The state was also compelled to find means and ways of accumulation. This often came in the form of taxation and other economic activities, such as agricultural and industrial production, from which the funds could form the economic base of the colonial state. This imperative was achieved when the state aligned itself to capitalist interests or enterprises in the colonies. ${ }^{108}$ In his study of British colonial rule in Kenya, Bruce Berman also hinted on the central role played by the colonial state in the social and economic livelihoods of the societies it presided over. The state's involvement often came because of conscious and deliberate interventions, which increased steadily with the passage of time, and saw the colonial state play a critical role in the political-economy of colonialism. To a significant extent, the colonial state also served as a dependent superstructure of capitalist development, as it became an instrument of violence and exploitation meted on the indigenous peoples, while at the same time setting up conducive conditions for capitalist accumulation. ${ }^{109}$ The imperatives of revenue and accumulation will form a significant chunk of this chapter's analysis, focusing on the Nyasaland government's involvement in land alienation, taxation, and control of African labor.

Studies that adopt "the economic perspective" and its influence on British imperial expansion include classical works by such scholars as J.A. Hobson (1902) and Thomas Ashcroft (1922), among others. ${ }^{110}$ Thomas Ashcroft explained that the period of "New Imperialism" emanated from

\footnotetext{
${ }^{108}$ Crawford Young, The African colonial state in comparative perspective (New Haven: Yale University Press, 1994), 35-40.

109 See Bruce Berman, Control and Crisis in colonial Kenya: The dialectic of domination (Athens, OH: Ohio University Press, 1990),1-9 and 23-43. Bruce Berman also argues that at a time of the 'articulation' of the capitalist and indigenous modes of production, the colonial state did not entirely play the role of only supporting the capitalist sector, but also straddled to help serve the interests of the indigenous or pre-capitalist sector. In that case, the indigenous sector did not get completely wiped out, as it helped to service the shortfalls of the capitalist sector, especially the low wages that were given to the Africans, which were supplemented by indigenous modes of production.

110 J.A. Hobson, Imperialism: A Study (London: James Nisbert and Co., 1902). See also Thomas Ashcroft. An Outline of Modern Imperialism (London: The Plebs League, 1922).
} 
the internal industrial transformation of the Western European countries, which subsequently stimulated a new period of international relations. The internal contradictions of the capitalist system (including lower wages, lower supplies of raw materials, rising debts, among others), created the need for the overseas expansion of the capitalist class. As the capitalist system of production began, it brought significant profits. But as production began to overflow, it reached a point when the European masses could no longer provide the much-needed market outlet, as many of the workers were replaced by machinery and many were paid lower wages, which led to "underconsumption.” There was thus need for the European businesses to find markets outside of Europe. Such processes also required the "exporters of surplus products" to export human resources, tasked with taking care of machinery, and/or to lay down transport and communication networks - i.e. the notion of "carrying civilization" to the ends of the earth. In the overseas destinations, the pioneer capitalists were also involved in such acts as land alienation, labor exploitation, and natural resource exploitation (the later to feed into European industrial production). In that case, "modern capitalism" moved on from being primarily economic-oriented to a phase of interfering in the political life of the native communities where it spread. The political occupation was meant to safeguard or provide defense for fresh fields of overseas investing of surplus capital from European industries. In Ashcroft's analysis, "imperialism" was a system that was rooted in the exploitation of the masses, both in the metropole and overseas. Eminent British politicians, such as Benjamin Disraeli (Conservative Prime Minister, 1874-1880) and Joseph Chamberlain (Colonial Secretary, 1895-1903) encouraged outward imperial expansion as avenues through which to invest surplus British capital. ${ }^{111}$

\footnotetext{
${ }^{111}$ Ashcroft, An Outline of Modern Imperialism, 1-9 and 12-14. See also P.J. Cain and A.G. Hopkins, "The Political Economy of British Overseas Expansion, 1750-1914," Economic History Review, New Series, 33, no.4 (Nov. 1980): 463-490. Cain and Hopkins also argued that British overseas expansion during this time can best be understood by an analysis of the economic conditions in the metropole that affected the modes and trajectory of overseas expansion.
} 
Building upon these classical studies, there have been studies that have been written by historians of empire, including the British Empire. P.J. Cain and A.G. Hopkins, adopting a similar approach to that of Ashcroft, also argued that British overseas expansion during the time can best be understood by considering how economic and political changes in the metropole affected the direction and trajectory of the expansion. Such studies explain the dynamics of the metropolitan economy as being the main determinants of imperial expansion, where its shortfalls were to be met by establishing overseas colonies. Adopting the political economy approach, they analyzed the economic developments in Britain and policy preferences of the British leaders and how they worked alongside the empire-builders, both private and official. The dynamics of the time included an uncertain and incomplete transition to industry; the threat posed by rival Western powers towards the acquisition of colonies; and the varying interests adopted by interest groups in the metropolitan cities, both state and private. ${ }^{112}$ Similarly, G.N. Sanderson, focusing on European imperial expansion in Africa as a whole, argued that by the late $19^{\text {th }}$ century, when most European countries were in an economic recession, the prospect of owning colonies in the interior of Africa seemed very enticing. It was pounced upon by both politicians and businessmen as a source of raw materials, markets, and an outlet of surplus capital with which to cure the malaise of the ailing European industrial economy. The interior of Africa was an El Dorado with vast, fertile, empty lands "awaiting the magic kiss of European energy, skill and capital." 113

See also Bernard Porter, Critics of empire: British radical attitudes to colonialism, 1895-1914 (New York: Macmillan, 1968), 40-48.

112 P.J. Cain and A.G. Hopkins, "The Political Economy of British Overseas Expansion," 465-466.

${ }^{113}$ G.N. Sanderson, "The European partition of Africa: origins and dynamics," in J.D. Fage and R. Oliver, eds., The Cambridge History of Africa, Vol.6, 1870-1905 (Cambridge: Cambridge University Press, 1985), 101-107. Apart from the economic motives, in the same chapter Sanderson posited that European imperial expansion was also to a significant extent, driven by such motives as "prestige", "strategy" and the "missionary influence". See also G.N. Uzoigwe, "European partition and conquest of Africa: an overview," in A. Adu Boahen, General History of Africa, Vol.7: Africa under colonial domination, 1880-1935 (California: University of California Press, 1985), 19-44. Uzoigwe outlined a number of theories to explain European imperial expansion, including: the economic theory, the psychological theories, the diplomatic theories, and the African dimension theory. 
In the overseas colonies, such economic motives were carried out by various groups of British citizens (of the so-called "capitalist class"), who had the capital to invest in return for profits. Such people migrated across the empire in search of economic opportunities, and often found themselves collaborating with the colonial state in search of opportunities and security. ${ }^{114}$ A.G. Hopkins and P.J. Cain have characterized the economic interests of the capitalist class as "gentlemanly capitalism", influenced by the business networks which they created in the metropole, before they embarked on overseas expansion. This class emerged in British society in the late $17^{\text {th }}$ century, and initially owned huge chunks of land and held commercial interests in the urban areas. With time, the city of London emerged as the hub of their business interests and interactions, where they also adopted elements of progressive and market-oriented ambitions. It was also in London that they took interest in business ventures in such areas as finance, manufacturing, distribution, and service provision. By the $18^{\text {th }}$ century, many of them also had links with leading political figures in Britain. And by the late $19^{\text {th }}$ century and early $20^{\text {th }}$ century, when Britain embarked on expansion into Africa, the capitalists saw it as an opportunity to invest their surplus capital, establish new markets, seek raw materials, and provide services in the overseas colonies. This was thought to provide compensation for the economic downturn they experienced both in Britain and the Americas. Some even ventured into Africa, the so-called "periphery," on mere speculation, receiving backing from some banks and the British government, considering the economic potential which colonization provided. ${ }^{115}$ The subsequent sections of this chapter will illustrate how the relationship between the capitalist class or the "gentlemanly

\footnotetext{
114 Ronald Robinson and John Gallagher, Africa and the Victorians: the climax of imperialism (New York: Anchor Books, 1968), 1-3.

115 P.J. Cain and A.G. Hopkins, British Imperialism, 1688-2015 $3^{\text {rd }}$ edition (London: Routledge, 2016), 149-164. See also P.J. Cain and A.G. Hopkins, "Gentlemanly capitalism and British expansion overseas II: New imperialism, 18501945," Economic History Review 40, no.1 (Feb. 1987): 1-26.
} 
capitalists" and the "administrative mind" (the colonial state) often undermined the "civilizing" aspect of British colonial rule in the Nyasaland Protectorate.

The "civilizing mission" perspective considers European overseas expansion as emanating from a sense of superiority which the Europeans adopted over other races, in heart and brain, and, above all in their political and social institutions. Their morality and religion were also regarded as superior, placing them (Europeans) as "God's chosen peoples." They felt duty-bound to subjugate the rest of the world in order to transfer the blessings of their superior civilization. There was also the view from the leading imperialists that due to the advanced nature of their "character", they were able to achieve commercial and industrial success. In cases where inferior races resisted European intrusion, they were often coerced until they accepted the law of God and of the conquerors. In other words, the imperial enthusiasts were willing to overlook any atrocities associated with British imperial expansion, so long as Britain undertook its duty of serving the colonized peoples. The colonized peoples were regarded as being "fortunate" to have fallen under British control. ${ }^{116}$

Prominent British politicians, including Joseph Chamberlain, were influenced by the "Social Darwinian" conceptualization of racial superiority. It gave the British the impetus to hold on to their existing colonial possessions or to create new territories - on the justification that since they belonged to a superior race, then formal colonization would be used as a "civilizing mission." Such views were similar to the "mission civilisatrice" ideology that influenced French imperial

\footnotetext{
${ }^{116}$ Leonard Woolf, Economic Imperialism (New York: Fertig, 1970), 15-18. See also Robinson and Gallagher, Africa and the Victorians, 1-3. See also Lugard, The Dual Mandate in British Tropical Africa, 617. See also Bernard Porter, Critics of empire: British radical attitudes to colonialism, 1895-1914 (New York: Macmillan, 1968), 48-55.
} 
expansion during the same age. ${ }^{117}$ Chamberlain had strongly-held beliefs that it was "the manifest destiny of his country to be a great colonizing and civilizing power." Britain, in his view, had the obligation to spread the values of her civilization overseas. In Africa, Chamberlain was of the view that the British peoples would help to abolish the slave trade, and create room for uplifting the livelihoods of the indigenous societies - "the duty of the landlord to develop his estate." 118 Chamberlain, among other issues, believed that the superiority of British civilization, justice, law, religion and Christianity were essential to positively transform "backward peoples" - who were allegedly still bound by bitter conflict and were living in ignorance and various forms of underdevelopment. Further, where the backward societies refused to be colonized, some form of brutality and/or trickery was justifiable to bring them under British colonial rule. ${ }^{119}$

A more recent study by Niall Ferguson makes similar claims about the proponents of empire in Victorian Britain, both missionaries and capitalists, who looked at African indigenous cultures as primitive, and that it was the duty of the imperialists to expand their civilization to such "backward" societies. The "civilization" was meant to include elements of "legitimate commerce"

\footnotetext{
117 William L. Strauss, Joseph Chamberlain and the Theory of Imperialism (Washington DC: American Council on Public Affairs, 1942), 10-12. One other influential politician of the liberal movement was Edmund Burke. To see his ideas on British imperialism, see Jennifer Pitts, A Turn to Empire: The rise of imperial liberalism in Britain and France (Princeton, NJ: Princeton University Press, 2005), 59-71. See also Peter J. Cain, "Character, 'ordered liberty', and the mission to civilize: British moral justification of Empire, 1870-1914," The Journal of Imperial and Commonwealth History, 40, no.4 (Nov. 2012): 557-578. See also D.M. Schreuder, "The cultural factor in Victorian imperialism: a case study of the British 'civilizing mission'," The Journal of Imperial and Commonwealth History, 4, no.3 (1976): 283-317.

${ }^{118}$ William L. Strauss, 60-65. See also Robert V. Kubicek, The Administration of Imperialism: Joseph Chamberlain at the Colonial Office (Durham, NC: Duke University Press, 1969), 68. See also Joseph M. Hodge, Triumph of the Expert: Agrarian Doctrines of Development and the Legacies of British Colonialism (Athens, OH: Ohio University Press, 2007),22-23. Hodge argued that Chamberlain's intervention was based on what was called the "imperial estates program", or "constructive imperialism", where the British government would take a leading role in the development of the colonies, rather than simply leave imperial expansion as the responsibility of the capitalist class. See also Alice L. Conklin, A Mission to Civilize: The Republican Idea of Empire in France and West Africa, 1895-1930 (Stanford, CA: Stanford University Press, 1997), 11-37. In Portuguese colonial Africa, the principle of "civilizing mission" was also a driving factor towards imperial expansion and rule. See Miguel Bandeira Jeronimo, The 'civilizing mission' of Portuguese colonialism, 1870-1930 (New York: Palgrave Macmillan, 2015).

${ }^{119}$ Ibid., 68-83 and 97-130. See also Lawrence James, Empires in the Sun: The Struggle for the Mastery of Africa. (New York: Pegasus Press, 2017), 3-140.
} 
and Christianity. The major contradiction with that school of thought, as argued by Ferguson, had been the "contamination" of the "civilizing mission" with "conquest" and its associated use of force, exploitation, and political domination designed to bolster Britain's control of global trade and politics, which negated the notion of "civilization." ${ }^{120}$ In the same vein, Aime Cesaire also questioned whether the Europeans had a "civilization" at all which they could spread to others. For Cesaire, the Europeans had failed to solve their own internal economic and social problems, including how to deal with the challenge of the rise of the proletarian class. They transferred their problems to the overseas colonies and used elements of trickery and deceit to access and exploit resources and colonize others. He also argued that it is utterly impossible to equate the process of colonization with the spread of civilization since all forms of colonization were devoid of human value. Rather, living under colonial rule meant being subjected to forced labor, punitive taxation measures, being dehumanized and degraded, denied justice, and losing personal property and natural resources, especially land. ${ }^{121}$

When British colonial rule was established in Nyasaland, it was the view of the colonial authorities that they had colonized uncivilized communities. The Africans were described as organized into family, "tribal" and village societies that were mostly primitive. It was thus the duty of the already civilized Britons to destroy the power of the "tribes" (ethnic groups) and guide them towards more advanced forms of government. The new form of government would help maintain law and order, by among other things ending the slave trade and inter-ethnic warfare. This would then make the colonial process a beneficial one to both the colonizer and the colonized. ${ }^{122}$ It is this school of thought, i.e. the "civilizing mission" school, that I intend to analyze further in this chapter. In doing

\footnotetext{
${ }^{120}$ Niall Ferguson, Empire: The Rise and Demise of the British World Order and the Lessons for Global Power (New York: Basic Books, 2002), 93-136 and 185-244.

${ }^{121}$ Aime Cesaire, Discourse on Colonialism (New York: Monthly Review Press, 1972), 31-46.

${ }^{122}$ Hector L. Duff, Nyasaland under the Foreign Office (London: George Bell and Sons, 1906), 187-199.
} 
so, I will argue that although the motives to bring about "civilization" might have driven the British into Nyasaland, they were soon overtaken by realities on the ground, including the reactions of the Africans and the availability of land, revenue and labor. These factors are often overlooked in imperial histories by sensationalist narratives. ${ }^{123}$

While there have emerged more recent works challenging the notion of the civilizing mission, such as those by Niall Ferguson and Alice Conklin as cited above, I concur with the work of Anne Phillips, who argued that British colonial rule in Africa tended to be more of a "makeshift settlement." British colonial rule in Africa was significantly ad-hoc and characterized by a lot of inconsistencies, and probably explains why it could not summarily transform African societies. This includes their political and socio-economic modes of organization, including the failure to completely eradicate the peasant mode of production. While the colonial experience had some positive aspects (as argued by the empire's apologetics), there were also elements of colonial exploitation of the African subjects. British colonial rule was implemented and operated through various constraints, both local and empire-wide, which then affected the way policies were formulated. This for instance saw the colonial state straddle to create alliances with European capitalists, and in other instances worked with African chiefs and their communities. ${ }^{124}$ In the process, it was often impossible to implement the principles of the "civilizing mission." I use and adopt Phillip's analysis to argue that in Nyasaland, the policies introduced by the colonial state in the Protectorate were in significant measures influenced by the conditions on the ground, and in significant measure due to the reactions of the Africans. This often undermined some of the assumptions which the British colonists had when they embarked into imperial expansion into

\footnotetext{
${ }^{123}$ For instance, see Griff Jones, Britain and Nyasaland: A Story of Inattention, Fitful care, Political Vacillation (London: George Allen and Unwin Ltd, 1964).

${ }^{124}$ Anne Phillips, The Enigma of Colonialism: British Policy in West Africa (London: James Currey, 1989), 1-14.
} 
what became the Nyasaland Protectorate. In the long run, those that held the "civilizing mission" perspective to heart, could not curb the negative excesses associated with British imperial expansion.

\section{The Colonial State and Land Policy Formulation}

The question of acquisition of "native-owned" land and imperial expansion has long historical roots, which many scholars have traced to European imperial expansion in the Western Hemisphere. According to Camila Boisen, the Europeans relied on the principle of Terra Nullius to justify their settlement and land appropriation from Native American communities from the sixteenth century onwards. The concept of Terra Nullius had its origins in Roman Law and referred to 'land belonging to no one or unoccupied or empty land,' in describing a territory not subject to sovereignty or ownership by any state. The indigenous peoples were regarded as stateless, and hence could not exercise property rights. The Europeans argued that what they took had been "waste" and under-cultivated land and were even prepared to use warfare where there was resistance by the indigenous peoples. The Europeans also argued that it had been their God-given right and duty to make the under-used land become productive for their own benefit and indeed for the indigenous peoples. The indigenous people had failed in their moral duty to flourish by under-utilizing the natural resources, and hence needed a more advanced society to help them transit towards prosperity and civilization. ${ }^{125}$

By the late eighteenth and throughout the nineteenth centuries, when European empires spread across Asia and Africa, such ideas found their home in the "principle of trusteeship." Trusteeship was based on the notion that Europeans had the God-given responsibility and duty to hold land in

\footnotetext{
${ }^{125}$ Camilla Boisen, "The Changing Moral Justification of Empire: From the Right to Colonize to the Obligation to Civilize," History of European Ideas 39, no.3 (2013): 337-341.
} 
trust for the indigenous peoples, until they had reached a stage of civilization at which they could earn the right of self-determination. Just like, Terra Nullius, the principle of trusteeship had its foundations in the moral justification for the appropriation of native land. Both principles were embedded in the concept of the civilizing mission, which recognized that in the long run the indigenous people would be given rights to own property, especially land. However, it was the moral duty of the Europeans to act as guardians of the land when colonization was in place. ${ }^{126}$ In British society, "Trusteeship" was imbedded in the 'humanitarian movement,' which centered its early attacks on slavery and all forms of human misery, including that caused by colonial exploitation and oppression. It consisted of people from all walks of life, including politicians, academics, explorers, and philanthropists, among others. The politician Edmund Burke, and the missionary and explorer, David Livingstone, were some of the movement's early proponents. They called for the commercial development of the colonies which would in the process help to improve the welfare of the indigenous peoples. ${ }^{127}$

The acquisition of land by British settlers in Nyasaland started "innocently" enough. It was the Christian missionaries who first began to acquire land from the mid-nineteenth century onwards. The early missionary societies went to Nyasaland following the reports and invitation of the British explorer and missionary, David Livingstone, who had hoped to replace slavery and the slave trade in the region with both legitimate commerce and Christianity. ${ }^{128}$ The missionary societies that heeded his call, such as the Universities Mission to Central Africa (UMCA) and the Church of

\footnotetext{
126 Ibid., 343-345.

127 British Information Services, "Britain and Trusteeship". Pamphlet published in 1946. Edmund Burke and other leading figures of the movement, such as Henry Maine and James Mill, belonged to the group of 'Liberal Imperialists', who helped to generate political and moral or ethical justifications of imperial rule. They argued that imperialism could only be justified if it helped to improve and civilize the colonized peoples. See Mantena, "The Crisis of Liberal Imperialism," 113-135.

128 John McCracken, A History of Malawi, pp.38-46. See also Alfred Sharpe, "The Geography and Economic Development of British Central Africa," The Geographical Journal 39, no.1 (Jan. 1912): 1-17.
} 
Scotland, argued that to raise the livelihoods of the Africans in Nyasaland, they needed to have access to lands of their own, where they could establish mission stations to grow food, conduct experiments, and work out the commercial viability of the country. Many of them were warmly welcomed by the local authorities, who agreed to give up some portions of their land in return for security, prestige, and other material benefits, such as guns, blankets, and clothing. Some local chiefs, such as Chief Kapeni, granted land to the Blantyre Mission to establish their mission site. The land in question was a dilapidated African village whose inhabitants had left running away from attacks by the Ngoni. Similarly, the Tonga people of present-day Nkhata-Bay District, welcomed the establishment of the Livingstonia Mission at Bandawe, under Robert Laws, in the hope that the missionaries would help provide security against persistent Ngoni attacks. ${ }^{129}$

However, a series of "unintended consequences" emerged after the Berlin Conference (18841885), when concession-seekers and settlers began to acquire land on an extensive scale from the African chiefs. Representatives of European companies such as the African Lakes Company (ALC) and British South Africa Company (BSAC), and other individual European investors and prospectors, began to entice African chiefs into signing "treaties" which gave up portions of their land. Many of the chiefs, who were illiterate, and not allowed to access all the terms of the treaties they were made to sign, ended up giving away huge portions of their territories, including the rights to land for settlement, cultivation, and mining. The witnesses of the signing ceremony were other Europeans and employees of the companies involved. When formal British rule was established in 1891, many of the chiefs expressed ignorance to the colonial state that they had actually "sold"

\footnotetext{
${ }^{129}$ Bangalore S. Krishnamurthy, "Land and Labor in Nyasaland, 1891-1914,” (PhD Diss., London University, 1964), 63-66.
} 
their land to the European capitalists. Many of them had also been duped into believing that some of the companies had been sent to do business under the authority of the British Government. ${ }^{130}$

When Harry H. Johnston became the Consul General and later Commissioner, he immediately realized that some of the European settlers harbored motives to exploit the indigenous people, and that many of them had dubiously acquired the lands they claimed to legally hold. He noted that many of them were less interested in uplifting the welfare of the indigenous people. It was out of that distrust for the European settlers, especially the planters, that in early 1892, the Commissioner instituted the process of inspecting all portions of land that had been claimed by the European settlers. The lands fell into two categories: claims to mineral rights and claims to land with or without mineral rights. During the process of land claims inspection, the commission tasked to do the job investigated the treaties that were claimed to have been signed by the African chiefs and the European settlers to determine whether a reasonable amount of compensation had been paid to the chiefs. And in cases where "insufficient" money had been paid, the European settlers were often required to pay an extra amount. The claims of land ownership by the European settlers were often confirmed or backed by either long-term occupation and improvements made on the land (such as cultivation and construction of buildings). Thereafter, after official confirmation, the Commissioner would issue a "Certificate of Claim" for the "legally" acquired portion of land. A "non-disturbance clause" was also inserted in the Certificate to ensure that Africans resident on the newly purchased lands were not haphazardly evacuated without the consent of the government. In most cases, the extra payments made by these settlers were as little as three pence for an acre, being the maximum price, one had to pay, especially in the Shire Highlands area which was

${ }^{130}$ Ibid., 66-70. See also Steven Press, Rogue Empires: Contracts and Conmen in Europe's Scramble for Africa (Cambridge, MA: Harvard University Press, 2017). 
favored by most of the settlers due to the cooler climatic conditions. In other outlying areas, the price paid to purchase portions of land was as low as a half penny per acre. ${ }^{131}$

Johnston embarked on that process, because, from his own words, he did not trust the transactions of the European settlers. He considered them as crooks who had come to Africa to exploit the Africans. In his description of the Europeans settlers in the Protectorate, Johnston often argued that they "comprised of decent young men, most of whom possessed a small capital, and had a desire to embark on a life which shall combine a profitable investment for their money, with no great need for elaborate technical education, and an open air life in a wild country with plenty of good sport, and a few or none of the restraints of civilization." He went on to argue that many of them had come to Nyasaland in search of cheap land and cheap labor. And that because of their exploitative motives, he warned that in no way should they be given powers to govern the Protectorate. ${ }^{132}$ In Johnston's words, he described the European settlers in the Protectorate as follows:

It sometimes seems to me that the bulk of these sturdy pioneers (excellent though the results of their work have been in developing the resources of the country) would, if allowed to govern this land, in their own way, use their power too selfishly in the interests of the white man. This I find to be the tendency everywhere the governing white men are not wholly disinterested, are not, that is to say paid to see fair play. From time to time, a planter rises to object to the natives being allowed to plant coffee, in case they should come into competition with him, or urges the Administration to use its power despotically to compel a black man to work for wages whether he will or not.

The ideal of the average European trader and planter in Tropical Africa would be a country where the black millions toil unremittingly for the benefit of the white man. They would see that the negroes were well fed and not treated with harshness, but anything like free will as to whether they went to work or not, or any attempt at

\footnotetext{
${ }^{131}$ Harry Hamilton Johnston, British Central Africa: An Attempt to Give Some Account of a Portion of the Territories under British Influence North of the Zambezi (New York: Edward Arnold, 1897), 112-113. See also FO: Confidential File No. 6502: 'Memo by Sir C. Hill on British Central Africa Land Claims'. July 28 ${ }^{\text {th }}$, 1894. See pp.33-36. Library of Congress. See also "Memorandum on Land Claims in the British Central Africa Protectorate, August 1893," pp.14. Adopted from FO 881/6383, Confidential File No.6383. Library of Congress.

132 Johnston, British Central Africa, 160 and 183.
} 
competing with the white man about education, or skilled labor would not be tolerated. $^{133}$

By the end of 1893, the Johnston administration had settled all the land claims and developed a new land policy which, though of dubious legality, laid down a pattern for the future development of the Protectorate. Under the new measures, the Commissioner stated that he would produce a "Certificate of Claim" only if he was satisfied with certain points, the criteria for which were summarized as follows: (1) Had the seller the right to sell? (2) Was there another claimant? (3) Was a reasonable price paid? (4) Was the claim a monopoly in the area? (5) Had the seller understood what he was doing? (6) Were there safeguards for the people living on the land in question? Andrew Ross argued that out of these guiding questions, question number one to five were the crux of the matter from the African point of view, especially because in "customary" (traditional) law and custom, chiefs did not have the right to dispose of land. In addition, it was doubtful if the concept of selling land was one known to the chiefs involved. Most of the chiefs, being illiterate, never thought that they were completely selling off the land. Rather they thought they were simply leasing it to the Europeans - and that the land would be returned to them (the chiefs) in years to come. ${ }^{134}$ By the end of the process of verifying the land ownership claims, a total of 66 Certificates of Claim had been registered, 59 of which had land rights, while seven had mineral rights, covering an area of 3,705,255 acres out of a total landholding of 25,161,924 acres. That meant that $15 \%$ of the total land area had been alienated for the European settlers. In the favored Shire Highlands, the European settlers took the finest arable lands (about 867,000 acres),

\footnotetext{
${ }^{133}$ Ibid., 183.

134 Andrew C. Ross, "The Blantyre Mission and the Problems of Land and Labor, 1891-1915," In Roderick J. Macdonald, ed., From Nyasaland to Malawi: Studies in Colonial History (Nairobi: East African Publishing House, 1975), 88-89.
} 
most of which was also densely populated by the indigenous peoples - thereby creating an acute problem over access to land for cultivation. ${ }^{135}$

Commissioner Johnston himself also oversaw the signing of dubious treaties with some African chiefs. He 'coaxed' the chiefs to sign treaties that saw them give away their land, offered to pay taxes, and to place their peoples under the authority of H.M. Government. The treaties in question appeared in the following format:

\section{Liwonde's Deed of Cession of Sovereign Rights, November 13, 1891}

I, LIWONDE, a Chief on the Upper Shire, do hereby cede to Her Majesty the Queen of Great Britain and Ireland, Empress of India, the full sovereign rights of my country.

I agree to the entire abolition of slavery and promise to aid to the best of my ability the officers of Her Majesty's Government and of the British Central African Administration in their endeavours to stop the transit of slaves across my territories, and to capture persons engaged in the Slave Trade.

I make over without reserve to Her Majesty's Government, or to those to whom Her Majesty may depute her rights, the collection of custom duties and revenue from foreigners, complete jurisdiction over all foreigners, and the right to search and work all minerals in my country. Further, I agree to pay the British Central African Administration an annual house tax to be computed at the rate of $6 \mathrm{~s}$. per house (or at the value of $6 \mathrm{~s}$. in foodstuffs or marketable products), in return for the protection afforded me by the police force of the Administration.

Given at Karungu, on the Upper Shire, this $13^{\text {th }}$ day of November 1891.

Signed: Liwonde

\section{Witness to signature:}

- H.H. Johnston (Her Majesty's Commissioner)

- Cecil Maguire (Captain, 2 ${ }^{\text {nd }}$ H.C. Lancers, British Central African Administration). ${ }^{136}$

\footnotetext{
${ }^{135}$ Bridglal Pachai, "Land Policies in Malawi: An Examination of the Colonial Legacy," Journal of African History 14, no.4 (1973): 683-684.

${ }^{136}$ Great Britain, British and Foreign State Papers, Vol. LXXXV, 1892-1893 (London: HMSO, 1899), 346-347. For a more recent study, see Press. Rogue Empires (Cambridge, MA: Harvard University Press, 2017).
} 
An analysis of the preparation and signing of these (and other related) title deeds clearly indicates that they were drafted by the European colonists and were made to be too technical and in a foreign language which the illiterate native chiefs and headmen could not have easily understood at a time when Western education had not been fully introduced and developed in the Protectorate. The title deeds also indicate that the notion of revenue collection essential for the survival of the colonial state was deliberately inserted by the framers of the "treaties" to support the day-to-day administration of the colonial state even though the chiefs in question did not have a chance to consult with their own subjects. Furthermore, such deeds did not indicate, as argued by the colonists, that the said chiefs and headmen had summarily or completely given away their customary rights to portions of land which they merely controlled as custodians. Edge Kanyongolo, writing from a legal perspective, also argued that the land transfers of the early colonial era were mostly frauds of dubious legal validity arrived at by "duping" the African leaders into giving away their land. The outcome of the "land grab" process was that it converted many of the African subsistence farmers into labor tenants on the newly created private estates of the European settlers. ${ }^{137}$

Elizabeth Colson summed it up well when she argued that it was inevitable that colonial governments should impinge upon the land rights of the people they conquered for several reasons. Firstly, because of the new economic system, which colonial governments stimulated, which was targeted towards exploitation of land and cash cropping - where the crops would be exported to meet the demands for imported goods. Secondly, because the colonial states regarded themselves

\footnotetext{
${ }^{137}$ Edge Kanyongolo, "Land Occupations in Malawi: Challenging the Neoliberal Legal Order," In Sam Moyo and Paris Yeros, eds., Reclaiming the Land: The Resurgence of Rural Movements in Africa, Asia and Latin America. (London: Zed Books, 2005), 121-122.
} 
as modicums for economic development, there was the need to divert some land to new uses through newly created systems of land tenure. The new land tenure systems were sometimes implemented with haste because the colonial authorities often felt that they had the political power, as representatives of their mother government in Europe to impose their views on the African subjects. That form of domination also included the imposition of European legal practices to be applicable elsewhere in the European overseas colonies. The colonial authorities often assumed that the full range of land rights covered by the concept of proprietary ownership must exist in Africa as they existed in Europe. If no private person appeared to hold such rights over a given area, then the colonial authorities assumed that the rights must be vested in the political unit (usually a village or chieftaincy) whose members used the area. Failing this, the land was supposed to belong to the newly created government which could then alienate the land on its own terms to commercial corporations or to European settlers, using the policy of "no land could be without an owner."138

Upon settling the land claims, the Johnston administration instituted new forms of land tenure, which replaced the customary land tenure system, where the chief as the custodian of the land, was not supposed to sell land to "outsiders," let alone to anyone, but rather to distribute it to his or her subjects. Under the new land tenure system, the European settlers (and some African elites) were given access to "Private Land" (with a Certificate of Claim indicating the parameters of their portion of land), while the colonial state had access to what became "Crown Land," where the state could construct its offices, roads, railways, canals, and other related structures without having to

\footnotetext{
${ }^{138}$ Elizabeth Colson, "The Impact of the Colonial Period on the Definition of Land Rights," In Victoria Turner, ed., Colonialism in Africa, 1870-1960. Vol.3: Profiles of Change: African Society and Colonial Rule (Cambridge: Cambridge University Press, 1971), 193-196.
} 
pay compensation. Most of the Africans were pushed into what became "Native Reserves."139 The "Crown Lands," which covered eighty-five percent of the Protectorate, referred to a condition where the British Crown became the owner of the land, either by purchase, concession, or forfeiture. Such lands were earmarked for the state to raise some revenue through rentals and sales to European settlers and companies, and for other development-related initiatives. ${ }^{140}$ Most of the land was taken from unwilling and "unconscious" African chiefs, many of whom had no idea that they had summarily given away their land. The grabbing of land from the Africans was a deliberate ploy by the colonial state to effectively control the Africans, starting with the control over land, the soil and the minerals that lay in it, with the Commissioner (later Governor) as the overseer of the land on behalf of the British Crown. The "Private Land" on the other hand was mostly occupied by European settlers, and by 1902 covered an area of over 3,700,000 acres. ${ }^{141}$

Apart from the individual claims to land by settler planters, huge portions of private lands went to the British South Africa Company (BSAC) of Cecil John Rhodes, which had freehold rights over land covering 2,700,000 acres in the Northern Province. This was land that practically covered the entire province (also known as the North Nyasa Province), which the BSAC earmarked for mineral exploration. In the Shire Highlands, some of the biggest portions of land were ceded to the Livingstone-Bruce Estates Company, that occupied about 320,000 acres in a single block, and the British Central Africa Company (BCAC) that occupied 170,000 acres of land in different parts of the Blantyre District. While the land alienation practices had robbed the Africans of their most

\footnotetext{
${ }^{139}$ Raymond Leslie Buell, The Native Problem in Africa, Vol.1 (New York: The Macmillan Company, 1928), 245.

${ }^{140}$ Nyasaland Protectorate, Annual Report on the Accounts, $31^{\text {st }}$ March 1912, CO 626/1 (Zomba: Government Printer, 1912). From 1907 to 1912 , the Government earned as high as $£ 427,714$ from the sale of Crown Lands. See also Nyasaland Protectorate, "Minutes of Proceedings of the Executive Council, Zomba. $4^{\text {th }}$ May 1908," CO 626/2 (Zomba: Government Printer, 1908).

${ }^{141}$ Clement Ng'ong'ola, "The State, Settlers, and Indigenes in the Evolution of Land Law and Policy in Malawi," The International Journal of African Historical Studies 23, no.1 (1990): 28-32.
} 
reliable natural resources (land), it also denied them the opportunity to practice "shifting cultivation" (where cultivable land was left to regain fertility while the farmers moved on to cultivate new portions of farmland). The Livingstone-Bruce Estates in Chiradzulu for instance, had about 15,000 Africans, who had been alienated from their land, and could be evicted at the discretion of the new land owners, especially when the tenants refused to work for rent. ${ }^{142}$ In 1902 , the colonial state's control over land was further cemented by the enactment of the British Central Africa Order-in-Council, 1902, which placed all lands (public and crown lands) in the Protectorate under His Majesty's Government. That meant that all those claiming ownership to land, except private land, were only doing so under the authority of the Crown, who had the first rights to all mines and minerals in such lands. ${ }^{143}$

The claims and counter-claims over the ownership of land in the protectorate continued well into the first decade of the twentieth-century. Colin Baker argued that several factors were at play to help explain the circumstances. Firstly, there was a shift from the pioneer collecting stage, based on collecting ivory and rubber, to a new stage of extensive settler cultivation of coffee, cotton, and a little later, tobacco. The shift required far more labor and large portions of land. Secondly, the contestations over land also increased once the required labor arrived, especially from Portuguese East Africa (present-day Mozambique). Many of the migrants from Mozambique, especially the Lomwe peoples settled in the Shire Highlands. Most of the migrant laborers ended up settling on the private estates, where the land owners began to demand rent in the form of labor from both the

\footnotetext{
${ }^{142}$ L.P. Mair, Native Policies in Africa. (New York: Negro Universities Press, 1936). This is a 1969 reprint, $108-109$. See also Raymond Leslie Buell, (1928), pp.245-246. See also Great Britain, Report for the year ending March 31, 1901, on the trade and general condition of the British Central Africa Protectorate (London: HMSO, October 1901). ${ }^{143}$ Orders of the King-in-Council Relating to the Nyasaland Protectorate in force on $31^{\text {st }}$ December 1913, "The British Central Africa Order-in-Council, 1902," (Originally published in the Gazette of 31 ${ }^{\text {st }}$ October 1902). See also Owen J.M. Kalinga, "European Settlers, African Apprehensions, and Colonial Economic Policy: The North Nyasa Native Reserves Commission of 1929," International Journal of African Historical Studies 17, no.4 (1984): $641-644$.
} 
new comers and the old native settlers - who could not be easily distinguished by the estate owners.

That then marked the beginning of the much-dreaded "Thangata System" ("thangata" means "help") in which the African residents on private estates were required to work for a certain portion of the year to pay their rent in the form of labor provided. ${ }^{144}$

One such case involving the contestation over land happened in 1903 which came before the High Court of Nyasaland and revolved around the question of the rights held by Africans living on estates originally "bought" by Europeans from native chiefs and later re-sold to other European settlers. The main facts of the case (Supervisor of Native Affairs vs Blantyre and East Africa Company Limited) were centered on the interpretation of the clause in the Certificates of Claim in the Thyolo and Ruo Estates in the Shire Highlands, which provided that the Africans resident on the estates when the land was bought or transferred to a European were not to be "disturbed or removed" without the sanction in writing of His Majesty's Commissioner. The Crown Prosecutor (Mr. J. Charles Casson) argued his case by insisting that the "non-disturbance clause" meant that the Africans could not be removed from the stated estates, and that they were supposed to enjoy access to natural resources which included access to land and flora. The prosecutor hinted on the Africans' need for land for cultivation, and on the continued rights over land held by some chiefs and headmen. Mr. R.S. Hynde, who sold the land to Blantyre and East Africa Company Limited (BEAC Limited), also gave his court statement in support of the prosecutor and His Majesty's Commissioner, by pointing out that the clause in his Certificate of Claim was based on African custom and guaranteed the African against disturbance so long as he liked to occupy the site and

\footnotetext{
${ }^{144}$ Colin Baker, Seeds of Trouble: Government Policy and Land Rights in Nyasaland, 1946-1964 (London: British Academic Press, 1993), 11-13. On the history of Alomwe people's migration into Nyasaland, see Wiseman Chijere Chirwa, "Alomwe and Mozambican Immigrant Labor in Colonial Malawi, 1890s-1945," International Journal of African Historical Studies 27, no.3, (1994): 527-529.
} 
gardens he had at the time the land was bought. Although the clause said nothing about the Africans' shifting cultivation practices, Mr. R.S. Hynde argued that it was held that the African would return to his land in the immediate future, as they would leave the previous plot to fallow, more especially that there was still enough Crown Land - where the African could encroach for some time before returning to the land under "Certificate of Claim."

In his judgment, High Court Judge J.J. Nunan, began by stating how crucial that case was to the question of land ownership in British Central Africa, and that at the end of it all, it would be a case of a "judge making a law" - and not a "judge applying or interpreting an existing law" as was required. He noted that, usually, judges act as custodians of a body of customary principles which have only to be applied to each new case as it arises and have the power to modify existing law from time-to-time depending on circumstances and the changing needs of society. The judge's ruling on the case ended up being detrimental to the land-holding interests of the chiefs and their subjects on private land. Among the key issues raised, the judge ruled that: (1) The chiefs and their people could only stay on the estates as tenants of the Company (BEAC Limited), and that they were supposed to renounce any claims they had on the sold land; (2) that as tenants the people were supposed to agree to provide two-months of work during the rainy season to the land owner in lieu of rent, and that those working for other Europeans were to pay a yearly rent for their house and gardens of six shillings per annum; (3) that as tenants they should never cut down timber on the banks of streams or any other place within the bounds of the estates, and they were also ordered not to build any new houses without the owner's permission; (4) the Company was also ordered to agree that it would pay the taxes of those people who worked on the estate for two months, so long as the tax remained at three shillings per year; (5) that the tenants in breach of the ruling would be liable for eviction from the estate, within a short notice issued by the Collector; (6) and 
that Africans who were working for other Europeans or paying a monetary rent would also be required to pay cash for taxes in addition to the rent charge for staying on the estate. In conclusion, the judge hinted that the "Certificates of Claim" issued in the early 1890s, had significant flaws. For instance, he raised several important questions regarding the "Claims": To whom were the rights secured by the Certificates of Claim? To the tribe? To the village community or to the individual African? What was the nature and extent of the rights so secured? How are the persons or bodies in whom the rights in-here to be ascertained and upon whom does the onus of proof lie? He argued further that although the "Certificates of Claim" and treaties were made with chiefs, the agreements were now null and void (had been nullified and without any legal binding) following the advent of European courts and magistrates who were the new custodians of the law. The village headmen no longer had rights over the lands where they and their peoples settled. ${ }^{145}$

At the conclusion of the court case, and acting on recommendations by Judge Nunan, the Acting Commissioner of the Protectorate, Major F.B. Pearce, appointed a Commission, consisting of Judge Nunan, the Chief Surveyor for the Protectorate, and the Superintendent of Native Affairs to inquire into and report upon the natives' rights to land. At the end of the inquiry, the Commission reported that up to May 1903, European landowners had recognized no established African land rights in so far as native land rights were concerned. The Africans resident on European-owned estates were, in most cases, asked to pay a rent in labor varying from three to six shillings per year (equal to one- or two-months' work). The recommendations from the Commission to His Majesty's Commissioner were summarized as follows: (1) European land owners were to set apart a portion of their estates, not to exceed one-tenth of the whole, for the creation of African reserves;

\footnotetext{
145 "In the High Court of British Central Africa: Supervisor of Native Affairs versus Blantyre and East Africa Company Limited," The Central African Times, May 9 ${ }^{\text {th }}, 1903$.
} 
(2) African residents on European estates were to be entitled to land for villages and food plantations on a basis of eight acres per family; and (3) Each African head of family had to pay a yearly rent of four shillings to the land owner (except for lands within three miles of the four townships of Zomba, Blantyre, Fort Johnston, and Chiromo, for which a rent of up to two shillings an acre might be paid). It was from these recommendations that the colonial government enacted "The Lands Ordinance (Natives Reserves) of 1904."146

In a nutshell, it became clear in the case of Nyasaland that the claims of appropriating land on trust to maximize its use for the benefit of humanity were false. While the early migrants, mostly Christian missionaries, had some "good" intentions, it became clear that after the Berlin Conference, the entry of the capitalist class and later the colonial state, meant that it was the commercial interests, rather than the "civilizing mission," that dominated the processes of land appropriation. It alienated Africans from their land regardless of the pre-contact systems of land tenure and land transfer. I contend that, in the case of Nyasaland, the appropriation of land for the commercial interests of the colonizers, should be understood as a manifestation of the notion that the colonial experience was a "makeshift settlement". As the colonial state straddled between meeting the interests of the European capitalist class and those of the indigenous people, it ended up depriving the Africans of their primary source of livelihood and subsistence. While the state needed the support of the settlers, whose resources and revenue would have been used in the development of the country that should not have been achieved by dubiously appropriating land from the indigenous people. While Commissioner Johnston sometimes sided with the indigenous peoples, when he declared that about eighty-five percent of the Protectorate should be under Crown

\footnotetext{
${ }^{146}$ Great Britain, Report on the Trade and General Condition of the British Central Africa Protectorate for 1903-04 (London: HMSO, September 1904), 35-41. See Annex no.3: Report by Mr. J.C. Casson, Superintendent of Native Affairs.
} 
lands, and thus ensuring that such lands did not fall under capitalist monopolies, it is impossible to absolve him and indeed the British government from the atrocities that were committed in the Protectorate, especially when it came to practices of land alienation and the denial of livelihoods for the Africans. Similarly, the labor and taxation policies, to be discussed in the next section, also reflected badly on the "good will," if any, of the colonizing power.

\section{The colonial state and "gentlemanly capitalism": access to African labor and the taxation regime}

The control of African labor and collection of revenue also became contested and were part and parcel of the "makeshift settlement" that characterized British colonial rule in Nyasaland. The two areas became avenues for the "legalization" of state oppression, as the colonial state worked towards meeting its revenue and accumulation imperatives, essential for its own survival. There were often cases of "collaboration" between the colonial state and European settlers in soliciting both labor and revenue (taxes) from the African population. The state needed revenue for it to survive and pay for administrative services, while the settlers needed a steady supply of labor, both agricultural and porterage. That collaboration contributed to what has been described elsewhere as a form of "primitive accumulation," in which the state used its powers and brute force, to compel Africans to provide their labor and taxes, aiding the colonial enterprise and fulfilling the interests of both the colonial state and the European settlers. ${ }^{147}$ By adopting the elements of "primitive capitalism," the colonial state then contradicted the concept of "civilizing mission," which in practice should have encouraged the African to voluntarily participate in the colonial enterprise

\footnotetext{
${ }^{147}$ Mathew Forstater, "Taxation and Primitive Accumulation: The Case of Colonial Africa," The Capitalist State and Its Economy: Democracy in Socialism Research in Political Economy, 22 (Elsevier Ltd. 2005): 51-65. See also Joel S. Migdal, Strong Societies and Weak States: State-Society Relations and State Capabilities in the Third World (Princeton, NJ: Princeton University Press, 1988), 70-71.
} 
rather than the coercion that ensued. By 1915, rules and regulations were enacted which compelled Africans to work for European settlers, and in turn, for the European employers to pay the taxes of their employees to the colonial state's coffers, a system that was from time-to-time abused by the employers usually through the extension of the period the laborers had to work or by not issuing the required work or tax certificate for the laborers.

It must be borne in mind that the colonial state was administered with very limited resources during the period under study. The late 19th and early 20th centuries were a time when the British government expected the colonies to be financially self-supporting, such that it only provided "grants-in-aid" from the Treasury only in instances where local revenue could not meet the necessary local expenditure, and often disallowed deliberate budgeting for a deficit in the colonies. ${ }^{148}$ Before the outbreak of the First World War, when the British Treasury committed itself to sending funds to the colonies, subventions were provided only to balance colonial budgets and pay the salaries of European officials. The Treasury was of the view that the colonial subjects should pay, through taxation, for the services provided by the colonial state. ${ }^{149}$ For the first two decades of colonial rule, the Nyasaland government, hampered by a lack of reliable sources of revenue from taxes and an underdeveloped agricultural and transport economy, survived on annual subsidies from the BSAC, which was giving the protectorate’s government an average of $£ 8,000$ per annum. ${ }^{150}$

\footnotetext{
${ }^{148}$ Sir Andrew Cohen, British Policy in Changing Africa. (London: Routledge and Kegan Paul, 1959), 16-17. See also Leigh A. Gardner, Taxing Colonial Africa: The Political Economy of British Imperialism (Oxford: Oxford University Press, 2012), 1-30.

${ }^{149}$ Stephen Constantine, The Making of British Colonial Development Policy, 1914-1940 (London: Frank Cass and Company, 1984), 9-23. See also Louis James L. Nthenda, "HM Treasury and the Problems of Nyasaland Public Finance, 1919-1940," (PhD Thesis, University of Oxford, 1972), i-iv and 1-22.

${ }^{150}$ S.S. Murray, A Handbook of Nyasaland (Zomba: Government Printer, 1932), 290-294. Note that there was a break in the subsidies between 1896 and 1903, following a substantial increase in income tax. On the lack of or limited funding opportunities in early colonial Nyasaland, see Louis James L. Nthenda, "HM Treasury and the problems of Nyasaland public finance, 1919-1940," 1-37.
} 
From this background, it became essential to attract European investment and impose tax collection as one of the first measures for the state's survival. The taxation regime, was also, as argued by Andrew Burton, an avenue through which the colonial state imposed its political authority on its subjects. It allowed the colonial state to impose its demands on the colonized peoples by demanding that they contribute to the costs of administering the colonies. While the government embarked on "uplifting the livelihoods" of the colonized peoples, the latter had to pay for the costs of security, good government, education, communications, medical attention, and agricultural activities, among others. This occurred irrespective of whether the taxes were collected by European officials or African intermediaries, such as chiefs, who received a percentage of the money raised. ${ }^{151}$ Michael Tuck, focusing on taxation in colonial Uganda, also argues that the taxation regime, apart from being an avenue for imposing colonial authority, was also one way of "monetizing" that colony's economy. The introduction of a new currency and collection of taxes compelled the colonial subjects to seek wage labor or grow cash crops to meet the taxation demands and to pay for other services. ${ }^{152}$ The treaties of occupation, signed with African chiefs, such as the one cited above, with Chief Liwonde, also clearly stipulated the centrality of tax collection, where the African chiefs committed themselves to collect taxes in return for both protection and payment for the costs of being placed under British rule. The "collaborating" chiefs received a $10 \%$ stipend from the taxes they collected. This also in significant measure undermined the concept of the "civilizing mission," especially as it exposed the weaknesses of the colonial enterprise. This was so because it was clear that the colonial state could not perform its duties without the input and effort of African "intermediaries," both the chiefs and other local colonial

\footnotetext{
151 Andrew Burton, "The eye of authority: 'native' taxation, colonial governance and resistance in inter-war Tanganyika," Journal of East African Studies 2, no.1 (March 2008): 75-81.

${ }^{152}$ Michael W. Tuck, "The Rupee Disease: taxation, authority, and social conditions in early colonial Uganda," The International Journal of African Historical Studies 39, no.2 (2006): 221-225.
} 
employees. The basic form of taxation in the colonies was the income tax (direct tax), which was initially collected through the pre-existing or newly created African administration structures headed by chiefs, most of whom worked under the supervision of British staff. While the amount of money for taxation tended to vary from colony-to-colony, the official names given to the taxes also varied from colony-to-colony, and in other instances totally different taxes were also imposed. ${ }^{153}$ In Nyasaland, there were two main forms of taxation, namely the hut tax and the poll tax. The former was intended to be paid by the male head of a household, and the latter had to be paid by all males above the age of sixteen. The Africans were compelled to pay taxes under duress, as those who failed to pay were subjected to various kinds of punitive measures, including having their household property confiscated, houses demolished, and, in some cases, women were held hostage until their spouses could pay the taxes. ${ }^{154}$

The process of tax collection in Nyasaland was institutionalized by Commissioner Harry $\mathrm{H}$. Johnston as early as 1892 , who, after deliberations with native authorities, estimated the number of hut occupants at three individuals, and hence fixed the annual hut tax at six shillings per annum. Initially, tax collection began in the southern province, before it was later applied to other parts of the protectorate. By then, the southern province had been significantly subdued by the incoming British colonists, hence creating conducive conditions to commence the taxation process. The initial payments were made in kind, before a full blown monetary-based taxation system was

\footnotetext{
${ }^{153}$ For instance, in Swaziland, the British colonial authorities imposed the poll, hut, and dog taxes. The latter was not imposed in Nyasaland. See Jonathan Crush, "colonial coercion and the Swazi tax revolt of 1903-1907," Political Geography Quarterly 4, no.3 (July 1985): 182.

${ }^{154}$ Nyasaland Protectorate, Direct Taxation of Natives in the Protectorate and other cognate matters, Report compiled by Mr. Eric Smith, Administrative Officer (Zomba: Government Printer, 1937), 6-8, CO 525/172. See also Denis Nkhwazi, "Presidential Leadership in Malawi: A Study in the reconciliation of historical fate with developmental concepts and political institutional creation (Malawi 1964-1969) as seen from the core of the First Presidency," (PhD Diss., University of Hamburg, Germany, 1971), 32-33. See also A.J. Hanna, The beginnings of Nyasaland and NorthEastern Rhodesia, 1859-95 (Oxford: Clarendon Press, 1956), 241-245. See also Simon Roberts, "The direct taxation of Africans in the Nyasaland protectorate, 1892-1939: some determinants of revenue policy," British Tax Review, 193 (1967): 192-206.
} 
implemented. Johnston's policy stipulated that the African chiefs were to be given 10 percent of the total tax proceeds. This served as some form of government subsidy and to coax them to collect more taxes from their subjects. According to Johnston, the Africans, especially those in the Lower Shire region, asked to be taxed by the incoming British colonists. Many of them had been accustomed to pay taxes to Portuguese authorities, and hence felt obligated to do the same when the British colonized their territories. That then explains why in the treaties that were signed with African chiefs, a clause of payment of taxes was inserted. ${ }^{155}$ Further amendments were made to the taxation regulations, including the regulations of 1894, which fixed the tax at 3 shillings, due and payable on the $31^{\text {st }}$ of December each year. In 1901, the maximum rate was fixed at 12 shillings per hut, with a rebate of half if the native had worked for a European for one month at the current rates of pay. In 1911 (Ordinance 13 of 1911), the tax remained at 12 shillings, whereas for 191213, the tax was revised down to 8 shillings. In the 1921 Tax Ordinance, the rebate system was abolished, and the tax was fixed at 6 shillings. ${ }^{156}$ The colonial authorities often waived taxing their European colleagues in the Protectorate, for fear of driving out the limited number of foreign investors, who were comparatively few. Many of them had already shown discontent at the lack of mineral resources worthy of mining at the time. This also raises questions about the extent of the "capital" that the European settlers took to Nyasaland, if one is to follow the notion of "gentlemanly capitalism," as discussed above. The capitalists who trekked to the overseas colonies should thus not be regarded as a homogenous entity. Many of those that went to Nyasaland were clearly of very limited financial means. In turn, what became imperative for the state was to collect

\footnotetext{
155 Johnston, British Central Africa, 110-111. See also British Central Africa, Report by Commissioner Johnston of the first three years' administration of the Eastern portion of British Central Africa (London: HMSO, 1894), 27-29. See also A.J. Hanna, The Beginnings of Nyasaland and North-Eastern Rhodesia, 241-245. See also Hector L. Duff, Nyasaland under the Foreign Office (London: George Bell and Sons, 1906), 349-353.

${ }^{156}$ Nyasaland Protectorate, Direct Taxation of Natives in the Protectorate and other cognate matters, Report compiled by Mr. Eric Smith, Administrative Officer (Zomba: Government Printer, 1937), 6-8, BNA: CO 525/172.
} 
as much money (in the form of taxes) from the Africans as possible, more especially as the protectorate had no major industries from which the government could collect extra revenues. ${ }^{157}$ It was also often difficult for the Nyasaland government to tax the Asian community in the protectorate. Although some of them had some relatively higher incomes, compared to the Africans, it was not easy for the government to calculate their income for taxation purposes. Thus, it was not until 1928 that a "non-native poll tax" began to be levied on the Asians, many of whom were private traders. ${ }^{158}$

Once full-scale hut tax collection began, the records indicate that the annual amounts increased each year, providing over fifty-percent of the local revenue by 1905 . The table below illustrates the trend:

\footnotetext{
${ }^{157}$ Griff Jones, Britain and Nyasaland: A Story of Inattention, Fitful care, Political Vacillation (London: George Allen and Unwin Ltd, 1964), 60-68.

${ }^{158}$ Simon Roberts, "The direct taxation of Africans in the Nyasaland protectorate, 1892-1939: some determinants of revenue policy," British Tax Review, 193 (1967): 192-206, see pp.194-195. For a history of the Asian (especially Indian community) in Malawi, see Floyd Dotson and Lillian O. Dotson, The Indian Minority of Zambia, Rhodesia and Malawi (New Haven: Yale University Press, 1968).
} 
Table 3.1: Tax Collection in Nyasaland Protectorate, 1895-1914

\begin{tabular}{cccc}
\hline Year & Total Revenue (£) & Amount Collected (£) & $\begin{array}{c}\text { Tax percentage } \\
\text { of local revenue }\end{array}$ \\
\hline $1895-6$ & No figures available & 4,704 & - \\
$1896-7$ & About 22,000 & 7,201 & 32.73 \\
$1897-8$ & No figures available & 8,083 & - \\
$1898-9$ & No figures available & 12,646 & - \\
$1899-1900$ & No figures available & 13,466 & - \\
$1900-01$ & 49,214 & 16,756 & 34.04 \\
$1901-02$ & 51,704 & 21,235 & 41.07 \\
$1902-03$ & 67,477 & 26,145 & 38.74 \\
$1903-04$ & 75,895 & 26,276 & 34.62 \\
$1904-05$ & 67,553 & 29,024 & 42.96 \\
$1905-06$ & 79,738 & 31,074 & 38.97 \\
$1906-07$ & 82,107 & 35,619 & 43.38 \\
$1907-08$ & 75,197 & 36,605 & 48.67 \\
$1908-09$ & 79,852 & 38,389 & 48.07 \\
$1909-10$ & 68,592 & 41,530 & 60.54 \\
$1910-11$ & 86,430 & 46,534 & 53.84 \\
$1911-12$ & 95,482 & 50,970 & 53.38 \\
$1912-13$ & 127,596 & 65,685 & 51.47 \\
$1913-14$ & 124,849 & 69,810 & 55.91 \\
\hline
\end{tabular}

Source: See the following Colonial Annual Reports for the Nyasaland Protectorate: 1905-'06, 1908-'09, 1912-'13, and 1913-'14. All these reports were published in London: HMSO. See also Nyasaland Protectorate, Report of the Treasurer with the financial statements of the Protectorate for the year 1913-1914 (Zomba: Government Printer, 1914), 319. See also Johnston, British Central Africa, 111-112 and 150. See also Handbook of Nyasaland (London: HMSO, 1920), 76. ${ }^{159}$

\footnotetext{
${ }^{159}$ Note that there are missing total revenue figures for the early part of revenue collection, and this could be explained as emanating from "underdeveloped" accounting structures, and also the erratic nature of the finances that were dispatched to the Protectorate, either from the BSAC or from the British Treasury, through "grants-in-aid". The figures in the table thus exclude the subsidies from the BSAC. See John McCracken, A History of Malawi (2012), 75-76. See also C.A. Baker, Johnston's administration, 1891-1897 (Zomba: Government Printer, 1971), 55-63. For instance, between 1891 and 1896, the BSAC subvention totaled £75,500, while the British Treasury "grants-in-aid" was $£ 54,000$.
} 
As the taxation regime progressed, it was also connected to the notion of labor demands by the European settler community, especially the planters. The European planters usually had problems to recruit African labor, when the laborers were needed, such as during the rainy season, as the laborers often chose to tend to their own agricultural gardens. ${ }^{160}$ As such, the planters, most of whom had limited economic means, often pressured the colonial state to institute measures that would compel African laborers to work in their estates and other enterprises. Such demands were often made through influential settler associations in the protectorate, such as the Chamber of Agriculture and Commerce and the Mlanje Planters Association, who among other things advocated that the African laborers under their watch should not be paid in cash, but rather that they should be paid in kind - while the money would be paid to the government as a form of taxation. The planters also advocated that the salaries for the Africans had to be deliberately kept low, as higher payments or salaries would have made them self-sufficient and abandon their jobs or abstain from working for Europeans. ${ }^{161}$ Following continued deliberations between the settlers and the state authorities, under Commissioner Alfred Sharpe (who succeeded Harry H. Johnston in 1897), the colonial state came up with a number of policies "legalizing" the association between the settlers' demands for native labor and the state's demands for revenue. Some of the measures agreed upon included the following: firstly, an estate owner or a planter was required to either pay the taxes of the entire African population residing on his estate, or none. In either case, the planter had to work closely with state authorities to make sure that all Africans of tax paying age and ability had paid their dues. Secondly, the planters were also given powers to employ Africans

\footnotetext{
${ }^{160}$ Nyasaland Protectorate, Annual Report of the Department of Agriculture. 31 $1^{\text {st }}$ March 1912, CO 626/1. (Zomba: Government Printer, 1912), 92-93. According to a former government official, Hector L. Duff, early colonial Nyasaland did not provide the European colonists with neither free labor (labor for its own sake) nor labor for personal gain or glory. And that explains why the colonial authorities had to devise means and ways of sourcing African labor. See Hector L. Duff, Nyasaland under the Foreign Office, 358-359.

161 "Mlanje Planters Association," The Central African Times, $22^{\text {nd }}$ July 1899.
} 
resident on their estates, while withholding a month's payment by sending it to government coffers through authorized tax collection officers. The estate owner was required to issue the laborers with a stamped tax receipt (or a tax certificate), a system which also ended up being abused, as planters often deliberately withheld the receipts and continued to demand more labor from the natives. ${ }^{162}$ Under further taxation regulations instituted in 1902, Africans who produced fake work or tax certificates were liable to a punishment of $£ 100$ or imprisonment for three calendar months, or to both fine and punishment. ${ }^{163}$

There was also the appalling Thangata system ("Thangata" means "help") in which some of the European planters demanded "free labor" from the Africans settled on their estates but could not be moved due to the "Non-Disturbance Clause," inserted on the Certificate of Claim. Under the Thangata system, which resembled European feudalism, Africans were required to pay "land rent" in form of their labor. The system was often subject to abuse, as the Africans ended up working for extended periods of time, more than what was agreed upon of two months. The payment for the first month was supposed to be sent to the government, in the form of tax, whereas the second month's payment was to be used to pay rent for settling on the farm. Many of the African workers under that system were forced to work for long working hours, could not grow their own crops, could not cut timber to make their own huts, and were subjected to various forms of corporal punishment for failing to meet set targets. Many of them had no choice but to live under such poor working conditions, for fear of being evicted from the private estates with the help of colonial

162 "Tax Collection," The Central African Times, $4^{\text {th }}$ April 1900.

163 "Native Hut Tax Regulations," The Central African Times, $11^{\text {th }}$ January 1902. See also Duff, Nyasaland under The Foreign Office, 349-372. 
administrative officials and police. Those who moved to crown lands often lived in densely overpopulated settlements. ${ }^{164}$

Attati Mpakati argued that the labor of the Africans under the Thangata system was often demanded by the European "landowner" at the peak cultivation period, which often prevented the African peasants from cultivating crops for their own families. Where they could grow cash crops, the "squatters" were often coerced to sell them to the landowner at the price dictated by him (the landowner). While the concept and practice of thangata was predominant in the southern region, there was also a similar practice in the central region. In the latter, European settlers introduced a system called the "visiting system", which entailed that an African family would stay on a farm owned by a European for a limited time while providing free labor. In return, the European settlers were expected to provide the "visiting" family with farm inputs and food, although such pledges were usually never honored. ${ }^{165}$ When the First World War broke out in 1914, the colonial authorities took advantage of the existing thangata labor system to forcibly enlist the Africans in Nyasaland to fight on behalf of Britain in the war. Many were enlisted to defend the protectorate's northern frontier, which bordered the German colony of Tanganyika (German East Africa). The Nyasaland Government ran a propaganda campaign to suggest that fighting in the war would

\footnotetext{
${ }^{164}$ B.S. Krishnamurthy, "Economic Policy, Land and Labor in Nyasaland, 1890-1914," In B. Pachai, ed., The Early History of Malawi (London: Longman Group Ltd, 1972), 391-396. See also Hector L. Duff, Nyasaland under The Foreign Office, 355-356. Colin Baker has argued elsewhere that the Thangata System came to be extensively used following the influx of laborers from the Portuguese territory of Portuguese East Africa, many of whom, as labor migrants, had no land of their own. The European settlers often began to treat the migrants and the indigenous Africans in the protectorate as a homogenous group. See Colin Baker, Seeds of Trouble: Government Policy and Land Rights in Nyasaland, 1946-1964 (London: British Academic Press, 1993), 11-13.

165 Attati Mpakati, "Malawi: The Birth of a Neo-Colonial State," African Review 3, Issue 1 (Jan. 1973): 37-38. See also Melvin Page, "The War of Thangata: Nyasaland and the East African Campaign, 1914-1918," Journal of African History, XIX, no.1 (1978): 87-88.
} 
prevent a German takeover of Nyasaland and would ensure that the Africans did not lose their portions of land. ${ }^{166}$

The colonial taxation regime was in significant measure the major driving force behind the rise of labor migration from Nyasaland to other colonies in the region. The migration of labor in a way also reduced the number of Africans who could be compelled to work under either the "Thangata" or "visiting system," and that meant that labor would remain a scare commodity. Most of the men in the protectorate were compelled to find meaningful employment in the mining areas of South Africa and the two Rhodesias (Northern and Southern), with an aim of raising funds to pay the taxes and pay for the deficit of having lost their access to the means of subsistence production. The major companies involved in recruiting labor from the Protectorate included the Witwatersrand Native Labor Association (WNLA) and the Rhodesia Native Labor Bureau (RNLB). These were companies set up by European settlers in South Africa (WNLA) and Southern Rhodesia (RNLB). They worked together with their respective colonial governments in British colonial Africa, especially British Central Africa, to recruit African laborers for the mining and plantation enterprises in the countries mentioned. The companies also helped the migrant laborers to remit significant sums of money to their respective countries, money that was deducted as payment of the poll and hut taxes discussed above. There were also other Africans who migrated without the assistance of the recruiting companies, to avoid the "yoke" and control of the recruiters. These were known as “independent migrants." They often took advantage of the protectorate's long unguarded borders to migrate. ${ }^{167}$ The salaries paid in South Africa and the two Rhodesias (Northern and Southern Rhodesia) were better than those paid by the settlers in Nyasaland, mainly

\footnotetext{
166 Page, "The War of Thangata: Nyasaland and the East African Campaign, 1914-1918," 88-89.

${ }^{167}$ Wiseman Chijere Chirwa, "Theba is power: rural labor migrancy and fishing in Malawi, 1890s-1985," (PhD Diss., Queen's University, Ontario, Canada, August 1992), 133-136.
} 
because of limited agricultural and industrial production. For instance, in Southern Rhodesia, a migrant farm laborer could be paid as much as 22 shillings per month; a domestic laborer was paid in the range of 15 to 60 shillings per month; and a mining laborer was paid between 20 to 40 shillings per month. In Nyasaland, most of such laborers were paid for the same period as little as 3 to 4 shillings. ${ }^{168}$

The agreement between the Nyasaland government and the foreign labor recruiting agencies did not always go down well with the European planters in the protectorate, who could not compete with the better wages paid by the mine and plantation owners in those two countries. At the beginning of 1900, the planters sent a petition to be acted upon by the Foreign Office. Some of the issues raised in that petition against the system of labor migration included the following: firstly, that the Africans who went to work in South Africa and Southern Rhodesia, for a period of six months or more, and later returned to the Protectorate, were bringing back unwanted vices and/or influences, including beer drinking habits and unruly behavior, which would be detrimental to agricultural production in the protectorate; secondly, that the long absence of men from their homes was detrimental to family and village livelihoods, and that it significantly encouraged the evil of concubinage on the part of the men and to that of unfaithfulness on the part of the women - who went out in search of money for survival; thirdly, that it was risky for the Africans to work in South Africa and Southern Rhodesia, where, despite being paid higher wages, they were not guaranteed the provision of proper medical care and security; and lastly, that it was not necessary to increase wages paid to African laborers in the Protectorate because the rates of pay were enough to sustain African families; that more pay would make Africans work only for a shorter term; and

\footnotetext{
${ }^{168}$ McCracken, A History of Malawi, 1859-1966, pp.83-87. See also Colonial Annual Report, British Central Africa Protectorate Report for 1906-'07 (London: HMSO, 1907), 22-25.
} 
also because the coffee industry in the Protectorate had also failed to produce the desired profits.

One outstanding point raised in that petition read as follows:

My Lord, Your petitioners desire also to point out that there is no primary reason why these natives should be taken away from B.C.A. seeing that there is ample work for them to be had in their own country at fair wages. B.C.A. depends upon its native population and hitherto has succeeded in carrying on a large industry by the aid of the natives and so long as the coffee industry is flourishing there will always be congenial work for the natives in their own country. It is hardly necessary to point out to Your Lordship that it is better for the country's progress that the natives should be employed in developing the resources of their own country than they should be taken four hundred miles away to work. ${ }^{169}$

At that stage, it was clear that the "alliance" between the settler planters (the "gentlemanly capitalists") on one hand, and the colonial state and the British Government, on the other, could not continue to be workable. In other words, it also put to test the so-called relationship between "gentlemanly capitalism" and the political and administrative leadership both in the metropole and in the Nyasaland protectorate. One also notes the limitations which the capitalists had in terms of influencing colonial policy formulation. It also shows, as Andrew Porter argued, that the "gentlemanly capitalists" did not significantly benefit, as is sometimes argued, from imperial favors and subsidies. The relationship between capital and the state was usually dynamic, influenced by both metropolitan and peripheral developments. ${ }^{170}$ And as Jonathan Crush put it, the colonial authorities at times found it to be a daunting task to provide favors necessary to sustain the conditions for capitalist production. The state had to take into consideration that it also had

\footnotetext{
169 "Petition prepared by the Committee of the B.C.A. Chamber of Agriculture and Commerce, for presentation through H.M. Commissioner to the Foreign Office," The Central African Times, February $3^{\text {rd }}, 1900$. See also The Central African Times. "Should B.C.A. be the Recruiting Ground for Labor for the Mines? Opinion of the Residents: An Emphatic 'No'! Meeting in Blantyre". Speaker after speaker at that meeting emphasized to both the Nyasaland and British Governments that it was not necessary to recruit labor from the Protectorate to support the mining industries in Southern Rhodesia and South Africa, as that would have derailed the Protectorate's agricultural and infrastructural development.

${ }^{170}$ Andrew Porter, “Gentlemanly capitalism and empire: The British experience since 1750?" Journal of Imperial and Commonwealth History 18, no.3 (1990): 268-270.
} 
other roles, including where it served as a guarantor of political and social order. As such, the colonial state would not continually coerce the Africans to meet the demands of the European settlers. ${ }^{171}$ The colonial authorities had their own interests in encouraging African labor migration and did not want to continually oppress the Africans to the point of denying them the opportunity to find alternative means of employment outside the Protectorate, so long as they fulfilled their tax obligations to the Nyasaland government's coffers. The colonial government's policy of encouraging labor migration to South Africa and Southern Rhodesia was best summarized by Reverend Alexander Hetherwick, Head of the Blantyre Mission, expressing the sentiments of Commissioner Alfred Sharpe:

The country was 'going down'. Coffee, its chief product, was a failure, there was nothing to take its place, and consequently a fresh outlet must be found for the labor of the people. The wages earned by those who went to the south under the proposed scheme would be paid to them on their return to the Protectorate, and this would bring a great increase of wealth to the country. Moreover, also in return for this concession to recruit in the Protectorate, South Africa would admit free of import duty some of our local products. And it was only a thousand they wanted - a thousand 'as an experiment' 172

In London, government authorities were also not keen to issue a policy that would place a ban on African labor migration, as the officials argued that the Africans of the Protectorate should be given the freedom to work where they wanted, both within and outside the Protectorate. For instance, Joseph Chamberlain, then Secretary of State for the Colonies, made the following remarks in the House of Commons:

\footnotetext{
171 Jonathan Crush, "colonial coercion and the Swazi tax revolt of 1903-1907," Political Geography Quarterly 4, no.3 (July 1985): 181. These were also the views of Sir Harry Johnston in Nyasaland. See British Central Africa Protectorate, Report on the Trade and General Conditions of the British Central Africa Protectorate (London: HM Stationery Office, August 1986), 14.

${ }^{172}$ Alexander Hetherwick, The Romance of Blantyre: How Livingstone's Dream Came True (London: James Clarke and Company, 1931), 129-130.
} 
Turning to other districts north of the Zambezi, I agree with my Right Honorable friend the member of the University of Cambridge that we have to be careful in any matter of this kind, and there can be no possible objection to laying on the table of the House regulations which have been framed. As I have said, it is expected now to put 1000 natives of Central Africa in the mines if they appreciate the life then in no doubt a much larger number will hereafter go there. ...And let me point out that it is a very unfair thing to say to the laborers in a particular colony or protectorate, 'You should not go, whether you like it or not where your labor will best be remunerated'. The feeling of anxiety to prevent laborers going from the Central Africa or East African Protectorates is the feeling of the people on the spot who are now getting the labor of these men for a quarter or a fifth of what the mines are willing to pay, because when they return they will demand larger wages from their former employers than are now being paid in these Protectorates. I think it would be wrong to lay down any general policy and to declare that the native laborer is practically to be adiscriptus gleboe; that he must not move from his own protectorate even if higher wages are offered to him elsewhere. ${ }^{173}$

From such policy formulations, the picture one gets is that the relationship between the colonial state and the European settlers tended to be influenced by conditions in the colony, both the wellbeing of the economy and the reactions and preferences of Africans. However, when the two sides (the government and European settlers) collaborated, they at times connived to create forms of "forced labor," of a slightly lesser magnitude than the system of slavery. The Africans, especially men, were compelled to abandon the subsistence forms of production, as they were forced to work for the Europeans where they were issued with either the work or taxation certificates. Subsistence agricultural production was often left for their spouses, which often limited the amount of produce per household with the loss of male labor supply. Some were compelled to find higher-paying jobs

\footnotetext{
173 “Commentary," The Central African Times. May $16^{\text {th }}$, 1903. See also Robert M. Maxon, Struggle for Kenya: The Loss and Reassertion of Imperial Initiative, 1912-1923 (Cranbury, NJ: Associated University Presses, 1993), 65-71. Maxon also argued along the same lines, that the Colonial Office in London, had been unwilling to put in place policies that would be equated to a system of forced labor for the benefit of the European settler farmers. This was despite the protests by European settlers in Kenya, and the recommendations of the National Labour Commission which presented its report in August 1913, which called for some form of forced labor and higher taxation to compel Africans to work on settler plantations. The Colonial Office went further to recommend that all labor contracts by the natives, had to be signed only in the presence of a Government officer who would see to it that the terms of the contract had been explained to the natives. It had been the Colonial Office's position to straddle between the satisfaction of settler and metropolitan needs on one hand, and maintaining local control and production, without creating sources of colonial tensions.
} 
outside the Protectorate, to pay for the cost of being placed under British colonial rule. For the Africans who failed to pay the taxes, they were subjected to all forms of harsh treatment by the colonial authorities. The state often dispatched small military and police expeditions to punish villagers who refused to pay tax by burning down their huts and confiscating their grain and livestock. In the 1890s, such aggressive methods were mainly confined to the Shire Highlands districts, and mostly around the townships of Zomba and Blantyre due to their proximity to the colonial capital. It was thus unsurprising that the imposition of the hut tax and bullying tactics of tax collection created discontent among the Africans, circumstances that were pounced upon by the Christian missionaries and the native elites such as Rev. John Chilembwe (discussed below) and his accomplices. ${ }^{174} \mathrm{~A}$ former colonial official, Hector Duff, highlighted that it was government policy to literally "hunt down" the Africans to pay the taxes as many of them took long to accept and recognize the authority of the colonial state. ${ }^{175}$

As in the earlier argument above, the revenue imperative of the colonial state and the labor demands of the settlers also helped to undermine the implementation of the civilizing mission. As the state needed revenue for its operations, and as the settlers needed African labor to enhance their production, they produced forms of forced labor that undermined the positive aspects of the civilizing mission. It became one of the major contradictions of colonial infiltration in Nyasaland, as the state relied on punitive taxation measures and forced labor sources, for the survival of the colonial enterprise. Clearly, that was not in the original script of the civilizing mission, as the conceptualization was undermined by the several factors. This included the fact that there were

\footnotetext{
${ }^{174}$ Tangri, "The Development of Modern African Politics and the Emergence of a Nationalist Movement in Colonial Malawi, 93-94. For similar anti-hut tax demonstrations in British colonial Africa, see Larry Denzer and Michael Crowder, "Bai Bureh and the Sierra Leone Hut Tax War of 1898," in Robert I. Rotberg and Ali M. Mazrui, eds., Protest and Power in Black Africa (New York: Oxford University Press, 1970), 169-212.

${ }^{175}$ Duff, Nyasaland Under the Foreign Office, 350.
} 
low levels of revenue collected by the colonial state, hence the imposition of punitive taxation measures to compel Africans to pay taxes. The fact that the supply of African labor was also erratic, where some Africans were still attached to subsistence production and others migrated to other colonies in search of labor, also undermined the colonial enterprise, which culminated in various forms of forced labor. As Anne Phillips argued elsewhere, the colonial state usually operated with a lot of constraints, either financial, recruitment, revenue collection, or accumulation. That then often compelled the colonial authorities to rely on African collaborators and the use of the state's coercive capacities. ${ }^{176}$

\section{African reactions to the alien land, labor, and taxation measures}

In significant measures, the failure to implement the civilizing mission, and the repression that characterized life under British colonial rule in Nyasaland during the period covered in this chapter, created an atmosphere of discontent against both the colonial state and most of the European settler community. The discontent appeared in multiple forms, some of which was through "passive resistance," as opposed to physical confrontation with the colonial authorities (such as "independent labor migration"), while in other cases, there was widespread violence used against the European colonists.

As alluded to in the previous chapter, there was an altercation or resistance of a traditional nature, led by the Prophetess Chanjiri in 1907, which was immediately subdued by the colonial authorities. The 1907 case bordered on native resistance to the taxation regime imposed by the colonial state, and within a short period had the impact of lowering the revenue collection by the state

\footnotetext{
${ }^{176}$ Anne Phillips, The enigma of colonialism: British policy in West Africa (London: James Curry, 1989), 10-13.
} 
authorities. ${ }^{177}$ It was not until January 1915, that further native discontent culminated into the outbreak of a major native uprising, the so-called "Chilembwe uprising," as it was led by Reverend John Chilembwe, who established an independent mission station known as Providence Industrial Mission (PIM), at Chiradzulu District. As a landowner and entrepreneur, Chilembwe and his fellow African smallholder farmers and businessmen had long harbored ambitions to compete in the colonial enterprise but had been hampered by the colonial policies of land alienation, forced labor on European-owned plantations, and the related taxation regime. Furthermore, some of Chilembwe's own flock at his mission had suffered immensely at the hands of the colonial authorities and the planters in the Shire Highlands. It was thus not surprising that the uprising begun with an attack on a European owned estate, known as the Livingstone-Bruce Estates, which bordered Chilembwe's mission station. The manager of the estate, a Mr. William Jervis Livingstone, was beheaded on $23^{\text {rd }}$ January 1915, alongside two other European males. Livingstone had long been associated with ill-treating Africans on the estate, including personally whipping his workers, and had also been implicated in the burning down of Chilembwe's church at PIM, as Livingstone argued that the church had been built on land that belonged to the Livingstone-Bruce Estates. ${ }^{178}$ In their actions, Rev. Chilembwe and his accomplices seized upon the grievances of their fellow Africans, and took up the mantle of trying to recreate the fabric and organization of the colonial state. Mekki Mtewa argued elsewhere that Chilembwe "played a Marxian game of an intermediary between those who possessed the means of production (the

\footnotetext{
177 Tangri, "The Development of Modern African Politics, 1-72. See also Colonial Annual Report, Nyasaland Protectorate report for 1907-08 (London: HMSO, September 1908), 22. For a rebellion of a similar nature and around the same time, see Jonathan Crush, "colonial coercion and the Swazi tax revolt of 1903-1907," Political Geography Quarterly 4, no.3 (July 1985): 179-190.

${ }^{178}$ Bridglal Pachai, Malawi: The History of the Nation. (London: Longman Group Limited, 1973), 220-221. See also Nyasaland Rising Commission of Inquiry (Zomba: Government Printer, 1916), BNA: WO/106/262. See also John McCracken, ed., Voices from the Chilembwe Rising: witness testimonies made to the Nyasaland Rising Commission of Inquiry, 1915 (Oxford: Oxford University Press, 2015), 572-574. This contains Mrs. Katherine Livingstone's written statement to the Commission of Inquiry, submitted on 2 February 1915.
} 
colonial state and the European settlers) and those who did not (the Africans)." ${ }^{179}$ The grievances of the Africans in the Protectorate were presented to the commission appointed to inquire into the major causes of the uprising. Among the key witnesses were Rev. Stephen M. Kundecha of the Blantyre Mission, Rev. Harry Kambwiri of the Church of Scotland Mission, the African businessman, Joseph Bismarck, and Elliot Kamwana of the Watch Tower Movement. Among the key issues raised were the following: demands for better housing conditions; demands to be offered opportunities to do business; disappointments of poor treatment by their European superiors at work and hatred of the thangata system; the freedom to cut trees for household use and to hunt wild animals; the ill-treatment of African soldiers during the war (First World War); the need for more comfort whenever an African was sentenced to death; the calls for the government to pay more attention to African petitions; the calls for periodic meetings between African representatives and the government; demands by Africans to be allowed to wear clothes and hats of their choice; the need for British laws to be translated into local languages; and the calls for a fairer taxation regime, one that was not abused by the government and European settlers. ${ }^{180}$

It was not until $3^{\text {rd }}$ February 1915 , that Chilembwe was himself captured and subsequently executed, alongside his brother, Morris, as they tried to escape into neighboring Portuguese East Africa, thereby officially marking the end of the uprising. The execution of the two fugitives was one of a series of "illegal" acts by the colonial authorities, as it contravened the "The Fugitive Offenders Act of 1881," which required that fugitives be pursued and brought before a magistrate

\footnotetext{
${ }^{179}$ Mekki Mtewa, "Problems of Oedipal Historicism: The Saga of John Chilembwe - the Malawian," Journal of Black Studies - African Cultural Dimensions, 8, no.2 (December 1977): 240-241.

${ }^{180}$ McCracken, ed., Voices from the Chilembwe Rising: witness testimonies made to the Nyasaland Rising Commission of Inquiry, 132-137, 142-159, 160-184 and 230.
} 
court. ${ }^{181}$ Most likely the colonial authorities did not want to raise another spectacle by bringing Chilembwe and his brother to a court of law.

\section{Conclusion}

This chapter has contributed to the historiography of Malawi's early colonial history, focusing on the late nineteenth century and early twentieth century, a historical period which defined the subsequent trajectory of British colonial rule in the country. The major focus has been on critically analyzing how the notion of the "civilizing mission" came to be applied in what was then called the Nyasaland Protectorate, which was used to justify, on moral and ethical grounds, Britain's colonial expansion. The analysis revolved around three major areas: colonial land, labor, and taxation policies vis-a-vis the revenue and accumulation imperatives of the colonial state. While one could argue that the original formulation of the civilizing mission did not have ill intentions, there were various local and empire-wide constraints that revolved around the system of land tenure, taxation and labor availability that ended up undermining the mission. What emerged on the ground, especially in the aftermath of the Berlin Conference, and the intrusion of the capitalist class, were elements of dubious modes of land appropriation, and forms of forced labor and revenue collection. Such policies and practices created room for African discontent, and hence formed the basis of the early forms of anti-colonial agitation in the early twentieth century. The peak of the African discontent came in the form of the 1915 native uprising led by Rev. John Chilembwe, leader of the PIM in the Shire Highlands. The next chapter builds upon this and analyzes the various forms of counter-insurgency measures employed by the state during the inter-

181 "The Fugitive Offenders Act, 1881," Orders of the King in Council Relating to the Nyasaland Protectorate, in force by $31^{\text {st }}$ December 1913 (Zomba: Government Printer, December 1913), 143-146. 
war period. It focuses on the use of excessive force and the offer of development opportunities as some of the measures employed by the colonial state. 
CHAPTER FOUR

THE WINNING OF HEARTS AND MINDS DURING AND AFTER THE 1915 AFRICAN UPRISING

Every punishment which is not derived from absolute necessity is tyrannous, says the great Montesquieu, a proposition which may be generalized as follows: every act of authority between one man and another which is not derived from absolute necessity is tyrannous. ${ }^{182}$

\section{Introduction}

This chapter discusses the counter-insurgency measures employed by the colonial state to suppress African resistance in Nyasaland during the period between 1915 and the late 1930s. I argue that the state counter-insurgency measures operated at two levels, figuratively described as "a carrot and a stick". Firstly, there was the use of brutal force, which included capital punishment (which came in the form of public executions or hangings for those alleged to have been directly involved in the native uprising); the turn to "para-military" group tactics through the Nyasaland Volunteer Reserve (NVR); the burning down of structures belonging to the insurgents; enacting strict laws of censorship; and also forcibly detaining and deporting some of the felons. Secondly, the colonial authorities also resorted to using tactics that were aimed at making one's association and support for the colonial state more attractive or appealing than supporting the "rebels" behind the uprising. By the 1920s and 1930s, such measures included the initiation of development and welfare programs that were for the benefit of the colonized in line with the tenets of the "civilizing mission." In doing so, this chapter argues that the origins of the development initiatives of the Nyasaland government were in significant measures influenced by the demands of the Africans,

\footnotetext{
182 Richard Bellamy, Beccaria: On crimes and punishments and other writings (Cambridge: Cambridge University Press, 2003), 10.
} 
some of which formed the backbone of the 1915 African uprising. The colonial state's response to meet such demands, was in many times against the needs of the "gentlemanly capitalists" then operating in the protectorate. I will also adopt the political-economy approach to focus on how the colonial state re-organized and upgraded its police force, following the findings and recommendations of the commission of inquiry, which had been instituted to investigate the causes of the uprising. The Nyasaland police force from then onwards became one of the major weapons of the "interventionist state", alongside the law, aimed at both detecting crime, preventing crime, and political surveillance.

\section{The use of brutal force}

The colonial authorities, initially caught unawares by the "sudden" occurrence of the 1915 native uprising, resorted to the use of brutal force through the armed forces from the King's African Rifles (KAR) and the Nyasaland police force. The use of brutal force was merely a continuation of the violence which characterized British colonial rule in most of colonial Africa, including Nyasaland, as a means of establishing domination and to deter others from challenging the authority of the colonial state.

One dimension of the assault on the insurgents was to follow the movements of Rev. Chilembwe, who had been on the run until the troops captured him alongside his brother, Morris Chilembwe, near the Nyasaland-Portuguese East Africa (Mozambique) border, in Mlanje District, on February $3^{\text {rd }}, 1915$. Despite Rev. Chilembwe's plea for mercy, as posited by Desmond D. Phiri, the askari (troops), “allegedly" Africans (Private Naluso and Sergeant Useni), deliberately executed him for fear that if they had travelled with him alive from Mlanje to Zomba (the colonial capital), it would have led to further native unrest. The Reverend's corpse was taken to Mlanje boma (district 
headquarters) on February $4^{\text {th }}, 1915$, where he was unceremoniously buried at what is present-day Esperanza Estate. ${ }^{183}$

As alluded to in the preceding chapter, the summary executions of Rev. Chilembwe and his brother, Morris were in contravention of "The Fugitive Offenders Act of 1881," to which the subjects of the Protectorate were subjected. The stated act provided that any fugitive, regardless of the crime committed had to be pursued and when captured brought before a magistrate court, which would have in the first place issued a warrant of arrest for the fugitive. However, in the case of Reverend Chilembwe and his brother, they were summarily executed without even being brought to a court of law, as the askari simply "took the law into their own hands" to mercilessly execute the two gentlemen. ${ }^{184}$ As Crawford Young noted, there was often the "temptation" by the colonial administrators to turn to "arbitrary authority", which was vested in the officials of the colonial administrations - such as judges, police chiefs, military commanders, prison staff - who could sometimes take matters in their own hands to interpret and implement what they felt was legally binding. ${ }^{185}$

From the correspondences exchanged between the Governor of Nyasaland and the Secretary of State for the Colonies, we also get a picture of how the British Government was involved in suppressing the native uprising. Governor George Smith sent a dispatch of the uprising to London, indicating its severity, especially referring to the murders of several Europeans and the attack on the government storehouse at Mandala in Blantyre. He reported to the Colonial Office (CO) that

\footnotetext{
${ }^{183}$ Desmond D. Phiri, Let Us Die for Africa: An African Perspective on the Life and Death of John Chilembwe of Nyasaland/Malawi (Blantyre, Malawi: Central Africana Ltd, 1999), 87. See also David Stuart-Mogg, "A Brief Investigation into the Genealogy of Pastor John Chilembwe of Nyasaland and Some Thoughts upon the Circumstances Surrounding his Death," Society of Malawi Journal 50, no. 1, 1997): 52-53.

184 "The Fugitive Offenders Act, 1881," Orders of the King in Council Relating to the Nyasaland Protectorate, in force by $31^{\text {st }}$ December 1913 (Zomba: Government Printer, December 1913), 143-146.

${ }^{185}$ Crawford Young, The African Colonial State in Contemporary Perspective (New Haven: Yale University Press, 1994), 107-116.
} 
he had called for reinforcements from the King's African Rifles and Portuguese East Africa. By January $28^{\text {th }}, 1915$, he sent another report to the CO, in which he reported that Rev. Chilembwe had not yet been captured, but that some rebels had been captured and three of them had been executed. On February $3^{\text {rd }}, 1915$, the day of the capture and subsequent murder of the Reverend, the CO informed Governor Smith that the British Government had sent more reinforcements from the War Office to help combat the uprising, as well as four maxim guns on tripod mountings, and 80,000 rounds of ammunition from British-controlled Ceylon. ${ }^{186}$

Aside from the executions of Rev. Chilembwe and his brother Morris, it also became imperative for state authorities to "rush to justice" to try the suspected accomplices and supporters of the uprising. Most of those suspected of being close allies of Rev. Chilembwe were handed capital punishment sentences and were summarily executed in public view. It must be noted that in England (hereafter the metropole), punishment by public execution had already been repealed by an Act of Parliament in 1868, and therefore it was hypocritical not to apply the same principle to felons in the colonies. Randall McGowen indicates that the calls for putting an end to public executions in England dated as far back as the mid- $18^{\text {th }}$ century, when those opposed to the practice argued that public hangings lacked the element of respecting human dignity. Leading English scholars and thinkers such as Henry Fielding and John Scott had for some time argued that the public hangings, apart from being poorly organized, also tended to corrupt public morality because of the violence which they promoted. Further to that, the scholars argued that violence, in whatever form, severed the link of civilization and sensitivity to human suffering, and rendered one insensitive to others, and even went further to insinuate that there was but a slight distance between

\footnotetext{
${ }^{186}$ Operations in Nyasaland: Dispatches exchanged between the Governor of Nyasaland and the Secretary of State for the Colonies, August 1914 to January 1916, British National Archives (hereafter BNA): WO/106/571.
} 
watching a public execution and committing a murder. In the British Parliament, the Liberals had for some time argued that public executions merely repeated the crime for which the offender committed, and that judicial murder was like any form of murder, which was contrary to Western tenets of civilization. ${ }^{187}$

Stacey Hynd has also contributed to the study of the history of public execution in British colonies, including Nyasaland. Her work suggests that it was a common practice by the British colonists to use public executions as a favorite form of public spectacle and citizenship lesson. The methods of execution were often based on the outlawed British models, but also adopted some local practices. In Nyasaland, for instance, the colonial authorities preferred to employ or use public hangings, which she argued was necessary for the British officials on the ground to continue with barbaric acts to convey the message of British power, order and the necessity of obeying the law. To do so, the state authorities allowed for the general public, especially male adults and members of the condemned person's village, to bear witness to the public hangings, in order to maximize the deterrent impact. ${ }^{188}$

The selective application of court sentences in the Protectorate (a common occurrence in other overseas British colonies, as highlighted in chapters 2 and 3 of this study) thus presented another aspect of the contradictions of the "British Empire Project." 189 One would have expected that this

\footnotetext{
${ }^{187}$ Randall McGowen, "Civilizing Punishment: The end of the public execution in England," Journal of British Studies 33, no.3 (July 1994): 257-277.

${ }^{188}$ Stacey Hynd, "Decorum or Deterrence? The politics of execution in Malawi, 1915-66," Cultural and Social History 5, Issue 4 (2008): 437-439. There were similar cases of public executions in other British colonies in Africa well into the post-World War II era. See for instance, David Anderson, Histories of the hanged: The dirty war in Kenya and the end of Empire (New York: W.W. Norton and Company, 2005). See also Caroline Elkins, Imperial Reckoning: The untold story of Britain's gulag in Kenya (New York: Henry Holt and Company, 2005).

189 The concept of "The Empire Project" was coined by John Darwin. He argued that between 1830 and 1970, the British authorities had created a "British-world system" with London as its center. From London, the British coordinated the administration of an empire which encompassed peoples of different nationalities and continents. The "project" also included colonies of rule, settlement colonies, protectorates, mandates, naval and military fortresses, informal colonies, spheres of interference, occupations, and treaty ports and concessions. See John Darwin, The
} 
being an "Empire" there would have been a uniform application of legal values and court sentences, and that acts that had been deemed to be primitive and barbaric in the metropole would also be deemed as such in the periphery of empire. In the case of Nyasaland, while we know that in total, 36 Africans ${ }^{190}$ were publicly executed as punishment for partaking in the 1915 uprising, we do not have the complete statistics of the number of Africans who perished during the period of the uprising, as there were some unrecorded cases where Africans were hunted down, whole villages set on fire and natives killed by the colonial authorities (police, soldiers, and members of the NVR). In cases where the state relied on non-state actors (especially the NVR) to conduct counter-insurgency on its behalf, it was not easy to achieve accountability. ${ }^{191}$

The public executions were not something that the colonial government could be ashamed of, especially as the colonial authorities had achieved their aim of teaching a hard lesson to those involved in the rising. The local print media covered several headlines to publicize the punishments handed out to the Africans. For instance, The Nyasaland Times of February $4^{\text {th }}, 1915$ had the following entry:

Since our last issue nothing of note has transpired. The country is now quiet. Many arrests have been made of those who participated in the murders and the raids and most of the ringleaders have been imprisoned. Among those who are alleged to have taken part and who have been arrested and are now awaiting trial are John Grey Kufa, Duncan Njilima, Wilson Foster, and Hugh Mataka. It is quite possible that some of these were not concerned in the trouble but their guilt or innocence will be soon proved as complete information is now in the hands of the Government....

\footnotetext{
Empire Project: The rise and fall of the British world system, 1830-1970 (Cambridge: Cambridge University Press, 2009), 1-20.

${ }^{190}$ Stacey Hynd, "The extreme penalty of the law: mercy and the death penalty as aspects of state power in colonial Nyasaland, 1904-47," Journal of Eastern African Studies 4, no.3 (2010): 547-548. Hynd notes that 50 of Chilembwe's followers were killed in battle, 36 others were publicly executed after the rising, and 300 others were subjected to collective fines and prison sentences.

${ }^{191}$ George Shepperson and Thomas Prince, leading authors on the Chilembwe uprising, note that there is no clear figure on the total number of Africans who perished in the uprising. See George Shepperson, Independent African: John Chilembwe and the origins, setting and significance of the Nyasaland Native Rising of 1915 (Edinburgh: Edinburgh University Press, 1958), 399-400.
} 
The Zomba Headman, Makangwala, who lives on Government land about eight miles from Zomba was tried by the High Court and sentenced to death in the usual manner. The sentence was carried out publicly at Zomba on Tuesday afternoon. ${ }^{192}$

The rush to justice in arriving at such death sentences was often questionable. To note that such high-profile cases bordering on treason, whose punishment was a death sentence (if found guilty) could have been concluded within a space of a fortnight, only shows how desperate the colonial authorities were to stamp their authority by turning to "the rule of law" to suppress the uprising. Another chilling entry in The Nyasaland Times of February $18^{\text {th }}, 1915$ read as follows:

During the past week there has continued an inflow of prisoners and witnesses into Zomba in connection with the Chilembwe affair. The High Court continues to deal in rotation with the large number of cases awaiting trial.

John Grey Kufa and Duncan Njilima have been found guilty of treason and sentenced to death. They were present at seditious meetings held by the late John Chilembwe and were deeply involved in his schemes. We understand John Grey made a confession to the Judge of his share in the matter. Seven other natives who took up arms have been executed. A number of natives whose part in the rising was small, they have been misled by the older and better educated boys have been sentenced to terms of imprisonment mostly of six months each with a certain number of lashes. ${ }^{193}$

Apart from the publicized executions of the felons, other atrocities were also committed by the colonial authorities, with the help of reserves from the KAR, divisions of the NVR, and policemen from across the country, who went from village-to-village, to round up those suspected of aiding the native uprising. Even some European settlers were involved in the counter-insurgency drive, an example being Mr. A.L. Bruce, owner of the Livingstone-Bruce Estates, where the Estate Manager, Mr. William Jervis Livingstone, had been beheaded during the native uprising. Mr. A.L. Bruce used his status to arrest some Africans and took written statements at his house in

\footnotetext{
192 "The Chilembwe Trouble: All Quiet," Nyasaland Times, February $4^{\text {th }}, 1915$.
}

193 “The Native Trouble: Zomba Notes," Nyasaland Times, February $18^{\text {th }}, 1915$. 
Chiradzulo. Members of the NVR also went as far as burning down and looting houses and property that belonged to suspected ring leaders such as Hugh Mataka, John Grey Kufa, and Duncan Njilima. Such village-to-village raids contributed to the rise in the numbers of fugitives most of whom made their way into the neighboring Portuguese territory of Mozambique. Landeg White noted that those captured were given summary trials and executed immediately. For instance, an African known as Hinges, was court-martialed and shot at his own village less than a kilometer from the Livingstone-Bruce Estates. Another close ally of Rev. Chilembwe, a Mr. David Kaduya, was caught while trying to escape, and was taken back to Chiradzulo boma, where he was shot in front of his estate workers. Three other accomplices of the Reverend, Wilson Zimba, Stephen Mkulichi and John Grey Kufa were hanged in public in Blantyre Township in midFebruary 1915. ${ }^{194}$

The African authorities (chiefs and headmen) from the concerned and suspected villages were also required to travel to the district headquarters (the boma) to make their statements before a resident magistrate, where they were coerced into making statements pleading their own innocence and that they would report to the colonial authorities the appearance of any such fugitives in their areas of jurisdiction. ${ }^{195}$ Apart from soliciting the support of the Chiefs, the colonial authorities also utilized the support of their Portuguese counterparts in neighboring Mozambique, where some of the fugitives had escaped to, from where intelligence gathered by the Portuguese authorities indicated that the fugitives had been planning to re-launch an assault on Nyasaland. One such exchange of intelligence notes read as follows: "Governor of Nyasaland reports that fugitive rebels

\footnotetext{
${ }^{194}$ Landeg White, Magomero: Portrait of an African Village (Cambridge: Cambridge University Press, 1989), 140143.

195 See for instance, Chief Fundi Matandika's Affidavit, BNA: CO 525/62. The Chief denied that any of his men had been involved in the native uprising, and that Chilembwe's men had not used his village in transit, hence he asked the colonial authorities to exempt his men from being fined.
} 
of native rising in Protectorate armed with rifles have established themselves in Portuguese East Africa just over border east of Lake Chilwa and have threatened Nyasaland natives approaching their villages. Please urge strongly that Governor General may be instructed to comply with urgent request which is being made to him for removal of these men from the frontier."196

Further references to intelligence-sharing and support from Portuguese East Africa were also mentioned in correspondences at the CO, including one from Sir Herbert Read to Sir George Fiddes, at the beginning of May 1915. Part of their communication relating to Nyasaland which indicated the sophisticated nature of counter-insurgency measures, read as follows:

This is the Governor's third dispatch ... reporting on the native rising. The rebellion has been completely crushed and steps have been taken against the majority of those who supported John Chilembwe, the rebel leader. A Commission of Inquiry under Judge Grant has been set up to investigate the whole question of the origin and cause of the rising, and the question of what is to be done with various missionary bodies is to await the Commission's report. All this is very good and efficient work and reflects great credit on the Nyasaland administration....

It will be remembered that the Governor telegraphed in February...to ask for Indian reinforcements. To obtain Indian troops was quite impossible, as well as inadvisable, and it was arranged that should an Emergency arise, assistance should be obtained from Portuguese East Africa by the Governor, through active Portuguese assistance was only to be invoked in the last resort. ${ }^{197}$

It is also captivating to note that the sharing of intelligence between the Nyasaland and Mozambican Governments continued beyond the 1915 uprising. For instance, after the First World War, we learn of another impending native uprising which was detected through confidential dispatches exchanged between the leadership of both governments. The rumored uprising was

\footnotetext{
${ }^{196}$ Foreign Office to Sir L. Carnegie in Lisbon. Telegram. February $7^{\text {th }}, 1916$, BNA: CO 525/70. See also memo from Mr. J.C. Casson, the Superintendent for Native Affairs in Nyasaland to the Chief Secretary. Confidential. April $11^{\text {th }}$, 1916, BNA: CO 525/67. That memo listed names of 17 rebels who were captured in Mozambique and were sent back to Nyasaland to be tried.

${ }^{197}$ Memo from Sir Herbert Read to Sir George Fiddes. Confidential. June $18^{\text {th }}$, 1915, BNA: CO 525/61.
} 
planned to take place in the Central Angoniland Province (Ntcheu District) in 1919, organized by the Ngoni peoples on the border between Nyasaland and Mozambique. One of the dispatches exchanged between the two governments read as follows:

...As it may interest Your Excellency I beg to inform you that H.E. the Acting Governor of the Tete District reports, on the $26^{\text {th }}$ instant (April), that the Administrator of Angonia states unofficially, from information imparted by 'Britishers' to the Guarda fiscal (constable) and others, that the Natives in the British Territory are badly disposed and that there will soon be a rebellion. Apparently it is chiefly in the southern part of British Territory that there are signs of rebellious tendencies, and that the cause of the ill-feeling among the Natives, which has shown itself for a long time, is the forcible recruitment carried out for war purposes. ${ }^{198}$

As indicated above, one other important resource used by the Nyasaland Government was the NVR, which was a "para-military"199 wing of the state, responsible for helping to maintain law and order on a day-to-day basis, and one whose members would be needed in the event of an emergency or internal trouble. The membership of the NVR were also more important to the colonial state because they played key roles in a number of areas, including the production of food and revenue generation (because they employed native laborers from whom the colonial state drew the hut taxes; and also because the state directly taxed the import and export services it offered to the European settlers), a process described as "the coming together of economic and political forces." 200 The NVR was established in 1901, and its membership was only opened to British citizens resident in Nyasaland. It began to appear in official colonial annual reports in the 1902-03

\footnotetext{
${ }^{198}$ Dispatch from Jose de Almeida (The Chief of the General Staff, at Lourenco Marques in Mozambique), addressed to H.B.M. Consul General in Mozambique and to the Nyasaland Government, June $11^{\text {th }}$, 1919. Malawi National Archives, hereafter MNA S2/25/19.

199 The notion of "para-military" as used in this study refers to the creation of an unofficial entity, but one which has powers like the military or a police force.

${ }^{200}$ See for instance, Michael Havinden and David Meredith, Colonialism and Development: Britain and its Tropical Colonies, 1850-1960 (London: Routledge, 1993), 16-21. The two scholars argued that in the tropical colonies, there were clear-cut instances where the state worked together with the European settlers to stifle the rise of an indigenous capitalist sector, and that colonial governments benefited from associating with the European producers and traders because the governments in question derived much of their revenue from the taxes on imports of such capitalists.
} 
annual report, where it was clearly stated that it was a grouping only open to European settlers resident in the Protectorate, who were earmarked for "para-military" training on a yearly basis. By the 1902-03 fiscal year the group's membership stood at 96 and had four sections across the Protectorate. The Blantyre section had 34 members; Zomba had 31; Chiromo had 19; and Fort Johnston had 12, making a total of 96 reservists. $^{201}$

In the 1907-1908 fiscal year the Legislative Council "officially" reorganized the NVR and began to allocate direct state funding to the activities of the group's various sections, providing the reserves with a grant of $£ 600$ for that year to be used for purchasing firearms. In 1908 , the "Volunteer Reserve Ordinance" also allowed for the appointment of an organizing secretary as the officer responsible for the general works of the NVR. In 1913, the post of staff officer was also created and was filled by Major C.W. Barton, C.M.G., D.S.O., Northamptonshire Regiment. ${ }^{202}$

In 1908, the enactment of Ordinance Number 18 of that year, also provided what became the key guiding principles of the NVR's various sections. Some of the key guiding principles were as follows: (1) For a section to be established, the organization had to submit names of not less than ten persons of over the age of 16 for approval by the Governor through the District Resident of the district in which its headquarters were to be fixed. Thereafter, the Governor was supposed to Gazette the Section to signify official state approval; (2) each section was only allowed to exist so long as the number did not fall below ten registered members. In case of a drop in the numbers below ten, all arms and other articles issued were supposed to be returned to the state, unless there

\footnotetext{
${ }^{201}$ Great Britain, Report on the Trade and General Condition of the British Central Africa Protectorate for the year 1902-1903 (London: HMSO, September 1903), 32-33. Note that the 1903-1904 Annual Report indicated an increase in membership of NVR to 125 members, all Britons.

202 "Nyasaland Volunteer Reserve, History," MNA: S1/397/31. This file contains an entry by Governor Thomas Shenton Whitelegge Thomas, who oversaw Nyasaland from 1929-1932, who wrote on the history of the NVR since 1908. His minute is dated February $5^{\text {th }}, 1931$.
} 
were special orders not to do so; (3) each section was supposed to hold an annual general meeting to be held in the second week of January, or a date to be determined by the government; (4) the members of each section were also required to attend the musketry course, with guidance from the National Rifle Association under agreeable army musketry regulations; (5) for one to be regarded as a full-time member of the NVR they had to (a) complete the musketry course; (b) undergo fifteen hours of military instruction at a section headquarters or under special arrangements made by the staff officer; (6) each section was entitled to draw 200 rounds of ammunition per annum free of charge, on account of each registered member who would fire thirty rounds on a range. Each Section was also entitled to purchase additional ammunition, at a cost price, up to 300 rounds per annum, or even more, as sanctioned by the Governor; (7) each section secretary was supposed to draw rifles, ammunition and equipment from the Organizing Secretary, who was responsible for the Quartermaster of the Kings African Rifles for them; (8) every registered member of a section was to be provided with a government rifle on his entering a bond with or without sureties; and (9) all the rifles handed out by the government remained government property and were not transferable to any other member of the section without the sanction of the section secretary. ${ }^{203}$

It was from the ranks of those with para-military training and allegiance to the colonial state such as members of the NVR, that Governor George Smith called to help in the suppression of the insurgency, both as patrol and combat officers when the 1915 uprising broke out. The reserves, for instance, were responsible for the capture of some of Rev. Chilembwe's accomplices, including those who were publicly executed, such as Wilson Zimba, Stephen Mkulichi and John Grey Kufa - who were all given summary trials and executed by hanging, allegedly on a large tree outside

${ }^{203}$ Nyasaland Protectorate, Proclamations, Rules and Notices Relating to the Nyasaland Protectorate in force on the $31^{\text {st }}$ December 1914 (Zomba: Government Printer, 1915), 17-23. 
the Town Hall in Blantyre Township. ${ }^{204}$ The NVRs were also responsible for extensive looting and the destruction of Rev. Chilembwe's church at Providence Industrial Mission Headquarters in Chiradzulo. They were also associated with numerous atrocities, the most chilling of which was their involvement in the public execution of suspected followers of Rev. Chilembwe, which meant that the NVRs had assumed powers both to police and try native "criminals" even though most of them had no legal training. Peter Charlton noted such atrocities in the following description:

One of Chilembwe's lieutenants and best men, the ex KAR Askari, John Kaduya, was shot and badly wounded in the leg during the fighting.... That same Monday, the four prisoners from the abortive assault on Mandala (the government storehouse) were put on trial. They confessed their involvement in the attack, and were tried, convicted and shot by an NVR firing party against the walls of the European prison in Blantyre later that afternoon. There was a large crowd present and the bodies were left where they fell until the following day. The firing party consisted of eight members of the Blantyre Section of the NVR: Messrs. Roe, Morrison, Fairbrother, Apps, Miskin, Haarseth, Jones, and J.A. Brown. It was the first of a number of similar quick trials meant to teach other potential supporters of Chilembwe a lesson in advance. ${ }^{205}$

British and Nyasaland government records also indicate that by August 1914, when Nyasaland was drawn into the hostilities of the First World War in German East Africa (Tanganyika), the NVR was also asked to supply its members to fight on behalf of Britain. By August 1914, the NVR had 181 members in seven sections, most of whom were in the Shire Highlands. Furthermore, the outbreak of the war also gave an immediate impetus for recruitment, such that about 400 more Britons joined the NVR, some coming from outside the Protectorate. By 1918, the membership of the NVR had swollen to 455 reserves, of whom 158 members saw service in the fighting line, and 180 were employed in various capacities on the lines of communication and at the bases in

\footnotetext{
${ }^{204}$ Peter Charlton, "Some Notes on the Nyasaland Volunteer Reserve," The Society of Malawi Journal 46, no.2 (1993): 35-38.

${ }^{205}$ Peter Charlton, Cinderella's Soldiers: A History of The Nyasaland Volunteer Reserve (United Kingdom: Dolman Scott, 2010), 97.
} 
connection with transport, supplies, and other such roles. 51 of the reserves received commission into the KAR and other branches of the Nyasaland Field Force. 21 of them were killed in action or died on active service, while large numbers were wounded or invalidated. ${ }^{206}$ After the end of the hostilities, the NVR continued to exist, and by 1932, it had ten sections at Zomba, Blantyre, Limbe, Indian Section, Mlanje, Fort Lister, Chiradzulu, Port Herald, Namwera, Dedza, and Mikolongwe. Enrollment rules and regulations were put in place for members to take the oath of allegiance that they would be required to appear for military service within the Protectorate when called out by the governor. ${ }^{207}$

This section has discussed the use of brutal force to suppress the 1915 uprising. These have been extensively covered by other earlier works on the subject, including those by Landeg White, Stacey Hynd, and George Shepperson and Thomas Price, as cited above. The "less brutal" or "non-brutal" measures utilized to suppress the uprising are however often omitted in Nyasaland's historiography. These included the use of fines, deportations and censorship, and later by the late 1920s, the use of development initiatives. All these efforts were aimed at deterring the recurrence of another uprising. Such measures will be discussed in the section that follows, with the argument that African agency became one of the primary forces towards the enactment of colonial era development policies and initiatives.

\footnotetext{
${ }^{206}$ Sir Charles Lucas, ed., The Empire at War, Volume 4 (London: Oxford University Press, 1924), 273-280. See also Minute from The Assistant Chief Secretary at Zomba to the Section Secretaries of the NVR, May $7^{\text {th }}, 1915$, BNA: CO 525/63. The Governor called for an increment of the numbers of Reserves involved in the defense of the Protectorate. See also BNA: CO 525/63: Minute from the Staff Officer, NVR, at Zomba to the Hon. Chief Secretary, November $12^{\text {th }}, 1915$, BNA: CO 526/63.

${ }^{207}$ A Handbook of Nyasaland (London: Crown Agents for the Colonies, 1932), 428-429.
} 


\section{Fines, Deportations, and Censorship}

This section analyzes how the colonial authorities also turned to the use of "soft-power" (or "less brutal") measures of counter-insurgency, through the imposition of fines and deportation of some of the "insurgents" and by enacting new rules and regulations on censorship. In their study of the development of "punishment” in Western societies, Georg Rusche and Otto Kirchheimer argued that it was not uncommon for European liberal societies to punish offenders and that such punishments were a means of providing protection and order to society. Punishments, such as imprisonment helped to contain offenders for some time, and where necessary to re-integrate them in society as useful members. The liberals also viewed the end result of punishment or penal treatment as being better than direct revenge or retribution; although in actual sense it is not possible to separate any form of punishment from revenge or retribution, as the two processes often work hand-in-hand to protect and promote social values that are deemed desirable by any particular society. One of the most commonly-given punishments were monetary fines, which were regarded as lesser punishments and were usually targeted at or reserved for specific upper classes - especially in times when the lower classes had limited access to finances. However, once money began to regularly circulate by the mid-nineteenth century, the fine became the most go-to form of punishment as a means of taking away wealth from criminals. The proponents of punishments through monetary fines argued that it was a good, cost-effective method because it cost nothing to the state while it procured the maximum penal effect. In using the fine as a form of punishment, the society, as represented by the state, received damages for the wrongs done instead of having to pay the costs of punishment in case of imprisonment. ${ }^{208}$

\footnotetext{
${ }^{208}$ Georg Rusche and Otto Kirchheimer, Punishment and Social Structure (New York: Russell and Russell, 1968), 166-169.
} 
The subject of deportation of convicts in the British Empire was historicized in the work of Javier Bleichmar, who acknowledged that there have been scholarly and legal debates on whether deportation of criminals is a punishment or not. His argument was that the framers of the "deportation court sentence" in the British Empire had always settled for deportation as a form of punishment, alongside other forms of punishment such as imprisonment or the death penalty. Bleichmar traced the banishment of criminals in the British Isles to as early as the twelfth-century when Anglo-Saxon institutions used banishment or deportation as a form of punishment. In those societies, anyone who committed a crime would first flee for refuge to consecrated soil for sanctuary, usually a sacred place that under Christian tradition would protect a man from punishment. The criminal then had 40 days after taking sanctuary to confess to the crime and take an oath to leave the kingdom and not return unless permitted to do so by the Crown. A convict's confession often gave them a safe passage to an assigned port from which departure from the kingdom was mandatory. However, due to public opposition to this form of punishment, in 1623, King James I abolished the punishment of banishment altogether. It was not until the early $18^{\text {th }}$ century that the punishment of banishment (or transportation) would re-appear in English society. Its proponents argued that it was a merciful act, in that the convict was provided an opportunity to make a fresh start in a new land. The punishment also served the state by removing from society individuals who had proven to be a danger to the community - like the death penalty.

As such, in late 1717, the "Transportation Bill" was introduced in the House of Commons, which led to the enactment of the "Transportation Act of 1718." Those who supported the bill argued that it would serve the purpose of relieving the society from robbery, burglary, and other felonies. The Transportation Act was revolutionary in terms of the administration of punishment in three key areas: Firstly, it created a statutory basis for a middle alternative to the death penalty and 
benefit of clergy. From then onwards, "transportation" became the normal sentence for those convicted of "clergyable" offences - such as the receiving and buying of stolen goods. Secondly, the act also gave the courts powers to directly order felons to be transported, but also to directly contract private merchants for the transportation of the felons. Previously, the final decision of transportation of convicts was made by the Crown after referral by the courts. Lastly, the act also allocated public funds to ensure that felons were in fact taken to the colonies and not let loose by unscrupulous merchants. The act provided that merchants would be paid a fee of $£ 3$ by the Treasury for each convict to be taken across the Atlantic. ${ }^{209}$

In the 1915 uprising in Nyasaland, a significant number of Africans, sometimes whole villages, were subjected to the punishment of paying fines for their role in the uprising. The fines in question had the approval of the British government, through the then Secretary of State for the Colonies, Andrew Bonar Law. The following minute illustrates that "seal of approval" from the British government: "I have the honor to acknowledge the receipt of your dispatch No.126 of the $21^{\text {st }}$ of June and to inform you that I approve of your action with regard to the infliction of fines on natives in certain districts in connection with the native rising." ${ }^{210}$ The orders for fines as a form of punishment emanated from the Collective Punishment Ordinance of 1909, from which Section 2(a) provided for a collective punishment to groups of people deemed to have colluded with or harbored or failed to take all reasonable means to prevent the escape of any criminal. ${ }^{211}$

\footnotetext{
${ }^{209}$ Javier Bleichmar, "Deportation as Punishment: A Historical Analysis of the British Practice of Banishment and its Impact on Modern Constitutional Law," Georgetown Immigration Law Journal 14 (Fall 1999): 115-126.

210 'Minute from Andrew Bonar Law, Secretary of State for the Colonies, to Governor George Smith of the Nyasaland Protectorate. June 1915': CO 525/65. Note that, elsewhere in British colonial Africa, fines had also been imposed as a form of punishment prior to the Nyasaland uprising of 1915. See for instance, Larry Denzer and Michael Crowder. "Bai Bureh and the Sierra Leone Hut Tax War of 1898", in Robert I. Rotberg and Ali M. Mazrui, eds., Protest and Power in Black Africa (New York: Oxford University Press, 1970), 169-212.

${ }^{211}$ Memorandum on the Orders made under the Collective Punishment Ordinance, 1909, in Nyasaland dispatch No126, June 21 ${ }^{\text {st }}$, 1915, BNA: CO 526/62.
} 
The Executive Council meeting of March $30^{\text {th }}, 1915$ analyzed intelligence reports indicating that some villages in the central and southern provinces had colluded with the "rebels" and had not rendered due assistance to the government. A fine of four shillings was fixed for those convicted an amount which was the equivalent of half the hut tax. The Executive Council passed the following resolution: "The Council advised and His Excellency ordered that under Section 2 the Ordinance should be applied to particular areas or localities where it has appeared that the inhabitants thereof had colluded with the authors of the rising and had not given active assistance in apprehending the rebels but that the question as to the exact areas, localities or villages to which the Ordinance should be applied be further considered on the receipt of Residents' reports on the subject." ${ }^{212}$ Below is a sample of how the orders to punish African felons through the payment of fines were worded:

I have the honour to inform you that it has been decided to impose the Collective Punishment Ordinance, 1909, to the following areas in your district, viz:- ... (certain areas as defined by the Executive Council with boundaries herewith set forth) on the ground that the inhabitants of such areas have colluded with the rebels and have not rendered that assistance expected of them in connection with the quelling of the recent native rising.

You should summon before you Chiefs of the District, take such evidence as in your opinion would be sufficient to prove the charge and then call upon the Chiefs to show cause why the Ordinance should not be applied.

I shall be obliged by your holding the enquiry as soon as possible and returning the minutes to me without delay. ${ }^{213}$

\footnotetext{
${ }^{212}$ Memorandum on the Orders made under the Collective Punishment Ordinance, 1909, in Nyasaland dispatch No.126, June 21 $1^{\text {st }}$, 1915, BNA: CO 525/62.

${ }^{213}$ Memo from Attorney-General, Allan Hogg, at Zomba and addressed to the District Residents at Zomba, Mlanje, Chiradzulo, and Ntcheu, April 28 ${ }^{\text {th }}$, 1915, BNA: CO 525/62. Note that in these Orders, the targeted Chiefs and their subjects were already suspected to be "guilty and hence had to prove their innocence," a verdict which was unthinkable under those conditions. For reference to see where these fines were implemented see BNA: CO 525/62: Official memo from the Nyasaland Government, June $16^{\text {th }}$, 1915, where Chiefs Kaduya, Fundi, Mkanda in the southern province were punished under the 1909 Ordinance.
} 
It is important to note that the application of these collective punishments under the Collective Punishment Ordinance, 1909, only helped to "legalize" and perpetuate British colonial dominance and repression. Most of the Africans subjected to the fines were already presumed "guilty" and subjected to the "staged" inquiries where they were expected to prove their innocence under district magistrates, who themselves were part and parcel of the colonial administrative machinery. Furthermore, the fines that were imposed, half the rate of a hut tax, were another form of state-led exploitation of the native peoples - whose land, labor and revenue had already been appropriated by the state authorities, as discussed in chapter three of this study. It was also immoral, insensitive, inhumane and unmerciful on the part of the British officials in the Protectorate to punish the Africans at a time when they were most needed to "fight for Britain" and the Empire in the First World War, with troops from Nyasaland essential in protecting Britain's East African interests and imperial possessions.

As already alluded to, it was common practice across the British Empire to deport felons since the twelfth-century, and later through the Transportation Act of 1718. In Nyasaland, the colonial authorities adopted the same principles during and after the 1915 uprising. The sentence of transportation or deportation had already been "legalized" or formalized through the enactment of the British Central Africa Order-in-Council of 1902, which had some of the following conditions: First, where an offender convicted before any court was sentenced to imprisonment, the commissioner, later governor, acting under Section 7 of the Foreign Jurisdiction Act of 1890, had the powers to order the convicted felon to be removed to some part of His Majesty's dominions out of the United Kingdom, and to a place where the recipient government had consented to receive the felons. Second, in cases where it was shown and proven to the commissioner that any person was conducting themselves so as to be dangerous to peace and good order in the Protectorate, or 
had been endeavoring to excite enmity between the people of Protectorate and His Majesty, or intriguing against His Majesty's power and authority in the Protectorate, the Commissioner had the powers, where he saw fit, to order that person to be deported from the Protectorate to any place as directed by the Commissioner. The said place could be in any of His Majesty's dominions, and that the convicted felon had no right to appeal against the Commissioner's decision or verdict. Third, where a person was deported and decided to return to the Protectorate without the permission in writing of the Secretary of State, that person was deemed guilty of committing an offence and liable on conviction to imprisonment for any period not exceeding three months, with or without a fine not exceeding $£ 50$, after-which the person could be deported again. ${ }^{214}$

The deportations that took place in Nyasaland received the full blessing of the British Government under the sanctions of an Order of His Majesty in Council, and was communicated to Governor George Smith, and later included in the Nyasaland Government Gazette of August 29 ${ }^{\text {th }}$, 1917. Part of the British Government's approval read as follows: “...And whereas by an Order of His Majesty the King-in-Council, bearing the $12^{\text {th }}$ day of August, 1915, His Majesty, by virtue and in exercise of the powers in that behalf by the Foreign Jurisdiction Acts, 1890 and 1913, or otherwise in His Majesty vested, was pleased, by and with the advice of His Privy Council, to order that the Colonial Prisoners Removal Act, 1869, should, from the date of the said Order, apply to the Nyasaland

214 "The British Central Africa Order-in-Council, 1902", first published in the British Central Africa Gazette, October $31^{\text {st }}, 1902$. Apart from the 1902 Order-in-Council, subsequent Acts were also enacted, dealing with the question of removal of prisoners from one British overseas possession to another. The following Acts attested to that: The Colonial Prisoners Removal Order-in-Council, 1907 (other Acts also followed in 1913, 1914, and 1915). And on May $26^{\text {th }}$ 1917, under what was titled 'Agreement with Mauritius Under the Colonial Prisoners Removal Act, 1869, Sanctioned by Order, 1917', an 'Agreement' was signed between the Governments of Nyasaland, Mauritius and the British Government, to allow for the transfer of prisoners from Nyasaland to Mauritius. 
Protectorate, as though that Protectorate were, within the meaning of the said Act, a Colony not having a Legislative Body..."215

This then gave powers to the Nyasaland government in the aftermath of the 1915 uprising, in conjunction with the $\mathrm{CO}$ to collaborate and deport those suspected to have taken part or assisted in the uprising, processes that affected both Africans and peoples of Western origin. On the side of the Africans, three religious leaders, with distant connections to Rev. Chilembwe, named Pastor Elliot Kamwana, Pastor Yohane Chirwa and Pastor W. Mwenda (all from the Watch Tower Movement) were all deported to Mauritius, at the beginning of December $1916 .{ }^{216}$ The exigencies of the charges and deportation of the three members of the clergy were that they had provided support to the native uprising and also that they had been carrying and distributing documents of a seditious character in the Protectorate. In the case of Pastor Elliot Kamwana, he had already been previously deported from the Protectorate in 1909, for his religious activities, and had only been allowed back into the Protectorate in September 1914, from his exile in Portuguese East Africa. According to colonial government intelligence sources, the three pastors had not been directly involved in the planning of the native uprising, however the reports noted that the pastors knew what was going on (were privy to the plans of the uprising), and that the three religious leaders had also been caught secretly authoring their own seditious document. The Nyasaland government also argued that pastor Elliot Kamwana was a keen ally and follower of Joseph Booth, the missionary suspected to have been one of the masterminds of the uprising. Elliot Kamwana was also accused of spreading false alarms where he predicted that the world would come to an end at

\footnotetext{
215 The Nyasaland Government Gazette, November $10^{\text {th }}$, 1917. The communication to Governor George Smith was made through Lord Chamberlain (Viscount Chilston) and Sir Maurice De Bunsen (Chancellor of the Exchequer).

216 'Minute from Governor George Smith of Nyasaland to Mr. Herbert Read at the Colonial Office, January $15^{\text {th }}$, 1917': CO 525/72. See also 'Confidential memo from Governor George Smith to the Secretary of State for the colonies, dated January $15^{\text {th }}, 1917^{\prime}$ : CO 525/72. The three members of the clergy would not be allowed to come back into Nyasaland until the mid-1930s.
} 
the end of 1914, following the second coming of Jesus Christ, due to the outbreak of the First World War. ${ }^{217}$

Several Western missionaries suspected of aiding the native uprising were also subjected to the punishment of deportation. One such person was the American missionary, Mr. Walter B. Cockerill, of the Seventh Day Baptist Church, who was deported from the Protectorate under Ordinance No.11 of 1914. He was ordered to proceed to Portuguese East Africa through Port Herald in the Lower Shire, on April $6^{\text {th }}, 1915 .^{218}$ Upon receiving the deportation orders, Mr. Cockerill vehemently protested, and wrote to Governor George Smith arguing that he had done nothing wrong to be given such type of treatment. He wrote to the Governor on April $9^{\text {th }}, 1915$ as follows: "Your order directing me to leave the Protectorate received. I hereby protest that I am not an enemy of the country and have been given no reason for being treated thus. I have heretofore obeyed the orders and laws of the Government and have been engaged in missionary work which I believe I have every right to do."219

Despite his plea for mercy and reconsideration, the Nyasaland government insisted that it would not reverse its decision, referring Mr. Cockerill to the 1914 Nyasaland Defense Ordinance, enacted to maintain peace and security in the Protectorate. Part of the reply from the Nyasaland Government's representative read as follows: "The right to which reference has been made above is more particularly vested in the Governor by the Nyasaland Defense Ordinance, 1914, and His Excellency is and must be sole judge of the sufficiency of the grounds which dictate the exercise of that right in any particular case. He has decided that the continued presence in this country of

\footnotetext{
217 Correspondences between Governor George Smith of Nyasaland and Sir Herbert Read at the Colonial Office. Confidential. July to August 1916, BNA: CO 525/68.

${ }^{218}$ Memo from the Chief Secretary, Mr. H.L. Duff, addressed to the District Resident at Blantyre. Confidential. April $6^{\text {th }}, 1915$, BNA: CO 525/62.

${ }^{219}$ Letter from Mr. Walter B. Cockerill to Governor George Smith of Nyasaland, April 9th, 1915, BNA: CO 525/62.
} 
certain persons, of whom you are one, is particularly undesirable in existing circumstances by reason of their teaching which, in His Excellency's judgment, tends to unsettle and disturb the minds of the native population. ${ }^{220}$

The other strategy of counter-insurgency, closely related to the employment of fines and deportations, was the state's use of strict rules and regulations of censorship. In 1916, the Nyasaland government enacted the "British Protectorates (Defense) Order-in-Council," which began the process of strict censorship of perceived seditious publications. Under the 1916 order, the following regulations were put in force: no person, either a proprietor or a manager of a telegraph line or operator of a telegraph line in the protectorate was to be allowed to dispatch any message unless and until it was first approved by a censor; no person, whether a proprietor or a manager of a printing press was allowed to publish and circulate their publication without first getting the approval of a censor; the contravention of these rules and regulations was to be punishable by imprisonment with or without hard labor for a term not exceeding six months, or by a fine not exceeding $£ 100$, or by both imprisonment and fine, or in extreme cases one would also be sentenced to death, if found to be assisting enemies of the state. ${ }^{221}$

In May 1917, the 1916 Defense Ordinance was also amended to include some of the following terms and conditions: First, that no person was to knowingly print, publish, circulate or have in possession any publication that contained seditious articles or articles likely to promote disaffection, alarm or despondency or to interfere with the success of the British Government and

\footnotetext{
${ }^{220}$ A.M.D. Turnbull, Assistant Chief Secretary of the Nyasaland Government, to Walter B. Cockerill, April 15 ${ }^{\text {th }}$, 1915, BNA: CO 525/62. A warrant of arrest and deportation of Cockerill issued through the District Resident at Blantyre, was signed by the Chief Secretary, Mr. H.L. Duff, on $15^{\text {th }}$ April 1915.

221 "The British Protectorates (Defense) Order-in-Council, 1916," in Nyasaland Government Gazette, April 1 1917. Note that the Censors included Judges of the High Court, the District Resident of each District, the Postmaster General, and the Superintendent of Native Affairs.
} 
the Nyasaland Government. Second, no person was allowed, without lawful authority, to transmit or post or convey or attempt to convey, to or from the Protectorate, or receive or have in possession of susceptible documents, and of documents whose writing was not clearly visible. Third, that proprietors or managers or operators of telegraph lines would dispatch information only after the approval of a government-appointed censor. Fourth, that all printed material in the protectorate had to first receive the approval of a government-appointed censor before circulation to the public. Five, the punishment for those found in contravention of these laws remained the same as that of 1916 (i.e. imprisonment for a time not exceeding six months, or a fine not exceeding $£ 100$, or both fine and imprisonment). ${ }^{22}$ Just as in the 1916 Defense Ordinance, the 1917 Ordinance did not specify which publications would be deemed unwelcome or seditious, and thus left the law subject to abuse by the state authorities.

In 1918, the colonial state also enacted the "Seditious Publication (Prohibition) Ordinance" which was essential for blocking the distribution of materials or documents that could incite more native resistance. The said ordinance targeted the prohibition of publications including newspapers, books, and other documents (such as paintings, photographs, and drawings). The ordinance was essential because of the perception and discovery that the organizers of the uprising, especially Rev. Chilembwe, had been in touch with dissidents such as the missionary Joseph Booth, who had been an "enemy" of the colonial state since the late 1890s. The 1918 ordinance targeted persons resident in the protectorate found in possession of the "unspecified" publications either as a printer, publisher, importer, seller, and distributor. It was incumbent upon state authorities to determine whether the said publication would incite violence, murder, hatred, and contempt against both the

222 "The British Protectorates (Defence) Order-in-Council, 1916," The Nyasaland Government Gazette, May 25 1917. 
British government and the Nyasaland government or indeed any British colonial possession. Once the authorities had made the determination, those charged under that law, had to have their publications forfeited, destroyed or otherwise disposed of as directed by the Governor. The 1918 ordinance also provided that any person who was found guilty of the offences outlined was to be imprisoned for life, or sometimes to a pay a fine not exceeding $£ 500$ depending on the severity of the case. ${ }^{223}$

\section{Commissions of Inquiry, Counter-insurgency, and Development}

Amidst the chaos created by the uprising, Governor George Smith, with approval of the CO, constituted a Commission of Inquiry (COI), to investigate the underlying causes of the 1915 disturbances. As I will discuss in chapters five and six, the subsequent leadership of the Nyasaland Protectorate in the 1950s and later independent Malawi between 1994 and 1996, would also adopt a similar strategy to investigate past atrocities to "catch" their opponents and to implicate the culprits and perpetrators. In almost all the cases discussed in this study, it came out very clearly that the findings of such inquiries were often "doctored" to suit the views of those with positions of power, especially where the practice has historically been that the findings of these commissions should only be made public upon the approval of the authority (either the governor or the state president). The flip side of the COI reports analyzed in this study is that some of their recommendations, where implemented, brought about positive outcomes for the natives/citizens of the country and were partly responsible for the establishment of pro-native welfare programs.

\footnotetext{
223 "The Seditious Publication (Prohibition) Ordinance, 1918," in Ordinances of the Nyasaland Protectorate for Year ended $31^{\text {st }}$ December 1913 (Zomba: Government Printer, 1919). See also “Order Number 3 of 1918," The Nyasaland Government Gazette, March 23 ${ }^{\text {rd }}, 1918$.
} 
The calls for a COI to be instituted came from a number of quarters, including the Nyasaland Legislative Council, religious bodies, and also from European settlers resident in the Protectorate. The Nyasaland Legislative Council, for instance, deliberated on the causes of the 1915 native uprising during its meetings in April 1915. During the deliberations, The Honorable and Rev. Dr. Laws moved a motion that a Commission of Inquiry be appointed to consist of representatives of the key interested parties in the Protectorate, to be tasked with inquiring into the origins, cause, history and the extent or scope of the native uprising. Furthermore, he suggested that the said Commission should inquire on whether any warnings had been given to the authorities; whether various steps had been taken for the suppression of the uprising; whether there were any grievances or other causes of the native discontent; and also to suggest remedies that could be used to prevent the outbreak of further uprisings. ${ }^{24}$

In its complaints to the $\mathrm{CO}$, following the detention of its missionaries in Nyasaland, the Church of Christ Mission, through its headquarters in Great Britain, also called for the establishment of a COI, which, church authorities argued, would help to absolve the detained missionaries of any wrong doing. The leadership of the church argued that the mere connections that existed between the missionaries and some of the rebels did not mean that the missionaries had been part and parcel of the native insurgency. ${ }^{225}$ There was also pressure for a commission from other interested groups, such as the Anti-Slavery and Aborigines Protection Society, from its headquarters in London, and the influential Chamber of Agriculture and Commerce in Nyasaland. Both groups also called on

\footnotetext{
224 “The Chilembwe Trouble: The Debate in the Council," The Nyasaland Times, April 22 $2^{\text {nd }}, 1915$.

${ }^{225}$ General Secretary of the Churches of Christ Foreign Missions Committee in Great Britain and Ireland, to the Under Secretary of State, July $9^{\text {th }}, 1915$, BNA: CO 525/65.
} 
the Nyasaland government to coordinate with the British government, to institute an inquiry to investigate the origins, causes, and history of the uprising. ${ }^{226}$

It was out of this pressure and upon recommendations from the CO that Governor George Smith set up a COI in May 1915. The commission was comprised of the following personnel: R.W. LyallGrant (Judge of the High Court and Chair of the Commission); Aubrey M. D. Turnbull, Esq. (Assistant Chief Secretary); Joseph C. Casson, Esq. (Superintendent of Native Affairs); The Venerable Arthur G.B. Glossop (Archdeacon of Likoma and of the Universities Mission to Central Africa); Claude Metcalfe, Esq. (from Blantyre, and a representative of the Planting and Commercial society, as Manager of the British Central Africa Company). The Commission was appointed under the Commission of Inquiry Ordinance of 1914, which gave powers to the Governor to institute such a body to investigate matters arising in the protectorate. The commission's terms of reference were to investigate a number of issues concerning the native uprising, with four key guiding principles: (1) the origin, causes and objects of the said rising, whether it was general or confined to particular classes of Africans, to what extent it could have been attributed to false ideas acquired and disseminated by emigrant Africans who had returned to the Protectorate, to correspondence between persons resident in other countries and local Africans or to literature circulated among the more educated Africans; (2) any alleged grievances of the Africans which led to the uprising, whether against Europeans generally or against particular

\footnotetext{
226 "Petition for Appointment of Commission Presented," Extract from The African World April 24 $4^{\text {th }}$ 1915, BNA: CO 525/65. See also Anti-Slavery and Aborigines Protection Society, to Hon. Lewis Harcourt, M.P., The Principal Secretary of State for the Colonies, May 10 ${ }^{\text {th }}$, 1915, BNA: CO 525/65. According to Bernard Porter, the Anti-Slavery and Aborigines Protection Society was founded in the 1830s. And since its inception had preached about moderating Britain's imperial destiny, by among other things encouraging the spread of Christian values and justice in Britain's colonial possessions. In other words, they were proponents of the "civilizing mission", addressed in chapter three of this study. See Bernard Porter, Critics of empire: British radical attitudes to colonialism, 1895-1914 (New York: Macmillan, 1968), 50-52.
} 
classes of the community; (3) the adequacy or otherwise of the means available for obtaining information on the state of African feeling; and (4) the effects of mission teaching - religious, educational, or individual - on the African mind and character. ${ }^{227}$

It is important to note that the commission was only comprised of European colonists (judicial, administrative, missionary, and planter personnel), and left out the Africans, whose grievances contributed to the uprising. Furthermore, in the accompanying notes to be acted upon by the commission, it seemed very clear that colonial authorities knew what had led to the uprising, but only constituted the commission either to be seen as a listening or caring government or to use the findings of the inquiry to the state's own advantage and to legitimize the violence that had been targeted against the African insurgents. For instance, the accompanying notes highlighted the following sentiments: (1) to find out if the uprising had only been led by educated Africans; (2) whether one of the key grievances of the natives revolved around the question of land alienation and distribution; (3) whether the Ethiopian Movement played a role in the native uprising; (4) whether the exploitation of African labor by European settlers played a role in the uprising; (5) whether Africans were unhappy with the general administration of justice in the Protectorate, especially in cases involving Whites and other colored classes; (6) to look into the effectiveness of the Nyasaland Police and other forms of district administration; and (7) to conduct a thorough analysis of the teachings and activities of Christian mission stations, especially their influence on the African mind. ${ }^{228}$

\footnotetext{
${ }^{227}$ Dispatch from Chief Secretary of the Nyasaland Protectorate, titled: Commission of Inquiry. May $8^{\text {th }}, 1915$, BNA: CO 525/61. See also The Commission Appointed by His Excellency the Governor to Inquire into Various Matters and Questions concerned with the Native Uprising within the Nyasaland Protectorate (Zomba: Government Printer, 1916), BNA: WO/106/262.

${ }^{228}$ Attachment by Hector L. Duff, Chief Secretary of the Nyasaland Government, sent to the Commission of Inquiry Chairperson, Judge Lyall-Grant, BNA: CO 525/61.
} 
The COI, under Judge Lyall-Grant, concluded its investigation and presented its report to Governor Smith by early 1916 . The findings of the inquiry were wide-ranging, and almost all the key areas pointed to issues already known to the colonial authorities, including: first, that the uprising had been largely engineered by, and almost confined to, the educated Africans. It was the educated Africans who often complained about ill-treatment, including writing letters to newspaper editors. That finding, clearly implicated Rev. Chilembwe and his accomplices, and other educated elites in the protectorate. And yet as has been explained in chapter three of this study, the grievances which the Africans had (over land, taxation, and labor) were not just concentrated on the demands of the elites, as they affected both the African elites and the ordinary people. Furthermore, when using brutal force to defeat the insurgents, the government authorities did not spare the ordinary people from the state-sponsored forms of violence. The report simply zeroed in on the teachings of Rev. Chilembwe and his misunderstandings with some European planters such as those from the Bruce Estates to conclude that the uprising was more personal to the Reverend rather than a wider expression against European rule. It also referred to Rev. Chilembwe's past experiences such as his close relationship with the deported missionary Joseph Booth and the Reverend's (Chilembwe) experiences in the USA where he received his pastoral training, as being the sources of his radical principles. Secondly, the report also blamed the teachings of Christian mission stations, both Western-led and African-led, where the teachings were said to be responsible for radicalizing the natives. As already alluded to, the relationship between the colonial state and the missionaries had, since the era of Sir Harry Johnston as commissioner, already been shaky, where the state authorities accused the missionaries of being hypocrites and self-righteous, while the missionaries, on the other hand, accused the state authorities of ill-treating the Africans. It has also been established that even before the appointment of the commission, the state authorities had 
already arrested, detained, and later deported some religious leaders of both African and Western origin. In the Shire Highlands area, some mission structures (in the form of schools and chapels) had been ransacked, destroyed and looted under state orders. ${ }^{229}$ As such, the findings of the commission simply vindicated the government's actions as they implicated the missionaries to have been part of the uprising.

From the key findings, it was clear that there was no space to blame the colonial state for the atrocities committed by its agents in the immediate aftermath of the uprising. As already highlighted, the state authorities embarked on a merciless execution of those suspected to have taken part in the uprising. The report also deliberately overlooked the destruction and looting that occurred in the Shire Highlands area, where whole villages were set on fire as punishment for their alleged complicity in the uprising. In a way, the report indirectly vindicated the state's use of violence, despite the unlawful and inhumane nature of the actions of the state's agents (the police, the NVR, and some soldiers) whose target had been to re-establish colonial dominance through violent means.

The commission's report also presented several recommendations to be addressed. First, it proposed that the colonial state had to take more strict control of certain forms of religious literature and missionary agencies of a certain type, especially those without satisfactory European control or without proper religious considerations. The state was urged, under those proposals, not to infringe upon the conditions set by the "Brussels Treaty" which guaranteed religious liberty and freedom of religious teaching. However, that caution did not apply to the threat posed by the Mohammedanism Movement due to its violent activities. Secondly, the commission also

${ }^{229}$ Report on the Government Commission of Inquiry into the Recent Native Rising, June 19 ${ }^{\text {th }}$, 1916, BNA: CO $525 / 71$. 
recommended that the colonial state should begin to take an active role in the "development" of the African - focusing on areas such as opening more education opportunities, and access to land and its related agricultural usage. This, as I argue in the rest of this study, represented the beginning of the use of "the carrot" as a means with which to fight against African resistance. There was a realization that the use of brutal force was an unsustainable means with which to deter Africans from challenging state authority. On the other hand, this also showed that African agency or input in the colonial enterprise, played a significant role in the determination of the formulation of colonial policies and practices. In the education sector, the report for instance suggested that the government should appoint a director of education; and an advisory board made up of members of the various missionary agencies in the country to co-operate with the government in dealing with the differences that appeared between the two sides. The report deplored the lack of government interest in the education sector, where the government had been subsidizing the sector with only $£ 1,000$ per year. Under this recommendation the report urged the state authorities to desist from simply using brutal force to defeat African insurgents, but by looking at means and ways of uplifting the livelihoods of the same Africans who had been accused of plotting to overthrow the colonial state. The report deplored the colonial state's lack of investment in native education, by making comparisons with government spending on education in other British colonies in Africa, as shown in Table 4.1 . 
Table 4.1: Comparing Government spending on Education in British Colonies, 1916

\begin{tabular}{ll}
\hline British Colony/Protectorate & Amount spent per pupil \\
\hline & \\
Cape Colony & $15 \mathrm{~s} 9 \mathrm{~d}$ per pupil \\
Natal & $14 \mathrm{~s} 4 \mathrm{~d}$ per pupil \\
Bechuanaland & $10 \mathrm{~s}$ per pupil \\
Basutoland & $13 \mathrm{~s} 5 \mathrm{~d}$ per pupil \\
Gold Coast & $6 \mathrm{~s} 3 \mathrm{~d}$ per pupil \\
Southern Nigeria & $10 \mathrm{~s}$ per pupil \\
Nyasaland & $2 \mathrm{~d}$ per pupil \\
\hline
\end{tabular}

Source: Report on the Government Commission of Inquiry into the Recent Native Rising, June $19^{\text {th }}, 1916$, BNA: CO 525/71.

It must be noted that in Nyasaland, the government's contribution to the education sector had been to support Christian mission schools, a practice which continued well into the 1920s. In 1923, the British Government instituted an advisory committee on African education in British tropical Africa to, among other things, investigate areas where colonial governments could contribute more to the education sector. The following year, in 1924, the committee coordinated with the PhelpsStokes Commission, where officials from the two concerned parties investigated the protectorate's educational systems and facilities. The Phelps-Stokes Commission was a US-based humanitarian organization, in existence since 1908, with special interests in education in tropical Africa. Among other issues highlighted in the report of the Phelps-Stokes Commission, were the deplorable conditions for African education in the protectorate, and the lack of government investment in the education sector. It also noted the general high levels of poverty for the Africans, including its 
description of Nyasaland as the poorest colony in Africa. It thus recommended the setting up of a Department of Education, to coordinate education provision in the country. ${ }^{230}$

It was not until May 1926 that a department of education was established, to take over "the burden" previously shouldered by the various missionary groups. In 1927, an Education Ordinance was also passed, which provided for the institution of a board of education to act as an advisory body on all educational matters, and for the appointment of provincial and district school committees to deal with native or local educational demands. ${ }^{231}$ In 1928-29, further government intervention led to the laying of the foundations of the Jeanes Training Center at Domasi in Zomba, which became the first state-funded teachers' training center in the protectorate. The government had also increased its annual subsidy to the education sector from the meagre $£ 1,000$ by granting the mission-led schools a figure of $£ 7,842$ in the 1928 fiscal year. ${ }^{232}$ By 1930 , the British government had also approved a grant to the Nyasaland government for a sum of $£ 8,040$ from the Colonial Development Fund, to be used for the establishment of a training institute and hostel, at which to train the natives in such areas as teaching; telegraphy and telephony; printing and composing; commercial and accounting work; carpentry, joinery and smith's work. ${ }^{233}$ In the 1938-39 annual budget (before the outbreak of the Second World War and its accompanying disturbances), the Nyasaland government provided a total of $£ 21,216$ to the education department, from which

\footnotetext{
230 Bridglal Pachai, Malawi: The History of the Nation (London: Longman Group Ltd, 1973), 172-174. For an understanding of the work of the Phelps-Stokes Commission in tropical Africa during the 1920s, see BNA: CO 1045/431: Phelps-Stokes Commission - Africa. In the Commission's study of developments in the tropical colonies, including Nyasaland, in the 1920s, it had the following aims: (a) to enquire on the education work in the colonies; (b) to investigate the education and socio-economic needs of the Africans; (c) to ascertain the extent to which such needs were being met by the relevant authorities; and (d) to assist in the formulation of plans for the education of Africans. ${ }^{231}$ Great Britain, Nyasaland Report for 1927 (London: HMSO, 1928), 18-20. See also Nyasaland Protectorate, Report of the Education Department for the period May $1^{\text {st }}$, 1926 to December 31 ${ }^{\text {st }}$, 1927 (Zomba: Government Printer, 1928), $5-10$.

${ }^{232}$ Great Britain, Nyasaland Report for 1928 (London: HMSO, 1929), 20-21.

${ }^{233}$ Great Britain, Nyasaland Report for 1930 (London: HMSO, 1931), 36-41.
} 
$£ 11,250$ was set aside for grants to mission schools. The previous year (1937), the government had spent a total of $£ 18,787$ on the education sector. ${ }^{234}$

By the 1920s, the policy perspective of the British government had become one which argued that opening more schools and the colonial government's involvement in the education sector would in a way contribute to economic development in the colonies. It was also the British government's position that the education opportunities would create a desire amongst the Africans to participate in the white man's enterprise - "which offered so many new opportunities for adventure and for earning money when the old tribal activities, migration, fighting, and hunting were becoming more and more restricted, and also to a general demand from the European trader or settler for African assistants, African artisans and labor". ${ }^{235}$ It also became imperative for the CO to encourage the education of Africans, because it needed the human resources to take up the responsibilities under the system of "Indirect Rule", which had been implemented in other British colonies, beginning with northern Nigeria, using more local personnel to assume government posts and responsibilities. The establishment of the departments of agriculture, forestry, and health, among others required large numbers of African assistants. Furthermore, there was also need for manpower to construct roads, harbors, and railways - duties that needed both the physical and mental know-how. ${ }^{236}$

By then, the view from the $\mathrm{CO}$ was that the provision of basic or elementary education (primary and secondary education) opportunities could also form part and parcel of the "civilizing mission"

\footnotetext{
${ }^{234}$ Great Britain, Rhodesia-Nyasaland Royal Commission Report (London: HMSO, 1939), 87-88.

235 Report on Education in British Tropical Africa, 1932, BNA: CO 847/1/4.

${ }^{236}$ Ibid. It was from that background this in 1923, the Secretary of State for the Colonies set up an advisory committee in London to advise him on all matters of African education, which in Nyasaland and other tropical colonies, worked together with the Phelps-Stokes Committee, as discussed above.
} 
or "trusteeship", a theme that has been extensively covered in chapter three of this study. With lessons drawn from British-ruled India, the curriculum was to among other things include such areas as arts and crafts, hygiene and sanitation, writing skills, and mathematics. It would also include religious education, which was thought to be essential towards replacing the supernatural beliefs of the Africans. African religious beliefs were deemed to be barbarous and inhuman, such that they had to be replaced by the European religious values. One of the leading proponents of this view was Sir Frederick Lugard, who argued as follows:

As applied to backward races, the word "education" must be used in its derivative sense as the "bringing forth" of the latent possibilities in the individual, or the community the guiding of the evolution of a race to a higher plane of thought and action. ...

In Africa, the object in view is to enable the African to "find himself" - to emerge from the habit of mind which has through centuries marked him out as the slave of other races; to show him the higher rungs of the ladder which lead from mere obedience to co-operation, from servile imitation to individual initiative and a sense of personal responsibility - in short, "a new way of life," with higher standards of duty and of efficiency. ${ }^{237}$

By the 1930s, as already alluded to, the Nyasaland government had begun to use extensive amounts of money from the annual budget to help in the education of Africans. Although the amount spent was not the largest chunk from the total revenue collected, the money was still significant and more substantive than the pre-World War One figures. The table below illustrates that perspective.

\footnotetext{
${ }^{237}$ See Education in Tropical Africa, August 1930, BNA: CO 879/123/12, African, No.1135. This piece was adopted and included in the CO file, from The Rt. Hon. Sir F.D. Lugard, "Education in Tropical Africa," The Edinburgh Review, July 1925. In his speech, Lugard also referred to the influential role of the Phelps-Stokes Commission and the advisory committee on African education, in shaping what became of British colonial education policies from the mid-1920s onwards. These issues have also been highlighted elsewhere by Joseph M. Hodge. See Joseph M. Hodge, Triumph of the expert: Agrarian doctrines of development and the legacies of British colonialism (Athens, OH: Ohio University Press, 2007), 126-134.
} 
Table 4.2: Percentages of Revenue Spent on African Education in Nyasaland, 1930-1934

\begin{tabular}{|c|c|c|c|}
\hline Year & Revenue (f) & $\begin{array}{c}\text { Expenditure on } \\
\text { Education (£) }\end{array}$ & $\begin{array}{c}\text { Percentage } \\
\text { spent on } \\
\text { education }\end{array}$ \\
\hline 1930 & 381,610 & 13,200 & 2.8 \\
\hline 1931 & 370,403 & 18,825 & 3.2 \\
\hline 1932 & 530,931 & 17,104 & 3.2 \\
\hline 1933 & 541,181 & 16,106 & 3 \\
\hline 1934 & 560,552 & 17,491 & 3.2 \\
\hline
\end{tabular}

Source: W.R. Bryant Mumford and B.N Parker, "Education in British African dependencies: A review of the 1935 annual reports on native education in Nyasaland, N. Rhodesia, Tanganyika, Uganda, Gold Coast, Nigeria and Sierra Leone," Journal of the Royal African Society (Jan.1937): 20. Adopted from Education of African Communities in Social and Economic Development in Native Territories, BNA: CO 847/9/1.

A COI appointed by the CO in 1937 to investigate Nyasaland's financial position and further development also discussed the progress of African education. The commission was led by R.D. Bell and worked in the Protectorate between October $15^{\text {th }}$ and December $4^{\text {th }}$, 1937. Among other issues, the report of the commission highlighted some notable state interventions in the education sector, beginning with the establishment of the Department of Education in 1926. In 1927, the first education ordinance was enacted which provided that the government should increase its grants to schools, based on the number of students in training. In 1930, another education ordinance was enacted, and it provided for the payment of grants by the government to schools where European and African teachers were employed and where English was the medium of instruction. Some 
funds were also provided to technical schools, where a trade or industry was taught in addition to literary instruction, and at boarding schools for girls. ${ }^{238}$

In 1928, the Nyasaland Government in conjunction with the Carnegie Corporation of New York established the Jeanes Training Center $^{239}$ at Domasi in Zomba. The Carnegie Corporation guaranteed to grant US $\$ 5,000$ a year for five years on condition that the government would contribute at least an equal amount. The original plan for the center was to give two-year courses of training to batches of twenty-four selected mission teachers and their wives. The intention was that the teachers would afterwards serve as supervisory teachers for the primary schools of their missions and also, with the help of their wives, assist in general rural uplift. In 1934, the government also began to use the center to train selected chiefs and their wives, in rural reconstruction and uplifting courses for a duration of four months. In 1936, further investments saw the British government pump in some funds amounting to $£ 1,750$ from the Colonial Development Fund, meant for paying additional European staff and housing expenses. Between 1928 and 1937, the Nyasaland government had spent a total of $£ 24,934$ on the center, whose outcomes had been the graduation of 75 supervisory teachers and sixty wives and the training of 19 African chiefs. In 1938, the year the report came out, the center had in its enrollment twentyfour trainee teachers and their wives, and twenty-two welfare workers and their wives. The twoyear courses given to the teachers/supervisors included, for the men - methods and practice of teaching; child study; social and class management; hygiene and sanitation; agriculture and nature studies; handwork; blackboard work and drawing; civics; book-keeping; singing; simple physical

\footnotetext{
${ }^{238}$ Great Britain, Report of the Commission Appointed to Inquire into the Financial Position and Further Development of Nyasaland (London: HMSO, 1938), 15-16.

${ }^{239}$ The conceptualization of the Jeanes Training Center was a "brain-child" of the Carnegie Corporation in New York. It was initiated in 1928, with plans to give training to cohorts of African teachers and their spouses, who would in turn help in the uplifting or development of the rural communities in tropical Africa, including Nyasaland. See Ibid., 1819.
} 
drill; and training in general village improvement work. The wives were instructed in mid-wifery; child welfare; hygiene and sick nursing; home-craft; cooking; sewing and handcrafts. The community workers' course, which also lasted two years, was designed by the Native Welfare Committee, and it included instruction in medicine; hygiene and sanitation; agriculture and soil management; forest policy and management; animal husbandry, and the use and preparation of manure. The training was provided by state technical officers from the medical, agricultural, forestry, and veterinary departments. ${ }^{240}$ It is important to note that the idea to offer the Africans instruction in improved methods of agriculture was also put across by the commission charged to investigate the causes of the outbreak of the 1915 uprising, to augment mission work, with a goal to improve the African as an individual and also his own community development. ${ }^{241}$

As highlighted above, it must be noted that it was only elementary forms of education that were offered to the Africans. Until the late 1930s, the Nyasaland authorities often complained and argued that the protectorate was not ready to offer university education, both due to lack of education facilities and finances to embark on such endeavors. Remarks by the Director of Education, T.N. Lacey, supported by Governor Sir H. Kittermaster, in 1934, supported that school of thought and policy framework as follows:

As I stated before the Advisory Committee in London, I am in complete agreement with these arguments as applied generally to British Tropical Africa. My only fear is that we in East and Central Africa may be rushed into university education long before we are ready for it. On the West Coast, owing largely to economic conditions, education generally is far more advanced than in East and Central Africa....

\footnotetext{
${ }^{240}$ Great Britain, Report of the Commission Appointed to Inquire into the Financial Position and Further Development of Nyasaland (London: HMSO, 1938),14-19. Note that the Native Welfare Committee comprised of the following officials: The Senior Provincial Commissioner; The Directors of Medical Services, Agriculture, and Education; The Conservator of Forests; The Chief Veterinary Officer; and The Assistant Chief Secretary.

${ }^{241}$ Nyasaland Rising Commission of Inquiry (Zomba: Government Printer, 1916), BNA: WO/106/262.
} 
Our most urgent need at present and for more years to come will be secondary education - and even this is impossible for financial reasons until the earning and spending power of the man in the village has increased considerably. ${ }^{242}$

The other notable recommendation from the report on the 1915 uprising tackled the question of redistribution of land (that is for Africans to have access to some form of life tenancy on land), and the position of Africans resident on private estates owned by European settlers, where most of the trouble leading to the uprising emanated from. The commission recommended that where there was enough land, the Africans should be allowed to build schools and churches for themselves; and deplored the unfriendly conditions at the Bruce Estates, where the African tenants had very limited rights to the land. The commission noted that at the Bruce Estates, the management operated a rent system where they refused to accept money payments, only African labor. Africans were forced to work for one month in the wet season for rent, and for another month also in the wet season for hut tax. A month was reckoned at 28 days actual work, and it was stated before the commission that in other instances, the Africans were compelled to work considerably longer periods. For instance, where an African had failed to complete a day's task, they were not given credit for the time they had worked, and hence forced to work extra days. ${ }^{243}$ The first step taken to resolve the land question came through the enactment of the "Native Rents (Private Estates) Ordinance of 1917." The ordinance intended to reduce the powers which land owners had over Africans resident on their estate, by, among other things, prohibiting the soliciting of the tenants' labor as payment for rent. The ordinance recommended that the land owner and the tenants should

\footnotetext{
242 (Higher education in Africa): memorandum by AT Lacey (Nyasaland) on the Currie Report, CO 847/4/3, no.28, enclosure, 29 October 1934. Lacey was replying to the findings of an Advisory Committee on Education, which released its report earlier that year. Adopted from S.R, Ashton and S.E. Stockwell, eds., Imperial Policy and Colonial Practice, 1925-1945, Part II: Economic Policy, Social Policies, and Colonial Research (London: HMSO, 1996), 244245

${ }^{243}$ Nyasaland Rising Commission of Inquiry (Zomba: Government Printer, 1916). BNA: WO/106/262 and BNA: CO $525 / 71$.
} 
enter into a contract in which the tenants would pay an agreed amount of money as rent whose amount had to be fixed by the governor. The said rent should then entitle the tenant to have a site for his hut and some cultivable land required to grow food crops for the subsistence of the tenant's family. It also required the estate owner to provide grass and other materials necessary for the erection and maintenance of his hut (if the materials were available on the estate). There was also a provision that the land owner could not forcibly remove the tenants from the estate, unless a notice, (given through the district resident), of not less than six months had been issued prior to the eviction. It also required that the tenants could not be evicted until they had been allowed to harvest their crops. ${ }^{244}$

As argued in chapter three of this study, there were limits to which the colonial authorities could continuously suppress the colonized subjects. The colonial state, as the one in Nyasaland, had to take into consideration the demands of the Africans, sometimes to the detriment of the demands of the "gentlemanly capitalists" then operating in Nyasaland. The maintenance of law and order and general stability in the protectorate was essential to assure the continuation of the colonial enterprise. The African communities were the major source of revenue (through taxes) and labor on which the colonial state relied. This, as I argue here and beyond, often included listening to and fulfilling the demands of the colonized peoples.

Anthony E. Woods Jr., in his discussion of the Nyasaland government's reactions to the 1915 uprising, argued that in the aftermath of the uprising, the colonial state had realized that it could no longer afford to overlook the native grievances, and that the enactment of the land tenure changes had been one of such new pro-African policies. He argued that, at that time, the colonial

\footnotetext{
244 "The Native Rents (Private Estates) Ordinance, 1917," Ordinances of the Nyasaland Protectorate for the year ended $31^{\text {st }}$ December 1917 (Zomba: Government Printer, 1918).
} 
authorities had reached a stage where they were prepared to come up with policies, some of which were antagonistic to capitalist (European settler) economic interests. In a way, as argued by Woods, that also marked a process where the state was becoming more and more autonomous from the influence of the settler capitalists. The new land tenure system allowed for Africans to own more land for the cultivation of both cash and subsistence crops. Woods hinted about the advantages of such a policy trend as follows: "The political basis for such decisions are relatively obvious. A population with a vested interest in land, no matter how disadvantageous vis-à-vis other groups in the country, is always less susceptible to rebel against authority. The state always has the means of revoking the small privileges granted at the first signs of discontent or rebellion." 245 Due to limited changes brought about by the "Native Rents (Private Estates) Ordinance of 1917," in 1920, Governor Smith also instituted another COI, under the "Commission of Inquiry Ordinance, 1914." That commission was tasked to look further into the question of land occupation and allocation in the protectorate, as a follow up to the recommendations of the 1917 "Native Rents (Private Estates) Ordinance", especially because the European settlers (land owners) had often disobeyed the rules and regulations of the 1917 Ordinance, including subjecting the tenants to the Thangata system. ${ }^{246}$ The 1920 commission was comprised of the following personnel: His Honor Edward St. John Jackson, Esq. (Judge of the High Court and Chair of the Commission); Claude Ambrose Cardew, Esq. (Senior District Resident); Jacobus Stewart Johnston McCall, Esq. (Director of Agriculture); Bertram Edward Lilley, Esq. (Lands Officer); The Rev. Alexander

\footnotetext{
${ }^{245}$ Anthony E. Woods Jr., "Political Autonomy and Administrative Policy in Nyasaland, 1915-1921," History Seminar, 1984/85, Paper No.9, Chancellor College, University of Malawi. Anthony Woods Jr. also hinted that by allowing the allocation of land for peasant cultivation, the colonial state also reduced its own obligations towards providing food to the African population. Furthermore, African cash crop production also helped to reduce levels of unemployment in the country, whereas food crop production was essential in the reduction and/or aversion of hunger.

${ }^{246}$ As discussed in chapter three of this study, under the Thangata System, the European settlers demanded "free" labor from Africans resident on their estate. This was in return for payment of land rent. It became one of the leading grievances and causes of 1915 uprising.
} 
Hetherwick (from the Blantyre Mission); John Scott, Esq. (Solicitor); Robert Spence Hynde, Esq. (Businessman); and Mr. Geoffrey Cheston. The commission's terms of reference were as follows: (1) to review the existing laws and policies of land tenure especially for non-Africans; (2) to find out if there were further areas where to set aside land for settlement of non-Africans; (3) to investigate the feasibility of creating reserves for the settlement of Africans, both in the rural areas and near townships; (4) to find means and ways of including the Africans in the cultivation of industrial and economic crops on Crown Lands; and (5) to investigate the status of Africans resident on private estates.

The 1920 Commission conducted its investigations between September and December of that year. Most of its sessions were conducted in Blantyre, and were open to the public, with the first 17 days set aside for discussion among the members on the scope of the inquiry, the collection of provisional views of members, and the discovery of points upon which the evidence of witnesses seemed desirable. In total, 44 individuals were summoned to give evidence before the commission, and of that number, 38, including eight Africans and five Asians, attended. Some of the commission's key findings and recommendations were as follows: firstly, the commission noted that the land tenure system of the native societies was that of a communal system. Under that system, there was no absolute ownership of land by an individual, as land was regarded as belonging to the community, with the head of each community being responsible for allocating land to households. The commission recommended to the government not to disrupt the African land tenure system, and not to institute the policy of creating "native reserves" (i.e. the collection of large numbers of African in defined areas), as doing so would have disrupted their access to water sources and expressed concern about the provision of proper sanitation conditions. Furthermore, "reserves," as experience had shown in other colonies, were said to be breeding 
grounds for bad behavior and sloth (laziness and reluctance to work). What was needed then was for the state to provide more access of land for native cultivation and settlement.

Secondly, the commission also recommended that the state should allow more Africans to be involved in cash-crop production, especially the cultivation of cotton and tobacco on public land (Crown Land). It was suggested that the increase in cash-crop production would have created more avenues for extraction of revenues by the state, while at the same time giving the Africans an opportunity to take part in the protectorate's commercial activities. However, there was need to limit African cash-crop production to only a maximum of three acres. Perhaps this was done to make sure that the African was not totally independent and had to rely on the colonial state for other social services. Another key recommendation by the Commission was that a system of land tenure should be devised which would have created individual land ownership by the natives, especially targeting the educated and propertied elite. In doing so, the Commission argued that it would have improved methods of native agriculture and the greater economy of the soil. The Commission also recommended that measures should be put in place to ensure that the "native" tenants resident on private estates should not be compelled to work for the land owner (under the Thangata system), but that a rent payment in cash could be the substitute mode of payment. And that where there was need to pay labor-rent, there was need to specify the amount of time one was expected to provide the labor. It was also recommended that the native tenants should be given a fixed tenure policy, starting from four years onwards, to stay on the private estates. It was also recommended that where the Africans were evicted by a land owner, the state should set aside some Crown Land for the resettlement of the evictees. ${ }^{247}$

\footnotetext{
${ }^{247}$ Nyasaland Protectorate, Report of the Commission to inquire into and report upon certain matters connected with the occupation of land in the Nyasaland Protectorate (Zomba: Government Printer, 1921).
} 
What came out clearly from the 1921 Land Commission Report was the need for the colonial state to begin to consider opening more socio-economic opportunities for the Africans. Since it was a largely agro-based economy, the settlement of the land question would have settled some of the grievances that led to the 1915 native uprising. Like the question of opening of education opportunities, the question of land re-distribution and re-allocation would perform the role of "a carrot" dangled towards the Africans that would encourage them to associate themselves with a government that cared for their concerns. Further changes were also made to the land tenure system, when in 1928 the government enacted the "Natives on Private Estates Ordinance," which created three categories for the Africans. Category one was called "exempted natives," and referred to domestic servants and temporary laborers. The second category was called "natives under special agreement" and it included those entitled to stay on the estate subject to a written contract and provided that they had to work for the land owner for not more than six months in any one year. The third category was called "resident natives" and it included those who had owned or resided in a hut on the estate for three years. Such Africans were liable to pay rent to the land owner at a figure determined by the district rent board subject to the governor's approval. The "resident native" was entitled to enough cultivable land to produce his own food supply but could also grow cash crops at the land owner's consent. ${ }^{248}$

In 1936 the Nyasaland government enacted the "Native Trust Land Order-in-Council," as a byproduct of the decision not to create "native reserves." The 1936 Order declared that all lands, other than those already alienated as Crown Lands (for state purposes or occupied by reserve forests or townships) had to be converted into "native trust lands," which were to be held for the

\footnotetext{
${ }^{248}$ Great Britain, Report of the Commission Appointed to Inquire into the Financial Position and Further Development of Nyasaland (London: HMSO, 1938), 23-31. See also Bridglal Pachai, Malawi: The History of the Nation (London: Longman Group Ltd, 1973), 104-106.
} 
use or common benefit, direct or indirect, of the natives of the protectorate. Under the 1936 order, the government also officially recognized the "native authorities" (African chiefs) as the guardians of the land for the community and that with time, the system would evolve to allow individual ownership of land. ${ }^{249}$ The "created" native trust lands were to be the third category in the land tenure system which also recognized "Crown Lands" and "Reserved Lands." Although African chiefs were recognized as custodians of "native trust lands," they were only doing so as representatives of the Secretary of State for the Colonies in whom the rights to the land had been vested. Rights of occupancy would be granted for a term of 99 years, at a rent revisable at intervals of not more than thirty-three years, but before any land grants were to be made, there was a requirement to consult the Native Authority of the area. From then onwards, Africans settled on Native Trust Lands stayed there free of rent, on conditions determined by African traditional law and custom. ${ }^{250}$ It is important to note that while the Nyasaland government, and to an extent the British government, showed their willingness to resolve the land question, and indirectly or directly, to aid African agriculture, there were minor benefits accrued to the Africans, because they were never given full rights towards ownership of the land. Such conditions, as I will argue in chapter five of this study, sowed the seeds of further land tenure troubles in the aftermath of the Second World War.

It also must be borne in mind that from the perspective of British government policies on colonial development after the First World War, the development and welfare measures were located along

\footnotetext{
${ }^{249}$ Lord Hailey, Native Administration and Political Development in British Tropical Africa, 1940-42 (Liechtenstein: Kraus-Thomson Organization Ltd, 1979 publication), 254-260.

${ }^{250}$ Lord Hailey, Native Administration in the British African Territories, Part II: Central Africa: Zanzibar, Nyasaland and Northern Rhodesia (London: His Majesty's Stationery Office, 1950), 62-64. Note that the Reserved Lands included land other than Crown Lands within the boundaries of a township, Government reserves at Government stations, forest reserves, and all lands and interests in land (other than yearly tenancies) alienated or otherwise disposed of prior to the enactment of the 1936 Order-in-Council. See also Great Britain, Report of the Commission Appointed to Inquire into the Financial Position and Further Development of Nyasaland (London: HMSO, 1938), 23-41.
} 
the same lines as the recommendations that were suggested by the Colonial Development Committee (CDC) which had been set up in December 1919. ${ }^{251}$ The CDC acknowledged that the British Treasury (BT) had been stretched in terms of spending its resources in the war effort, and hence could not be expected to continue spending its meagre resources in supplementing colonial economies. As such there were recommendations, among other things, that it would be important to tap into the agricultural and mineral resources of the colonies, where the subjects would produce raw materials for British industries, and have the capacity to supply a great variety of foodstuffs to the United Kingdom. To British government officials, the colonial empire was at that time regarded as one with huge potential to revive the British economy which had been battered severely by Britain's participation in the First World War. ${ }^{252}$ In other words, the kind of development that was initiated during the inter-war period, while it benefited the colonized peoples, had been deliberately planned to aid and revive the British economy.

In the same vein, the Conservative-led British government of the late 1920s also enacted the Colonial Development Act (CDA) of 1929, which, although it contributed towards the boosting of colonial economies through monetary grants and loans, had also been specifically passed to help in the improvement of trade or commerce and industry and in turn also reduce the levels of unemployment in the United Kingdom (UK). By the late 1920s and early 1930s, Britain's unemployment levels had reached as high as over ten percent hence the need to create avenues for increased production in the colonies, to create more employment opportunities for British citizens, as was argued by Leo Amery, the Conservative Secretary of State for the Colonies. One of the key

\footnotetext{
${ }^{251}$ Stephen Constantine, The Making of British Colonial Development Policy, 1914-1940 (London: Frank Cass and Company, 1984), 47-52.

${ }^{252}$ Ibid., 33-49. Note that prior to the formation of the CDC, the British Government had also instituted a similar Commission, called the Imperial Development Board, which also called for state interventionist development policies, including the need for the establishment of a British Trade Bank to help finance new projects in the colonies.
} 
issues raised by the Act was how the $\mathrm{BT}$, in conjunction with the $\mathrm{CO}$ could advance money to the colonies for purposes of developing agriculture and industry, which in turn would help to promote commerce and industry in the UK. Another issue was to provide funds to such sectors as agricultural production (through provision of farm machinery and other related equipment); improvements in the communication sector; construction of harbors or improvements in existing ones; promotion of education and scientific research; provision and promotion of the public health sector; improvement of water supply and electricity generation - all aimed at meeting the existing socio-economic needs in the colonies. Finally, the Act was designed as a cure for unemployment in the UK..$^{253}$

The latter was also a point of view shared by Stanley Baldwin, British Prime Minister between 1924 and 1929, when he made the following remarks at the Annual Conference of the Conservative Party on November $21^{\text {st }}, 1929$ : “Our progress depends on our capacity to visualize the Empire, the Dominions and colonies alike, as one eternal and indestructible unit for production, for consumption, for distribution, for the maintenance and improvement of the lot of those who, under Providence, are dwellers within the confines of our Commonwealth." ${ }^{254}$ It was clear from the remarks by the Prime Minister, that the Conservatives believed that time had come for more state intervention in development in all overseas British possessions, hence the Party's support for the CDA of 1929.

\footnotetext{
${ }^{253}$ Constantine, The Making of British Colonial Development Policy, 164-189. See also Great Britain, Colonial Development Act, 1929 (London: H.M. Stationery Office, 1929). In the same vein, see also E.R. Wicker, "Colonial Development and Welfare, 1929-1957: The Evolution of a Policy," Social and Economic Studies 7, no.4 (Dec. 1958): 170-192.

${ }^{254}$ John Barnes and David Nicholson, eds., The Empire at Bay: The Leo Amery Diaries, 1929-1945 (London: Hutchinson, 1988), 5.
} 
D.J. Morgan also hinted that when the Act was enacted in 1929, it provided for the first time, regular funds for the development of the colonies. The Act led to the setting up of a Colonial Development Fund (CDF), into which the British Parliament annually voted such sums as were estimated to be needed, up to an annual maximum of $£ 1$ million. The funding targeted several development-related areas, including improvements in transport, harbor facilities, fisheries, forestry, surveys, land reclamation and irrigation, electric power, water supplies, mining, research and instruction methods of agriculture and industry, and the promotion of public health. ${ }^{255}$

It was out of the enactment of the CDA in 1929, that the Nyasaland Government received extensive amounts of funding from the British Treasury (BT), amounting to $£ 726,534$ between 1930 and 1936. Out of that amount, $£ 500,000$ was earmarked for the purpose of meeting the interest charges on the Nyasaland Guarantee Loan. Governor Thomas Shenton of Nyasaland had persuaded the Colonial Development Act Committee (CDAC), chaired by Sir Basil Blackett, that it was essential for Nyasaland to receive funds under the Act, as its proceeds would aid the development of both the native and European settler sectors. He argued that the funds, if provided, would help to improve the welfare of the natives (targeting sectors such as education, public health, agricultural production, and food supply), who would in turn be more productive in providing the much-needed labor for European settler production. In turn, that was also going to positively contribute towards the enhancement of the British economy. ${ }^{256}$ The table below gives a picture of the distribution of the rest of the funds:

\footnotetext{
${ }^{255}$ D.J. Morgan, The Official History of Colonial Development. Volume 1: The Origins of British Aid Policy, 19241945 (New Jersey: Humanities Press, 1980), 44-45.

${ }^{256}$ Ibid., pp.52-54. See also Great Britain, Report of the Commission Appointed to Inquire into the Financial Position and Further Development of Nyasaland' (London: HMSO, 1938), 114-115.
} 
Table 4.3: Disbursement of Colonial Development Funds, 1930-1936

\section{TARGETED SECTOR}

Hospitals and Public Health

Water Supply

Geological Survey

Agricultural Development

Public Works

Telegraph and Telephone System

Veterinary Department

Agricultural Surveys

Jeanes Training Center

Financial Commission

Miscellaneous

\section{$\operatorname{AMOUNT}(\mathfrak{f})$}

78,284

75,430

18,000

15,000

12,386

12,310

7,630

3,500

1,750

1,400

844

\section{Total}

$£ 226,534$

Source: Great Britain, Report of the Commission Appointed to Inquire into the Financial Position and Further Development of Nyasaland (London: HMSO, 1938), 114-115. See also Colonial Annual Reports for Nyasaland for 1930-1938. Note that this table excludes expenditure on education, which has already been covered extensively above.

This section has advanced the argument that the origins of the colonial state's involvement in the development of Nyasaland was in significant measure influenced by the outbreak and aftermath of the 1915 uprising. The findings and recommendations of the commission tasked to investigate the origins of the uprising, as discussed above, to a large extent called upon the colonial authorities to find means and ways of uplifting the socio-economic livelihoods of the Africans. Some of the measures recommended and policies introduced by the colonial state were detriment to the needs of the "gentlemanly capitalists' resident in the protectorate. The colonial state had to straddle to meet the interests of both the Africans and the European settlers, while also meeting the state's own imperatives. An analysis of the origins of colonial development policies and initiatives in Nyasaland, must therefore consider the influence or input of the demands put across by the 
Africans, of which the Chilembwe uprising of 1915 was the peak of such demands. The section that follows considers the role that the Nyasaland police force played in enhancing colonial counter-insurgency initiatives.

\section{The reorganization and role of the Police Force}

The other key recommendation that came out of the 1915 uprising commission report was for the Nyasaland government to make improvements in the police system. Specifically, it was recommended that the police officers receive more training fit for the discharge of their duties. There was need, the report stated, for better training, to focus on the detection of crime. It was noted that a large amount of crime in the protectorate often went undetected and unpunished, and deplored the use of the Collective Punishments Ordinance, because it failed to bring the criminals to justice. The report also recommended the establishment of a central police training depot, to be run by expert European staff, with experience to handle native-caused trouble. ${ }^{257}$

In discussing the development of colonial policing in the Nyasaland Protectorate, I concur with the work of Martin Thomas, who argues for the adoption of the "political-economy approach" in the study of the development of colonial policing in the British, French and Belgian empires. ${ }^{258}$ Thomas posited that one can understand the activities of the colonial police by analyzing the existing political-economy, or simply put, to make connections between the politics of imperial oppression and the economic structures of the European colonies. He pointed to the development of the colonial state and its needs for revenue (tax collection), land, and labor, which could best be attained when the colonial state, through the police force, had been able to maintain law and order

\footnotetext{
${ }^{257}$ Nyasaland Rising Commission of Inquiry, BNA: CO 525/71.

${ }^{258}$ Martin Thomas, Violence and Colonial Order: Police, Workers and Protest in the European Colonial Empires, 1918-1940 (Cambridge: Cambridge University Press, 2012), 25-27.
} 
or to combat internal threats. The police forces were serving colonial states that had entangled themselves in the economic development and exploitation of the colonies, at the level of production of primary goods; export of those goods; and the control of native labor. ${ }^{259}$ In the case of Nyasaland, as already discussed in chapter three of this study, the colonial state had a "handson approach" or "interventionist approach" in matters relating to land alienation, revenue collection, and labor allocation, hence the turn to the police force to enforce and reinforce those imperatives. In other words, state repression, through the police force, became crucial to entrench the political economy of British colonialism in Nyasaland.

Mathieu Deflem provides an important background towards the history of British colonial policing in Africa, focusing on the Nyasaland, Gold Coast, and Kenya colonies. He posited that in the British Empire, policing services developed at two main levels. The first group was that of the Metropolitan Police, which was first established in London in 1829, and was tasked to perform the role of a civil police force aimed at the preservation of law and order and the prevention and detection of crime. That group was not organized as a military force, but rather as a civilian force, put in place to enforce the law, rather than serve the interests of any political government. The second group was that of the Royal Irish Constabulary (RIC), which was established in 1836, initially to deal with the disturbances in British-occupied Ireland. The latter group was organized like a military force, where the police agents lived in a barracks and the police units were headed by a commander who reported directly to the British administration in Ireland. As British colonial rule spread to Africa in the late nineteenth-century, it was the policemen from the RIC who were deemed fit to serve in the colonies, as it was argued that force was better suited to establish,

\footnotetext{
${ }^{259}$ Ibid., 25-27. See also Martin Thomas, "Policing the Colonial Crowd: Patterns of Policing in the European Empires during the Depression Years," In Andrew S. Thompson, Writing Imperial Histories (Manchester: Manchester University Press, 2013), 143-167.
} 
maintain, and secure the enforcement of British imposed colonial laws. It was later in the colonial period, after the formative years had passed, that some form of civil policing was employed in the African colonies, to replace the more militant forms of policing. ${ }^{260}$

C. Marlow, a former Assistant Commissioner of Police in both the Nyasaland and later Malawi governments, documented a history of the Malawi Police Force since its inception in the late nineteenth century. He traced the history of the police force to as far back as 1891, when Sir Harry Hamilton Johnston, appointed Captain Cecil M. Maguire, to form a military force to police the protectorate. The initial police force comprised of seventy volunteers from the Indian Army, mainly Sikhs, some volunteers from Zanzibar, and some British officers, with responsibilities to help maintain law and order, to suppress the slave trade, and to keep a close guard against the territorial ambitions of the Portuguese in neighboring Portuguese East Africa (Mozambique). By 1893, some African regular troops also formed part of the police force. In 1896, further changes were approved when the government approved to form a body of policemen to be attached to each district, a system which continued up to 1921. These police officers worked under a district commissioner, whose office received state funding to pay the officers. Due to lack of national guiding principles for the police officers, it was common for the policemen to abuse their powers and to go beyond their jurisdiction to demand fowls, food, and beer, and even women from the local population. ${ }^{261}$ The sentiments were also expressed in a dispatch from the Governor of Nyasaland, Hubert Young (1932-1934), to the Secretary of State for the Colonies, when he hinted

\footnotetext{
${ }^{260}$ Mathieu Deflem, "Law Enforcement in British Colonial Africa: A Comparative Analysis of Imperial Policing in Nyasaland, the Gold Coast, and Kenya," Police Studies 17, no.1 (1994): 45-68. See also Sir Charles Jeffries (Deputy Under-Secretary of State for the Colonies), The Colonial Police (London: Max Parrish and Co. Ltd, 1952), 23-25. Another equally important source on colonial policing is that by Georgina Sinclair. See Sinclair, Georgina. At the end of the line: Colonial Policing and the Imperial Endgame, 1945-1980 (Manchester: Manchester University Press, 2006).

${ }^{261}$ C. Marlow, A History of the Malawi Police Force (1971), 1-4. See also John McCracken, "Coercion and control in Nyasaland: aspects of the history of a colonial police force," Journal of African History 27, no.1 (1986): 127-147.
} 
that prior to 1920, the Nyasaland Police consisted entirely of separate native units, stationed at various district headquarters, and served under respective district administrative officers. Most of the African policemen were recruited locally targeting those who had served in the KAR, and hence with limited or no police training. ${ }^{262}$

Following the recommendations of the commission on the 1915 uprising, after the First World War, Governor Smith began a process of reforming the police force. In 1919, he proposed (to the Secretary of State for the Colonies) the need to appoint a chief commissioner of the police force, and to have a European officer in each district. The Governor also suggested a uniform training for all police officers, and that the policemen should continue to be armed and organized as a quasimilitary police unit as a symbol of authority and to deal with extensive revolts beyond the scope of a civil police, and also that the numbers of police personnel had to be increased with more policemen trained as detectives. All these proposals were duly approved by the London-based authorities. The changes were deemed necessary to provide the answers to the shortfalls in policing, where the police had failed to detect the outbreak of the 1915 uprising. The proposed changes began with the appointment of Major Francis Trant Stephens (a former soldier in the KAR) as the chief commissioner of the police force in 1920. Governor George Smith approved the appointment of Major Stephens because of his extensive experience working amongst Africans, as he had also previously served in the British South Africa Police since 1903. His first major contribution was to set up the Criminal Investigation Department (CID), headed by a European police officer, whose role was to detect serious crimes in the country. Major Stephens' military background and re-organization of the police force, is said to have begun a process of

\footnotetext{
${ }^{262}$ Nyasaland Governor, Hubert Young, to the Secretary of State for the Colonies, Sir Philip Cunliffe-Lister, on the re-organization of the Nyasaland Police Force. Confidential. October $24^{\text {th }}$, 1933. MNA: S1/1729/27.
} 
diverting the police from its civil responsibilities to a more militant force than had previously been the case before the native uprising. In 1921, Major Stephens oversaw the establishment of a Fingerprint Bureau based at Zomba, to detect serious criminals and crimes. Further changes in the Police Force led to the establishment of a Police Intelligence Bureau in 1939, whose role was primarily to deal with the threat posed by pro-Nazi and pro-Fascist organizations in East Africa, who might have infiltrated in Nyasaland. When World War II broke out, the Bureau increased its censorship activities, and arrested all German nationals in the country, along with other enemy aliens (especially Italian nationals) who were rounded up by the police in $1940 .{ }^{263}$ From 1921 onwards, the re-organization of the police force occurred in the following statistical details, both in terms of personnel and funding:

${ }^{263}$ Marlow, A History of the Malawi Police Force (1971), 10-21. See Great Britain, Annual Report for Nyasaland for 1921 (London: HMSO, 1922). See also Governor George Smith to Chapelries, London, on the appointment of Major Stephens, May $5^{\text {th }}$, 1920, MNA: S1/152/19. See also Enclosure in Dispatch Nyasaland No.298 of $18^{\text {th }}$ August 1919, MNA: S1/152/19. 
Table 4.4: Nyasaland Police Reinforcements, 1921-1938

\begin{tabular}{cccccc}
\hline Year & $\begin{array}{c}\text { No. of } \\
\text { European } \\
\text { Officers }\end{array}$ & $\begin{array}{c}\text { No. of Assistant } \\
\text { Superintendents }\end{array}$ & $\begin{array}{c}\text { Asian } \\
\text { Policemen }\end{array}$ & $\begin{array}{c}\text { African } \\
\text { Ranks }\end{array}$ & $\begin{array}{c}\text { Budgeted } \\
\text { Funds (£) }\end{array}$ \\
\hline 1921 & 1 & 7 & - & 450 & - \\
1922 & 2 & 11 & - & 441 & - \\
1923 & 13 & - & - & 457 & 13,616 \\
1924 & 12 & - & - & 440 & 12,904 \\
1925 & 13 & - & - & 459 & 14,801 \\
1926 & - & - & - & - & - \\
1927 & 14 & - & - & 474 & 16,144 \\
1928 & 14 & - & - & 502 & 16,977 \\
1929 & 14 & 2 & - & 521 & 18,910 \\
1930 & 14 & 2 & 3 & 515 & 19,724 \\
1931 & 13 & 2 & 3 & 500 & - \\
1932 & 13 & 2 & 3 & 496 & - \\
1933 & 13 & 2 & 3 & 496 & - \\
1934 & 13 & 2 & 3 & 496 & - \\
1935 & 13 & 2 & 3 & 489 & - \\
1936 & 13 & 2 & 3 & 499 & - \\
1937 & 11 & 3 & 3 & 499 & - \\
1938 & 9 & 5 & 3 & 499 & - \\
& & & & & \\
\hline
\end{tabular}

Source: Nyasaland Protectorate, Colonial Annual Reports for Nyasaland from 1921-1938. ${ }^{264}$

From 1920/21 onwards, the Nyasaland policemen took up such roles as warders of district prisons; revenue collectors; court servers and messengers; while the chief commissioner of police also served as the chief inspector of prisons. ${ }^{265}$ It was also the re-organized police force that began the

\footnotetext{
${ }^{264}$ Note that most of the police posts were in the Southern Province and a few posts in the Northern Province, until after World War II. That was the case because of the increased presence of European settlers in those parts of the Protectorate, who were of economic benefit to the Government, hence the need for police protection. See also MNA: S1/1729/27: Police Establishments, 1927-1934. The settlers, through "The Convention of Nyasaland Associations," persuaded the Government to provide more police protection, especially European Inspectors. See MNA: S1/1729/27.

${ }^{265}$ Governor George Smith to the Secretary of State for the Colonies. Confidential. August $18^{\text {th }}, 1919$. MNA: $\mathrm{S} 1 / 152 / 19$.
} 
process of political surveillance of those suspected to be enemies of the state. One high profile case was that of a Mr. Joshua Chateka of the Seventh Day Baptist, who had close links with the deported American missionary, Walter B. Cockerill, and had been previously detained at Mlanje Prison in 1915. When he was released the following year, he was warned against further inciting of the natives to challenge the authority of the government, and he was also marked as an expolitical prisoner. In November 1922, the district magistrate at Lilongwe and the police commissioner of the central province both recommended that Mr. Chateka should be reimprisoned, and that he should be locked up for the rest of his life. To arrive at that decision, the government used divide-and-rule tactics, where it summoned two headmen, Masula and Chimdidi (both from Lilongwe District), to implicate Mr. Chateka, that he had been inciting people in their areas of jurisdiction to disobey state orders. The recommendation from the police commissioner, which received full approval from Governor Smith, read as follows:

I notice that Joshua's second arrest was due to the fact that he preached in contravention of the conditions under which he was released; not that he preached sedition. It seems rather best to keep him as a political prisoner for the rest of his life because he could not resist the temptation to talk in public. Also I think his detention rather tends to give him and his followers a sense of fictitious importance. ...If Joshua were released, I should not have the slightest fear of his getting sufficient following in Lilongwe to be a nuisance. My only doubt is whether any headman can be found willing to let him live in his village. ${ }^{266}$

It was not until October 1930, that the political detainee, Mr. Joshua Chateka, who was detained at Port Herald Prison, located over 500 miles from his home in Lilongwe District, for eight good years, was finally released. The order for his release was issued by Governor Thomas Shenton

${ }^{266}$ Political Cases: Joshua Chateka, 1922-1930, MNA: S2/39/22. 
Whitelegge Thomas (1929-1932), who had been informed that Mr. Chateka had proven to be of good conduct while in police custody. ${ }^{267}$

Another equally compelling case was that of the detention of Mr. David Shirt, a resident of Ntcheu District, and a member of the Church of Christ, and a keen supporter of the teachings of Rev. Chilembwe. Mr. Shirt too was implicated of misconduct when the police and the courts issued a subpoena for three headmen (Kwataine, Kachimanga, and Mingola) to present themselves in court where they gave evidence before Magistrate H.C.J. Barker at Ntcheu, where Mr. Shirt was accused of preaching sedition. The Acting Provincial Commissioner for the Central Province made the following recommendation on Mr. Shirt's case:

It will be noted that Shirt admits that he is preaching the doctrine of the Church of Christ as expounded by one Njirayafa, a disciple of Mr. Hollis who was deported after the rebellion of 1915. The Resident, Ntcheu, appears to be under some misapprehension as to the cause of David Shirt's original sentence of imprisonment and his finding is lacking in precision, but the evidence and the attitude of Shirt convinces me that the continued presence of this native at large in the Ntcheu or any other District would be dangerous to peace, order and good government, and I therefore wish to recommend that he be detained as a political prisoner for such time as His Excellency the Governor may consider necessary. ${ }^{268}$

Another case of "political imprisonment" in which the Nyasaland police was heavily involved was the detention of a Mr. Isa Macdonald Lawrence from 1923 to 1928. Lawrence was accused and charged of possessing "seditious literature" and associating with the Providence Industrial Mission (PIM) of Rev. Chilembwe. The Nyasaland Police personnel and customs officials found

\footnotetext{
${ }^{267}$ Political Cases: Joshua Chateka, 1922-1930, MNA: S2/39/22. See also MNA: S2/39/22, memo from Governor George Smith to the District Resident at Lilongwe. In the memo of July $5^{\text {th }} 1918$, the Governor issued instructions using police-sourced intelligence, to detain Mr. Jackson Banda, as a political prisoner at Nkhota-Kota Prison, as he was deemed to be dangerous to peace, order, and good governance in the Protectorate. Nkhota-Kota Prison was approximately 300 miles from Lilongwe District.

268 Political Cases: David Shirt, 1923-1924, MNA: S2/102/23. This was a confidential memo from the Acting Provincial Commissioner, Central Province, to the Chief Secretary at Zomba. December $14^{\text {th }} 1923$. The detention of Mr. Shirt was approved under the Political Removal and Detention of Natives Ordinance.
} 
Mr. Lawrence with the said seditious literature, in the form of two newsletters called The Negro World (an organ of Marcus Garvey's teachings) and The Workers Herald as he crossed the border between Nyasaland and Mozambique in 1923. The Workers Herald was published by the Industrial Commercial Workers Union of Africa, whose headquarters was in Johannesburg in South Africa, an organization which Mr. Lawrence had expressed interest to join.

Upon his arrest, Lawrence's case was committed to the high court, where he was charged with being in contravention of Section 4(2) Seditious Publication Ordinance of 1918, which prohibited the publication, possession, and distribution of "anti-government" literature. The evidence from the Government side was provided by Assistant Superintendent of the CID, Mr. Victor Colin Curnock, who had been responsible for issuing the warrant of arrest when Mr. Lawrence was found in possession of the newsletters. In his judgment, Judge C.F. Belcher, noted that the accused had been associating with radical movements such as that led by Marcus Garvey (through The Negro World) and the Russian Bolsheviks (through The Workers Herald), both of which promoted an anticipated world revolution. The judge thus sentenced him to three years imprisonment with hard labor, and to be deported from the Protectorate at the end of his prison stint. ${ }^{269}$ The National Secretary of the Workers Union (mentioned above), a man from Nyasaland, named Clements Kadalie, who exchanged several correspondences with Mr. Lawrence prior to his detention (on the latter's intention to join the Trade Union), sent a letter of protest to London directed to the Secretary for Dominion Affairs, to complain about the ill-treatment of Mr. Lawrence. Part of that letter read as follows:

...According to Judge Belcher of the Nyasaland High Court, I fail to be convinced that The Workers Herald referred to by His Honor, a few copies of which I am forwarding to you for your perusal, is in any way seditious. If The Workers Herald which is the

\footnotetext{
${ }^{269}$ High Court of Nyasaland, Cause No.11 of 1926: Rex versus Mr. Isa Macdonald Lawrence. September $22^{\text {nd }}, 1926$. MNA: S2/50/23.
} 
official organ of a legitimate Trade Union, is seditious, then I submit all Labor papers, such as The New Leader, Daily Herald, etc, etc, published in London and elsewhere in the British Commonwealth of Nations must also be labelled as 'seditious literature'. But the conviction of this African Native in Nyasaland, whose sentence to three years hard labor coupled with deportation from his own native land, one would describe as outrageous, is that which proves the atrocities being perpetrated upon the African communities under British rule in Africa. There is much brutality on the natives under British rule in Africa than what has already been known throughout the civilized world. I submit Sir, the sentence passed upon Macdonald Lawrence in Nyasaland High Court will evoke the anger of all the civilized black men and women, who in the long run in desperation will look upon British rule with greatest contempt. ${ }^{270}$

It is clear from the case studies (involving Messrs. Joshua Chateka, David Shirt, and Isa Macdonald Lawrence) that the Nyasaland police force had since its re-organization become a very important "weapon" in counter-insurgency, especially the detection of crime and recommending and implementing the harsh prison sentences for those convicted. There was also a very strong connection between the activities of the police force, the courts system, and the Office of the Attorney-General, to bring the implicated "insurgents" to "justice". It was in such processes that we notice some of the atrocities committed by the colonial state in the protectorate, as had been the case elsewhere in British colonial Africa. The activities of the Nyasaland police force will be significantly discussed in the chapter that follows (chapter five), where by the late 1950s, Nyasaland was described as a "police state" following the declaration of the 1959 state of emergency. Similar police tactics would also become the order of the day in post-colonial Malawi, as I will highlight in chapter six of this study.

\footnotetext{
${ }^{270}$ Clements Kadalie, National Secretary and on behalf of the Industrial and Commercial Workers Union of Africa, to The Right Hon. Col. S. Amery, Secretary for Dominion Affairs. October $20^{\text {th }}, 1926$, MNA: S2/50/23. See also from the same file (MNA: S2/50/23): Acting Commissioner of Police to the Acting Chief Secretary, at Zomba. January $29^{\text {th }}, 1927$.
} 


\section{Conclusion}

This chapter has tackled the question of state-organized forms of counter-insurgency, using both "the carrot and the stick". It has focused on the immediate reaction by the colonial state towards the outbreak of the 1915 African uprising in Nyasaland, and the actions taken by the state during the inter-war period, between 1919 and 1939. I have argued that the state used tactics that included the use of brutal force (such as public executions, imprisonment, looting of houses belonging to insurgents, heavy fines, and deportations). I have also explored the concept of "politicaleconomy", by examining how the colonial state turned to both the police and the legal system, as organs of the state, with the former detecting and detaining insurgents, and the latter passing out stiff punishments on the insurgents, which became the chief means through which the state reestablished and maintained its authority and domination. The chapter also hints that there were limits to which the colonial state could use brutal tactics against the colonized, hence the dangling of "the carrot" which I have argued that for the period under study, had been recommended by the commission that investigated the causes and origins of the 1915 uprising, whose report called for the provision of education and employment opportunities (within the colonial structures), and also through giving back some portions of land to the Africans, whose economy was agro-based and hence dependent on the land. The "carrot" strategy was one where the colonial state-initiated development and welfare programs that were for the benefit of the colonized peoples, which meant that with "political will", it was possible for the colonial experience to be worthwhile for the colonized peoples. It has also been highlighted that the advent of the colonial state's involvement in the development and uplifting the socio-economic livelihoods in Nyasaland had much more to do with the input and influence of the Africans. The measures employed by the colonial state were in many instances detrimental to the needs of the European settlers. The next chapter covers the 
period after the Second World War up to the early 1960s. It revolves around the analysis of the notion of the ambiguity of the concept of "development", especially how its implementation or lack thereof became the basis of African discontent and the rise of radical nationalism, challenging the authority of the colonial state. In turn, the colonial state also employed similar "carrot and stick" measures that had been initiated during the inter-war period. 


\title{
CHAPTER FIVE
}

\section{THE POLITICS OF DEVELOPMENT AND THE DEVELOPMENT OF POLITICS IN THE LATE COLONIAL PERIOD}

\begin{abstract}
Today it is avowed by the Charter of the United Nations that the interests of the inhabitants of non-self-governing territories are paramount, that the Colonial Powers accept a sacred trust to promote to the utmost the well-being of their inhabitants, and that the purpose of the administering power is to develop self-government and promote constructive measures of development. The clause in the Charter owes its presence to British and Commonwealth advocacy and expresses the objectives of British colonial policy. ${ }^{271}$
\end{abstract}

\section{Introduction}

This chapter examines the background to the colonial state's involvement in the development of the Nyasaland protectorate, which became one of the major colonial policy initiatives immediately before and after the Second World War. I will concentrate on the Colonial Development Acts of 1929, 1940 and 1945, and the related development programs implemented in Nyasaland under these Acts. These acts serve as precursors to the establishment of the Central African Federation (CAF) from 1953 to 1963, when the state adopted both a state-led development agenda and an integrated approach to colonial development. I will argue that these state-led development initiatives, although they had good intentions, also came with some hidden agendas. That helps to explain why they lacked the requisite support from local people. An analysis of the development programs will help show that despite the claims that they were primarily meant for the socioeconomic development of Africans, in practice they were also designed to boost the economy of the metropole and its allies. By zeroing in on the $\mathrm{CAF}$, for instance, I will highlight that much as

271 "The Future of the African Colonies", Speech by The Rt. Hon. Arthur Creech Jones, P.C., Cust Foundation Lecture at the University of Nottingham, March $9^{\text {th }}, 1951$. 
it was touted to be beneficial to the inhabitants (of all races) in the concerned territories, the scheme itself served metropolitan (British) and to an extent American, political and economic interests at the height of the Cold War. The lack of substantive support from Africans in the three territories created the impetus for the establishment and consolidation of nationalist movements, many of which attained mass support by attacking the federal scheme. In Nyasaland, the main nationalist movement was the Nyasaland African Congress (NAC), which was established in 1944. The appearance of widespread opposition against the federation compelled the colonial authorities to create counter-insurgency measures that would help check those who challenged the authority of the colonial state and promote the spirit of protectionism for the state's economic interests. I will specifically focus on such measures as the use of brutal force, through the police force, and the offer of development opportunities to the African masses during the late colonial era.

\section{The State and Colonial Development in Nyasaland, 1891-1953}

The concept of development has been defined differently by various scholars. As argued by M.P. Cowen and R.W. Shenton, the concept of "development," should be viewed from two main perspectives. Firstly, development should be analyzed as a process of enlarging people's choices, of enhancing participatory democratic processes, and their ability to have a say in the decisions that shape their lives. Development can also be defined as the means to carry out a nation's development goals and of promoting economic growth, equity and national self-reliance. This conceptualization encompasses the notion that there must be a goal or by-product of the process of development. ${ }^{272}$ This chapter explores both the processes and perceived goals of the

\footnotetext{
${ }^{272}$ M.P. Cowen and R.W. Shenton, Doctrines of Development (London: Routledge, 1996), 4-5. See also Joseph M. Hodge and Gerald Hodl, "Introduction," in Joseph M. Hodge, et al, eds., Developing Africa: Concepts and Practices in twentieth-century imperialism (Manchester: Manchester University Press, 2014), 3-5. In the same vein, the Human Development Report of the UN, 1991, characterized 'development' as a process that enlarges the range of people's choices to make development more democratic and participatory. These choices should include access to income and
} 
development initiatives in Nyasaland focusing on the period after the Second World War. It sustains the argument that "development" as it occurred in colonial era Malawi was often a contested process and was at times opposed by Africans if it did not meet their short term and long-term needs at the time.

The initiation of or lack of development programs in the Nyasaland protectorate should be traced back to the mid nineteenth century, when the British government established the protectorate. This involves an examination of the private or mercantilist values and "official mind" of Victorian Britons, with regards to the question of development programs in Britain's tropical colonies. Ronald Robinson and John Gallagher argued that the official and private (or public) mind of the late nineteenth century was one which did not necessarily favor the continued outward expansion of the British Empire, which would involve the setting up of colonial states. Most of the capitalist class favored an improvement in the human conditions of the people they traded with, elsewhere, but were not in favor of an interventionist state in their enterprise. In that atmosphere, as argued by Robinson and Gallagher, a "formal empire" tended to be thought of as an auxiliary, in much the same way as the liberal state in the United Kingdom (UK). All that was needed was for the capitalists (traders and farmers) and missionaries to take up the roles of liberating the producers of Africa and Asia, in the hope that the indigenous people would be incorporated in the liberal British world view. This spirit of free trade zones also influenced British politicians, especially at a time when the British Treasury usually had less money to spare for more colonial activities - especially in areas where the actual economic potential had not yet been proven. For Africa, up to the 1880s,

employment opportunities, education and health, and a clean and safe physical environment. Everyone should also have the opportunity to participate fully in community decisions and to enjoy human, economic, and political freedoms. See United Nations, Human Development Report, 1991 (Oxford: Oxford University Press, 1991), 1. Under the UN definition, 'development' could represent the 'processes' and the 'end results' of all actions being taken to uplift the livelihoods of a given people. 
British merchants and politicians had been concerned with the coastal areas of the continent, to keep the sea-ways around the continent safe, open, and clear of rival powers - hence the Empire's concentration on coastal areas such as Egypt, West Africa, South Africa, and Zanzibar in East Africa. $^{273}$

That however did not mean that there were no advocates for "constructive" or state-led development in the tropical colonies. We know for instance that Joseph Chamberlain, Colonial Secretary from 1895 to 1903 , tried his best to advocate for more funding towards development programs in the British colonies. Robert V. Kubicek (1969), for instance quoted Joseph Chamberlain as having called for colonial development in the following passage:

... (It is) Not enough to occupy certain great spaces of the world's surface unless you can make the best of them, unless you are willing to develop them. We are landlords of a great estate; it is the duty of the landlord to develop his estate .... In my opinion ... it would be the wisest course for the Government of this country to use British capital and British credit to create an instrument of trade (i.e. railways) in all ... new important countries. I firmly believe that not only would they in so doing give an immediate impetus to British trade and industry in the manufacture of the machinery that is necessary for that purpose, but that in the long run ... they would sooner or later earn a large reward either directly or indirectly. ${ }^{274}$

Wm. Roger Louis, writing about the lives of Joseph Chamberlain and Leo Amery, both former Colonial Secretaries, argued that the two men's insistence on colonial development in the British colonies and dominions was motivated by the perceived benefit for Britain's own economic development. As Roger Louis hinted: "In substance it was a sophisticated version of the old mercantilist system whereby Britain would become the workshop of the colonies which in turn would provide markets and raw materials. The British Empire would emerge as a single and

\footnotetext{
${ }^{273}$ Ronald Robinson and John Gallagher, Africa and the Victorians: The Climax of Imperialism (New York: Anchor Books, 1968 edition), 1-18.

${ }^{274}$ Robert V. Kubicek, The Administration of Imperialism: Joseph Chamberlain at the Colonial Office (Durham, NC: Duke University Press, 1969), 68.
} 
prosperous economic unit with an unbroken tariff wall around it, which in turn would enhance British power throughout the world. Prosperity within the Empire would improve conditions within the United Kingdom. Imperial strength would guarantee British security against Germany and the United States."275

As Colonial Secretary, Joseph Chamberlain developed what was known as an "Imperial Estates Program" - in which he wanted the British Government to provide capital and credit for railways and improved harbors in the underdeveloped colonies of tropical Africa, and an irrigation system and a railway system in British-ruled Cyprus. He also called for credit grants and loans to be provided to help revive the economies of the West Indian Sugar Islands. His argument had been that the provision of British imperial aid would promote the economic and political viability of the regions, attract private investors and provide ultimately lucrative markets and raw materials for British industry. However, one major stumbling block for such plans was the lack of support from the British Treasury, an arm of the government which controlled state expenditure. Under Mr. Hicks Beach, as Chancellor of the Exchequer, the Treasury viewed Chamberlain's demand for funds within the context of the government's general financial position, which by the late 1890s was not necessarily a healthy one. Hence it was not possible, by the late 1890s and early 1900s,

\footnotetext{
${ }^{275}$ Wm. Roger Louis, In the Name of God, Go! Leo Amery and the British Empire in the Age of Churchill (London: W.W. Norton and Company, 1992), 52-53. See also Michael Havinden and David Meredith, Colonialism and Development: Britain and its Tropical Colonies, 1850-1960, 87. The two scholars argued that Joseph Chamberlain had fears that Britain's power, wealth and prestige had been on the wane, and that Britain could not compete with other imperial powers such as Germany, USA and Russia - hence the need to have a prosperous empire and contented subjects, with the ability to raise sufficient revenues and produce raw materials to drive Britain's industries and/or economic growth. In other words, if Britain were to be successful, it would also translate into prosperity for the colonies. In the same vein, see also Stephen Constantine, The Making of British Colonial Development Policy, 19141940 (London: Frank Cass and Company, 1984), 9-12. See also Peter T. Marsh, Joseph Chamberlain: Entrepreneur in Politics (New Haven: Yale University Press, 1994), 406-447. According to Peter T. Marsh, apart from investments aimed at boosting the British economy, it was also Chamberlain's efforts that contributed to the British Government's involvement in research on tropical medicine (especially in tracing the causes and cure for malaria); and the cultivation of cotton and general botany. See also Joseph M. Hodge, Joseph M. Hodge, Triumph of the Expert: Agrarian Doctrines of Development and the Legacies of British Colonialism (Athens, OH: Ohio University Press, 2007), 21-24.
} 
for the government to conduct a state interventionist type of development, to promote the welfare of the colonized peoples in the poorer overseas territories, as much as the Colonial Secretary had wanted. The fears of the Treasury had been that it was a risky adventure for the government to provide loans to the overseas territories when there was no guarantee that the loans would have been paid back. ${ }^{276}$

Joseph M. Hodge also argued that what held the hand of the Treasury from supporting Chamberlain's campaign for colonial development was that, firstly, it had connections with the interests of financial speculators, monopoly capitalists, and concessionary companies who were said to be at the root cause of the Anglo-Boer War in South Africa (1899-1902). There was also apathy due to the military expansion and upheaval that characterized the so-called "Scramble for Africa." Britain emerged out of the war and the pacification efforts with an unprecedented public debt, such that the Treasury was unwilling to approve or provide extra funding towards costly military interventions and ambitious colonial development projects. Furthermore the Treasury also

\footnotetext{
${ }^{276}$ Robert V. Kubicek, The Administration of Imperialism: Joseph Chamberlain at the Colonial Office, 69-83. See also Michael Havinden and David Meredith, Colonialism and Development: Britain and its Tropical Colonies, 18501960., 87-88. The two authors also argued along the same lines that the British Treasury refused to invest public money in colonial development or to guarantee loans raised on the commercial money market; and without a Treasury guarantee, such loans would only be raised at rates of interest which were far higher than most colonies would reasonably be expected to pay, especially for long-term loans. See also J. Forbes Munro, Britain in Tropical Africa, 1880-1960: Economic Relationships and Impact (London: Macmillan Press, 1984), 23-24. Munro called Joseph Chamberlain's campaign for colonial development as a form of 'Constructive Imperialism' whereby it was a duty of the Government to transform the economically-backward colonies that would not have developed without imperial assistance - in areas such as transport, communication, agricultural research, health care, and other related technical services. In the same vein, Toyin Falola described the efforts by Joseph Chamberlain, as one of working towards implementing a doctrine of 'Imperial Responsibility' which would have led to the use of money raised in Britain for development projects in the colonies, which in return would have also brought about markets and raw materials essential for British industries and the economy. See Toyin Falola, Development Planning and Decolonization in Nigeria (Tallahassee: University of Florida, 1996)., 9. See also Ronald Hyam, Elgin and Churchill at the Colonial Office: The Watershed of the Empire-Commonwealth (London: Macmillan Press, 1968), 428-435. Ronald Hyam also argued that Lord Elgin, who succeeded Chamberlain as Colonial Secretary, also continued with his predecessor's efforts to develop the colonies and protectorates, in the hope that their raw materials would have been beneficial for Imperial Britain, amid international competition. Lord Elgin and his Liberal colleagues had often argued that African territories, if they were developed, would have been self-supporting, and hence stop draining the resources of the British tax payer.
} 
referred to the scandals and colonial resistance in Africa, most notably on the west coast, where a hut tax war took place in 1898 in Sierra Leone; and also the atrocities of King Leopold's Congo Free State at the end of the nineteenth century. ${ }^{277}$ The arguments by critics of imperialism at that stage had been that the Anglo-Boer War had been inspired by British imperial demands in South Africa. It had been interpreted as a war between two nations and opposing political and economic interests, rather than a mere chapter in the history of the industrialization of Africa. That meant that imperialism had reached a stage where it was ready to send its adherents to war. The war had also shown the close connection that existed between economics and politics, where politics covered the shortfalls of economics. The government was thus seen to be essential to bail out capitalists from the economic downturn of the late nineteenth and early twentieth centuries. ${ }^{278}$

Stephen Constantine also questioned the willingness of the Treasury and indeed the government to accelerate the economic development of the colonial empire through either grants or loans or other forms of direct aid. However, there were also other associated reasons, which included, firstly that the Colonial Office (CO) was itself to blame, because of its own understanding of colonial development - one in which the officials simply wanted to increase the production of primary products (raw materials) and not to institute structural changes in the local economy, nor industrialization. The other reason had been that there was a limited relationship that existed between the $\mathrm{CO}$ and the other parts of the colonial empire. The empire was highly decentralized, with limited communication between the colonial governors and the $\mathrm{CO}$. The $\mathrm{CO}$ had simply given itself a supervisory role, which limited the CO's access to internal developments within colonies.

\footnotetext{
277 Joseph M. Hodge, Triumph of the Expert: Agrarian Doctrines of Development and the Legacies of British Colonialism (Athens, OH: Ohio University Press, 2007), 47-48.

${ }^{278}$ See J.A. Hobson, Imperialism (Michigan: The University of Michigan Press, 1965). I used the 2011 edition, see introduction by Philip Siegelman, v-xvi. For a comprehensive study of the Anglo-Boer War, see the following works: Martin Meredith, The British, The Boers, and the Making of South Africa: Diamonds, Gold and War (Great Britain: Simon and Schuster UK Ltd, 2007).
} 
In that case, the $\mathrm{CO}$ did not even have an empire-wide development plan, as that was regarded as a responsibility of officials in the colonies. There was also an assumption by many in the $\mathrm{CO}$ that it was private enterprise and not the state that was responsible for the economic development of colonial territories. The assumption was that if the $\mathrm{CO}$ had initiated development schemes, it would likely obstruct the proper functioning of private businessmen who needed less state intervention to practice in a laissez faire atmosphere. The $\mathrm{CO}$ was also pre-occupied with the doctrine of "trusteeship" - whereby the CO claimed that its primary administrative concern was with the welfare and rights of subject colonial peoples, and not necessarily participating in the direct investment of state funds in colonial development programs. ${ }^{279}$

In the case of Nyasaland, it was not until the 1890s that the British government was finally convinced of the need to establish a formal empire. The motives for the occupation of Nyasaland were mainly strategic, to drive out the Portuguese who had been approaching the Shire Highlands - an area which the British government intended to secure to serve the interests of British traders, planters, and missionaries operating in the area, and in need of access to the Zambezi river for transportation. To the north-east of Nyasaland, the Germans had also begun to show imperial interests, which led to the colonization of German East Africa ( later Tanganyika), which again compelled the British government to move in faster, to block the Germans from occupying the northern part of Lake Nyasa (now Lake Malawi), where the British firm African Lakes Corporation

\footnotetext{
${ }^{279}$ See Stephen Constantine, The Making of British Colonial Development Policy, 1914-1940 (London: Frank Cass and Company, 1984), 12-23. In the same vein, see also Ronald Hyam, Elgin and Churchill at the Colonial Office: The Watershed of the Empire-Commonwealth (London: Macmillan Press, 1968), 468-474. Ronald Hyam also argued along the same lines of a cautious British or Edwardian Government towards involvement and investment in colonial development. Hyam, whose book focused on the period between 1903 and 1908, when Lord Elgin was the Colonial Secretary having succeeded his fellow Liberal, Joseph Chamberlain, mentioned such factors such as (1) the desire to avoid spending the British tax payer's money in the colonies; (2) the denial for support from the British Treasury, which often rejected development programs suggested by colonial governors; (3) the arguments by leading thinkers both within and outside government that the colonies had to be self-supporting; (4) and also the notion that the government authorities did not want to be seen as if they had been favoring African colonial possessions.
} 
(ALC) and missionaries had been operating since the early 1880s. Even when the decision to establish a protectorate over Nyasaland between 1889 and 1891 was finally made, some in the British government remained reluctant to commit government funds for the project, and it had to take the persuasion of Lord Salisbury (then British Prime Minister) by Sir Harry Johnston (the first Commissioner of Nyasaland), that it would be worthwhile to establish the protectorate. Sir Harry Johnston had even initially suggested, without success, that the protectorate should be administered by Cecil John Rhodes and his British South Africa Company (BSAC), which was allowed to subsidize funding to the Nyasaland government to the sum of $£ 10,000$ per annum up to 1895, when the arrangement ceased. ${ }^{280}$ In the 1903-04 fiscal year the subsidies from the BSAC to the Nyasaland government were resumed and continued until 1911. The following sums of money were provided to subsidize the administration of Nyasaland: 1903-04 (£10,435); 1904-05 (£5,350); 1905-06 (£7,350); 1906-07 (£7,350); 1907-08 (£8,000); 1908-09 (£10,000); 1909-10 (£8,000); $1910-11(£ 8,000){ }^{281}$

In this atmosphere, where the British government was unwilling to commit itself to the formal colonization of the protectorate, and where the policy of laissez-faire championed by British mercantilists had been dominant, it was unexpected at least in the immediate future that concern for the people's welfare would have been among the government's top priorities. The British authorities expected the economic development of the tropical colonies to be taken up as a

\footnotetext{
${ }^{280}$ Griff Jones, Britain and Nyasaland: A Story of Inattention, Fitful care, Political vacillation (London: George Allen and Unwin Ltd, 1964), 31-45. See also Harry Hamilton Johnston, British Central Africa: An Attempt to Give Some Account of A Portion of the Territories Under British Influence North of the Zambezi (New York: Edward Arnold, 1897), 111-112. The proposal for Cecil Rhodes met with stiff resistance from both the British authorities in London, and the European settlers in the protectorate. In London, there was suspicion of the relationship between Rhodes and Johnston, while in Nyasaland, the settlers, especially the missionaries, were not in favor of being placed under a capitalist of Rhodes' stature. See John McCracken, A History of Malawi, 1859-1966 (Great Britain: James Currey, 2012), 57. See also Bridglal Pachai, Land and Politics in Malawi, 1875-1975 (Ontario, Canada: The Limestone Press, 1978), 160-161.

${ }^{281}$ A Handbook of Nyasaland (Zomba: Government Printer, 1932), 290-294.
} 
responsibility of capable colonial government and private international investors. As I have discussed in chapters two and three of this study, the top priorities of the colonial state in the early years had been to maintain law and order, to provide security (to European settlers), and to find means of revenue collection (which led to the imposition of the hut tax in the early 1890s). This background provides a clear picture about why there was limited development, if any at all, in the tropical colonies before the outbreak of the First World War. If the Treasury released any funds at all, they were meant for balancing the budgets of colonial states, rather than the funding of colonial development. It was expected of colonial governments to raise their own revenue or raise loans to fund internal developmental needs. I have for instance discussed in chapter three of this study, how the Nyasaland government initiated the hut tax as soon as the colonial state was established in the 1890s, and that the local chiefs who signed the "treaties" to acknowledge their being placed under British colonial authority, were also compelled to agree that they would pay taxes to the colonial state. Part of the reason for the lack of colonial development, in colonies of East and Central Africa, where Nyasaland was located, as already highlighted above, was the lack of commitment along that line by government administrators, based on the belief in the principles of free trade and less state intervention. It was argued in some quarters that the economic benefits of free trade would have been obtained without incurring further costs of colonial administration. That was true for Nyasaland and explains why the British government dilly-dallied in assuming full control of the protectorate after the 1884 - 85 Berlin Conference. I have argued in chapter four of this study, that it was not until after the 1915 native uprising, that the Nyasaland Government, now "aware" of the grievances of the natives, began to roll out welfare development programs for the colonized 
peoples - in agricultural production, land re-distribution and provision of education opportunities. $^{282}$

I have also highlighted, in chapter four, that it was not until 1929-1930, that a consistent development program was put in place, under the Colonial Development Act (CDA) of 1929, whose aim had been to both revive the ailing colonial economies, and to create employment opportunities for British citizens, both in the UK and in the colonies. This was particularly important to sort out the mess created by the Great Depression. Between 1930 and 1936, Nyasaland benefitted from the CDA of 1929 , to the sum of $£ 726,534$. Once disbursed, the funds served in the sectors of agricultural production, public health, water supply, public works, geological survey, and the communication sector. ${ }^{283}$ It is also clear from that background, that the type of development that was initiated in the late 1920s, and particularly since the enactment of the CDA of 1929, onwards, was one in which the state was at the center of planning, funding, and implementing development programs, i.e. an interventionist state development program or statedirected development. ${ }^{284}$ According to Atul Kohli once the state began to take a more central role in economic development, there developed a "protectionist," rather than a laissez faire economic policy, which meant the beginning of blocking out potential competitors. The state became a key player on tariffs, subsidies, credit control, manpower training, technology promotion, and bureaucratic cooperation. $^{285}$

\footnotetext{
${ }^{282}$ Nyasaland Rising Commission of Inquiry (Zomba: Government Printer, 1916), BNA: WO/106/262.

${ }^{283}$ Great Britain, Report of the Commission Appointed to Inquire into the Financial Position and Further Development of Nyasaland (London: HMSO, 1938), 114-115.

${ }^{284}$ See for instance, Atul Kohli. State-Directed Development: Political Power and Industrialization in the Global World (Cambridge: Cambridge University Press, 2004).

${ }^{285}$ Ibid., 6-7.
} 
In Nyasaland, the state had to intervene in the development sector because, as already alluded to in chapter three of this study, most of the European settlers in the country were of limited economic means, and hence could not spearhead the country's economic development. Along the same lines, Mapopa Chipeta argued that most of the European capitalist settlers in the country, who were members of the Chamber of Agriculture and Commerce (established in 1895), relied on the goodwill of the Nyasaland government to provide them with access to land and cheap (sometimes free) labor resources, and better trade policies, including lower rates of imports and exports. This induced the colonial state to take an active role in the country's economic development, especially where the private sector had been unable to spearhead the development of the country. ${ }^{286}$ Furthermore, the onset of the Great Depression also bankrupted many of the settler farmers. The future of a settler-led economy looked bleak, and by the early 1930s most of the settlers had exhausted their credit facilities at the commercial banks and many could not repay the loans. Between 1929 and 1939, the colonial government advanced loans amounting to $£ 34,868$ to a total of 188 settler farmers, especially those that had leased land from the government. However, that initiative did not yield positive results, as by 1935 , most settler farms in the southern and central provinces were abandoned and many of the settlers left the country for Southern Rhodesia. Of the estimated 400 settler plantations in 1928, only 82 remained in operation by 1936, of which 50 were predominantly tobacco farms and the remainder produced tea, sisal, and cotton. As such, by the eve of the Second World War, it was clear that a settler-led economy had failed to take root in the country, hence the need for state intervention. ${ }^{287}$

\footnotetext{
${ }^{286}$ Mapopa O.J. Chipeta, "Labor in Colonial Malawi: A Study of the Growth and Development of the Malawian Working Class, 1891-1961" (PhD Thesis, History Department, Dalhousie University, Canada, October 1986), 28-32.

${ }^{287}$ Ibid., 42-44. About the Great Depression, it's important to consider that most of the British colonies felt the impact of the economic downturn, largely due to the dependent colonial economies that were created. See for instance, Moses E. Ochonu, Colonial Meltdown: Northern Nigeria in the Great Depression (Athens, OH: Ohio University Press, 2009). Similarly, Leigh A. Gardner, using the case studies of Kenya and Northern Rhodesia, also argues that the
} 
By the 1930s, however, as already alluded to, British colonial policy had changed, which saw the state being more-interventionist in the political and socio-economic aspects of the colonized peoples, although its development and implementation tended to vary from colony to colony. The view from the $\mathrm{CO}$ was summarized in 1938 as follows:

Our task presumably in the Colonial Office is to lead Colonial people to a larger and a fuller life, to make them capable of realizing their own potentialities and to enable them to appreciate the moral standards and ethical values upon which we in Europe set store. That implies quite clearly many other things besides merely material prosperity. It means the development of social and political institutions: it means the steady increase of educational facilities: it means the improvement of the health of the communities and, above all, it means the inculcation by precept and by example of certain ethical and moral standards to which we attain importance. ${ }^{288}$

In July 1940, the British government, not surprisingly, followed up its earlier colonial development efforts by enacting the Colonial Development and Welfare Act, (hereafter CDWA, 1940), which was another significant step in the process of state-led development. According to D.J. Morgan, the Act came into being following deliberations between the Treasury and the $\mathrm{CO}$, where it was agreed to come up with a new ten-year colonial development program, for a maximum of $£ 5$ million a year, distributed to colonial governments to cover for both capital schemes and recurrent expenditure on certain specified services. In his support for the Colonial Development Bill, the Secretary of State for the Colonies, Malcolm MacDonald, is said to have reiterated Britain's commitment to colonial development, hinting that "it establishes the duty of taxpayers in this

\footnotetext{
Depression had a severe impact on colonial budgets, especially as many experienced a reduction in the amount of revenue collected. See Leigh A. Gardner, Taxing Colonial Africa: The Political Economy of British Imperialism, 133144. Similarly, the Depression also affected the former European colonies and mostly dependent economies (especially on the USA) of Latin America. Once the private sector had been negatively affected, it contributed to more state intervention in the economy, including the rise of 'protectionism' and import substitution industrialization (ISI). See Rosemary Thorp, "Introduction," in Rosemary Thorp, ed., Latin America in the 1930s: the role of the periphery in world crisis (London: The Macmillan Press, 1984), 1-15. On Latin America, see also Carlos F. Diaz Alejandro, "Latin America in Depression, 1929-1939," Center discussion Paper no. 344 (Yale University, Economic Growth Center, March 1980): 1-41.

288 The Crucial Problem of Imperial Development, no.15. Royal Empire Society (London: Longmans, Green and Co., 1938), 72-73. The remarks were made by the Under-Secretary of State for the Colonies.
} 
country to contribute directly and for its own sake towards the development of the colonial peoples for whose good government the taxpayers of this country are ultimately responsible". ${ }^{289}$ Colonial governments were thus asked to prepare development plans that could be funded under the new Act (CDWA, 1940), particularly focusing on the improvement of the economic position of the colonies, so that they could finance their own social and economic services (especially health care and building human capacity) in the long run. However, due to the increasing intensity of the Second World War, most of such plans were rarely implemented until after the war was over in 1945.290

For instance, John McCracken observes that Nyasaland only benefitted to the tune of about $£ 100,000$ from the CDWA, 1940. He argued that among other reasons, those funds were channeled to the Nyasaland government to stimulate the protectorate's economy, and to guard against American anti-imperialist pressure, whereby the United States Government had often condemned colonial rule's exploitative policies and practices. ${ }^{291}$ In other instances, the British government was also receiving funds from the colonies to support the war effort. For instance, between 1940 and 1942, the Nyasaland government submitted a sum of $£ 117,000$. In 1943, a further $£ 15,000$ was "subscribed" by the people of Nyasaland to various war funds. In the same year, the Nyasaland government also lent a further $£ 100,000$ to the British government, free of interest, which brought the total amount of money given or lent to the British Government to $£ 427,000{ }^{292}$

\footnotetext{
289 D.J. Morgan, The Official History of Colonial Development: Volume 1: The Origins of British Aid Policy, 19241945 (New Jersey: Humanities Press, 1980), 85.

290 D.J. Morgan, The Official History of Colonial Development: Volume 1: The Origins of British Aid Policy, 19241945 (New Jersey: Humanities Press, 1980), 80-90. See also Great Britain, Colonial Development and Welfare Act, 1940: Report on the Operation of the Act to $31^{\text {st }}$ October 1942 (London: HM Stationery Office, Feb. 1943).

${ }^{291}$ John McCracken, A History of Malawi, 1859-1966 (Great Britain: James Currey, 2012), 241.

292 Speech by Governor H.E. Sir Edmund Richards, in the Proceedings of the Legislative Council of Nyasaland, $59^{\text {th }}$ Session, December $7^{\text {th }}, 1943$.
} 
Due to the obstacles faced by the CDWA of 1940, as outlined above, the British government enacted the CDWA of 1945, whose aim was to extend the development program for a further ten years. The 1945 Act also addressed the shortfalls of both the 1929 and 1940 Development Acts, especially in terms of the amount of funds provided to the colonies. It was suggested by the Secretary of State for the Colonies that the figures proposed in the 1940 Act had to be doubled, and also that the annual limit of funds released by the British government had to be increased in stages over the next ten year period, providing a maximum of $£ 10$ million for three years up to 1948-49, a maximum of $£ 15$ million from 1949-53, and a maximum of $£ 20$ million from 1953-56. These grants were mainly targeted at providing funds for research and the development of higher education. By the end of the deliberations on the Act, a compromise was reached between the Treasury and the $\mathrm{CO}$, where it was agreed that a total of $£ 120$ million would be set aside under the CDWA of 1945 , to be utilized between 1946 and $1956 .{ }^{293}$ British colonies could draw money from the fund during that ten-year period, with an annual maximum of $£ 17.5$ million (instead of the previous $£ 5.5$ ), of which a maximum of $£ 1$ million could be spent on research. ${ }^{294}$ In London, the enactment of the CDWA of 1945 was also positively welcomed by King George VI, as he made the following remarks in the House of Commons: "The development of the Colonial Territories and the welfare of their peoples will continue to receive the attention of My Government, and they will introduce legislation to supplement the sums made available for these purposes by the Colonial Development Welfare Act, 1945.”295

\footnotetext{
${ }^{293}$ D.J. Morgan, The Official History of Colonial Development: Volume 1: The Origins of British Aid Policy, 19241945, 198-200. In the same vein, see also the work of Toyin Falola, Development Planning and Decolonization in Nigeria (Tallahassee: University of Florida, 1996). See also 'Speech by Hon. Arthur Creech Jones, Secretary of State for the Colonies, House of Commons Session on Colonial Affairs, July 29 ${ }^{\text {th }}, 1947$, Vol. 441.

${ }^{294}$ Toyin Falola, Development Planning and Decolonization in Nigeria., 51-53. Note that between 1946 and 1948, a total of 14,520,000 British Pounds was spent in disbursing funds under the CDWA of 1945. For this see 'Speech by Hon. Arthur Creech Jones, House of Commons Session, June 22 ${ }^{\text {nd }}, 1949$, Vol.66.

${ }^{295}$ Speech by King George VI, House of Commons Debates, Vol. 480, October 31 st 1950.
} 
While the above-mentioned transactions affected the empire at large, in Nyasaland, the story of whether the protectorate benefitted, if any at all, from the CDWA of 1945, can be traced from the reports compiled by the Post War Development Committee (PWDC). The PWDC was put in place in Nyasaland by Governor Sir Edmund Charles Richards in 1943, and it consisted of the following officials: The Chief Secretary (Chairperson); The Financial Secretary; Six Honorable Unofficial Members of the Legislative Council; and Mr. J. Marshall of the African Lakes Corporation (ALC). The PWDC adopted an integrated approach of development planning, which saw the colonial government combine different aspects of development initiatives in the protectorate. The committee was responsible for overseeing all development-related matters, such as education for all races in the country, public health, the training of medical personnel, the incidence of disease and of lunacy, agriculture development (both European and native), and transport and communication. ${ }^{296}$

A study of the roles played by the PWDC thus challenges the proposition by Colin Baker (1994), that Sir Geoffrey Colby, who became Governor of Nyasaland between 1948 and 1956, was the "Development Governor." ${ }^{297}$ It is fair to state, that although Governor Colby played an important role in the economic development of the country, his predecessor, Governor Sir Charles Edmund Richards, also played an important role worth acknowledging. For instance, in his maiden speech in the Legco, Governor Colby also acknowledged the work that his predecessor had done in as far as the development of the country had progressed, by making the following remarks: "Since I

\footnotetext{
${ }^{296}$ Summary of the Proceedings of the Legislative Council of Nyasaland, $59^{\text {th }}$ Session, December $7^{\text {th }}, 1943$. In the same vein, Toyin Falola described such type of development planning as an 'Integrated Approach of Development Planning'. In that case, there was a combination of a set of individual projects into a few sectoral programs, such as transportation, energy, education, and agriculture. See Toyin Falola, Development Planning and Decolonization in Nigeria, xviii.

${ }^{297}$ Colin Baker, Development Governor: A Biography of Sir Geoffrey Colby (London: British Academic Press, 1994). Colin Baker's work praised Governor Colby as being responsible for laying the economic foundation upon which the economy of independent Malawi was later built.
} 
arrived here, I have made a careful study of the Development Plan. At the present time the various development proposals are contained in the reports of the Post War Development Committee. In order that the Plan can be presented in a self-contained form I am causing a White Paper to be published shortly which will set out in a concise form the various departmental plans of the Government." 298

In continuation of the development agenda across the empire, in 1948, the Labor government established the Colonial Development Corporation (CDC), as an organ to take up the responsibilities of recommending the funding and implementation of colonial development projects. The CDC was placed under the Secretary of State for the Colonies, following the enactment of "The Overseas Resources Development Act of 1948," in which the Secretary of State was responsible for appointing directors of the CDC, made up of a minimum of four directors and a maximum of ten. The government provided an initial operating capital of $£ 160$ million, to be split between the CDC and the Overseas Food Corporation. In 1949, the Secretary of State for the Colonies, James Griffiths, moved a motion in the House of Commons, to analyze the Annual Report and Statement of Accounts of the CDC for the year 1949. He made the following remarks to open the deliberations:

This organization, still in its infancy, is already showing itself to be a powerful instrument for economic development in the Colonial Territories, and it is already clear beyond doubt that when its resources are fully deployed it will undoubtedly have considerable influence on both the rate and the direction of economic progress in those Colonies. I believe it will make a contribution not only to the economic well-being of the people in those territories, but also to that of the sterling area and of the world. I think it is therefore right that the operations of the corporation, its method of work and

\footnotetext{
${ }^{298}$ Speech by Governor Geoffrey Colby, Esq., In Record of the Proceedings of a Meeting of the Legislative Council, Zomba, July $19^{\text {th }}, 1948$.
} 
its achievements, should receive the scrutiny of the House, as indeed is required by the statue which the Corporation was set up. ${ }^{299}$

The section below continues with the analysis of the efforts of the British government, in collaboration with its colonial states, to get more involved in colonial development. In the British territories of Nyasaland, Southern Rhodesia, and Northern Rhodesia, such efforts culminated in the creation of the Central African Federation (CAF), a political entity which existed from 1953 to 1963 . I will argue that since the Federation was imposed on the African natives, it emerged as the focal point of the agitation for independence in the three territories.

\section{Federation and the ambiguity of development, 1953-1963}

This section continues with the analysis of the colonial state's involvement in the development narrative, a process that culminated in the creation of the Central African Federation (CAF), a political entity which brought together the three British territories of Nyasaland, Southern Rhodesia (now Zimbabwe), and Northern Rhodesia (now Zambia). I argue that the decision should not be studied in isolation, but as part and parcel of the history and efforts of creating a state-led and integrated approach to colonial development, which has been discussed in the previous section. I will demonstrate that in creating the federation, the touted economic or developmental gains were not just for the benefit of Africans, as it was superficially presented, but rather, to also serve the developmental and economic needs of the metropole. As Gilbert Rist argued, it is often wrong to suggest that only countries in the global South (most of which were former European colonies) were and still are deserving targets for developmental intervention. Instead, all countries, in one

\footnotetext{
${ }^{299}$ Speech by Hon. James Griffiths, the Secretary of State for the Colonies, in the House of Commons, Session on the Colonial Development Corporation, October $19^{\text {th }}, 1950$. For a historical background of the official mind behind the establishment of the CDC, see the work of E.R. Wicker, "The Colonial Development Corporation, 1948 - '54," The Review of Economic Studies 23, no.3 (1955-1956): 213-228.
} 
way or the other deserve development-related intervention. ${ }^{300}$ Furthermore, I will also illustrate how the Cold War played an important role in accelerating the creation of the Federation. It was due to the vested economic and political interests that it became important to create counterinsurgency measures aimed at suppressing all forms of anti-Federation resistance in the three territories, and in Nyasaland in particular.

In his memoirs, Sir Roy Welensky (the Federation's Prime Minister from 1956-1963), pointed out that during the deliberations that led to the establishment of the CAF, there was always a desire by the European settlers and the British government to maximize the exploitation of mineral resources in the two Rhodesias and Nyasaland. The argument raised was that there was no need to accelerate political development for the Africans, as that would have "naturally" flowed if and when there was economic health or development (i.e. that without economic health, there could be no political development). ${ }^{301}$ Along the same lines of argument, Oliver Lyttelton (later Lord Chandos), who was the Secretary of State for the Colonies from 1951 to 1954, argued in his memoirs, that due to the economic benefits to be attained from the creation of the federation, the "official point of view" had been that there was no need to bow down to opposition demands (both in the metropole and in the concerned territories). In the United Kingdom (UK), the Labor Party leadership opposed the creation of the federation, since it was against the wishes of the African inhabitants. While African political leaders argued that the federation would only delay and derail the decolonization process, while also promoting the dominance of the European settlers. Lord Chandos described most of the Africans as being illiterate who did not even have the term "federation" in the vocabulary of their

\footnotetext{
${ }^{300}$ Gilbert Rist, The History of Development: From Western Origins to Global Faith, $3^{\text {rd }}$ edition (London: Zed Books, 2010), 11-12.

${ }^{301}$ Sir Roy Welensky, Welensky's 4000 Days: The Life and Death of the Federation of Rhodesia and Nyasaland. (London: Collins Clear-Type Press, 1964), 46-47.
} 
native languages, hence they could not even comprehend what the concept stood for. ${ }^{302}$ In Nyasaland, "the administrative mind," led by Governor Geoffrey Colby, also held similar sentiments, where the authorities argued that the protectorate was bound to reap significant economic benefits from the federal scheme. ${ }^{303}$

These sentiments were also raised in a message from Her Majesty Queen Elizabeth II, to the peoples of the three territories in the federation:

Today, when the Constitution of the Federation of Rhodesia and Nyasaland comes into operation, I send to you, and through you to all my people in the Federation, my heartfelt good wishes.

I pray that the blessing of the Almighty God may rest upon the people of the Federation, and that, living together in increasing fellowship and goodwill, they may use their combined efforts for the advancement of all. May those with whom the burden of government will rest be guided with wisdom in the tasks ahead.

An inspiring vision has been vouchsafed to you. To realise it will call for sustained endeavours in so developing the resources of the Federation as to make possible a better living for all by the expansion of education, health and other services. These endeavours will meet with the sympathy of all those who, in every part of the world, look with goodwill upon your efforts and wish for the Federation a great and successful future.

To you all I declare my sympathy in your resolve to fulfil the great ideals to which we are devoted. 304

Aside from the economic benefits, another covert determining factor was political. Michael Collins, in his study of the creation of federations, with focus on the CAF, in the post-World War Two era, argued that on the part of the British authorities, their aim had been to revive the British Empire in the aftermath of the war and amidst the ensuing nationalist drive. The creation of the

\footnotetext{
302 Oliver Lyttleton, The Memoirs of Lord Chandos: An Unexpected View from the Summit (New York: The New American Library of World Literature, 1963), 369-372.

${ }^{303}$ Speech by The Hon. C.W.F. Footman, Esq., The Nyasaland Government Chief Secretary. Legislative Council Proceedings, $8^{\text {th }}$ December 1952.

${ }^{304}$ Message from Her Majesty, Nyasaland Government Gazette, General Notice No.514 (Zomba: Government Printer, December 1952).
} 
federation, in imperial thought, was meant to create a larger political entity, one in which the European settlers would continue to control political power and colonial resources. At the time, the British authorities were clearly not ready to hand over political power to the African majority under newly-established nation-states. ${ }^{305}$ There is also the notion that the British authorities feared the infiltration of communism in their territories. This argument is centered on the outbreak and spread of the Cold War, whose peak was from 1947 to the late 1980s, whereby the capitalistinfluenced Western powers (led by the USA) sought to outwit the communist-influenced Eastern powers (led by the USSR) in an ongoing ideological warfare. ${ }^{306}$ In establishing the federation, part of the reasoning had been to create a strong state, essential for hampering the spread of communism. The talks to establish the federation accelerated in the aftermath of the Second World War, especially following the infiltration of communism in Asia, leading to the outbreak of such wars as the Korean War (1950-1953). The "official mind" at the time believed that territories in the Middle East and Africa would be the next targets, hence the need to form a buffer against the global spread of communism. ${ }^{307}$ At that time, the communist countries, led by the USSR, sought to take advantage of the grievances of the colonized peoples, especially material and racial-based discrimination - in which the minority European settlers dominated them, both politically and economically. Communist propaganda was said to have found a fertile ground in societies where the Africans were agitating for political and economic opportunities. Between 1948 and 1950, the Foreign Office (FO) instituted a general survey of communist activities and movements across the

\footnotetext{
${ }^{305}$ Michael Collins, "Decolonization and the 'Federal-Moment'," Diplomacy and Statecraft 24, no.1 (Feb.2013): 21 23.

306 For a comprehensive history of the Cold War, see Odd Arne Westad, The Global Cold War: Third World Interventions and the Making of Our Times (Cambridge: Cambridge University Press, 2007),8-72.

${ }^{307}$ Welensky, Welensky's 4000 Days, 47. There was fear among many at the CO that the British territories in Central Africa would have been targets of the spread of communism which had already been posing a threat in South Africa. Since there were thousands of migrant laborers from Nyasaland and the two Rhodesias working in South Africa, it was feared that upon their return to their homes, they would have helped in spreading communism. See Colin Baker, Development Governor: A Biography of Sir Geoffrey Colby (London: British Academic Press, 1994), $252-255$.
} 
African continent. In general, the report indicated that the spread of Communism had not been as rapid as previously anticipated, but still warned that there was need for the British government to remain vigilant. ${ }^{308}$ There were also numerous motions in the House of Commons, where MPs expressed worries about the spread of communism across Europe, and in Britain's colonial empire. ${ }^{309}$

It is no wonder, therefore, that once the Federation was established, one of the primary agencies to be created under the federation was the Federal Security and Intelligence Bureau (FSIB), to help maintain security and monitor the threat posed by the potential spread of communism in the region. The FSIB's headquarters was in Salisbury, Southern Rhodesia, the capital of the Federation. The first leader of the FSIB was a Mr. Maurice "Bob" de Quehen, formerly of the MI5. ${ }^{310}$ Philip Murphy also posited that intelligence gathering became one of the major pre-occupations of British Government officials in the post-World War II era, and that explains the setting up of the FSIB in June 1954. The FSIB was there to coordinate intelligence gathering in the Federation, in liaison with the police's special branch in each of the three territories. ${ }^{311}$ There were also security-based collaborations between the British and US security organs, monitoring developments in the federation. The US operated through the National Security Agency (NSA) in the USA and later the Central Intelligence Agency (CIA) established in 1947. The British Government worked

\footnotetext{
${ }^{308}$ A Survey of Communism in Africa, Extract from a Paper by the Research Department, Foreign Office. BNA: CO $537 / 5263$.

${ }^{309}$ Speech by Mr. Follick, MP for Loughborough Constituency, Parliamentary Debates, House of Commons Official Report, $5^{\text {th }}$ Series, Vol.473. March $27^{\text {th }}$ to April $6^{\text {th }}$, 1950., 287-288. See also Speech by the Right Hon. Clement Attlee, the British PM in the House of Commons, Parliamentary Debates, House of Commons Official Report, $5^{\text {th }}$ Series, Vol.478. July $24^{\text {th }}$ to October $26^{\text {th }}$, 1950., 951-954. See also BNA: CO 1035/126: Official Committee on CounterSubversion in Colonial Territories - Communism in Africa, 1956 Report. This was a Committee established by the British Government to counter the spread of Communism in Africa, by coordinating with intelligence organs in each of the British Territories.

310 Calder Walton, Empire of Secrets: British Intelligence, The Cold War, and the Twilight of Empire (London: William Collins, 2013), 278-279.

${ }^{311}$ Philip Murphy, "Intelligence and Decolonization: The Life and Death of the Federal Intelligence and Security Bureau, 1954-63," Journal of Imperial and Commonwealth History 29, no.2 (2008): 106-112.
} 
through the Government Communication Headquarters (GCHQ) and later through the MI6 (Britain's Secret Intelligence Service for Foreign Affairs). ${ }^{312}$

There are also arguments that Britain had ambitions to be regarded as a "Third Leading Power" during the Cold War and had therefore put in place plans to develop its own nuclear weapons. The federation was thus earmarked as an area where to source minerals, especially uranium which was essential in making the nuclear weapons was abundant. The most commercially-viable source of uranium was discovered in Northern Rhodesia in 1951, hence the need to press ahead with the federation plans, fearing that a delay would have provided room for either the USA or USSR to interfere. The US also immediately jumped in to offer support to the British authorities to enhance the mining efforts, in the form of finances, equipment, and other facilities. The US had intentions to use the uranium to be used for weaponry in the Korean War, and as a response to the USSR's unexpected atom bomb test in $1949 .{ }^{313}$ Other equally attractive minerals included copper, coal, chrome, zinc, and asbestos. The three territories were also a source of settler-grown varieties of coffee, tea, and tobacco. This background (of increased state intervention in development and domination of the economy) provided the impetus for the creation of strong counter-insurgency strategies, to block the potential spread of communism, to block the rise of African opposition, and to create room for continued colonial exploitation of the territories. I address such measures in the subsequent sections.

\footnotetext{
312 Jonathon Bloch and Patrick Fitzgerald, British Intelligence and Covert Action (Ireland; Brandon Book Publishers, 1983), 59-70. See also Dispatch from the US Consul General at Salisbury (Mr. Harold Sims), to the Department of State, Foreign Relations of the United States, 1952-1954, Vol. XI, Part 1, Africa and South Asia, Document 128. In that dispatch, there was information on the meeting between US Government officials and those from Southern Rhodesia, led by the PM, Sir Godfrey M. Huggins, in which the discussions revolved around the US access to raw materials from the Rhodesias. In return, the US delegation promised to provide financial support towards improvements in the transport sector, especially the construction of railways and provision of locomotives.

${ }^{313}$ L.J. Butler, "The Central African Federation and Britain's Post-War Nuclear Programme: Reconsidering the Connections," The Journal of Imperial and Commonwealth History 36, no.3 (Sept. 2008): 509-514.
} 


\section{Counter-insurgency and some dirty work of empire}

In this section, I argue that it was due to the increased levels of state interventionism that Nyasaland witnessed a significant rise in the levels and forms of African resistance until the end of the federation in 1963. The anti-federation resistance occurred both through the work of the leading nationalist party, the Nyasaland African Congress (NAC), and the African traditional leaders who rallied their subjects to oppose the federal scheme. Furthermore, just like the previous disturbances in the protectorate (for instance, the African uprising of 1915), there were also other factors (socioeconomic and political) that coincided with the anti-Federation resistance. The country's leading nationalist movement, the NAC, fed-off from the anti-federation atmosphere, by exploiting every African grievance as part of the party's anti-Federation initiative. I will highlight some case studies of those forms of African resistance, before discussing the counter-insurgency measures employed by the state to suppress the various forms of opposition and resistance.

Similar to the 1915 native disturbances (see chapter 3), the Shire Highlands became the center of the anti-federation movement and agitation. Colin Legum in 1953, hinted that the disturbances were inter-mixed with the African hunger for land, an issue that had not been resolved (from the Africans' perspective) since the enactment of the 1902 Order-in-Council (which placed all the land in the protectorate under ownership of His Majesty's Government). Legum likened the 1953 disturbances to the Mau Mau uprising in Kenya, and the Witwatersrand African uprising in South Africa, by pinpointing several similarities: Firstly, just like the Kenya highlands uprising, the Nyasaland episode also occurred in an area which was exclusively owned by European settlers. The only difference was that in Kenya the settlers were individual farmers, whereas in Nyasaland, they were plantation owners. Secondly, just like in the Witwatersrand mining belt, there was a shortage of local labor to work in the plantations. That shortage motivated the employers to look 
elsewhere for labor, including outside the country, something which in the Shire Highlands, created a challenge in terms of scarcity of land for cultivation. Many of the labor migrants experienced two main types of land and labor tenancy. There was one system where the plantation worker, as squatter, was allowed access to a small garden to cultivate crops for his own household. He was paid a wage for his work and was not required to pay rent for his ground. Then there was the category of African tenant farmers who were not employees on the plantation. These were asked to pay rent, which was calculated in relation to the wages earned in the area, which in the early 1950s was pegged at $£ 3$ per year. By the early 1940s, the second category of tenants had already been at loggerheads with the plantation owners, especially over the tenants' non-ability to pay rent, and the efforts of the plantation owners to evict the rent-defaulters. ${ }^{314}$

It was due to these disagreements on the land tenure system that His Majesty's Government appointed the so-called Abrahams Commission in 1946. The commission collected its data in the protectorate between July $28^{\text {th }}$ and October $4^{\text {th }}$, in which some of the findings seemed to predict what would later occur as African disturbances from 1953 onwards. The report of the commission noted that there was congestion of African population in the Shire Highlands (referring to the districts of Thyolo, Mulanje, Chiradzulo, Zomba and Blantyre), noting that approximately 652,700 Africans (31 percent of the total population of the protectorate) were living on 2,677,520 acres of land (11 percent of the whole land area of the Protectorate). Furthermore, in terms of population density, the whole country had 42.55 people to the square mile - while in the Shire Highlands the population density was 156.6 people per square mile. These were the issues that lay behind some

\footnotetext{
314 Colin Legum, "Background to the Disturbances in Nyasaland," Supplement to the Information Digest, no.11. (London: African Bureau, 1953). For a comprehensive study on the origins of the Mau Mau uprising in colonial Kenya, see David W. Throup, Economic and Social Origins of Mau Mau (London: James Currey, 1988).
} 
of the anti-federation protests in the country. ${ }^{315}$ This was also the view shared by many in London, who argued that the 1953 disturbances had very little to do with the anger about the establishment of the federation, but instead had been instigated by politicians who had their own political ambitions. In the Thyolo district disturbances, the understanding had been that the land tenure system was to blame, especially the announcement earlier that year, by the British Central Africa Company, that it would start charging additional rent to tenants residing on the Company's land. ${ }^{316}$ In the central province, anti-Federation demonstrations also served as an "Achilles heel" for the colonial authorities. The Africans, led by their chiefs, had been particularly displeased that promises made by two successive British Secretaries of State for the Colonies, Arthur Creech Jones and James Griffiths, had not been kept. Both had visited Nyasaland and assured them that the federation would only be implemented with the approval of the African community. In the central province district of Ntcheu, Chief Philip Gomani, who served as the paramount chief of the Ngoni peoples, issued an order to his followers to disobey the colonial state, by among other things contravening state conservation (of natural resources) policies. He also called on his subjects to disobey agricultural extension advisers, to boycott the ceremonies to celebrate the coronation of Queen Elizabeth II, and to stop paying the hut tax. The government intervened to stop the disturbances, through the police force and the DC's office at Ntcheu boma, urging the chief to withdraw his order. However, when the chief refused to withdraw the order, Governor Geoffrey Colby issued an order to suspend the chief, and removed him from his headquarters, even though by that time the chief was not in good health. When riots broke out following attempts by the

\footnotetext{
${ }^{315}$ Nyasaland Protectorate, Land Commission Report, 1946, Vol. 1. Prepared by The Right Hon. Sir Sidney Abrahams (Zomba: Government Printer, 1946).

${ }^{316}$ Passive Resistance in Nyasaland to Central African Federation, BNA: CO 35/6851. See also BNA: CO 1015/1133: Governor's Reports, Nyasaland: Dispatch by Governor Geoffrey Colby, to the Rt. Hon. Alan Lennox-Boyd, the Secretary of State for the Colonies, July $30^{\text {th }}, 1956$.
} 
police to arrest the chief, a significant number of the Africans were arrested, including the chief's son, Willard. The chief himself managed to escape into the neighboring Portuguese territory of Mozambique. At the end of June 1953, the Portuguese authorities arrested and returned the fugitive chief to Nyasaland, who was later detained at the Central Prison in Zomba. ${ }^{317}$

The colonial authorities often argued that although there was no direct link between the Nyasaland disturbances of the early 1950s and the Mau Mau uprising in Kenya, there were strong similarities in their dynamics, especially on the role played by chiefs in coaxing their subjects to oppose the colonial state. By the early 1950s, the government authorities had lost their control over African affairs, as most of the chiefs were subjected to the demands of the radical nationalist elements, to which the chiefs obliged, for fear of betraying their own people. The Nyasaland Intelligence Report of November 1952 emphasized these points:

With regard to Africans the stage has now been reached when any African entering into discussion or speaking in favor of Federation is accused of receiving money and of being a traitor who is prepared to sell his people and his country to the Europeans and is often subject to victimization. Nevertheless, there are some bold spirits who still wish to continue discussions with Europeans....

The Chiefs, the great majority of whom have always been apathetic, now find themselves in the position of having to side with Congress against the Government or to side with the Government against the Congress, thereby laying themselves open to a charge of betraying their people. As a way out of their dilemma, many of the Chiefs are therefore adopting the role of figureheads voicing the opinion of the vocal elements. To what extent the events in Kenya are influencing the attitude of the Chiefs is not known, but it is noticeable that they have been more inclined to subordinate themselves to Congress since the Mau Mau disturbances started. ${ }^{318}$

\footnotetext{
317 Geoffrey J. Morton, The Just Job: Some Experiences of a Colonial Policeman (London: Hodder and Stoughton, 1957), 299-311. Note that Mr. Geoffrey J. Morton, was involved in the force removal of Chief Gomani, while serving as a Police Officer in Nyasaland in 1953. See also BNA: CO 1015/464: 'Nyasaland Political Intelligence Report'. See, the attached memo from Chief Gomani to the District Commissioner at Ntcheu and the Magistrate at Mlanda in Ntcheu district.

${ }^{318}$ BNA: CO 1015/464: Nyasaland Political Intelligence Report for November 1952. Note that earlier that month, the Paramount Chiefs in the country had convened a meeting in Lilongwe, where they issued a communique that they all rejected the imposition of the Federation. Some of the Chiefs were also part of the delegation of Chiefs and Congress officials who went to London in April 1952, to challenge the setting up of the Federation. The delegation included Mr. J.R.N. Chinyama of the NAC; Chief Kumsamala; Mr. O.E. Chirwa of the NAC; and Mr. E. Ntepuka. In January
} 
The general atmosphere of the country was summarized by Governor Geoffrey Colby in his dispatch to the Secretary of State for the Colonies at the beginning of July 1953, part of which read as follows:

...A certain amount of agitation which was noticeable in past weeks on the B.C.A. Company's estates in the Thyolo district, where tenants were refusing to pay rent, has at any rate not increased. ... It is probable that during the next few weeks Congress will intensify its attempts to seduce the chiefs from their loyalty to the government. Wholesale defection of the Native Authorities would of course make things very difficult indeed and it is now the first concern of government to support those chiefs who are loyal, and to buttress the waverers. If this can be done successfully for the next six to eight weeks, it is at least reasonable to hope that if the Congress tries to put into effect its threat of 'country-wide civil disobedience when Federation is announced' the campaign will fizzle out without much harm being done. ${ }^{319}$

The governor also made the following statement in the Nyasaland legislative assembly:

The year was unhappily marred by outbreaks of violence in the Southern Province. These outbreaks were the culmination of a campaign of subversive and false propaganda which had been going on for a period of two or three years during which members of the African Congress, encouraged by trouble-makers from outside the territory, directed their efforts to misleading the people and undermining confidence in the administration.

In April this year the African Congress circulated a number a number of resolutions passed at a public meeting which enjoined the people not to obey agricultural and other laws and not to pay their taxes. This foolish and reprehensible action was the immediate cause of the ensuing unrest and disturbances: innocent and law-abiding folk were confused by the Congress announcement which was reinforced by wide-spread intimidation: many local people went in constant fear as a result.

I personally warned the President-General and other members of Congress where this foolishness would lead, but my warnings went unheeded and events took their melancholy and inevitable course - so-called non-violence developed into violence -

1953, the Chiefs, under the guidance of Dr. Hastings Banda (then resident in London), issued a petition to H.M. Queen Elizabeth II, against the establishment of the Federation. See 'Petition Against Central African Federation'. Signed by Chiefs Sombo, Gomani, Maganga, Kuntaja, M’belwa, and other Congress leaders including Dr. Banda, Mr. I.C.K. Muwamba, and Mr. B.W. Mathew Phiri. Source: The H.K. Banda Archive. This archive is located at the Indiana University Library and although not properly arranged, has material relating to Malawi's first president, Dr. Hastings Kamuzu Banda, hence 'the H.K. Banda Archive.'

319 Political Intelligence Report on Nyasaland for June 1953: Dispatch from Governor Geoffrey Colby to the Secretary of State for the Colonies, July $3^{\text {rd }}, 1953$, BNA: CO 1015/464. The Report covered all the three provinces of the country, in which the Governor reported that almost all the major Chiefs in the country had in one way or the other participated in encouraging the non-Federal movement. 
lives were lost, property was destroyed, great expense to the territory was caused and incalculable damage done to previously harmonious race relations. ${ }^{320}$

From the reports, it was clear that the opposition to the federation came from a wide-range of stake holders across the country, both political movements and non-political ones. Such broad opposition necessitated the need for the government put in place measures to suppress the rise of the anti-federation disturbances, which I will discuss as having characterized the lifespan of the federal government between 1953 and 1963. Similar to previous measures discussed in chapter four of this study, the counter-insurgency measures adopted were in the form of "the stick and the carrot." Such strategies ranged from strengthening the role of the police force and its intelligence gathering activities; detention of those in opposition to the federation; outlawing of opposition political movements; making changes to the country's legal codes; and offering some developmental programs to the African communities.

\section{"The Stick" and Counter-insurgency}

Apart from the arrests and detention of the most radical elements of the anti-federation movement, one other important initial reaction of the Nyasaland government was to rush to the use of propaganda, in creating and finding possible links between the disturbances and the spread of the Soviet-type of communism. ${ }^{321}$ The main target was the NAC whose activities were heavily linked to socialist movements in the metropole, particularly the Fabian Society which was founded in

\footnotetext{
${ }^{320}$ Address by His Excellency Governor Geoffrey Colby, in Record of the proceedings of the $68^{\text {th }}$ Session of the Nyasaland Legislative Council, 30 November to $1^{\text {st }}$ December 1953.

${ }^{321}$ Political Intelligence Report for Nyasaland for June 1952: Dispatch from Governor Geoffrey Colby to the Secretary of State for the Colonies, July $3^{\text {rd }}$, 1953, BNA: CO 1015/464.
} 
1884 in Britain and always had strong links with the Labor Party. The following statement from the Nyasaland government attested to this line of thought and propaganda:

There is no doubt that the Congress has greatly added to its prestige as a result of its campaigning efforts... Congress has announced its intention of creating and staffing separate headquarters in each province, with general headquarters in Lilongwe. It has reduced its entrance fee from 5/- to 3d., with the idea of building up its membership and creating a powerful national movement embracing all Nyasaland Africans including civil servants and police. It is said that thousands of membership cards are to be printed in the United Kingdom and there are rumors that a Congress newspaper is to be started; machinery is also to be evolved with a view to sending regularly political news to the Fabian Society and the African Colonial Bureau in London. The President-General has declared that Congress' aim is self-government within five years. ${ }^{322}$

When the anti-federation resistance moved beyond non-cooperation and turned violent, the country's security forces, especially the police forces and some troops from the Kings African Rifles, were compelled to intervene. The Nyasaland police force was beefed up (as provided for in the Police Ordinance of July 1953) with police reinforcements from other British territories in the region to deal with the acts of resistance. Through that arrangement, fifty policemen were sent from Tanganyika, 100 riot squad policemen from Northern Rhodesia, and a 100 more from Southern Rhodesia. These policemen were involved in arresting and detaining those involved in the disturbances, where in the process eleven Africans were shot dead and seventy-two others were wounded. ${ }^{323}$

The CO also came up with a counterinsurgency strategy, known as "Operation Bessie," which was initiated by Oliver Lyttleton (the Secretary of State for the Colonies) and General Erskine. The socalled operation would involve flying a battalion of troops from the Kings African Rifles to

\footnotetext{
${ }^{322}$ Political Intelligence Report for Nyasaland for May 1952, BNA: CO 1015/464.

${ }^{323}$ Monthly Political Intelligence Reports for Nyasaland, August and September 1953, BNA: CO 1015/465. Note that due to the rise of Congress-led disturbances, the Nyasaland Police also began to refuse permission for the party leaders to hold public rallies. See also BNA: DO 35/6851: Passive Resistance in Nyasaland to Central African Federation. See also The Times, "Congress Leaders sent to Gaol," August 23 ${ }^{\text {rd }}, 1953$.
} 
Nyasaland if the African trouble reached unmanageable levels as had been the case in the Mau Mau uprising in Kenya. The operation would also involve spending increased resources (monetary and material) to beef up the Nyasaland police force and encouraging more police and troop reinforcements from the two Rhodesias. ${ }^{324}$ In Nyasaland itself, Governor Colby was also contemplating declaring a state of emergency, if the disturbances increased in intensity, especially following the rise in cases of intimidation by Congress authorities. ${ }^{325}$

The country's penal code was also amended at the end of 1955 to include the more serious charge of treason for all those suspected of leading the anti-federation movement and agitations. The penalty for treason was death or life imprisonment if convicted. The treason clause in the penal code, which applied to those who challenged the authority of the imperial crown of the United Kingdom and its representatives in the dominions, colonies, and protectorates, was presented as follows:

Any person who encompasses, imagines, invents, devises or intends any act, matter or theory the compassing, imagining, inventing, devising or intending whereof is treason by the law of England for the time being in force, and expresses, utters or declares such compassing, imagining, inventing, devising or intending by publishing and printing or writing or by any overt act which, if done in England, would be deemed to be treason according to the law of England for the time being in force, is guilty of the offence termed treason and shall be liable to suffer death.

Any person who instigates any foreigner to invade the Protectorate with an armed force is guilty of treason and is liable to the punishment of death.

Any person who (1) becomes an accessory after the fact or (2) knowing that any person intends to commit treason, does not give information thereof with all reasonable dispatch to the Governor, a District Officer, Magistrate, or Officer of Police or use other reasonable endeavors to prevent the commission of the offence, is guilty of the felony termed misprision of treason, and is liable to imprisonment for life....

Any person who, without lawful authority, carries on, or makes preparation for carrying on, or aids in or advises the carrying on of, or preparation for, any war or warlike

\footnotetext{
${ }^{324}$ Passive Resistance in Nyasaland to Central African Federation, BNA: DO 35/6851.

${ }^{325}$ Passive Resistance in Nyasaland to Central African Federation: Dispatch from Governor Colby to the Secretary of State for the Colonies, August 22 ${ }^{\text {nd }}, 1953$, BNA: DO 35/6851.
} 
undertaking with, for, by, or against any native chief, or with, for, by, or against any band of natives, is guilty of a felony, and is liable to imprisonment for life. ${ }^{326}$

A clause was also inserted under the 1955 laws for the crime of sedition, which had similar undertones to the clause on treason. Those deemed to be of "seditious intent" were those who were implicated in challenging or exciting disaffection against the British crown and its representatives across the empire (i.e. the government of the protectorate or the CAF). Also charged under the new laws were those accused of promoting a feeling of ill-will and hostility between different classes of the population of the protectorate or any of the territories. Those convicted under the clause, were liable for a first offence to imprisonment for five years or to a fine not exceeding $£ 400$ or to both imprisonment and fine, and for a subsequent offence to imprisonment for seven years. ${ }^{327}$

Under the 1955 laws, the Nyasaland governor was also given powers of censorship targeted at banning or outlawing publications that were deemed to be seditious in nature. The publications in question included the following: all written and printed matter; any gramophone or other record, perforated roll, recording tape, cinematograph film or other related materials. It was incumbent upon the governor to declare any of these publications to be contrary to the public interest, and thus empowered him to prohibit either their publication or importation in the country. Those convicted of importing, publishing, and distribution such prohibited publications would be given penalties ranging from a fine of up to $£ 400$; or to pay both the fine and be sent to prison for four years; and had their publication forfeited. These offences were deemed to be seditious so long as it could be proven that they would bring in hatred and disaffection against the British crown, heirs or successors, or indeed the government of the protectorate or of the federation; and, that they

\footnotetext{
${ }^{326}$ Nyasaland Government, Penal Code and the Criminal Procedure of the Nyasaland Protectorate, Consolidated Edition, $31^{\text {st }}$ December 1955 (Zomba: Government Printer, 1955), 24-25.

${ }^{327}$ Ibid.,28-29.
} 
would have excited residents of the protectorate to overthrow their government of the protectorate and of the federation. ${ }^{328}$

The laws also provided the colonial state authorities with powers to regulate or deny permission to any form of African public assemblies of three or more persons. The Penal Code provided the following powers to the state:

When three or more persons assemble with intent to commit an offence, or, being assembled with intent to carry out some common purpose, conduct themselves in such a manner as to cause persons in the neighborhood reasonably to fear that the persons so assembled will commit a breach of the peace, or will by such assembly needlessly and without any reasonable occasion provoke other persons to commit a breach of the peace, they are an unlawful assembly. It is immaterial that the original assembling was lawful if, being assembled, they conduct themselves with a common purpose in such manner as aforesaid. When an unlawful assembly has begun to execute the purpose for which it assembled by a breach of the peace and to the terror of the public, the assembly is called a riot, and the persons assembled are said to be riotously assembled. Any person who takes part in an unlawful assembly is guilty of a misdemeanor and is liable to imprisonment to one year. ${ }^{329}$

By 1957, the colonial authorities, had also inserted a clause in the penal code, which gave the powers that be a more authoritarian role, one in which the state would outlaw any of such societies deemed to be 'seditious and dangerous' to the country. The governor was given the following powers:

Wherever the Governor in Council is satisfied from the information or advice which he deems to be reliable that the doctrines held or disseminated by any society, organization, or body of persons whether corporate or incorporate established in the Protectorate either before or after the commencement of this Ordinance, are seditious, or detrimental or dangerous to the maintenance of public security or public order, the Governor may,

\footnotetext{
${ }^{328}$ Ibid., 26-28. See for instance, Edwin S. Munger. "Racial Tension in Nyasaland," American Universities Field Staff. October 1956, 1-12.

${ }^{329}$ Penal Code and the Criminal Procedure of the Nyasaland Protectorate, Consolidated Edition, $31^{\text {st }}$ December 1955 (Zomba: Government Printer, 1955), 36. See also "Nyasaland Police," Chapter 64 of The Laws of Nyasaland, Vol. II. January 1957 (Zomba: Government Printer, 1957). Note also that under the 1957 Penal Code, the Police Force was given powers to disrupt such unlawful assemblies, take the suspects to court, where sentences included a fine not exceeding 50 British Pounds or to imprisonment for a term not exceeding one year or to both such fine and imprisonment.
} 
if he thinks fit, by order under his hand and the public seal of the Protectorate direct that society, organization or body of persons shall cease operations in the Protectorate within such time as may be specified in the order... 330

Some of the Africans deemed to be members of the 'seditious and dangerous societies' ended up being detained without any court trial. Under the 'Political Removal and Detention of Africans Ordinance, 1957, powers were given to the governor and district commissioners, to detain and where necessary order the removal from a locality those challenging the authority of the state. Those detained were not provided the right to appeal against their detention or removal from a stated location. ${ }^{331}$

\section{"The Carrot" and Counterinsurgency}

Apart from introducing such strict counter-insurgency measures (i.e. "the stick”), other measures were put in place to attract African support for the colonial state. For instance, on the question of land tenure, the laws of the protectorate were amended in favor of some African societies, especially focusing on the troubled southern province where disturbances had begun partly due to land shortages. That came through the amendment of the "Natives on Private Estates Ordinance," which secured the land tenure system for Africans resident on private estates. The 1957 Ordinance was worded as follows: "Subject to the provisions of this Ordinance, every resident African shall be entitled on the estate on which he resides to the allocation of a site for his dwelling and to the use of such extent of cultivable land as he had under cultivation on the date on which this Ordinance came into operation: Provided that no resident African shall be entitled to the use of a

\footnotetext{
330 “The Seditious and Dangerous Societies Ordinance," Section 50, of The Laws of Nyasaland, Vol. II. January 1957. Those found guilty of breaching that Ordinance were liable to a term of imprisonment not exceeding three months or to a fine not exceeding 50 British Pounds or to both.

331 “The Political Removal and Detention of Africans Ordinance," Chapter 77 of The Laws of Nyasaland, Vol. II. January 1957.
} 
greater area of cultivable land than he and his wife and his sons and daughters are capable of cultivating without assistance: Provided further that no resident African shall be entitled to the use cultivable land unless he maintains it in efficient agricultural use." ${ }^{332}$ This land ordinance was important because of the country's long history of reliance of agricultural production, mainly of the subsistence kind. Furthermore, Governor Colby also made proposals to several of the larger estates, especially in the southern province, to give up portions of land that were not under cultivation, to be used by the government for resettlement of African families, within a period of five years. ${ }^{33}$

There were also improvements in the transport sector, especially in the construction of paved roads. According to Henry A. Thiessen, there was only 5 miles of paved roads in the entire country in 1948. However, once the federation was established, the development of the road network became one of the leading projects in the country's development agenda. The roads themselves were deemed to be essential to complement the railroad network in transporting agricultural products. By 1961, the road network consisted of 6,127 miles of roads, of which paved roads covered 295.5 miles; all weather roads covered 872 miles; all season roads (roads that were impassable for a few days during the rainy season, but usually open throughout the year) covered 1,398 miles; whereas dry weather roads covered 3,561 miles. Most of these good roads were in the southern province, with one major paved road for the Central Province connecting Lilongwe to the lakeshore district of Salima before later connecting to the lake port at Chipoka. In the northern province, there was an all-weather road that connected the main economic hub of Mzuzu to the lakeshore district of Nkhata-Bay, and another that connected Chendo with the port of

\footnotetext{
332 "The Africans on Private Estates Ordinance, 1957," Chapter 78, of The Laws of Nyasaland, Vol. II. January 1957. See also R.W. Kettlewell. “Agricultural Change in Nyasaland: 1945-1960”. Reprinted from Food Research Institute Studies, no.3 (1965): 229-285. See pp.239-247.

${ }^{333}$ Colin Baker, Development Governor: A Biography of Sir Geoffrey Colby (London: I.B. Tauris, 1994), 238-239.
} 
Karonga. Most of the roads constructed in the rural districts or remote areas were essential in transporting farmers' produce and were also constructed under a self-help program of the Nyasaland government. The very same roads were also used by agricultural extension and veterinary service personnel. ${ }^{334}$ The table below illustrates the increased amounts of government expenditure in the construction of road networks:

Table 5.1: Expenditure by the Nyasaland and Federal Governments on Road Building and Maintenance, 1948-1958

\begin{tabular}{|c|c|c|}
\hline Financial Year & $\begin{array}{c}\text { Construction and } \\
\text { Reconstruction }(\mathfrak{f})\end{array}$ & Maintenance (f) \\
\hline 1948 & 17,000 & 37,000 \\
\hline 1949 & 116,000 & 58,000 \\
\hline 1950 & 112,000 & 86,000 \\
\hline 1951 & 297,000 & 70,000 \\
\hline 1952 & 322,000 & 86,000 \\
\hline $\begin{array}{l}\text { 1953/54 (18 } \\
\text { months) }\end{array}$ & 639,000 & 155,000 \\
\hline $1954 / 55$ & 387,000 & 114,000 \\
\hline $1955 / 56$ & 595,000 & 130,000 \\
\hline $1956 / 58$ & 877,000 & 158,000 \\
\hline $1957 / 58$ & 494,000 & 203,000 \\
\hline TOTAL & $£ 3,856,000$ & $£ 1,097,000$ \\
\hline
\end{tabular}

Source: Henry A. Thiessen. 'Some Remarks on Transportation and Economic Development in Nyasaland'. March $18^{\text {th }}$, 1963. Unpublished. Sourced from the H.K. Banda Archive. ${ }^{335}$

\footnotetext{
${ }^{334}$ See Henry A. Thiessen, 'Some Remarks on Transportation and Economic Development in Nyasaland'. March $18^{\text {th }}$, 1963. Unpublished. Sourced from the H.K. Banda Archive, Indiana University Library. Note also that there were also improvements in the Air Transport sector during the lifespan of the Federation. Air services had only been introduced in the country in 1951 and had achieved the following statistics in a space of seven years: for the route between Blantyre (Nyasaland) and Salisbury (Southern Rhodesia) for 1951 carried 5,130 passengers; and by 1957, the same route transported 12,605 passengers. In the same vein, see also Federation of Rhodesia and Nyasaland. Report on an Economic Survey of Nyasaland, 1958-1959' (Salisbury: Government Printer, 1960), 87-103. Source: H.K. Banda Archive.

${ }^{335}$ See also "Federation and Nyasaland: The Facts" (Salisbury: Government Printer, 1962), 13-16. Source: H.K. Banda Archive.
} 
The Federal government also used the health sector as an arena of winning the "hearts and minds" of the Africans. There were state-sponsored, deliberate investments of money and other material resources in the country's health sector during the lifespan of the federation. In a propaganda pamphlet produced by the Federal government in 1962, for instance, it was established that funding for Nyasaland's health sector had quadrupled when contrasting the figures of 1952 and 1961. In 1952 (one year before the Federation was established), the Nyasaland government spent only $£ 310,395$ on its health services. But in 1961 , the Federal Government spent $£ 1,220,873$ on the health sector. The report also hinted at the infrastructural changes in the sector, when, for instance, it highlighted that in 1953 Nyasaland only had 19 hospitals, but by 1961, the number had risen to 30. The number of hospital beds also increased by fifty percent, and admissions rose from 36,000 to 83,000 . The numbers of outpatient attendance also soared from 1,141,000 in 1953 to almost $6,200,000$ in 1961. There was also improvement in hospital staff personnel, from the 1,567 medical staff in 1954, to more than 2,000 in 1961. By 1961, Nyasaland also had seventy-three qualified nurses (including four matrons), compared to 1954, when there were only twenty-five nurses, none of whom was a matron. However, the report also had some political connotations, when it praised the efforts of the Federal and Nyasaland governments, while deploring and demonizing the works of the leading nationalist movement in the country, the Malawi Congress Party (MCP), as being anti-development through its campaign of disturbance and resistance. The following statement illustrates that line of state-sponsored propaganda:

...But this happy picture was sadly marred some 18 months ago when a campaign of disturbance and intimidation was started against the Federal health services. It is an amazing situation when an allegedly responsible political party, purporting to be able to govern the country, wantonly and flagrantly puts the lives of hundreds of thousands of its people into jeopardy in order to make political scoring points....

The efforts of Ministry of Health teams to vaccinate the people of Nyasaland against smallpox and other diseases were largely frustrated by leading officials of this political 
party who, while taking great care to obtain their own vaccinations, travelled around the country, urging villagers and schoolchildren to boycott the vaccinations. ${ }^{336}$

This 1962 propaganda report also praised government efforts to improve the education sector, amid the rising tide of opposition. The framers of the report, for instance, noted that by 1953 , there was no secondary education institution for Europeans in the country; the same applied for Asians who had no secondary school; while only one government secondary school served the Africans. Only eight Africans throughout the protectorate were receiving higher education. Once the federal government took over, the report stated, it embarked on a massive improvement of the sector, including building more schools, training more teachers, encouraging in-service training, and the use of audio-visual services. In the first six years of the federation, the number of Asian and African (Colored) primary schools increased from only one in 1954 to 27 in 1960, while in the same period, enrolments soared from 133 to 3,430, an increase of 2,500 percent. During the same period, some Asian and African students were also allowed to attend the federal secondary school in Bulawayo, while another was being built at Blantyre in the southern province at a cost of more than $£ 100,000$. Hostels for students (both boys and girls) were also constructed at the Blantyre school at a total amount of $£ 145,000$. The Federal government also set aside nearly $£ 45,000$ which was earmarked for scholarship purposes for students from Nyasaland to attend the University College of Rhodesia and Nyasaland in Southern Rhodesia. By 1962, fifty-seven Africans from Nyasaland had benefited from the Federal scholarship program at an average cost of $£ 320$ per year. Just as in the health sector, the Federal government deplored the works of the nationalist movement (MCP), accusing its officials of overtly intimidating Africans who were willing to accept Federal

\footnotetext{
${ }^{336}$ Ibid., 6-9.
} 
aid for university training. ${ }^{337}$ In that way, developments in the education sector were similarly being used to contrast the roles of the $\mathrm{CAF}$ and the radical nationalist movement. The same argument was also mentioned in the report when it blamed the extremist politicians for sabotaging the Nkula Falls Hydro-Electric Project which the Federal government had planned to commence in 1962, with an estimated government expenditure of $£ 3$ million, and a capacity of 24 megawatts. $^{338}$

The picture that was being painted from such claims, whether realistic or "doctored,"was that Nyasaland had benefited from its inclusion in the federation, and that the Africans were bound to gain more by supporting the government of the day, rather than siding with the nationalists. It was noted, for instance, in the protectorate's economic survey for 1958-1959, that by being part of the federation, Nyasaland had broadened the sources of funds earmarked for development programs. For instance, prior to the federation, development funds were coming entirely from the meagre local revenue; and from grants and loans guaranteed by the British government. However, since the federation, the sources of development funds included further avenues: special loans; the African Development and Welfare Fund; internal and external borrowing from the Federation government; and, revenues collected by the Federation government. The framers of the economic survey summarized their perspective as follows:

From our examination of Nyasaland's economy, we are convinced that the country's economic development has been accelerated as a direct consequence of its federal association with the two Rhodesias and that the economic benefits which have been enjoyed have been substantial. We think it right to state this view in the forefront of our

\footnotetext{
${ }^{337}$ Federation of Rhodesia and Nyasaland, Federation and Nyasaland: The Facts (Salisbury: Government Printer, 1962), 10-12.

${ }^{338}$ R.W. Kettlewell, a former director of agriculture in Nyasaland had a contrary view on the Shire Valley Project (of which the Nkula Falls Hydro-Electric Power Program was an important component). He argued that the reason why it collapsed was not necessarily because of sabotage by nationalist politicians, but rather because the huge amount of money needed to implement it in the region of $£ 80$ million. For this, see R.W. Kettlewell, "Agricultural Change in Nyasaland: 1945-1960”. Reprinted from Food Research Institute Studies V, no.3 (1965): 251.
} 
Report. In doing so we are anxious not to overstate the position. It is not suggested that in the years prior to Federation no economic development occurred; nor need it be suggested that a return to the former political status of the country would necessarily mean that no further expansion would take place in the future. But, as we see it, the evidence is conclusive that the greater rate of economic development which has occurred since 1953 must be attributed to the constitutional changes which were made in that year and that this greater rate of development could not be maintained if Nyasaland were to depend entirely upon its own resources. ${ }^{339}$

\section{Policing the anti-Federation Insurgency}

In this section, this study continues with the argument that the roles and operations of the police force during the colonial period can best be understood by employing the political economy approach. This is based on the argument that the police operations in the late colonial era, covered in this chapter, reflected the political and economic climate of the time, which included the need for the police to cover up for the "protectionist" policies of the state. In Nyasaland, in the immediate aftermath of the Second World War, the police force underwent multiple phases of reorganization to suit the prevailing political and economic needs of the time, including cases where the police force became essential in tracking down the suspected "enemies of the state." Under the 1946 Police Ordinance, the duties of the Nyasaland Police Force were as follows:

...employed in ... the Protectorate for the prevention of crime, the apprehension of offenders, the preservation of law and order, the protection of property and the due enforcement of all laws and regulation with which they are directly charged; and as a military force when called upon ... to discharge such military duties within or without

\footnotetext{
${ }^{339}$ British Government, Federation of Rhodesia and Nyasaland: Report on an Economic Survey of Nyasaland, 19581959 (London: HMSO, 1960), 1 and 62-64. Note that other independent studies on the economic advantages of the Federation to three Territories, found the issue to be inconclusive and almost impossible to determine precisely what the Federation had contributed to each of the economies concerned, especially considering other variables of the time. A report by Arthur Hazelwood and P.D. Henderson (1960), for instance argued that the economic case for the Federation had been generalized and overstated, and that most of the standard arguments had been invalid, of slight importance, or acceptable only with serious qualifications. Of the three Territories in the Federation, it was Southern Rhodesia that benefited the most in terms of stimulation to the economy. See Arthur Hazelwood and P.D. Henderson, Nyasaland: The Economics of Federation (Oxford: Basil Blackwell and Mott Ltd, 1960), 17-31.
} 
the Protectorate as may be required of them by, or under the authority of the Governor; and for the performance of all such duties shall be entitled to carry arms. ${ }^{340}$

Apart from adopting more of the military roles, the Nyasaland police force also began to receive policemen from other troubled spots of the empire and from recently decolonized areas, such as Palestine and India. By the early 1950s, the police force had the following offices and branches: Office of the Commissioner; Special Branch; Criminal Investigation Department; Signals Branch; Police Training School and Band; Pay and Quartermaster; Immigration and Passport Control; Police Reserve; and Firearms Registry. ${ }^{341}$ Out of these police branches, it would be the Special Branch that would play an important role in the counterinsurgency activities during the era of the federation. Its roles included serving as an alternative and additional source of gathering information on the political activists in the country. The Special Branch had replaced the former Nyasaland Political Intelligence Bureau (NPIB), which was established in August 1939, and placed under the Commissioner of Police. The Intelligence Bureau's key duties included compiling political intelligence bulletins and coordinating with other intelligence organizations in the region. A secretariat was established to keep files of intelligence documents and to keep track of records and addresses of those under police surveillance, especially suspects and politically dangerous persons. Its documents were filed separately from other police papers, or criminal records, and were only handled by a few selected persons, preferably non-Africans. The Bureau itself would also deal with other African affairs such as bazaar gossip, the trend of "native thought" and other special persons in the native communities. Hence, it was deemed to be fatal if such information would have leaked back to the Africans through native clerks. Other duties of the Bureau also focused on censorship, targeted at undesirable literature and propaganda. As such, the Bureau's

\footnotetext{
${ }^{340}$ Marlow, A History of the Malawi Police Force (1971), 23-24.

${ }^{341}$ Ibid, 26.
} 
office was provided with an ultra violet lamp, to be used to detect the presence or otherwise of writing in invisible ink. ${ }^{342}$ These responsibilities were taken over by the Special Branch in the postWorld War II era and became 'handy' during the disturbances against the CAF from 1953 onwards.

When the 1953 disturbances broke out, and having noticed the inadequacy of the regular police, the state authorities established another branch known as the Police Mobile Force (PMF). The PMF, which in 1954 numbered fourteen European officers most of whom had served in Palestine, and about 200 Africans, was trained and equipped to deal with situations requiring mobile force reserves at short notice. The PMF also served as a training ground for newly appointed European policemen in the protectorate before they were transferred to new stations. Furthermore, from 1954 onwards, there was an increased rate of expansion for the police, following the creation of new police stations, police posts and quarters, to improve the protectorate's surveillance and security services. ${ }^{343}$ By 1958, the PMF consisted of six highly trained platoons, each consisting of European police officers and thirty-three African rank and file, most of whom were former soldiers in the Kings African Rifles (KAR). The policemen were placed under a superintendent, who had to make sure that his platoons were always ready for emergency operations in cases of civil disturbances and riots. ${ }^{344}$

The police restructuring measures were important throughout the lifespan of the federation, because, as already alluded to, most of the traditional authorities had either willingly or forcibly pledged their allegiance to the anti-federation movement, something which was self-defeating to

\footnotetext{
${ }^{342}$ Political Intelligence Bureau, 1939. MNA: S2/140/39.

${ }^{343}$ Cyril Marlow, A History of the Malawi Police Force (1971), 27-28. See also John McCracken, "Coercion and Control in Nyasaland: Aspects of the History of a Colonial Police Force," The Journal of African History, 27, no.1, (1986): 127-147. See pp139-140.

${ }^{344}$ MNA: PMF Reports, 1958-1964.
} 
the policy of indirect rule, with its heavy reliance on African chiefs to run some government affairs.

This was highlighted in a State Intelligence Dispatch of September 1953, which stated:

The situation in Nyasaland has shown that any Native Authorities, mostly in the Southern Province, hitherto loyal to the Government, have been so undermined by Congress that they cannot with certainty be relied upon to maintain law and order among their people and to resist the strong influence exerted upon them by Congress agitators. Those who still repose their faith in Government are bewildered and do not know which way to turn. The mass of loyal subjects who are tired of demonstrations and of seeing police and military operating primarily as anti-riot squads would probably welcome a return to normal conditions. It is of course obviously important at this time when Congress have been jolted by the arrest of many of their ringleaders, and show signs of climbing down, to bolster the morale of the loyal element by carrying out as much preventive and normal police patrolling as possible. It is satisfactory to know that patrolling is being carried out in increasing measure because, quite apart from the fact that the uniform branch should itself collect much useful information, it acts in a preventive and complementary role to the C.I.D. and Special Branch, thereby indirectly reducing the weight of the problems with which the latter have to deal. ${ }^{345}$

Through these measures, the Special Branch was organized to operate at two levels. The first level was semi-operational and was mainly concerned with providing advice to the police and the state of any impending native disturbances. The second level was mainly to cover strategic and longterm operations, including the investigation of underlying causes of native uprisings. The second level was particularly important as the police had learnt that most of the native disturbances followed a similar "modus operandi", which also suggested that there was some measure of planning, rather than being merely sporadic incidents. It was also recommended that the officers of the Special Branch (both European and African) had to be of high caliber, and that the European officers employed in the Nyasaland Special Branch should acquaint themselves with the local

\footnotetext{
${ }^{345}$ Police and Constabulary - Reorganization of Nyasaland Special Branch, September 1953, BNA: CO 968/275.
} 
language dialects and all traditional beliefs or customs, to assist them in conducting their duties of analyzing and African movements and organizations. ${ }^{346}$

The "political policing" roles of the Nyasaland Police became even more important from mid1958 onwards, following the re-organization of the Nyasaland African Congress (NAC). According to one of the leading figures of the party, M.W. Kanyama Chiume, significant changes appeared in the party beginning from early July 1958, when Dr. Hastings Kamuzu Banda, a member of the party who had been in exile for over three decades, returned to the country upon the invitation of the locally-based party leaders to spearhead the nationalist and anti-Federation cause, and also to revive the party, as it had been undergoing its own internal challenges and had begun to lose its support base. When Dr. Banda returned to Nyasaland, he was welcomed by demonstrations of enthusiasm from the African peoples, and he also had the immediate impact of re-organizing the party into a well-disciplined political movement unanimous in its aims of selfgovernment and secession from the CAF. Africans looked to him as their "Messiah" or "Savior," who would deliver them from the bondage of the federation and British colonial rule, hence the massive following and out-pouring of support. For instance, from having about 80 branches in mid-1958, the number increased to about 200 branches by the close of that year. The party's national secretariat also became well-organized, and was equipped with duplicating and other machinery, used to print the party's newsletter, The Kwacha. The party's rallies also began to attract a lot of support, with people travelling long distances to hear Dr. Banda speak. Most of the traditional leaders (chiefs) also began to boycott meetings with the governors (both federal and protectorate) and their representatives, and instead pledged their allegiance to the ANC. Many of

\footnotetext{
${ }^{346}$ Ibid. See also BNA: FCO 141/14237, Report of the visit to Nyasaland, by Mr. J.A. Harrison, the Security Intelligence Adviser at the Colonial Office, December $9^{\text {th }}, 1957$.
} 
the chiefs might have anticipated that independence from British rule was within reach, hence the need to side with the re-energized nationalist movement.

In December 1958, Dr. Banda and M.W. Chiume, went to Accra, Ghana, to represent the party at the All-African People's Conference. At the Conference, which was held from $5^{\text {th }}$ to $13^{\text {th }}$ December 1958, Dr. Banda was said to be re-energized following his deliberations with other leading nationalist figures from across the continent, such that when he returned to the country in January 1959, he began to preach that the country would soon gain self-government and secession, while stressing that his followers had to adopt non-violent strategies. ${ }^{347}$

Due to incidences of African unrest, the Nyasaland police initiated a campaign of violence against African crowds and supporters of Dr. Banda and the NAC. The police would send their personnel to the public rallies, who often provoked the situation by interfering in the activities of the Africans, which from time-to-time culminated in stone throwing at the police by the Africans. The police force was also responsible for coming up with tramped-up charges of Congress functionaries, such that by February 1959, close to 300 Africans had either been fined or imprisoned under such charges. Among them included 37 women who were beaten by the police in Zomba in January 1959. ${ }^{348}$ The perceptions of the police were reflected in the 1959 annual police report, which stated:

The disregard for law and order and contempt for authority which was being displayed by adherents of the Nyasaland African Congress towards the end of 1958 continued unabated in the New Year. The pattern followed appeared to be to provoke incidents by deliberately flouting the law. There were cases of stoning cars after meetings and abuse of and, at times, assaults on Government officers and others engaged in enforcing legislation such as Agricultural and Forestry Rules. In some instances demonstrations were staged, not only at Native Courts, but also in Magistrates' Courts when offenders were brought to trial. At large public meetings for which permission had been granted

\footnotetext{
${ }^{347}$ M.W. Kanyama Chiume, Nyasaland Speaks: An Appeal to the British People (London: The Union of Democratic Control Press, 1959), 7-9. See also 'Annual Report of the Nyasaland Police Force, December 1959. Malawiana Section, Chancellor College Library, Malawi.

348 Kanyama Chiume, "Secession the only solution," In James Duffy and Robert A. Manners, Africa Speaks (New York: Van Nostrand Company, 1961), 157.
} 
intemperate speeches were made and, in addition, there was evidence that a large number of small meetings were being held without permission in rural areas. The authority of Chiefs was being undermined and Chiefs themselves subjected to intimidation.... ${ }^{349}$

The police infiltration of the Congress rallies was also in part influenced by leaked information from the December 1958 All-African People's Conference, where it was noted that the nationalist leaders from the federation had pledged themselves to drive the Europeans out of Central Africa, preferably through non-violent means, but violence was also advocated in other circumstances. That was allegedly to be done with the help of Ghana and the support of the communist regimes from the East. It was no wonder that the charge of communism figured often in the public speeches of the Federal Prime Minister, Sir Roy Welensky, during the first two months of 1959, as he and his officials painted the nationalist movements as communist implants in the three territories. ${ }^{350}$

In a way, there was some form of authenticity to the claims about the role of communists in the anti-Federation movements due to what transpired at the Accra conference. A report compiled in January 1959 from the conference seemed to back the claims that the African nationalists were significantly being influenced by Soviet communism. Although the host of the conference, Dr. Kwame Nkrumah, then Prime Minister of Ghana, had attempted to assure the Western powers, especially the British and US governments, that the communist bloc would not control the proceedings of the conference, that was not necessarily the way things turned out to be. For instance, Russia sent a strong seven-man official delegation, more than any other overseas power, which also represented the greatest number of communist leaders ever gathered south of the Sahara Desert, hoping to manipulate the anti-colonial and nationalist movements. Behind the scenes, the

\footnotetext{
349 'Annual Report of the Nyasaland Police Force, December 1959.

${ }^{350}$ Channing B. Richardson, "The Federation of Rhodesia and Nyasaland," Africa Today Pamphlets, no.4, (1960), 67.
} 
Russian government had also already put in place a standing offer of $£ 100$ a month salary, plus an office, a typewriter, and a telephone, for almost any African from a colonial territory who wanted to set up a political party office in Cairo, Egypt, where President Gamal Abdel Nasser, was keen to help fellow Africans remove the yoke of European colonial rule. ${ }^{351}$

In Nyasaland, by December 1958, the government also issued a serious warning to those involved in the disturbances, telling them that the government would not tolerate elements of lawlessness.

The Acting Chief Secretary, P.W. Youens, made these remarks in the Legislative Council:

If Honourable members consider that this government will be diverted from its belief in Federation by evil deeds they are wrong. Entirely wrong. Let them disabuse themselves. This government will not bow to hooliganism. It will do everything it can to seek it out and stamp it out. That these incidents which have given rise to this debate occurred is to be greatly deplored. That they should have happened in a territory of such traditional friendliness as Nyasaland is a bitter thought. That innocent passers-by, going about their lawful occasion should have been harmed is a shameful thing... Such acts of hooliganism and unprovoked violence are vile things, in whatever name or cause they are committed. Nothing good ever came or ever will come of them... Men who incite or permit such acts are evil men, and if there is justice in this world, and I believe there is, they will be rooted out... ${ }^{352}$

Such sentiments, made by one of the Nyasaland government's highest-ranking officials, clearly stipulated that the government had been preparing to "eliminate" troublesome elements in the country. The main target by this time was clearly the re-energized Nyasaland African Congress (NAC), whose members were feeding off from the energy of Dr. Banda and other radical young leaders of the party. It would only be a matter of months, as highlighted in the next section, when a state of emergency was declared in the country.

\footnotetext{
351 'All-African People's Conference, Accra, Ghana'. Report compiled by Edwin S. Munger, for American Universities Field Staff, January 1959. Source: H.K. Banda Archive.

352 "Motions," In Record of the proceedings of the $2^{\text {nd }}$ meeting of the $73^{\text {rd }}$ session of the Nyasaland Legislative Council," $4^{\text {th }}$ December 1958.
} 


\section{Counter-insurgency and the 1959 State of Emergency}

As already alluded to, following the disturbances and commotion created by the return of Dr. Banda and the subsequent reorganization and radicalization of the NAC, the Nyasaland government seemed to be preparing for "the worst." Perhaps afraid of being outdone by the nationalists, Governor Sir Robert Armitage decided to strike first. Having consulted and received the backing of both the Federal and British governments, on March $3^{\text {rd }}, 1959$, the governor declared a State of Emergency using intelligence briefings of the plans by the Congress to embark on a plot of disturbance and violence, including the purported murder of Europeans in the country. Under what was called "Operation Sunrise", the security forces planned and implemented the arrest of "hard core" Congress leaders. A second operation was also planned to pacify the disturbed areas, while a third was also in the pipeline to eliminate the NAC. Most of the policemen involved in the operations came from within the Federation and the neighboring British territory of Tanganyika. The policemen were issued with instructions to round up all political activists and radical members of the congress in follow up operations throughout the country. ${ }^{353}$ The stated police and military reinforcements arrived in Nyasaland by the end of February 1959, following requests by Armitage for a supply of forces from the Royal Rhodesian Regiment (RRR), comprised mainly of European troops, and KAR. The plans were for the deployment of three regular battalions of the KAR and RRR, complimented by two further battalions of European territorials, plus one hundred members of the British Southern Africa Police (BSAP), thirty European and seventy Africans. There was

\footnotetext{
${ }^{353}$ Philip Murphy, Alan Lennox-Boyd: A Biography (London: I.B. Tauris and Co. Ltd, 1999), 203-208. According to Murphy, the decision to declare the Emergency in Nyasaland was agreed upon at Cabinet level in London, following intelligence information shared by the Colonial Office, through both Mr. Lennox-Boyd and Julian Amery, the Colonial Secretary and Under Secretary of State, respectively. There was a feeling by those in the CO, of the need to act fast to avoid the 'blood bath' like that of the Mau Mau uprising in Kenya. See also Great Britain, "Federation of Rhodesia and Nyasaland: Conclusions of a meeting held in the Prime Minister's room, House of Commons, Friday $27^{\text {th }}$ February, 1959 (Great Britain: Her Majesty’s Government, February 1959).
} 
also going to be a Tanganyika platoon of sixty troops who would enter the Nyasaland territory from the northern part of the protectorate. ${ }^{354}$ Philip Murphy argued that the Colonial Secretary, Alan Lennox-Boyd, felt duty-bound to support the Nyasaland governor, because in the governor's previous posting in Cyprus, he (Lennox Boyd), had repeatedly denied his requests for a security clamp-down against nationalist agitators, in which the dilly-dallying of the CO presented room for the growth of the opposition camp, leading to the disturbances of 1954-1955. As such, the colonial secretary felt compelled to rely on the intelligence reports dispatched by the Nyasaland governor. $^{355}$

When the emergency was declared on March $3^{\text {rd }}$, hundreds of congress leaders (both local and national), including Dr. Banda, were arrested by Special Branch policemen, and later placed in detention without being tried in court. Out-going telegraph traffic was monitored, including press telegrams, while curfews were also imposed in the urban centers and townships. Dr. Banda was captured (alongside his personal bodyguard and later cabinet minister, Yatuta Chisiza) at dawn at his home in Blantyre in a carefully planned arrest involving six groups of policemen, from both the Special Branch and the PMF, mostly made up of European officers, and also with support of three platoons from the D Company of the $2^{\text {nd }}$ Battalion of the Kings African Rifles. The large group of security forces was needed to counter the anticipated resistance of Dr. Banda's bodyguards (some of whom were shot at). About 60 of them spent the night at his house on the night of the operations, in anticipation of their leader's impending arrest. After his arrest, Special

\footnotetext{
${ }^{354}$ Philip Murphy, ed., British Documents on the End of Empire: Central Africa, Part II: Crisis and Dissolution. (London: The Stationery Office, 2005), 17-24. Adopted from CO 1015/1516, no.139: 'Unrest in the Federation': Letter from Sir A. Benson to W.L. Gorell Barnes, based on a meeting of Heads of Government, Salisbury, Southern Rhodesia.

355 Philip Murphy, Alan Lennox-Boyd: A Biography, 206-207. See also Colin Baker, Retreat from Empire: Sir Robert Armitage in Africa and Cyprus (London: Tauris Academic Press, 1998), 98-169. See also Philip Murphy, "A Police State? The Nyasaland Emergency and Colonial Intelligence," Journal of Southern African Studies, 36, no.4, (December 2010): 765-767.
} 
Branch policemen also went to the Congress Secretariat and his private clinic in the city, allegedly to search and clear any suspected arms and documents used to indoctrinate Dr. Banda's followers and patients, respectively. ${ }^{356}$ By the end of April 1959, over 1,000 Africans had been detained without trial and over 2,000 had been convicted of political offences. The sentences of those convicted were harsh, ranging from four months to twenty-two years, while others paid fines or had their property confiscated, depending on the seriousness of the offence. The NAC was also outlawed and immediately ceased to exist as a legally recognized political entity ${ }^{357}$ In conducting the arrests, Armitage had at his disposal the following troop reinforcements: military (2 Territorial Force Battalions, 4 Independent Territorial Force Companies, 3 African Battalions, a total of 11 Territorial Force Companies and 9 African Companies, and 1 Platoon of armored cars); police (9 Platoons from the Nyasaland PMF, 2 Platoons from the Tanganyika Police, and 4 sections of the BSAP); and the Royal Rhodesian Air Force (7 Vampires, 10 Provosts of whom 7 were armed, 2 Pembrokes, 1 Beaver, and 1 Cessna). The Nyasaland government's intention in bringing such reinforcements had been to achieve an immediate restoration of law and order in the protectorate. $^{358}$

The arrests of the congress leaders sparked widespread protests in some of the major urban centers in the country. One of the most important protests (due to the high casualty figures), took place at

\footnotetext{
${ }^{356}$ Colin Baker, State of Emergency: Crisis in Central Africa, Nyasaland, 1959-1960 (London: Tauris Academic Studies, 1997), 40-46. Other top Congress leaders were also arrested in the days that followed, including Henry M. Chipembere, Lali Lubani, Dunduzu Chisiza, Kapombe Nyasulu, etcetera, and these were sent to detention centers, including the Kanjedza Detention Centre (in Nyasaland) and other two centers at Khami and Gwelo in Southern Rhodesia.

${ }^{357}$ Paul Chiudza Banda and Gift Wasambo Kayira, "The 1959 State of Emergency in Nyasaland: Process and Political Implications". The Society of Malawi Journal, 65, no.2 (2012): 1-19. See pp1-5. See also Philip Murphy, ed., British Documents on the End of Empire: Central Africa, Part II. Pp.29-34. Sourced from CO 1015/1494, No. 114: 'Nyasaland Emergency': Letter from Sir R. Armitage to J.C. Morgan: Enclosure to 180.

${ }^{358}$ Philip Murphy, ed., British Documents on the End of Empire: Central Africa, Part II, 29-34. Adopted from CO 1015/1494, no.144: 'Nyasaland Emergency': Letter from Sir R. Armitage to J.C. Morgan. Enclosure: Operation Instruction No. 2/59 from the Nyasaland Operations Committee.
} 
Nkhata-Bay district center in the northern province. A protest organized by the local people saw them attack the district prison and later the M.V. Mpasa, which was a ship that would have been used to transfer political detainees to the main prison in the colonial capital at Zomba. The NkhataBay district commissioner, John Brock, called for police and military reinforcements to help him execute the orders, especially following the rumors that the Africans had plotted to protest before their leaders would be transported to Zomba. The demonstrators were allegedly defiant and rude in the eyes of the security forces, some daring the security forces to shoot them, as they were ready to both die and kill for their country. In the Nkhata-Bay demonstrations, 21 demonstrators were mercilessly killed by the security forces, some from the RRR, under the orders of the district commissioner, while twenty-nine others were severely injured. ${ }^{359}$ In other separate incidents in the following weeks, about 30 Africans were also reportedly killed by the security forces, which brought the total number of those killed during the Emergency to over 50. There were also numerous cases where Africans were dispersed through the throwing of tear gas canisters and using baton charges. Sir Robert Armitage also launched a "campaign of harassment", designed to eradicate Congress leadership and doctrines, which was characterized by frequent police patrols where houses were searched, documents seized, and widespread arrests were made. Orders were given to police officers and/or soldiers to search without warrant any premises of suspected congress operatives, which led to the arrest of some, even where their membership of congress had not been confirmed..$^{360}$

One of the detained Congress leaders narrated his ordeal in a 2009 interview:

\footnotetext{
${ }^{359}$ British Government, Report of the Nyasaland Commission of Inquiry (London: H.M. Stationery Office, July 1959), 94-125. See also Colin Baker, State of Emergency: Crisis in Central Africa, Nyasaland, 1959-1960 (London: Tauris Academic Studies, 1997), 50-51.

360 John McCracken, A History of Malawi, 1859-1966, 354-356. See also 'Report of the Nyasaland Commission of Inquiry' (1959),129-131.
} 
The night of my arrest, I was forewarned by a Mr. Musa Gama, that we were going to be arrested. As such, on that night (March $3^{\text {rd }}$, 1959), I was not surprised to see the policemen come to my house. They came at around $3 \mathrm{am}$, and immediately began breaking into my house. I immediately woke up and told them to stop their actions and arrest me. The policemen then demanded that I should show them where I was keeping party membership cards and receipts. They also demanded that I should give them the list of Congress members. When I gave them all that information they arrested me and also took away all the party funds that I was keeping in my house. When they took me to the police station, I found out that there were other Congress members in handcuffs, including Mr. Musa Gama, and other fellow party leaders in Zomba. We were then placed under the guard of troops from Somaliland as we were being kept at Zomba Prison. The prison conditions were very appalling. Imagine, we were just given one blanket each, and they confiscated all our clothes. We were also given just one meal per day. We were also prohibited from speaking anything to do with the Congress.... ${ }^{361}$

At the Federal government level, the leadership did not hesitate to link the disturbances in Nyasaland (and the other two territories) to the influence of the spread of the Russian Communism. That perception was reflected in a communique from Sir Roy Welensky, the Federal Prime Minister, who was fed with information by the Federal Security Intelligence Bureau (FSIB), within a week of the Nyasaland arrests. Welensky wrote:

The Nyasaland uprising plans were inspired at the Accra Conference in Ghana. I must register a protest that plans of this nature should have been evolved at a Conference held in that country. I do not consider this a friendly act to a fellow Member State of the Commonwealth. At the Accra Conference, the Russians had a strong team and what is more, we have it from factual evidence that direct contact was made between the Russian representative and certain of the African leaders from the Federation.

The Federation has tried hard to bring the African into a system of government and the African Federal Parliamentary representation now amounts to twenty-five percent. I believe that the prospects of a successful multi-racial society are good. As the African shows a capability of participating in Government and State development, he will be given a bigger say in running the Federation. ${ }^{362}$

\footnotetext{
${ }^{361}$ Oral Interview with Mr. Arabson Namate, conducted in 2009, by Professor Kings M. Phiri (Lead Researcher) and Paul Chiudza Banda (Graduate Research Assistant). Arabson Namate was arrested while serving as a District Treasurer for the NAC at Zomba, the colonial capital of present-day Malawi.

362 'Security Situation in Nyasaland': Statement by Sir Roy Welensky, Federal Prime Minister'. March 10 ${ }^{\text {th }}$, 1959: CO $1035 / 143$. From the same file, see also 'Report of the Federal Intelligence and Security Bureau (FISB) of the Federation of Rhodesia and Nyasaland'. The FISB report hinted that on December $14^{\text {th }}, 1958$, Dr. Banda and others present at the Accra Conference, attended a private meeting called by the Soviet delegation, at which the Russians
} 
Clearly, Sir Roy Welensky and others around him had not succeeded in drawing the interests of the Africans to the idea and concept of the CAF, hence the disturbances that arose in each of the three territories. In April 1959, following pressure from the opposition benches and other concerned quarters, including the media, the Conservative government in Britain appointed a Commission of Inquiry, chaired by Justice Patrick Devlin (hence "The Devlin Commission”). He was assisted by Messrs. J. Ure Primrose, P. Wyn-Harris, and E.T. Williams, as committee members. The Commission was charged with the responsibility to inquire into the causes of the Nyasaland disturbances and the response of the colonial state prior to and after the Declaration of the Emergency. The commissioners collected their information in Nyasaland between April and May of that year, and in June they travelled to Southern Rhodesia to interview some of the political detainees. In total, there was evidence collected from 455 individual witnesses, and about 1,300 witnesses in groups. They also analyzed various memoranda and government documents.

The report of the commission highlighted that in the disturbances that took place from January to March 1959, about 51 Africans had been killed, and over 80 others were wounded. There was also a possibility that the numbers of those injured might have been more than what was accounted for, especially where those injured did not seek treatment at government hospitals or health centers. The atrocities in question were part of three key "Operations" ordered by Governor Sir Robert Armitage. The first was "Operation Sunrise", which led to the arrest in the early hours of March $3^{\text {rd }}, 1959$, of the so-called "hard-core" leaders of Congress and their subsequent detention. The second operation began on March $9^{\text {th }}$ and was aimed at restoring law and order in areas where groups of disaffected people were still operating under the leadership of Congress. Most of the

pushed the Communist line, and advised the Africans to use any means to obtain freedom, and to use Communism if they thought it would help. 
casualties (six deaths and five injuries) occurred through actions initiated by the security forces, and not necessarily because of African agitation. The third began on April $13^{\text {th }}$ and was aimed at "stamping out Congress" and to return the country to a governable condition, without necessarily employing lethal force. ${ }^{363}$

In the final report, the commissioners deplored the rush to use firearms and military force to subdue the African disturbances. Referring to the Nyasaland Police Standing Orders, the police were supposed to use long batons to disperse crowds as a first resort. If the disorderly crowds were too large and the force available was too small, then they were allowed to use smoke grenades. Firearms were only accepted as a last resort and could only be used upon an executive order from the executive, administrative, and security arms of the government, having initially gauged the numbers, temper, and threat posed by the masses. The biggest regret to the commissioners was their discovery that during the disturbances, the only force that was available was the military one (one where firearms had to be used by soldiers and other policemen using lethal force), rather than minimum means of crowd control. ${ }^{364}$

The report of the commission also hinted that the actions of the Nyasaland government, through its executive and security arms, were arrived at based on mere rumors and hearsay. The government had acted on reports that the Congress leadership had organized a country-wide campaign of violence targeted at destroying government property and a plot to murder Europeans, especially those in government service. That was based on secret information allegedly gathered from some informants at meetings of the Congress in January and February of that year. However, in the commission's findings, there were four main issues that were agreed at the meetings, for

\footnotetext{
${ }^{363}$ British Government, Report of the Nyasaland Commission of Inquiry (London: H.M. Stationery Office, July 1959), 1-6. ${ }^{364}$ Ibid., 39-41.
} 
which the Nyasaland police nor other state intelligence or security operatives were not invited to attend. Firstly, that a Mr. Yatuta K. Chisiza should be appointed as a private secretary and as a sort of bodyguard to Dr. Banda; that the Congress should keep a black list of "stooges and quislings", which would include both politicians and traditional leaders opposed to the policies of Dr. Banda and the NAC; the approval of the policy of sabotage - which would involve the cutting of telephone wires, blocking of roads, destruction of bridges, etc. and also a campaign of defiance, which would include holding public meetings without seeking police permission; and a general approval of a policy of resisting with violence any attempts to enforce unpopular laws, and attempts to arrest those who broke them. ${ }^{365}$

Although there were elements of violence mentioned at the meetings, the commission found that there were no plans to murder Europeans in the country. Furthermore, no official report was ever made public or published for the authorities to back their claims and actions. The practice, since 1954, had been that the Special Branch of the Nyasaland police had been keeping a keen eye on political activities, and maintained a list of "suspects" whom it could have arrested on the Declaration of an Emergency. As such, the purported murder plot or a blood bath, was only mentioned following such "misplaced" intelligence reports. ${ }^{366}$ The security forces however went

\footnotetext{
${ }^{365}$ Ibid., 48-50. For the Intelligence Dispatch from the Nyasaland Government to the British Government, see Philip Murphy, ed., British Documents on the End of Empire: Central Africa, Part II. Pp.10-15. The Dispatch was drawn from WP 240/1, ff 1-7, and it provided the touted intelligence report from information gathered by the Special Branch about the Congress meetings at the end of January $1959\left(24^{\text {th }}\right.$ and $25^{\text {th }}$ January 1959). The Nyasaland Special Branch intelligence report can also be accessed from CO 1035/143: Security Situation in Nyasaland, 1957-1959. Titled: 'The Emergency Conference of the Nyasaland African Congress held at Blantyre on the $24^{\text {th }}$ and $25^{\text {th }}$ January $1959^{\text {'. See }}$ also CO 1035/144: Security Situation in Nyasaland, 1957-1959. Titled: 'Sabotage - Nyasaland, 1959'.

366 Report of the Nyasaland Commission of Inquiry (1959), 75-87. For instance, the police report mentioned the following: (a) That future Congress meetings would be held in the bush, and that those attending them should resort to violence; (b) that if Dr. Banda were to be arrested, on a day proposed as 'R-Day', some Congress leaders, including Messrs. Chipembere, Chisiza, and Chiume, and Mrs. Chibambo, should run the party in their leader's absence; and (c) to engage in a violent campaign, which would include destroying state property, and also the assassination of Government officials, including the Governor and other senior officers in the police, provincial, and district administration.
} 
ahead and used the illegal measures of force, during the operations, most of which were conducted at night, which increased the likelihood of the abuse of the suspects. Further abuse of police powers was observed in a number of areas, for instance, the erection of impromptu road blocks across the country; the organizing of extensive search operations; the burning of houses belonging to suspects, especially Congress leaders; charging of collective fines (as an extra-judicial form of punishment, for instance, in Mulanje District, where the district commissioner imposed a fine of $£ 8,734$ to cover damage assessed at $£ 8,510$ for government structures that had been destroyed); confiscation of implements (such as axes, choppers, and pangas) from the houses that were searched during the operations. These measures were synonymous with a "police state," especially because at no time during the investigations, did government officials express any regret or disapproval of the atrocities committed prior to and during the Emergency. ${ }^{367}$

It was thus clear from the findings of the Devlin Commission that there were instances where intelligence reports and activities of the police force were misleading and detrimental to the general goodwill towards the government, respectively, sometimes bringing the colonial state into disrepute. In the absence of the purported "murder plot", there was no need to employ maximum force in the process of subduing the native disturbances, most of which were conducted by unarmed Africans, who simply expressed their unhappiness with the way the government was being run. What was also deplorable was the harsh conditions which the political detainees underwent during their time especially at Kanjedza Detention Camp. ${ }^{368}$ As argued by Georgina

\footnotetext{
${ }^{367}$ Report of the Nyasaland Commission of Inquiry (1959), 126-142. See also 'Governor's Report on current situation in Nyasaland, 1957-1959': CO 1015/1839. In a dispatch to the Colonial Office, dated April 18 ${ }^{\text {th }}, 1959$, the Nyasaland Governor indicated that it had been necessary to impose the fines in areas where the natives had caused extensive damage to property, communications and people's livelihoods. He stated that the fines were targeted at individuals, of whom the highest fine had been 30/-d. per person.

${ }^{368}$ See for instance, E.D. Mwasi. "Reminiscences of my detention". Society of Malawi Journal, 59, no.2 (2006), 4049. See also "Kanjedza Concluded," Dissent, Issue no.12, $22^{\text {nd }}$ October 1959, 1-7. Source: H.K. Banda Archive.
} 
Sinclair, the police forces truly became pawns that were utilized to fulfill the interests of the politicians of the time. ${ }^{369}$ Elsewhere, Philip Murphy posited that the use of the term "police state" by the Devlin Commission, referring to the tough and punitive measures employed by the security forces, was very embarrassing for the both the British and Nyasaland governments, as during the Second World War and later during the Cold War, such terminology had been more associated with the Fascist and Communist regimes, and their associated human rights abuses, thereby posing serious questions about how colonial affairs were being handled at the time. ${ }^{370}$

When Prime Minister, Harold Macmillan, visited Nyasaland in January 1960, he saw for himself the levels of police brutality, following a scuffle that occurred on January $26^{\text {th }}$, as he addressed delegates to a state-sponsored luncheon at Ryall's Hotel in Blantyre. We know more about the incidents of that day from a Commission of Inquiry, set up by Sir Glyn Jones (Armitage's successor), in early February 1960. The Commission was chaired by Judge Frederick Southworth (hence "The Southworth Commission") of the High Court of Nyasaland. A total of 81 witnesses, from Nyasaland and from outside the country gave evidence between February and April of that year. Some eyewitness accounts of the disturbances appeared as newspaper articles in The London Times and The News Chronicle and were included in the Southworth Commission Report. As one witness reported:

Before leaving Nyasaland today, Mr. Macmillan was the object of another hostile, and this time more violent, demonstration. A crowd of a few hundred Africans had assembled quietly outside the hotel at Blantyre where the Prime Minister was due to arrive to attend a civic luncheon, given by the mayor of Blantyre-Limbe and councilors. As the official party arrived the crowd suddenly produced banners and set up a prolonged growlingly cry, that continued throughout the half-hour of the demonstration.

\footnotetext{
${ }^{369}$ Georgina Sinclair, At the end of the line: Colonial Policing and the Imperial Endgame, 1945-1980 (Manchester: Manchester University Press, 2006), 153-154, and 189-207.

${ }^{370}$ Murphy, "A Police State? The Nyasaland Emergency and Colonial Intelligence", Journal of Southern African Studies 36, no.4, (December 2010): 774-778.
} 
A hardcore of about a hundred Africans began pushing through the small police cordon. Some managed to get through and ran up and down the road waving banners and shouting 'All we want is Banda now'. Soon stones and mud were flying as the police reserves moved in. Four demonstrators picked out for arrest, but when they were taken to a police van dozens more offered themselves for arrest amid cries of 'Freedom' and loud applause from the watching crowd, the vast majority of whom were no more than spectators. Only some half a dozen Africans could be packed into the small van, though later another 20 were encouraged to run into a larger one that had been brought up.

Meanwhile, the Police had cordoned off the demonstrators and were holding them back with some difficulty. Apart from trying to push the police backwards the demonstrators' main tactics were knocking off policemen's caps and screaming 'Give us Banda' in their faces, for which many of them were rapped with hard canes. One or two Africans, including a woman who had been shouting 'Give us back our Messiah', were knocked down, but no one was seriously hurt. ${ }^{371}$

One of the key witnesses was the Commissioner of Police, Mr. Long, who in his testimony admitted that the police acted under his orders, with the intention to remove the ringleaders of the demonstration. He mentioned that the actions of the demonstrators had almost made it impossible to avoid confrontation with the police. Among his key responsibilities, the commissioner stated that he gave up his official vehicle, a Land Rover, to be used in the arrest of the native demonstrators. He also mentioned that he himself arrested one of the ring leaders, following a photograph of the incident which was presented as part of the inquiry. However, Long, upon being pressed, admitted that some of the actions of his policemen were uncalled for, especially when they failed to supervise the demonstrations, rather than rushing to use force. That failure was in part blamed on the limited numbers of police personnel, and the lack of experience by some of the officers, some of whom had only a year or two of police service. In his closing remarks, Long told the inquiry that under the prevailing conditions, he was generally pleased with the conduct of the

\footnotetext{
${ }^{371}$ Nyasaland Government, The Southworth Commission Report, May 1960. Newspaper article by The Times. January $26^{\text {th }}$, 1960, 'Howling Crowd Greets Mr. Macmillan: Blantyre Africans break cordon, 'Give Us Banda'., pp.4-5. Source: H.K. Banda Archive.
} 
policemen. He also said that shortly after the incident, he was introduced to Macmillan, at the airport, where the Prime Minister congratulated him on the conduct of the police. ${ }^{372}$

In summing up the report, the commission agreed with a cross section of journalists and other independent observers, that the incident of January $26^{\text {th }}, 1960$, could be described as a "riot", which only lasted for about an hour or so. The African protestors, who numbered between 800 and a thousand, carried placards outside the hotel where the Prime Minster was to speak. About 35 of the more active demonstrators were removed from the scene by police personnel, during a "kickabout" involving the police against the Africans and some Africans against the police, causing some minor injuries on either side, for a period of about forty minutes. The report, unlike that of the Devlin Commission, cited above, however, fell short of condemning the actions of the police. For instance, it referred to the injuries suffered by the African protestors as less severe and went on to describe an injury suffered by one witness, a Miss Phombeya, as "only covering an area of one square inch, and probably no more than the area of a penny postage stamp. And that the amount of blood that was shed would not be enough to test the capacity of an ordinary mustard spoon." 373 The report also blamed the media for blowing the disturbances out of proportion, through “irresponsible reporting," aimed at creating an impression that Nyasaland was ungovernable. ${ }^{374}$

\footnotetext{
372 Nyasaland Government, The Southworth Commission Report, May 1960, 17-23.

373 The Southworth Commission Report, May 1960, 112-126.

374 The Southworth Commission Report, May 1960, 37 and 112-126. Note that as an employee of the Nyasaland Government, it was almost inevitable that Justice Southworth would rule in favor of the state. The release of the Commission's report was also widely celebrated by the Nyasaland government, especially Governor Armitage, as it exonerated the Nyasaland police, and indirectly, the Armitage administration. See "Address by His Excellency," In Record of the proceedings of the $1^{\text {st }}$ meeting of the $75^{\text {th }}$ Session of the Nyasaland Legislative Council," $4^{\text {th }}$ July 1960.
} 


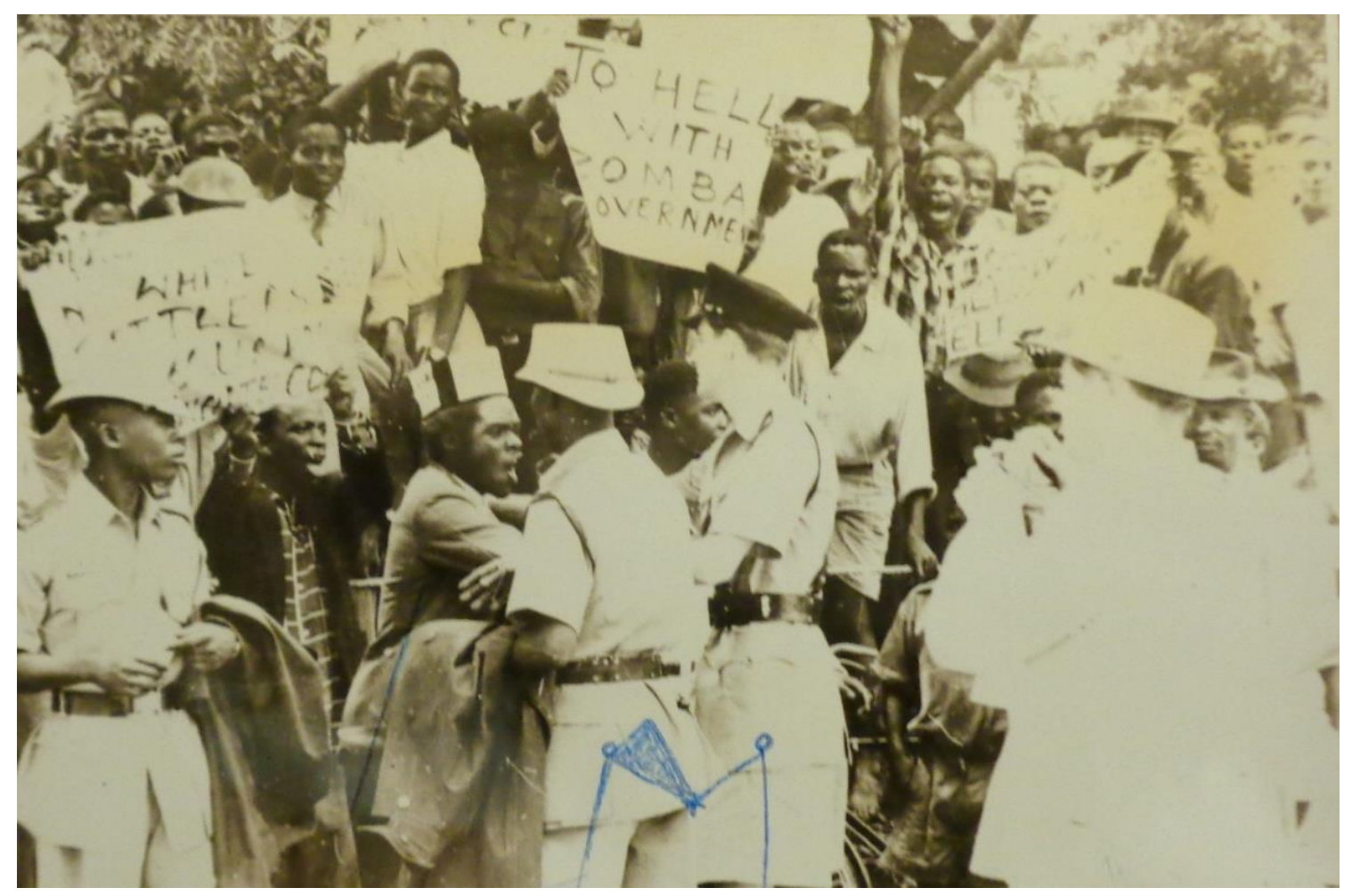

Figure 5.1: Rejecting imperialism amidst the blowing 'winds of change': Native protestors outside of Ryalls Hotel, Blantyre, Nyasaland, on January $26^{\text {th }}$, 1960. The Rt. Hon. Harold Macmillan was in the Hotel addressing delegates to a state-sponsored luncheon. Source: H.K. Banda Archive.

By the end of that year (1960), a Bill was also passed in the Legislative Council (Legco), leading to the establishment of the "Nyasaland Police Reserve". The Reserve was comprised of persons above the age of 18 , who would be called upon by the police commissioner during emergencies. The Bill's sponsor, P.W. Youens, then Acting Chief Secretary, argued that the Reserve was needed to support the maintenance of law and order in the country in collaboration with the local police and other parts of the CAF. The main function of the reserves was to police the activities of political organizations, which were said to be the source of trouble in the country. ${ }^{375}$

375 "Nyasaland Police Reserve Bill," In Record of the proceedings of the $2^{\text {nd }}$ meeting of the $75^{\text {th }}$ session of the Nyasaland Legco," 6 ${ }^{\text {th }}$ December 1960. 
While the events in Nyasaland had left an indelible mark on Macmillan and other colonial officials, ${ }^{376}$ it is also arguable that indeed Nyasaland had indeed become a "police state", where even the Prime Minister commended the use of brutality against the Africans. It would however not take long before the CAF was disbanded in 1963, and independence granted to Nyasaland in July 1964. The post-colonial leadership, as I will argue in chapter six, continued with most of the policies, structures, and practices of the predecessor colonial state.

\section{Conclusion}

This chapter has examined the efforts of the colonial state's involvement in the protectorate's economy and development narrative, especially in the post-World War II era. It has been highlighted that colonial development efforts were often accompanied by hidden agendas or motives, both political and economic, and were meant to satisfy the needs of both the colonies and the metropole. Using the case study of the creation of the CAF (1953-1963), it has been highlighted that because the project did not have substantial African support, the opposition to the CAF became a fertile breeding ground for the rise of radical forms of nationalism, in the form of the NAC and later the MCP. The rise of such anti-colonial discontent was met with various forms of counterinsurgency employed by the colonial state. I have focused on the use of police brutality and the enactment of laws to deter further African unrest. On the other hand, there were also several development initiatives (in the education, transport, health, and agricultural sectors) employed by the state to win the support of the Africans. The next chapter focuses on the post-colonial state in Malawi, where effort will be made to show that there was a continuation of some of the policies, institutions, and practices employed by its colonial predecessor. This would include such practices

\footnotetext{
${ }^{376}$ A week after witnessing the Nyasaland disturbances, Macmillan delivered the famous "Winds of Change speech", in South Africa. See 'Speech by Rt. Hon. Harold Macmillan, Prime Minister of the United Kingdom, to the Houses of Parliament, Cape Town'. Wednesday, $3^{\text {rd }}$ February 1960.
} 
as "developmentalism"; political policing; the enactment of strict laws; and the use of "carrots" or development initiatives to deter opposition against the state. 


\section{CHAPTER SIX}

\section{POST-COLONIAL MALAWI: THE DYNAMICS OF AN "IMPORTED STATE"}

Then there is the problem of initiative. If a nationalist movement is to achieve the goal of independence, it is vitally important that one of the leaders should be elevated well above the others; that his former equals should look upon themselves as his juniors; that they should accept his decision as final; and that they should pledge loyalty to his leadership. But once independence has been achieved, the problem of reconciling submissiveness to the top leader and individual initiative on the part of the second-level leaders arises. To a man who has been surrounded by submissive associates for a long time, the exercise of initiative by his associates is easily misconstrued as a sign of rivalry and disloyalty. ${ }^{377}$

\section{Introduction}

This chapter focuses on the processes involved in the making of the post-colonial state in Malawi, from 1964 to 1994, covering the regime of Malawi's first post-colonial head of state, Dr. Hastings Kamuzu Banda. The focus is on the fact that since Malawi emerged as a "developmental state," the leadership developed "protectionist" tendencies, where opposition to the state was not tolerated. This involved closing spaces for both political and economic participation for individuals and other interested groups, such as trade unions and political parties. The 'protectionism' in question contributed to both the rise of anti-state resistance, to which the state reacted by creating counter-insurgency (or counter-opposition) measures, which, as I will discuss, came in multiple forms, including the use of brutal force; the enactment of repressive laws; and the offer of development opportunities. I also highlight how the West, especially the British and American governments, helped to consolidate and prolong the Banda regime, as the Malawian leader was

\footnotetext{
377 D.K. Chisiza, "The Temper, Aspirations and Problems of Contemporary Africa", in E.F. Jackson, ed., Economic Development in Africa: Papers presented to the Nyasaland Economic Symposium, Blantyre, July $18^{\text {th }}-28^{\text {th }} 1962$ (Oxford: Basil Blackwell, 1965), 7.
} 
regarded as an important ally during the Cold War. Here, the argument is that the post-colonial state in Malawi owed its survival and longevity to the Western support it received, without which it could have easily been toppled.

\section{Contextualizing the post-colonial state in Africa}

There has been a wide range of scholarship that has focused on the dynamics of the African postcolonial state since the 1960 s. The concept of the "state" has been defined by various scholars, including Joel S. Migdal, who posited that an ideal definition of state should be: it is an organization, composed of numerous agencies led and coordinated by the state's leadership (executive authority) that has the ability to make and implement the binding rules for all the people as well as the parameters of rule-making for other social organizations in a given territory, using force if necessary to have its way. ${ }^{378}$ Migdal posited further that wherever the "state" has developed, it has had the capacity to make a difference, in one way or the other, in the people it governs, sometimes successfully and sometimes not as planned. Those that succeed are regarded as "strong states" and those that fail are regarded as "weak states." This analysis then positions or locates "states" as arenas of contestation. He used this definition to create a model described as "state-society relations," whereby the actions of the state affect people's livelihoods, but also the actions of the people can dictate the way the state is organized and run. ${ }^{379}$

In this section, I will discuss some of the key issues and debates, most of which revolve around a pessimistic view of what has become of the post-colonial state since the age of independence. One of the key scholars on the subject is Young, whose works have left an indelible mark on the study

\footnotetext{
${ }^{378}$ Joel S. Migdal, Strong Societies and Weak States: State-Society Relations and State Capabilities in the Third World (Princeton, NJ: Princeton University Press, 1988), 19.

${ }^{379}$ Ibid., xiii-xxi; and 3-9.
} 
of both the colonial and post-colonial state in Africa. In his analysis of the "post-colonial state" in Africa, Crawford Young presented what I adopt to be a convincing argument that scholars of African must adopt parameters regarding the time line for post-colonial Africa. He posited that the label "post-colonial state" in African studies should only be used to describe dynamics in African states between the age of independence in the early 1960s, and the early 1990s, immediately after the Cold War, and the collapse of the Soviet Union. He argued that for those three to four decades, it could be arguable that there was a significant, sometimes wholesale, importation of the routines, practices, and mentalities of the African colonial state into its post-colonial successor. From the mid-1990s onwards, Young argues, both at the level of semantics and practicality, that the concept of the "post-colonial state" begins to lose its usefulness, especially as many African countries, due to the political and economic changes that took place, experienced a significant shift in the structures and systems of government, away from those inherited from European colonial masters. Since the mid-1990s, the dominating powers of the state have been significantly reduced, and the concept of bula matari ("he who crashes rocks"), or Leviathan, as was the case during the colonial period, bears only a remote resemblance. ${ }^{380}$ In the case of Malawi, I will discuss the factors behind the fall of the post-colonial state in chapter seven of this study.

According to Young, some of the core elements of the colonial state that were transferred to the "post-colonial state" could be summarized as follows: first, the models of development, especially state-led development and control of the economy, that were adopted wholesale by the postcolonial state. The post-colonial state took over the responsibilities of fighting in the wars against poverty, ignorance, and disease, and as the manager of transformation. Secondly, the silent

\footnotetext{
${ }^{380}$ Crawford Young, "The End of the Post-Colonial State in Africa? Reflections on Changing African Political Dynamics," African Affairs, 103, no.410 (Jan. 2004): 23-25.
} 
codification of laws and legal codes from the colonial to the post-colonial state. In most countries, there was simply a transfer of colonial era legal codes, disregarding the existence of pre-colonial African legal systems, a process which helped to reproduce systems and/or practices of the colonial era. Thirdly, apart from continuity, the post-colonial states also built upon the existing colonial structures, policies and practices, as the new (post-colonial) elites took over power at a time when there was overwhelming confidence in state-led development initiatives in which many leaders preached against reliance upon the market but advocated for state-led development strategies. Last but not least, the position to be adopted by the state in the "East versus West" Cold War rivalry was also adopted from the colonial state. The new African states became a diplomatic battlefield, and became a target for international aid, both military and economic, essential for both state and nation-building in the post-colonial era. Lastly, the creation of single-party regimes, and centralized authority in a single ruler, was also something adopted from decades of European colonial rule. Political competition was not entertained, as that was deemed to be detrimental to cohesiveness and national unity. Hence the citizens were expected to be obedient and loyal to the state, the political party, and the ruler. ${ }^{381}$

Most studies on the post-colonial state in Africa have adopted Marxist and underdevelopment approaches. Under the former, there was a tendency from most of the scholarship to conceptualize and analyze the modern state, as posited by Bertrand Badie and Pierre Birnbaum, from the perspective that "the economic structure of a society is the real foundation on which arises a legal political superstructure." 382 On the other hand, those in the underdevelopment school have tended

\footnotetext{
381 Crawford Young, "The End of the Post-Colonial State in Africa? Reflections on Changing African Political Dynamics," 29-38.

382 Bertrand Badie and Pierre Birnbaum, The Sociology of the State (Chicago: The University of Chicago Press, 1983), 3.
} 
to concentrate on the limited or lack of economic and political grwoth of the post-colonial state, with some of the factors traced back to hundreds of years of contacts with the West. ${ }^{383}$

Crawford Young identified six key phases of the state in Africa, from the late 1950s to the close of the $20^{\text {th }}$ century and early $21^{\text {st }}$ century (see chapter one of this dissertation). This study falls under five of the six phases identified by Young, and from his analysis, one gets the picture that African states have since independence been affected by one crisis after another. The crises range from authoritarian leadership, economic downturns, failed "developmentalism," civil wars, neocolonialism, and more recently the lingering impacts of the Structural Adjustment Programs (SAPs) imposed by the Bretton Woods Institutions. ${ }^{384}$

There is also scholarship that argues that the states that emerged in post-colonial Africa, can be described as "imported states." This includes works by Bertrand Badie, Pierre Englebert and Kevin C. Dunn. Bertrand Badie, for his part, argued that the current model of a "state" is of Western origin, having been formulated during the Middle Ages and enhanced during the age of Enlightenment. It was European colonialism and conquest, which was responsible for transferring the Western models of statehood to the non-Western world (i.e. that there was a diffusion of political thought, institutions, and practices as well as legal codes and economic theories, from the shores of Europe and North America towards the south and the east). Even after decolonization in the early 1960s, for most of the former colonies (in Africa and Asia), the characteristics of Western models of government both in the metropole and in the former colonies, were not discarded, but rather continued to be the building blocks for the post-colonial state, which in a sense also tended

\footnotetext{
${ }^{383}$ See for instance, Walter Rodney, How Europe underdeveloped Africa (London: Bogle L'Ouverture, 1972).

384 Crawford Young, The State in Postcolonial Africa: Fifty Years of Independence, 1960-201. (Wisconsin: The University of Wisconsin Press, 2012), 10-28. See also Frederick Cooper, Africa since 1940: The Past of the Present. (Cambridge: Cambridge University Press, 2002), 85-89 and 156-186.
} 
to universalize the Western models of government. For instance, in the immediate aftermath of European colonial rule, the post-colonial states adopted or "imported" tendencies of state-led developmentalism and authoritarianism from their colonial era predecessors. These two tendencies or practices progressed together, from Western origins, where "the Western prince is the one who super-legitimizes his order and justifies the constitution of an international system based on his legal system and its institutions. The prince of a developing society (or the nationalist elites, most of whom were educated in the Western world) had however to include some form of authoritarianism tendencies for him to back the claims of modernizing his own state."385

\section{The Malawian post-colonial state and its development model}

Anyone who talks about development in this country must not have a narrow view of what development is. All I had to do was to get independence. Once I was independent, my people were independent, this country was independent, I too could go to New York, go to Washington, go to London and borrow money. My job is to develop this country because the political struggle is over. To wage war against three enemies - poverty, ignorance, and disease and to do this, to fight these three, all of us have to be busy. I must find money to build bridges, to build roads, to do many other things, schools and run our University. You have a part to play because we cannot develop this country by the old methods.... 386

As alluded to above, the post-colonial state in Malawi could be regarded as an "imported state."

This refers to the continuation of practices, structures, and ideologies that were previously employed by the colonial state and were emulated by the successor post-colonial state. There are

\footnotetext{
${ }^{385}$ Bertrand Badie, The Imported State: The Westernization of the Political Order (California: Stanford University Press, 2000), 48-77. See also Pierre Englebert and Kevin C. Dunn, Inside African Politics (London: Lynne Rienner Publishers, 2013), 48. In the same vein, see also Cooper, Africa since 1940: 5-6. Cooper posited that both the late colonial and post-colonial governments in Africa were 'Gate-Keeper States,' in a way that the developmentalism of both states influenced the leadership to stifle the economic and political opportunities of those in the opposition. See also Jean-Francois Bayart. The State in Africa: Politics of the Belly, $2^{\text {nd }}$ edition. (Cambridge, UK: Polity Press, 2009), 60-61. Bayart also argued that the 'development' claims of most post-colonial states, created a loophole from which the states were able to ban attempts of political competition and social protest.

386 "Speech by Dr. H.K. Banda, Malawi Parliament, July 1965," Adopted from Malawi at War: Against Poverty, Disease and Ignorance. Source: H.K. Banda Archive.
} 
two key similarities that I will draw upon. Firstly, similar to what transpired in the late colonial era, the post-colonial government also embarked on state-led or interventionist control and management of the economy and the development narrative, where the state was involved in comprehensive development planning and large-scale public investment (such a state may be described as a "developmental state"). In part, that was because some colonial officials remained in the country's civil service or as advisors of the new government and kept adhering to the colonial development policies. Secondly, there was a tendency by the postcolonial ruling elite (formerly the nationalist elite) to block the rise of any opposition elements, and they employed propaganda tactics such as labelling them as communist implants, as a strategy used to gain the sympathy of Western powers, while "blinding" them to the human rights abuses of the state. Like most leaders of post-colonial Africa and beyond, Malawi's leader believed in the power of the state to shape post-colonial society, where the state and the institutions under it would be used create a new social order, in the image of the leader.

The first post-colonial Development Plan (1965-1969) outlined four main areas, that placed the government at the center of the development agenda and initiatives. The areas included: the expansion of agricultural production, to meet the demands of the domestic and export markets; improvement of the communication and transport infrastructure; expansion of facilities for secondary and tertiary education, to build the human resources to work in government and the private sector; and the encouragement of industrialization by the private sector and parastatals. The plan also clearly stipulated the need to maintain political stability in the country by, among other things removing all forms of political opposition. It expressed the following sentiments: "Development is never easy. But the difficulties involved in developing a nation are nevertheless greatly eased if the nation possesses political stability. This Malawi has. At the head of 
Government is a popular, elected and undisputed leader. Behind the Government stand the people whose support was evidenced more recently and clearly at the April General Election. There is, therefore, no dissipation of resources or energy over disputes as to who is to conduct policy or what policy is to be followed. This is a major asset." ${ }^{387}$ The 1965-1969 Development Plan, was followed by other similar policy documents, titled "Development Policies," in which the government retained keen interest in development and controlling the economy. ${ }^{388}$

Dr. Banda also clearly stipulated the path which his government would take in the Cold War rivalry. He acknowledged, in a speech, delivered at a debating society in Zomba, in 1964, that there had been a tendency by colonial authorities to label those in the opposition, including himself, as communists. Furthermore, he stated that the post-colonial states in Africa were left with tough decisions on which camp to side with. As for his preference, he made it clear that he was in favor of the middle ground - i.e. the compromise between capitalism and communism - where the state would have a stake in the economy (hence encouraging the spirit of protectionism), while also allowing some form of independence for private ownership of the means and proceeds of production. On the question of the Cold War, he mentioned that he would not drag his country into the East vs West rivalry, rather that he would be open to diplomatic relationships with countries that would help to improve Malawi's economy and that of its four million people. ${ }^{389}$ As I will discuss later in the chapter, Dr. Banda ended up changing his seemingly "non-aligned" position when Malawi gained independence.

\footnotetext{
${ }^{387}$ Malawi Government, Development Plan, 1965-1969 (Zomba: Government Printer, 1965), 7.

${ }^{388}$ World Bank Report No. 3082a-MAI: Malawi Growth and Structural Change: A Basic Report. February 1982., 49.

389 “What is Communism? ” Speech by Dr. Hastings Kamuzu Banda, Prime Minister of Malawi, at the Zomba Debating Society, April 1964. Source: Center for Research Libraries, Chicago.
} 


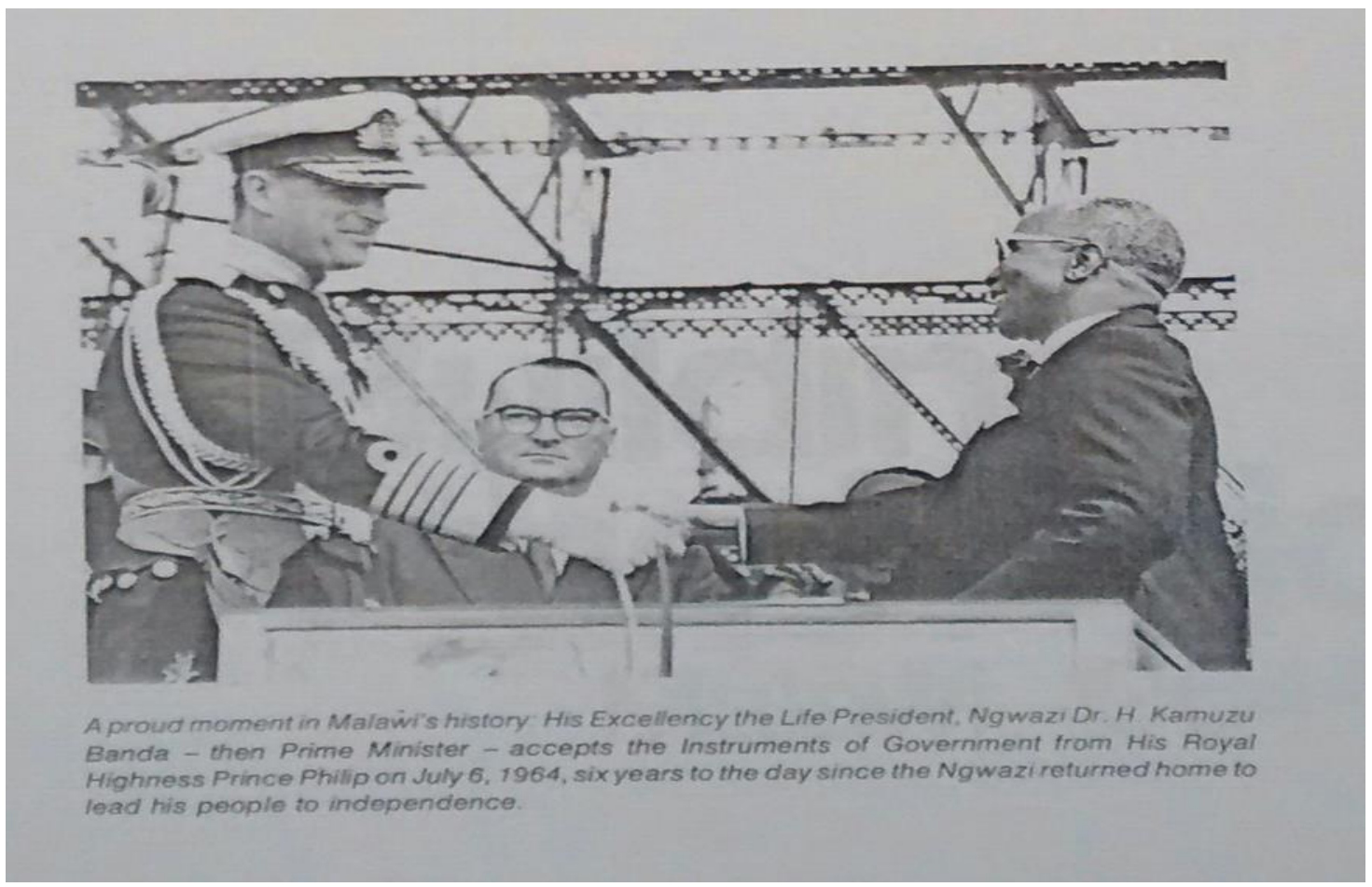

Figure 6.1: Image depicting the handover of power from the colonial to the post-colonial state in July 1964. I argue in this chapter that that was merely symbolic, as what emerged in the postcolonial period, was merely a continuation of the policies and practices that had served and sustained the colonial regime, particularly Banda's admiration of the British model of economic development, i.e. that of a 'developmental state.' Source: Malawi, 1964-1974: Building the Nation. 1974. H.K. Banda Archive.

\section{The Postcolonial Development Model}

Once Dr. Banda settled on that model of development and state control and management of the economy, he made sure that it was implemented when he became head of state in July 1964. His government was involved in such areas as in agricultural production, credit control, manpower training, transportation, and beverage production, leading to a situation where there was almost no clear-cut distinction between the public and private sectors. There was a tendency for public officers to treat public resources as their personal patrimony. There were also cases where that socalled "developmental state" tended to equate rapid economic growth with national security and 
described these as the priority areas of the state, while any form of opposition was despised as dragging and derailing the development agenda. ${ }^{390}$

There were two main conglomerates, where the Banda regime was heavily involved in the control and management of the economy. Due to the vested interests in the country's economy, Dr. Banda and those around him, were not willing to allow any form of opposition in the form of political parties or individuals, to operate in the country, as doing so threatened their political and economic base. This then continued the trend of a "gate-keeper state," 391 which I discussed in chapter five of this study. In the process, those who clung to political power did so not just for the sake of retaining a political position, but also because of the economic gains associated with political power. In the process, the state, through these conglomerates, encouraged the principles of import substitution industrialization (ISI) $)^{392}$ where the state encouraged domestic production, to reduce the importation of basic products. The MCP elite and Dr. Banda's relatives held leadership positions, mostly as trustees and board members, in the companies under the conglomerates. As posited by Guy Mhone the state's strategy of intervention and participation in the Malawian economy led to the manipulation of the political and economic spaces, often in favor of the state president, his relatives and party cohorts. ${ }^{393}$

\footnotetext{
${ }^{390}$ See for instance, Atul Kohli, State-Directed Development: Political Power and Industrialization in the Global Periphery (Cambridge: Cambridge University Press, 2004), 6-10.

${ }^{391}$ See for instance, Cooper, Africa since 1940: 5-6. Cooper argued that such type of statism could be described as 'a Gate-Keeper State', where the state (both colonial and post-colonial) in Africa, maintained its power through coercion, patronage, and scapegoating of opponents. More importantly, that allowed the authorities to control the economic and political opportunities or entrance points (i.e. 'the gate') for their subjects. It was government planning that was essential in driving the economic and political life of the state. See also Crawford Young, "The African Colonial State and its political legacy," in Donald Rothchild and Naomi Chazan, eds., The precarious balance: state and society in Africa (Boulder: Westview Press, 1988), 56-60.

${ }^{392}$ See for instance, Beluce Bellucci, "The State in Africa," The Perspective of the World View 2, no.3 (Dec. 2010): 26-30.

${ }^{393}$ Guy Mhone, "Political Economy," in Guy C.Z. Mhone, ed., Malawi at the Crossroads: The Post-Colonial Political Economy (Harare: SAPES Books, 1992), 1-11.
} 
The first conglomerate was the Malawi Development Corporation (MDC), which was established in January 1964, through an Act of Parliament, and was also heralded as one of the most important outcomes of the 1962-65 Development Plan. Among the key functions and terms of reference for the establishment of MDC were the following: (a) to develop the agricultural, commercial, industrial, and mineral resources and the economy of Malawi; (b) to have the power either alone or in association with other bodies or persons - of operating commercial or business activities or enterprises - be they agricultural, industrial, commercial, or mining related; (c) and to promote, assist or finance any project - through providing training, loans and/or grants - to projects that had similar aims as that of MDC and the Malawi government. In terms of funding, the MDC was also empowered to source funds from both within Malawi (from the government and the private sector) and also from foreign investors and donors agencies and countries, and also to channel its profits to the Malawi government. ${ }^{394}$ The government, working through the MDC, went into joint ventures or operated singularly, leading to stakes in a number of companies, including the Commercial Bank of Malawi; the National Oil Company; Carlsberg Brewery; The Match Company (Malawi) Limited; United Transport Malawi Limited; City Developments Limited; Packaging Industries Malawi Limited; Pipe Extruders Limited; Brick and Tile Company Limited; B\&C Metal Products Limited; Malawi Motors Limited; Cold Storage Company Limited; Import and Export Company Limited; among others. ${ }^{395}$

\footnotetext{
${ }^{394}$ Malawi Government, Malawi Government Gazette, Ordinance No.13 of 1964: Malawi Development Corporation

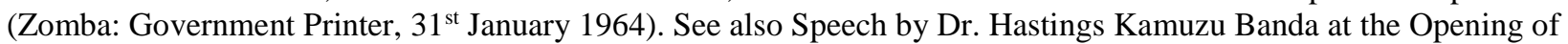
the Distillery Factory Company in Blantyre, $24^{\text {th }}$ February 1967. Source: Center for Research Libraries, Chicago. The Malawi Distilleries Company was a subsidiary of MDC but was also partly owned by a London-based Consortium, called Gilbey. See also 'Dr. Banda's State Address to the Opening of Parliament'. July $2^{\text {nd }}$, 1971. Source: Center for Research Libraries, Chicago.

${ }^{395}$ Speech by His Excellency the President to Parliament on July $28^{\text {th }}$, 1970. See also Malawi Government, Malawi Development Corporation: Ten Years of Progress (Zomba: Government Printer, April $\left.9^{\text {th }}, 1974\right)$.
} 
Dr. Banda liked the association that emerged between his government, the MDC, and the country's development agenda. In a speech delivered to parliament in 1968, he argued as follows: "Therefore, the government must go into business through the MDC. We are not going to close the private enterprises and say, 'Oh No, you must not do this, you must not do that.' No, we are going to compete. But I must not deceive anyone. When I was introducing the bill to create or establish the MDC, I made it quite clear that where business and private enterprise is willing to risk its capital, the Government will let private enterprise do business, but where private enterprise is shy, afraid, unwilling to risk its capital, then the Government has to step in." ${ }^{396}$ The song below, adopted from the speech, supports that notion:

\section{Song Number One:}

Eeee Ngwazi lero

Zikomo a Ngwazi

Tithokoza Ngwazi lero

Commercial Bankiyi

Wamangitsa ndani?

Aaaa! Ngwazi!

Chitukuko chonsechi

Wabweretsa ndani?

Aaaa! Ngwazi! Ngwazi! Ngwazi!

Zikomo a Ngwazi tithokoza Ngwazi.
Eeee Ngwazi today

Thank you Ngwazi

We thank the Ngwazi today

This Commercial Bank

Who has constructed it

Aaaa it's the Ngwazi

All this Development

Who has brought it?

Aaaa Ngwazi! Ngwazi! Ngwazi!

Thanks to the Ngwazi. ${ }^{397}$

\footnotetext{
${ }^{396}$ Speech by Dr. H.K. Banda, to the Parliament of Malawi, October $14^{\text {th }}$, 1968. Source: Center for Research Libraries (CRL), Chicago.

${ }^{397}$ Speech by Dr. Hastings K. Banda, at the Opening of the Commercial Bank of Malawi, Head Office, Blantyre, May $29^{\text {th }}$, 1976. Note that the MDC survived for almost a decade after the fall of Banda, before it was eventually liquidated. By then many of its subsidiary companies had already been privatized. Source: CRL, Chicago.
} 
Dr. Banda also held substantive business interests in a private company called the Press Group of Companies (PGC), which began as an off-shoot of a company called The Malawi Press (established in 1961), which published the newspaper of Dr. Banda's own political party, the MCP. In 1969, the company diversified and diverted to become more of Banda's personal company, as Life President of the MCP, under the name of Press Holdings Limited (PHL), with Dr. Banda owning ninety-nine percent of the conglomerates' shares. Dr. Banda also regarded the PGC as an agent of development, but also a source of employment for thousands of Malawians. However, with the passage of time, the PGC began to be incorporated into the state system, or became a "semi-state" organ, including cases where the government guaranteed loans for the conglomerate. That was often the case because there was often no separation of powers between Dr. Banda, the party, and the state. There were eight wholly-owned subsidiary companies under the PHL, namely: Press Farming Limited; Hardware and General Dealers Limited; Press Trading Limited; Press Industries Limited; Press Produce Limited; Press Agencies Limited; Press Transport Limited; and Press Properties Limited. Furthermore, the Group was also a major shareholder in some of the country's major banks, including 38.4 percent in the National Bank of Malawi, and 40 percent in the Commercial Bank of Malawi. ${ }^{398}$ The Group also had business partnerships with other domestic and foreign or international conglomerates, either as a subsidiary or an associate, which included the following: African Lakes (UK); CMI (Belgium); Bergers (South Africa); Boart International (South Africa); British Petroleum (UK); Carlsberg International (Denmark); I.D.V. (UK); Namib Group (South Africa); Premier Group (South Africa); Standard Chartered (UK); Truworths

\footnotetext{
${ }^{398}$ Malawi: Ten Years of Progress, in Progress International, February 1974, 19. See also The World Bank, Report and Recommendation of the President of the International Development Association on a proposed credit of SDR 51.9 Million to the Republic of Malawi for a Second Structural Adjustment Project, November 29 ${ }^{\text {th }}$, 1983., pp.7, 25-26, and 40. Although the PGC was 'officially' a private entity, the conglomerate's monopoly on the economy, meant that it was included in the SAPs (which I cover in Chapter 7), implemented by the Bretton Woods Institutions.
} 
(Zimbabwe); Universal Leaf (USA); and Swaziland Tyres (Swaziland). ${ }^{399}$ By the early 1970s, the PGC's economic monopoly had already reached worrying levels, with secret dispatches exchanged between the British High Commissioner in Malawi and his superiors in London. There was concern with the way the PGC was involved in land grabbing and easing out other businesses, both locally-owned and foreign-owned. ${ }^{400}$ By 1993/94, the conglomerate was still one of the major players in the country's economy, with an estimated thirty-percent of the country's formal GDP, and offered employment to about 23,000 people, mostly Malawian citizens. ${ }^{401}$ In 1997, following the change of government, from the MCP to the United Democratic Front (UDF), the PGC was stripped away from the control of the Banda family and the MCP, following a protracted court battle. In 1996, the UDF-led government passed "The Press Trust Reconstruction Bill” (later “Act"), in the National Assembly. The conglomerate became a "Trust," hereafter "Press Trust," working for the benefit of all Malawians, rather than just being a private entity. While "Press Trust" still owns some of the companies established during the Banda regime, it is no longer as large as it used to be. Currently, it uses the proceeds from the businesses in ensuring the socioeconomic well-being of Malawians. ${ }^{402}$

By the late 1960s, there were already brewing signs of discontent emanating from the top politicians in the country. Many of them were dismayed at the self-enrichment activities of the president and his close allies. They deemed this to be against the communal ownership of property that was characteristic of African communities, and hence concluded that Dr. Banda's capitalist

\footnotetext{
${ }^{399}$ Press in the 90s: Questions and Answers. Published by the Press Corporation Limited, January 1995. Source: H.K. Banda Archive.

${ }^{400}$ British High Commission, Blantyre, Malawi to the FCO: 'The President's Press Group,' February $2^{\text {nd }}, 1972$. Confidential. Political Situation in Malawi, 1972, BNA: FCO 45/1227.

${ }^{401}$ Press in the 90s: Questions and Answers. Published by the Press Corporation Limited, January 1995. Source: H.K. Banda Archive.

402 Jan Kees van Donge, "The Fate of an African 'Chaebol': Malawi's Press Corporation after Democratization". Journal of Modern African Studies 40, no.4 (Dec. 2002): 662-663.
} 
tendencies had been adopted from his lengthy stay out of the country. Those deemed to be critical to Banda's policies were soon replaced. This included such names as Mr. Kumbweza (central region minister), Mr. Chibambo (northern region minister, and Mr. Aleke Banda (finance minister). Some of them confided their concerns with Glyn Jones, the last British Governor, who had stayed on as an advisor to the newly independent government. ${ }^{403}$ The rise and growth of opposition to Dr. Banda from within the party (MCP) ranks, even saw the British authorities begin to raise questions about how long he would stay on as president. Many of the diplomatic reports even predicted that Dr. Banda would be out of office by 1974, when Malawi celebrated a decade of independence. ${ }^{404}$ However, Dr. Banda stayed on until the early 1990 s, as will be discussed in chapter seven.

\section{The Opposition - Communism Nexus under the Banda Regime}

Since Dr. Banda had envisaged a state-led development agenda and had also acquired the stakes in the above-mentioned conglomerates, he was, like the colonial state, not ready to accept any form of opposition to himself and his government, as that threatened both his political and economic positions. And just like the late colonial state, Dr. Banda also turned to the communist ideology, as a label with which to describe the opposition elements in both his own party and outside. In the words of one of Dr. Banda's former nationalist colleagues, Dunduzu Chisiza, "it was almost a

\footnotetext{
${ }^{403}$ Minute from Mr. Allison, British High Commission in Malawi, to the FCO, titled Dr. Banda's position in Malawi, April 1969. BNA: FCO 29/291: Malawi political and administrative affairs (internal), criticisms against Dr. Banda. See also Confidential dispatch from Mr. W. Peter, FCO, Central African Department, to Mr. Parker, at the FCO, $8^{\text {th }}$ April 1969. BNA: FCO 29/291: Malawi political and administrative affairs (internal), criticisms against Dr. Banda. ${ }^{404}$ Confidential dispatch from Mr. William Wilson, FCO, Central and Southern African Department, to Mr. Fingland," $23^{\text {rd }}$ April 1970. BNA: FCO 45/755: Review of internal political developments in Malawi, 1970. See also "Malawi: How long can Dr. Banda last?" Memo from the British High Commissioner to Malawi, Mr. T.S. Tull, to the Secretary of State for Foreign and Commonwealth Affairs, Diplomatic Report No.257/70. $8^{\text {th }}$ April 1970. BNA: FCO 45/755: Review of internal political developments in Malawi, 1970.
} 
universal tendency in the less developed regions of the world, that if the ruling party or the leader was pro-West, the opposition was deemed to be pro-East." ${ }^{\prime 405}$

A good example was the fall out in his cabinet (i.e. the cabinet crisis) which took place barely two months after independence in July 1964, following differences in both domestic and foreign policy-formulation. At the end of the "crisis" three cabinet ministers were fired, while three others resigned in solidarity with their fired colleagues. ${ }^{406}$ One important cause, related to the subject of this study, was Dr. Banda's preference for a slow-rate of "Africanization," in which he retained European officers in his government and the security service. It was the officials in the intelligence and security services, mostly British, who began to feed Dr. Banda with intelligence reports that some of his radical cabinet ministers were communist sympathizers who were determined to overthrow him and establish a communist system of government. Most of the officials were the very same British officers who had identified the NAC politicians as communists during the disturbances of the late 1950s. ${ }^{407}$ Such trends, where officials from the metropole remained influential in post-colonial Africa, often resulted in a conveniently moderate African leadership, which maintained the status quo and continued to entertain western interests. The "mercenaries" left behind in the former colonies to serve the newly independent African states often undermined

\footnotetext{
${ }^{405}$ D.K. Chisiza, Realities of African Independence (London: The African Publications Trust, 1961), 10-11.

${ }^{406}$ The factors that led to the Crisis revolved around both domestic and foreign policies, and these have been widely discussed elsewhere. See Henry B.M. Chipembere, "Malawi in Crisis," Ufahamu: A Journal of African Studies, 11, no.1 (1981): 80-83. See also Colin Baker, Revolt of the Ministers: The Malawi Cabinet Crisis, 1964-1965 (London: I.B Tauris Publishers, 2001).

${ }^{407}$ Henry B.M. Chipembere. "Malawi in Crisis," 80-83. Among the most important European security officials, was that Banda maintained Britons to head both the police and the army, until the early 1970s. See also Nyasaland Intelligence Report, May 1964, BNA: FCO 141/142/14234: Nyasaland Intelligence Reports, January to June 1964. This report noted that some communist literature, spread by Communist Chinese and USSR operatives, was being distributed in some parts of the country. In the northern region city of Mzuzu, a pro-communist group called 'Mzuzu communist study group' had also been launched, with a Mr. Bernard Singini as its first chairman.
} 
the whole concept of "decolonization," often leading to the elimination of revolutionary nationalism. ${ }^{408}$

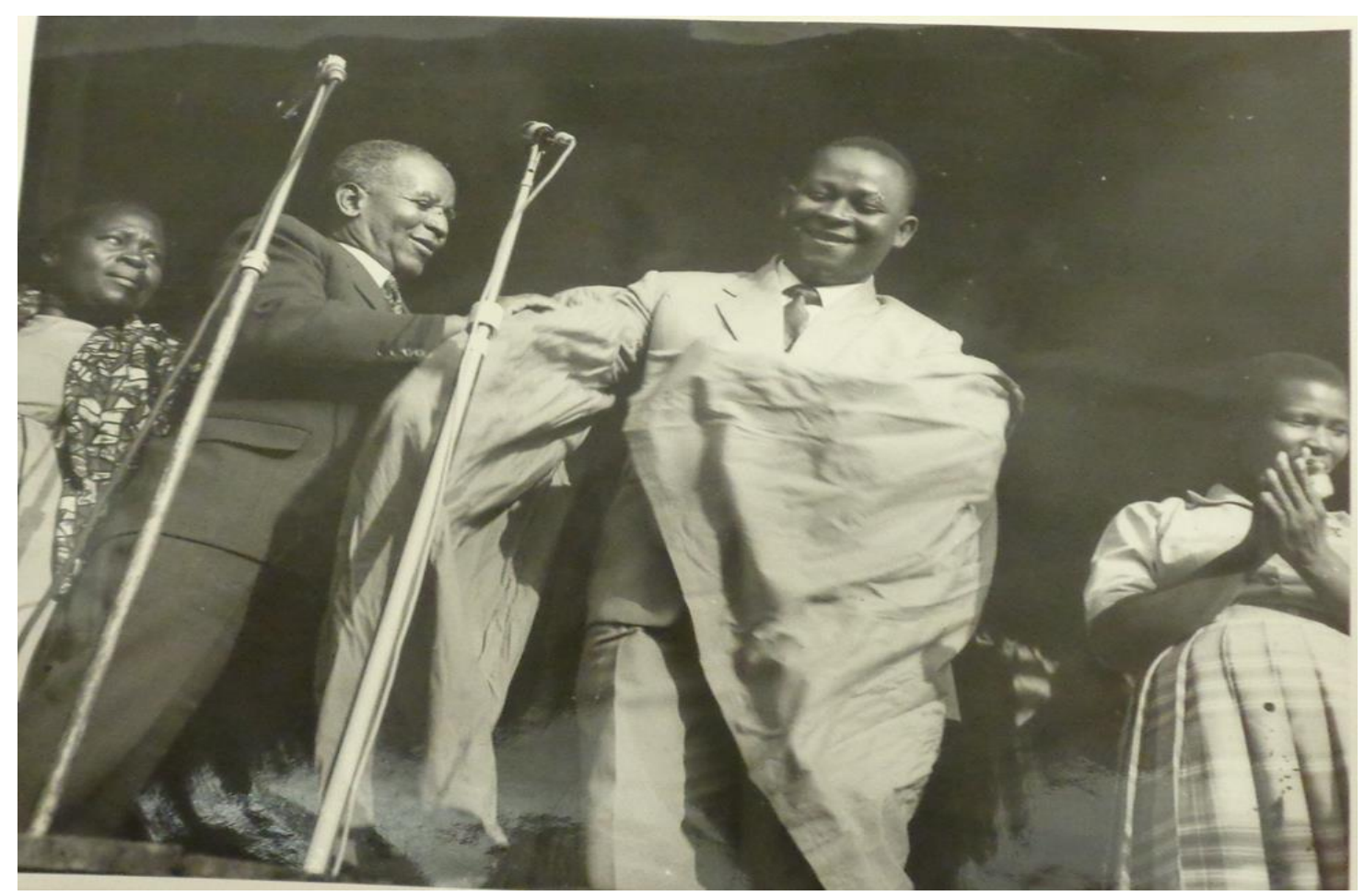

Figure 6.2: Dr. H.K. Banda (left) and Henry M. Chipembere (one of the Cabinet Ministers who resigned during the Cabinet Crisis), during campaigning for Legislative Council positions, 1962. Source: H.K. Banda Archive.

To gain both the Malawian public and Western sympathy, and to protect his own position, Dr. Banda also embarked on a propaganda campaign to label the dismissed cabinet ministers as communist sympathizers. Specifically, he began spreading information that some of the ministers had received bribes from Communist China (the People's Republic of China), to push for the

\footnotetext{
${ }^{408}$ Mueni wa Muiu and Guy Martin, A New Paradigm of the African State (New York: Palgrave Macmillan, 2009), $56-58$.
} 
establishment of diplomatic relations between the two countries. He insinuated that some of his cabinet ministers had met with the Chinese Ambassador in neighboring Tanzania, where they were promised that Malawi would be given $£ 18$ million, if it entered diplomatic relations with China. Dr. Banda's argument was that since he himself had met with the same ambassador, a Mr. Ho Ying, who promised to give Malawi only $£ 6$ million, it meant that his ministers had been bribed in his absence. ${ }^{409}$ The notion that the cabinet ministers were communist implants seemed to make sense especially as all of them fled either to neighboring Tanzania or Zambia, countries whose leaders had adopted pro-socialist policies, ujamaa in Tanzania, and "humanism" in Zambia.

Once he gained the confidence of the Malawian public and the international community, Dr. Banda embarked on a process to consolidate his position. For instance, in 1966 he amended the country's constitution in which he outlawed all opposition political parties. In 1971, the constitution was again amended allow him to serve as "president for life," arguing that political stability would ensure continued economic development in the country. ${ }^{410}$ The so-called "development," as I have discussed above, was mainly for the self-aggrandizement of Dr. Banda and his cronies. Dr. Banda also adopted characteristics of a "paternalist despot," in which he took state matters as his own personal responsibility, and was thus willing to use lethal force and a patronage-based system to alienate his perceived political enemies and/or those deemed to be detrimental to the development agenda, while handsomely rewarding those who were his close allies. ${ }^{411}$ In other words, he sought

\footnotetext{
${ }^{409}$ Speech by Dr. H. Kamuzu Banda, in Parliament of Malawi Official Report of Proceedings. $2^{\text {nd }}$ meeting, $1^{\text {st }}$ Session, September $8^{\text {th }}, 1964$.

${ }^{410}$ Paul Chiudza Banda, "Hastings Kamuzu Banda: How the Cold War Sustained Bad Leadership in Malawi, 19641994". In Baba G. Jallow, ed. Leadership in postcolonial Africa: Trends Transformed by Independence (New York: Palgrave Macmillan, 2014), 28-33.

${ }^{411}$ Robert H. Jackson and Carl G. Rosberg, Personal Rule in Black Afric. (Los Angeles: University of California Press, 1982), 159-167. See also Frantz Fanon, The Wretched of the Earth. (New York: Grove Press, 1961), 12 and 68-72. See also Amnesty International, "Malawi: Prison conditions, cruel punishment and detention without trial," February 1992.
} 
to retain political power, not simply for personal glory, but also for material advantage, as is common in patrimonial and neo-patrimonial systems. ${ }^{412}$ Dr. Banda, who had no vice or deputy, and held the position of Minister of Defense throughout his reign, oversaw the multiple atrocities of his tenure. ${ }^{413}$ A cross section of Malawians suffered under his 30 year regime, many of them run into self-imposed exiles (including all the ministers who were fired or resigned during the cabinet crisis), while a majority of others, regarded as "enemies of the state" (including members of the clergy, the media, the academia, the civil service, and the business community) were thrown into detention camps (at Mikuyu in Zomba District; and Dzaleka in Dowa District), where many served time without being tried in a court of law. ${ }^{414}$ Public executions of government critics were also the order of the day. ${ }^{415}$ Under the "Forfeiture Act," passed into law in 1966, most of those deemed to be a threat to the regime, also had their property confiscated by the state, concurrent with the jail terms or detentions most of them were serving. The "forfeited" property and businesses were handed over to members of the regime, which fed into the patronage system the regime had created. The charge of "treason," like its colonial era predecessor, was also made to be very "fluid," and was from time-to-time used by the authorities to legitimize the arrest of

\footnotetext{
412 Jean-Francois Medard, "The Underdeveloped State in Africa: Political Clientelism or Neo-Patrimonialism?" In Christopher Clapham, ed., Private Patronage and Public Power: Political Clientelism in the Modern State (New York: St. Martin's Press, 1982), 181-182.

${ }^{413}$ See for instance, "Kamuzu calls on the Nation to crush the Rebels ruthlessly - What Chipembere has done is treason," Malawi News, February 19 ${ }^{\text {th }}, 1965$. This case was about a rebellion led by one of the former Cabinet Ministers, in the Eastern Region District of Mangochi.

${ }^{414}$ British High Commission, Blantyre, Malawi, to the FCO, November $8^{\text {th }}$, 1972. Confidential. Political Situation in Malawi, BNA: FCO 45/1227. See also Speech by His Excellency the Life President, Ngwazi Dr. H. Kamuzu Banda, at a mass rally, Moto Village, Mangochi District. September $30^{\text {th }}$, 1974. Dr. Banda admitted in his speech, to have sent Government operatives, to attack Moto Village (Chipembere's home village), where hundreds of suspects were rounded up and their homes set on fire. Source: CRL, Chicago. See also "Where Silence Rules: The suppression of dissent in Malawi," Africa Watch Report, October 1990. See also Paul Chiudza Banda, "Hastings Kamuzu Banda: How the Cold War Sustained Bad Leadership in Malawi, 1964-1994," 28-33.

${ }^{415}$ See for instance, Dispatch from the Acting British High Commissioner to Malawi to the Commonwealth Relations Office, November $6^{\text {th }}, 1965$. Confidential. BNA: DO 224/23: Internal Political Situation in Malawi. This case related to the public hanging of Medson Silombela, a key ally of Henry M. Chipembere. See also Dispatch from Messrs. Graham and Mansfield, to the FCO'. September $5^{\text {th }}$, 1977. Confidential. BNA: FCO 45/2169: Malawi Internal Political Situation, 1977. The latter case related to the public hanging of Albert A. Muwalo Nqumayo, a former cabinet minister.
} 
government critics. ${ }^{416}$ Under the 1968 laws, one could be convicted of treason for the following conditions: firstly, if they prepared, endeavored, or conspired to overthrow the lawfully constituted Government by force or other unlawful means; secondly, if they prepared, endeavored, or conspired to procure by force any alteration of the law or the policies of the lawfully constituted Government; thirdly, if they prepared, endeavored, or conspired to carry out by force any enterprise which would, if effected, usurp the executive power of the State; and lastly, if they incited or assisted any person or conspired to invade the Republic with force or unlawfully to subject any part of the Republic to armed attack by land, sea, or assisted in the preparation of any such invasions or attacks. The punishment for treason was a mandatory death sentence. The laws also prescribed that hiding information on anyone suspected to be involved in a treasonous crime would also be guilty and would be liable to imprisonment - for - life. ${ }^{417}$

Many of the critics were accused of not adhering to the "four corner stones" of his government and political party, namely: Unity; Loyalty; Obedience and Discipline. ${ }^{418}$ Dr. Banda used the "four corner stones" ideology to instill party discipline in the run up to the independence period, during the "cabinet crisis," and continued to rely on it for the rest of reign. In his own words, during the "cabinet crisis," he stated the following: "What are the four cornerstones on which our party, our government, our state, was built? Here they are. Unity, Loyalty, Discipline, and Obedience. These are the four cornerstones on which destruction of the Malawi Congress Party - destruction of the Malawi Government, destruction of the Malawi State itself, Mr. Speaker, stands. Once these four

\footnotetext{
${ }^{416}$ Amnesty International, "Malawi: Human Rights Violations 25 Years after Independence," September 1989. See also Laws of Malawi: Penal Code, 1968: Chapter VI and Chapter VII. See also Forfeiture Act, 1966, in the Malawi Government Gazette, July 8 ${ }^{\text {th }}$, 1966: from The Republic of Malawi (Constitution Act), 1966, No.23 of 1966.

${ }^{417}$ See Chapter VII, Laws of Malawi. Penal Code, 1968, "Treason and other Offences against the Government's Authority."

${ }^{418}$ L.H. Gann, "Malawi, Zambia and Zimbabwe", in Peter Duignan and Robert H. Jackson, Politics and Government in African States, 1960-1985 (California: Hoover Institution Press, 1986), 191-194.
} 
cornerstones are broken away, one by one, the obedience, unity, loyalty, discipline, responsibility, there is no Malawi Congress Party. There is no government, no Malawi government in this country, and there is no state, the state of Malawi. What do we get? Another Congo? Is that what anyone in this country wants? (Interjection: No! No!). ... Once there is no unity, no loyalty, no discipline, no obedience, we are finished; we are finished. Just as the Congo." ${ }^{419}$

\footnotetext{
${ }^{419}$ See Motion by the Prime Minister, Dr. H.K. Banda, in Malawi Government, Parliament of Malawi, Official Report of the Proceedings, $2^{\text {nd }}$ Meeting, First Session, $8^{\text {th }}$ and $9^{\text {th }}$ September 1964 (Zomba: Government Printer, 1964), 10. Note that the atrocities and human rights violations committed by the Banda regime were well-known to the international community, including the UN and the country's major bilateral donors. However, as will be discussed later in the chapter, many of them did not act because of the on-going Cold War. See for instance, "Human Rights in B.L.S.M.": Dispatch from the British High Commission, Lilongwe, Malawi, to the FCO, April 27 $7^{\text {th }}$ 1978. Appendage from the UN High Commission on Human Rights, Geneva, sitting from 6 February to 10 March 1978. Adopted from BNA: FCO 45/2205: "Human Rights in B.L.S.M." See also "Dispatch from Mr. Quayle, FCO, Central and Southern Africa Department, to the British High Commission, Lilongwe, Malawi, titled 'Human Rights in Malawi', dated $16^{\text {th }}$ February 1978," BNA: FCO 45/2205: "Human Rights in B.L.S.M." see also "Dispatch from the British High Commission, Lilongwe, Malawi, to the FCO, United Nations Department, titled 'Human Rights and Foreign Policy'." $18^{\text {th }}$ January 1978," BNA: FCO 45/2205: "Human Rights in B.L.S.M." See also "Memo from the British High Commissioner in Malawi, to the FCO, addressed to Mr. H.MS. Reid, titled 'Political detainees in Malawi," 11 November 1977. BNA: FCO 45/2169: Malawi Internal Political Situation, 1977.
} 


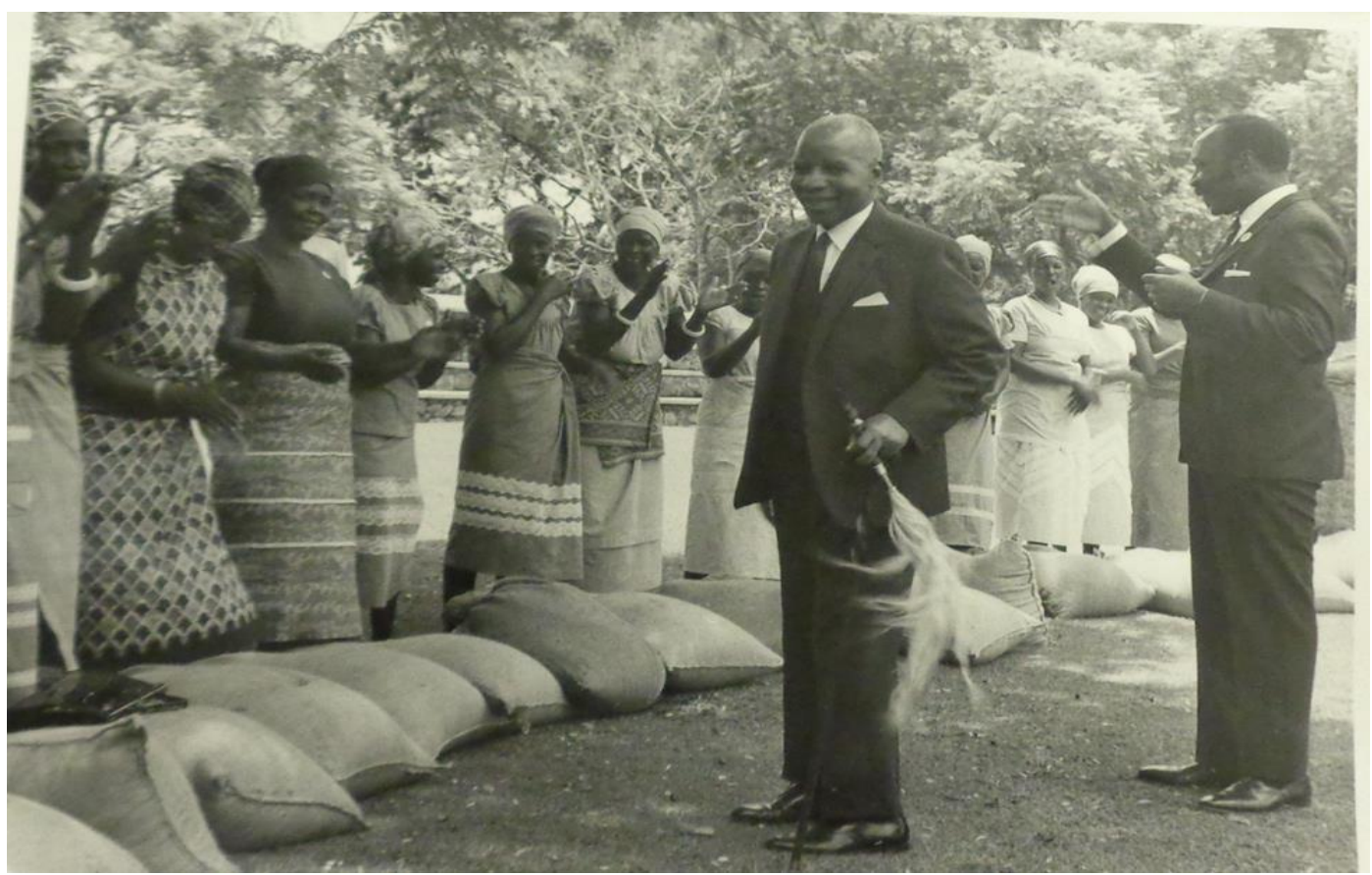

Figure 6.3: In better days. Dr. Banda to the left, and Albert A. Muwalo Nqumayo, early 1970s, admiring farm products by Malawian women. Later that decade, Banda would give orders for the execution of Muwalo. Muwalo was a Cabinet Minister and the Administrative Secretary of the MCP. In 1977, he was charged with treason, accused of plotting to overthrow Dr. Banda. Source: H.K. Banda Archive. See also Memo from the British High Commission Office, Malawi to the FCO, Central and Southern African Department, titled 'The Treason Trial,' 31 ${ }^{\text {st }}$ January 1977. Confidential. BNA: FCO 45/2169: Malawi Internal Political Situation, 1977.

\section{The Role of the Party and Women as Political Pawns}

In this section, and the two that follow (on the youth and the police force), I posit that Dr. Banda relied on a set of institutions to consolidate his regime. "Institutions" in their nature, have historically adopted both physical and non-physical forms. ${ }^{420}$ The physical aspects often focus on the legally established organizations, while the non-physical aspects revolve around such things as the values, customs, rules and regulations, codes of conduct, beliefs, and practices associated

\footnotetext{
${ }^{420}$ See definitions by: Walter C. Neale, “Institutions," Journal of Economic Issues 21, no.3 (Sept. 1987): 1177-1186. See also Douglas C. North, "Institutions," The Journal of Economic Perspectives 5, no.1 (Winter 1991): 97-98. See also Geoffrey M. Hodgson, “What are Institutions?” Journal of Economic Issues 40, no.1 (March 2006): 1-5.
} 
with one's membership of an organization. In other cases, the non-physical aspects are also influenced by the prevailing political climate. In adopting that perspective, I focus on how the ruling party, its organs, and the Malawi Police Force, were at the center of the counter-insurgency measures of the post-colonial state. Membership in such organizations not only shaped one's behavior, but also ensured the continuity of certain actions over the duration of the post-colonial state.

The Banda regime created the notion that only the one-party state under the MCP, would guarantee development in the country. That often came through public pronouncements by the Party's leadership, and through other official publications. The Department of Information was on numerous occasions compelled to produce pro-MCP pamphlets to highlight the major development initiatives championed by Dr. Banda and the MCP. In such publications, it was often made clear that only the MCP under the leadership of the "life president" had the ability to develop the country beyond recognition. In one of such publications, the party was praised as follows:

Over three decades have passed since the mighty MCP was formed to mobilize the people in the fight for political freedom and independence. In those short but eventful years, the Party under the wise and foresighted leadership of the Life President, Ngwazi Dr. H. Kamuzu Banda, has more than delivered the goods. The MCP manifesto of 1960 pledged, among other things to combat the three deadly enemies, namely ignorance, poverty, and disease. These pledges have been fulfilled. Throughout Malawi today there is remarkable evidence of progress in the fight against these enemies.... In light of what has been said above, one cannot talk of development in Malawi without recognizing the Party's crucial role. The Party has played an important role in all fields of development. It is, itself, an agent of change. The Party's platform is used in the dissemination of information to the people at the grassroots level on various projects. The Party has continued to be instrumental in mobilizing the masses in various self-help projects throughout the country. ${ }^{421}$

\footnotetext{
421 Malawi Government, The Ngwazi and Malawi: A Success Story of Development and Prosperity (Blantyre: Department of Information, 1992), 5-6. MNA: PAM 4,161. In the same vein, see also Malawi Government, Malawi: Ten Years of Progress (Blantyre: Department of Information, 1974), MNA: PAM 982. See also Malawi Government, The Economic Development of Malawi since Independence (Blantyre: Department of Information, 1975), MNA: PAM 2,825 .
} 
Those deemed to contravene the position and dictates of the party were regarded as enemies of not just the MCP, but also of the state, and of the people of Malawi in general. During its annual conventions, the party's leadership passed a series of resolutions, most of which were turned into law, to eliminate all forms of opposition in the country. Those targeted included politicians, business leaders, and other religious groups, who opposed the party's policies. Members of the Jehovah's Witnesses religious sect were, for instance, among the most to suffer from the party's long arm of the law, especially as the sect ordered its members not to buy party (MCP) membership cards, not to pay taxes, and not to patronize secular politics. The party leadership would on various occasions confiscate property and businesses owned by the Witnesses and ordered that the Witnesses be dismissed from their civil service jobs. Such measures saw many of them flee into exile, settling in neighboring Zambia (13,000 by 1972) and Mozambique (12,500 by 1972). ${ }^{422}$

Dr. Banda also mobilized and extensively utilized the country's women towards the consolidation of his political position. The women were often utilized as development and propaganda agents of the regime. The main women's organization, which operated under the MCP was the Women's League (later League of Malawi Women (LMW). The League was established in the mid-1950s and played a key role in the anti-Federation (CAF) struggles. Following the 1959 State of Emergency, and the outlawing of the NAC, the Women's League was also banned. When the MCP was launched in 1959, the Women's League rebranded and became the LMW, and Mrs. Margaret

\footnotetext{
${ }^{422}$ Malawi Congress Party Annual Convention Resolutions, 1965-1975. MNA PAM 2,835. See also Government of Malawi, History and Hope in Malawi. Repression, Suffering and Human Rights under Dr. Kamuzu Banda, 1964-1994 (National Compensation Tribunal, March 2005), 15-16. See also "Jehovah's Witnesses or Mboni, are ignorant fools," Malawi News, February $28^{\text {th }}, 1974$. That newspaper entry, quoted Dr. Banda's speech from a public rally he held in Zomba on February $23^{\text {rd }} 1964$, where he condemned the Witnesses for disobeying State and Party authorities, including their refusal to pay taxes, contrary to Biblical teachings of Jesus Christ, who Banda quoted as having said "Give unto Caesar what belongs unto Caesar, and give unto God what belongs to God". See also dispatch from British High Commission, Blantyre, Malawi, to the FCO, November $8^{\text {th }}$, 1972. Confidential. Political Situation in Malawi. BNA: FCO 45/1227.
} 
Mlanga became its first chairperson in 1960. The aims of LMW remained constant, and among others included the fight for the freedom of the country's citizens through the abolition of the Federation; the campaign for the release of all political prisoners; and finally, the education of local women about their political and socio-economic rights. ${ }^{423}$ By 1961 , the LMW registered a total of 551 branches across the country; 69 in the Northern Province, 73 in the Central, and 249 in the Southern region. And because of their crucial role in fighting against the colonial state, Dr. Banda had already began making promises that he would reward the women with higher political positions, including seats in the Legislative Council (later Parliament) when Malawi attained its independence. ${ }^{424}$

While the women from the LMW were "repaid" for the loyalty to the party and Dr. Banda in particular, after independence their influence increased, reaching its peak in the mid-1980s. In 1984, the Malawi government approved the establishment of the National Commission on Women in Development (NCWD) which operated under the Ministry of Community Services and the Office of President and Cabinet (OPC). Since the OPC was under Dr. Banda's stewardship, it meant that women's welfare, under the NCWD, was officially under the watchful eye of the State President. It was also the climax of the realization that women were a major factor in the country's development. ${ }^{425}$ The following year, 1985, Dr. Banda, alongside his longtime "Official Hostess," Madam Cecilia T. Kadzamira, established a women's developmental organization, called Chitukuko cha Amai M'Malawi (CCAM), which literally means "Women's Development in

\footnotetext{
${ }^{423}$ Vera Mlangazuwa Chirwa, Fearless Fighter: An Autobiography (London; Zed Books, 2007), 44-45.

424 Joey Power, Political Culture and Nationalism in Malawi: Building Kwacha (New York: University of Rochester Press, 2010), 145-147.

425 Paula Rae Brody, “Chitukuko cha Amayi M'Malawi: The Story of CCAM, 1985-1993.” Unpublished book manuscript. $3^{\text {rd }}$ draft. Source: H.K Banda Archive, Indiana University Library., pp. iv-v.
} 
Malawi," with Madam Kadzamira as the patron. ${ }^{426}$ The CCAM was regarded as a development organ of the LMW, with both organizations placed directly under Party authorities. The CCAM was directly placed under the OPC, which meant that it had access to state resources. It operated several development programs, chief among them being several farms where free labor was sought from women in the name of "self-help," and the proceeds, both agricultural and hand-craft based, were deemed to be women's contribution to the country's development agenda. ${ }^{427}$ There were also wide-spread claims that although the women worked hard in the CCAM projects, the moneys raised were often diverted into private accounts of Party officials. ${ }^{428}$

Banda would also from time-to-time adopt traditional powers by describing himself as "Nkhoswe Number 1," literally referring to himself as the protector and defender of Malawian women, from any possible abuse from their husbands and other males alike. In May 1964, for instance, Banda introduced the "Mbumba Protection Bill," intended to promote family stability, strengthen marriages, and provide security to women and children from being abused by men. The Bill also allowed women to inherit property upon the demise of their spouse. ${ }^{429}$ Banda also included Malawian women in his overseas trips, and constructed houses for some of the leaders of the CCAM and the LMW. He regarded the foreign trips as a learning experience for the women, who

\footnotetext{
${ }^{426}$ Ibid., 2-3. Source: H.K. Banda Archive, Indiana University. According to Paula Rae Brody, there were six major aims behind the establishment of the CCAM, as follows: (1) To promote the integration of women in development, especially in rural areas; (2) To encourage the acquisition of business skills among women so as to facilitate their involvement in income generating enterprises; (3) To assist the women partake in the national program of community development and welfare, by raising funds to help disadvantaged and marginalized communities; (4) To promote the unity of all women in the country, to secure their increasing role in development; (5) To encourage action-oriented research in conjunction with the National Commission on Women in Development; and (6) To promote awareness of the social and cultural values associated with the women's central role in the home, family, and community.

${ }^{427}$ Bakili Muluzi, et al, Democracy with a Price: The History of Malawi since 1900 (Blantyre, Malawi: Jhango Heinemann, 1999), 94-96. See also Malawi Government, Malawi: 27 Years of Peace and Development (Blantyre: Department of Information,1991).

428 "Where Silence Rules: The Suppression of Dissent in Malawi." An Africa Watch Report, October 1990, 20-21.

429 “Wives to inherit Property - Ngwazi," Malawi News, May 29 ${ }^{\text {th }}$, 1964. See also Nyasaland Protectorate, Proceedings of the $1^{\text {st }}$ Meeting of the $1^{\text {st }}$ session of the National Assembly, $2^{\text {nd }}$ day, 27th May 1964, "The Wills and Inheritance (Kamuzu's Mbumba's Protection) Bill” (Zomba: Government Printer, 1964), 32-35.
} 
could apply what they learned abroad to uplift their own livelihoods. ${ }^{430}$ Malawian women composed or sang various pro-Banda songs at public rallies, such as the following:

\section{Song Number Two:}

Popanda a Ngwazi tikadafa,

Tikadafa, tikadafa,

Inde, inde, a Ngwazi mwatiombola,

A Ngwazi adatiombola,

Eeee,

M'manja mwa atsamunda,

Eeee,

Inde, inde, inde, inde,

A Ngwazi adatiombola,

Amayi tikunyada,

Eeee,

Chifukwa cha a Ngwazi,

Eeee,

Inde, inde, inde, inde,

A Ngwazi adatiombola.
(Without the Ngwazi we could have died)

(We could have died, we could have died)

(Yes, Yes, Mr. Ngwazi you rescued us)

(The Ngwazi rescued us)

(Eeee)

(From the hands of colonial masters)

(Eeee)

(Yes, Yes, Yes, Yes)

(The Ngwazi rescued us)

(As women we are walking with pomp)

(Eeee)

(Because of the Ngwazi)

(Eeee)

(Yes, Yes, Yes, Yes)

(The Ngwazi rescued us). ${ }^{431}$

430 "Busy Time for Mbumba," Malawi News, June $8^{\text {th }}$, 1980. See also "Ngwazi promises more trips for Mbumba," Malawi News, August $15^{\text {th }}$ to $21^{\text {st }}, 1981$.

${ }^{431}$ Speech by His Excellency the Life President, Ngwazi Dr. H. Kamuzu Banda, on the $20^{\text {th }}$ Anniversary Celebrations of His Return Home, July $1^{\text {st }}$, 1978. Source: CRL, Chicago. 


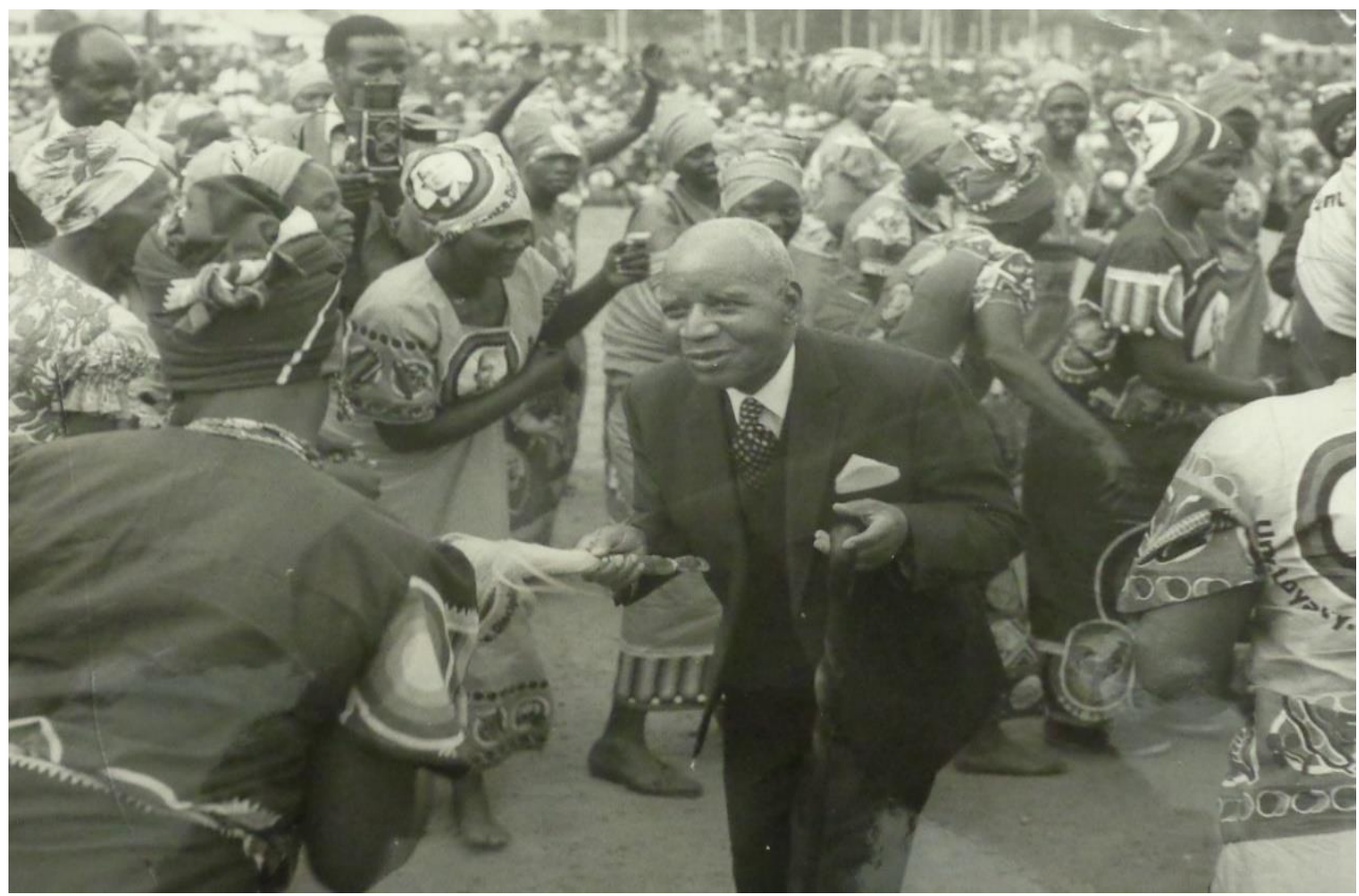

Figure 6.4: Dr. Banda dancing along to songs and dances performed by members of the Women's League of his MCP. Undated. Note that the women's attire had Dr. Banda's face on it. Also note the flywhisk in Banda's right hand, which was used as a symbol connecting him to his traditional Malawian and African roots. Source: H.K. Banda Archive. 


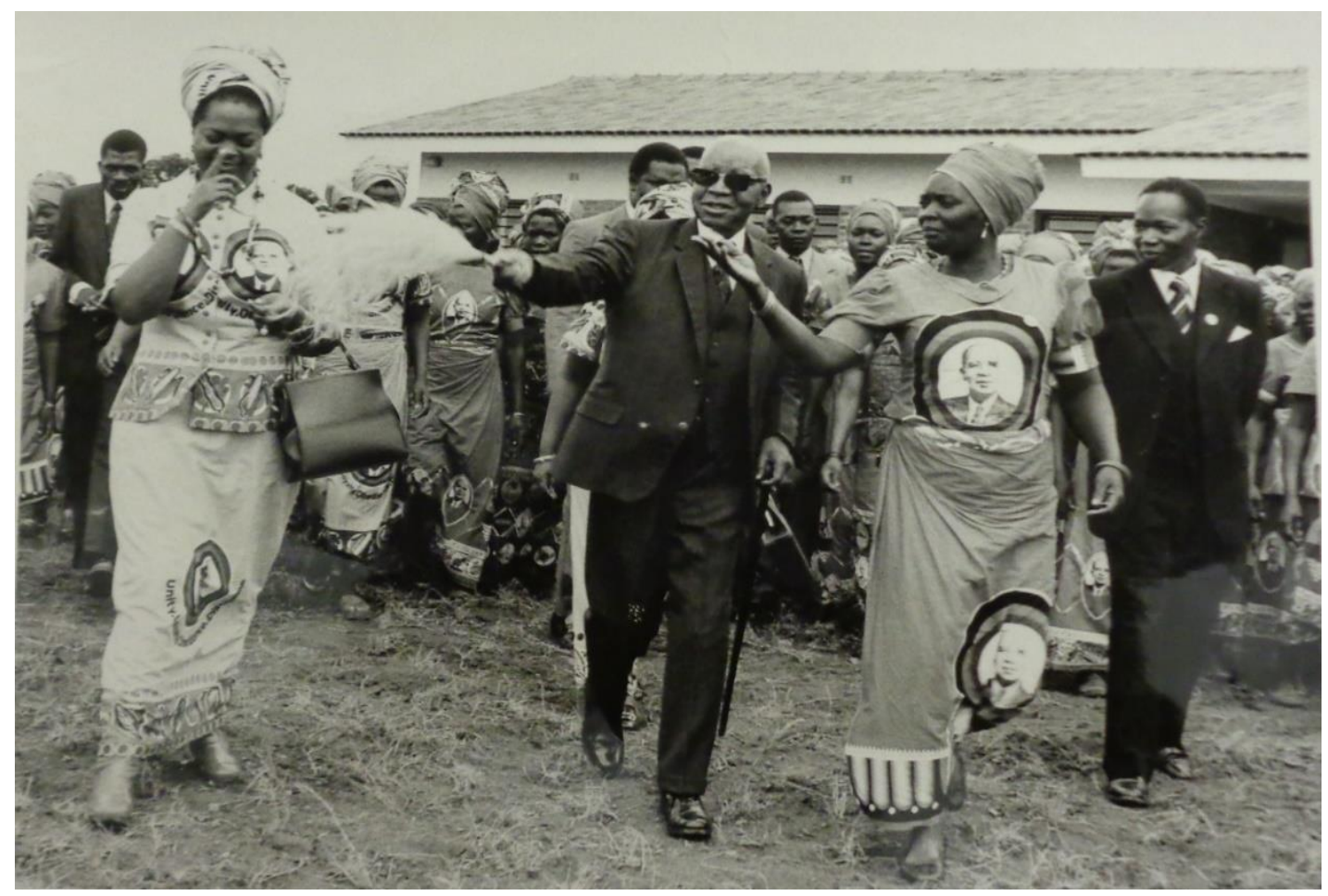

Figure 6.5: Dr. Banda (center), and Mama Cecilia T. Kadzamira (the Official Hostess) on the extreme left, preside over the official handover of a house built by the Banda government as a reward to women members of the Women's League, in 1978. Source: H.K. Banda Archive.

\section{Malawian Youth, Political Pawns and Counter-Insurgency}

Similar to the roles that women of the CCAM and LMW played under the Banda regime, in this sub-section I argue that Malawian youth also played a dual role in Banda's counter-insurgency strategy. On the one side, young Malawians who belonged to two interconnected and interrelated movements, namely the Youth League, and the Malawi Young Pioneers (MYP), were used as development agents, while on the other hand, they served the interests of the ruling elite who oversaw the youth commit various atrocities associated with the Banda regime, terrorizing the perceived "enemies of the state." Among other memorable development projects, the two movements worked together during the so-called "Youth Week" programs, held in March of each 
year, where the members participated in construction of structures such as school blocks, teachers' houses, and post offices. However, it was in the instances where the two youth movements served as the party's and the state's "political police" and spied on suspected opposition elements that they helped serve the purpose of maintaining regime stability and political and economic security and power for the ruling elite.

The Youth League, established in the late 1950s, under the NAC and later the MCP, was initially meant to be a training ground for future leaders of the party. The youths were to be trained in all aspects of party affairs, including political, social, and economic responsibilities. Some of the main duties of the League were as follows: (1) to follow orders and obey instructions from the party leader, Dr. Banda; (2) to help in publicizing party meetings, and to maintain order at political rallies; (3) to participate in and help publicize various party developmental agendas; (4) and to help in recruiting more members into the party to increase membership. ${ }^{432}$ While some of these duties were neutral and non-confrontational, it did not take long for the Youth Leaguers to start operating as party hooligans. In the late colonial era, and indeed after independence, it was the Youth Leaguers who were responsible for several altercations with members of other political movements, and those deemed to be "enemies of the state." The party leaders were, at times, unapologetic of the atrocities committed by the members of the Youth League in the early 1960s, as the following statement by Hon. Henry M. Chipembere, then Minister of Local Government, attests:

If he did give us that permission to perpetuate acts of vengeance ... we would let loose our Youth League on them, and, Mr. Speaker, you probably know our Youth League. We have tough boys in the Youth League only one boy is enough to fix Mr. Peterkins. Even now, as I speak, even now, as I speak, the hands of the Youth Leaguers are itching. They want action, but it is this great man (Dr. Banda) who is controlling them, because

\footnotetext{
432 "Role of Youth League," The Times, June $1^{\text {st }}$, 1961. See also "The duty of the League of Malawi Youth," Malawi News, March 27 $7^{\text {th }}, 1964$.
} 
as far as Africans are concerned his word is law. But should he ever say one day 'Go ahead boys and do what you can'...then it is common knowledge, isn't it, that we are the masters at the art of incitement, aren't we? If people like us stand on a platform of 10,000 people, for instance, here in Zomba, like the rally that we had here last week of 20,000, if we told a crowd 'Go ahead, phani mfiti ('kill a witch'), what would happen here? They should remember, they should remember, that their friends in the Congo have seen real trouble when law and order did in fact break down. When, in Africa, law and order breaks down, it does indeed break down.... ${ }^{433}$

According to intelligence records from the Special Branch of the Nyasaland Police, most of the late colonial era cases of violence, intimidation, and arson, against non-MCP supporters, were perpetrated by members of the Youth League. By 1961, the League had 551 branches across the country, distributed as follows: Northern Province (126 branches); Central Province (114 branches); and Southern Province (311 branches), with a Mr. C.D. Chindongo, as the National Chairman. The MCP leadership, including Dr. Banda, were also fond of referring to the Youth Leaguers, as "the Malawi Police," and could entertain the youths' actions, such a forming a "guard of honor" for Banda on his arrival at public rallies. ${ }^{434}$

The Malawi Young Pioneers (MYP) was another youth-based movement that served the Banda regime. On the one hand, the MYP youths were associated with developmental programs, while on the other hand, they were also associated with various atrocities committed by the regime. The initial stages towards the establishment of the MYP dated back to early 1963, when Banda sent a delegation of his cabinet ministers, led by Kanyama Chiume (then Minister of Education, Social Development, and Information), on a familiarization tour and youth leadership course in Ghana. In Ghana, a similar movement (known as the Young Pioneers Movement) had been established by

\footnotetext{
${ }^{433}$ Motion by Hon. Henry M. Chipembere, Minister of Local Government, in Nyasaland Protectorate, Proceedings of the $8^{\text {th }}$ Meeting of the $76^{\text {th }}$ Session of Legislative Assembly. 9th to $16^{\text {th }}$ July 1963 (Zomba: Government Printer, 1963), ${ }^{434}$ Malawi Congress Party, 1960-1962: The League of Malawi Youth, $4^{\text {th }}$ edition: Dispatch from the Special Branch, Zomba, October $31^{\text {st }}, 1961$ and December 29 $9^{\text {th }}$, 1961. BNA: CO 1015/2445.
} 
President Kwame Nkrumah. The initial plans for the movement, to work alongside the Youth League, would give the youth the opportunity to contribute to the country's economic development while also improving their own livelihoods, through training in such areas as carpentry, mechanics, building construction, agricultural production, and brick laying, among others. The earmarked headquarters of the MYP was a location which later came to be known as Nasawa Training Base, in Zomba District, following its formal establishment on August $11^{\text {th }}, 1963$. The first National Council that was put in place to oversee the transition, was headed by Banda as its National Patron (and later Commander-in-Chief), and several of his cabinet colleagues served as executive committee members. ${ }^{435}$ Even before the base at Nasawa was fully launched, Banda had already sent nine Malawian youths for training in Ghana, on the understanding that these would serve as the "foundation" on which to build the MYP. ${ }^{436}$ Apart from the support from Ghana, the MYPs were also trained by Israeli officials, some of whom would come to Malawi, while in other instances, it was MYP members and trainees who would go to Israel for training. ${ }^{437}$ The first Israeli official to go to Malawi under this arrangement, was a Mr. P. Gomen, former leader of "Gadna," the Israeli National Youth Movement, who was appointed as an advisor to the MYP. In March 1964, he was joined by a team of three other instructors, namely Mesrrs. P. Lavie, Uri Yanay, and Ran Lachman. ${ }^{438}$ The code of conduct for MYPs consisted of the following concepts: patriotism;

\footnotetext{
435 "Ngwazi introduces Young Pioneering," Malawi News, July 19 ${ }^{\text {th }}$, 1963. See also Kwame Nkhrumah. Africa Must Unite. 2nd edition (New York: International Publishers, 1972), 130-131.

436 "Ngwazi to Rejuvenate Youths into Pioneers," Malawi News, August 2nd 1963.

437 “Chiume urges Pioneers to help Party, Government Develop Malawi," Malawi News. August $16^{\text {th }}, 1963$. See also D.D. Phiri. History of Malawi, Vol.2 (Blantyre, Malawi: College Publishing Company Ltd, 2010), 312-315. Note that the MYP members, trained in agricultural production were usually dispatched to man the various agricultural and settlement schemes across the country.

438 "Youth in Malawi: Security and Progress with the Malawi Young Pioneers". Source: Malawiana Section, Chancellor College Library, University of Malawi.
} 
discipline; loyalty; unity; obedience; honesty; self-sacrifice; punctuality; humility; hard-work; and courage. $^{439}$

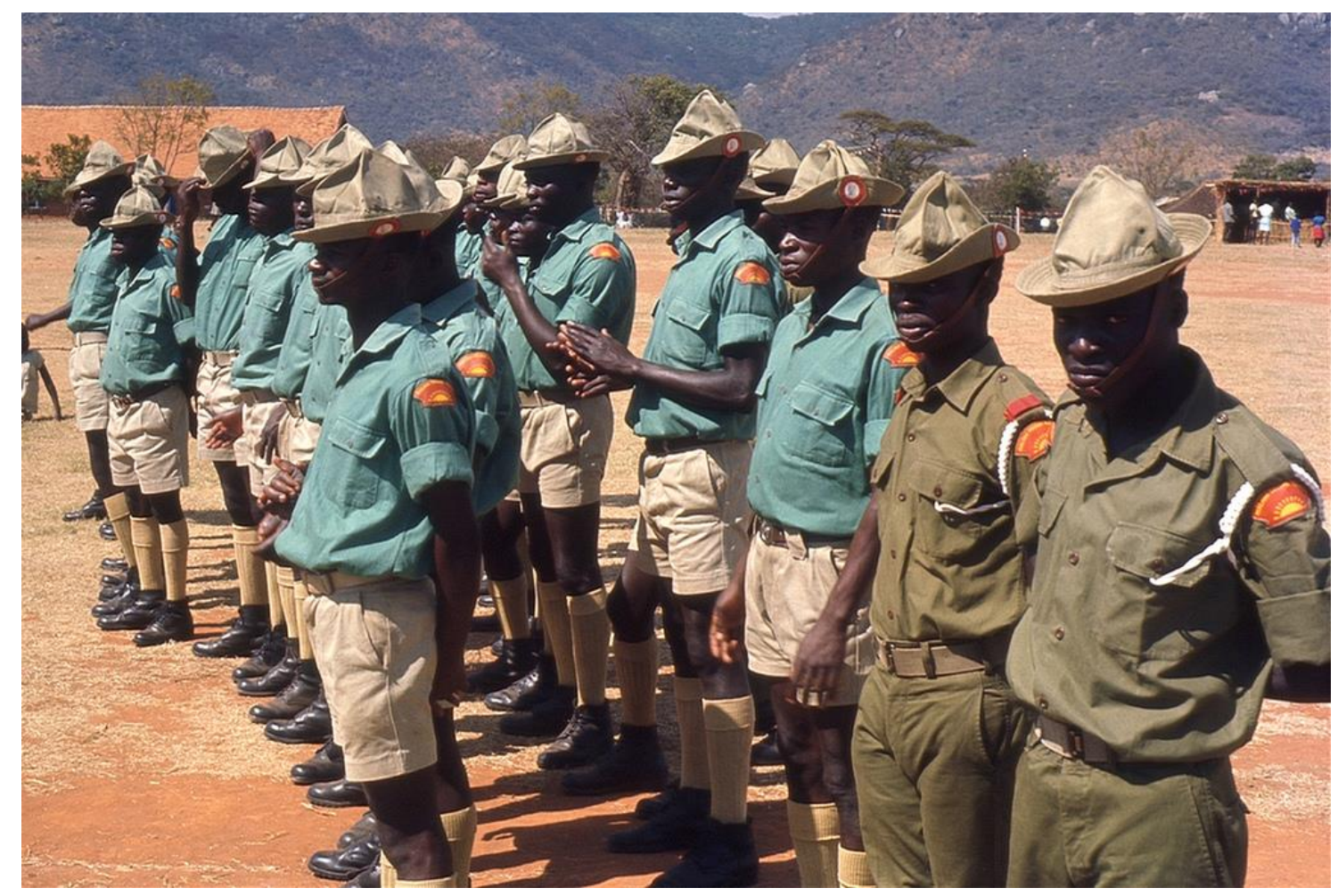

Figure 6.6: The Malawi Young Pioneers, c.1968. Performing at the Second Anniversary of Malawi's Republican status. Take note of the military-influenced attire/uniforms, signifying the notion that the MYP was a 'para-military' arm of the regime. Source: www.nyasatimes.com

439 "Youth in Malawi: Security and Progress with the Malawi Young Pioneers." Source: Malawiana Section, Chancellor College Library, University of Malawi. 


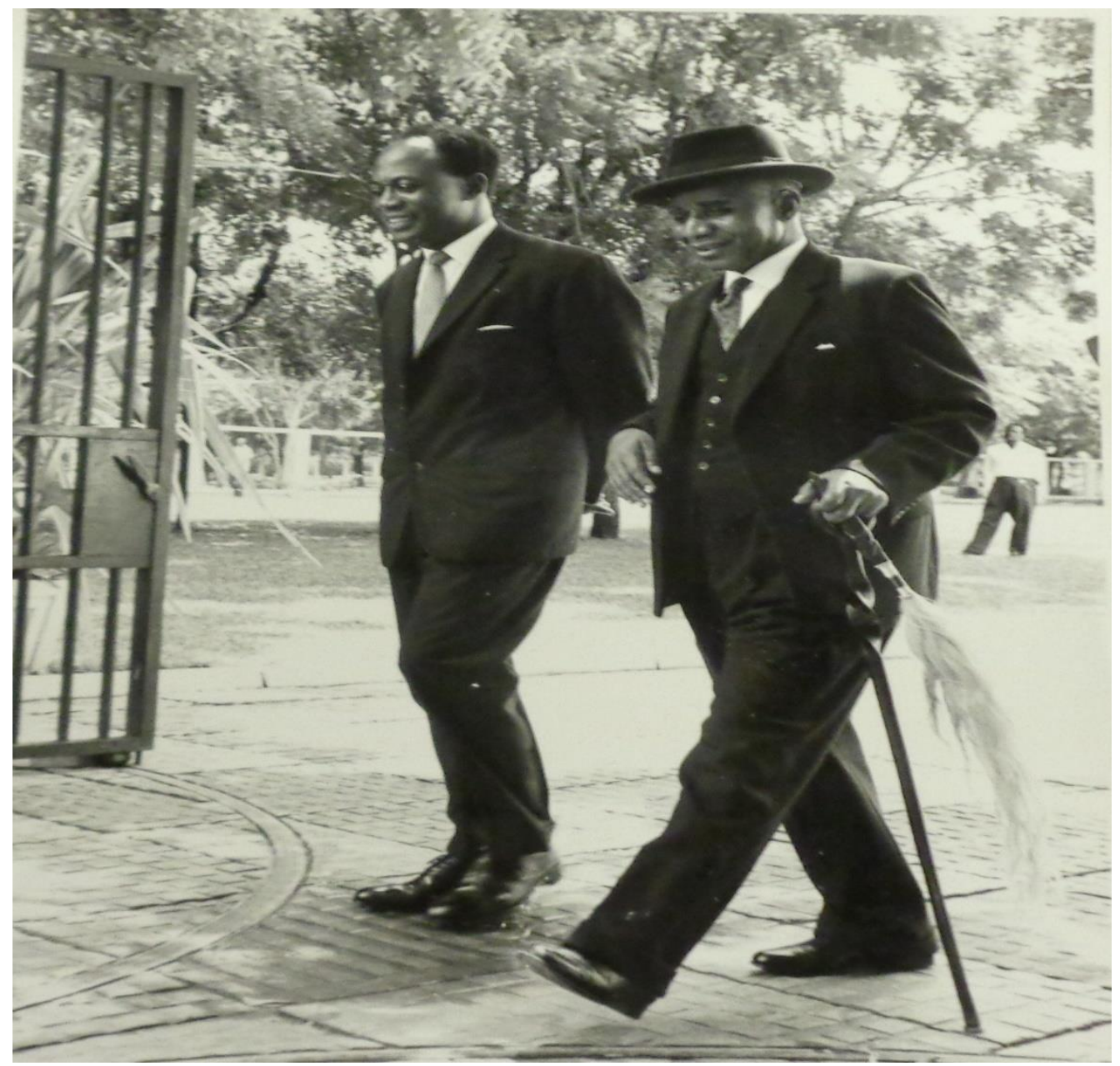

Figure 6.7: Dr. Banda, to the right, and Ghana's President, Kwame Nkrumah, early 1960s. Dr. Banda was a keen admirer of some of Kwame Nkrumah's policies, including that of establishing a youth movement. The Ghana youth movement was known as Young Pioneers Movement, while the Malawian one became the Malawi Young Pioneers (MYP). Source: H.K. Banda Archive. See also Kwame Nkrumah, second printing, Africa Must Unite (New York: International Publishers, 1972), 130.

At the end of 1963, in his capacity as the patron of the MYP, Banda embarked on a re-organization process, when he dissolved the MYP's National Council, which was responsible for the launch of the organization, and announced that he had appointed the Secretary General of the MCP, Mr. 
Aleke Banda ${ }^{440}$ who was also editor of the Malawi News (MCP's propaganda newspaper), and then Director-General Designate of Malawi Radio, later Malawi Broadcasting Corporation (MBC), as the new chairperson of a national committee to run the affairs of the MYP, a position which he would hold until the early 1970s. Aleke Banda, as chair of a new national committee, was supposed to be directly reporting to Dr. Banda as the National Patron. Dr. Banda also moved to allay the fears of many who feared that the Youth League would be dissolved following the establishment of the MYP, when he stated that both youth organizations would continue to operate under the Party's stewardship. Seeking to clarify the position of the two organizations, Banda made the following remarks in his address to the Malawi nation:

I would like to make it quite clear, in few but clear and unmistakable words or sentences. I did not dissolve the Youth League. I did not substitute the Youth League by the Young Pioneers. I did not abolish the Youth League, I repeat, and I did not put in its place, the Young Pioneers.

When the Young Pioneers movement was organized, it was never my intention to abolish the Youth League and to put in its place the Young Pioneers. As I said at Nasawa, the Young Pioneers was simply a Spearhead of the Youth League, an organization within the Youth League and not outside the Youth League or an organization to supersede or to replace the Youth League. Similarly, it was never my intention that the Young Pioneers should be independent of the Malawi Congress Party or that it should have nothing to do with it....441

It was not until 1965, that what began as a party youth movement, was formally incorporated as a government entity. Under the Young Pioneers Act of1965, the MYP was formally recognized as a youth organization, which was there to provide training and discipline to the country's youths. Under the 1965 Act, some of the following issues were clarified: (1) that all members of the MYP

\footnotetext{
${ }^{440}$ Note that Aleke Banda was not a blood relation of Dr. Hastings Kamuzu Banda. The name Banda happens to be one of the common names in Malawi. Similarly, I, as the author of this study, have no personal relationship to both Dr. Banda and Aleke Banda.

441 "Malawi Young Pioneers is under the Malawi Congress Party - Kamuzu reorganizes Malawi Young Pioneers," Malawi News, December 6 ${ }^{\text {th }}, 1963$.
} 
were also members of the MCP; (2) that at all times, the Commander-in-Chief of the MYP, shall be a cabinet minister; (3) that all MYPs shall wear such uniforms and insignia of rank as the minister would authorize from time-to-time; (4) that the minister had powers to call upon the MYPs to support the country's security forces for purposes of the preservation of law and order and public security; (5) that the MYPs as government servants, were authorized to carry and use weapons similar to those of the security forces; (6) and that every Young Pioneer be given powers, duties, and protection similar to a police officer acting in the execution of his duties. ${ }^{442}$

The MYP also served its purpose as one of the "development arms" of the regime. At its training bases, agriculture was the main course in the program and the curricula comprised of the following areas: (1) Theory and Practice in improved methods of agriculture and selection for Settlement Schemes; (2) Civics and Citizenship; Government Policies and National Institutions; (3) Youth Leadership Techniques, including social activities, such as sports and physical training; (4) Literacy and Basic Education; (5) Rural Vocational Training; (6) Hygiene, First Aid, and Health Education; and (7) Home-craft Training for girls. ${ }^{443}$ Thousands of Malawian youths underwent such training courses, and in one way or the other significantly contributed to the country's development, and indeed uplifted their own livelihoods, especially where they did not have access to university education in what was then the only university in the country, the University of Malawi. ${ }^{444}$ The thought-process of the state and party authorities to come up with such curricula and training programs came from the following conceptualization: "A young and growing nation

\footnotetext{
442 “The Young Pioneers Act, 1965”. In Malawi Government Gazette Supplement. March 19 ${ }^{\text {th }}, 1965$.

443 MNA: PAM 984. "Guide to a career in the Malawi Young Pioneers". (Blantyre, Malawi: Department of Information, 1970). See also MNA PAM 4,584. "Malawi Young Pioneers National Headquarters - Basic Working Orders". February 1967.

${ }^{444}$ To substantiate the developmental claims, the MYP through the Department of Information, from time-to-time, released information and produced pamphlets and other newsletters, updating Malawians of the developmental successes associated with the MYP. See for instance, MNA: PAM 985. "Malawi Young Pioneers - Spearhead for Progress". (Blantyre, Malawi: Department of Information. October 1972).
} 
can ill afford to leave its youth completely out of the development process. If they are not encouraged to take part in constructive work, the young have a tendency of drifting into the towns and cities where they often turn to non-constructive and undesirable activities. But since they are more receptive to change and to new ideas than adults, their energies can be harnessed for the development of the country and nation-building." 445

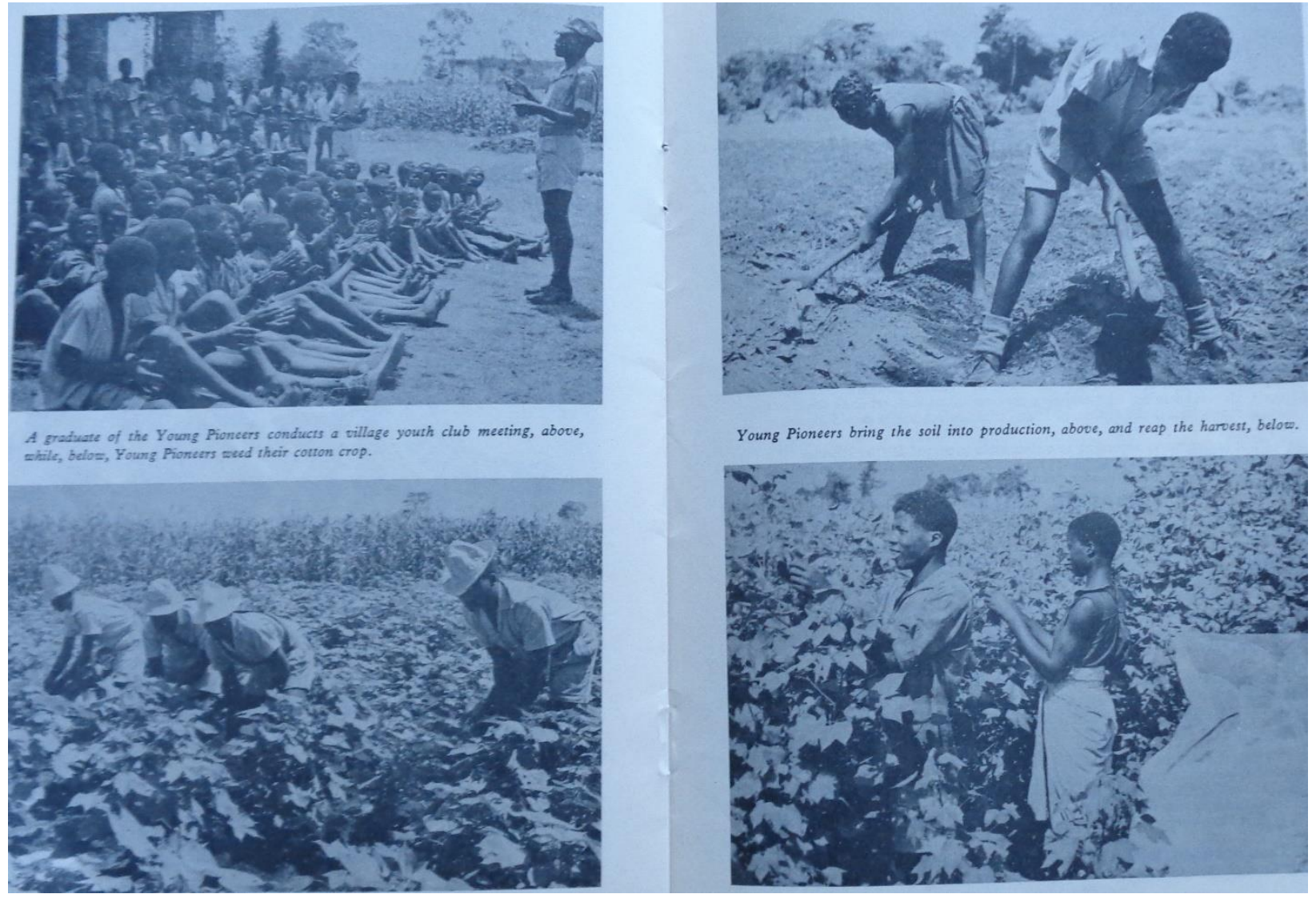

Figure 6.8: It was government policy to involve the MYP members in various development programs, including the focus on agricultural production as the images above illustrate. Source: Malawi Young Pioneers, MNA: PAM 986.

445 "Malawi Young Pioneers - Spearhead for Progress". (Blantyre, Malawi: Department of Information. October 1972). MNA: PAM 985. See also The Times. March $9^{\text {th }}$, 1967. "We would be poor if... - President praises Young Pioneers". See also "Malawi Young Pioneers Activities in 1967". Issued by the MYP Training and Operations Department, Limbe, 1967. See also Malawi News. March 28 ${ }^{\text {th }}$, 1969. "No Ideological Movements Here - Youth: Our Army for Development". 
It was however the "security branch" or "security functions" of the MYP, and the "police" powers given to its members, that left an indelible mark on the country's post-colonial history. As the "ears" and "eyes" of the Banda regime, that branch was responsible for numerous atrocities associated with the regime. As all members of the MYP did, they were required to pledge their allegiance to Dr. Banda. All the security branch members of the MYP were handed powers like those of the Malawi Police, where they could arrest people without a warrant issued by the courts. Furthermore, the police were also prohibited from arresting members of the MYP without prior consultation with officers in charge of MYP bases. Such powers made the MYP members to seem more valuable to the Party, the State, and to Banda himself, and created room or loopholes for the MYP to be involved in numerous atrocities. ${ }^{446}$ The MYP security branch, began to take significant shape following the 1964 cabinet crisis, and the various reports, some propaganda-based, that some of the exiled cabinet ministers were planning to launch attacks, aided by foreign forces, to overthrow the regime. From then onwards, Banda openly encouraged MYP trainees to be taught how to use firearms, so that they could protect the regime. ${ }^{447}$ By early 1965, Banda had also come up with plans to only recruit members from the MYP and the Youth League into the Malawi Army, to increase the security of his own position. His argument was that since 'ninety-nine' percent of the country's citizens owed their allegiance to the MCP, it was befitting that Malawi Army troops should comprise of MCP members. ${ }^{448}$

\footnotetext{
${ }^{446}$ Bakili Muluzi, et al, Democracy with a Price: The History of Malawi since 1900 (Blantyre, Malawi: Jhango Heinemann, 1999), 93-94.

447 “P.M. Presents certificates to M.Y.P. Graduates - They will all learn to shoot," Malawi News. November $3^{\text {rd }}, 1964$. 448 "Kamuzu announces the formation of a Territorial Unit," Malawi News, January 29 ${ }^{\text {th }}, 1965$. The so-called 'Territorial Unit', comprised of a collaborative effort from members of the MYP, the Youth League, and the Malawi Army, to secure the nation. See also "Malawi Young Pioneers to support Security Forces," Malawi News, March $26^{\text {th }}$, 1965.
} 
An analysis of confidential dispatches from the British High Commissioner's Office in Malawi, for the mid-1960s, indicates that the operations of the MYP were already becoming an 'eyesore' for the former colonial masters. The British were particularly worried about the rapid rate at which the Malawi government was arming and providing paramilitary training to MYP cadres. For instance, on August $11^{\text {th }} 1965$, the British High Commissioner reported as having held a meeting with the Malawi Army Commander, Colonel Lewis (a British citizen), when the Colonel briefed the High Commissioner that he had just been informed by Mr. Aleke Banda, that the MYP had purchased weapons from an un-mentioned "friendly" country, as follows: 300 Rifles; 13 subMachines Guns; and 300 Grenades. The said weapons were stored at the MYP's secret training base, at Mount View Estate (owned by the MYP), in the southern region district of Thyolo. The Mount View Estate was then used as the headquarters of the MYP's "intelligence organization." By August 1965, about 200 MYP cadres had been trained to use different types of weapons, including those used by the police. The "secret" Training Base at Mount View was run with the support of the Israeli Embassy to Malawi, where the plan had been to produce MYP graduates who could compliment police activities throughout the country, and also some to be deployed in the police force, in the army, and in various government ministries (especially as body guards of top government officials). ${ }^{449}$ Later that month (August 1965), the Deputy Police Commissioner, Mr. Moore, also reported that $£ 20,000$ worth of ammunition had been purchased by the Malawi government. However, instead of the ammunition going to the police, it was diverted to MYP

\footnotetext{
449 Dispatch complied by the British High Commissioner to Malawi on his meeting with the Army Commander, August $11^{\text {th }}, 1965$, 'Malawi Young Pioneers and the Youth League.' Confidential. BNA: DO 224/28. See also British High Commissioner to Malawi, to the Commonwealth Relations Office," November 12 ${ }^{\text {th }}$, 1966, 'Malawi Young Pioneers and Youth League.' Confidential. BNA DO 224/28.
} 
Training Bases. Furthermore, some MYP cadres were also imposed on the police force to work alongside police officers on police check points (road blocks). ${ }^{450}$

The youths from both the Youth League and the MYP were responsible for committing most of the atrocities of the Banda regime. Firstly, they were responsible for enforcing Party discipline at public rallies, where the youths were given roles to control crowds and spy on those who were suspected to be troublemakers. The MYPs were posted to various education institutions where they acted as State agents spying on both learners and teachers. There were also spying services from the MYP-run training bases and settlement schemes across the country. From the bases, the members were able to monitor and spy on events taking place in the countryside. The Youth Leaguers were fond of putting on red shirts, and through their country-wide membership were responsible for harassing Malawians, especially those who did not carry with them the Party (MCP) membership card; and enforced the collection of "gifts" to be presented to Dr. Banda. They were also used as Banda's "ground troops" for spying on suspected enemies, and enforcing the Party's four cornerstones, of Unity, Loyalty, Obedience, and Discipline. ${ }^{451}$

\section{The Malawi Police Force and its Role in Political Policing}

Similar to the analysis of the role of the police force during the colonial period, the application of the 'political economy' approach also becomes handy for the post-colonial era. The operations of the police force became a mirror reflection of the political and economic developments of the postcolonial era. The post-colonial leadership, as highlighted in this chapter, had vested interests in the country's economy, and had also put in place measures to retain political power if they lived,

\footnotetext{
450 British High Commissioner to Malawi, to the Commonwealth Relations Office, titled: Arms for the Young Pioneers, August 21 ${ }^{\text {st }}$, 1965. Malawi Young Pioneers and Youth League. BNA: DO 224/28.

${ }^{451}$ Government of Malawi, History and Hope in Malawi. Repression, Suffering and Human Rights under Dr. Kamuzu Banda, 1964-1994 (National Compensation Tribunal, March 2005), 57-59. See also "MYP Terrorizing the Lower Shire," The Enquirer, November $9^{\text {th }}$ to $15^{\text {th }} 1993$.
} 
including where Dr. Banda was constitutionally allowed to be "president for life." As such, the police became the tool with which to deter the rise of or operations of perceived political opponents, especially because access to political power ensured one access to economic power.

The development of the Malawi Police Force, just like other government departments, was not fast-tracked to include Africans in the top management positions. Banda's slow 'Africanization' policy saw him retain some of the top colonial British policemen into the post-colonial era. For instance, the Police Commissioner, Mr. P. Long, O.B.E., who was appointed in that position in 1964, retained his post until July 1971, when he was replaced by a Malawian, Mr. Mc. J. Kamwana, himself a British-trained policeman having attended various police training courses at the Hendon Police Training School in England (1968), and also at the Scottish Police College, Tulliallan, Scotland (1969). ${ }^{452}$ Banda himself also retained the position of Commander-in-Chief of the armed forces and the police force. The Police Force itself also retained such colonial era branches, which included General Administration; the CID; the Special Branch; Police Mobile Force (PMF); Finance Branch; Radio Communication; Traffic and Transport; Immigration; the Training School; and the Depot. ${ }^{453}$

Furthermore, to emphasize the continued influence of British police training methods in the Malawian police system, Dr. Banda also preferred to send high ranking police officers to Great Britain for further training. Such training opportunities were widely reported in the local press, as it helped signify the continued diplomatic relations between the two countries. For instance, in July 1971, the Malawi News reported that three members of the Malawi Police Force were among

\footnotetext{
452 Cyril Marlow, A History of the Malawi Police Force (1971), 29-37. See also "Kamwana takes over as Commissioner of Police," Malawi News, July $22^{\text {nd }}, 1971$.

${ }^{453}$ Malawi Government, Annual Report of the Malawi Police Force for the year ended $31^{\text {st }}$ December 1966 (Zomba, Malawi: Government Printer, 1967).
} 
fifteen police officers who had just completed an eleven-week overseas command course at the Dishforth Wing of the Police College, North East England. The police officers from Malawi included Superintendent J.B. Mweso (from the CID Headquarters at Zomba), and Superintendents R. Mijoso and B.G. Kumwembe, both from the Police Headquarters at Zomba. The newspaper report also noted that this was not the first time the three policemen had been trained in Britain. Superintendent B.G. Kumwembe gave the following remarks about his police training in Britain: 'From every point of view, including the study of police methods the opportunity to meet British people in their own homes and to see sophisticated systems of crime detection, road traffic speed control and industrial security, it has been a very worthwhile course. ${ }^{454}$ Superintendent Mweso on his part was impressed with the scientific developments he had seen in Britain, including things like working with computers, electronic aids, and forensic science, which had not yet been incorporated in the Malawian policing system. ${ }^{455}$ The point being driven home here, is that, Banda had envisaged very little change between what developed as the policing system during the colonial era, to what developed in the post-colonial period. As someone who had spent over four decades in the West (USA and Britain), he had come to admire their policing systems and standards and hence wanted the same to apply to Malawi. Furthermore, maintaining British officials (especially the non-partisan ones) in government organs, also helped to create a smooth transition from the colonial to the post-colonial period, and the avoidance of political instability as had happened in other African countries. It was from that perspective that Banda retained all the organs of the Malawi Police that had existed in the colonial period, including the notorious CID and the Special Branch, to carry out functions like those of the late colonial era. ${ }^{456}$

\footnotetext{
454 “Malawi Police Officers on British Course," Malawi News, July $2^{\text {nd }}, 1971$.

455 Ibid.

${ }^{456}$ See for instance, Malawi Police Force: Annual Report for the Year ended $31^{\text {st }}$ December 1966 (1967). Source: Chancellor College Library, Malawiana Section. The report in question, indicated a continuation of police branches
} 


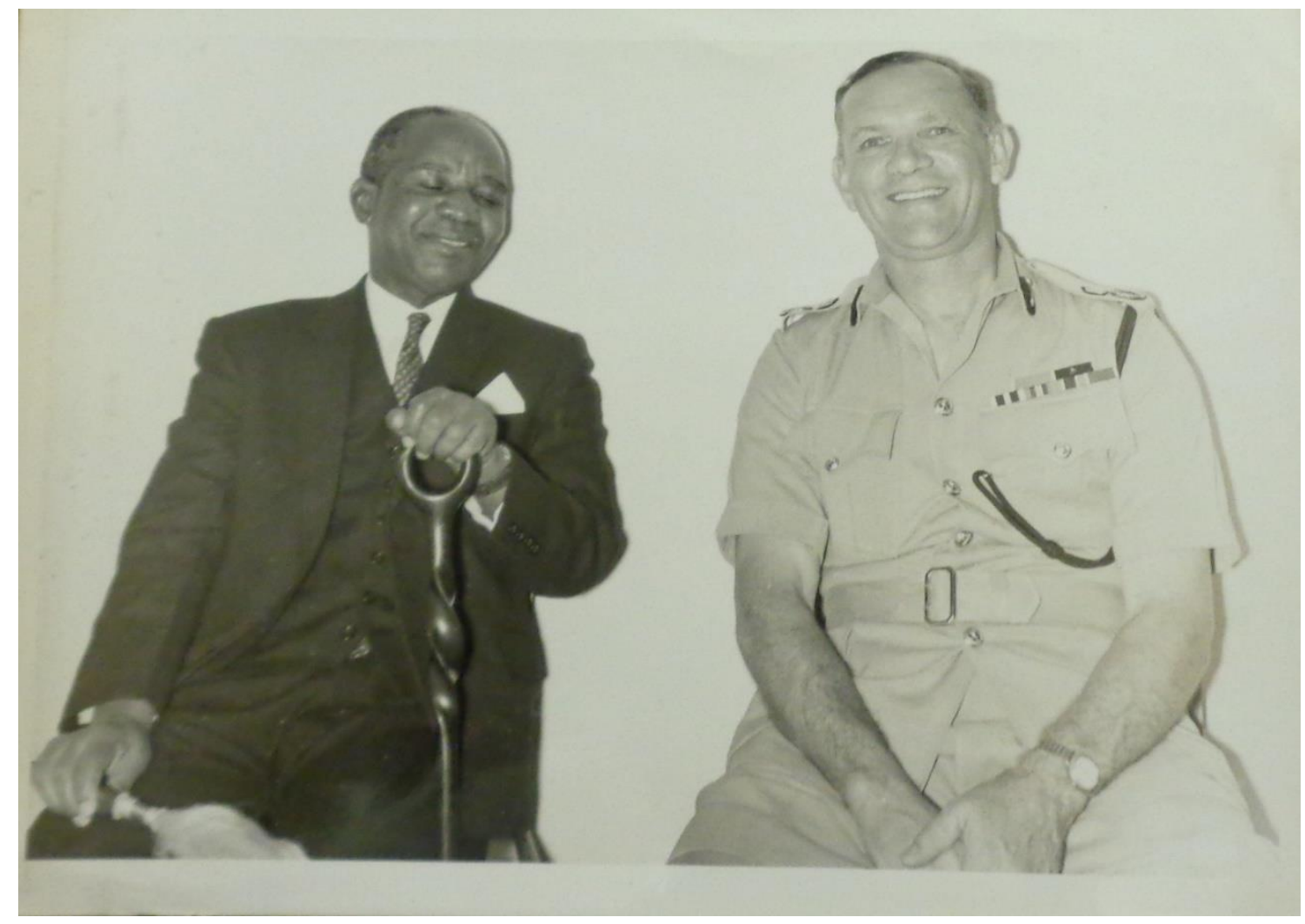

Figure 6.9: Dr. Banda, left, with Police Commissioner J.V. Mullin, in Nyasaland, 1962. Commissioner Mullin had been appointed to his position in 1958. Due to the 'slow Africanization policy', Banda retained such expatriate personnel in his administration. Source: H.K. Banda Archive.

At the swearing-in ceremony of Commissioner Mc J. Kamwana in July 1971, President Banda revealed what he termed as 'the motto of the Malawi Police force,' which he explained as "Ex Populo, Pro Populo" - which meant "From the People, For the People." He stated that what this meant was that the police force was not there to suppress the people or to give trouble to the people, rather to protect them. He also stated that it had always been his policy not to rush into the 
"Africanization" of both the police force and the civil service at large, as some of his former cabinet ministers had demanded, arguing that he felt that Malawi did not have a well-trained native workforce to take over the key government posts. He could only Africanize his workforce, when he was assured that they had received substantial training. In his parting words to the out-going Police Commissioner, Mr. P. Long, O.B.E., Dr. Banda affirmed that position when he said: “Thank you for training my boy”. Furthermore, he mentioned that he would still retain some European officers in the police force to work under the new Commissioner, including another British citizen, Mr. F.B. Chevallier, who was retained as Deputy Police Commissioner until his retirement in February $1973 .{ }^{457}$ All that while, Banda also retained a British national, a Mr. B.C. Roberts, who served as the Attorney-General, and also as Permanent Secretary to the Office of the President and Secretary to the Cabinet, who retired in May 1972. ${ }^{458}$ It was also not until May 1972, that Brigadier Graciano Matewere was appointed as the first Malawian to head the Army replacing an expatriate officer, and was promoted to the rank of Major-General. ${ }^{459}$ Until 1972, Banda also retained a British citizen, Captain Savage, as his Chief Bodyguard. ${ }^{460}$

From this background, then, it was unsurprising that Banda was reluctant to depart from employing a policing system that would be different from its colonial era predecessor. What had changed over the years was merely the personnel, but the structures and techniques of colonial policing and indeed security forces in general, remained intact. Among other powers, officers of the Malawi

457 “Kamwana takes over as Commissioner of Police," Malawi News, July 22 ${ }^{\text {nd }}, 1971 . \quad$ See also Malawi News. February $2^{\text {nd }}, 1973$. "Deputy Police Chief Retires". See also "Dispatch from the British High Commissioner to Malawi, Mr. W.R. Haydon to the FCO, addressed to Hon. Sir Alec-Douglas Home". $11^{\text {th }}$ July 1972. Titled 'No Africanization for the sake of Africanization - but Africanization all the same'. Adopted from FCO 45/1227: Internal Political Situation in Malawi, 1972.

458 “Jaffu to head Malawi Civil Service,” Malawi News, January $7^{\text {th }}$, 1972. On Mr. B.C. Roberts' retirement, Banda replaced him with the first Malawian to head the Civil Service, Mr. George Jaffu, and a Mr. R.A. Banda, to serve as the new Attorney General.

459 “Matewere now Major-General," Malawi News, May 30"th 1972.

${ }^{460}$ Political Situation in Malawi, 1972, see Memo from the British High Commission, Blantyre, Malawi, to the Foreign and Commonwealth Office. Confidential. October $11^{\text {th }}$, 1972, BNA: FCO 45/1227. 
Police Force were given constitutional powers to arrest people without any warrant, so long as the police officer(s) involved deemed one's conduct as constituting 'reasonable grounds' for breaching peace and threatening the country's stability. ${ }^{461}$

As a result, there are many cases involving police brutality in post-colonial Malawi. ${ }^{462}$ One prominent case was the merciless murder of three cabinet ministers and a sitting Member of Parliament (MP), on May $17^{\text {th }}, 1983$, at Thambani, in the southern region district of Mwanza. When the murders occurred, the Banda regime reported the deaths of the four politicians, namely Messrs. Dick T. Matenje (Minister Without Portfolio; and also Secretary General and Administrative Secretary of the MCP), Aaron E. Gadama (Minister for the Central Region), Twaibu J. Sangala (Minister of Health), and David Chiwanga (MP, and formerly Minister for Housing and Community Development between 1981 and 1982), as being merely a 'car accident' that had occurred as the politicians were about to escape into neighboring Mozambique, having had disagreements with the regime. However, when Banda lost in the 1994 general elections, his successor, Bakili Muluzi, seeking to legitimize his own ascendance to power, immediately instituted a commission of inquiry, to investigate the Mwanza murders. The commission was appointed at the end of June 1994 and started to conduct its hearings on July $11^{\text {th }}$, 1994 . The chairperson of the commission was a Supreme Court Judge, Michael Mtegha, and was assisted by twelve other members during the hearings, towards the production of the overall findings, which were presented to President Muluzi on December 23 ${ }^{\text {rd }}, 1994$.

The Commission of Inquiry, also known as "the Mtegha Commission," was charged with the responsibility to consider, determine, and inquire into all aspects of the deceased persons,

\footnotetext{
${ }^{461}$ Laws of Malawi: Criminal Procedure and Evidence Code, 1969-1973. Part III: General Provisions.

${ }^{462}$ Government of Malawi: History and Hope in Malawi. Repression, Suffering and Human Rights under Dr. Kamuzu Banda, 1964-1994 (2005).
} 
including: (1) the circumstances and causes of the deaths; (2) the place or places where each of the deceased persons died and the hospital, if any, where he was certified dead; (3) the condition of the body of each deceased person when the body was being delivered to the place of burial and the manner and mode in which the body was so delivered; (4) the identity of the person or persons who delivered the body of each deceased person to the place of burial; (5) the funeral arrangements and the conduct and pronouncements of those in authority at the time; (6) the instructions, messages or explanations, if any, that were issued or given in each case by those who delivered the body; (7) the explanations, if any, given to the relatives as to what caused the death or, if the deceased was killed by any person, why he was killed; (8) the conduct and mode of the burial, and the threats, if any, issued to members of the family or to any other person and by whom; (9) examination of the post-mortem reports on each of the deceased persons and/or of the oral testimony of those who conducted the post-mortem examinations; (10) and if evidence tends to show that the deceased persons were killed by any person, then the commissioners had to identify the people involved in the murders; who gave the instruction for the murders; and also to ascertain if the killers received some form of reward for their actions. ${ }^{463}$

Between July and early December 1994, the commission received testimony from over 160 witnesses, from which the final report was generated. The findings of the commission indicated that the killings of the four politicians were done by Malawian policemen. The process began on May $14^{\text {th }}$, 1983, when the then Inspector General of Police, Mr. Mc J. Kamwana, ordered Mr. McPherson Bervin Itimu, then Commissioner of Police and head of the Special Branch in the Malawi Police Force, to have the four politicians arrested and later killed. The arrests were planned

${ }^{463}$ Republic of Malawi, Commission of Inquiry: Mwanza Road Accident (Limbe: Civic Offices, December 1994), 24. 
for May $17^{\text {th }}, 1983$, a day when Parliament was meeting for a special session at Parliament Building in Zomba, to pass some bills and look at some electoral rule changes, in readiness for a general election in June 1983. Upon receiving the instructions, Mr. Itimu sought the assistance of two other senior police officers, both from the Special Branch Headquarters in Lilongwe, namely Mr. Lywell Ezron Ngwata (who held the rank of Assistant Commissioner of Police); and Mr. Victor W. Maunde (who held the rank of Senior Superintendent of Police). The two officers arrived in Zomba on May $16^{\text {th }}$, 1983. When they got to Zomba, they also sought the support of another police branch, known as "The Special Operations Squad," headed by a Mr. L.J. Maluwaya, who was reporting directly to the Police Inspector General. The Special Operations Squad had been formed by Kamwana in 1977, however its responsibilities were largely unknown to most police officers, except that its officers were involved in patrols and gathering political intelligence. The Squad's members (with membership drawn from branches of the Police Force, including the Special Branch, Criminal Investigation Department, Police Mobile Force, and General Duties Officers), were required to be in civilian clothing and to use unmarked police vehicles.

When the entire team of police officers assembled at the Police College in Zomba, they laid out the plan by which to have the four politicians killed. It would start with erecting impromptu police road blocks; arrest the four politicians; keep them at a secluded place while waiting for official directives, with each politician kept in a separate room (in the Special Branch offices) to avoid chances of their communication. After the parliamentary deliberations of May $17^{\text {th }}, 1983$, the policemen who manned the road blocks arrested three of the four politicians, from the different vehicles they were travelling in. Mr. Chiwanga was picked later in the day, as he was on his way to hand himself to the police following a notice sent to his relations. On the night of the same day, the four politicians were transported to Mikuyu Detention Center, where each was allocated to a 
separate cell. On May $18^{\text {th }}$, Mr. Maluwaya and his team of police officers went to Mikuyu to collect the four politicians, and initially told them that they had been freed, and asked all of them to ride a Blue Peugeot, which belonged to the MCP, and was driven by one of the politicians, Mr. Matenje, while a police officer (from the Special Operations Squad) was also one of the passengers. That was when all the four gentlemen knew that they had all been arrested together. The Blue Peugeot travelled towards Zomba, sandwiched between two unmarked police vehicles occupied by members of the squad. From Zomba, the politicians were directed to drive to Blantyre, on the understanding that they would be freed there at the MCP regional premises.

However, the politicians were not freed as they had been told. Instead, they were later that night driven to the Special Branch sub-office at Limbe, Blantyre. That same night, Kamwana instructed the Commissioner of Police, Southern Region, Mr. Andrew Makina, to issue a press release on the state-run Malawi Broadcasting Corporation (MBC) to the effect that the four politicians were missing and that anybody who saw them or knew of their whereabouts should report to the nearest police station. The first announcement was made on MBC that same night at 10:05 pm, while a second announcement was made the following morning at 6:05 am, even though the four politicians were still in police custody. From the Special Branch sub-office at Limbe, the politicians, placed in handcuffs, were driven in an unmarked police Land Rover towards Mwanza district, a district that borders Mozambique to the south-west. There were three vehicles on that trip, with the Land Rover sandwiched between two unmarked police cars full of armed policemen. Having reached Mwanza district headquarters, the convoy of cars branched into a forest road, a dusty road to Thambani, some eleven kilometers away from the tarmac road that goes towards the Malawi-Mozambique border post. It was on the road to Thambani where the four politicians were mercilessly killed using hammers and other sharp objects, and probably fire arms. The politicians, 
now dead, were then placed in the Blue Peugeot, which had all its doors locked, and the car was rolled towards a river bank to make it appear as if the politicians had been involved in a car accident. By midnight of May $18^{\text {th }}$ and towards the wee hours of May $19^{\text {th }}$, the four politicians had been summarily killed. However, the car did not roll into the Thambani River, as it was blocked by a tree some twenty meters from the edge of the road where the killings were conducted. The policemen also tried to cover the blood spots from the road where the killings were made, by spilling some top soil on the spots. Later that month, each of the police officers involved in the merciless murders was rewarded with a check of MK1, 000.00 from the Police Headquarters, while the senior police officers involved received amounts ranging from MK3, 000.00 to MK4, 000.00. The Blue Peugeot, allegedly involved in a "car accident" was discovered by a passer-by driver on the morning of May $19^{\text {th }}$, who later alerted his bosses at Mwanza Hospital and then later other district administrative and security officials at the Mwanza boma. ${ }^{464}$

While there was enough incriminating evidence from other policemen and medical doctors who went to the scene of the "accident," the Banda regime did not dare to pursue the matter with the respect it deserved, especially since the murdered politicians were all members of the MCP National Executive Committee, three of them were cabinet ministers, while the other was a former cabinet minister and a serving Member of Parliament. The car (Blue Peugeot) itself was not damaged at all, except for a broken indicator light on the right-hand front side; while some of the deceased's bodies were found with big wounds on their heads, others with distorted tongues. No funeral arrangements were made or announced by either the MCP or the Malawi government, which was not a normal procedure when a senior party or government official had died. No party or government officials were also present at the funeral ceremonies for each of the four murdered

\footnotetext{
${ }^{464}$ Republic of Malawi, Commission of Inquiry: Mwanza Road Accident, 8-63.
} 
politicians, nor did the Head of State send any condolence message. The only official representation, if any, was that of some plain clothed policemen from the Special Branch, at each of the four funeral ceremonies. The only statement that came from the government side was to announce on national radio that the four politicians had died in a car accident as they were escaping to Zimbabwe when they met their fate. All members of Banda's cabinet at the time of the murders, who testified before the Commission also stated that the issue of the deaths of the four politicians was never discussed at any subsequent cabinet meeting nor at the MCP Executive Committee meetings, due to the "culture of silence" that existed at the time. ${ }^{465}$

The commission's other findings indicated that the four murdered politicians, as members of the MCP National Executive Committee, were part and parcel of discussions purporting to the choice of an individual who would act as a caretaker president, while Dr. Banda was out of the country to seek medical care. It was revealed that while Dr. Banda favored Mr. John Z.U. Tembo, who was the uncle to Banda's Official Hostess, Miss Cecilia Kadzamira, the other politicians had not been in favor of the suggestion, hence their subsequent murders. Miss Kadzamira and Mr. Tembo were part of the so-called "inner circle" that ruled the country, alongside the ailing and aging Banda. That evidence, was supported by the testimony given by Mrs. Kamwana, wife to the then deceased Inspector General of Police, who told the Commission, that the orders to have the four politicians murdered, given to her deceased husband, actually came from Banda and Tembo, both of whom had called upon Mr. Kamwana to "eliminate" the politicians because they had refused to support the temporary handover of power to Tembo. The commissioners interviewed Dr. Banda on November $28^{\text {th }}, 1994$, after being earlier denied that chance due to requests and medical reports

465 Ibid., 8-63. 
received from the Banda camp that the former President had been in poor health for some time, due both to depression and hearing impairment. Due in part to his old age, and maybe "coaching" on the part of his lawyers, the interview with Banda did not yield the information or implicating evidence that the commissioners had intended to hear. In the commission's view, Banda and his camp, had made calculated efforts to frustrate the commissioners. The commission's final assessment concluded that the killings were premediated, brutal, and diabolic, and that the Malawi Police Force was involved in the killings following orders from Dr. Banda and Mr. Tembo. ${ }^{466}$

${ }^{466}$ Ibid., 67-85. Tembo himself was interested in the position, at it would have ensured the Banda-Tembo-Kadzamira control of the economy and hence the government. For instance, at the peak of his powers, Tembo was chairperson of more than ten companies and/or organizations with strong links to the regime, and these included: University of Malawi Council; Press Holdings; Air Malawi; Limbe Leaf Tobacco Company; New Building Society; Oil Company of Malawi; National Insurance Company; and Commercial Bank of Malawi, among others. 


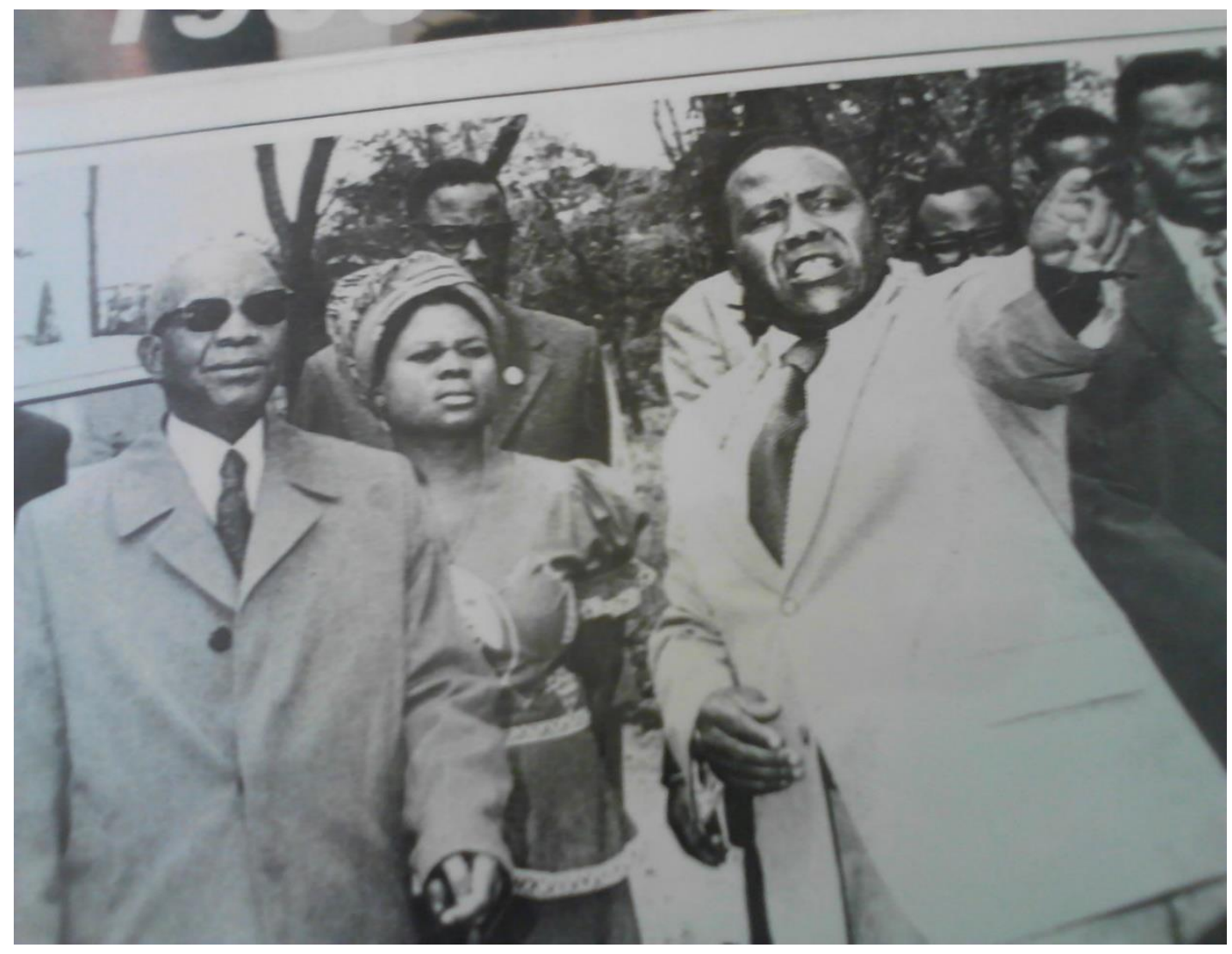

Figure 6.10: Dr. Banda, on the extreme left, is seen here with Hon. Aaron Gadama, on the right, pointing towards something. Banda would later be implicated in Gadama's murder, alongside three other prominent politicians, in May 1983. Source: H.K. Banda Archive.

The murders of the four politicians at the hands of the Malawi Police Force, clearly indicated how the security men had become "political pawns" or "puppets" that were used by the Banda regime to "eliminate" critics of the regime. ${ }^{467}$ As I have discussed above, there were numerous case studies where many were eliminated, some from the civil service, the private sector, and politicians. However, this case was probably the climax of Banda's ruthlessness, especially the fact that he issued orders to have his own cabinet ministers to be murdered. The evidence presented before the

467 See for instance, Joey Power, Political Culture and Nationalism in Malawi: Building Kwacha (New York: University of Rochester Press, 2010), 177-201. Power argues that since the kind of politics which led to the elimination (by killing) of political opponents has over the years been described as 'kuthana politics' (which literally meant 'to finish somebody off'). 
Commission clearly implicated Banda and his inner circle, which explains why none of the top politicians went to the funeral ceremonies of the murdered politicians, something which was and still is, unusual for a Head of State, or other cabinet ministers, to skip the funeral ceremony of a cabinet minister or members of the party executive committee of the then only political party in the country. Although the so-called members of the "inner circle" were acquitted in the court case that followed, that was just a case of technicalities, rather than the lack of incriminating evidence. ${ }^{468}$ According to the Emergency Arrangements which the country was following at the time, which had been drafted by Mr. Bryan Roberts (the former Chief Secretary and Attorney General), alongside Dr. Banda, in 1972, when Dr. Banda was in the country, he alone had the powers to order the movement of troops and police, except when an emergency was so sudden that the Army and Commissioner of Police could act on Banda's behalf. ${ }^{469}$ Since there was no "emergency" in May 1983, therefore it is only fair to conclude that it was Banda who ordered the movement of policemen, from Lilongwe, Zomba, and Blantyre, to commit the murders of his cabinet ministers.

\section{Western support and the consolidation of the Banda regime}

The previous sections of this chapter have laid emphasis on the local institutions that served the counter-insurgency measures of the Banda regime. However, the Malawian post-colonial state did not survive only by using these locally-available resources. Rather, one must also focus on the role of the international community to help in the consolidation of the regime. In this section, I focus

\footnotetext{
${ }^{468}$ See for instance, Jan Kees van Donge, "The Mwanza Trial as a Search for a Usable Malawian Political Past," African Affairs 97, no.386 (Jan. 1989): 91-118.

${ }^{469}$ Memo from the British High Commission, Blantyre, Malawi, titled 'Malawi: Emergency Arrangements,' June $7^{\text {th }}$, 1972, Political Situation in Malawi, 1972. BNA: FCO 45/1227. This was also like a conclusion arrived at by the US government, through the CIA and its representatives in Malawi. See "Confidential dispatch, CIA, Directorate of Intelligence, titled 'Malawi: Troubled times ahead,' dated July $15^{\text {th }}$, 1983”. Source: Library of Congress.
} 
on the relationship which Dr. Banda and his government cultivated with two of Malawi's most important bilateral donors, namely the British and American governments. The former being the country's former colonial "master," and the latter, being the leader of the Western bloc during the Cold War, and one of Malawi's most important sources of budgetary and development aid since independence.

These bilateral donors and other international agencies, such as the Bretton Woods Institutions, worked together with the Banda regime, despite its flaws, as Banda and the state he governed were a representation of the people both nationally and internationally. The inclusion of the two bilateral donor states in this study, also concurs with the argument that for Malawi, as was the case in other post-colonial African states, it is impossible to envisage state survival without some form of foreign support or intervention. In the case of the former metropole, their continued interest in African states tended to favor the stability of the post-colonial state, which often assured the retention of the metropole's economic interests. In turn, the African rulers were rewarded, usually with economic and material aid, but also security assistance, in cases of uprisings or suspected coups. Such provision of aid helped to cement an effective central government, which the former metropole could deal with. The relations that ensued in the post-colonial era, thus, were beneficial to both the African states and the former colonial power, and to an extent the USA, which often sided with the former colonial powers. ${ }^{470}$

Christopher Clapham argued that there were three main interests which the former metropole harbored for its continued relations with post-colonial African states. Firstly, the need to ensure

\footnotetext{
${ }^{470}$ An important source on this argument is Elizabeth Schmidt, Foreign Intervention in Africa: From the Cold War to the War on Terror (Cambridge: Cambridge University Press, 2013). See also Crawford Young, "The End of the PostColonial State in Africa?" 31. See also Christopher Clapham, Africa and the International System: The Politics of State Survival (Cambridge: Cambridge University Press, 1996), 77-105.
} 
“territorial security." That was important as it would preserve the state's integrity against secession and dismemberment. Secondly, the need to ensure "state security." This represented the desire to help the African states to establish effective central government structures, including providing aid to such departments as the judiciary, the army, the police, and other expatriate expertise. The third level of support revolved around the assurance of "regime security." This involved making sure that there was no interference by other interested states in the affairs of the former colonies. ${ }^{471}$

The British and American governments had already agreed by the late 1950s on the need to maintain their influence on the former colonies after independence. They made it clear that it would not be in their interest to see the former colonies fall into the hands of the Eastern bloc led by the Russians. For instance, in a dispatch of a meeting held in April 1957 between government officials from the two countries, these sentiments were raised:

Because of Tropical Africa's political, economic and military importance to the West, it is imperative that the present dominant Western political influence in this part of the world be maintained. It would be a major victory for the Sino-Soviet bloc if Tropical Africa could be detached from the West. There is conclusive evidence that the leaders of the communist bloc have the long-term objective of dominating Tropical Africa. Although their ultimate aim is presumably the Sovietization of the continent, their purpose in the present is to detach Tropical Africa from the West, both economically and politically, thus weakening the position of the Metropolitan powers and the rest of the free world. Our two governments have a common purpose in combating these aims.

The best counter to Soviet aims is to pursue systematically the constructive policy of leading dependencies as rapidly as is practicable toward stable self-government or independence in such a way that these governments are willing and able to preserve their political and economic ties with the West. In the opinion of Her Majesty's Government, present British colonial policy is a sincere attempt to achieve this purpose. ${ }^{472}$

\footnotetext{
${ }^{471}$ Clapham, Africa and the International System: The Politics of State Survival, 80-83.

472 “Assessment, agreed with Mr. Dulles, of communist interference in tropical Africa: circular tel (no.67), from Mr. Selwyn Lloyd (FO) to British representatives in Africa," 10 April 1957, FO 371/125292. Adopted from Ronald Hyam and Wm. Roger Louis, eds., The Conservative Government and the end of Empire, 1957-1964. Part II: Economics, International Relations, and the Commonwealth (London: The Stationery Office, 2000), 231-233. See also "Assessment of communist influence in tropical Africa: dispatch from Mr. Lennox Boyd to African governors. Annex,
} 300 
Before Malawi gained its independence in 1964, Dr. Banda seemed to be in favor of the "NonAligned Movement," ${ }^{473}$ and was open to working with the super powers, either from the Western or Eastern blocs, but after independence, and especially in the aftermath of the "cabinet crisis," his position completely shifted to be a Western ally. His remarks in a 1960 interview, attest to that: "If anybody comes to me and says 'Dr. Banda, we'll give you a loan and if you get our loan, well, you must have nothing to do with the Russians' (or anybody else), I'll say 'No, thank you'. I want to be entirely independent, I do not want to be committed to anyone. I do not want anyone to take me for granted. I would refuse in the same way if the Russians came and offered me anything. I do not want to be committed either to the West or the East; I know what I want but I am not going to have anybody taking it for granted that I am in his pocket, whether it be Washington or Moscow."474

\section{Malawi and Britain: Post-Colonial Relations}

For the British government, it should be noted that part of their involvement in Malawi in 1964, had to do with the fact that Malawi had not yet attained her "Republic status." That meant that Malawi still had a British Governor-General, in the name of Sir Glynn Jones, while Dr. Banda was the Prime Minister until July 1966 when Dr. Banda assumed the position of State President. At the independence luncheon in July 1964, Dr. Banda is said to have assured the British government of

\footnotetext{
'The political objectives of British policy in the African dependent territories',' 28 June 1957, FO 371/125293. Adopted from Hyam and Louis, eds., The Conservative Government and the end of Empire, 1957-1964. Part II, 233235. See also "Countering communism in Africa: FO dispatch (no 101, by C.F.R. Barclay) to British representatives in Africa," 9 Nov. 1962, CO 1027/382, no.9. Adopted from Hyam and Louis, eds., The Conservative Government and the end of Empire, 1957-1964. Part II, 262-264.

${ }^{473}$ See Christopher J. Lee, "Between a Moment and an Era: The Origins and Afterlives of Bandung," In Christopher J. Lee, ed., Making A World After Empire: The Bandung Moment and its Political Afterlives (Athens, Ohio: Ohio University Press, 2010), 1-44. The Non-Aligned Movement was established at the Bandung Conference in 1955, comprising of the formerly colonized world, and intended to maintain a neutral ground during the Cold War rivalry. 474 "Talking about Africa: Hastings Banda and Tom Mboya in Conversation with John Freeman," The Listener, September $1^{\text {st }}, 1960$.
} 
Malawi's continued relations with Britain, no matter the circumstances. He made the following statement to HM's representative, Prince Philip, the Duke of Edinburgh: "You are the only people who sent me to gaol yesterday and invite me to Buckingham Palace tomorrow. I think the Commonwealth is the best club in the world, so I still work with Britain... For myself, I have no quarrel with the British, and I want to work with you and stay within the Commonwealth." ${ }^{~} 475$ And from the onset of the Cabinet Crisis and in its immediate aftermath, the British authorities were concerned with making sure that there was political and economic stability in the country, while also supporting a key ally in the Cold War. As argued by Joseph Frankel and Gaynor Johnson, Britain's foreign policy in the aftermath of both the Second World War and the decolonization era that followed, was one in which the British authorities made significant efforts to revive Britain's declining world and imperial power. Britain realized her new status as a "major second rank power" but was determined to maintain a global presence and influence, through her input in matters of global security and economic development. Britain was also interested in working towards reviving her own ailing economy, devastated in the aftermath of the war. This saw her continue diplomatic relations with her former colonies, including co-opting them in the Commonwealth, where for long periods Britain remained the largest customer and the largest supplier of manufactured goods to the member countries, except Canada. ${ }^{476}$

An analysis of Britain's aid to Malawi, and the confidential reports and memos from the British government officials (both in Malawi and in London), from 1964 onwards, attest to this perspective. For instance, a confidential dispatch by the British High Commissioner to Malawi,

\footnotetext{
475 "Dr. Banda to adopt policy of flexible neutralism: Malawi's belief in value of the Commonwealth," The Times, July $7^{\text {th }}, 1964$.

476 Joseph Frankel, British Foreign Policy, 1945-1973. (London: Oxford University Press, 1975), 1-13, and 221-227. See also Gaynor Johnson, "Introduction: The Foreign Office and British Diplomacy in the twentieth century," In Gaynor Johnson, ed., The Foreign Office and British Diplomacy in the Twentieth Century (London: Routledge, 2005), $1-6$.
} 
Mr. D.L. Cole, on the major causes of the cabinet crisis, clearly pinpointed that Dr. Banda had been partly to blame for the outbreak of the crisis. Among other things, it noted his authoritarian tendencies and his preference to continue trusting and working with British colonial officers, rather than employing or promoting Africans to top government positions. The High Commissioner also doubted Banda's claims that the cabinet ministers had intended to overthrow and murder him, as sheer fantasy. On the other hand, he sided with Banda's claims that some of his ministers (especially the Minister of External Affairs, Kanyama Chiume) had been in contact with Communist Chinese government officials, highlighting the efforts of Chinese officials to penetrate Malawi. He even went further to suggest that after the crisis, Mr. Chiume went to Dar-es-Salaam, Tanzania, to look for Chinese money. ${ }^{477}$

Having taken note of the unstable political climate in the country, Mr. Cole hinted that the British government's priority should be to ensure that there was political stability in the country and that the only leader to support was Dr. Banda. He was the only person who could ensure stability in the newly independent country. Furthermore, he was a key ally in the Cold War, as follows:

The outline of future British policy towards Malawi thus seemed clear. We must support the Government of Dr. Banda which seemed to promise stability, anti-communism, realism and moderation in foreign policy, and slow but sensible progress in its internal political development. We must continue to give Malawi economic aid in appropriate doses both because of its satisfactory political orientation, which must be preserved, and in recognition of a certain moral obligation towards a country which, after the bitter controversy of Federation, had attained its independence prematurely in precarious economic circumstances. ${ }^{478}$

\footnotetext{
${ }^{477}$ Dispatch from the British High Commissioner to Malawi, Mr. D.L. Cole, titled 'Malawi: Ministerial Revolt against Dr. Banda.' Sent to the Secretary of State for Commonwealth Relations. October $14^{\text {th }} 1964$. Confidential. BNA: DO/201/15. C.R.O. Ref.: CAO 41/3/06. No. 108.

${ }^{478}$ Dispatch from the British High Commissioner to Malawi, Mr. D.L. Cole, titled 'Malawi: British Policy'. Sent to the Secretary of State for Commonwealth Relations. October $27^{\text {th }} 1964$. Confidential. BNA: DO/201/15. C.R.O. Ref.: CAO 733/2/02. No. 109. Note that there were other officials at the Colonial Office (CO) who were against linking British aid to her former colonies to the Cold War. They argued that doing so only encouraged the Russians and the Chinese to give more aid. Furthermore, it also encouraged the competition between the East and the West. See "Aid policy: The Cold War and independence: CO minutes by J.S. Bennett, D.J. Kirkness and W.B.L. Monson," CO
} 
The British and American governments were particularly interested in maintaining political stability in the country. As such, through their representatives in Malawi (British High Commissioner to Malawi, Mr. David Cole; and the US Ambassador to Malawi, Mr. Gilstrap), they whisked out of the country some of the ministers involved in the cabinet crisis. For instance, Minister Henry M. Chipembere was provided a "safe way" to the United States by the two governments with the assistance of Malawi police authorities. This followed a botched uprising which Chipembere had engineered in his home District of Mangochi. ${ }^{479}$ It was clear from that perspective that the international community, especially Britain, was more interested in maintaining both economic and political stability in the country. They were willing to support the Banda government despite acknowledging his authoritarian tendencies, including acknowledging that the Banda regime ran a series of detention centers for political detainees. He was regarded as an important ally in the Cold War in Africa. The British authorities argued that only when there was political and economic stability in Malawi, would it ensure the country's continued support in the Cold War, and would also allow the people of Malawi to enjoy "the fruits of independence." They were determined to avoid "another Congo" (where political instability ensued immediately after independence) in Malawi, hinting that political and economic instability would have brought national tragedy and horror, anti-Western sentiments and communism in all its most virulent forms. There were also sentiments expressed that at independence, there were still about 20,000

852/2236, no.4, 3-4 Sept. 1964. Adopted from Hyam and Louis, eds., The Conservative Government and the end of Empire, 1957-1964. Part II, 155-158.

${ }^{479}$ Dispatch from British High Commissioner to Malawi, H.E. David Cole, to Mr. N.D. Newton, at the Commonwealth Relations Office. September 6 ${ }^{\text {th }}$, 1965. Malawi Political Crisis. BNA: DO 183/565. See also Secret Dispatch No.5. From the British High Commission, Zomba, Malawi: 'Malawi: Chipembere's Escape'. July 9 , 1965. BNA: DO $183 / 565$. 
British citizens in Malawi, many of whom were business persons. It was the responsibility of the British government to provide a conducive environment for their business operations. ${ }^{480}$

The need to ensure both economic and political stability also saw Britain insist that its former African colonies (who became members of the Commonwealth) had to remain within the sterling system, which often meant that governments, like the one in Malawi, remained bound by metropolitan financial and economic systems. ${ }^{481}$ For Malawi, it was not until 1971 that she dropped the sterling system in favor of her own currency, the Malawi Kwacha. It also allowed for closer and "softer" trade ties between Britain and her former colonies. For instance, in the case of Malawi, until 1975, one-third of British goods were imported duty free, while over 95 percent of British goods also enjoyed a measure of preference. On the other hand, Britain also imported Malawi's products, especially tobacco, tea, groundnuts, cotton, and maize. Twenty five percent of Malawi's exports were sent to Britain. For the period 1964 to 1973, for instance, forty percent of Malawi's tobacco was exported to Britain. ${ }^{482}$

There is overwhelming evidence of Britain's continued support to the Malawi government for the period under study, which indicated the high levels of "dependence" in the then newly

\footnotetext{
${ }^{480}$ Ibid. See also 'British Policy in Malawi over the next four years.' Confidential dispatch from the British High Commissioner to Malawi (Mr. T.S. Tull) to the Foreign and Commonwealth Office (FCO), 11 April 1970. BNA: FCO/45/770. See also BNA: FCO 59/627, No.89: Malawi: first impressions: dispatch from W.R. Haydon (Blantyre) to Sir A. Douglas Home'. 18 August 1971. In S.R. Ashton and Wm Roger Louis, eds. British Documents on the end of Empire: East of the Suez and the Commonwealth, 1964-1971, Part III: Dependent Territories, Africa, Economics, Race (London: The Stationery Office, 2004), 424-429. See also 'Malawi: Internal - Detentions'. Confidential dispatch from the British High Commission to the FCO. 5 August 1977. BNA: FCO/45/2169.

${ }^{481}$ Yusuf Bangura, Britain and Commonwealth Africa: The politics of economic relations, 1951-75 (Manchester: Manchester University Press, 1983), pp.24-30.

${ }^{482}$ Ibid., pp.118-119, and 125. The concept and advantages of placing the former British colonies and member states of the Commonwealth under the Sterling area, were outlined in a dispatch from the British Treasury in 1958. It allowed the members to easily conduct international trade; hold their financial reserves in sterling; and to use London as their main source of external capital. See "The advantages of membership of the Sterling Area: memorandum by Sir L. Rowan for officials' Working Party on Sterling Area," $2^{\text {nd }}$ October 1958, T 236/5362. Adopted from Hyam and Louis, eds., The Conservative Government and the end of Empire, 1957-1964. Part II, 15-21. Note: "T" stands for "Treasury". This memo was circulated to the Foreign Office (FO), Colonial Office (CO), and the Commonwealth Relations Office (CRO).
} 
"independent" country. In a study commissioned by the British government and assigned to the Overseas Development Institute (ODI) in 1974-75, it was stipulated that Britain remained committed towards financing Malawi's budgetary requirements and other development-related projects, ensuring that there was security, stability and prosperity in its former colony. The funds provided came in the form of grants and loans for development projects; grants and loans for nonproject purposes (which included budgetary aid, import finance, pensions, and disaster relief); and technical assistance, which was mostly grant aid. In the case of former British colonies receiving such aid, between 1964 and 1975, only India, Pakistan, and Kenya, received more than Malawi. In terms of the amount of money involved, between 1964 and 1972, Britain disbursed the sum of $£ 80.3$ million gross to the Malawi government. In per capita terms, British aid to Malawi averaged roughly $£ 1.80$ per head of the country’s population per year. Such aid helped to stabilize Malawi’s economy, making it one of Africa's success stories since the age of independence. ${ }^{483}$

These sentiments were also confirmed in a dispatch from the British High Commissioner to Malawi, K.G. Ritchie, to the Foreign and Commonwealth Office (FCO) in May 1974, as follows:

The Malawians are comparatively law-abiding people, who seem to respond to constant appeals for greater economic effort from a dynamic Life President and a government determined to achieve progress by, on the whole, sound and well-planned measures. These in turn are attracting attention. In 1971, my predecessor remarked that British aid was greater than that of all (other) countries put together. Although we provided 65\% of all net aid to Malawi during its first seven years of independence and still remain and are likely to remain - the largest single donor, we are by no means alone. Others are now recognizing Malawi's needs and its current ability to use development funds in an efficient and effective manner... British aid will therefore continue to be applied as

\footnotetext{
${ }^{483}$ Kathryn Morton, Aid and Dependence: British Aid to Malawi (London: Holmes and Meier Publishers, Inc., 1975), 51-62. See also Bangura, Britain and Commonwealth Africa, pp.171-172. Bangura posited that because Malawi attained her independence without having an established taxable capacity, her revenue could not match the needed expenditure, hence the need for continued British aid. See also Carolyn McMaster, Malawi: Foreign Policy and Development (London: Julian Friedmann Publishers, 1974), pp.78-87. See also Philip Short, Banda (London: Routledge and Kegan Paul, 1974), 231-250.
} 
in the past to improve the basic infrastructure and to projects benefitting rural areas and the lower income groups. ${ }^{484}$

Britain was compelled to provide such aid to the Malawi government, because the latter faced numerous challenges at independence. First, there were high levels of poverty in the country. The challenge was that the country lacked the resources with which to reduce the levels of poverty, a development which worried not just the British government, but also the international community at large. Although there was some economic development under the CAF, at independence, Malawi still ranked among the poorest countries in the world. In 1964, the country's average growth domestic product (GDP) per head was only $£ 20$ (roughly 39.5 Malawi Kwacha). Over 90 percent of the African population lived in rural areas, with subsistence agriculture as their major source of livelihood. Out of the 4.8 million citizens, only about 130,000 were in wage employment, while about 2,000,000 others migrated to work within the mining areas of the southern African region. The Malawian economy was also in stagnant form, at least since 1962, following the uncertainties created by the pending dissolution of the CAF. ${ }^{485}$

Secondly, one of the country's budgetary challenges emanated from the roles which the government inherited from the CAF. During the federal period, the Nyasaland government increased its provision of social services to Africans, mostly using resources generated from across the federal government. However, after the federation was dissolved at the end of 1963, the Nyasaland and later the Malawi government had the task of financing the services that were provided by both the federal government and the territorial government. Furthermore, the

484 "Aid to Malawi”. Dispatch from the British High Commissioner to Malawi, K.G. Ritchie to the FCO, $29^{\text {th }}$ April 1974. BNA: FCO 45/1655. Apart from British aid, the memo also recognized aid from the US Government, Canada, West Germany, Denmark, the UN, International Development Agency (IDA), and the African Development Bank (ADB).

${ }^{485}$ Kathryn Morton, Aid and Dependence: British Aid to Malawi (London: Holmes and Meier Publishers, Inc., 1975), 12. 
territorial government inherited the debts that had been incurred by the federal government. All these provided challenges for the then newly independent government to pay for services and balance its books. For instance, while the government generated an estimated local revenue of MK (Malawi Kwacha) 16 million, the estimated government expenditure was at MK31.2 million. Other related shortfalls included the lack of a central banking system and an underdeveloped banking sector. Previously, such services were centered in the federal capital, Salisbury, Southern Rhodesia. Similarly, when it came to preparation of development plans, the expertise was based in Southern Rhodesia. Furthermore, the lack of proper statistical services often hampered the required planning for the management of the economy. ${ }^{486}$

The newly independent country also lacked skilled manpower. During the first five decades of the colonial period, both the government and Western missionaries mainly focused on the provision of basic or primary education. While the situation slightly improved after the Second World War, by 1960 , there were only four secondary schools, while opportunities for vocational training were also limited. It was not until 1963 that the government established the Staff Training College, at Mpemba, in Blantyre, meant to provide in-service training to African civil servants. This background meant that at independence, Malawi still needed to rely on the expatriate community to draw plans for development, administration, and run some of the businesses. It is thus unsurprising that in 1964, the expatriates held most of the senior administrative positions in the civil service and predominated in several professional and technical spheres in the public and private sector. ${ }^{487}$

\footnotetext{
486 Ibid., 13-14.

${ }^{487}$ Ibid., 14-15.
} 
The country's economic infrastructure also remained largely underdeveloped. Dr. Banda inherited very little in terms of the transport, communication, and electric power outlay needed to boost the country's agro-based economy. For instance, the country only had a single railway system connecting some parts of the southern and central region, for a total of 289 miles. However, most of the railway line was in a state of disrepair. The paved road network was only up to 6,000 miles, a majority of which were unusable during the rainy season. ${ }^{488}$

From this background, it is clear to note why Britain felt compelled to continue funding the Banda regime. While the report produced by the ODI only covered up to the 1974-75 fiscal year, this study provides evidence of Britain's continued financial commitment to the Malawi government. Further details of British aid to Malawi, for the period 1975 to 1978 indicate that the British government committed to disburse $£ 15$ million for capital aid. Of that figure, $£ 12$ million was made available on grant terms, whereas the remaining $£ 3$ million was set aside as an interest free loan. A further $£ 3$ million was set aside by HMG as contingency funds, meant to be released in emergency circumstances. ${ }^{489}$ By the 1979-80 financial year, the British Government had provided a total $£ 140$ million (from 1964 to 1979-80) as grant aid to the Malawi Government. The British government also converted all outstanding loans owed by the Malawi Government, into grants. That decision helped to ease Malawi's burden of repaying the loans which would have reduced Malawi's foreign exchange resources. ${ }^{490}$ The loans in question fell under a scheme known as "UK Development Loan," which the Malawi government used in various sectors, including transport and communication, agriculture, health, and education. Further funding to the Malawi Government

\footnotetext{
488 Ibid., 15-16.

489 'Aid to Malawi from UK'. Memo signed by Mr. D.J. Kirkness, House of Commons, 17 May 1974. BNA: FCO/45/1655. The Malawi Government was represented by the Min. of Finance, Hon. D.J. Matenje.

${ }^{490}$ Interview with the British High Commissioner to Malawi, titled 'Perspectives: Sir Michael Scott - No country can afford by itself to fight the war against poverty,' Malawi News, 27 January 1980.
} 
was also extended through the "British Development Fund." ${ }^{491}$ Most of the funds provided by the British government were overseen by British expatriates who were retained in the civil service while others served as consultants and advisors to Dr. Banda. ${ }^{492}$

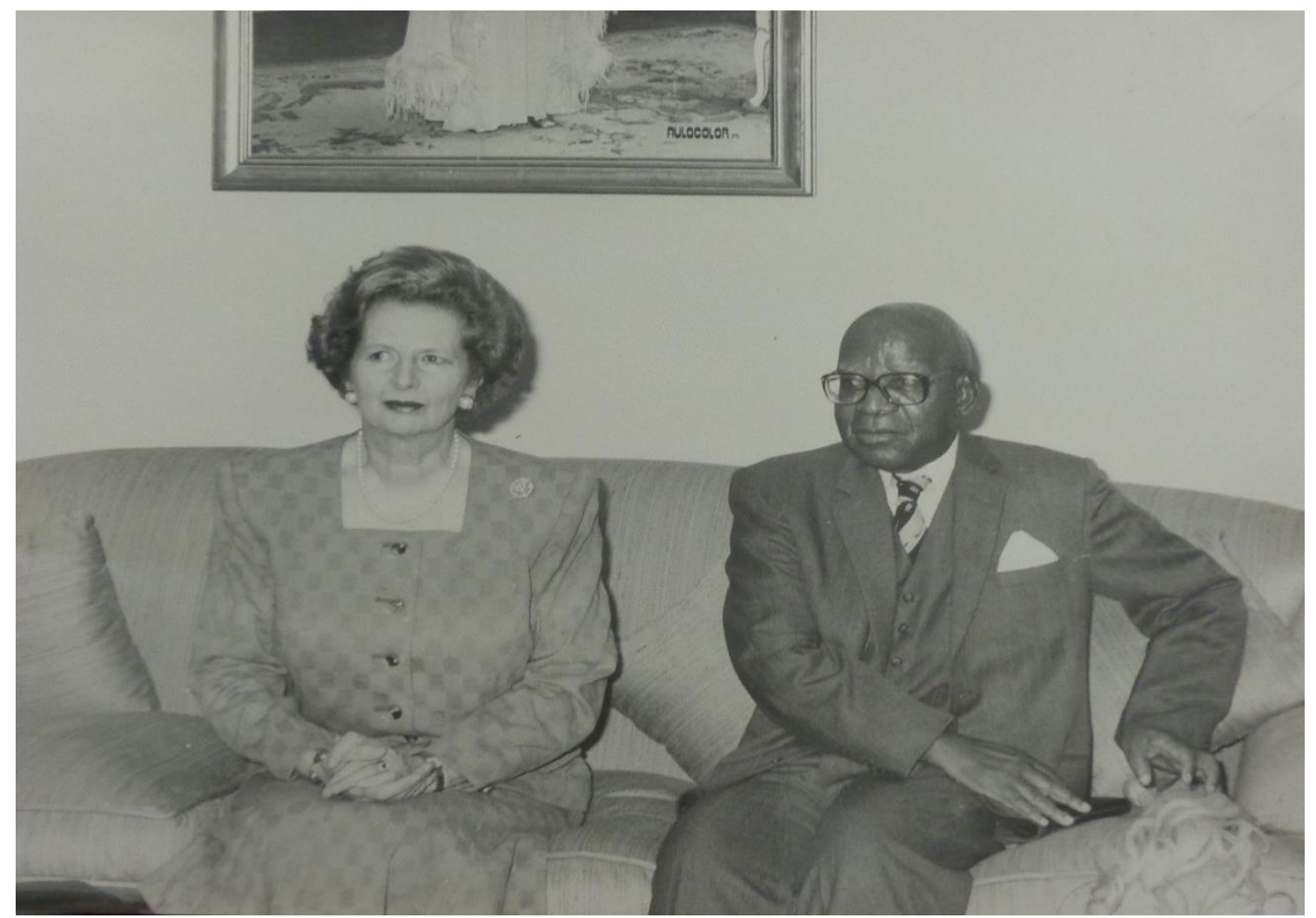

Figure 6.11: Dr. Banda meeting with Margaret Thatcher, the Conservative British Prime Minister, early 1980s. A clear indication of the good relations between Malawi and Britain. Source: H.K. Banda Archive.

${ }^{491}$ Malawi Government, Economic Report for 1972 (Zomba: Government Press, 1972), 36-42. See also Malawi Government, Economic Report for 1979 (Zomba: Government Press, 1979), 79 and 87.

${ }^{492}$ Confidential dispatch from P.M. Foster, FCO, Central and Southern African Department, to Mr. Aspin, May 13 ${ }^{\text {th }}$, 1974." Aid to Malawi. BNA: FCO 45/1655. 


\section{Malawi and US Bilateral Relations}

Like Malawi-British relations, discussed in the sub-section above, Malawi retained cordial bilateral relations with the US government for the post-colonial period covered in this chapter. The American government was convinced and comfortable to work with the Banda regime, because of his open support for the West during the Cold War. American aid to Malawi was provided in monetary, material, and personnel terms. That had been the foreign policy direction of the American government, to focus on providing aid to African governments from 1961 onwards. Since the ascendancy of President John F. Kennedy to power in 1961, the US government's approach towards Africa had been one which left no chance to let the USSR and China influence the turn of events in the yet to be independent or the newly independent states. There were deliberate efforts on the part of the American Government to directly intervene in African affairs and initiate contacts with African leaders. He held the view that for the USA to win the Cold War, there was need to prevent the postcolonial states in Africa from falling under the trap and influence of the USSR. ${ }^{493}$ During his short stint as US President, he (President Kennedy) had personally received African leaders at the White House as follows: eleven in 1961; ten in 1962; and seven in 1963. ${ }^{494}$ In May 1961, President Kennedy met with Dr. Hastings Kamuzu Banda, then leader of the opposition MCP, at the White House. ${ }^{495}$ From then onwards, the US foreign policy towards Malawi, would be guided by political, cultural, and economic considerations. Politically, the US

\footnotetext{
${ }^{493}$ Philip Muehlenbeck, Betting on the Africans: John F. Kennedy's Courting of African Nationalist Leaders (Oxford: Oxford University Press, 2012). See also National Security Council. 'National Security Memorandum No.39 Southern Africa'. Washington DC, April 10 $0^{\text {th }}$ 1969. Source: Library of Congress. See also Frank Costigliola, "US foreign policy from Kennedy to Johnson," In Melvyn P. Leffler and Odd Arne Westad, eds., The Cambridge History of the Cold War, Vol.2: Crises and Détente (Cambridge: Cambridge University Press, 2010), 112-133.

${ }^{494}$ James N. Giglio, The Presidency of John F. Kennedy (Kansas: The University of Kansas State, 1991), p.223. See also JFK Library: 'William H. Attwood Oral History Statement, 11/8/1965'. Mr. Attwood served as a member of JFK's Presidential Campaign, and later as US Ambassador to Guinea from 1961-1963; and Kenya from 1963-1966. 495 John F. Kennedy Library and Museum. 'Meeting with Hastings Kamuzu Banda, Prime Minister of Nyasaland'.
} 
needed allies in the Cold War, especially working alongside the USA as a voting bloc at the UN where one-third of the member states were African. Culturally, it considered the historical links between African Americans and Africans in the continent. Economically, the US looked to Africa as a source of mineral, petroleum, and agricultural commodities, while also serving as a market for US manufactured goods. ${ }^{496}$ Such objectives, could only be attained, in the eyes of the American authorities, when African states were able to maintain peace and stability, had access to development aid and trade opportunities, and where racial and political justice prevailed. ${ }^{497}$

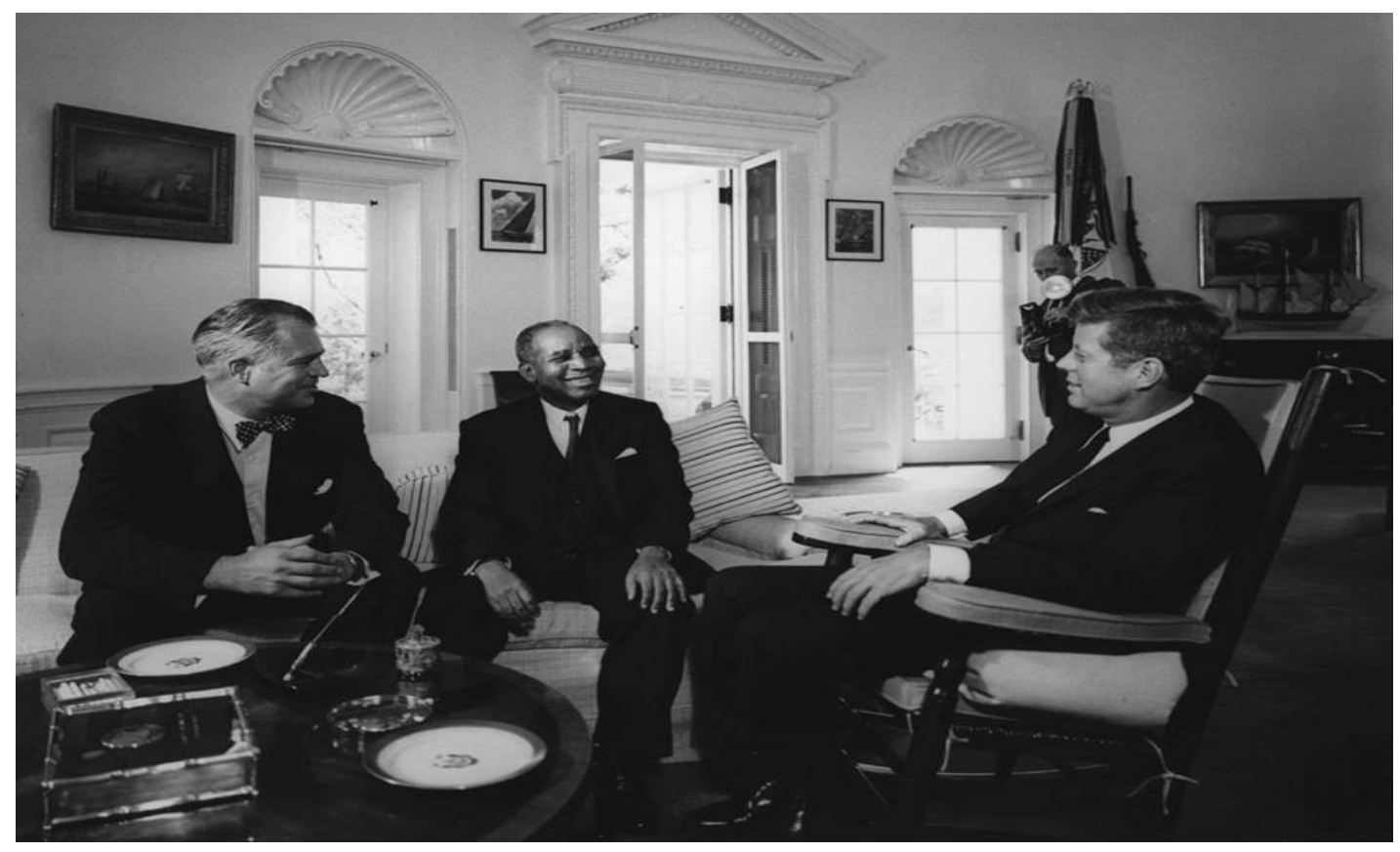

Figure 6.12: Meeting between Dr. Hastings Kamuzu Banda (of Nyasaland) and President John F. Kennedy (USA), at the White House, May 1961. Sitting on the far left was Hon. G. Mennen Williams, the Assistant Secretary of State for African Affairs. Source: John F. Kennedy Library and Museum.

\footnotetext{
496 "The United States and Africa - Building Positive Relations". Address by Secretary of State Vance before the Annual Convention of the NAACP, in Elaine P. Adam, ed., American Foreign Relations 1977: A Documentary Record (New York: New York University Press, 1979), 310-319.

497 “Africa". President Nixon's Second Annual Report to the Congress on United States Foreign Policy, February 25, 1971, in Richard P. Stebbins and Elaine P. Adams, eds., American Foreign Relations 1971: A Documentary Record. (New York: New York University Press, 1976), 380-385.
} 
At independence in 1964, the US government was one of the first to establish formal diplomatic relations with Malawi. That same year, the US government began to dispatch Peace Corps Volunteers (an institution established by President Kennedy in 1961) to Malawi to work in the rural areas of the country in the areas of agriculture, health and sanitation, water supply, fisheries, and credit union development. ${ }^{498}$ The Americans also monitored with keen interest the events surrounding the 1964 cabinet crisis, and it was clear that they were in support of Banda's continued stay in power as he was a key US ally, despite noting that he had authoritarian tendencies. ${ }^{499}$ A CIA Report of September 5-8, 1964, hinted: "Malawi (Nyasaland): Yet another African state is in trouble. The Cabinet of pro-Western Prime Minister Banda is in virtual revolt against his highhanded methods." ${ }^{\circ 00}$ The CIA also keenly followed the activities of the former Cabinet Ministers, all of whom had gone into exile. It alerted the Malawi government of the plans of the dissidents to assassinate "pro-Western Prime Minister Banda." remarks on the dissidents, and in doing so the Americans also helped Banda to gain public sympathy and to cement his political position. Later that year, in December, Dr. Banda visited the State Department, in Washington DC, where he was assured of US government support, to deal with the communist elements in the Southern African region, especially in Zimbabwe, Zambia, Tanzania, and the Congo. ${ }^{502}$ Unlike the other countries in the region, Dr. Banda did not tolerate the spread of communism in Malawi. Furthermore, he opened diplomatic relations with such pro-

\footnotetext{
${ }^{498}$ US Government, The Peace Corps in Malawi (Washington DC, 1980). Source: Library of Congress.

499 Alongside the Ivory Coast, by the 1980s, Malawi was the other country to refuse to open diplomatic relations and to receive aid from the Soviet Union. See Zaki Laidi, The Super-Powers and Africa: The Constraints of a Rivalry, 1960-1990 (Chicago: The University of Chicago Press, 1990), 174.

500 Central Intelligence Agency (CIA), 'Malawi (Nyasaland): The President's Review.' Top Secret. 5-8 September 1964. Sanitized copy approved for release 2015/07/24. Source: Library of Congress.

${ }^{501}$ CIA Report, 'Malawi,' in The President's Daily Brief. 2 July 1965. Sanitized copy approved for release 2015/07/24. Source: Library of Congress.

502 US Department of State, 'Outgoing Telegram - to the US Embassy, Blantyre, Malawi.' Titled, 'Malawi - Banda Visit." December $8^{\text {th }}, 1964$.
} 
Western countries such as South Africa and Portugal, despite being called upon by the Organization of African Unity (OAU) to desist from doing so. ${ }^{503}$

There were also confidential American government reports that Dr. Banda would from time-totime take advantage of his support for the West, to 'demand' financial aid from the US government. A CIA Report for 6 May 1966 read as follows:

Malawi - formerly the British Protectorate of Nyasaland, is desperately seeking money. The US Ambassador says that the government has badly overspent, thanks to Prime Minister Banda's determination to 'push buttons, throw switches, and cut ribbons to dramatize his political sagacity, economic savvy, and planning genius'. The Ambassador is worried that the West may have to submit to 'financial whitemail' or see Dr. Banda either appeal to the East for aid or lead the country's economy down the Nkrumah road. Malawi's Finance Minister in fact has already suggested that the US should be willing to offer $\$ 50$ million, 'the amount Banda has saved the US by delivering Africa from communism'. 504

It was in that atmosphere that in June 1967, as a Cold War ally, Dr. Banda paid a visit to President Lyndon Johnson at the White House, where the Malawi leader was praised for supporting America's war in Vietnam. In his public pronouncements of December 1966, Dr. Banda had apparently praised the efforts of the US to bring peace to Vietnam, unlike the Communist Chinese and the North Vietnamese, who in his words "stood in the way of peace." In the preparatory minutes of the meeting between the two Heads of State, it was indicated that Dr. Banda had to be praised for being an important ally of the US in Southern Africa, and one who had adopted a pragmatic approach on international affairs. In return, the US government promised to increase the monetary aid to the Malawi Government, which by 1967 had totaled a little over $\$ 10$ million. The

\footnotetext{
${ }^{503}$ See for instance, Paul Chiudza Banda, "Hastings Kamuzu Banda: How the Cold War influenced bad leadership in Malawi," in Baba G. Jallow, Jallow, Baba G. Leadership in Postcolonial Africa: Trends Transformed by Independence (New York: Palgrave Macmillan, 2014), 33-37.

${ }^{504}$ CIA Report, 'Malawi,' in The President's Daily Brief. Top Secret. 6 May 1966. Sanitized copy approved for release 2015/07/24. Source: Library of Congress.
} 
US government also promised to continue with the Peace Corps Volunteer Program, whose number stood at 160 in 1967 . Further monetary aid was also promised towards the completion of the Lake Shore (Lake Malawi) road (which cuts across the southern, central and northern regions of the country), and the development of a wood pulp project at Viphya in northern Malawi. ${ }^{505}$ By mid-1968, the US government had honored its pledge of funding the Lake Shore road project, for an initial sum of $\$ 3$ million which Dr. Banda announced to Malawians. ${ }^{506}$ The road was funded by the US government through the United States Agency for International Development (USAID), and was constructed by an American construction firm which brought with it engineers and construction materials and equipment from the USA. The construction work was completed in 1972. ${ }^{507}$

In August 1969, an American Congressional delegation visited Malawi and met with Dr. Banda, and the Congressmen were reportedly pleased to have found a strong anti-communist ally in the Malawi leader. In the delegation's report, compiled by Hon. Charles C. Diggs Jr. (Michigan) and Hon. Lester L. Wolff (New York), the Congressmen noted with delight that since independence from Britain, and despite being a poor country, the country's leadership, under Dr. Banda, did not accept aid from communist sources, and had also refused to establish diplomatic relations with any

\footnotetext{
505 'Background paper and talking points for President Johnson's meeting with President H. Kamuzu Banda of Malawi'. US: Department of State. June $7^{\text {th }}$, 1967. Declassified Document. Note that the minutes were from Mr. Davin Dean Rusk, then US Secretary of State. URL: http://tinyurl.galegroup.com/tinyurl/3YFx29. See also Harold D. Nelson, et al. Area Handbook for Malawi. (Washington DC: American University, 1975), 175-189.

506 'Remarks by His Excellency the President Ngwazi Dr. Kamuzu Banda'. Made at a Dinner Party, Lilongwe Town Hall, April $4^{\text {th }}$ 1968. See also Dr. Banda's New Year Message, Dec. $31^{\text {st }}$, 1968. Source: CFL, Chicago.

507 Malawi Government, Economic Report for 1971 (Zomba: Government Press, 1971), 65. See also Malawi Government, Economic Report for 1973 (Zomba: Government Printer,1973), 39. For a study of US foreign policy towards Southern Africa, see Department of State, Policy Planning Council. "National Policy Paper: Southern Africa". $3^{\text {rd }}$ Draft, Revised, November 1968. Among the key targets for Southern Africa, included: (a) maximum recognition of US Government instruments of aid, such as the Peace Corps; (b) encourage provision of US financial and technical aid; (c) active cooperation at the international level, such as the UN; and (d) encourage their non-cooperation with white minority regimes in the region. See pp. iv-vi.
} 
Communist country. As such, further US aid was promised to the Malawi leadership due to the country's continued alliance with the Western powers. ${ }^{508}$

In a newspaper interview, the American Ambassador to Malawi, Mr. Harold Horan, expressed his country's commitment to providing development aid to the Malawi Government. Despite Banda's appalling human rights record, he pledged his government's total support to the Banda regime. He for instance clearly stated: "The Life President's priorities are very similar to ones set by our Congress - emphasis on agriculture, aid to the rural population and concern for basic human rights... Our plans for the immediate future, subject off course to Congressional approval of funds, focus on the agricultural sector, training and rural development.... It is a policy based on the President's (Jimmy Carter) commitment to human rights ...to consider a recipient country's observance of internationally recognized rights. Internationally recognized rights are those which enjoy a world-wide consensus and are found in documents like the UN's Universal Declaration of Human Rights."509 The Ambassador also mentioned that as a sign of the US government's commitment to its bilateral ties with Malawi, it had appointed, for the first time in Malawi, a permanent USAID Representative, a Mrs. Vivian Anderson. ${ }^{510}$ At the end of August 1980, the US government showing further commitment, through USAID, also granted the Malawi government a grant of \$15.1 million, earmarked for three main projects, namely: Expansion of an engineering project at the University of Malawi; the provision of piped water in rural areas; and the establishment of the Malawi Union of Savings and Credit Co-operative Organization

\footnotetext{
508 "Report of the Special Study Mission to Southern Africa". Compiled by the Committee on Foreign Affairs, House of Representatives. October $10^{\text {th }}$, 1969. Source: H.K. Banda Archive. Note that as of the late 1980s, only two countries in Africa, Malawi and Ivory Coast, had refused to establish diplomatic relations with the Soviet Union. See Zaki Laidi, The Super-Powers and Africa: The Constraints of a Rivalry, 1960-1990 (Chicago: The University of Chicago Press, 1990), 174.

509 "Perspective: Harold Horan - U.S. Ambassador to Malawi," Malawi News. February 1980.

510 "Perspective: Harold Horan - U.S. Ambassador to Malawi," Malawi News, February 1980.
} 
(MUSCCO). ${ }^{511}$ Such trends continued throughout Banda's reign, as had been the case in other pro-Western African states, at least until the late 1980s and early 1990s, when the Cold War ended. ${ }^{512}$ Only then, as I will discuss in chapter seven, did the Western powers begin to call for political and economic liberalization in African states, if they were to continue enjoying Western aid.

\section{Conclusion}

This chapter has discussed the notion that our understanding of the political-economy of postcolonial Malawi, roughly 1964 to 1994, should be regarded as a continuation, adoption, and adaptation of processes that began in the late colonial era, hence the notion of an 'imported state.' It has focused on such areas as the notion of the 'developmental state' and its associated antiopposition stance, whereby the post-colonial state emerged as an arena of contestation. I have also highlighted the specific roles that the country's women, the youth and the police force, played to enhance the post-colonial state. Locating the state within the international ideological climate of the Cold War, it has also been highlighted that the Western powers helped to consolidate and prolong the Banda regime despite the country's appalling human rights record. Dr. Banda was a reliable Cold War ally for the Western powers, and this saw him decline to receive aid or open diplomatic relations with countries belonging to the Eastern bloc, including the Soviet Union and Communist China. The next chapter focuses on the fall of the Banda regime, or in the argument

\footnotetext{
511 "MK12 Million for Malawi - U.S. Government to assist in three projects," Malawi News, August $31^{\text {st }} 1980$. See also Malawi: Country Development Strategy Statement. Prepared by the US Agency for International Development, Washington DC. January 1982. Source: Library of Congress, Washington DC. See also Malawi Government. Economic Report for 1979 (Zomba: Government Press, 1979), 77-83.

512 On continued cordial relations between Malawi and the USA, see US Government, "Background Notes: Malawi". (Washington DC: Department of State, 1989), 5. A CIA Report of July 1983, maintained the position that Dr. Banda was a Western ally in southern Africa, who was supposed to be accorded US support. See "Confidential dispatch, CIA, Directorate of Intelligence, titled 'Malawi: Troubled times ahead', July 15 ${ }^{\text {th }}, 1983$, pp.7-10. Source: Library of Congress.
} 
of this study, the end of the post-colonial state, which I argue could be discussed as having emanated from both national and transnational forces. 


\section{CHAPTER SEVEN}

\section{EPILOGUE: BANDA'S DOWNFALL - THE END OF THE POST-COLONIAL STATE?}

The 1993 human development report released by the UNDP confirms that Malawi has eighty-two percent of its population in absolute poverty. Over two million Malawians have no access to health services and 4.7 million have no access to safe drinking water. Other miserable statistics show that for every one thousand people there are 238 radios, three daily newspapers, six telephone installations, and zero television for every nine million people. ${ }^{513}$

\section{Introduction}

In this chapter, I argue that Banda's downfall in the early 1990s, had much more to do with the country's economic downturn. By that time, the State could no longer continue with the principle of "protectionism" for its political and economic interests due to wide-spread economic challenges, especially following the economic downturn which the government and indeed the country begun to face since the $1979 / 80$ fiscal year. By the end of the 1980s and early 1990s, the country's economy was significantly controlled by conditions and aid from the international community, which significantly weakened the reach which the government had in the first fifteen to twenty years after independence. After the Cold War in the late 1980s and early 1990s, the same international community also began to pressure the Banda regime to liberalize the economic and political systems and withheld their aid to Malawi until such policy changes had been implemented. This then sustains the argument raised in chapter one of this study, that the country's history, colonial and post-colonial, can only be understood as having been influenced by global developments. In this case, the "winds of change" that blew across the globe following the end of the Cold War also affected Malawi and saw the traditional donor countries and the Bretton Woods Institutions, exert pressure for the country's leadership to institute liberal changes. The domestic

513 “Bandanomics and Poverty, Part I," The Enquirer, August $2^{\text {nd }}$ to $8^{\text {th }} 1993$. 
pressure for regime change soon followed, and among the key issues raised by the pressure groups, both religious and secular, was on the need for both political and economic liberalization, and the need for respect of peoples' personal liberties. Such calls, which were a sign of the agency of the Malawian peoples, attracted the support of the rural poor and the urban laboring masses, who had suffered for decades under the authoritarian regime but had had no voice of their own to air out their concerns. In the period between 1990 and 1992, the country also suffered a serious drought, which helped to widen the gap between the rich and the poor, especially as the subsequent famine had serious repercussions on the livelihoods of the rural poor. I also sustain the argument, raised in chapter six of this study, that the fall of Banda in May 1994, following his loss in the general elections, should be regarded as having marked the end of the so-called "post-colonial state," where most of the instruments, policies, systems, and so on, that had been 'imported' from the colonial state had now been significantly altered. Such changes significantly altered or watered down the "Bula Matari" or "Leviathan" powers which the state had imported from its colonial era predecessor.

\section{The international push for regime change}

As discussed in chapter six of this study, Dr. Banda had throughout his reign enjoyed substantial economic support from the international community, a development which significantly helped to sustain the country's economy and indeed his own political position since independence. This study specifically focused on the support from Great Britain (the former colonial power) and the USA (Britain's ally and leader of the Western bloc during the Cold War). However, from time-totime, the relationship had its own points of tension. For instance, from the late 1970s onwards, some tensions appeared between Dr. Banda and the British Government, as the latter refused to fund some of Banda's long-term development goals and projects- especially when it came to 
Banda's high priority for symbolic investments, such as the construction of presidential palaces in Lilongwe and Blantyre; the construction of the new capital city at Lilongwe; and the construction of Banda's private school, known as Kamuzu Academy, a lavish project modelled on a British “public school," which was completed in $1981 .^{514}$

In part, due to that British aid, the Malawian economy boomed for the first eight years or so after independence, such that the Malawi leader even had the audacity to send a letter to the British Prime Minister, the Right Hon. Edward R.G. Heath, M.P., in 1973, telling the British leader to suspend the budgetary aid which the British Government had been sending to Malawi, while the aid that was disbursed as development loans, and for technical assistance, among others, could still continue. Part of Banda's letter read as follows:

\section{My Dear Prime Minister,}

In your present preoccupation, with so many domestic and international problems, I felt that you might welcome hearing one matter, at least, which is not a new problem, but is the ending of an old one.

From the time when Malawi became an independent sovereign member of the Commonwealth, Her Majesty's Government has, most generously, provided financial aid in support of our recurrent budget, as well as other forms of assistance related directly to our development. This budgetary aid, though essential, particularly in our early years of independence, and received by Malawi with gratitude, was, however, as both our Governments have frequently made clear, not a form of assistance which either wished to see continued a day longer than was essential.

At the time of our independence, in 1964, though I made clear our determination to balance our recurrent budget as quickly as possible, and bring to an end this form of assistance, I am afraid that many international observers, and outside 'experts', were very skeptical of our ability to deliver the goods. This skepticism, though diminished, persisted among some of the international experts, even after, in turn, I had set 1975 as our target date for the ending of budgetary aid, and, later, our two Governments had agreed, at the final annual financial aid talks in February 1971, that 1973/74 would be the last year of such aid.

I am, therefore, very pleased indeed to be able to tell you that our revised estimates of revenue and expenditure for 1972/73 indicate that we are likely to end the current financial year with a true

${ }^{514}$ Jonathan Kydd, "Malawi in the 1970s: Development Policies and Economic Change," In Malawi: An Alternative Pattern of Development. Conference/Seminar Proceedings no.25, Center of African Studies, University of Edinburgh. May $24^{\text {th }}$ and $25^{\text {th }}, 1984 ., 293-312$. 
surplus, though, instead of the budgeted deficit. In this light, and in the light of our budget estimates for the 1973/74 financial year, which will be presented to Parliament on $15^{\text {th }}$ March, my Government has decided that it will not call on the budgetary aid agreed for the current financial year, or in future. Indeed, our last effective drawing will have been that in the 1971/72 financial year, when our actual deficit finally turned out to be only $£ 100,000 \ldots$

My Government, my people and I are most grateful for the Budgetary Aid Malawi has received in the past - as we are glad that it is no longer required. We shall not forget the support we have received from our oldest friends.

With kindest personal regards,

\section{H. Kamuzu Banda,}

\section{President of the Republic of Malawi. ${ }^{515}$}

The period of economic boom that Banda had referred to early in the 1970s decade, was merely short-lived, as by the 1979/1980 fiscal year, the Malawian economy had begun to show a downward spiral. Banda had himself declared the 1970s as "a decade of economic construction and political consolidation." The perception then, had been that since the early forms of opposition against the regime had been decimated, hence the need to totally focus on economic development and political consolidation. ${ }^{516}$ Politically, I have highlighted that it was in 1971, when Banda was confirmed as the country's "life president," having already served in that capacity for his Party since the early 1960s; while economically, I have highlighted that it was in the 1970s decade, when most of the investments under the two conglomerates (MDC and PGC), were put in place.

\footnotetext{
515 "Confidential dispatch from H. Kamuzu Banda, President of the Republic of Malawi, to the Right Hon. Edward R.G. Heath, M.P., British Prime Minister and First Lord of the Treasury," March 9 ${ }^{\text {th }}$, 1973. Source: H.K. Banda Archive.

516 Malawi News. July 3 ${ }^{\text {rd }}$, 1970. “1970 Decade of Economic Construction and Political Consolidation”. See also Frederick L. Pryor, Malawi and Madagascar: The Political Economy of Poverty, Equity and Growth (Oxford: Oxford University Press, 1990), 43-48. Pryor argued along the same lines that the period between 1964 and 1979, was a period of significant economic growth in Malawi. From 1964 to 1968, the government was primarily interested in the consolidation and restricting of the economy, while from 1968 to 1979, the government promoted an all-out economic growth. For those first 15 years after independence, Banda had significant control over the economy, but from 1980 onwards, it was left to government and international technocrats to reverse the economic downturn.
} 
However, by the close of that decade, it had become increasingly clear that the economy was in recession. Confidential information contained in some cables, mostly exchanged between the British High Commission in Malawi, and the Foreign and Commonwealth Office in London, indicated that the debt crisis of the Malawi Government and the companies run by Banda (under the Press Group of Companies) had reached alarming levels. The Bank of England, one of the major lenders to the Malawi Government's coffers, also raised its concerns about the direction of the Malawi economy as early as 1980, as follows:

We here view with deep concern the apparent re-emergence of Banda's infatuation with expensive, non-productive, prestige projects. Spending on these types of projects is precisely what is not required at this moment in time. Not only will such expenditure increase the resources gap, but it will also reduce the chances of Malawi meeting the performance criteria in the fiscal field laid down in the current IMF program. We are also worried that Malawi appears set to take a further debt on (expensive) commercial terms. The implications for the country's debt service burden could be extremely grave. In addition, the authorities appear to us, were they to take on such commitments, to run the very real risk of breaching the undertaking given to the IMF not to contract more than the equivalent of MK25m of public and publicly-guaranteed external debt with a maturity of between one and twelve years during the period of the IMF program. ${ }^{517}$

Apart from the concerns raised by the Bank of England, similar sentiments were also issued to the Banda regime, from another important international money-lender, hereafter, the Bank of America (BAM). As the Americans were considering lending money to Banda, in the region of $\$ 70 \mathrm{~m}$, they also stipulated that they would only be willing to do so, if the Banda government had reduced its expenditure on expensive projects. For instance, the BAM was not in favor of Banda's funding of

\footnotetext{
${ }^{517}$ Malawi Internal Political Situation, 1980, BNA: FCO 105/366. See in particular, 'Confidential dispatch from the Bank of England, signed by Mr. J.A. Howard, to the FCO'. September $4^{\text {th }}, 1980$. One of the expensive projects being referred to in the dispatch was an international high school, known as The Kamuzu Academy, solely owned by Banda, built in his home district of Kasungu.
} 
such expensive projects as the Kamuzu Academy; a new Presidential Palace in Lilongwe; and a Faculty of Humanities Building at the University of Malawi. ${ }^{518}$

A diagnosis from the British High Commission staff in consultation with Malawi Government officials, indicated that there were four main causes of the economic downturn by the turn of the 1980s decade, namely: (1) the rocketing global oil prices. Since Malawi was not an oil producing country, she had to rely on oil imports, and hence any price increase on the international market, also affected Malawi; (2) huge debts incurred by the government, including those from the IMF, and the National Westminster Bank. Unfortunately, most of the money was spent on luxurious projects as highlighted above; (3) in 1980, Malawi was also hit by a partial failure of the maize crop (the country's staple food), low returns on tobacco, and dangerous rises in the levels of Lake Malawi; and (4) the underperformance of most state-run companies - parastatals, most of whom had been turned into receivership, while others had been forced to trim their operations, and retrench employees. Hence recommendations were made by the British High Commission in Malawi, for the British Government to continue offering budgetary aid to the Malawi Government. ${ }^{519}$ The same year, the US Embassy in Lilongwe, also made a commitment to provide food aid to Malawi, for an amount of $\$ 9 \mathrm{~m} .{ }^{520}$ The World Bank Economic Report for Malawi released in February 1982, also diagnosed a number of shortfalls in the Malawi economy as of the late 1970s, including (1) the economic challenges posed by the disturbances in neighboring Mozambique, where the civil war which had hit the country since independence from Portugal had

\footnotetext{
${ }^{518}$ Malawi Internal Political Situation, 1980, BNA: FCO 105/366. See, confidential dispatch from the British High Commissioner to Malawi, H.E. Mr. W. Peters, to the FCO, titled 'Malawi Financial Crisis'. August $21^{\text {st }}, 1980$.

${ }^{519}$ Malawi Internal Political Situation, 1980, BNA: FCO 105/366. See, dispatch from the British High Commission in Malawi to the FCO, titled 'Malawi 1980: A Climacteric Year'. July 18 ${ }^{\text {th }}, 1980$.

${ }^{520}$ Malawi Internal Political Situation, 1980, BNA: FCO 105/365. See, dispatch from the British High Commission in Lilongwe, to the FCO, titled 'Malawi Financial Crisis'. May 27 ${ }^{\text {th }}$, 1980. See also Frederick L. Pryor, Malawi and Madagascar: The Political Economy of Poverty, Equity and Growth (Oxford: Oxford University Press, 1990), 47-48.
} 
blocked Malawi's access to the ports of Beira and Nacala, a process which affected Malawi's imports and exports; (2) the falling global prices for Malawi's main export crops, especially tobacco and tea, accompanied by rapid increases in import prices (especially for fuels, fertilizers, and transport), all of which led to a reduction, by twenty-five percent, of the trade output and in flow by the mid-1970s; (3) the Report also deplored the expansion of government expenditures which outstripped the growth in revenues, which led to larger budgetary deficits and increased borrowing from the domestic banking system. ${ }^{521}$ Keith Somerville, who worked as a British Broadcasting Corporation (BBC) correspondent in Malawi in the 1970s and 1980s, reiterated in his 2015 publication that aside from the country's back-tracking from its democratic path, the economic and social conditions were highly appalling. He experienced the decline of the Malawian economy, characterized by fuel shortages, lack of basic consumer goods, including the most basic items as toilet papers. Where food stuffs were available, the prices had skyrocketed. He also reported of increasing levels of impoverishment and malnutrition, which led to high mortality rates among the country's children - coming out of such diseases as measles, diarrhea and malaria. ${ }^{522}$

It was in that perspective that in early 1980, Sir Michael Scott, then out-going British High Commissioner to Malawi, reiterated his government's commitment in supporting the Banda regime. He mentioned, in a newspaper interview, that Britain had continued to be one of Malawi's trading partners, and the largest purchaser of Malawi's exports, particularly tea and tobacco. Britain's principal exports to Malawi were in the form of metals and manufactured goods, transport, and machinery. On bilateral aid, he stated that between 1964 and 1979, Britain had

\footnotetext{
${ }^{521}$ World Bank Report No. 3082a-MAI: "Malawi Growth and Structural Change: A Basic Report". February 1982., ix-xxv.

${ }^{522}$ Keith Somerville, Africa's Long Road since Independence: The Many Histories of a Continent (London: Hurst and Company, 2015), xi-xii. See also "Confidential dispatch, CIA, Directorate of Intelligence, titled "Malawi: Troubled times ahead', dated July $15^{\text {th }}$, 1983." See pp.4-6.
} 
granted aid to the Malawi government amounting to $£ 140$ million. By the close of 1979, the British Government had also converted all outstanding loans owed by the Malawi Government, into grants. Such a call was made to relieve Malawi of the burden of repaying the loans and thus reducing the call on Malawi's foreign exchange resources. He mentioned that it was the British Government's belief that for its former colonies to be stable, it was not just because of political developments, but more importantly there also had to be economic development. Therefore, Britain was not in a position to impose its own will on what system of government its former colonies had selected to pursue, however what was important was that there had to be stable economic development. ${ }^{523}$

On the part of the US government, its "non-conditional" assistance to the Banda regime only stretched to as far as the end of the Cold War hostilities. In the aftermath of the Cold War, the focus of the US Government began to shift, as it began to link its economic aid to the liberalization of the politico-economy. In September 1991, US Vice President, Dan Quayle paid a visit to Malawi to meet with Dr. Banda to urge him to liberalize the country's political system. The following year, in June 1992, the US Congress' Subcommittee on Africa, also met and deliberated on among other things, the deteriorating abuse of human rights and the lack of political liberalization in Malawi. The June $23^{\text {rd }}, 1992$ meeting was chaired by Hon. Mervyn M. Dymally, and focused on events in Malawi, Kenya, and Somalia. The committee heard testimonies of field officers and leaders of

\footnotetext{
523 "Perspective: Sir Michael Scott - No country can afford by itself to fight the war against poverty," Malawi News, January $27^{\text {th }}$, 1980. See also Malawi News. October $8^{\text {th }}$, 1971. "MK120 million given to Malawi since 1964 says Wood". That news article quoted the sentiments of Mr. Richard Wood, the then British Minister of Overseas Development, who was on a State Visit to Malawi, meant to meet with Dr. Banda. See also Malawi News, November $2^{\text {nd }}, 1971$. "CDC Projects in Malawi worth MK10 Million". In that newspaper article, the Malawian Finance Minister, Aleke Banda, commended the role of the Commonwealth Development Corporation (CDC) in investing in some of the country's development projects, including the small-holders tea authority in Thyolo District; Kasungu Flue Cured Tobacco Authority; the Malawi Housing Corporation; the Malawi Hotels Limited; and also NKula Hydro-Electric Power Project in the Lower Shire.
} 
international non-governmental organizations (including a report from Amnesty International) and other political pressure groups from the three countries. In presenting the state of conditions in Malawi, Mr. Herman J. Cohen, then Assistant Secretary of State, Bureau of African Affairs, clearly stipulated that although the US and Malawi had enjoyed cordial relations for a long time, especially due to Malawi's pro-Western policies and values, the US government had now become concerned with Malawi's lack of respect for fundamental human rights and the absence of progress toward a more open political environment. Mr. Cohen stated that the US government was unhappy with such human rights abuses as political detentions, controlled press, harsh laws curbing speech and expression, and the single-party political system. ${ }^{524}$ The Executive Director of TRANSAFRICA, Mr. Randall Robinson, clearly mentioned that the end of the Cold War, meant the US would no longer tolerate human rights abuses in the countries that were beneficiaries of US aid, as follows:

With respect to Kenya and Malawi, both nations have recently had to grapple with internal political movements that are at various stages of maturity. In each case, however, courageous citizens have faced the brunt of brutal government repression at high personal cost.

Today, I call on the U.S. Congress to support these brave and precedented efforts, and to do all it can to bolster the larger movement of democratization in Africa. The United States must take a strong stand to foster the development of the formation of opposition movements in Kenya and Malawi that are preparing the way for the establishment of multiparty societies.

We are entering a new era of global politics, vastly different from the Cold War era. Stability and security interests will no longer mute national concerns about good governance and respect for civil liberties. Kenya and Malawi - both stalwart allies of the United States against the erstwhile 'communist menace' - must now recognize that times have changed along with American expectations. The obstinate rulers of these nations must be urged to follow new trends toward government accountability. We must not forget our responsibility to serve as a catalyst to spur the international pressure that will ultimately nurture the political and economic development of Africa's emerging

\footnotetext{
${ }^{524}$ A Review of U.S. Policy and Current Events in Kenya, Malawi, and Somalia. Hearing before the Subcommittee on Africa of the Committee on Foreign Affairs, House of Representatives. $102^{\text {nd }}$ Congress, $2^{\text {nd }}$ Session. June $23^{\text {rd }}, 1992$. , 7-8.
} 
democracies. The administration must disregard the tunnel vision of the past and begin to acknowledge all atrocities committed by friend and foe alike. ${ }^{525}$

The following spring, in March1993, the concerns raised at the June 1992 Congressional hearing, were followed by a joint resolution released by the US Senate and Congress, following a motion moved by Senator Edward Kennedy, Massachusetts, to withdraw US aid to Malawi unless several conditions were met by the Malawi government. The conditions set in the joint resolution to suspend aid were as follows: the Congress (1) strongly condemns the Malawi government's continued incarceration and harassment of dissidents; the restriction of freedoms of speech, press and assembly; and the repeated, short-term arrests of opposition leaders in order to impede their prodemocracy efforts; (2) further condemns all efforts by the Malawian Government to limit the ability of political parties and popular organizations to campaign in relation to the upcoming referendum; (3) strongly urges the Government of Malawi to consider the recommendations of the United Nations Technical Team on the Conduct of a Free and Fair Referendum on the Issue of a One Party/Multiparty System in Malawi; (4) calls upon the Government of Malawi to release immediately all political prisoners, including Chakufwa Chihana, and demands that the Government immediately cease arresting opponents for the peaceful expression of their views; (5) commends the actions of the United States and the United Nations in support of democratic change in Malawi and the freedom of expression and human rights and encourages the President and the Secretary of State to work closely with other governments to these ends, and; (6) calls upon the President and Secretary of State to ensure that the United States development assistance program bears relation to the Government of Malawi's progress toward an open political system and respect for human rights and to work to ensure that the assistance of other governments and multilateral

\footnotetext{
525 Ibid., 17.
} 
institutions is directed toward these same goals. Furthermore, the joint resolution clearly stipulated that only when the US Congress was satisfied with the changes implemented by the Banda regime, would the US president and his government be given powers to resume financial aid to Malawi. ${ }^{526}$

At the same time, the World Bank, also began to pressure the Banda regime to change its political and economic system. The World Bank officially began its operations in post-colonial Malawi in 1965, following the enactment of the "Bretton Woods Agreement Act, 1965" by the Malawi government, through the National Assembly. Through the 1965 Act, the government of Malawi committed itself to abide by the Bank's rules and regulations, and to accept the terms and conditions of any financial arrangement that the Bank would set under its Board of Governors. The Banda government also committed itself to adhere to all monetary payments that would be demanded by the Bank from time-to-time, which would ensure Malawi's continued membership to the Bank. The Reserve Bank of Malawi, was, under the 1965 Act, designated to be the depository of all funds from the World Bank. ${ }^{527}$

From then onwards, the Bank was involved in financing several development projects in the country. The Bank's first project in the country was to finance the construction of the M1 Road connecting the colonial capital at Zomba and Malawi's current capital city, at Lilongwe. Between 1966 and 1971, when the project was completed, the Bank provided the Banda regime with a sum of $\$ 11,990,000$. In 1974 , a further $\$ 10 \mathrm{~m}$ was approved and released by the Bank for the construction of the Lilongwe-Kasungu Road, Kasungu being Banda's district of birth and origin. In 1977, the Bank approved a further $\$ 10.5 \mathrm{~m}$ for the stretching of the road from Kasungu to the

\footnotetext{
526 The Senate of the United States, $103^{\text {rd }}$ Congress, $1^{\text {st }}$ Session: Joint Resolution regarding the Government of Malawi's arrest of opponents and suppression of freedoms, and conditioning assistance for Malawi. March $26^{\text {th }}$, 1993.

${ }^{527}$ Malawi Government Gazette, February 19 ${ }^{\text {th }}$, 1965: "The Bretton Woods Agreement Act, 1965.”
} 
neighboring district of Mzimba. ${ }^{528}$ One other main project where the World Bank had been heavily involved, alongside the International Development Association (IDA), was the financing of the Lilongwe Land Development Project, where a portion of land covering 1.1 million acres lying to the west of the present-day City of Lilongwe, was earmarked for extensive agricultural production. The project, which cost the Bank a total of $\$ 8.5 \mathrm{~m}$, adopted an integrated model, involving the distribution of farm inputs (such as seeds and fertilizers); funding of agricultural extension services; land re-organization; and the general development of infrastructure (in the form of markets, roads, conservation measures, and other social amenities). The project targeted about half a million people in the area, with a view towards individual ownership of land to ensure the security of tenure and the right of title, with the hope that it would help raise agricultural productivity by increasing the yields through the adopted agricultural methods. ${ }^{529}$

When the Malawian economy began to falter from 1979/80 onwards, it was also the intervention of the World Bank, through its Structural Adjustment Programs (SAPs), which helped to bail out the ailing Malawian economy. ${ }^{530}$ The World Bank recommended a restructuring of the country's economy, which would involve the improvement of the financial viability of the country's

\footnotetext{
528 “The World Bank and Malawi's Main National Highway”. From http://go.worldbank.org/6T9OA3EXJ0 . 2013. Note also that between 1966 and 2013, the World Bank had supplied the Malawi Government with funding amount to $\$ 2.5$ billion.

529 "Project to continue for 15 Years," Malawi News, June 29th 1973 . See also Frederick L. Pryor, Malawi and Madagascar: The Political Economy of Poverty, Equity and Growth (Oxford: Oxford University Press, 1990), 72-75. Pryor highlighted that some of the main projects which the World Bank was involved in Malawi in the 1960s, included the following: (1) The Karonga Rural Development Project, located in the Northern Region; (2) the Lilongwe Land Development Project, in the Central Region; (3) the Lakeshore Project, in the Central Region; and (4) the Shire Valley Agricultural Development Project, in the Southern Province. The four projects lasted for about a decade, before later being replaced by the National Rural Development Program. See also The Lilongwe Land Development Program is IDA Financed. March 1972. Source: Library of Congress (African Section).

${ }^{530}$ A good starting point for studying the SAPs in the so-called Third World is that by Daniel M. Schydlowsky, ed., Structural Adjustment: Retrospect and Prospect (London: Praeger Publishers, 1995). See also Lionel Demery, "Structural Adjustment: its origins, rationale and achievements," in Giovanni Andrea Cornia and Gerald K. Helleiner, eds., From Adjustment to Development in Africa: conflict, controversy, convergence, consensus? (London: Macmillan Press Ltd., 1994), 25-48. See also Nicholas Van de Walle, African Economies and the Politics of Permanent Crisis, 1979-1999 (Cambridge: Cambridge University Press, 2001).
} 
statutory organizations, and also minimizing the banking sector's financial commitments to the public sector. In a confidential dispatch from the British High Commissioner, Mr. W. Peters, following his meeting with Mr. John Z.U. Tembo, the Reserve Bank of Malawi Governor, the latter was said to have thrashed out details of his meetings with World Bank officials who came to Malawi in mid-1980. Mr. Tembo acknowledged that the government was in a deep economic hole, such that it sought more funding than what the World Bank had initially offered. One of the main problems for the economic downturn had been the civil war in neighboring Mozambique, which meant that goods coming into Malawi through Mozambican ports of Beira and Nacala, were blocked. Some of the High Commissioner's sentiments on the Malawi economy were as follows:

As you know from paragraph five of my letter of 26 August, the World Bank appraisal team for the proposed structural adjustment loan began arriving in Malawi some ten days ago. I have quizzed Mr. J.Z.U. Tembo, Governor of the Reserve Bank of Malawi, and Mr. Julius Malange, Principal Secretary of the Ministry of Finance, about the way the negotiations are going. They have been quite frank with me, saying that, initially, the differences between the World Bank team's position and that of the Malawi Government was quite wide; the team came with suggestions for a structural adjustment loan of around \$32 million, whereas the Malawi target was upwards of $\$ 60$ million to $\$ 70$ million. Mr. Tembo was somewhat pessimistic about this when we met on 1 September....Mr Malange appeared satisfied with the direction of the talks and took note of my assurance to him that, when the time came for the appraisal team's recommendations to be studied by the Board, the British representative would do his best to ensure a positive outcome...

Malange is clearly in favor of a high proportion of program aid because this is better adopted to help is Ministry out of its difficult corner; however, even he acknowledged that there should be an admixture of capital aid because otherwise the revenue earning capacity of the Malawi economy could not be expected to grow. Tembo made it clear that he hoped for a judicious mix of program and capital aid. ${ }^{531}$

Following the deliberations, in June 1981, the Minister of Finance, Mr. Chakakala Chaziya, introduced the so-called International Bank for Reconstruction and Development (Structural

\footnotetext{
${ }^{531}$ Malawi Internal Political Situation, 1980, BNA: FCO 105/366. See, confidential dispatch from the British High Commissioner to Malawi, H.E. Mr. W. Peters, to the FCO'. September $5^{\text {th }}, 1980$.
} 
Adjustment Loan) Authorization Bill, 1981, which empowered the Minister to borrow the equivalent of $\$ 15$ million in various international currencies. The proceeds from the loans were to be used for covering the SAPs as prescribed by the World Bank. ${ }^{532}$ The official World Bank Loan Authorization Document indicated that the Malawi Government had committed itself to undertaking a comprehensive economic program for short-term stabilization, the medium-term adjustment and long-term development of its economy. The Loan Agreement, which covered the years 1981 and 1982, covered an amount of $\$ 45,000,000$. The interest for the Loan was pegged at nine and three fifths percent per annum on the principal amount of the Loan withdrawn from timeto-time, payable on June $15^{\text {th }}$ and December $15^{\text {th }}$ each year. ${ }^{533}$ The recommendations that the World Bank passed on to Third World countries and states at the time, had been significantly influenced by the so-called "Washington Consensus," which was tied to the enactment of neoliberal principles and policies. The focus of the consensus (whose main ideas came from two Washington-based thinks tanks, the pro-Republican American Enterprise Institute for Public Policy Research; and the pro-Democrat Institute for International Economics), was to champion the return to the earlier theories that revolved around free, liberal and unfettered markets. The socalled consensus condemned the tenets of the ISI and socialism, as these pertained to the Third World and to the communist regimes of Eastern Europe. Once adopted by the US government, the consensus was transferred unto the Bretton Woods Institutions, and other developmental banks,

532 "MK100 Loan Authority sought by Government - Economy will be restructured, Minister tells Parliament," Malawi News, June $27^{\text {th }}-$ July $3^{\text {rd }}, 1981$.

533 "Loan Agreement (Structural Adjustment Loan) between the Republic of Malawi and the International Bank for Reconstruction and Development". July $2^{\text {nd }}, 1981$. Loan No. 2026 MAI. Note also that a further Structural Adjustment Loan amounting to $\$ 55$ million was agreed between the World Bank and the Malawi Government in November 1983. The borrowed funds were to be used for the Malawi Government's program of economic recovery as a follow-up to the June-July 1981 Loan Agreement. For more details, see The World Bank - "Report and Recommendation of the President of the International Development Association on a Proposed Credit of SDR 51.9 Million (\$55 million) to the Republic of Malawi, for a Second Structural Adjustment Project". November 29 ${ }^{\text {th }}$, 1983. The 1983 Loan Agreement also lamented the heavy losses incurred by the conglomerates of MDC and Press Holdings Limited, and the associated drain the losses had on the Malawian economy. (see pp6-7 of the Report). 
where the US was one of the major financial donors. ${ }^{534}$ Under the neo-liberal turn, there was also the argument that "economic freedom was an indispensable means towards the achievement of political freedom," and that such processes and goals could best be attained "by getting the state out of the way and letting the engines of capitalism run their inevitable course." ${ }^{, 535}$

The World Bank had also instituted several studies since the late 1970s to analyze the main causes of the economic downturn which many sub-Saharan African countries, including Malawi, had begun to face at the time. The most widely-acknowledged of those reports was the so-called "Berg Report" of 1981, named after Elliot Berg, who chaired the World Bank team tasked to analyze the major constraints to development in the continent. The Berg Report focused on some structural forces for Africa's economic stagnation, and grouped the forces as falling under internal and external explanations. The internal forces included questions over underdeveloped human resources, where most governments had to rely on expatriate staff; political and military conflicts in most states since independence; the adoption of colonial systems and structures by most states, including systems of education, health care, and government administration, most of which had limited success; the inheritance of colonial economic systems, and more especially development projects that started in the late colonial era (after the Second World War), which however, had still left many Africans in the realm of subsistence production. That, augmented with limited investment in education, also meant that most African states had limited personnel with access to tertiary education. There was also the general lack or limited access to health facilities, a condition also inherited from the colonial era. The Berg Report also blamed Africa's climatic and geographical conditions, most of which were/are "preeminently tropical," and hence posed as an

\footnotetext{
${ }^{534}$ Howard J. Wiarda, Political Development in Emerging Nations: Is there still a Third World? (California: Wadsworth and Thomson Learning, 2004), 120-121.

${ }^{535}$ Michael E. Latham, The Right Kind of Revolution: Modernization, Development, and U.S. Foreign Policy from the Cold War to the Present. (Ithaca: Cornell University Press, 2011), 175-182.
} 
obstacle to development, due to unfertile soils, most of which had deficiencies in organic materials. Lastly, Africa's rapid population growth, which was no longer able to fit into African agrarian systems of extensive land use, such as the shifting cultivation, long farrow periods, and the limited use of manure and off-farm inputs. The external forces, as highlighted in the Berg Report, included the following: the soaring of oil prices at the international market, especially the two oil price hikes of 1973-74 and 1978-80, following disturbances in the Middle East, a condition which led many countries to fall into debts to cover the costs of importing the oil; there was also the swelling of external debts, incurred by most governments to meet the demands for other essential commodities, at a time when most African products had not been doing well at international markets due to various trade-restriction based policies. ${ }^{536}$

Similar sentiments, as those raised in the World Bank and by the Berg Report, were also highlighted by the former US Secretary of Defense, Robert S. McNamara, in a public lecture, on November $1^{\text {st }}, 1985$, which was hosted by the World Bank. His speech highlighted four critical challenging areas which sub-Saharan African countries, including Malawi, faced during the 1980s. Firstly, he lamented the declining levels of per capita domestic growth rates which had begun to fall by the late 1970s. To concur with the findings of earlier World Bank reports, McNamara argued that the economic challenges had both domestic and international causes. Domestically, he pinpointed the over-valued exchange rates that discriminated against exports; mounting fiscal deficits; and a variety of burdensome government interventions and controls in the production process. He also blamed what he termed "the encroachment of the state or the political elite" in almost every economic activity, who were only interested in self-accumulation rather than in the

536 The World Bank, Accelerated Development in Sub-Saharan Africa: An Agenda for Action (Washington, DC, 1981), 1-23. 
development of the state. The leaders of African countries were also blamed for initiating poor economic policies, most of which had increased the debt crisis. Some of the global or international economic forces included the severe decline in prices of commodities; the persistent recessions; and the increasing protectionism by international players. The second significant challenge, as highlighted by McNamara, was the rampant growth of population in most African countries, an issue which he referred to as "a ticking time bomb" in most of the countries. The challenge for many countries for the high population growth rates, with population densities of as high as forty persons per square kilometer, was the access to basic resources and states' ability to provide amenities such as health care and education. The other equally important challenge for African states was the widespread ecological degradation across the continent. He deplored such processes including widespread deforestation, soil erosion, the falling water tables, and the general overusage of the ecosystems. Such processes were responsible for the persistence of drought and subsequent famines in most of sub-Saharan Africa. Lastly, he deplored the general lack of financial resources in most of the countries, and called on the international community to come up interventions that would help the countries in such areas as funding to support structural adjustments essential for long-term economic growth; investing in physical infrastructure and human resource development; support the fight against desertification and environmental degradation; and also for humanitarian efforts to assist the victims of famine. ${ }^{537}$

The following was the chronology of events of the intervention of the Bretton Woods institutions in Malawi between 1979 and 1986: October 1979 (IMF Stand-by Agreement, to run for 30 months); April 1980 (IMF Revised Stand-by Agreement, to run for 24 months); June 1981 (World

\footnotetext{
${ }^{537}$ Robert S. McNamara, "The Challenges for Sub-Saharan Africa." Speech delivered at the Sir John Crawford Memorial Lecture. Washington D.C., November $1^{\text {st }}, 1985 ., 1-32$.
} 
Bank Structural Adjustment Loan I); August 1982 (IMF Stand-by Agreement, to last for 12 months); September 1982 (Paris Club Agreement on Debt Rescheduling); March 1983 (London Club Agreement on Debt Rescheduling); April 1983 (World Bank/International Fund for Agricultural Development Smallholder Fertilizer Loan); September 1983 (IMF Extended Fund Facility Agreement, to last for 36 months); October 1983 (Paris Club Agreement on Debt Rescheduling); December 1983 (World Bank Structural Adjustment Credit II); December 1985 (World Bank Structural Adjustment Credit III); March 1986 (Consultative Group Agreement on External Aid); April 1986 (Cancellation of IMF Extended Fund Facility Agreement); and December 1986 (World Bank Supplement to Structural Adjustment Credit III). ${ }^{538}$ From 1979 onwards, staff from both the IMF and World Bank played an important role to help galvanize and re-construct the Malawian economy, sometimes overseeing the spending or utilization of funds that came from the Bretton Woods institutions and other international money-lending institutions. Among other recommendations made, was that the government had to relinquish its hold on parastatals, such as Malawi Housing Corporation (MHC); Malawi Book Service (MBS); Blantyre Water Board; Lilongwe Water Board; and the Electricity Supply Commission of Malawi (ESCOM), through what became known as the privatization process. That also included the overhaul the financial and management structure of the MDC, Press Holdings Limited, and ADMARC. ${ }^{539}$ In other words, the SAPs recommended the dilution of the "overdeveloped" state, which had been a main characteristic of the Malawian state since the late colonial period. Other

\footnotetext{
${ }^{538}$ Ravi Gulhati, Malawi: Promising Reforms, Bad Luck (Washington, DC: The World Bank, 1989), 36.

${ }^{539}$ Ibid., 45-49.
} 
scholars even argue that the SAPs in a way "transferred sovereignty away from African states into the hands of the Bretton Woods Institutions". ${ }^{540}$

From the World Bank's long history of involvement in Malawi's economic planning and development, it was thus unsurprising that the Bank was among the international donor and money-lending agencies (influenced by the principles of the Washington Consensus) that was involved in the push for economic and political liberalization in Malawi. Since the World Bank was historically of Western origin, it was, in ideological orientation bound to favor the liberal values promoted by the USA and its Western allies especially after the economic downturn of the 1970s. The main target at the time were the economically vulnerable states, many of which were "developmental" in structure and ideology. The liberal values being promoted since the early 1980s shifted from merely economic concerns towards calls for political change as well. As posited by David William and Tom Young, since the late 1980s, the World Bank had begun to employ the concept of "governance" in its approach towards the "Third World" where it applied the SAPs. The concept of "governance" had two main elements, where, firstly, there was a "technical stream," concerned with the building blocks of a liberal capitalist state focusing on the rule of law. Secondly, there was the "civil society stream," with special emphasis on the notion that a vigorous civil society would help to hold states to account. Through civil society institutions, the Bank would emphasize the recognition of certain liberal political virtues without the Bank itself necessarily being in the forefront advocating for liberal democracy. By then, the Bank had also come to realize that the SAPs were not producing positive results in many countries, for which some of the reasons were to be found in social and political systems of the target countries. These

\footnotetext{
${ }^{540}$ See for instance, James Ferguson, Global Shadows: Africa in the neoliberal world order (Durham: Duke University Press, 2006), 77-79 and 100-101.
} 
factors, combined with the "triumph" of the West led by the USA during the Cold War, compelled the Bank to insist on pushing the "liberal agenda" in its approach to the countries that received aid and loans under the SAPs. The spread of the "liberal ideology" then was also fueled by the globalization agenda, in which predominantly Western ideologies, such as "liberalism" were spread and encouraged, at times undermining the sovereign rights of "Third World" countries to choose their own political trajectories. ${ }^{541}$

In the case of Malawi, World Bank personnel participated in and chaired what was designated as "The Consultative Group," which focused on recommending liberalization measures during the late 1980s and early 1990s. After its May 1992 meeting, the Consultative Group, through the World Bank headquarters, communicated the following message to Banda:

\section{Your Excellency,}

The Consultative Group meeting chaired by the World Bank, which took place in Paris, May 1113, 1992, raised a number of issues of fundamental importance to the future of Malawi. While all donors paid tribute to Malawi's strong record of economic management, deep concern was expressed about the lack of progress in basic freedoms and human rights in Malawi, and the need for early implementation of appropriate reforms in these areas. Most donors refused to make any new aid commitments at the meeting, leaving a significant gap in respect of Malawi's external financing requirements. Donors agreed that further consultations among the Consultative Group would take place only after they see tangible and irreversible evidence of a fundamental transformation in the treatment of human rights issues in your country.

This is a critical juncture in Malawi's history. The very severe drought currently afflicting the country and the recent industrial unrest have made the economic situation even more precarious, and threaten to undermine the economic reforms pursued by Malawi in recent years. Given the concerns, the donor community will be carefully watching developments in Malawi to monitor progress in improving the environment for basic freedoms and human rights. While we are planning to continue to process new loans in support of investments and policy reforms, concrete action by the Government on issues of concern to the donor community is essential if the

\footnotetext{
${ }^{541}$ David Williams and Tom Young, "The World Bank and the liberal project," in David Moore, ed., The World Bank, Development, Poverty, Hegemony (South Africa: University of KwaZulu Natal Press, 2007), 203-216. See also David Moore, "Sail on ship of state: neoliberalism, globalization and the governance of Africa," in David Moore, ed., The World Bank, Development, Poverty, Hegemony (2007), 227-261. See also Graham Harrison, "The World Bank and the construction of governance states in Africa," in David Moore, ed., The World Bank, Development, Poverty, Hegemony (2007), 369-386.
} 
combination of multilateral and bilateral financing required by the economic adjustment program is to remain in place. I hope, therefore, that your Government will take all necessary and urgent steps to follow up on the conclusions of the Paris meeting, thus allowing an early resumption of consultations on future donor assistance to Malawi.

Sincerely,

\section{Lewis T. Preston}

\section{(President, World Bank). ${ }^{542}$}

The cutting of the budgetary and developmental aid to the Malawi Government occurred at a particularly critical juncture in the country. The country had been undergoing a drought which contributed to massive food shortages, as well as shortages of foreign currency needed to purchase foodstuffs and other manufactured products from outside the country. The 1991-92 drought, which also affected other Southern African countries, was particularly more devastating for Malawi, as in part, its mitigation was also challenged by the civil war in neighboring Mozambique, which saw an increase in the number of refugees trekking into Malawi, and also more importantly the cutting off of Malawi's trade routes to the sea through the Mozambican ports of Nacala and Beira. Such conditions helped to weaken further Banda's grip on the country's political and economic system, especially where the precedence had now been set that his government could not go on without international donor support. ${ }^{543}$

\footnotetext{
542 'Letter from the World Bank President, Lewis T. Preston, to Dr. H.K. Banda'. May 27 ${ }^{\text {th }}$ 1992. See also "Letter from Stephen Denning, Director of the Southern African Department, World Bank, to Hon. L.J. Chimango, Minister of Finance in Malawi." May 27 $7^{\text {th }}$ 1992. Source: H.K. Banda Archive. For a study that focuses on the World Bank and its influence on political and economic policy changes in Africa, see Graham Harrison, "The World Bank, governance and theories of political action in Africa," British Journal of Politics and International Relations, 7, no.2 (May 2005): 240-260. While initially the Bank did not entangle itself in recommending political changes, since the early 1980s, it pursued policies that called for liberalization, at both economic and political levels. See pp.241-247.

${ }^{543}$ Tony Woods, "The High Costs of Obstinacy: Banda hangs on," Southern Africa Report, 8, no.2 (November 1992):17-21. See also Edward Clay, et al., "Malawi and Southern Africa: Climatic Variability and Economic Performance.” World Bank Working Paper Series no.7, 2003, viii.
} 


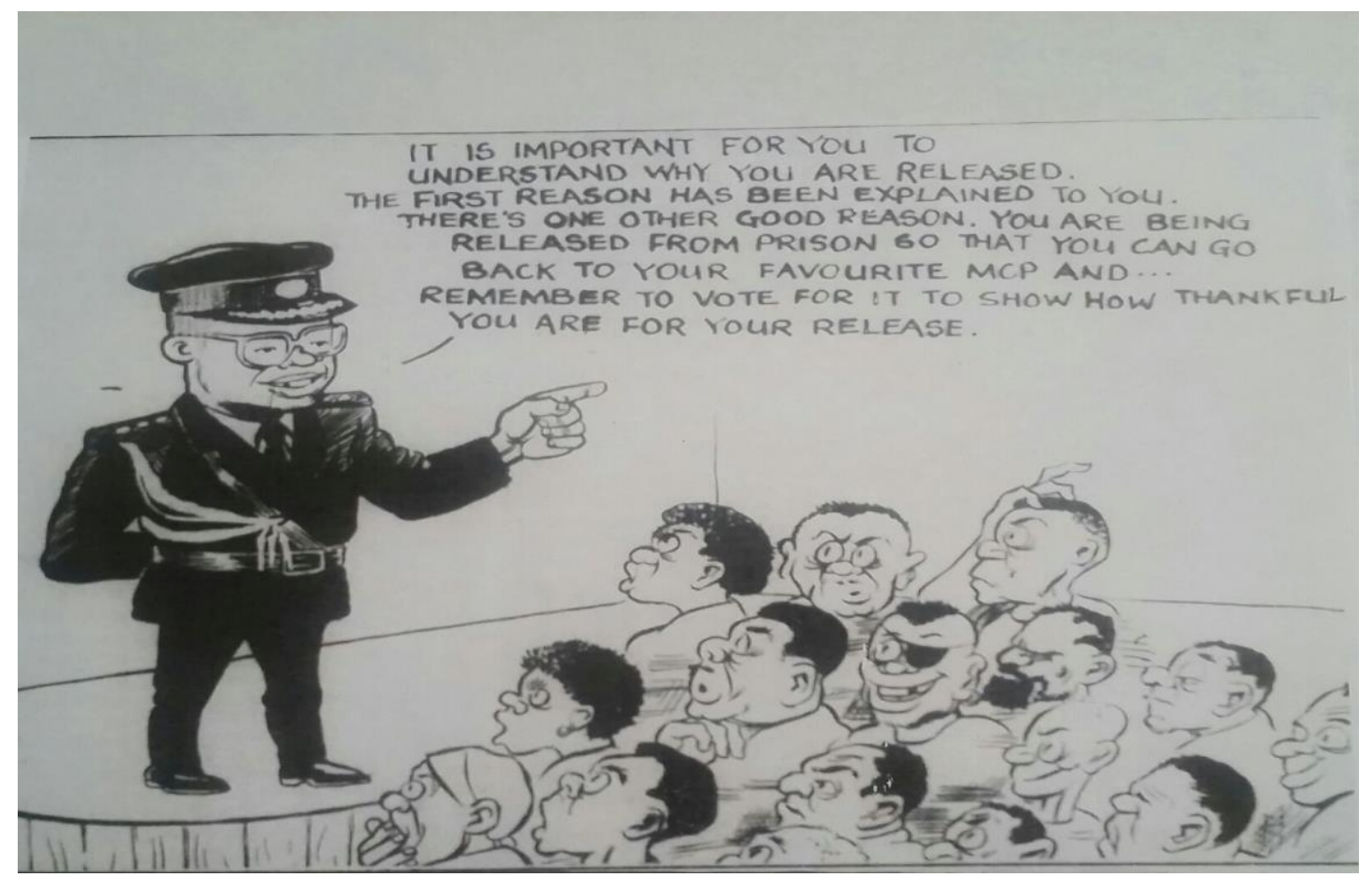

Figure 7.1: A cartoon depicting the Inspector General of the Malawi Police Force, c.1993, Mr. McWilliam Lunguzi, instructing political prisoners to be thankful for their release (following both domestic and international pressure for political liberalization) and vote for Dr. Banda and the MCP. November 1993. Source: The Enquirer, November 1993.

\section{Domestic forces for regime change}

The international pressure for political and economic liberalization, and more especially the pulling out of budgetary aid to the Malawi Government, opened room for local opposition elements to come out in the open to challenge the Banda regime. Many had begun to openly criticize the regime, especially mocking Banda's claims that Malawi was a democratic country, ${ }^{544}$ when it was a one-party state. There was also a unanimous outcry that despite Banda's touting of his government as an economic success story, the claimed material benefits had not necessarily

\footnotetext{
544 "Malawi is a Democratic State," Malawi News, May $16^{\text {th }}$, 1969. From time-to-time, Banda used to argue that Democracy in Malawi should not be compared to or equated to Democracy elsewhere, especially in the West. What was important, in his view, was that people had the choice to elect their local representatives. See also Malawi News, June 29 $9^{\text {th }}$, 1974. "Malawi: A One-Party State by will of Majority."
} 
trickled down to improve the livelihoods of the rural poor and the urban working classes. It was thus inevitable that the early pressure groups called for the liberalization of both the economic and political systems, a "song" which at the time was being sang loudly by the international community.

The immediate internal pressure for political and economic liberalization, and the general respect of people's human rights began following the issuing of the so-called "Pastoral Letter" by the country's Roman Catholic Bishops, titled "Living Our Faith," at the beginning of March 1992. The Letter, which was duplicated into 16,000 copies and distributed to Catholic diocese and churches across the country, deplored the general and rampant abuse of people's rights under the Banda regime, and the alarming levels of state inefficiency which had contributed to the rise in levels of poverty. Although Banda had tried to suppress the Bishops by threatening them with arrest, setting on fire the publishing house that published the letter, and declaring the Pastoral Letter to be a seditious document, the threats fell on deaf ears, and only seemed to fuel further unrest across the country. It was in the aftermath of the success of the Bishops' Letter that several pro-democracy movements also came out in the open to challenge Banda's authority. The earliest of them to appear were the Interim Committee for a Democratic Alliance (ICDA), which later became the Alliance for Democracy (led by a Trade Unionist, Chakufwa Chihana, whom Banda had dismissed from the MCP in the early 1960s). The other key pro-democracy movement was the United Democratic Party (UDP), later United Democratic Front (UDF), led by Bakili Muluzi (the man who later succeeded Banda), alongside his fellow businessmen who had not been part of the regime for some time, having fallen out of favor with Banda or his cronies at some point. ${ }^{545}$ It was

\footnotetext{
${ }^{545}$ See Paul Chiudza Banda, "Hastings Kamuzu Banda: How the Cold War Sustained Bad Leadership in Malawi," In Baba G. Jallow, Leadership in Postcolonial Africa: Trends Transformed by Independence (New York: Palgrave Macmillan, 2014), 39-40. Apart from the Roman Catholic clergy, in June 1992, the leadership of the Church of Central African Presbyterian (CCAP), also wrote their own letter to the head of state. It was entitled "The nation of Malawi
} 
highly likely that the Bishops and the opposition pressure groups were significantly encouraged by the stance that had been taken by the international donor community, to deny budgetary aid to authoritarian governments in the Third World, including Malawi. The international donor community, as highlighted above, was much concerned with withholding their monetary aid to countries that continued with "keeping the gate shut," and thus left little or no room for political and economic opportunities for the majority.

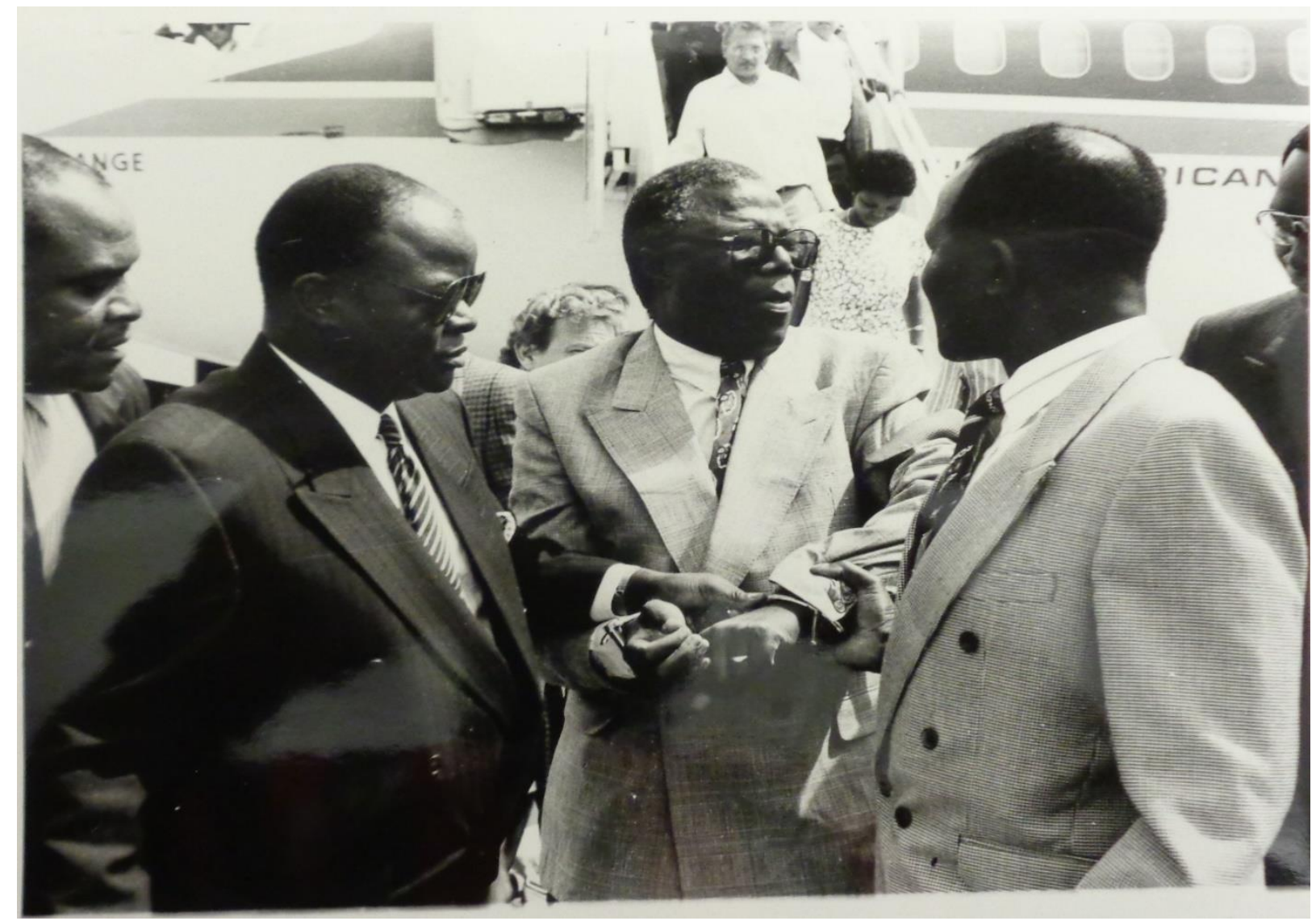

Figure 7.2: Chakufwa Chihana (center), leader of the ICDA, was immediately placed in handcuffs by Banda's state agents, as he alighted from a plane at Kamuzu International Airport, 1992. Notice that in the background, some passengers were still alighting from the plane. Source: H.K. Banda Archive.

in crisis," and among other issues, addressed the country's appalling human rights record. See Tony Woods, "The High Costs of Obstinacy: Banda hangs on," Southern Africa Report 8, no.2 (November 1992): 19. 
For instance, when one analyzes the campaign messages and statements of the leaders of the promulti-party democracy movement, it is clear that most of them being businessmen had wanted a share of the national "economic cake." They often equated or associated ascendancy to political power with the access of economic or material resources, with which to reward their own clientele, which Jean-Francois Bayart described as "politics of the belly." 546 The man who succeeded Banda as President, Bakili Muluzi, had served Banda both in the MCP (as Secretary General), and also as a cabinet minister. He then resigned from the Party in the late 1979s, to concentrate on his personal businesses. In the business sector, Muluzi was also prominent, as he held such positions as the Deputy Chairman of the Malawi Chamber of Commerce and Industry; Chairman of the Southern African Development Community (SADC) National Business Council; and, as of 1993, he was the Chairman of the Malawi Road Transporters Association. In a newspaper interview, in the run-up to the 1994 general elections, which Banda lost, Muluzi was in the forefront to call for a liberalization of the economy, which he argued had been monopolized by Banda and his cronies. He made the following remarks:

Take the Banking sector for example. Malawi has only two banks. The Chairman of Commercial Bank is the Chairman of Press Corporation, where the Chairman of National Bank is employed. Press has substantial shareholding in both banks which are effectively one bank. You cannot expect to have a free competitive banking sector in that way. Another example is that the same Chairman is also the Chairman of Air Malawi and Minister of State in the President's Office. As a result of his influence, all government travel bookings are made directly with the airline. This creates a monopoly of the Travel Agency sector by the Airline and in the process private agencies cannot thrive. The Travel Agency Sector in Malawi is not a free and competitive sector. There are scores and scores of examples I can give you.... Look at ADMARC. They have a complete monopoly over all smallholder tobacco in Malawi. The average man producing tobacco has no access to a competitive market where a price can be obtained

\footnotetext{
546 Jean-Francois Bayart, The State in Africa: The Politics of the Belly, $2^{\text {nd }}$ edition (Cambridge, UK: Polity Press, 2009), 228-259. In using the phrase 'politics of the belly', Bayart argued that it could be used to refer to a number of instances, characteristic of African politics, including: (1) the high levels of corruption; (2) where political power is passed on to one's relations; (3) the food shortages and the politics around them; (4) the notions of personal aggrandizement for most leaders; (5) the high levels of nepotism in most countries; and also (6) the high levels of corpulence by the political elite.
} 
on the basis of market forces. Instead, ADMARC sets prices which by all means guarantee them a profit, and I mean a profit. There are too many distortions in the economy. ${ }^{547}$

There was also a significant contribution by junior workers in both the main stream civil service and state-run companies (the so-called parastatals), who embarked on various strikes and demonstrations between 1992 and 1994. In April and May 1992, for instance, policemen shot at and allegedly killed over thirty demonstrating workers in the city of Blantyre. In May 1992 (May $6^{\text {th }}$ to $8^{\text {th }}$ ), for instance, workers from David Whitehead fabric factory (which was partly owned by MDC), embarked on widespread demonstrations in the city of Blantyre, where their actions led to the looting and destruction of property which belonged to the Banda clique, especially targeting the People's Trading Center (PTC) chain of stores. Apparently, the PTC stores were run by the PGC. That also helped to indicate the close connection between the people's economic and political grievances. The massacre of the unarmed demonstrators was carried out by the Malawi Police after the Army had allegedly refused to participate in the annihilation of anti-government demonstrators or rioters, of whom twenty were mercilessly massacred within two days. ${ }^{548}$ By August 1993, junior civil servants had also given an ultimatum to Banda to give them a 100 percent salary increment, and also a general review of their own conditions of service. Having had their demands ignored, the junior civil servants went on a strike on September $2^{\text {nd }}$, 1993, blocking major roads in the cities, especially in Blantyre, where Banda had his official residence. Some of the striking civil servants could be heard airing out their grievances against the regime, as follows: "we also want to lead comfortable lives...we have been surviving on okra, mustard leaves, and

547 "Muluzi and his perspectives on the Malawi economy," The Enquirer, August $2^{\text {nd }}$ to $8^{\text {th }} 1993$. Note that the 'Chairman' Muluzi was referring to was Mr. John Z.U. Tembo, who was the Uncle to Ms. Cecilia Kadzamira, Banda's so-called "Official Hostess."

548 "Our Politicized Police Force," The Enquirer, November $2^{\text {nd }}$ to $8^{\text {th }} 1993$. See also Tony Woods, "The High Costs of Obstinacy: Banda hangs on," Southern Africa Report 8, no.2 (November 1992): 17-21. 
other wild vegetables without tasting meat all these years. So, we now want a better life.",549 University students, from the two constituent colleges of the University of Malawi, namely Chancellor College and the Polytechnic, also joined the striking and demonstrating workers. The Malawi Police Force responded by arresting seventy-five students at the Polytechnic, while many were also beaten up and tortured by the security forces. ${ }^{550}$

By the early 1990s, the situation was also made complicated by Banda's aging status (he was in his early 90s), which also significantly affected his grip on both the country's economy and political dynamics. As I have argued above, the economic downturn which the country had been experiencing since the late 1970s and throughout the 1980s, needed a steady hand, which Banda could obviously not provide, due to both old age and ill-health. In late 1993 (October 2nd, 1993) for instance, the president underwent a brain surgery at a South African hospital (Garden City Clinic in Johannesburg), such that for the remainder of that year, he was replaced by an interim Presidential Council, made up of a triumvirate of cabinet ministers, John Z.U. Tembo, Gwanda Chakuamba, and Robinson Chirwa. Each of the three men represented the country's three main administrative regions, hereafter, Central, Southern, and Northern Regions, respectively. That move was necessary since Banda did not have a vice president throughout his thirty-year reign, therefore the Presidential Council filled the void left by the ailing Banda. ${ }^{551}$ Under the 1966 Constitution, a provision was made under Chapter III, Section 13, for a Presidential Council to be appointed under the following conditions: "Whenever there is a vacancy in the office of President,

\footnotetext{
549 "Strike smells politics - Civil Servants return to work," The Enquirer, September 9 $9^{\text {th }}$ to $16^{\text {th }} 1993$.

550 John Lloyd Lwanda, Kamuzu Banda of Malawi: A Study in Promise, Power and Legacy (Zomba: Kachere Series, 2009), 480-481.

551 "Presidential Council - Malawi heads for a Constitutional Crisis," The Enquirer, October $12^{\text {th }}$ to $18^{\text {th }} 1993$. Note that the international community had already been concerned with Banda's ageing since the early 1980s, and often raised this in their confidential diplomatic and intelligence reports. See for instance, "Confidential dispatch, CIA, Directorate of Intelligence, titled 'Malawi: Troubled times ahead,' July 15 ${ }^{\text {th }}, 1983$ '.
} 
or the President is so incapacitated as to be unable to appoint a Presidential Commission." The constitution thus provided for such a council to be appointed, to be headed by the Secretary General of the Party (MCP); to be joined by two cabinet ministers, each of whom had to be an executive member of the MCP; and that the said Presidential Council would remain in power until a new President assumed office. ${ }^{52}$ An analysis of the constitutional provision leading to the appointment of the Presidential Council, in that case, meant that since he was not dead, then there was no vacancy, however, he was incapacitated, which meant that he was unable to appoint a Presidential Commission. For a man who was in his 90 s, to undergo a brain surgery meant that there was a significant reduction in his mental and physical capacities, and perhaps not worthy to continue performing the functions of Head of State and Government. Even when he resumed his position as President in early 1994, he was still not in tip-top shape. During the campaign period for the 1994 general elections, Banda had to cancel or postpone some scheduled public rallies due to his deteriorating health condition. There were also rumors circulating in the country that he had been flown back to South African for a follow-up brain surgery. In early May 1994, he also turned down the invitation to attend the swearing in ceremony of Nelson Mandela in South Africa, having received medical advice not to fly long distances. Instead, he sent a delegation of three cabinet ministers, namely: John Z.U. Tembo (Minister of State); Hetherwick Ntaba (Minister of Foreign Affairs); and Gwanda Chakwamba (Minister of Home Affairs). ${ }^{553}$

Following the pro-multiparty outcome of the June 1993 National Referendum (63 percent voted in favor), there were several changes brought in that eventually reduced some of Banda's powers. It was when the Presidential Council was in power that some constitutional amendments were

\footnotetext{
${ }^{552}$ Republic of Malawi Constitution, 1966. Chapter III: The President.

553 “Kamuzu's Health Doubtful," The Independent, May $10^{\text {th }}$ to $16^{\text {th }}, 1994$.
} 
made to liberalize the political and economic systems. In November 1993, the National Assembly convened, under pressure from both the international and local pressure groups, to repeal some of the country's repressive laws. The internal pressure came from such groups as the Public Affairs Committee (PAC), made up mainly of representatives from the clergy; and the National Consultative Committee (NCC), which mainly comprised of politicians and businessmen; who held discussions with the Government side, represented by a Presidential Committee on Dialogue (PCD). Among the amendments made, were the repeal of the Forfeiture Act; amendment of the Preservation of Public Security Act (associated with "detention without trial"); and also, the amendment of the Decency in Dress Act (which previously prohibited women from wearing miniskirts or any such short dresses). The meeting also agreed to disarm the MYPs and the Youth Leaguers, as there was no longer need to maintain party-paramilitary wings. ${ }^{554}$ In mid-September 1993, Banda was also forced to relinquish the powers and/or honor he enjoyed as the "life president" of the country, while he retained powers to be life president of the MCP. Section IX of the country's constitution, which conferred Banda the honor of being a "life president" was repealed, following consultations involving the PAC, NCC, and PCD. The report sent to Dr. Banda on the need to repeal the said Section clearly stipulated that the Section was no longer compatible with the spirit of the new multi-party democracy dispensation, hence the need to repeal the Section. Banda was however assured that, should the MCP win the 1994 general elections, then the title of 'Life President' would be re-conferred upon him. ${ }^{55}$

While the government side dilly-dallied to disarm the MYP, it was an altercation in early December 1993, between MYP members (from Kaning'ina MYP Base) and Malawi Army soldiers

\footnotetext{
554 "Editorial," The Enquirer, November 23 ${ }^{\text {rd }}$ to $29^{\text {th }} 1993$.

555 "Memorandum to His Excellency, the Life President - Repeal of Section IX of the Constitution." From: H.M. Ntaba, Vice Chairperson of the Presidential Committee on Dialogue. September 17 ${ }^{\text {th }}$, 1993. Source: H.K. Banda Archive.
} 
(from Moyale Barracks), which helped to significantly change the course of events. An altercation which started at a pub in the northern region city of Mzuzu, between some soldiers and MYP members, soon became a country-wide battle between the two camps. The MYP members involved in the altercation left the pub to collect firearms from a nearby MYP base, and waylaid the soldiers, on their way out of the pub. They managed to kill one soldier and wounded three others. One of the wounded soldiers died the following day, December $3^{\text {rd }}, 1993$. That began an all-out fight between the two sides, with the soldiers attacking MYP offices and camps throughout the country to disarm the Youth Movement in what was locally named as "Operation Bwezani" (literally meaning "operation give back"), in reference to the fire arms which Banda diverted to the MYP, as they were originally supposed to be for use by the Malawi Army soldiers. During the operation, which nearly turned into a civil war, the soldiers ransacked MYP offices across the country, attacked members of the MYP and their households, and also created room for civilian demonstrators and sympathizers to attack business premises known to have been under the ownership of Banda and his inner-circle, especially the People's Trading Center (PTC) chain of stores, which was run by the Press Group of Companies. In the capital city, Lilongwe, the soldiers attacked the headquarters of the MYP, known as Youth House; they also attacked and nearly demolished the Kamuzu Institute for Youth, which was the sports mecca of the Youth Movement. Furthermore, truckloads of captured members of the MYP were also driven across the capital city to an unknown location. In the ensuing disturbances, especially in the country's main cities, more than ten civilian deaths were also reported. It was then that the Presidential Council issued a directive, on December $5^{\text {th }}$ for the MYPs to be totally disarmed. ${ }^{556}$

\footnotetext{
556 “Malawi Army - From Silence to Thunder," The Enquirer, December $7^{\text {th }}$, 1993. See also The Chronicle, December 1993, "Malawi Army disarms Kamuzu's Army." See also James Tengatenga, "Operation Bwezani: A Theological Response". In Matembo S. Nzunda and Kenneth R. Ross, eds., Church, Law, and Political Transition in Malawi, 1992-'94 (Gweru, Zimbabwe: Mambo Press, 1995), 101-109.
} 
Rather surprisingly, at the end of 1993, the Malawi Army General, General Yohane, a Banda appointee, was "forced" to retire early from his position, allegedly due to condemnation from the civil society, especially the National Consultative Council (NCC), following continued Army repression of MYP members and MYP premises, and rumors of continued unrest in the Army, well into 1994. He was forced to retire alongside other top Army brass, Brigadier Manyozo and Major-General Liabunya. ${ }^{557}$ In the run-up to the May 1994 general elections, however, there were some anxieties spreading across the country following rumors that most of the MYP members, especially those from the Security Branch, had actually not been disarmed, but had actually escaped into neighboring Mozambique, where they set up a camp at Milanje, to prepare an all-out war of revenge against the Malawi Army and any other party which would win the 1994 general elections other than the MCP. There were rumors that they run-away MYPs were still under the command of John Z.U. Tembo, who had become a de-facto leader of the country, due to Banda's old age and ailment. ${ }^{558}$

Banda subsequently lost the May $17^{\text {th }}, 1994$ general elections, which marked the end of an era of one of Africa's longest serving dictatorships. The presidential election was contested among four candidates, namely: Dr. Banda (MCP); Bakili Muluzi, from the United Democratic Front (UDF); Chakufwa Chihana, from the Allinance for Democracy (AFORD), and; Kamlepo Kalua, from the Malawi Democratic Party (MDP). The statistical results of the 1994 General Elections, that ousted Banda from power, were as follows: Bakili Muluzi of the UDF (47.2 percent); Hastings Kamuzu

557 "Stop Press - General Yohane Retires," The Chronicle, December 1993.

558 "Army must detain Tembo - MYP," The Chronicle, February $15^{\text {th }}$ to $21^{\text {st }} 1994$. The newspaper article claimed to have been in touch with some of the run-away MYPs in Mozambique, who demanded that John Z.U. Tembo be arrested for his role in the atrocities committed by the MYPs. The exiled MYPs were also said to have complained about being neglected by Tembo and others. 
Banda of the MCP (33.5 percent); Chakufwa Chihana of AFORD (18.9 percent); and Kamlepo Kalua of MDP (0.5 percent). ${ }^{559}$

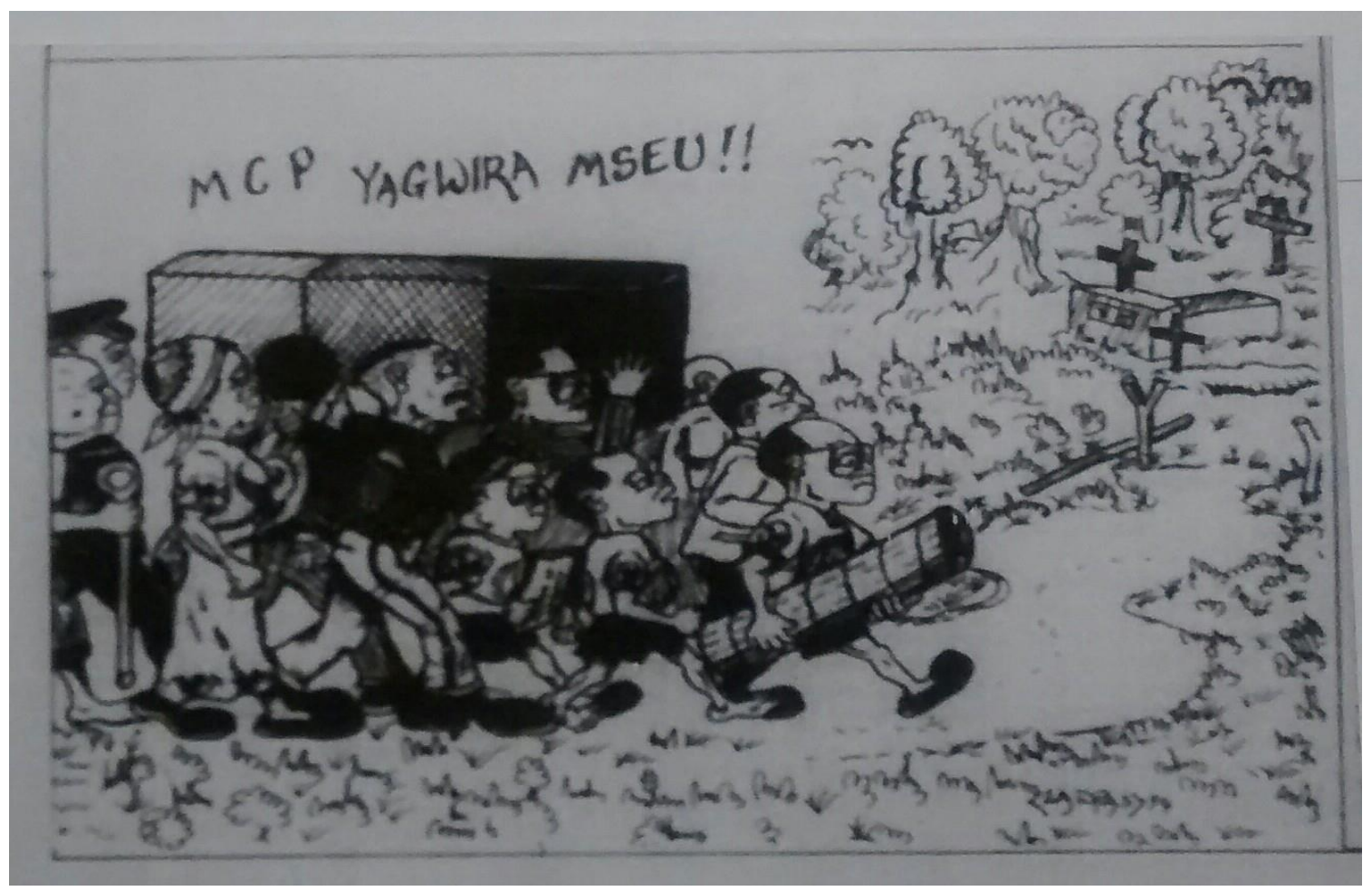

Figure 7.3: A cartoon depicting the likelihood that Dr. Banda and his MCP were on their way to losing the May 1994 General Elections. The cartoon was published merely four days before the elections and depicted purported MCP members taking their party's coffin to the graveyard for burial. The phrase 'MCP yagwira mseu!!' was used to represent the notion that 'the MCP was on its way to the graveyard, literally'. Source: The Enquirer, May $16^{\text {th }}$ to $19^{\text {th }}, 1994$.

The following were Banda's parting words to the Malawi nation on May $19^{\text {th }}, 1994$, a statement which I argue as I close the discussion, marked the end of the post-colonial state, and ushered in a new economic and political dispensation in the country, from May 1994 onwards.

${ }^{559}$ See H. Meinhardt, Free at Last! Malawi’s Democratic Transition (Lilongwe: NICE, 2004), 316. 


\section{Bwanas and Donas,}

The general elections which we were all waiting for have now come and passed peacefully and orderly.

Although the results have not been officially confirmed and announced, there is every indication from the votes that have been counted so far, and announced on Malawi Broadcasting Corporation (MBC), that Mr. Bakili Muluzi is the clear winner on the contest for the Presidency.

I wish to congratulate him wholeheartedly for his victory. May I offer him my full support and cooperation as he takes over the Presidency of this country. As one of the incoming opposition parties, I wish to assure him that the Malawi Congress Party (MCP) will work with the United Democratic Front (UDF) Government in building a better democratic Malawi.

Personally, I wish to thank all Malawians for having allowed me to be your leader for the past thirty-one years. You listened to me when I requested you to uphold the four cornerstones of the Malawi Congress Party, namely: Unity, Loyalty, Obedience, and Discipline. In a way, those have served as pillars for our long-standing political stability and for continuing social and economic development....

I am aware that politicians said so many unkind things about each other during this heated campaign. This is the nature of partisan democratic competition. Now is the time to bury all our political differences and work together for a united and prosperous Malawi.

\section{Bwanas and Donas, \\ Thank you very much. ${ }^{560}$}

\section{The state-of-affairs in the post-Banda era}

Since the downfall of the Banda regime in 1994, the Malawian state has undergone several substantial constitutional, political, and economic changes. Although some elements of the Banda regime still linger on, including those of police brutality, I argue that we should not continue to refer to the state as a "post-colonial state." The systems and practices that still linger on are certainly there only in "diluted" form and thus must not be attributed as having emanated from the colonial period.

560 “Ngwazi congratulates Muluzi," Daily Times, May 20"th 1994. 
For instance, in 1995 a constitution was enacted to go along with the new multi-party democratic dispensation, which among other things brought back the bill of rights which had been removed from the constitution since 1966. There were also other human rights-related amendments, including the creation of the Malawi Human Rights Commission, the office of the Ombudsman, and the clarification of the role that the police force would play in democratic era Malawi. For instance, the police were now compelled not to take orders from politicians, not to become members of a political party, and that they had to discharge their duties with impartiality ${ }^{561}$ Under the 2010 Republican Constitution, as amended, the name of the police was also changed from a Police Force to Police Service, hence the current name of Malawi Police Service (MPS). ${ }^{562}$

There have also been other reforms in the Malawi police, leading to the inclusion of the component of human rights in the police training school curriculum. This has happened as Malawi is now a member of the International Human Rights Manual Drafting project, which began in 1999, which was implemented in Malawi in 2005. At the time of launching the manual, there was an atmosphere of hope in as far as the protection of human rights was concerned, if the sentiments of the then Police Inspector General were anything to go by:

You are all aware that central to the democratization process of this country is the Bill of Rights. The Bill of Rights relates primarily although not exclusively, to the relationship between the state and its people.... I believe that the implementation of this human rights training comes in at an opportune time when we are desirous of fulfilling our aspirations of becoming more humane and responsive police service. As a police service, we have never taken for granted the mutual relationship between us and the community as a result of our other efforts like community policing. We believe that this Training Manual will help us consolidate our efforts. I say this on the basis of my firm belief that in countries where human rights are constitutionally protected, the

\footnotetext{
${ }^{561}$ Constitution of the Republic of Malawi, 1995. See Chapter X, XI, XII and XV.

562 Constitution of the Republic of Malawi, 2010. Chapter Xv: The Police.
} 
relationship between the police and the citizenry can more easily be of co-operation and support. $^{563}$

The second chapter of the training manual also includes an overview of the meaning of human rights; and a classification of human rights (civil, political, economic, social, cultural, and solidarity rights). It also refers to various documents that have been issued internationally such as the Universal Declaration of Human Rights (UDHR) of 1948; and the African Charter on Human and People's Rights (ACHPR) of 1981, to promote the human rights agenda. It also includes a brief overview of the historical trajectory of the human rights agenda in Malawi, starting from the colonial era, thru the post-colonial era, and the post-Cold War era. It also highlights the roles that the police played when they were used as instruments of oppression, in such a way that the police had wide powers to deny people their rights through vicious interrogations, detentions without trial, and other cruel interrogation methods. ${ }^{564}$

On the political scene, Malawi is no longer a one-party state having embraced multi-party democracy following the 1993 national referendum. Under the constitution of Malawi, every citizen enjoys the freedom of association, which includes then right to establish political parties provided they are approved by the office of the registrar of political parties. Malawians are no longer forced to belong to the Malawi Congress Party (MCP) as had been the case when Dr. Banda was in power. ${ }^{565}$ Malawi now has over 40 legally-registered political parties, although many of them are non-operational, and only exist in name. Since the 1994 general elections that led to the downfall of the Banda regime, there have also been periodic general and by-elections, where

\footnotetext{
${ }^{563}$ Malawi Police: Police Training Manual on Human Rights. $2^{\text {nd }}$ Edition. See Preface to the First Edition, by Mrs. M.D. Nangwale, Inspector General, Malawi Police Service.

${ }^{564}$ Malawi Police: Police Training Manual on Human Rights. $2^{\text {nd }}$ Edition. Chapter Two: Police Work and Human Rights.

${ }^{565}$ Constitution of the Republic of Malawi, 2010. Chapter ix: Human Rights.
} 
candidates from political parties and other independent candidates have exercised their constitutionally-given rights. ${ }^{566}$ This has been a complete departure from the state of affairs during the Banda regime, where since 1971 when Dr. Banda became the "life president," Malawians were barred from voting for a state president. Since the 1994 general elections, Malawi has now been ruled by three other political parties other than the MCP. These parties include the United Democratic Front (UDF), the Democratic Progressive Party (DPP), and the People's Party (PP). Presidents Bakili Muluzi, Bingu wa Mutharika, Joyce Banda, and Peter wa Mutharika, have all been beneficiaries of the new democratic dispensation.

The Malawian state is no longer as "over-developed" as it used to be. In the post-Banda era, most of the previously state-owned businesses were privatized, following recommendation from the World Bank and the International Monetary Fund (IMF). These Bretton Woods institutions have since the late $20^{\text {th }}$ century, as part of the neo-liberal agenda, encouraged the privatization of stateowned businesses to improve or increase productivity, efficiency, and output. Countries like Malawi who were subjected to the SAPs were given the privatization of state-owned businesses as one of the conditions to access aid and monetary grants. ${ }^{567}$ In Malawi, the march towards privatization began in the early 1980s, when the government was compelled to establish the Department of Statutory Bodies (DSB), to among other things monitor and control the operations of state-owned enterprises. But by the end of the Banda regime, the results were still discouraging,

\footnotetext{
566 See for instance, Paul Chiudza Banda, "The 2009 General Elections: process, results, and lessons," Society of Malawi Journal 63, no.2 (2010): 4:14. See also Nandin Patel and Michael Wahman, "The presidential, parliamentary, and local elections in Malawi, May 2014," Africa Spectrum 50, no.1 (2015): 79-92.

567 See for instance, Nancy Brune, et al, "The International Monetary Fund and the global spread of privatization," IMF Staff Papers 51, no.2 (2004): 195-204.
} 
as many of the enterprises posted low accountability levels and still had limited managerial autonomy. The targeted companies during this first phase included ADMARC, PGC, and MDC. ${ }^{568}$

When Bakili Muluzi and the UDF came to power in 1994, the government initiated the second phase of the privatization program. This saw the government establish the privatization commission to oversee the restructuring and sale of state-owned businesses. About 150 companies were targeted during this second phase. Among other reasons for this, the government sought to bring about efficiency in the economy; increase competition and reduce state monopoly in the business sector; promote participation by the Malawian public in doing business; and to raise the much-needed revenue for the government. ${ }^{569}$ This saw the sale of such companies as the Cold Storage, Malawi Book Service, Malawi Distilleries Limited, Nzeru Radio Company, Grain and Milling Limited, Portland Cement Company, Blantyre Dairy Limited, and Wood Industries Corporation, among others. ${ }^{570}$

While studies about privatization of state-owned enterprises indicate that there are improved levels of efficiency and generally better profit margins, ${ }^{571}$ there are several downsides to such policy changes. For instance, Ernest Harsch, in his studies on the effects of privatization programs across the African continent, argues that they have been accompanied by both political and socioeconomic risks and challenges. The privatization programs, including that of the Malawi government, has led to retrenchment of workers, has been followed by strikes by workers, closure of some companies, and the prominence of foreigners who have bought some of the companies.

\footnotetext{
${ }^{568}$ Ephraim Chirwa, "Privatization and Technical Efficiency: Evidence from the manufacturing sector in Malawi," African Development Bank (Oxford, UK: Blackwell Publishers, 2001): 276-278.

${ }^{569}$ Ibid., 278-279. See also "Malawi: The Privatization Commission," http://www.winne.com/malawi/to16.html. Downloaded on May $17^{\text {th }}, 2019$.

${ }^{570}$ Chirwa, "Privatization and Technical Efficiency," 290.

${ }^{571}$ Ibid., 291-294.
} 
Furthermore, the privatization process has had little or no impact at all on broader development goals of most African countries. Most of the proceeds from privatization have either gone to foreign business owners or the few African elites and politicians who purchased the companies. ${ }^{572}$ It is thus imperative upon the subsequent post-Banda governments in Malawi to ensure that the leaders should minimize the job losses, to link the privatization program to Malawi's broader development goals, and to make sure that there is more local or Malawian ownership of the former state enterprises. Only then can the privatization program play a significant role in the livelihoods of the people of Malawi.

\section{Conclusion}

In this chapter, I have focused on the downfall of the regime of Malawi's first post-colonial Head of State, Dr. Hastings Kamuzu Banda, which took place in May 1994. I have sustained the argument that the downfall of the regime represented the end of the post-colonial state in Malawi. I have argued that the downfall of Banda had much more to do with the economic downturn which Malawi began to encounter since the 1979/80 fiscal year, which then allowed for intervention in the country's economy, by major bilateral donors and the Bretton Woods Institutions. Once Banda's Malawi lost its economic autonomy, it gave room to the international community to dictate the country's economic and later political path (with their ready-made political and economic policies), leading to the conditions for aid of the late 1980s and early 1990s. By then, the once strong Malawian state, had lost a significant chunk of its sovereignty and had to be influenced by liberalization policies of the West. Furthermore, Banda's own old age and ill health, meant that he could not provide the kind of leadership that Malawi needed at such a time of

\footnotetext{
${ }^{572}$ Ernest Harsch, "Privatization shifts gears in Africa: more concern for public acceptance and development impact but problems remain," Africa Recovery (April 2000): 8-17.
} 
economic recession. If Banda had been of a younger age, and indeed if the economy had been doing well, maybe Banda would have withstood the pressure (both international, and later domestic). I have also highlighted that the issues that were raised by the international community, were the very same issues that the local opposition elements pounced upon, an important indication of the agency which Malawians had to shape the future political and socio-economic development of the country. The end of the post-colonial state itself and indeed the fall of Banda's authoritarian rule, could not be described as a bad development, especially because of its lack of adherence to liberal principles and the associated abuse of people's rights. As Plato stated: "Death is not the worst thing that can happen to men."${ }^{.573}$

${ }^{573}$ Plato, In Quote Me: World's Most Inspiring Words (Compiled by Uplifting Publications. Undated), 58. 


\section{CHAPTER EIGHT}

\section{CONCLUSION}

Must not all things at the last be swallowed up in death ${ }^{574}$

This dissertation adopted the long-duree historical approach, by discussing the history of colonial and post-colonial Malawi, from 1891-1994, rather than merely focusing on a shorter period of time to discuss some of the major issues for the country's history. ${ }^{575}$ In discussing the notion of "state counter-insurgency," I have weighed through various local and transnational spaces and documents, to analyze the different ways both the colonial and post-colonial states used the resources at their disposal to eliminate different forms of opposition against the state. The journey has thus taken this study into political, social, and economic grievances that influenced the country's citizens to challenge the authority and legitimacy of the state; and there has also been focus on the different ways which the state responded to the citizens' agitation, where I have highlighted that although there is a tendency in most scholarship to focus on the use of force (especially through the police force and other para-military agencies of the state) by authoritarian regimes, there is also need to focus on the non-brutal or the more peaceful means through which the states under study responded to the rise of opposition. In this study, I have used such terms as "winning hearts and minds" and "the stick and the carrot," to refer to the different ways in which the state carried out what I refer to as "counter-insurgency." I have also adopted and sustained the argument that in the case of Malawi, there is need to have clear-cut demarcations on such dates as what is meant by the "colonial state" and the "post-colonial state." I have argued that for the

\footnotetext{
${ }^{574}$ Plato, In Quote Me: World's Most Inspiring Words (Compiled by Uplifting Publications. Undated), 59.

${ }^{575}$ For a study of the Longue durée historical approach, see Jo Guldi and David Armitage, The History Manifesto (Cambridge: Cambridge University Press, 2014), 14-60. The notion of longue durée is synonymous with the notion of writing trans-temporal history, where one studies the history of a society or an individual over a long period of time, rather than merely events and process over a few or so years.
} 
colonial state, our focus should be on the period between 1891 and 1964; while the post-colonial state should be considered as having stretched from 1964 to 1994 . My analysis of the rise of insurgencies and the accompanying counter-insurgency measures has been guided by insights from the political-economy approach.

In chapter two, focus was on the first two decades of British rule in Nyasaland, roughly between 1891 and 1910. That was a period when the colonial state was being established, and required, in most cases, the use of state-sponsored brutality to deal with resisting Africans. I have argued that it was the sight of material needs or benefits that determined the kind of relationship that existed at the time. The colonial authorities were keen to set up conducive conditions for the operation of European enterprises in the country, hence the need to eliminate all forms of opposition in the country. In that perspective, most of what could be termed as counter-insurgency, came in the form of "the stick" against the resisting native societies, where I have adopted Crawford Young's notion of bula matari (literally "he who crushes rocks").

In chapter three, the study has revolved around a critical analysis of the principle of "civilizing mission," as it applied to Nyasaland. I have argued that since the colonial enterprise was a "makeshift settlement," it was often impossible to fully apply it (the civilizing mission). In part, the African discontent against the land, labor and taxation policies of the colonial state led to the uprising of 1915, which is widely described as the "Chilembwe uprising." In chapter four, I have focused on the notion of "winning hearts and minds" as it pertained to the time of the 1915 "native uprising," both during and after, roughly between 1915 and 1930. I have focused on the use of both "the stick and the carrot," as measures employed by the colonial state to defeat the insurgents. Unlike other works, on the native uprising, most of whom have concentrated on the use of brutal force, especially the killing of Chilembwe and the execution of his accomplices, I have highlighted 
how the initiation of development and welfare programs for the benefit of the colonized peoples, was also used as a counter-insurgency measure. I have focused on the question of changes in the land tenure system, and the disbursement of funds towards such areas as water supply, agricultural development, public health, education, and communication systems, among others. I have also stretched my focus on the colonial police, by adopting the political-economy approach, to argue that the operations of the Nyasaland Police significantly reflected the organization of the Nyasaland society of the time. We also see at this time, the creation of the paramilitary group, known as the Nyasaland Volunteer Reserve, whose activities and importance to the colonial state, perhaps matched what we later saw in the post-colonial state, through the Malawi Young Pioneers. The Volunteer Reserves served in both capacities of development, and as an army-in-waiting for the colonial state; and while it started as a non-state actor, its activities were soon legalized and were funded from state coffers.

In chapter five, this study has tackled the question of the ambiguity of colonial notions of development, and how that contributed to the rise of radical forms of nationalism in the post-World War Two era. I have traced the colonial state's involvement in the development of the Nyasaland Protectorate from the late 1920s onwards, from the enactment of the Colonial Development Act of 1929, through the Colonial Development and Welfare Act of 1940 and 1945, and through the work of the Colonial Development Corporation. I have highlighted the notion that the British authorities were not initially interested in developing their tropical colonies, as the laissez faire beliefs from the late $19^{\text {th }}$ century to the mid-1920s, had been that colonial development initiatives should be left as a domain for private enterprises. However, following the failure of the private sector to take up that responsibility, it now became incumbent upon the colonial state to take up the responsibility. With regards to Nyasaland, I have highlighted that the peak of that state-led 
development came through the formation of the Central African Federation (CAF). The ambiguity of the notion of development at the time was in the fact that the federation, just like the other development initiatives, was not necessarily meant for the benefit of the "natives," as was claimed by the colonial authorities. The development initiatives were targeted at serving the exploitative interest of the colonial authorities, and after World War Two, joined by the USA, to extract as much as possible, from Britain's colonial possessions in Tropical Africa. During that phase, the major forms of "native" insurgency contributed to the declaration of the 1959 State of Emergency, where by the end of the hostilities, close to fifty Africans were killed, tens of others were wounded, and hundreds of others were detained without trial. The leaders of the African nationalist movements in the federation were also referred to as "communist implants" even though there had not been significant evidence to justify such claims. In as far as counter-insurgency was concerned at that stage, notions of "the stick and the carrot" also prevailed, where such measures as brutal force (through the activities of the Nyasaland police force), legalization of state oppression through the enactment of repressive laws, and indeed the establishment of development initiatives for the benefit of the both the colonizer and the colonized were initiated.

In chapter six, the focus shifted to the post-colonial state, which I have argued stretched from 1964 to 1994. For that period, I have argued that what Malawi had was "an imported state" for which one could trace the continuation of practices and systems that operated under British rule into the post-colonial period. I have focused on the area of state-led development initiatives, which I have argued were a continuation from the late colonial era. Once Dr. Banda, the Malawi leader from 1964 to 1994, adopted that policy, he and his cronies created a system which adopted a "protectionist" approach, which barred others from accessing the economic and political opportunities of the time. I have focused on two conglomerates that were controlled under the neo- 
patrimonial regime of Banda, namely the Malawi Development Corporation (MDC) and the Press Group of Companies (PGC), where I have argued that so far as these companies were doing well, Banda and his cronies were not willing to liberalize the country's economic and political space. Here, the notion of lack of liberalism that we saw in the colonial state, also continued in its postcolonial successor. And just as under the colonial state, we also saw the use of both "the stick" and "the carrot," in Banda's counter-insurgency tactics. I have also departed from most studies that over-concentrate on the brutality of the Banda regime, especially through the enactment of repressive laws, and also the brutal tactics of the Malawi Police Force and two Youth Movements of the MYP and the Youth League, to focus on the notion that "development" was also at the center of Banda's tactics to prolong his stay in power for three decades. He incorporated the youth and women, as the main groups through which to carry out his development agenda but was also quick to utilize them to attack his political opponents. One also must consider how the international community, during the era of the Cold War, helped to prolong the authoritarian regimes in postcolonial Africa, whereby in this study I have focused on the roles played by the British government, the American government, and the Bretton Woods Institutions, especially the World Bank.

In chapter seven, I have argued that the fall of Banda after the 1994 general elections marked the end of the post-colonial state in Malawi. I have attributed the developments that led to Banda's exit from power, as emanating from the economic downturn or recession which the country began to face since the 1979/80 fiscal year. The economic downturn was brought about by both international and domestic forces, including the increase in global oil prices; huge debts incurred by the Banda regime; environmental challenges; the under-performance of state-run companies; and the civil war in neighboring Mozambique, which blocked Malawi's access to the ports of Nacala and Beira. From then onwards, Banda lost control of the economy, and had to rely on 
foreign aid from bilateral donors and the Bretton Woods institutions, through the Structural Adjustment Programs (SAPs). By the late 1980s and early 1990s, the international money lenders and aid providers, had shifted from simply giving their resources to Malawi, but had also begun to demand the liberalization of the regime as a condition for the continuation of the aid program. I have highlighted that after the end of the Cold War, the Western powers were no longer in the mood to entertain the wide-spread abuses of human rights in countries that relied on Western support for both budgetary and developmental aid. The international pressure soon began to encourage domestic forms of opposition against the regime, which ranged from members of the clergy, political movements, and the general citizenship. The economic hardships which the country faced were also compounded by Banda's ill-health and old age, which meant that it became almost inevitable that Banda had to go, as the center of his regime, which was maintained by controlling the economy and the brutality associated with it, could no longer hold in the midst of both international and domestic pressure. The post-Banda era in Malawi is significantly different, in such areas as political liberalization, economic liberalization, and limited police brutality. However, the international community continues to play a significant role in influencing policymaking.

From this analysis, this study has shown that there are certain elements of state management or administration that one can trace to have started in the colonial period and were subsequently imported into the post-colonial period. Such an argument has been supported by the two main historical approaches that I adopted for this study. The longue durée approach has been utilized to investigate the recurring themes in terms of the rise of resistance and state counter-insurgency over the long historical period covered in this study, focusing on both the colonial and post-colonial eras. The political-economy approach has also been used to discuss how economic needs 
determined what form of government was established, and also how the system of government also determined the kind of economic system which the country had over the study period.

\section{Legacies}

From what has been explored in this study, there are several lessons that can be drawn by current and future scholars on the history of British imperialism and the Malawian post-colonial state. Firstly, that there is need to recognize that the end of European colonial rule (or decolonization), did not necessarily mean an abrupt departure from principles, systems, and practices of the colonial period. While I picked the umbrella term of "counter-insurgency" for this study, analyses that consider such forms of continuation can concentrate on all sorts of areas that states are involved in. Among the key issues that were included in this study, included such areas as land tenure; taxation; labor distribution; abuse of the police force or service; the role of women and the youth in development; the developmental state; and the role of the international community in the operations of both the colonial and post-colonial state, among others. In this, I have highlighted that the question of who controls the country's resources (human, material, and natural resources), has been and would probably be a point of contention for so many years to come.

One other significant area that has consumed space in this study is the notion of the ambiguity of development. I have argued in this study, that "development" or "development aid" as it was used by both the colonial and post-colonial states always came with some 'strings attached.' Under the colonial state, the development and development projects initiated under the 1929, 1940, and 1945 Development Acts, and later the Central African Federation (CAF), were not simply meant for the benefit of the Africans, but had more to do with serving the interests of the colonizer, both during the era of the Great Depression (late 1920s and throughout the 1930s) and also in the post-World War II era, where development projects were meant to supply raw materials to British industries 
and also providing employment opportunities for British nationals. In the post-colonial era, what was termed as "development" by the Banda regime, also similarly served the interests of the ruling elite and those in the inner circle, and that what was served as "development" to the masses were but crumbs of what the ruling elite had as left-overs from their tables. I have also highlighted how the notion of "development" can both be analyzed as a source dispute in society (such as the claims of developing the Africans towards the establishment of the Federation), and that governments can also utilize the same notion of "development" to win the hearts and minds of those in the opposition camp.

Along the same lines of argument, I have also highlighted the notion of foreign intervention in the economic and political decision-making processes of the country. One can trace this to the late colonial era when foreign powers, especially the USA, were part and parcel of the decision to create the CAF. In post-colonial Malawi, one can also see the role of the international community influencing the operations of the state. This was mainly the case due to the on-going Cold War, which saw African leaders being compelled to support either the Western or Eastern bloc. It was also the very same Western powers who called for regime change in the post-Cold War era. More detailed studies need to be conducted to evaluate the impacts which the "imported" liberal or neoliberal ideologies have had in the country since the time of their imposition. In most African countries, the route taken since the SAPs were introduced has been at best unrecognizable and anarchist, with no clear-cut positive economic changes to uplift the livelihoods of the masses. Another equally important and related area to study is the performance of the civil society organizations that begun to receive extensive international donor support to provide checks and balances to the post-colonial and other successor states since the introduction of the SAPs. 
I have also zeroed-in on the role played by the police in the history of the country. For both regimes, I have used the political-economy approach, to argue that the operations of the police, as did most of the governments' security forces reflected the kind of political and economic developments that country was going through, and that over the years, through the actions of the police, Malawians citizens, some unaccounted for, lost their lives and property at the hands of the police forces. While there have been changes in the administration and activities of the Malawi police since 1994, Malawians must remain cautious as on several occasions the police have resorted to return to their old ways when the institution was known as a "police force." I have also sustained the argument that with the downfall of Banda in 1994, historians and other scholars in the field, should consider it as the end of the post-colonial state. It would be unfair, in my view to continue attributing the operations of the Malawian state, and indeed any other such states, in the $21^{\text {st }}$ century, to still be affected or influenced by the era of British colonial rule. Some, if not most, of the leaders that came to power after the end of the Cold War, have or had no connection whatsoever to the era of British colonial rule. Doing so would liberate Africans and other such formerly colonized states to find better solutions to the overwhelming problems affecting each individual country, rather than always focusing on the colonial period.

I have also highlighted how important it is to focus on the notion of how the international community can make or break a regime. In the colonial era, I have for instance discussed how the USA, especially after the Second World War, became a major force in influencing British colonialism, both at the level of encouraging and partaking in colonial exploitation and later discouraging continued colonial rule, to serve US interests during the era of the Cold War. In the case of post-colonial Malawi, I have highlighted how the international community provided monetary and material aid to the Banda regime which helped to prolong the regime roughly 
between 1964 and the late 1980s, despite the appalling human rights record of the regime. This includes the roles played by the British and American governments, and the Bretton Woods institutions, especially the World Bank. Banda's position during the Cold War, influenced the Western powers to ignore the lack of liberalism in the country, and their unflinching support contributed to a condition where Banda alienated himself from his own people. Only when the Cold War was over, did they condition their aid to political and economic liberalism.

One other issue that has dominated the analysis of both the colonial and post-colonial states is that of liberalism. I have analyzed the notion of the lack of liberalism during the era of British rule, despite the fact that in Britain itself the society was guided by liberal principles, which however the colonists did not want to employ in their African colonies, despite it being a so-called "Empire Project," which would have meant the application of the same principles across the empire. The African, often regarded as barbaric and uncivilized, was looked upon as someone undeserving of enjoying privileges enjoyed by European citizens, both in the metropole and in the overseas colonies. Many Africans were alienated from their lands, subjected to forced labor, deported from their colonies, forced to pay heavy fines, and worse still killed under the authority of British rule. Many of those who ordered and indeed committed such atrocities were never tried in any court of law. Turning to the post-colonial state, I have also highlighted how, despite the claims by the ruling elite, that Malawi was under a democratic system, there was wide-spread abuse of human rights during the life-span of the Banda regime. Many of those who were behind the atrocities had suffered under British rule, either directly or indirectly, and despite promising a change of system in the post-colonial period, ended up violating the rights of the "decolonized." Worse still, many of the perpetrators of the atrocities were not subjected to account for their complicity. The political and administrative system of the day protected them from exposure and accountability. One only 
hopes that many will draw lessons from this study and provide the necessary kind of leadership. As the saying goes: "the world would be happier if its leaders had more vision and fewer nightmares." 576

${ }^{576}$ Vern McLellan, Wise Words and Quotes (Illinois: Tyndale House Publishers, Inc., 1998), 159. 


\section{BIBLIOGRAPHY}

\section{(A) PRIMARY SOURCES}

\section{FROM THE MALAWI NATIONAL ARCHIVES}

MNA S2/25/19: Official Correspondences.

MNA S1/397/31: Official correspondences.

MNA S1/397/31: Nyasaland Volunteer Reserve, History.

MNA S2/68/19: Chilembwe Rising, 1915 - Deportations.

MNA S1/68/19: Political Prisoners, Deportation, 1918-1921.

MNA S1/1179/19: Political Prisoners, Deportation, 1919-1923.

MNA S1/1729/27: Official Correspondence - reorganization of the Nyasaland Police Force.

MNA S1/152/19: Official Correspondence.

MNA/S2/39/22: Political Cases, 1922-1930.

MNA S2/102/23: Political Cases, 1923-1924.

MNA S2/50/23: Republic Vs. Mr. Isa Macdonald Lawrence., 1926.

MNA S34/1/3/1: Native Unrest, Southern Province, 1939-1940.

MNA S2/140/39: Political Intelligence Bureau, 1939.

MNA: PMF Reports, 1958-1964.

MNA PAM 2,835: Malawi Congress Party Annual Convention Resolutions, 1965-1975. MNA PAM 4,350: Mikuyu Prison Museum. 
MNA PAM 4,161: The Ngwazi and Malawi: A Success Story of Development and Prosperity. Produced by the Malawi Department of Information, 1992.

MNA PAM 982: Malawi: Ten Years of Progress, 1974.

MNA PAM 2,825: The Economic Development of Malawi since Independence. Blantyre, Malawi; Department of Information, 1975.

MNA PAM 984. "Guide to a career in the Malawi Young Pioneers".

MNA PAM 4,584. "Malawi Young Pioneers National Headquarters - Basic Working Orders". February 1967.

MNA PAM 985. "Malawi Young Pioneers - Spearhead for Progress”. October 1972.

\section{MALAWIANA COLLECTION (CHANCELLOR COLLEGE LIBRARY,} MALAWI)

"Youth in Malawi: Security and Progress with the Malawi Young Pioneers".

'Malawi Police Force: Annual Report for the Year ended 31st December 1966.'

'Annual Report of the Malawi Police Force - For the Period 1971-1972.'

\section{FROM THE BRITISH NATIONAL ARCHIVES}

WO/106/262: 'The Commission Appointed by His Excellency the Governor to Inquire into Various Matters and Questions concerned with the Native Uprising within the Nyasaland Protectorate'. Zomba: Government Printer, 1916.

CO 525/198/5: Post War Development Committee Report on Education.

CO 525/198/2: Report of the Post War Development Committee for the Nyasaland Protectorate, 1945.

CO 525/210/1: Post War Development Committee: Public Health Plan, 1947-1948. 
CO 525/210/2: Post War Development Committee, Finance, 1947.

CO 525/198/7: Post War Development Committee: Report on Demobilization.

CO 1035/126: Official Committee on Counter-Subversion in Colonial Territories Communism in Africa, 1956 Report.

DO 35/6851: Passive Resistance in Nyasaland to Central African Federation.

CO 1015/1133: Governor's Reports, Nyasaland: Dispatch by Governor Geoffrey Colby, to the Rt. Hon. Alan Lennox-Boyd.

CO 1015/464: Nyasaland Political Intelligence Reports, 1952-1953.

CO 1015/465: Monthly Political Intelligence Reports for Nyasaland, August and September 1953.

DO 35/6851: Passive Resistance in Nyasaland to Central African Federation.

CO 968/275: Police and Constabulary - Reorganization of Nyasaland Special Branch. September 1953.

FCO 141/14237: 'Report of the visit to Nyasaland, by Mr. J.A. Harrison, the Security Intelligence Adviser at the Colonial Office'.

CO 1015/1838: Governor's Reports: Nyasaland. October 1957.

CO 1035/143: Security Situation in Nyasaland, 1957-1959.

DO 35/7476: Position of Nyasaland Detainees, 1959.

CO 1035/119: Counter-subversion in colonial territories: Central African Federation.

CO 1035/144: Security Situation in Nyasaland, 1957-1959.

CO 1015/1839: Governor's Report on current situation in Nyasaland, 1957-1959.

DO 35/7689: Official Correspondences.

DO 35/7689: Publicity and Propaganda in Nyasaland. 
CO 1015/1527: 'Political Situation in Nyasaland, 1959.

FCO 105/365: Malawi Internal Political Situation, 1980.

FCO 105/366: Malawi Internal Political Situation, 1980.

FCO 45/1227: Political Situation in Malawi, 1972.

DO 183/565: Malawi Political Crisis, 1965.

DO 224/23: Internal Political Situation in Malawi, July 1965 - April 1966.

FCO 45/1227: Political Situation in Malawi, 1972.

FCO 45/2169: Malawi Internal Political Situation, 1977.

DO 224/28: Malawi Young Pioneers and Youth League.

FCO 141/142/14234: Nyasaland Intelligence Reports, January to June 1964

FCO 29/291: Malawi political and administrative affairs (internal), criticisms against Dr. Banda.

FCO 45/755: Review of internal political developments in Malawi, 1970.

FCO 45/1227: Internal Political Situation in Malawi, 1972.

FCO 45/2169: Malawi Internal Political Situation, 1977.

CO 1045/431: Phelps-Stokes Commission - Africa.

CO 847/9/1: Education of African Communities in Social and Economic Development in Native Territories.

CO 879/123/12: Education in Tropical Africa, Colonial Office, August 1930. African, No.1135.

\section{FROM SYRACUSE UNIVERSITY ARCHIVE}

WO 106/571: Operations in Nyasaland. 
CO 527/70: Official Correspondences.

CO 525/67: Official Correspondences.

CO 525/61: Official Correspondences.

CO 525/63: Official Correspondences.

CO 525/68: Official Correspondences; and Nyasaland Volunteer Reserve Rewards, 1915.

CO 525/62: Official Correspondences.

CO 525/65: Official Correspondences.

CO 525/72: Official Correspondences.

CO 525/71: 'Report on the Government Commission of Inquiry into the Recent Native Rising'. June $19^{\text {th }} 1916$.

DO 183/565: Official Correspondences from the British High Commission, Malawi, 1965. FCO 105/365: Malawi Internal Political Situation, 1980.

CO 1015/2445: Malawi Congress Party, 1960-1962.

CO 525/138: Tax Regulations in Nyasaland.

\section{FROM H.K. BANDA ARCHIVE (INDIANA UNIVERSITY LIBRARY)}

Nyasaland Chiefs' Petition against Central African Federation, April 1952.

Thiessen, Henry A. 'Some Remarks on Transportation and Economic Development in Nyasaland'. March 18 ${ }^{\text {th }}, 1963$.

'Federation of Rhodesia and Nyasaland: Report on an Economic Survey of Nyasaland, 1958-1959' (1960).

Kanyama Chiume, M.W. "Nyasaland Speaks: An Appeal to the British People”. 1959. 
'Federation and Nyasaland: The Facts'. Salisbury: Government Printer, 1962. Produced by the Publications Department of the Federal Public Relations Department.

'Confidential dispatch from H. Kamuzu Banda, President of the Republic of Malawi, to the Right Hon. Edward R.G. Heath, M.P., British Prime Minister and First Lord of the Treasury'. March 9th, 1973.

'Letter from the World Bank to Dr. Banda'. May 27 1992.

'Memorandum to His Excellency, the Life President - Repeal of Section IX of the Constitution'. From: H.M. Ntaba, Vice Chairperson of the Presidential Committee on Dialogue'. September 17th, 1993.

'Malawi at War: Against Poverty, Disease and Ignorance.'

'The Republic of Malawi: The Challenge Met'. Published by the Malawi Information Department, June 1976.

Malawi Development Corporation: Ten Years of Progress. 9th April 1974.

‘Malawi: Ten Years of Progress'. In Progress International, February 1974.

This is Malawi, Vol.4, No.7, July 1974.

Malawi, 1964-1974: Building the Nation. 1974.

'The Truth and Myth about Press Trust'. January 1996.

'Press in the 90s: Questions and Answers'. Published by the Press Corporation Limited, January 1995 .

'Malawi: Dialogue and Development.' Published by Africa Publications Trust, London Nyasaland Government: Press Release No. 69/63: Dr. Banda to be Sworn-in as Premier on February 1. January 25th, 1963.

Republic of Malawi: Commission of Inquiry: Mwanza Road Accident. December 1994. 
"Report of the Special Study Mission to Southern Africa". Compiled by the Committee on Foreign Affairs, House of Representatives. October 10th, 1969.

Brody, Paula Rae. Chitukuko Cha Amayi M'Malawi: The Story of CCAM, 1985-1993. Unpublished book manuscript. $3^{\text {rd }}$ draft. August 1994.

'Report on the All-African People's Conference', compiled by Edwin S. Munger, for American Universities Field Staff, January 1959.

The Listener. "Talking about Africa: Hastings Banda and Tom Mboya in Conversation with John Freeman”. September 1 $1^{\text {st }}, 1960$.

\section{FROM JOHN F. KENNEDY PRESIDENTIAL LIBRARY AND MUSEUM}

Image of Meeting between Dr. Hastings Kamuzu Banda (of Nyasaland) and President John F. Kennedy (USA), at the White House, May 1961.

'William H. Attwood Oral History Statement, 11/8/1965'.

\section{FROM LIBRARY OF CONGRESS (WASHINGTON, DC)}

Phiri, Canaan R.K. "The Viphya Tung Scheme, 1945-1968: A Futile Strategy to 'Awaken the Dead North”. History Seminar Paper, 1987/88, No.6. Chancellor College, University of Malawi.

Woods, Anthony E. "Political Autonomy and Administrative Policy in Nyasaland, 19151921”. History Seminar, 1984/85, Paper No.9, Chancellor College, University of Malawi. Foreign Relations of the United States, 1952-1954, Vol. XI, Part 1, Africa and South Asia, Document 124. January $31^{\text {st }}, 1952$.

Foreign Relations of the United States, 1952-1954, Vol. XI, Part 1, Africa and South Asia, Document 128. 
Foreign Relations of the United States, 1952-1954, Vol. XI, Part 1, Africa and South Asia, Document 136. May $8^{\text {th }}, 1953$.

Foreign Relations of the United States, 1961-1963, Vol. XXI, Africa. Document 320. May 2nd, 1961.

Foreign Relations of the United States, 1964-1968, Vol. XXIV, Africa. Document 184:

Draft National Security Action Memorandum. Washington, DC. Undated.

Botzaris, Alejandro. “Communist Penetration in Africa.” Lisbon, 1961.

The Times. "Dr. Banda to adopt policy of flexible neutralism: Malawi's belief in value of the Commonwealth". July $7^{\text {th }}, 1964$.

US Department of State. 'Outgoing Telegram - to the US Embassy, Blantyre, Malawi'. Titled, "Malawi - Banda Visit". December 8 $8^{\text {th }}, 1964$.

President Banda's State Visit to the Republic of China. Pamphlet, Library of Congress. 1967.

Department of State, Policy Planning Council. "National Policy Paper: Southern Africa". $3^{\text {rd }}$ Draft, Revised, November 1968.

'Malawi: Country Development Strategy Statement'. Prepared by the US Agency for International Development, Washington DC. January 1982.

A Review of U.S. Policy and Current Events in Kenya, Malawi, and Somalia. Hearing before the Subcommittee on Africa of the Committee on Foreign Affairs, House of Representatives. 102nd Congress, 2nd Session. June 23rd, 1992.

The Senate of the United States, 103rd Congress, 1st Session: Joint Resolution regarding the Government of Malawi's arrest of opponents and suppression of freedoms, and conditioning assistance for Malawi'. March 26th, 1993. 
The Lilongwe Land Development Program is IDA Financed. March 1972.

Malawi Development Corporation: Reports and Accounts, 1964-1966.

Annual Report of the Malawi Police Force for the year ended 31 st December 1966. Zomba, Malawi: Government Printer, 1967.

Annual Report of the Malawi Police Force for the year ended 31st December 1967. Zomba, Malawi: Government Printer, 1968.

Amnesty International Briefing: Malawi, August 1976.

DO/201/15: Confidential dispatch from the British High Commissioner to Malawi, Mr. D.L. Cole, titled 'Malawi: British Policy'.

National Security Council. 'National Security Memorandum No.39 - Southern Africa'. Washington DC, April $10^{\text {th }} 1969$.

The Peace Corps in Malawi. Washington DC, 1980.

Central Intelligence Agency (CIA): 'The President's Review'. Top Secret. 5-8 September 1964.

CIA: ‘The President’s Daily Brief’. 2 July 1965.

CIA Report. Top Secret. 6 May 1966.

US Government. "Background Notes: Malawi”. (Washington DC: Department of State, 1989).

Foreign Office - Military Collection, File No.322: British Central Africa, 1896-1898.

Foreign Office (FO 881/6383, Confidential File No.6383) - Memorandum on Land Claims in the British Central Africa Protectorate, August 1893. FCO 45/2205: Human Rights in B.L.S.M.

CIA, Directorate of Intelligence: 'Malawi: Troubles times ahead'. July $15^{\text {th }}, 1983$. 


\section{GOVERNMENT PUBLICATIONS}

British and Foreign State Papers, Vol. LXXXV, 1892-1893.

Colonial Annual Report for the British Central Africa Protectorate, 1900.

Colonial Annual Report for the British Central Africa Protectorate, 1901.

The British Central Africa Order-in-Council, 1902. In British Central Africa Gazette.

October $31^{\text {st }}, 1902$.

Colonial Annual Report for the British Central Africa Protectorate, 1902-1903.

Colonial Annual Report for the British Central Africa Protectorate, 1903-1904.

Colonial Annual Reports for the Nyasaland Protectorate: 1905-1906.

Colonial Annual Reports for the Nyasaland Protectorate: 1906-1907.

The Nyasaland Order-in-Council, 1907. In British Central Africa Gazette (Extraordinary). October $21^{\text {st }}, 1907$.

Speech by Sir Alfred Sharpe, at the $2^{\text {nd }}$ Ordinary Meeting of the Session. Hotel Metropole, UK. December 10 $0^{\text {th }}, 1907$.

Colonial Annual Report for Nyasaland, 1907-’08.

The Nyasaland Gazette. June 30 1908.

Colonial Annual Report for Nyasaland, 1912-'13.

'Nyasaland Protectorate: Annual Report of the Department of Agriculture. $31^{\text {st }}$ March 1912': CO 626/1

Colonial Annual Reports for the Nyasaland Protectorate, 1913-'14.

Orders of the King in Council Relating to the Nyasaland Protectorate, in force by $31^{\text {st }}$ December 1913. 
'The Seditious Publication (Prohibition) Ordinance, 1918'. In Ordinances of the Nyasaland Protectorate for Year ended 31 ${ }^{\text {st }}$ December 1913.

Proclamations, Rules and Notices Relating to the Nyasaland Protectorate in force on the $31^{\text {st }}$ December 1914”.

The Nyasaland Government Gazette, Vol. XXIII, No.1, Order Number 5 of 1916, dated June $31^{\text {st }}, 1916$.

The British Protectorates (Defense) Order-in-Council, 1916. Nyasaland Government Gazette. April 1 ${ }^{\text {st }}, 1917$.

The British Protectorates (Defense) Order-in-Council, 1916'. The Nyasaland Government Gazette. May $25^{\text {th }}, 1917$.

The Nyasaland Government Gazette, November $10^{\text {th }}, 1917$.

The Native Rents (Private Estates) Ordinance, 1917'. Ordinances of the Nyasaland Protectorate for the year ended $31^{\text {st }}$ December 1917.

The Nyasaland Government Gazette, March 23 ${ }^{\text {rd }}, 1918$.

Colonial Annual Report for Nyasaland, 1920.

Handbook of Nyasaland. Prepared under the Direction of the Historical Section of the Foreign Office, No.95. London: H.M. Stationery Office, 1920.

Report of the Commission to Inquire into and Report upon Certain Matters Connected with the Occupation of Land in the Nyasaland Protectorate'. Zomba: Government Printer, 1921.

Colonial Annual Report for Nyasaland, 1927.

Colonial Annual Report for Nyasaland, 1928.

Colonial Development Act, 1929. London: H.M. Stationery Office, 1929. 
Report of the Commission on Closer Union of the Dependencies in Eastern and Central Africa'. London; H.M. Stationery Office, 1929.

Colonial Annual Report for Nyasaland, 1930.

CO 847/1/4: 'Report on Education in British Tropical Africa'. 1932.

The Laws of Nyasaland, Vol. II, 1933. London: C.F. Roworth Ltd, 1934.

Colonial Annual Report for Nyasaland, 1934.

Report on Education of African Communities'. In Economic and Social Development in Native Territories. 1937.

Report of the Commission Appointed to Inquire into the Financial Position and Further Development of Nyasaland'. London: His Majesty’s Stationery Office, 1938.

Rhodesia-Nyasaland Royal Commission Report'. Presented to Parliament by Command of His Majesty, March 1939.

Rhodesia-Nyasaland Royal Commission Report. London; H.M. Stationery Office, 1939.

Colonial Development and Welfare Act, 1940: Report on the Operation of the Act to $31^{\text {st }}$ October 1942'. London: HM Stationery Office, Feb. 1943.

Proceedings of the Legislative Council of Nyasaland'. $59^{\text {th }}$ Session, December $7^{\text {th }}, 1943$.

Record of the Proceedings of a Meeting of the $60^{\text {th }}$ Session of the Legislative Council, December $5^{\text {th }}, 1944$.

Nyasaland Protectorate: Land Commission Report, 1946, Vol. 1'. Prepared by The Right Hon. Sir Sidney Abrahams, P.C. Zomba: Government Printer, 1946. 
British Information Services. "Britain and Trusteeship". 1946.

Speech by Hon. Arthur Creech Jones, Secretary of State for the Colonies, House of Commons Session on Colonial Affairs, July 29 $9^{\text {th }}$ 1947, Vol. 441.

Record of the Proceedings of a Meeting of the Legislative Council'. Held at Zomba, July $19^{\text {th }}, 1948$.

Parliamentary Debates, House of Commons Official Report, $5^{\text {th }}$ Series, Vol.472. March $1^{\text {st }}$ to March $24^{\text {th }}, 1950$.

Parliamentary Debates, House of Commons Official Report, $5^{\text {th }}$ Series, Vol.473. March $27^{\text {th }}$ to April $6^{\text {th }}, 1950$.

Parliamentary Debates, House of Commons Official Report, $5^{\text {th }}$ Series, Vol.478. July $24^{\text {th }}$ to October $26^{\text {th }}, 1950$.

Speech by Hon. James Griffiths, the Secretary of State for the Colonies, in the House of Commons, Session on the Colonial Development Corporation'. October $19^{\text {th }}, 1950$.

Speech by King George VI', House of Commons Debates, Vol. 480. October 31 ${ }^{\text {st }}, 1950$.

Speech by The Rt. Hon. Arthur Creech Jones, P.C., Cust Foundation Lecture at the University of Nottingham, March $9^{\text {th }}, 1951$.

Speech by The Hon. C.W.F. Footman, Esq., The Nyasaland Government Chief Secretary in the Nyasaland Legislative Council'. December $8^{\text {th }}, 1952$.

The Federation of Rhodesia and Nyasaland (Constitution) Order-in-Council, 1953. August $1^{\text {st }}, 1953$. 
Penal Code and the Criminal Procedure of the Nyasaland Protectorate'. Consolidated Edition, $31^{\text {st }}$ December 1955. Zomba: Government Printer, 1955.

The Laws of Nyasaland, Vol. II. January 1957.

Federation of Rhodesia and Nyasaland: A Guide for the Investor. London, June 1959.

Colonial Office: Report of the Nyasaland Commission of Inquiry'. London: H.M. Stationery Office, July 1959.

Federation of Rhodesia and Nyasaland Newsletter. July $3^{\text {rd }}$, 1959. 'Information Services being expanded'.

Annual Report of the Nyasaland Police Force, December 1959.

Nyasaland Government: The Southworth Commission Report'. May 1960.

Speech by Rt. Hon. Harold Macmillan, Prime Minister of the United Kingdom, to the Houses of Parliament, Cape Town. Wednesday, $3^{\text {rd }}$ February 1960.

Report by the Advisory Commission on the Review of the Constitution of Rhodesia and Nyasaland. October 1960.

Proceedings of the 1st Meeting of the 76th Session of the Legislative Council. November 28th and 29th, 1961.

Nyasaland Development Plan, 1962-1965. Zomba: Government Printer, 1962.

Proceedings of the 8th Meeting of the 76th Session of Legislative Assembly. 9th to 16th July, 1963. 
Proceedings of the 8th Meeting of the 76th Session of Legislative Assembly. 9th to 16th July 1963.

Malawi Government Gazette: Ordinance No.13 of 1964: Malawi Development Corporation.

Parliament of Malawi, Official Report of the Proceedings. 2nd Meeting, First Session, 8th and 9th September 1964.

Malawi Government Gazette. February 19th, 1965: 'The Bretton Woods Agreement Act, $1965^{\prime}$

Malawi Government Gazette Supplement. March 19th, 1965.

The Constitution of The Republic of Malawi, 1966.

Malawi Government: Development Plan, 1965-1969. Zomba, Malawi: Government Printer, 1965.

'Forfeiture Act, 1966'. In the Malawi Government Gazette, July 8th, 1966: from The Republic of Malawi (Constitution Act), 1966, No.23 of 1966.

Laws of Malawi. Penal Code, 1968. Chapter VII: Treason and other Offences against the Government's Authority.

Malawi Government Gazette, April 8th, 1968: 'The Censorship and Control of Entertainment Act, 1968'.

The Constitution of The Republic of Malawi, 1972.

The Constitution of The Republic of Malawi, 1995. 
The Constitution of The Republic of Malawi, 2010.

Laws of Malawi: Criminal Procedure and Evidence Code, 1969-1973.

Government of Malawi: History and Hope in Malawi. Repression, Suffering and Human Rights under Dr. Катиzu Banda, 1964-1994. Prepared by the National Compensation Tribunal, March 2005.

Malawi Police: Training Manual on Human Rights.

\section{FROM CENTER FOR RESEARCH LIBRARIES}

The Central African Times. July 22 ${ }^{\text {nd }}, 1899$.

The Central African Times. August $5^{\text {th }}, 1899$.

The Central African Times. September $2^{\text {nd }}, 1899$.

The Central African Times. October $14^{\text {th }}, 1899$.

The Central African Times. November $11^{\text {th }}, 1899$.

The Central African Times. February $3^{\text {rd }}, 1900$.

The Central African Times. February $17^{\text {th }}, 1900$.

The Central African Times. March 11 $1^{\text {th }}, 1900$.

The Central African Times. April 4 ${ }^{\text {th }}, 1900$.

The Central African Times. January $11^{\text {th }}, 1902$.

The Central African Times. February 22 ${ }^{\text {nd }}, 1902$.

The Central African Times. November $1^{\text {st }}, 1902$.

The Central African Times. November 6 ${ }^{\text {th }}, 1902$.

The Central African Times. November $8^{\text {th }}, 1902$.

The Central African Times. November 15 ${ }^{\text {th }}, 1902$. 
The Central African Times. November 22 $2^{\text {nd }}, 1902$.

The Central African Times. April 23 ${ }^{\text {rd }}, 1903$.

The Central African Times. May 9 ${ }^{\text {th }}, 1903$.

The Central African Times. May 16 ${ }^{\text {th }}, 1903$.

The Central African Times. January 30 ${ }^{\text {th }}, 1904$.

The Central African Times. March 24 ${ }^{\text {th }}, 1905$.

The Central African Times. May 6 ${ }^{\text {th }}, 1905$.

The Central African Times. July $8^{\text {th }}, 1905$.

The Central African Times. June 23 ${ }^{\text {rd }}, 1906$.

The Central African Times. August $4^{\text {th }}, 1906$.

The Central African Times. February 16 ${ }^{\text {th }}, 1907$.

The Central African Times. March 23 ${ }^{\text {rd }}, 1907$.

The Central African Times. March $14^{\text {th }}, 1908$.

The Central African Times. March $14^{\text {th }}, 1908$.

The Times. March 31 ${ }^{\text {st }}, 1908$.

The Nyasaland Times. March 20"th 1913.

The Nyasaland Times. April 16 1914.

The Nyasaland Times. February $4^{\text {th }}, 1915$.

The Nyasaland Times. February $18^{\text {th }}, 1915$.

The Nyasaland Times. April 22 1915.

The Times. 'Communism in Africa: Marxist Propaganda in the British Territories'.

November $23^{\text {rd }}, 1951$.

The Times. August 22 nd 1953. 
The Times. August 23 ${ }^{\text {rd }}, 1953$.

The Nyasaland Times. January 20 1959.

The Nyasaland Times. February 20 1959.

The Daily Telegraph. August 10 ${ }^{\text {th }}, 1959$.

The Daily Telegraph. August 24 ${ }^{\text {th }}, 1959$.

The Times. June $1^{\text {st }}, 1961$.

Malawi News. December $23^{\text {rd }}, 1961$.

Malawi News. June $1^{\text {st }}, 1962$.

Malawi News. June 29 1962.

Malawi News. December $14^{\text {th }}, 1962$.

Malawi News. December 28 $8^{\text {th }}, 1962$.

Malawi News. January 25 ${ }^{\text {th }}, 1963$.

Malawi News. July 19 1963.

Malawi News. August 2 $2^{\text {nd }}, 1963$.

Malawi News. August 16 ${ }^{\text {th }}, 1963$.

Malawi News. September 13 ${ }^{\text {th }}, 1963$.

Malawi News. November $1^{\text {st }}, 1963$.

Malawi News. December $6^{\text {th }}, 1963$.

Malawi News. February 28 $8^{\text {th }}, 1964$.

Malawi News. April 1 ${ }^{\text {st }}, 1964$.

Malawi News. May 27 1964.

Malawi News. May 29 1964.

Malawi News. November $3^{\text {rd }}, 1964$. 
Malawi News. January 29 $9^{\text {th }}, 1965$.

Malawi News. February $19^{\text {th }}, 1965$.

Malawi News. March 26 ${ }^{\text {th }}, 1965$.

Malawi News. February $6^{\text {th }}, 1966$.

Malawi News. April 15 $5^{\text {th }}, 1966$.

Malawi News. April 19 1966.

Malawi News. January 20 ${ }^{\text {th }}, 1967$.

Malawi News. March 9 $9^{\text {th }}, 1967$.

Malawi News. October 20"th 1967.

Malawi News. March 28 $8^{\text {th }}, 1969$.

Malawi News. May 16 $6^{\text {th }} 1969$.

The Times. October $6^{\text {th }}, 1969$.

Malawi News. July $3^{\text {rd }}, 1970$.

Malawi News. July $2^{\text {nd }}, 1971$.

Malawi News. July 9 $9^{\text {th }}, 1971$.

Malawi News. July 22 $2^{\text {nd }}, 1971$.

Malawi News. November $2^{\text {nd }}, 1971$.

Malawi News. January $7^{\text {th }}, 1972$.

Malawi News. May 30"th 1972.

Malawi News. February $2^{\text {nd }}, 1973$.

Malawi News. March 9 , $^{\text {th }} 1973$.

Malawi News. June 29 1973.

Malawi News. March 2 1974. 
Malawi News. June 29 $9^{\text {th }}, 1974$.

Malawi News. September 1 $1^{\text {st }}, 1974$.

Malawi News. January 26 $6^{\text {th }}, 1977$.

Malawi News. February 19 1977.

Malawi News. February $26^{\text {th }}, 1977$.

Malawi News. April 23 $3^{\text {rd }}, 1977$.

Malawi News. January 27th 1980.

Malawi News. June $8^{\text {th }}, 1980$.

Malawi News. August 31 ${ }^{\text {st }}, 1980$.

Malawi News. June 27th - July 3rd, 1981.

Malawi News. August $15^{\text {th }}$ to $21^{\text {st }}, 1981$.

Malawi News. October $8^{\text {th }}, 1981$.

The Enquirer. August 2nd to $8^{\text {th }}, 1993$.

The Enquirer. October 12 to $18^{\text {th }}, 1993$.

The Enquirer. November 2nd to $8^{\text {th }}, 1993$.

The Enquirer. November $9^{\text {th }}$ to $16^{\text {th }}, 1993$.

The Enquirer. November 23rd to $29^{\text {th }}, 1993$.

The Enquirer. December $7^{\text {th }}, 1993$.

The Chronicle. December 1993.

The Chronicle. February $15^{\text {th }}$ to $21^{\text {st }}, 1994$.

The Enquirer. April 12 ${ }^{\text {th }}, 1994$.

The Independent. May 10th to $16^{\text {th }}, 1994$.

The Enquirer. May 16th to 19th, 1994. 
Daily Times. May 20 $0^{\text {th }}, 1994$.

The Nation. February $16^{\text {th }}, 1995$.

'What is Communism?'Speech by Dr. Hastings Kamuzu Banda, Prime Minister of Malawi, at the Zomba Debating Society, April 1964.

Speech by His Excellency the Life President, Ngwazi Dr. H. Kamuzu Banda', at a mass rally, Moto Village, Mangochi District. September 30th, 1974.

'Speech by His Excellency the Life President, Ngwazi Dr. H. Kamuzu Banda, at the Opening Ceremony of the MCP Convention, at Zomba Catholic Secondary School'. September 24th, 1978.

'Speech by His Excellency the Life President, Ngwazi Dr. H. Kamuzu Banda, on the 20th Anniversary Celebrations of His Return Home'. July 1st, 1978.

\section{UNPUBLISHED DISSERRATIONS/THESES AND SEMINAR PAPERS}

Atz, James Robert. "The British Colonial Police Service: A Study of its Organization and its Operations in Six British African Colonies". (PhD Diss., Temple University, January 1988).

Barnekov, Timothy Kiel. "An Inquiry into the Development of Native Administration in Nyasaland, 1888-1839”. (Masters Thesis, Department of Political Science, San Jose State College). Included in a compilation by Syracuse University, at the Maxwell Graduate School of Citizenship and Public Affairs, The Program of East African Studies, Occasional Paper No.48, June 1967. 
Chipeta, Mapopa O.J. "Labor in Colonial Malawi: A Study of the Growth and Development of the Malawian Working Class, 1891-1961". (PhD Thesis, History Department, Dalhousie University, Canada, October 1986).

Chirwa, Wiseman Chijere. "Theba is power: rural labor migrancy and fishing in Malawi, 1890s-1985”. (PhD Diss., Queen's University, Ontario, Canada, August 1992).

Dvorin, Eugene P. "The Central African Federation: A Political Analysis". (PhD Diss., Department of Political Science, University of California, Los Angeles, August 1955).

Krishnamurthy, Bangalore S. "Land and Labor in Nyasaland, 1891-1914". (PhD Diss., London University, 1964).

Nkhwazi, Denis. "Presidential Leadership in Malawi: A Study in the reconciliation of historical fate with developmental concepts and political institutional creation (Malawi 1964-1969) as seen from the core of the First Presidency,” (PhD Dissertation, University of Hamburg, Germany, 1971).

Nthenda, Louis James L. "H.M. Treasury and the Problems of Nyasaland Public Finance, 1919-1940.” (PhD Thesis, University of Oxford, 1972). 
Tangri, Roger K. "The Development of Modern African Politics and the Emergence of a Nationalist Movement in Colonial Malawi, 1891-1958”. (PhD Thesis, Faculty of Social Sciences, University of Edinburgh, August 1970).

Volman, Daniel Henry. "United States Foreign Policy and the Decolonization of British Central Africa (Zimbabwe, Zambia, and Malawi), 1945-1965”. (PhD Diss., History Department, University of California, Los Angeles. 1991).

White, Bayla Francis. "Political and Economic Interests and the Creation of the Federation of Rhodesia and Nyasaland". (MA Thesis in Economic and Social Studies, Faculty of Economic and Social Studies, University of Manchester, 1964).

Woods Jr, Anthony E. "Political Autonomy and Administrative Policy in Nyasaland, 19151921”. (History Seminar, 1984/85, Paper No.9, Chancellor College, University of Malawi).

Volman, Daniel Henry. "United States Foreign Policy and the Decolonization of British Central Africa (Zimbabwe, Zambia, and Malawi), 1945-1965". (PhD Diss., History Department, University of California, Los Angeles. 1991).

\section{ORAL TRADITION}

Oral Interview with Mr. Arabson Namate, conducted in 2009, by Professor Kings M. Phiri (Lead Researcher) and Paul Chiudza Banda (Graduate Research Assistant). 


\section{(B) SECONDARY SOURCES}

\section{BOOKS}

Abbink, Jon, et al, eds., Rethinking Resistance: Revolt and Violence in African History. Boston: Brill, 2003.

Adam, Elaine P., ed., American Foreign Relations 1977: A Documentary Record. New York: New York University Press, 1979.

Ake, Claude. A Political Economy of Africa. New York: Longman Inc., 1981.

Amin, Samir. Accumulation on a world scale: a critique of the theory of underdevelopment. New York: Monthly Review Press, 1974.

Anderson David, Histories of the hanged: The dirty war in Kenya and the end of Empire. New York: W.W. Norton and Company, 2005.

Appiah, Kwame A. and Henry Louis Gates, eds., Africana: The Encyclopedia of the African American Experience. New York: Basic Books, 1999.

Ashcroft, Thomas. An Outline of Modern Imperialism. London: The Plebs League, 1922.

Ashton, S.R. and S.E. Stockwell, eds., Imperial Policy and Colonial Practice, 1925-1945, Part II: Economic Policy, Social Policies, and Colonial Research. London: HMSO, 1996.

Ashton, S.R. and Wm Roger Louis, eds. British Documents on the end of Empire: East of the Suez and the Commonwealth, 1964-1971, Part III: Dependent Territories, Africa, Economics, Race. London: The Stationery Office, 2004. 
Badie, Bertrand and Pierre Birnbaum. The Sociology of the State. Chicago: The University of Chicago Press, 1983.

Badie, Bertrand. The Imported State: The Westernization of the Political Order. California: Stanford University Press, 2000.

Baker, C.A. Johnston's administration, 1891-1897. Zomba: Government Printer, 1971.

Baker, Colin. Seeds of Trouble: Government Policy and Land Rights in Nyasaland, 1946-1964. London: British Academic Press, 1993.

Baker, Colin. Development Governor: A Biography of Sir Geoffrey Colby. London: British Academic Press, 1994.

Baker, Colin. State of Emergency: Crisis in Central Africa, Nyasaland, 1959-1960. London: Tauris Academic Studies, 1997.

Bangura, Yusuf. Britain and Commonwealth Africa: The politics of economic relations, 1951-75. (Manchester: Manchester University Press, 1983).

Barnes, John and David Nicholson. Eds. The Empire at Bay: The Leo Amery Diaries, 1929-1945. London: Hutchinson, 1988.

Bayart, Jean-Francois. The African State: The Politics of the Belly. $2^{\text {nd }}$ edition. Cambridge, UK: Polity Press, 2009.

Bell, Duncan, ed., Victorian Visions of Global Order. Cambridge: Cambridge University Press, 2007.

Bellamy, Richard. Beccaria: On crimes and punishments and other writings. Cambridge: Cambridge University Press. 
Bennet, Huw. Fighting the Mau Mau: The British Army and Counter-insurgency in the Kenya

Emergency. Cambridge: Cambridge University Press, 2013.

Berger, Stefan et al, eds. Writing History: Theory and Practice. $2^{\text {nd }}$ Edition. New York: Bloomsbury Academic Press, 2010.

Berman, Bruce. Control and Crisis in colonial Kenya: The dialectic of domination. Athens, OH: Ohio University Press, 1990.

Berman, Bruce and John Lonsdale, eds., Unhappy Valley: conflict in Kenya and Africa. Book one: state and class. Athens, OH: Ohio University Press, 1992.

Bloch, Jonathon and Patrick Fitzgerald. British Intelligence and Covert Action. Ireland; Brandon Book Publishers, 1983.

Boahen, Adu A. General History of Africa, Vol.7: Africa under colonial domination, 1880-1935. California: University of California Press, 1985.

Boeder, Robert B. Alfred Sharpe of Nyasaland. Blantyre, Malawi: Society of Malawi, 1980.

Branch, Daniel. Defeating Mau Mau, Creating Kenya: Counterinsurgency, Civil War and Decolonization. Cambridge: Cambridge University Press, 2009.

Buell, Raymond Leslie. The Native Problem in Africa, Vol.1. New York: The Macmillan Company, 1928.

Cain, P.J. and A.G. Hopkins. British Imperialism, 1688-2015. $3^{\text {rd }}$ edition. London: Routledge, 2016.

Carruthers, Susan L. Winning Hearts and Minds: British Governments, the Media and Colonial Counter-Insurgency, 1944-1960. London: Leicester University Press, 1995. 
Cesaire, Aime. Discourse on Colonialism. New York: Monthly Review Press, 1972.

Chamberlain, M.E. The scramble for Africa, $3^{\text {rd }}$ edition. London: Longman, 2010.

Charlton, Peter. Cinderella's Soldiers: A History of The Nyasaland Volunteer Reserve. United Kingdom: Dolman Scott, 2010.

Cheeseman, Nic, et al, eds., The African Affairs Reader: key texts in politics, development, and international relations. Oxford: Oxford University Press, 2017.

Chirwa, Vera Mlangazuwa. Fearless Fighter: An Autobiography. London: Zed Books, 2007.

Chisiza, D.K. Realities of African Independence. (London: The African Publications Trust, 1961).

Clapham, Christopher, ed., Private Patronage and Public Power: Political Clientelism in the Modern State. New York: St. Martin’s Press, 1982.

Clapham, Christopher. Africa and the International System: The Politics of State Survival. Cambridge: Cambridge University Press, 1996.

Cohen, Andrew Sir. British Policy in Changing Africa. London: Routledge and Kegan Paul, 1959. Cohen, Andrew. The Politics and Economics of Decolonization in Africa: The Failed Experiment of the Central African Federation. London: I.B. Tauris, 2017.

Conklin, Alice L. A Mission to Civilize: The Republican Idea of Empire in France and West Africa, 1895-1930. Stanford, CA: Stanford University Press, 1997.

Conklin, Alice L. and Ian Christopher Fletcher, eds., European Imperialism, 1830-1930. New York: Houghton Mifflin and Company, 1999. 
Constantine, Stephen. The Making of British Colonial Development Policy, 1914-1940. London:

Frank Cass and Company, 1984.

Cooper, Frederick. African since 1940: The Past of the Present. Cambridge: Cambridge University Press, 2002.

Cooper, Frederick. Colonialism in Question: theory, knowledge, history. Berkeley, CA: University of California Press, 2005.

Cornia, Giovanni Andrea and Gerald K. Helleiner, eds., From Adjustment to Development in Africa: conflict, controversy, convergence, consensus? London: Macmillan Press Ltd., 1994.

Cowen, M.P. and R.W. Shenton. Doctrines of Development. London: Routledge, 1996.

Crowder, Michael, ed., The Cambridge History of Africa, Vol.8: c.1940-c.1975. Cambridge: Cambridge University Press, 1984.

Darwin, John. Britain and Decolonization: The Retreat from Empire in the Post-War World. New York: Macmillan, 1988.

Darwin, John. The Empire Project: The Rise and Fall of the British World-System, 1830-1970. Cambridge: Cambridge University Press, 2009.

Dotson Floyd and Lillian O. Dotson. The Indian Minority of Zambia, Rhodesia and Malawi. New Haven: Yale University Press, 1968.

Duff, Hector Livingston. Nyasaland Under the Foreign Office. London: George Bell and Sons, 1906.

Duffy, James and Robert A. Manners. Africa Speaks. New York: Van Nostrand Company, 1961. 
Duignan, Peter and Robert H. Jackson. Politics and Government in African States, 1960-1985. California: Hoover Institution Press, 1986.

Elkins, Caroline. Imperial Reckoning: The untold story of Britain's gulag in Kenya. New York: Henry Holt and Company, 2005.

Englebert, Pierre and Kevin C. Dunn. Inside African Politics. London: Lynne Rienner Publishers, 2013.

Fage, J.D. and R. Oliver, eds., The Cambridge History of Africa, Vol.6, 1870-1905. Cambridge: Cambridge University Press, 1985.

Falola, Toyin. Development Planning and Decolonization in Nigeria. Tallahassee: University of Florida, 1996.

Falola, Toyin, ed., Africa: Colonial Africa, Vol.3, 1885-1939. Durham, North Carolina: Carolina Academic Press, 2002.

Falola, Toyin. Colonialism and Violence in Nigeria. Bloomington, IN: Indiana University Press, 2009.

Falola, Toyin and Emily Brownell, eds., Africa, Empire and Globalization: Essays in Honor of A.G. Hopkins. Durham, N.C.: Carolina Academic Press, 2011.

Fanon, Frantz. The Wretched of the Earth. New York: Grove Press, 1961.

Ferguson, Niall. Empire: The Rise and Demise of the British World Order and the Lessons for Global Power. New York: Basic Books, 2002.

Ferguson, James. Global Shadows: Africa in the neoliberal world order. Durham: Duke University Press, 2006. 
Fieldhouse, D.K. The Colonial Empires: A Comparative Survey from the Eighteenth Century. $2^{\text {nd }}$ edition. New York: Dell Publishing Co., Inc., 1982.

Frankel, Joseph. British Foreign Policy, 1945-1973. London: Oxford University Press, 1975.

French, David. The British Way in Counter-Insurgency, 1945-1967. Oxford: Oxford University Press, 2011.

Gann, L.H. and Peter Duignan. Burden of Empire: An Appraisal of Western Colonialism in Africa South of the Sahara. Stanford, California: Hoover Institution Press, 1967. 1971 edition.

Gardner, Leigh A. Taxing Colonial Africa: The Political Economy of British Imperialism. Oxford: Oxford University Press, 2012.

Gegout, Catherine. Why Europe Intervenes in Africa: Security, Prestige and the Legacy of Colonialism. Oxford: Oxford University Press, 2017.

Gifford, Prosser and Wm. Roger Louis, eds. Britain and Germany in Africa: Imperial Rivalry and Colonial Rule. New Haven and London: Yale University Press, 1967.

Giglio, James N. The Presidency of John F. Kennedy. Kansas: The University of Kansas State, 1991.

Greene, Anna and Kathleen Troup. The Houses of History: A critical reader in twentieth-century history and theory. Manchester: Manchester University Press, 2016.

Gulhati, Ravi. Malawi: Promising Reforms, Bad Luck. Washington, DC: The World Bank, 1989.

Guldi, Jo and David Armitage. The History Manifesto. Cambridge: Cambridge University Press, 2014. 
Hailey, Lord. Native Administration in the British African Territories, Part II: Central Africa: Zanzibar, Nyasaland and Northern Rhodesia. London: His Majesty's Stationery Office, 1950.

Hailey, Lord. Native Administration and Political Development in British Tropical Africa, 194042. Liechtenstein: Kraus-Thomson Organization Ltd, 1979 publication.

Hanna, A.J. The Beginnings of Nyasaland and North-Eastern Rhodesia, 1859-95. Oxford: Clarendon Press, 1956.

Harlow, Barbara and Mia Carter, eds., Archives of Empire, Volume II: The Scramble for Africa. Durham and London: Duke University Press, 2003.

Havinden, Michael and David Meredith. Colonialism and Development: Britain and its Tropical Colonies, 1850-1960. London: Routledge, 1993.

Henige, David P. Colonial Governors, from the $15^{\text {th }}$ century to the present. Milwaukee: The University of Wisconsin Press, 1970.

Herbst, Jeffrey. States and Power in Africa: Comparative Lessons in Authority and Control. New Jersey: Princeton University Press, 2000.

Hetherwick, Alexander. The Romance of Blantyre: How Livingstone's Dream Came True. London: James Clarke and Company, 1931.

Hobbes, Thomas. Leviathan. London: Penguin Books, 1985 Reprint.

Hobsbawm, Eric and Terence Ranger, eds., The invention of tradition. Cambridge: Cambridge University Press, 1983.

Hobson, J.A. Imperialism: A Study. London: James Nisbert and Co., 1902. 
Hodge, Joseph M. Triumph of the Expert: Agrarian Doctrines of Development and the Legacies of British Colonialism. Athens, OH: Ohio University Press, 2007.

Hodge, Joseph M. et al, eds., Developing Africa: concepts and practices in twentieth-century colonialism. Manchester: Manchester University Press, 2014.

Hyam, Ronald. Elgin and Churchill at the Colonial Office: The Watershed of the EmpireCommonwealth. London: Macmillan Press, 1968.

Hyam, Ronald and Wm. Roger Louis, eds., The Conservative Government and the end of Empire, 1957-1964. Part II: Economics, International Relations, and the Commonwealth. London: The Stationery Office, 2000.

Jackson, E.F., ed., Economic Development in Africa: Papers presented to the Nyasaland Economic Symposium, Blantyre, July $18^{\text {th }}-28^{\text {th }}$ 1962. Oxford: Basil Blackwell, 1965.

Jackson, Robert H. and Carl G. Rosberg. Personal Rule in Black Africa. Los Angeles: University of California Press, 1982.

Jallow, Baba G. Leadership in Postcolonial Africa: Trends Transformed by Independence. New York: Palgrave Macmillan, 2014.

James, Lawrence. Empires in the Sun: The Struggle for the Mastery of Africa. New York: Pegasus Press, 2017.

Jeffries, Charles. The Colonial Police. London: Max Parrish and Co. Ltd, 1952.

Jeffries, Charles. The Colonial Office. London: George Allen and Unwin Ltd, 1956.

Jeronimo, Miguel Bandeira. The 'civilizing mission' of Portuguese colonialism, 1870-1930. New York: Palgrave Macmillan, 2015. 
Johnson, Gaynor, ed., The Foreign Office and British Diplomacy in the Twentieth Century. London: Routledge, 2005.

Johnston, Harry Hamilton. British Central Africa: An Attempt to Give Some Account of A Portion of the Territories Under British Influence North of the Zambezi. New York: Edward Arnold, 1897.

Jones, Griff. Britain and Nyasaland: A Story of Inattention, Fitful care, Political Vacillation. London: George Allen and Unwin Ltd, 1964.

Knaplund, Paul. Gladstone and Britain's Imperial Policy. New York: The Macmillan Company, 1927.

Kohli, Atul. State-Directed Development: Political Power and Industrialization in the Global World. Cambridge: Cambridge University Press, 2004.

Kolsky, Elizabeth. Colonial Justice in British India: white violence and the rule of law. Cambridge: Cambridge University Press, 2010.

Kubicek, Robert V. The Administration of Imperialism: Joseph Chamberlain at the Colonial Office. Durham, NC: Duke University Press, 1969.

Laidi, Zaki. The Super-Powers and Africa: The Constraints of a Rivalry, 1960-1990. Chicago: The University of Chicago Press, 1990.

Latham, Michael E. The Right Kind of Revolution: Modernization, Development, and U.S. Foreign Policy from the Cold War to the Present. Ithaca: Cornell University Press, 2011.

Lee, Christopher J. ed., Making A World After Empire: The Bandung Moment and its Political Afterlives. Athens, Ohio: Ohio University Press, 2010. 
Leffler, Melvyn P. and Odd Arne Westad, eds., The Cambridge History of the Cold War, Vol.2:

Crises and Détente. Cambridge: Cambridge University Press, 2010.

Legum, Colin. "Background to the Disturbances in Nyasaland". Supplement to the Information Digest, No.11. London: African Bureau, 1953.

Levtzion, Nehemiah and Randall L. Pouwels, eds., The History of Islam in Africa. Athens, $\mathrm{OH}$ : Ohio University Press, 2000.

Linstrum, Erik. Ruling Minds: Psychology in the British Empire. Cambridge, MA: Harvard University Press, 2016.

Louis, Wm. Roger. In the Name of God, Go! Leo Amery and the British Empire in the Age of Churchill. London: W.W. Norton and Company, 1992.

Low, D.A. Fabrication of Empire: The British and the Uganda Kingdoms, 1890-1902. Cambridge: Cambridge University Press, 2009.

Lucas, Charles Sir., ed., The Empire at War. Volume 4. London: Oxford University Press, 1924.

Lugard, John Dealtry. The Dual Mandate in British Tropical Africa. London: William Blackwood and Sons, 1922. 2012 edition., published by Forgotten Books.

Lwanda, John Lloyd. Kamuzu Banda of Malawi: A Study in Promise, Power and Legacy. Zomba: Kachere Series, 2009.

Lyttleton, Oliver. The Memoirs of Lord Chandos: An Unexpected View from the Summit. New York: The New American Library of World Literature, 1963.

Macdonald, Roderick J., ed., From Nyasaland to Malawi: Studies in Colonial History. Nairobi, Kenya: East African Publishing House, 1975. 
Mair, L.P. Native Policies in Africa. New York: Negro Universities Press, 1936.

Majumdar, Rochona. Writing Postcolonial History. New York: Bloomsbury Academic, 2010.

Malawi Government. Economic Report for 1971. Zomba: Government Press, 1971.

Malawi Government. Economic Report for 1979. Zomba: Government Press, 1979.

Malawi: An Alternative Pattern of Development. Conference/Seminar Proceedings No.25, Center of African Studies, University of Edinburgh. May $24^{\text {th }}$ and $25^{\text {th }}, 1984$.

Marlow, C. A History of the Malawi Police Force. 1971.

Marsh, Peter T. Joseph Chamberlain: Entrepreneur in Politics. New Haven: Yale University Press, 1994.

Maugham, R.C.F. Africa as I Have Known It: Nyasaland-East Africa-Liberia-Senegal. (New York: Negro Universities Press, 1969).

Maxon, Robert M. Struggle for Kenya: The Loss and Reassertion of Imperial Initiative, 19121923. Cranbury, NJ: Associated University Presses, 1993.

McCracken, John. A History of Malawi, 1859-1966. UK: James Currey Ltd, 2012.

McCracken, John, ed., Voices from the Chilembwe Rising: witness testimonies made to the Nyasaland Rising Commission of Inquiry, 1915. Oxford: Oxford University Press, 2015.

McMaster, Carolyn. Malawi: Foreign Policy and Development. London: Julian Friedmann Publishers, 1974.

Meinhardt, H. Free at Last! Malawi's Democratic Transition. Lilongwe: NICE, 2004. 
Melson, Robert. Revolution and Genocide: on the origins of the Armenian genocide and the holocaust. Chicago: The University of Chicago Press, 1992.

Memmi, Albert. The Colonizer and the Colonized. New York: Orion Press, 1965.

Mhone, Guy C.Z. Malawi at the Crossroads: The Post-Colonial Political Economy. Harare: SAPES Books, 1992.

Migdal, Joel S. Strong Societies and Weak States: State-Society Relations and State Capabilities in the Third World. Princeton, NJ: Princeton University Press, 1988.

Mockaitis, Thomas R. British Counterinsurgency, 1919-60. New York: St. Martin's Press, 1990.

Morgan, D.J. The Official History of Colonial Development. Volume 1: The Origins of British Aid Policy, 1924-1945. New Jersey: Humanities Press, 1980.

Moore, David, ed., The World Bank, Development, Poverty, Hegemony. South Africa: University of KwaZulu Natal Press, 2007.

Morris-Jones, W.H. and Georges Fischer, eds., Decolonization and After: The British and French Experience. London: Frank Cass, 1980.

Morton, Geoffrey J. The Just Job: Some Experiences of a Colonial Policeman. London: Hodder and Stoughton, 1957.

Morton, Kathryn. Aid and Dependence: British Aid to Malawi. London: Holmes and Meier Publishers, Inc., 1975.

Moyo, Sam and Paris Yeros. Eds. Reclaiming the Land: The Resurgence of Rural Movements in Africa, Asia and Latin America. London: Zed Books, 2005. 
Muehlenbeck, Philip. Betting on the Africans: John F. Kennedy's Courting of African Nationalist Leaders. Oxford: Oxford University Press, 2012.

Muiu, Mueni wa and Guy Martin. A New Paradigm of the African State. New York: Palgrave Macmillan, 2009.

Muluzi, Bakili, et al. Democracy with a Price: The History of Malawi since 1900. Blantyre, Malawi: Jhango Heinemann, 1999.

Mulwafu, Wapulumuka O. Conservation Song: A History of Peasant-State Relations and the Environment in Malawi, 1860-2000. Cambridge, UK: The White Horse Press, 2011.

Munro, J. Forbes. Britain in Tropical Africa, 1880-1960: Economic Relationships and Impact. London: Macmillan Press, 1984.

Murphy, Philip. Alan Lennox-Boyd: A Biography. London: I.B. Tauris and Co. Ltd, 1999.

Murphy, Philip, ed., British Documents on the End of Empire: Central Africa, Part II: Crisis and Dissolution. London: The Stationery Office, 2005.

Murray, S.S. (compiler). A Handbook of Nyasaland. Zomba: Government Printer, 1932.

Nelson, Harold, D., et al. Area Handbook for Malawi. Washington DC: American University, 1975.

Nkrumah, Kwame. Africa Must Unite. $2^{\text {nd }}$ edition. New York: International Publishers, 1972)

Nzunda, Matembo S. and Kenneth R. Ross. Church, Law, and Political Transition in Malawi, 1992- ’94. Gweru, Zimbabwe: Mambo Press, 1995. 
Ochonu, Moses E. Colonial Meltdown: Northern Nigeria in the Great Depression. Athens, OH: Ohio University Press, 2009.

Oliver, Roland. Sir Harry Johnston and the Scramble for Africa. London: Chatto and Windus, 1959.

Pachai, Bridglal, ed., The Early History of Malawi. London: Longman Group Ltd, 1972.

Pachai Bridglal. Malawi: The History of the Nation. London: Longman Group Limited, 1973.

Pachai Bridglal. Land and Politics in Malawi, 1875-1975. Ontario, Canada: The Limestone Press, 1978.

Parsons, Timothy H. The Rule of Empires: Those who built them, those who endured them, and why they always fall. Oxford: Oxford University Press, 2010.

Phillips, Anne. The enigma of colonialism: British policy in West Africa. London: James Curry, 1989.

Phiri, Desmond D. Let Us Die for Africa: An African Perspective on the Life and Death of John Chilembwe of Nyasaland/Malawi. Blantyre, Malawi: Central Africana Ltd, 1999.

Pike, John G. Malawi: A Political and Economic History. New York: Frederick A. Praeger Publishers, 1968.

Pitts, Jennifer. A Turn to Empire: The rise of imperial liberalism in Britain and France. Princeton, NJ: Princeton University Press, 2005.

Porter, Bernard. Critics of empire: British radical attitudes to colonialism, 1895-1914. New York: Macmillan, 1968. 
Power, Joey. Political Culture and Nationalism in Malawi: Building Kwacha. New York: University of Rochester Press, 2010.

Press, Steven. Rogue Empires: Contracts and Conmen in Europe's Scramble for Africa. MA: Harvard University Press, 2017.

Price, Steven D., ed., 1001 Smartest Things Ever Said. Connecticut: The Lyons Press, 2005.

Pryor, Frederick L. Malawi and Madagascar: The Political Economy of Poverty, Equity and Growth. Oxford: Oxford University Press, 1990.

Rist, Gilbert. The History of Development: From Western Origins to Global Faith. $3^{\text {rd }}$ edition. London: Zed Books, 2010.

Roberts, Clifton C. Tangled Justice: Some Reasons for a Change in Policy in Africa. New York: Negro Universities Press, 1937.

Robinson, Ronald and John Gallagher. Africa and the Victorians: The Climax of Imperialism. New York: Anchor Books, 1968 edition.

Rodney, Walter. How Europe underdeveloped Africa. London: Bogle L’Ouverture, 1972.

Rotberg, Robert I. and Ali M. Mazrui, eds. Protest and Power in Black Africa. New York: Oxford University Press, 1970.

Rothchild, Donald and Naomi Chazan, eds., The precarious balance: state and society in Africa. Boulder: Westview Press, 1988.

Rusche, Georg and Otto Kirchheimer. Punishment and Social Structure. New York: Russell and Russell, 1968. 
Samatar, Abdi Ismail and Ahmed I. Samatar. Eds. The African State: Reconsiderations. New Hampshire: Heinemann, 2002.

Saunier, Pierre-Yves. Transnational History: Theory and History. New York: Palgrave Macmillan, 2013.

Schmidt, Elizabeth. Foreign Intervention in Africa: From the Cold War to the War on Terror. Cambridge: Cambridge University Press, 2013.

Schydlowsky, Daniel M., ed., Structural Adjustment: Retrospect and Prospect. London: Praeger Publishers, 1995.

Shepperson, George and Thomas Price. Independent African: John Chilembwe and the Origins, Setting and Significance of the Nyasaland Native Rising of 1915. Edinburgh: Edinburgh University Press, 1958.

Short, Philip. Banda. London: Routledge and Kegan Paul, 1974.

Sinclair, Georgina. At the end of the line: Colonial Policing and the Imperial Endgame, 19451980. Manchester: Manchester University Press, 2006.

Sindima, Harvey J. Malawi's First Republic: An Economic and Political Analysis. New York: University Press of America, 2002.

Somerville, Keith. Africa's Long Road since Independence: The Many Histories of a Continent. London: Hurst and Company, 2015.

Strauss, William L. Joseph Chamberlain and the Theory of Imperialism. Washington DC: American Council on Public Affairs, 1942. 
The Crucial Problem of Imperial Development. No.15. Royal Empire Society. London: Longmans, Green and Co., 1938).

The World Bank. Accelerated Development in Sub-Saharan Africa: An Agenda for Action. Washington, DC, 1981.

The World Bank. "Report and Recommendation of the President of the International Development Association on a proposed credit of SDR 51.9 Million to the Republic of Malawi for a Second Structural Adjustment Project.” November 29 1983.

Thomas, Martin. Violence and Colonial Order: Police, Workers and Protest in the European Colonial Empires, 1918-1940. Cambridge: Cambridge University Press, 2012.

Thompson, Andrew S. Writing Imperial Histories. Manchester: Manchester University Press, 2013.

Thompson, Robert. Defeating Communist Insurgency: The Lessons of Malaya and Vietnam. New York: Frederick A. Praeger Publishers, 1966.

Thorp, Rosemary, ed., Latin America in the 1930s: the role of the periphery in world crisis. London: The Macmillan Press, 1984.

Throup, David W. Economic and Social Origins of Mau Mau. London: James Currey, 1988.

Turner, Victoria, ed., Colonialism in Africa, 1870-1960. Vol.3: Profiles of Change: African Society and Colonial Rule. Cambridge: Cambridge University Press, 1971.

United Nations. Human Development Report, 1991. Oxford: Oxford University Press, 1991.

USAID: Malawi: Country Development Strategy Statement. Washington, DC, 1982. 
Van de Walle, Nicholas. African Economies and the Politics of Permanent Crisis, 1979-1999. Cambridge: Cambridge University Press, 2001.

Walton, Calder. Empire of Secrets: British Intelligence, The Cold War, and the Twilight of Empire. London: William Collins, 2013.

Welensky, Roy. Welensky's 4000 Days: The Life and Death of the Federation of Rhodesia and Nyasaland. London: Collins Clear-Type Press, 1964.

Westad, Odd Arne. The Global Cold War: Third World Interventions and the Making of Our Times. Cambridge: Cambridge University Press, 2007.

Weiner, Martin J. An Empire on Trial: race, murder, and justice under British rule, 1870-1935. Cambridge: Cambridge University Press, 2009.

White, Landeg. Magomero: Portrait of an African Village. Cambridge: Cambridge University Press, 1989.

Wiarda, Howard J. Political Development in Emerging Nations: Is there still a Third World? California: Wadsworth and Thomson Learning, 2004.

Williams, David T. Malawi: The Politics of Despair. Ithaca: Cornell University Press, 1975.

Woddis, Jack. Africa: The Roots of Revolt. New York: The Citadel Press, 1960.

Woolf, Leonard. Economic Imperialism. New York: Fertig, 1970.

Young, Crawford. The African Colonial State in Contemporary Perspective. New Haven: Yale University Press, 1994. 
Young, Crawford. The State in Postcolonial Africa: Fifty Years of Independence, 1960-2010.

Wisconsin: The University of Wisconsin Press, 2012.

Zeilig, Leo, ed., Class Struggle and Resistance in Africa. $2^{\text {nd }}$ edition. Chicago, IL: Haymarket Books, 2009.

Zeleza, Paul Tiyambe. Africa's Resurgence: Domestic, Global and Diaspora Transformations. Los Angeles, CA: TSEHAI publisher, 2014.

\section{JOURNAL ARTICLES AND ONLINE SOURCES}

Alejandro, Carlos F. Diaz. "Latin America in Depression, 1929-1939.” Center discussion Paper no. 344 (Yale University, Economic Growth Center, March 1980): 1-41.

Austen, Ralph A. "Africa and globalization: colonialism, decolonization and the postcolonial malaise.” Journal of Global History, Issue 1 (2006): 403-408.

Baker, Colin. "A hundred years ago: The Nyasaland Order-in-Council, 1907." Society of Malawi Journal, 60, no.2 (2007): 1-5.

Bayart, Jean-Francois and Stephen Ellis. "Africa in world history: a history of extraversion." African Affairs, Vol.99, No.935, Centenary Issue: a hundred years of Africa (April 2000): 217267.

Bellucci, Beluce. "The State in Africa." The Perspective of the World View. 2, no.3 (Dec. 2010): $9-42$.

Bleichmar, Javier. "Deportation as Punishment: A Historical Analysis of the British Practice of Banishment and its Impact on Modern Constitutional Law." Georgetown Immigration Law Journal, 14, (Fall 1999): 115-163. 
Boisen, Camilla. "The Changing Moral Justification of Empire: From the Right to Colonize to the Obligation to Civilize." History of European Ideas, 39, no.3 (2013): 335-353.

Burton, Andrew. "The eye of authority: 'native' taxation, colonial governance and resistance in inter-war Tanganyika." Journal of East African Studies, 2, no.1 (March 2008): 74-94.

Brune, Nancy, et al, "The International Monetary Fund and the global spread of privatization," IMF Staff Papers 51, no.2 (2004): 195-219.

Bryant, W.R. Mumford and B.N Parker. "Education in British African dependencies: A review of the 1935 annual reports on native education in Nyasaland, N. Rhodesia, Tanganyika, Uganda, Gold Coast, Nigeria and Sierra Leone." Journal of the Royal African Society (Jan.1937): 17-32.

Butler, L.J. “The Central African Federation and Britain's Post-War Nuclear Programme: Reconsidering the Connections." The Journal of Imperial and Commonwealth History, 36, no.3 (Sept. 2008): 509-525.

Cain, P.J. and A.G. Hopkins. “The Political Economy of British Overseas Expansion, 1750-1914.” The Economic History Review, New Series, 33, no.4 (Nov. 1980): 463-490.

Cain, P.J. and A.G. Hopkins. "Gentlemanly capitalism and British expansion overseas II: New imperialism, 1850-1945.” The Economic History Review, 40, no.1 (Feb. 1987), 1-26.

Cain, Peter J. "Character, 'ordered liberty', and the mission to civilize: British moral justification of Empire, 1870-1914." The Journal of Imperial and Commonwealth History, 40, no.4 (Nov. 2012): 557-578.

Charlton, Peter. "Some Notes on the Nyasaland Volunteer Reserve." The Society of Malawi Journal, 46, no.2 (1993): 25-51. 
Chijere Chirwa, Wiseman. "Alomwe and Mozambican Immigrant Labor in Colonial Malawi, 1890s-1945." The International Journal of African Historical Studies, 27, no.3 (1994): 525-550.

Chipembere, Henry B.M. "Malawi in Crisis". In Ufahamu: A Journal of African Studies, 11, No.1, (1981): 76-96.

Chiudza Banda, Paul. "The 2009 General Elections: process, results, and lessons," Society of Malawi Journal 63, no.2 (2010): 4:14.

Chiudza Banda, Paul and Gift Wasambo Kayira. "The 1959 State of Emergency in Nyasaland: Process and Political Implications.” The Society of Malawi Journal, 65, no.2 (2012): 1-19.

Chirwa, Ephraim. "Privatization and technical efficiency: evidence from the manufacturing sector in Malawi," African Development Bank (Oxford, UK: Blackwell Publishers, 2001): 276-307.

Clay, Edward, et al. "Malawi and Southern Africa: Climatic Variability and Economic Performance.” World Bank Working Paper Series No.7, 2003.

Coleman, James S. "The Resurrection of Political Economy." Mawazo, 1, Issue 1, (June 1967): 31-40.

Collins, Michael. "Decolonization and the 'Federal Moment'," Diplomacy and Statecraft, 24, no.1 (February 2013): 21-40.

Cooper, Frederick. "Conflict and Connection: Rethinking Colonial African History." American Historical Review, 99, no.5 (Dec. 1994): 1516-1545.

Crowder, Michael. "Whose Dream was It Anyway? Twenty-Five Years of African Independence." African Affairs, 86, no. 342, (January 1987): 7-24. 
Crush, Jonathan. "colonial coercion and the Swazi tax revolt of 1903-1907." Political Geography Quarterly, 4, no.3 (July 1985): 179-190.

Deflem, Mathieu. "Law Enforcement in British Colonial Africa: A Comparative Analysis of Imperial Policing in Nyasaland, the Gold Coast, and Kenya." Police Studies, 17, no.1, (1994): 4568.

Dissent, Issue No.12, $22^{\text {nd }}$ October 1959.

Dixon, Paul. “'Hearts and Minds'? British Counter-Insurgency from Malaya to Iraq.” Journal of Strategic Studies, 32, no.3, (June 2009): 353-381.

Doornbos, Martin. "The African State in Academic Debate: Retrospect and Prospect." The Journal of Modern African Studies, 28, no.2 (June 1990): 179-198.

Forstater, Mathew. "Taxation and Primitive Accumulation: The Case of Colonial Africa". The Capitalist State and Its Economy: Democracy in Socialism Research in Political Economy, Vol. 22. Elsevier Ltd. 2005.

Harrison, Graham. "The World Bank, governance and theories of political action in Africa," British Journal of Politics and International Relations, 7, no.2 (May 2005), 240-260.

Harsch, Ernest. "Privatization shifts gears in Africa: more concern for public acceptance and development impact but problems remain," Africa Recovery (April 2000): 8-17.

Hodgson, Geoffrey M. "What are Institutions?" Journal of Economic Issues, 40, no.1 (March 2006): $1-25$. 
Hooker, J.R. "Witnesses and Watchtower in the Rhodesias and Nyasaland," Journal of African History, 6, no.1 (1965), 91-106.

Hussein, Iza. "Circulations of law: colonial precedents, contemporary questions," Onati SocioLegal Series, 2, no.7 (2012), 18-32.

Hynd, Stacey. "Decorum or Deterrence? The Politics of Execution in Malawi, 1915-66." Cultural and Social History, 5, Issue 4 (2008): 437-448.

Hynd, Stacey. "The extreme penalty of the law: mercy and the death penalty as aspects of state power in colonial Nyasaland, 1904-47." Journal of Eastern African Studies 4, no.3 (2010): 542559.

Hynd, Stacey. "Law, violence and penal reform: state responses to crime and disorder in colonial Malawi, 1900-1959.” Journal of Southern African Studies, 37, no.3 (Sept. 2011): 431-447.

Isaacman, Allen and Barbara Isaacman. "Resistance and Collaboration in Southern and Central Africa, 1850-1920.” The International Journal of African Historical Studies, 10, no.1, (1977): 3162.

Johnston, H.H. "The British Central Africa Protectorate." The Geographical Journal, 5, no.3, (March 1895): 193-217.

Kalinga, Owen J.M. "European Settlers, African Apprehensions, and Colonial Economic Policy: The North Nyasa Native Reserves Commission of 1929." The International Journal of African Historical Studies, 17, no.4 (1984): 641-656.

Kettlewell, R.W. “Agricultural Change in Nyasaland: 1945-1960.” Reprinted from Food Research Institute Studies, no.3, (1965): 229-285. 
Langworthy III, Harry W. "Joseph Booth, prophet of radical change in Central and South Africa, 1891-1915," Journal of Religion in Africa 16, no.1 (February 1986): 22-43.

Lodhi, Abdulaziz Y. "Muslims in Eastern Africa - Their past and present." Nordic Journal of African Studies, 3, no.1 (1994): 88-98.

Lovejoy, Paul and J.S. Hogendorn. "Revolutionary Mahdism and resistance to colonial rule in the Sokoto Caliphate, 1905-6.” Journal of African History, 31, no.2 (1990): 217-244.

McCracken, John. "Coercion and Control in Nyasaland: aspects of the history of a colonial police force". The Journal of African History 27, no.1 (1986): 127-147.

McGowen, Randall. "Civilizing Punishment: The End of the Public Execution in England". The Journal of British Studies, 33, no.3, (July 1994): 257-282.

Mpakati, Attati. "Malawi: The Birth of a Neo-Colonial State." African Review, 3, Issue 1 (Jan. 1973): 33-68.

Mtewa, Mekki. "Problems of Oedipal Historicism: The Saga of John Chilembwe - the Malawian." Journal of Black Studies - African Cultural Dimensions, 8, no.2 (December 1977): 227-250.

Munger, Edwin S. "Racial Tension in Nyasaland." American Universities Field Staff. October 1956.

Murphy, Philip. "Intelligence and Decolonization: The Life and Death of the Federal Intelligence and Security Bureau, 1954-63." The Journal of Imperial and Commonwealth History, 29, no.2, (2008): 101-130.

Murphy, Philip. “A Police State? The Nyasaland Emergency and Colonial Intelligence.” Journal of Southern African Studies, 36, no.4, (December 2010): 765-780. 
Mwasi, E.D. "Reminiscences of my detention." Society of Malawi Journal. 59, no.2 (2006): 4049.

Neale, Walter C. “Institutions”. Journal of Economic Issues, 21, no.3 (Sept. 1987): 1177-1206.

Ng'ong'ola, Clement. "The State, Settlers, and Indigenes in the Evolution of Land Law and Policy in Malawi." The International Journal of African Historical Studies, 23, no.1 (1990): 27-58.

North, Douglas C. "Institutions.” The Journal of Economic Perspectives, 5, no.1 (Winter 1991): $97-112$.

O'Brien, Donal Cruise. “Towards an 'Islamic Policy' in French West Africa, 1854-1914.” Journal of African History, 8, no.2 (1967): 303-316.

Pachai, Bridglal. "Land Policies in Malawi: An Examination of the Colonial Legacy." The Journal of African History, 14, no.4 (1973): 681-698.

Page, Melvin. "The War of Thangata: Nyasaland and the East African Campaign, 1914-1918." Journal of African History, XIX, no.1 (1978): 87-100.

Patel Nandin and Michael Wahman. "The presidential, parliamentary and local elections in Malawi, May 2014,” Africa Spectrum, 50, no.1 (2015): 79-92.

Porter, Andrew. 'Gentlemanly capitalism and empire: The British experience since 1750?' The Journal of Imperial and Commonwealth History, 18, no.3 (1990): 265-295.

Reynolds, Jonathan. "Good and Bad Muslims: Islam and Indirect Rule in Northern Nigeria." International Journal of African Historical Studies, 34, no.3 (2001): 601-618.

Richardson, Channing B. "The Federation of Rhodesia and Nyasaland." Africa Today Pamphlets, no.4, 1960. 
Roberts, Simon. "The direct taxation of Africans in the Nyasaland protectorate, 1892-1939: some determinants of revenue policy,” British Tax Review, 193 (1967): 192-206.

Schreuder, D.M. "The cultural factor in Victorian imperialism: a case study of the British 'civilizing mission'.” The Journal of Imperial and Commonwealth History, 4, no.3 (1976): 283317.

Sharpe, Alfred. "The Geography and Economic Development of British Central Africa." The Geographical Journal, 39, no.1 (Jan. 1912): 1-17.

Stuart-Mogg, David. "A Brief Investigation into the Genealogy of Pastor John Chilembwe of Nyasaland and Some Thoughts upon the Circumstances Surrounding his Death." The Society of Malawi Journal, 50, no. 1 (1997): 44-58.

Tuck, Michael W. "The Rupee Disease: taxation, authority, and social conditions in early colonial Uganda.” The International Journal of African Historical Studies, 39, no.2 (2006): 221-245.

Vail Leroy and Landeg White. "Forms of Resistance: Songs and perceptions of power in colonial Mozambique." American Historical Review, 88, no.4 (Oct. 1983): 883-919.

van Donge, Jan Kees. "The Fate of an African 'Chaebol': Malawi's Press Corporation after Democratization." The Journal of Modern African Studies, 40, no.4 (Dec. 2002): 651-681.

Wicker, E.R. "The Colonial Development Corporation, 1948 - '54." The Review of Economic Studies, 23, no.3 (1955-1956): 213-228.

Young, Crawford. "The End of the Post-Colonial State in Africa? Reflections on Changing African Political Dynamics." African Affairs, 103, no.410 (Jan. 2004): 23-49. 
